$\theta r-2042$

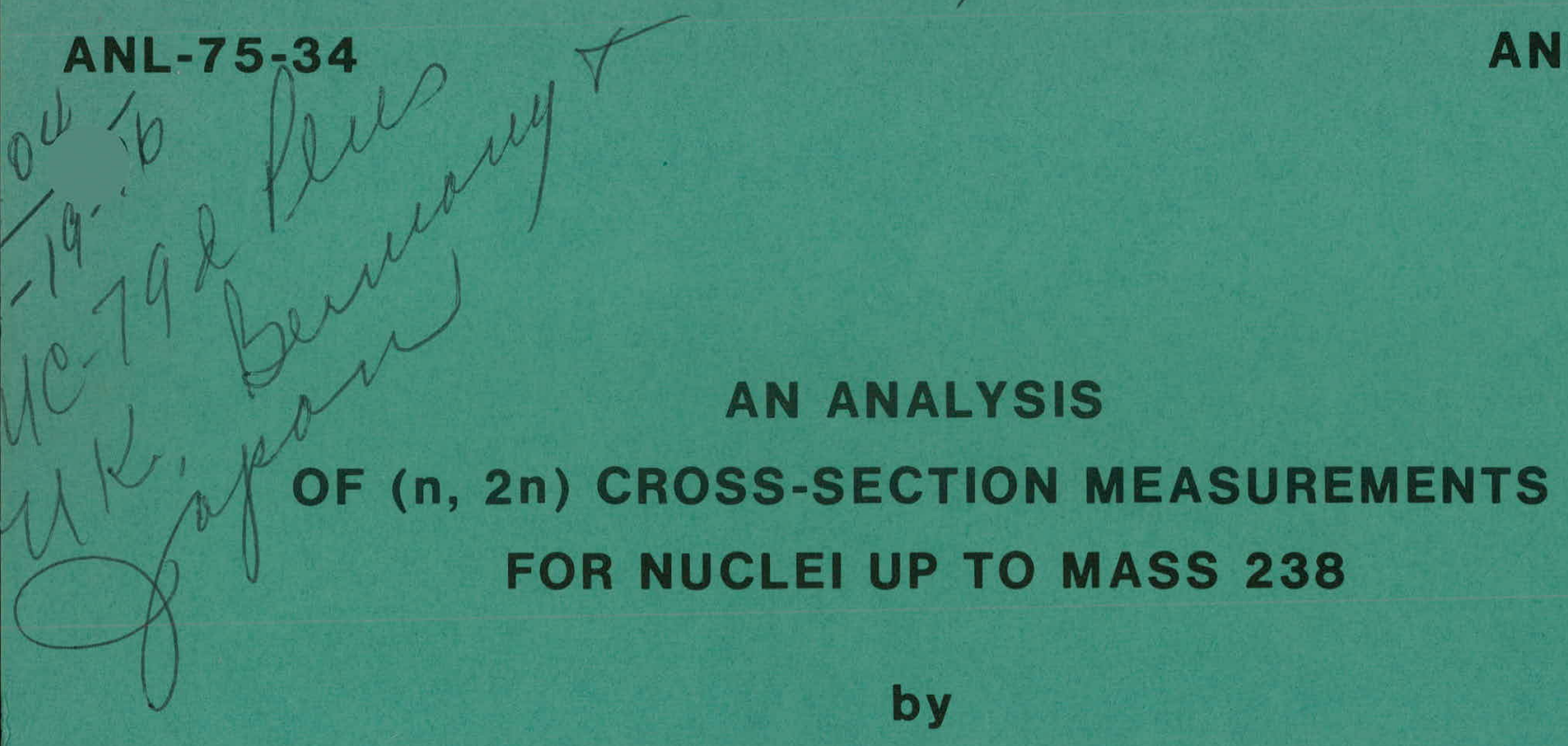

\author{
W. G. Davey, R. W. Goin, \\ and J. R. Ross
}

BASE TECHNOLOGY
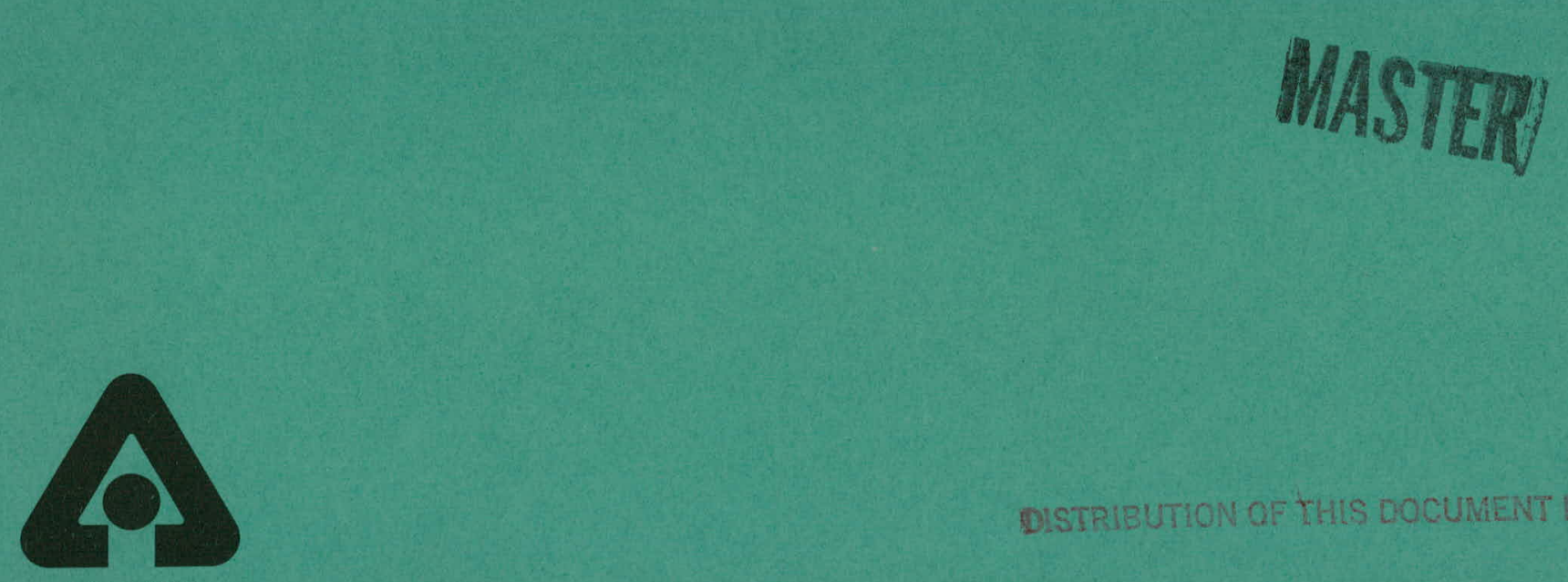

ARGONNE NATIONAL LABORATORY, ARGONNE, ILLINOIS Prepared for the U. S. ENERGY RESEARCH AND DEVELOPMENT ADMINISTRATION under Contract W-31-109-Eng-38 


\section{DISCLAIMER}

This report was prepared as an account of work sponsored by an agency of the United States Government. Neither the United States Government nor any agency Thereof, nor any of their employees, makes any warranty, express or implied, or assumes any legal liability or responsibility for the accuracy, completeness, or usefulness of any information, apparatus, product, or process disclosed, or represents that its use would not infringe privately owned rights. Reference herein to any specific commercial product, process, or service by trade name, trademark, manufacturer, or otherwise does not necessarily constitute or imply its endorsement, recommendation, or favoring by the United States Government or any agency thereof. The views and opinions of authors expressed herein do not necessarily state or reflect those of the United States Government or any agency thereof. 


\section{DISCLAIMER}

Portions of this document may be illegible in electronic image products. Images are produced from the best available original document. 
The facilities of Argonne National Laboratory are owned by the United States Government. Under the terms of a contract (W-31-109-Eng-38) between the U. S. Energy Research and Development Administration, Argonne Universities Association and The University of Chicago, the University employs the staff and operates the Laboratory in accordance with policies and programs formulated, approved and reviewed by the Association.

\section{MEMBERS OF ARGONNE UNIVERSITIES ASSOCIATION}

The University of Arizona

Carnegie-Mellon University

Case Western Reserve University

The University of Chicago

University of Cincinnati

Illinois Institute of Technology

University of Illinois

Indiana University

Iowa State University

The University of Iowa
Kansas State University

The University of Kansas

Loyola University

Marquette University

Michigan State University

The University of Michigan

University of Minnesota

University of Missouri

Northwestern University

University of Notre Dame
The Ohio State University

Ohio University

The Pennsylvania State University

Purdue University

Saint Louis University

Southern Illinois University

The University of Texas at Austin

Washington University

Wayne State University

The University of Wisconsin

\section{NOTICE}

This report was prepared as an account of work sponsored by the United States Government. Neither the United States nor the United States Energy Research and Development Administration, nor any of their employees, nor any of their contractors, subcontractors, or their employees, makes any warranty, express or implied, or assumes any legal liability or responsibility for the accuracy, completeness or usefulness of any information, apparatus, product or process disclosed, or represents that its use would not infringe privately-owned rights. Mention of commercial products, their manufacturers, or their suppliers in this publication does not imply or connote approval or disapproval of the product by Argonne National Laboratory or the U. S. Energy Research and Development Administration.

Printed in the United States of America Available from

National Technical Information Service

U. S. Department of Commerce 5285 Port Royal Road

Springfield, Virginia 22161

Price: Printed Copy $\$ 8.50$; Microfiche $\$ 2.25$ 
ANL-75-34

\section{ARGONNE NATIONAL LABORATORY}

9700 South Cass Avenue

Argonne, Illinois 60439

AN ANALYSIS OF $(n, 2 n)$ CROSS-SECTION MEASUREMENTS

FOR NUCLEI UP TO MASS 238

by

W. G. Davey,* R. W. Goin, and J. R. Ross

\section{June 1975}

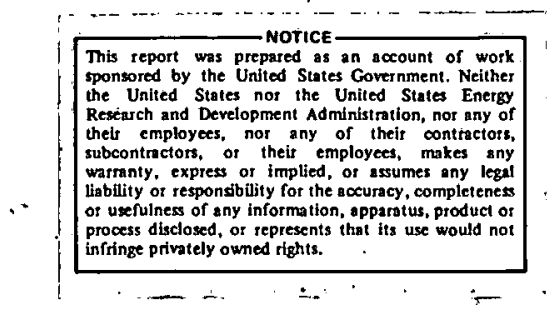

* Now at Los Alamós Scientific Laboratory 


\section{THIS PAGE \\ WAS INTENTIONALLY \\ LEFT BLANK}


TABLE OF CONTENTS

$\underline{\text { Page }}$

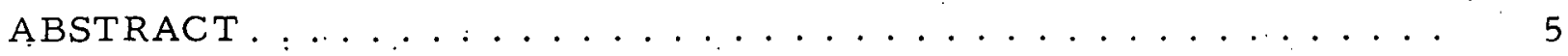

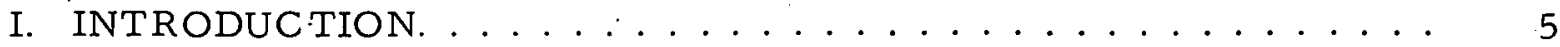

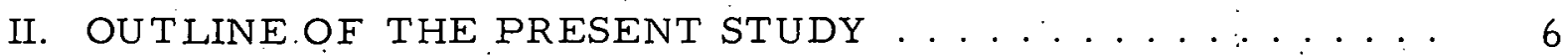

III. ENERGY DEPENDENCE OF THE NONELASTIC CROSS

SECTION ....................... 10

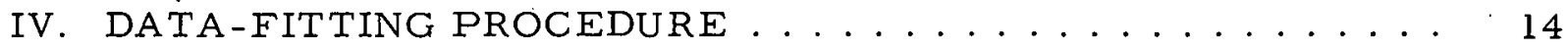

A. Derivation of the Adjusted Cross Section. . . . . . . . 14

B. Energy Range of Fitted $\sigma(n, 2 n)$ Data. . . . . . . . . 14

C. Fitting Procedure ........................ 15

V. RESULTS OF THE FITTING PROCEDURES . . . . . . . . 15

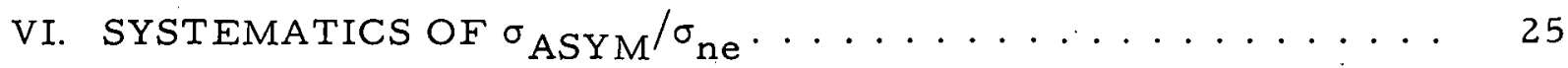

VII. SYSTEMATICS OF $\mathrm{T}$ AND $\propto$ DATA $\ldots \ldots \ldots \ldots \ldots \ldots \ldots$

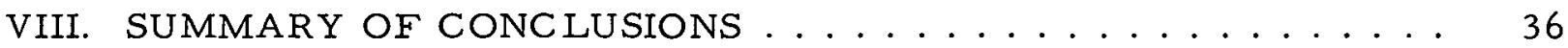

APPENDIXES

A. List of Data References . . . . . . . . . . . . . 37

B. $(n, 2 n)$ Cross-section Data, Fitted to Constant-temperature Model and to Level-density Model ............... 41

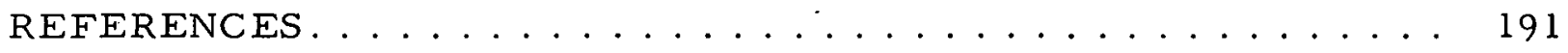




\section{LIST OF FIGURES}

No.

Title

Page

1. Typical Fit of Data to the Constant-temperature Nuclear Model. .

2. Correlation of the Level-density Parameter, $\dot{\alpha}$, from the Leastsquares Calculations with Target Mass Number ........... 8

3. Empirical Correlation of the Least-squares-fixed Parameter $\sigma_{\text {ASYM }}(\mathrm{n}, 2 \mathrm{n}) \ldots \ldots \ldots \ldots \ldots$

4. Nonelastic Cross Section as a Function of $\mathrm{A}$ and Energy ...... 11

5. Slope and Intercept for Higher Range of A . . . . . . . . . 12

6. Percentage Change in $\sigma_{\text {ne }}$ vs Incident Neutron Energy . . . . . . 13.

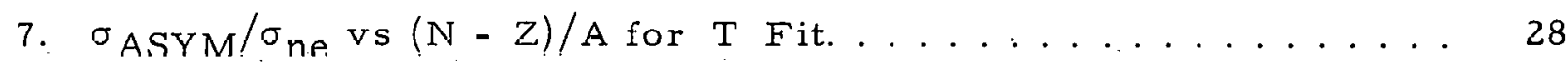

8. $\sigma_{\text {ASYM }} / \sigma_{n e}$ vs $(N-Z) / A$ for $\alpha$ Fit. . . . . . . ..... 28

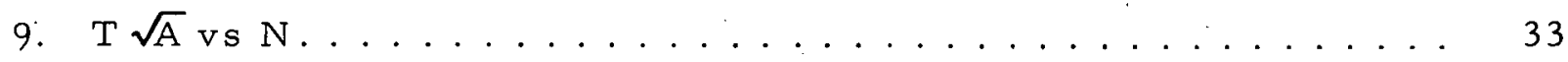

10. $\alpha / \mathrm{A}$ vs $\mathrm{N} \ldots \ldots \ldots \ldots 33$

11. Distribution of $\mathrm{T} \sqrt{\mathrm{A}}$ for Nuclei with $\mathrm{A} \gtrless 120 \ldots . . \ldots 34$

12. Distribution of $\alpha / A$ for Nuclei with $A \gtrless 120 \ldots \ldots 34$

\section{TIST OF TABLES}

No.

Tille

I. Summary of Data Fits. ...................... 16

II. $\sigma_{\text {ASYM }} / \sigma_{\text {ne }}$ vs $(\mathrm{N}-\mathrm{Z}) / \mathrm{A}$ for $\mathrm{T}$ and $\alpha$ Fits ............ 26

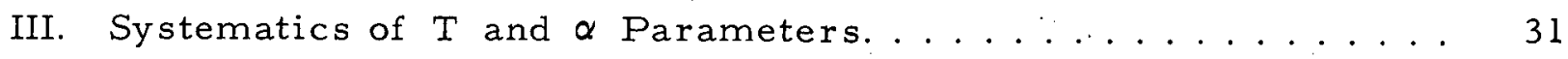

IV. Systematics of $\mathrm{T} \sqrt{\mathrm{A}}$ and $\alpha / \mathrm{A}$ for Magic-number Target Nuclei. . 35 


\title{
AN ANALYSIS OF (n, 2n) CROSS-SECTION MEASUREMENTS FOR NUCLEI UP TO MASS 238
}

by

\author{
W. G. Davey, R. W. Goin, \\ and J. R. Ross
}

\begin{abstract}
ABSTRAC'
All suitable measurements of the energy dependence of $(n, 2 n)$ cross sections of all isotopes up to mass 238 have been analyzed. The objectives were to display the quality of the measured data for each isotope and to examine the systematic de pendence of the $(n, 2 n)$ cross section upon $N, Z$, and $A$. Graphs and tables are presented of the ratio of the asymptotic $(n, 2 n)$ and nonelastic cross section to the neutron-asymmetry parameter $(N-Z) / A$. Similar data are presented for the derived $n u-$ clear temperature, $T$, and level-density parameter, $\alpha$, as a function of $\mathrm{N}, \mathrm{Z}$, and $\mathrm{A}$.
\end{abstract}

This analysis of the results of over 145 experiments on 61 isotopes is essentially a complete review of the current status of $(n, 2 n)$ cross-section measurements.

\section{INTRODUCTION}

In a D-T fusion reactor, one neutron is produced for each tritium nucleus destroyed and, in a self-sustaining system, it is essential that this neutron be used to breed additional tritium by reactions in ${ }^{6} \mathrm{Li}$ and ${ }^{7} \mathrm{Li}$. To achieve this end, a breeding blanket containing lithium in some form must be wrapped around the fusioning region (plasma or pellet), and this blanket must not only allow a tritium breeding ratio greater than unity, but must also permit efficient removal (as heat) of about three-fourths of the energy generated in the fusion reactor and contribute substantially towards shielding. The inability in practice of surrounding the fusioning region completely results in leakage losses, and neutron capture in structural and coolant components causes additional losses. Clearly, the initial single neutron per fusion must be multiplied to satisfy these and other sources of loss, and $(n, 2 n)$ reactions in the blanket generally provide the multiplication mechanism.

In a given projected fusion-reactor design, only a limited number of isotopes are included, but there are many existing projected designs and many more will undoubtedly evolve as fusion-reactor studies progress. Consequently, 
there is a clear need for reasonably accurate knowledge of ( $n, 2 n$ ) cross sections for a wide range of isotopes. Such high-energy cross sections as these tend to be incomplete both in the energy range covered and in the number of isotopes studied; furthermore, the many measurements obtained over the past two decades are, superficially at least, more characterized by their differences than by their agreements. Additionally, the fact that the resulting nucleus may often decay in more than one way can mean that some apparently good measurements are only measurements of part of the ( $n, 2 n)$ cross section. A wellknown example of this latter case in fusion-reactor studies is that of niobium, where the earlier data used were in error by a factor of more than two.

A possible solution is, of course, to attempt to establish the systematics of the behavior of $(n, 2 n)$ cross sections. In this way, incomplete or erroneous measurements may be identified, measurements made on different isotopes may be used to supplement each other, and, finally and hopefully, good predictions may be made of cross sections even where they have not been measured. This approach has been used many times but has not, in general, addressed itself to a wide range of data. In fact, as we discuss in the next section, some widely used calculations are based upon an important early study which necessarily examined a limited range of experimental data. Consequently, although the conclusions of these studies are not necessarily in error, the experimental verification is limited and the degree of elaboration used may not introduce significant improvement in the accuracy of prediction.

The intent in the present work is to extend the range of the experimental work studied to cover essentially all the experimental data available up to mass 238. We have also introduced some modifications and hopefully improvements over earlier work, but the prime objective has been completeness and not sophistication. In fact, we should state at the outset that our work indicates a considerable degree of confusion and even contradiction and does not provide sufficiently accurate predictions of $(n, 2 n)$ cross sections for all materials of fusion-reactor interest; one of our conclusions is that further experiments are needed. However, we believe that certain broad trends are confirmed, the existence of magic-number effects is examined, and, at minimum, a complete status report is provided with benefit to future studies.

\section{OUTLINE OF THE PRESENT STUDY}

This work consists of the study of the energy-dependent (shape) measurements of $(n, 2 n)$ cross sections.

The pioneer work in the elucidation of $(n, 2 n)$ systematics was performed in Los Alamos in 1961 by Barr, Browne, and Gilmore in their analysis of the measurements of Prestwood and Bayhurst ${ }^{2}$ and one measurement of Knight, Smith, and Warren. ${ }^{3}$ The data (for 15 isotopes) were chosen on the basis that they were recent, covered an extensive energy range, and were. 
performed in the same laboratory using consistent experimental methods. These conditions offered a good possibility of identifying systematic behavior.

Barr, Browne, and Gilmore fitted each set of data assuming the statis tical model was applicable and that the level density was described, first, by

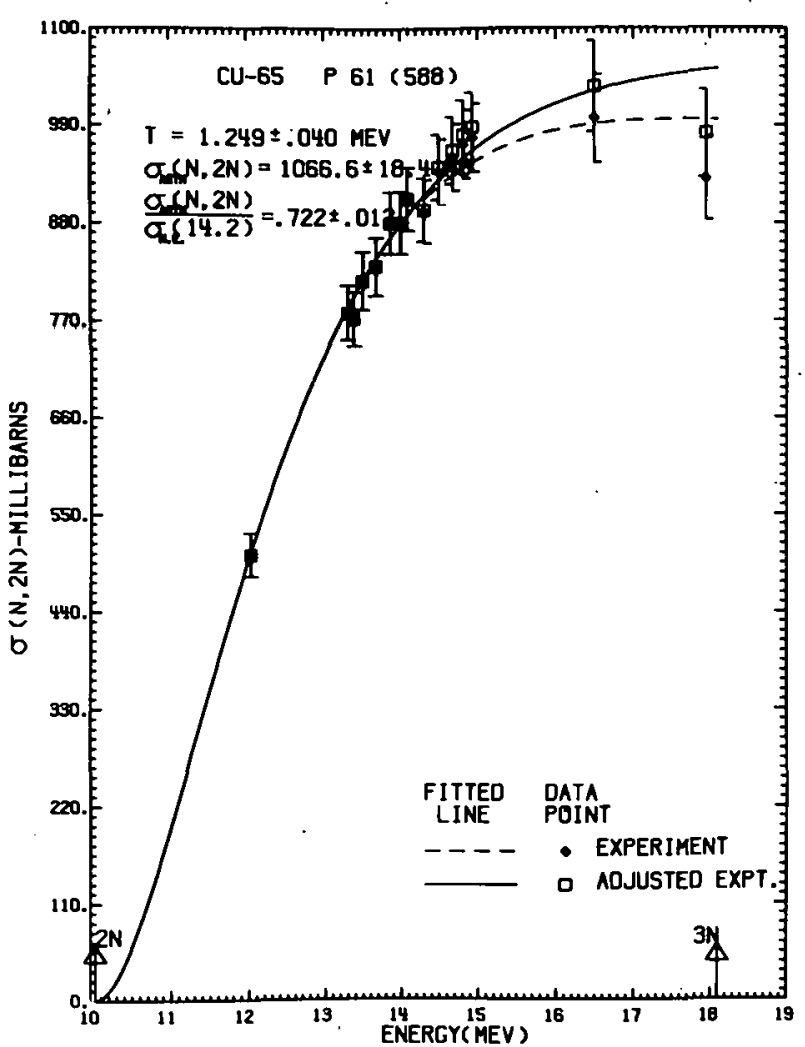

Fig. 1. Typical Fit of Data to the Constanttemperature Nuclear Model. ANL Neg. No. 103-B11676. the Fermi-gas model and second by an alternative formula including the pairing energy. In the fitting procedure, data points for energies above the $(n, 3 n)$ thresholds were not included and each $(n, 2 n)$ cross section was extrapolated to a constant, asymptotic value, $\sigma_{\text {ASYM }}$, which was equated to the cross section for any compound nucleus decay by neutron emission.* In this procedure, the value of the level-density parameter, $\alpha$, was determined by the shape of the cross section as a function of energy, but not by the absolute values of the cross sections. The asymptotic cross sec-a tion was, of course, dependent upon the magnitude of the measured values and also, to a varying degree, upon the choice of fitting formula and the fitted value of $\alpha$, depending, in part, upon how near the highest-energy measured points approached an asymptotic value (see Fig. 1).

Implicit in the fitting formula was the assumption that the compoundnucleus -formation cross section was constant over the energy range of the measurements. The formula also as sumed that the inelastic and the $(n, 2 n)$ reactions are competitive, and that reactions competing with the $(n, 2 n)$ cross section are either constant over the range of the measurement, or are negligible.

Using the Fermi-gas formula, Barr, Browne, and Gilmore found that the level-density parameter was reasonably well described by

$$
\alpha=\mathrm{A} / 13 \mathrm{MeV}^{-1} \text {, }
$$

where $A$ is the target mass number for nuclei between the lowest mass studied, 40 , and about 120 , but that a modified formula

*The asymptotic cross section for any neutron emission from the compound nucleus was denoted by $\sigma(n, M)$ in Ref. 1. 


$$
\alpha=10\left(1-1.49 e^{-0.017 \mathrm{~A}}\right) \mathrm{MeV}^{-1}
$$

had to be used to include the single additional point $\left({ }^{238} \mathrm{U}\right)$ above mass 120 (see Fig. 2).

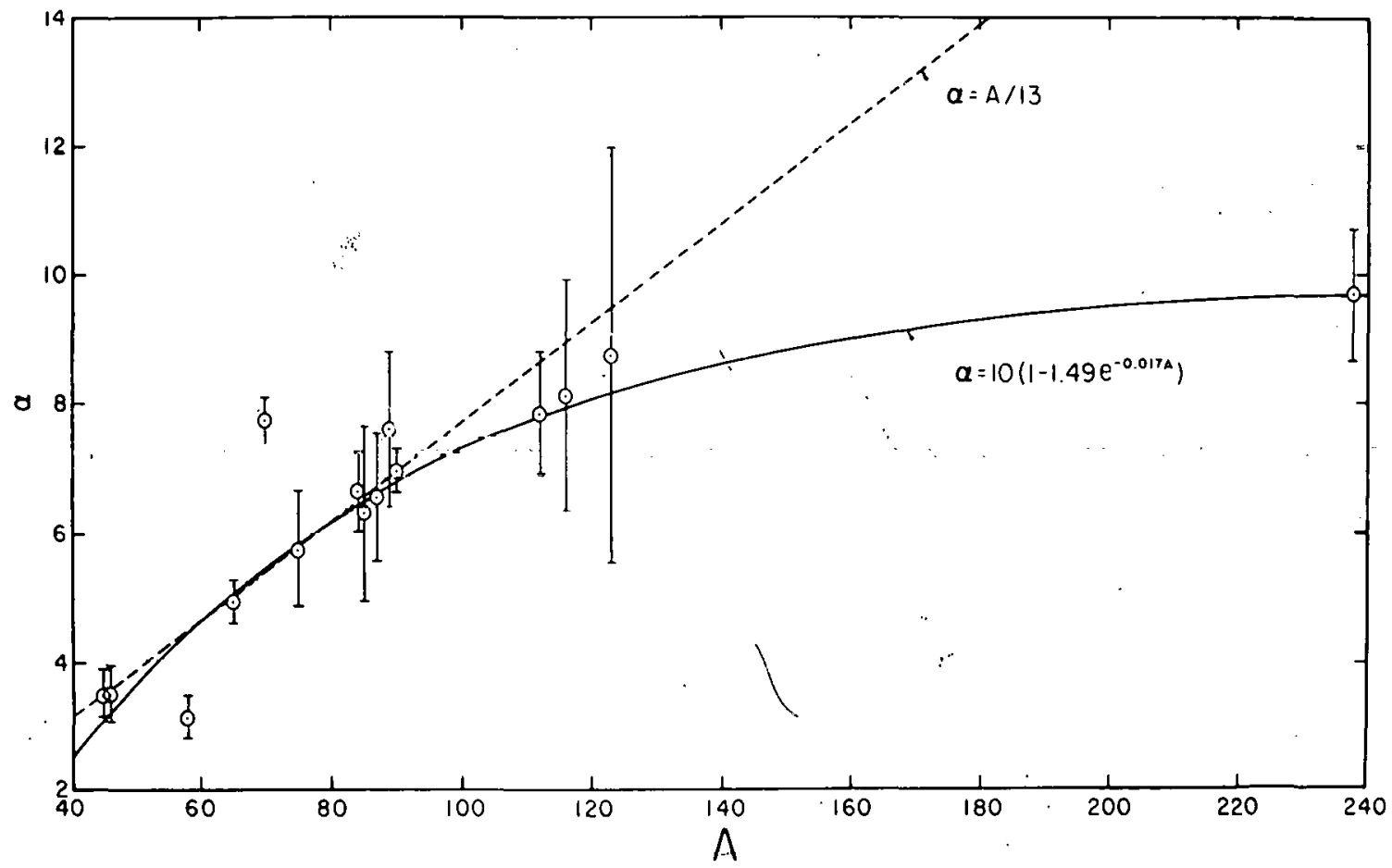

Fig. 2. Correlation of the Level-density Parameter, $\alpha$, from the Least-squares Calculations with Target Mass Number. ANL Neg. Nu, 103-B11667.

Perhaps even more importantly, they found that the ratio $\sigma_{\mathrm{ASYM}} / \sigma_{\mathrm{ne}}$, where $\sigma_{n e}$ is the nonelastic cross section (equated to the compound-nucleus formation cross section), was well described as a function of the neutron excess parameter ( $-Z$ )/A by the empirical relationship (see Fig. 3)

$$
\frac{\sigma_{\text {ASYM }}}{\sigma_{\text {ne }}}=1-1.754 \mathrm{e}^{-18.14(\mathrm{~N}-\mathrm{Z}) / \mathrm{A}} \text {. }
$$

Only one experimental point deviated significantly from the curve shown in Fig. 3, and this could plausibly be attributed to errors arising from the uncertainty in the decay scheme of the relevant isotope.

In deriving this formula, they assumed thal one was nut dependent on energy and was given by the formula of Flerov and Talyzin, ${ }^{4}$ namely

$$
\sigma_{\text {ne }}=\pi\left(0.12 \mathrm{~A}^{1 / 3}+0.21\right)^{2} \text { barns. }
$$

This formula was derived in 1957 and was based entirely upon measurements at and near $14 \mathrm{MeV}$. 


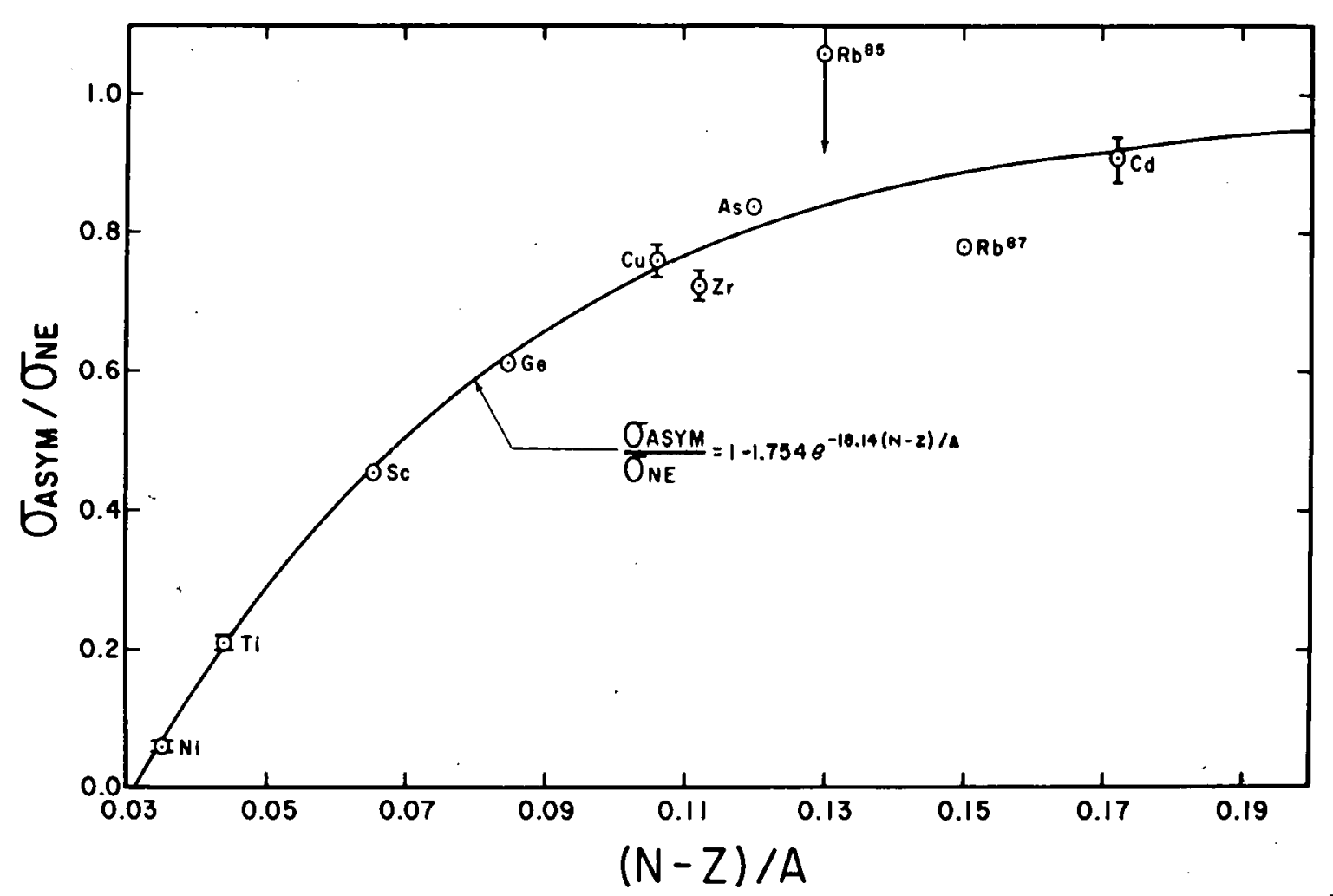

Fig. 3. Empirical Correlation of the Least-squares-fixed Parameter $\sigma_{A S Y M}(n, 2 n)$. ANL Neg. No. 103-B11578.

We have described the work of Barr, Browne, and Gilmore in some detail because it is the basis of our own and other studies of ( $n, 2 n)$ system atics. Here we must note that the empirical relationship for $\sigma_{A S Y M}$ defined by Eqs. 3 and 4 is strictly valid only for the particular formulas used by Barr, Browne, and Gilmore, and the level-density parameters given by Eq. 1 or 2 . Thus, for example, the widely used study by Pearlstein ${ }^{5}$ (recently extended to include other reactions ${ }^{6}$ ), which uses the relationships of Eqs. 3 and 4 but, for example, level-density formulas not derived from ( $n, 2 n)$ measurements, and which include shell effects (and differing in Refs. 5 and 6), includes this inconsistency.

Our own work is closely based upon the work of Barr, Browne, and Gilmore, but differs from it in the following respects:

1. We have used the many measurements of the nonelastic cross section to allow for the significant decrease that occurs at energies above about $14 \mathrm{MeV}$.

2. We have analyzed essentially all the measured (n, $2 n)$ energydependent data available up to mid-1973. The data obtained in each experiment were analyzed separately to avoid sources of error arising from mixing in consistent data and included about 150 sets of data for over six isotopes. 
3. We have fitted two formulas, based on a constant-temperature model and a level-density formulation. The level-density formula is somewhat simpler than that used by Barr, Browne, and Gilmore.

4. We have not included in the analysis any data points that lie close to the $(n, 2 n)$ threshold, since we believe that uncertainties in the neutron energies could give inordinate errors in the fitted parameters if these data points are not deleted. As with Barr, Browne, and Gilmore, all data points at and above the $(n, 3 n)$ threshold are deleted.

The sources of data included all traceable sources up to and including the 1973 Supplement to the CINDA Index. ${ }^{7}$ The microfilm data listing prepared by Livermore ${ }^{8}$ was very valuable in the data search, and references to that file are included in the sources given later.

\section{EPJERGY DEPERJDENJCE OF THE IJOPNELA3TIC CROSS SECTION}

As discussed in the previous section, analyses of $(n, 2 n)$ cross sections must make some postulate regarding the energy dependence of the compound nucleus formation cross section (or nonelastic cross section), and in all prior analyses, it has been assumed that this is not energy-dependent. This assumption is certainly incorrect, since measurements exist that show that this cross section decreases significantly in the 15 - to $20-\mathrm{MeV}$ range, the energy of the onset of the decrease being less for lower-mass nuclei. Since (n, $2 n$ ) reactions lie largely in this energy range, significant errors can be made by not including this effect for medium - and low-mass nuclei, al though the effect is small for high-mass nuclei.

The procedure we have adopted here is to collect and analyze all available measurements of the nonelastic cross section in the range of about $10-$ $100 \mathrm{MeV}$ and obtain empirical fits to these data as a function of neutron energy and target mass. The parameters entering into these fits were then plotted, and smoothed functions of these were used to correct for the energy and mass dependence. Details of the se latter are given in Sec. IV.

The experimental data available are very numerous and details are relegated to Appendix $A$, and only the results of the analyses and fits will be discussed at this point. However, we would note that the Flerov-Talyzin data often used to describe the nonelastic cross section (see Sec. II) represent only one set of experiments at one energy, whereas nearly 50 sets of data available from about 10 to $1400 \mathrm{MeV}$ have been used in the present work.

The measurements of the mass and energy dependence of $\sigma_{\text {ne }}$ are illus trated in Fig. 4. Here we show weighted means of some of the experimental data obtained for the energy ranges 7-9, 9-11,12-13,13.9-14, and 14.8-20 MeV, and at $21.0,25.5,29.2,55,81,105$, and $140 \mathrm{MeV}$, together with fitted curves. Here the plots are of $\sqrt{\sigma / \pi}$ versus $A^{1 / 3}$, since a linear relationship is anticipated 
for the simple case of a black, constant-density nucleus and many of the points are well-described by this relationship: Experimental errors have been omitted in the interest of clarity, but they are generally quite small and of the order of the deviations of the points from the fitted lines.

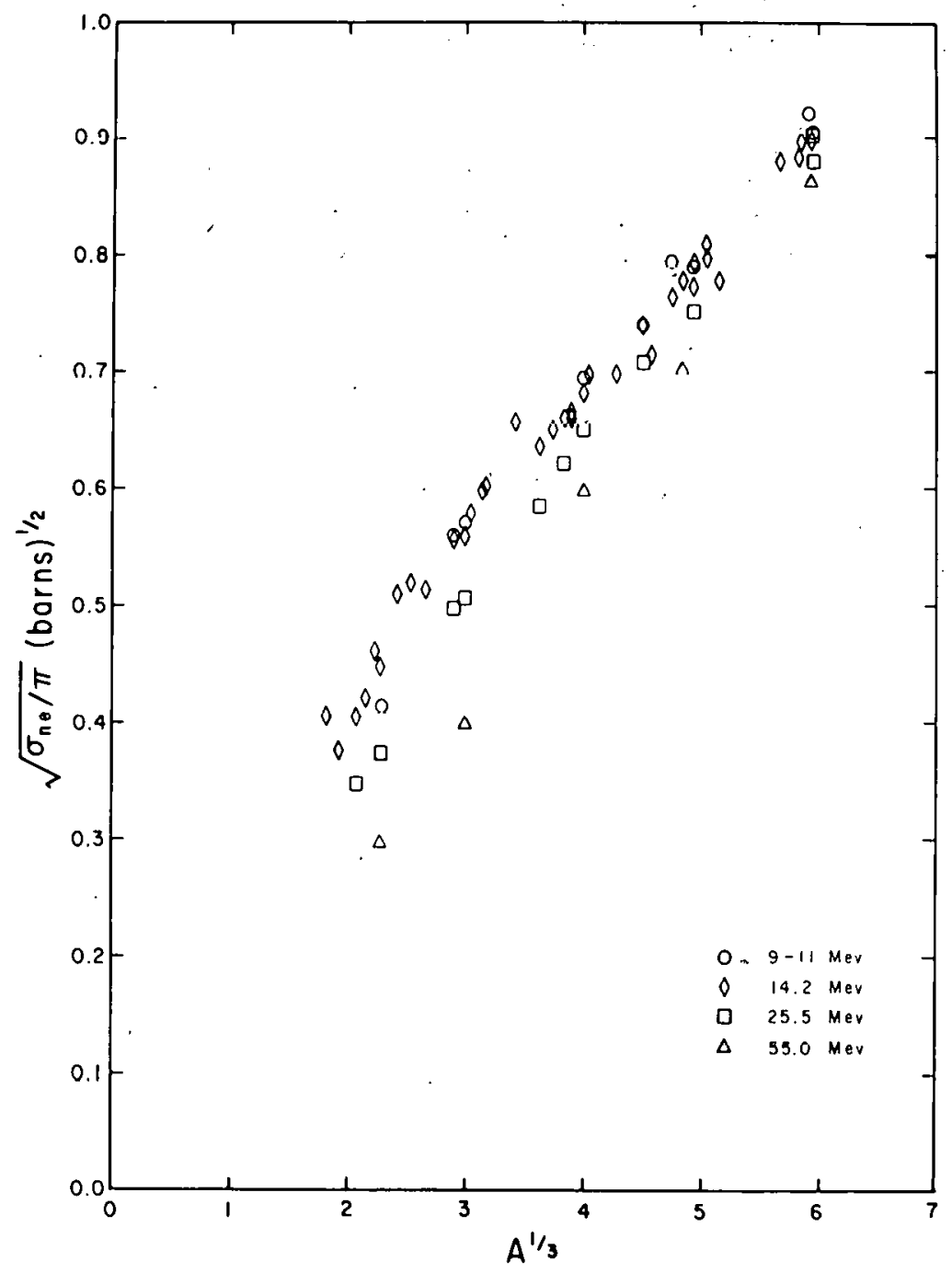

Fig. 4. Nonelastic Cross Section as a Function of $\mathrm{A}$ and Energy. ANL Neg. No. 103-B11669.

As can be seen, very many elements have been studied close to $14.2 \mathrm{MeV}$ and, indeed, most of the experimental points plotted here are the weighted mean values of several separate experiments. At other energies the information is. much more sparse, and at the higher energies the data points usually represent the result of only one experiment. Clearly, a linear relationship is always satisfactory and usually an excellent representation of the data for nuclei of mass greater than about 25-30, and it is only in the case of the 14-MeV data that there is sufficient detail to indicate that a better fit would be a higher order curve passing through the origin. In general, a linear fit to each set of data for masses greater than about 25 does not pass through the origin and the 
small number of lower mass points (often only one) indicate that the general shape for all energies is a downward-curving plot passing through the origin as shown by the $14-\mathrm{MeV}$ data. Furthermore, the experimental data below $14 \mathrm{MeV}$ show no significant evidence that they differ from the more precise and complete $14-\mathrm{MeV}$ values, and we conclude that the nonelastic cross section is constant for all nuclei up to at least this energy.

In view of the above observations, we have chosen to represent the nonelastic cross section at each neutron energy by two linear relationships be tween $\sqrt{\sigma / \pi}$ and $\mathrm{A}^{1 / 3}$. For nuclear masses up to $\mathrm{A}^{1 / 3}=3$, a "low-mass" line, which passes through the origin, was used. Above $A^{1 / 3}=3$, a "high-mass" linear fit to the experimental data was used. The slope and intercepts of the "high-mass" line are determined by plotting these parameters for the experimental energies and fitting smooth curves through these plots. These parameters are shown in Fig. 5. The slope of the low-mass line is determined by plotting the shapes of lines passing through the origin and the experimental $\sqrt{\sigma / \pi}$ data for carbon, the only material for which a reasonably large number of measurements are available.

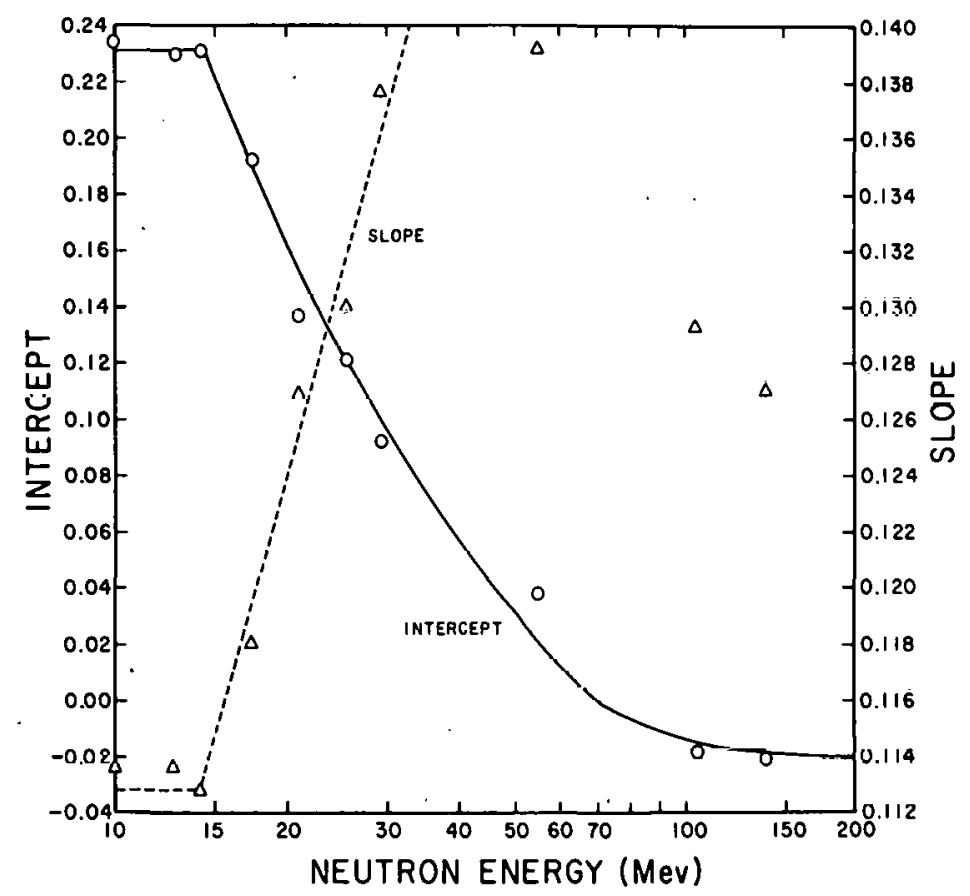

Fig. 5

Slope and Intercept for Higher Range of A. ANL Neg. No. 103-B11668.

For energies $514.2 \mathrm{MeV}, \sigma_{\text {ne }}$ was defined by the lines

$$
\sqrt{\sigma / \pi}=0.1960 \mathrm{~A}^{1 / 3}
$$

for $0 \leq A^{1 / 3} \leq 2.785$, and

$$
\sqrt{\sigma / \pi}=0.2317+0.1128 \mathrm{~A}^{1 / 3}
$$

for $A^{1 / 3} \geq 2.785$. 
For energies $>14.2 \mathrm{MeV}$, somewhat more complicated relationships were found to be necessary, since a smooth plot was best obtained using a logarithmic plot and the intersection of the two lines was energy-dependent.

For the lower-mass range, we have (from the carbon data)

$$
\sqrt{\sigma / \pi}=[0.1960-0.00167(\mathrm{E}-14.2)] \mathrm{A}^{1 / 3} \text {, }
$$

and for the higher range,

$$
\begin{aligned}
\sqrt{\sigma / \pi}= & 0.2317-0.2189(\ln \mathrm{E}-\ln 14.2)+0.04777(\ln E-\ln 14.2)^{2} \\
& +[0.1128 \pm 0.03263(\ln t-\ln 14.2)] \mathrm{A}^{1 / 3},
\end{aligned}
$$

and these intersect at

$$
\mathrm{A}^{1 / 3}=\frac{0.2317-0.2189(\ln E-\ln 14.2)+0.04777(\ln E-\ln 14.2)^{2}}{0.0832-0.00167(E-14.2)-0.0326(\ln E-\ln 14.2)} .
$$

The movement of the point of intersection with energy is not large and, for example, at $E=30 \mathrm{MeV}$.occurs at $A^{1 / 3}=2.92$, compared with the value of 2.785 at $14.2 \mathrm{MeV}$.

These relationships should only be used up to about $30 \mathrm{MeV}$, since they do not fit well at higher energies (see Fig. 5). An illustration of the correction for the energy dependence of $\sigma_{\text {ne }}$ for several nuclear masses that results from this representation is shown in Fig. 6. It can be seen that very significant corrections are involved for many nuclei. The correction is approximately linear over the most important energy range up to $20 \mathrm{MeV}$ and leads to some probable nonphysical behavior. Most importantly, the correction for low-mass nuclei (illustrated by carbon) is actually less than for some highermass nuclei (such as aluminum). This is hardly reasonable, but it is difficult to see how an improved description could be obtained using the existing experimental data.

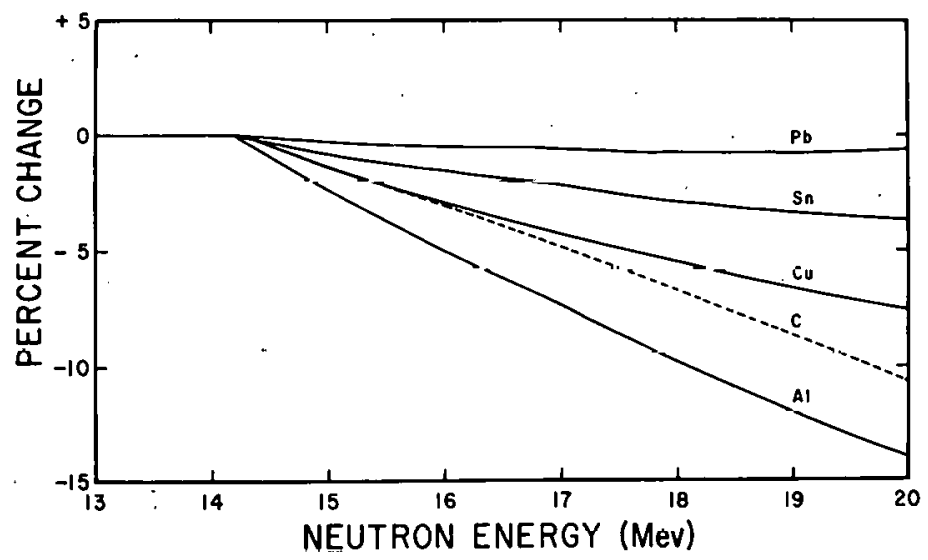

Fig. 6

Percentage Change in $\sigma_{\text {ne }}$ vs Incident Neutron Energy. ANL Neg. No. 103-B11666. 
In addition, the percentage correction per MeV decreases slightly with increasing energy (the lines of Fig. 6 a re concave), whereas it might be expected that the reverse behavior would be true (lines of Fig. 6 would be convex). This detail is hardly important in view of the error that must be associated with this correction, but it is an indication that an improved de scription would be of value. However, for all but the lightest nuclei, the correction increases with decreasing mass (for a given energy) as expected, and overall it is not unreasonable, considering the lack of precise and detailed measurements.

We conclude that the nonelastic correction we apply is likely to be adequate for masses above about 27, but is doubtful for lower masses when the correction is large. In practice, this only affects the results for carbon, since the corrections for other elements (fluorine, sodium) are fairly small.

The method of "correcting" for the decrease in $\sigma_{\text {ne }}$ at higher energies is to divide the measured $\sigma(n, 2 n)$ by the ratio $\sigma_{n e}(E) / \sigma_{n e}(14.2 \mathrm{MeV})$. This is described in Sec. IV. The fitted curves and tables discussed in Sec. V show the effect of the "correction" for $\sigma_{n e}$ in the form of the "adjusted" cross sections.

\section{DATA-FITTING PROCEDURE}

\section{A. Derivation of the Adjusted Cross Section}

The measured $(n, 2 n)$ cross sections above $14.2 \mathrm{MeV}$ do not include effects of the variation of the compound-nucleus-formation cross section. Therefore, the measured values were corrected to reflect the "true" total $(n, 2 n)$ cross sections. This correction was done by calculating $\sigma_{n e}(E) /$ $\sigma_{n e}(14.2 \mathrm{MeV})$ for each measured energy value (as discussed in Sec. III) and dividing the measured $(n ; 2 n)$ cross section by the ratio. Below $14.2 \mathrm{MeV}$, no correction was made.

The resulting "adjusted" $(\mathrm{n}, 2 \mathrm{n})$ cross sections are given in each table in Appendix B, together with the measured values. The corrections were small $(<20 \%$, except for the low mass isotopes. (See comments in Sec. III.)

B. Energy Range of Fitted $\sigma(n, 2 n)$ Data

All data above the $(n, 3 n)$ threshold were rejected because the $(n, 3 n)$ re action competes with and thus decreases $\sigma(n, 2 n)$, and this was not included in the correction formulas.

Data close to the $(n, 2 n)$ threshold, $E_{t}$, were also rejected due to the great effect of errors in the measured energy data upon the fitting parameters. For all cases, data were rejected below $E_{t}+T$, where $T$ (the nuclear temperature) is roughly estimated from the work of Barr, Browne, and Gilmore and was as sumed to be $\mathrm{T}=\mathrm{A} / 13$. 
Having an exact value of $T$ for this purpose is not important, since it affects very few data points, but, because of the high fractional errors, it is important to reject data close to the threshold.

This method follows the intent of the Barr, Browne, and Gilmore suggestion that the fit should be in the midportion of the energy range from the $(n, 2 n)$ threshold to the $(n, 3 n)$ threshold, although Barr, Browne, and Gilmore did not reject data near the $(n, 2 n)$ threshold. We speculate that the rejection of data between $E_{t}$ and $E_{t}+T$ is the primary reason that our fit of the Prestwood-Bayhurst data give a consistently better fit. (See, for example; ${ }^{58} \mathrm{Ni}$ in Apperidix B.)

\section{Fitting Procedure}

The "correcled" ( $n, 2 n)$ cross-section data were fitted to expressions that describe two nuclear models as suggested by Barr, Browne, and Gilmore. The first, the constant-temperature model, is

$$
\sigma(n, 2 n)=\sigma_{A S Y M}\left[1-\left(1+\frac{E_{n}-E_{t}}{T}\right) \exp \left(-\frac{E_{n}-E_{t}}{T}\right)\right],
$$

in which the asymptotic ( $n, 2 n$ ) cross section, $\sigma_{A S Y M}$, and the nuclear temperature, $T$, were obtained by least-squares fitting of the corrected data.

The second formula was the level-density model in which the leveldensity parameter, $\alpha$, was the fitting parameter rather than a constant temperature, $\mathrm{T}$ :

$$
\sigma(n, 2 n)=\sigma_{A S Y M}\left\{1-\left[1+\frac{E_{n}-E_{t}}{\left(E_{n} / \alpha\right)^{1 / 2}}\right] \exp \left[-\frac{E_{n}-E_{t}}{\left(E_{n} / \alpha\right)^{1 / 2}}\right]\right\} .
$$

The least-squares fitting was done using a generalized weighted leastsquares-fitting program on the SEL $840 \mathrm{MP}$ computer. ${ }^{*}$ The data were weighted using the inverse square of the experimental uncertainties as weights.

\section{RESULTS OF THE FITTING PROCEDURES}

The detailed experimental data, the same data corrected for the variation of the nonelastic cross section, and the fitted parameters for the constant temperature fit are given in the tables and graphs of Appendix B. The equivalent data for the level-density $\alpha$ fit are also given in Appendix B. The results of all of these fits are summarized in Table $I$. In both appendixes and in Table I, the reference quoted is the listing given in Appendix A, which refers exclusively to the origins of the experimental data. The reference system

*This computer program is based upon a least-squares-fitting code developed by J. Gardner Atkinson at The University of Texas at Austin, Texas, which in turn was based upon the work in Ref, 9. 
TABLE I. Summary of Data Fits

\begin{tabular}{|c|c|c|c|c|c|c|c|c|c|}
\hline \multirow{2}{*}{$\begin{array}{l}\mathrm{Z}^{\mathrm{N}} \mathrm{A} \\
\frac{\mathrm{N}-\mathrm{Z}}{\mathrm{A}} \\
\end{array}$} & \multirow[b]{2}{*}{ Ref. } & \multicolumn{4}{|c|}{ T Fit } & \multicolumn{4}{|c|}{ a Fit } \\
\hline & & $\begin{array}{r}\mathrm{T} \mathrm{MeV} \\
(\Delta \mathrm{T}) \\
\end{array}$ & Mean & $\begin{array}{c}\sigma_{\text {ASYM }} / \sigma_{\text {ne }} \\
\underline{(\Delta \sigma / \sigma)}\end{array}$ & Mean & $\begin{array}{l}a \mathrm{MeV}^{-1} \\
(\Delta a) \\
\end{array}$ & Mean & $\begin{array}{c}\sigma_{\mathrm{ASYM}} / \sigma_{\mathrm{ne}} \\
\underline{(\Delta \sigma / \sigma)}\end{array}$ & Mean \\
\hline \multirow{3}{*}{$\begin{array}{l}{ }_{6}^{6} C^{12} \\
(0.00000)\end{array}$} & A 73 & $\begin{array}{l}6.173 \\
0.750\end{array}$ & $\begin{array}{l}4.690 \\
0.406\end{array}$ & $\begin{array}{l}0.1008 \\
0.0159\end{array}$ & $\begin{array}{l}0.0479 \\
0.0038\end{array}$ & $\begin{array}{l}0.339 \\
0.137\end{array}$ & $\begin{array}{l}0.454 \\
0.127\end{array}$ & $\begin{array}{l}0.1685 \\
0.0508\end{array}$ & $\begin{array}{l}0.0529 \\
0.0067\end{array}$ \\
\hline & B 61 & $\begin{array}{l}4.409 \\
0.541\end{array}$ & & $\begin{array}{l}0.0479 \\
0.0043\end{array}$ & & $\begin{array}{l}1.091 \\
0.335\end{array}$ & & $\begin{array}{l}0.0559 \\
0.0076\end{array}$ & \\
\hline & B 52 & $\begin{array}{l}2.790 \\
1.064\end{array}$ & & $\begin{array}{l}0.0271 \\
0.0100\end{array}$ & & $\begin{array}{l}2.427 \\
2.143\end{array}$ & & $\begin{array}{l}0.0315 \\
0.0149\end{array}$ & \\
\hline \multirow{4}{*}{$\begin{array}{l}{ }_{7}^{7} \mathrm{~N}^{14} \\
(0.00000)\end{array}$} & B 65 & $\begin{array}{l}1.729 \\
0.075\end{array}$ & $\begin{array}{l}1.738 \\
0.070\end{array}$ & $\begin{array}{l}0.0181 \\
0.0006\end{array}$ & $\begin{array}{l}0.0182 \\
0.0006\end{array}$ & $\begin{array}{l}4.005 \\
0.463\end{array}$ & $\begin{array}{l}3.938 \\
0.416\end{array}$ & $\begin{array}{l}0.0198 \\
0.0010\end{array}$ & $\begin{array}{l}0.0199 \\
0.0009\end{array}$ \\
\hline & B 61 & $\begin{array}{l}1.865 \\
0.633\end{array}$ & & $\begin{array}{l}0.0171 \\
0.0028\end{array}$ & & $\begin{array}{l}3.914 \\
2.723\end{array}$ & & $\begin{array}{l}0.0181 \\
0.0036\end{array}$ & \\
\hline & $F 60$ & $\begin{array}{l}1.791 \\
0.204\end{array}$ & & $\begin{array}{l}0.0192 \\
0.0017\end{array}$ & & $\begin{array}{l}3.623 \\
1.01 \%\end{array}$ & & $\begin{array}{l}0.0215 \\
0.0027\end{array}$ & \\
\hline & P 60 & $\begin{array}{l}3.613^{a} \\
0.684 \\
\end{array}$ & & $\begin{array}{l}0.0498 \\
0.0137 \\
\end{array}$ & & $\begin{array}{l}0.473^{\mathrm{a}} \\
0.287 \\
\end{array}$ & & $\begin{array}{l}0.0965 \\
0.0477 \\
\end{array}$ & \\
\hline $\begin{array}{l}{ }_{8}^{8} 0^{16} \\
(0.00000) \\
\end{array}$ & B $6 I$ & $\begin{array}{l}9.194 \\
2.307\end{array}$ & . & $\begin{array}{l}0.0666 \\
0.0214\end{array}$ & & No Fit & & . & \\
\hline \multirow{7}{*}{$\begin{array}{l}{ }_{9}^{10} F^{l y} \\
(0.05263)\end{array}$} & V 68 & $\begin{array}{l}3.689^{\mathrm{a}} \\
0.323\end{array}$ & $\begin{array}{l}2.770 \\
0.084\end{array}$ & $\begin{array}{l}4.5961^{a} \\
0.5894\end{array}$ & $\begin{array}{l}0.1636 \\
0.0061\end{array}$ & $\begin{array}{l}0.414^{a} \\
0.117\end{array}$ & $\begin{array}{l}1.063 \\
0.104\end{array}$ & $\begin{array}{l}9.4620^{\mathrm{a}} \\
2.2135\end{array}$ & $\begin{array}{l}0.2191 \\
0.0147\end{array}$ \\
\hline & M 67 & $\begin{array}{l}2.662 \\
0.157\end{array}$ & . & $\begin{array}{l}0.1542 \\
0.0105\end{array}$ & & $\begin{array}{l}1.309 \\
0.242\end{array}$ & & $\begin{array}{l}0.201 \% \\
0.0242\end{array}$ & \\
\hline & B 65 & $\begin{array}{l}2.895 \\
0.127\end{array}$ & & $\begin{array}{l}0.1645 \\
0.0081\end{array}$ & & $\begin{array}{l}1.068 \\
0.157\end{array}$ & & $\begin{array}{l}0.2242 \\
0.0213\end{array}$ & . \\
\hline & P 65 & $\begin{array}{l}1.496^{\mathrm{a}} \\
0.161\end{array}$ & & $\begin{array}{l}0.1160^{\mathrm{a}} \\
0.0057\end{array}$ & & $\begin{array}{l}5.752^{a} \\
1.281\end{array}$ & & $\begin{array}{l}0.1206^{a} \\
0.0069\end{array}$ & \\
\hline & R 63 & $\begin{array}{l}3.371 \\
0.357\end{array}$ & & $\begin{array}{l}0.2338 \\
0.0342\end{array}$ & & $\begin{array}{l}0.610 \\
0.213\end{array}$ & & $\begin{array}{l}0.3960 \\
0.1072 .\end{array}$ & \\
\hline & B 61 & $\begin{array}{l}2.794 \\
0.269\end{array}$ & & $\begin{array}{l}0.2611^{\mathrm{a}} \\
0.0235\end{array}$ & & $\begin{array}{l}1.353 \\
0.343\end{array}$ & & $\begin{array}{l}0.3226^{a} \\
0.0448\end{array}$ & \\
\hline & $P 60$ & $\begin{array}{l}2.252 \\
0.248 \\
\end{array}$ & & $\begin{array}{l}0.1694 \\
0.0216 \\
\end{array}$ & & $\begin{array}{l}1.786 \\
0.484 \\
\end{array}$ & & $\begin{array}{l}0.2236 \\
0.0396 \\
\end{array}$ & \\
\hline \multirow{3}{*}{$\begin{array}{l}1 \frac{2}{1} \mathrm{Nad}^{23} \\
(0.04348)\end{array}$} & $M 67$ & $\begin{array}{l}1.621 \\
0.151\end{array}$ & $\begin{array}{l}1.854 \\
0.057\end{array}$ & $\begin{array}{l}0.1346 \\
0.0094\end{array}$ & $\begin{array}{l}0.1626^{c} \\
0.0661\end{array}$ & $\begin{array}{l}5.083 \\
1.077\end{array}$ & $\begin{array}{l}3.463 \\
0.252\end{array}$ & $\begin{array}{l}0.1461 \\
0.0129\end{array}$ & $\begin{array}{l}0.1828^{C} \\
0.0779\end{array}$ \\
\hline & L 65 & $\begin{array}{l}1.911 \\
0.062\end{array}$ & & $\begin{array}{l}0.2885 \\
0.0099\end{array}$ & $\cdot$ & $\begin{array}{l}3.363 \\
0.259\end{array}$ & & $\begin{array}{l}0.3323 \\
0.0146\end{array}$ & \\
\hline & PI 65 & $\begin{array}{l}1.027 \\
0.416 \\
\end{array}$ & & $\begin{array}{l}0.0646 \\
0.0175 \\
\end{array}$ & & $\begin{array}{r}11.553 \\
8.940 \\
\end{array}$ & & $\begin{array}{l}0.0701 \\
0.0203 \\
\end{array}$ & \\
\hline
\end{tabular}


TABLE I. (Contd.)

\begin{tabular}{|c|c|c|c|c|c|c|c|c|c|c|}
\hline \multirow{2}{*}{$\begin{array}{l}\begin{array}{l}\mathrm{N} \\
\mathrm{Z}\end{array} \\
\frac{\mathrm{N}-\mathrm{Z}}{\mathrm{A}} \\
\end{array}$} & \multirow{2}{*}{\multicolumn{2}{|c|}{ Ref. }} & \multicolumn{4}{|c|}{ T Fit } & \multicolumn{4}{|c|}{ a Fit } \\
\hline & & & $\begin{array}{r}\mathrm{T} \mathrm{MeV} \\
(\Delta \mathrm{T}) \\
\end{array}$ & Mean & $\begin{array}{c}\sigma_{\mathrm{ASYM}} / \sigma_{\mathrm{ne}} \\
(\Delta \sigma / \sigma)\end{array}$ & Mean & $\begin{array}{l}a \mathrm{MeV}^{-1} \\
(\Delta a) \\
\end{array}$ & Mean & $\begin{array}{c}\sigma_{\text {ASYM }} / \sigma_{\text {ne }} \\
(\Delta \sigma / \sigma)\end{array}$ & Mean \\
\hline $\begin{array}{l}16 \mathrm{P}^{31} \\
15 \\
(0.03226) \\
\end{array}$ & B & 63 & $\begin{array}{l}1.909 \\
0.133\end{array}$ & & $\begin{array}{l}0.0721 \\
0.0048\end{array}$ & & $\begin{array}{l}3.439 \\
0.506\end{array}$ & & $\begin{array}{l}0.0816 \\
0.0063\end{array}$ & : \\
\hline \multirow{2}{*}{$\begin{array}{l}20 \mathrm{~K}^{39} \\
(0.02564)\end{array}$} & $\mathrm{A}$ & 65 & $\begin{array}{l}3.338 \\
1.667\end{array}$ & $\begin{array}{l}2.263 \\
0.196\end{array}$ & $\begin{array}{l}0.0252 \\
0.0188\end{array}$ & $\begin{array}{l}0.0312 \\
0.0030\end{array}$ & $\begin{array}{l}0.761 \\
1.071\end{array}$ & $\begin{array}{l}2.061 \\
0.423\end{array}$ & $\begin{array}{l}0.0416 \\
0.0476\end{array}$ & $\begin{array}{l}0.0389 \\
0.0048\end{array}$ \\
\hline & B & 65 & $\begin{array}{l}2.248 \\
0.197 \\
\end{array}$ & & $\begin{array}{l}0.0314 \\
0.0030 \\
\end{array}$ & & $\begin{array}{l}2.301 \\
0.460 \\
\end{array}$ & . & $\begin{array}{l}0.0389 \\
0.0048 \\
\end{array}$ & \\
\hline \multirow{2}{*}{$\begin{array}{l}22^{24} S c^{45} \\
(0.06667)\end{array}$} & $\mathrm{A}$ & 64 & $\begin{array}{l}1.063 \\
0.059\end{array}$ & $\begin{array}{l}1.420^{c} \\
0.358\end{array}$ & $\begin{array}{l}0.3524 \\
0.0125\end{array}$ & $\begin{array}{l}0.4267^{c} \\
0.0743\end{array}$ & $\begin{array}{r}11.102 \\
1.434\end{array}$ & $\begin{array}{l}7.424^{c} \\
3.678\end{array}$ & $\begin{array}{l}0.3651 \\
0.0161\end{array}$ & $\begin{array}{l}0.4598^{c} \\
0.0947\end{array}$ \\
\hline & $\mathrm{P}$ & 61 & $\begin{array}{l}1.778 \\
0.084 \\
\end{array}$ & & $\begin{array}{l}0.5011 \\
0.0260 \\
\end{array}$ & . & $\begin{array}{l}3.746 \\
0.500 \\
\end{array}$ & & $\begin{array}{l}0.5546 \\
0.0428 \\
\end{array}$ & \\
\hline \multirow{3}{*}{$\begin{array}{l}{ }_{24}^{24} \mathrm{Ti}^{46} \\
(0.04348)\end{array}$} & $\mathrm{P}$ & 66 & $\begin{array}{l}2.548 \\
0.112\end{array}$ & $\begin{array}{l}2.050^{c} \\
0.314^{c}\end{array}$ & $\begin{array}{l}0.3189 \\
0.0158\end{array}$ & $\begin{array}{l}0.2626^{c} \\
0.0319\end{array}$ & $\begin{array}{l}1.817 \\
0.300\end{array}$ & $\begin{array}{l}3.593^{\mathrm{C}} \\
1.378\end{array}$ & $\begin{array}{l}0.3990 \\
0.0415\end{array}$ & $\begin{array}{l}0.3121^{\mathrm{c}} \\
0.0501\end{array}$ \\
\hline & B & 6.5 & $\begin{array}{l}1.468 \\
0.056\end{array}$ & & $\begin{array}{l}0.2084 \\
0.0067\end{array}$ & & $\begin{array}{l}6.306 \\
0.679\end{array}$ & & $\begin{array}{l}0.2253 \\
0.0111\end{array}$ & \\
\hline & $\mathrm{P}$ & 61. & $\begin{array}{l}2.133 \\
0.292 \\
\end{array}$ & & $\begin{array}{l}0.2606 \\
0.0375 \\
\end{array}$ & & $\begin{array}{l}2.655 \\
0.971 \\
\end{array}$ & & $\begin{array}{l}0.3120 \\
0.0665 \\
\end{array}$ & \\
\hline $\begin{array}{l}26 \mathrm{Cr}^{50} \\
(0.04000) \\
\end{array}$ & $\mathrm{B}$ & 66 & $\begin{array}{l}1.778 \\
0.111\end{array}$ & & $\begin{array}{l}0.0850 \\
0.0045\end{array}$ & & $\begin{array}{l}4.129 \\
0.493\end{array}$ & & $\begin{array}{l}0.0949 \\
0.0053\end{array}$ & \\
\hline $\begin{array}{l}28 \mathrm{Cr}^{52} \\
(0.07692) \\
\end{array}$ & B & 67 & $\begin{array}{l}1.131 \\
0.075\end{array}$ & & $\begin{array}{l}0.4194 \\
0.0186\end{array}$ & & $\begin{array}{r}10.374 \\
1.688\end{array}$ & & $\begin{array}{l}0.4330 \\
0.0248\end{array}$ & \\
\hline \multirow{3}{*}{$\begin{array}{l}{ }^{30} \mathrm{Mn}^{55} \\
25^{5} \\
(0.09091)\end{array}$} & B & 69 & $\begin{array}{l}1.197 \\
0.087\end{array}$ & $\begin{array}{l}1.219 \\
0.024\end{array}$ & $\begin{array}{l}0.6722 \\
0.0188\end{array}$ & $\begin{array}{l}0.6855 \\
0.0124\end{array}$ & $\begin{array}{l}8.729 \\
1.440\end{array}$ & $\begin{array}{l}7.341 \\
0.273\end{array}$ & $\begin{array}{l}0.6914 \\
0.0247\end{array}$ & $\begin{array}{l}0.7043 \\
0.0158\end{array}$ \\
\hline & $M$ & 67 & $\begin{array}{l}1.224 \\
0.053\end{array}$ & & $\begin{array}{l}0.6958 \\
0.0165\end{array}$ & & $\begin{array}{l}8.283 \\
0.823\end{array}$ & & $\begin{array}{l}0.7133 \\
0.0206\end{array}$ & \\
\hline & $P$ & 65 & $\begin{array}{l}1.303 \\
0.028 \\
\end{array}$ & & $\begin{array}{l}0.8592^{\mathrm{a}} \\
0.0099 \\
\end{array}$ & . & $\begin{array}{l}7.162 \\
0.295 \\
\end{array}$ & & $\begin{array}{l}0.8918^{\mathrm{a}} \\
0.0106 \\
\end{array}$ & \\
\hline \multirow{2}{*}{$\begin{array}{l}{ }_{26}^{28} \mathrm{Fe}^{54} \\
(0.03704)\end{array}$} & $\mathrm{B}$ & 72 & $\begin{array}{l}1.268 \\
0.089\end{array}$ & $\begin{array}{l}1.284 \\
0.088\end{array}$ & $\begin{array}{l}0.0536 \\
0.0034\end{array}$ & $\begin{array}{l}0.0538 \\
0.0034\end{array}$ & $\begin{array}{l}8.539 \\
1.342\end{array}$ & $\begin{array}{l}4.773 \\
0.912\end{array}$ & $\begin{array}{l}0.0576 \\
0.0043\end{array}$ & $\begin{array}{l}0.0577 \\
0.0043\end{array}$ \\
\hline & A & 68 & $\begin{array}{l}2.588 \\
0.801 \\
\end{array}$ & & $\begin{array}{l}0.2174 \\
0.0903 \\
\end{array}$ & & $\begin{array}{l}1.548 \\
1.242 \\
\end{array}$ & & $\begin{array}{l}0.3004 \\
0.1766 \\
\end{array}$ & \\
\hline
\end{tabular}


TABLE I. (Contd.)

\begin{tabular}{|c|c|c|c|c|c|c|c|c|c|}
\hline \multirow{2}{*}{$\begin{array}{l}\mathrm{N} X \mathrm{~A} \\
\frac{\mathrm{N}-\mathrm{Z}}{\mathrm{A}} \\
\end{array}$} & \multirow[b]{2}{*}{ Ref. } & \multicolumn{4}{|c|}{ T Fit } & \multicolumn{4}{|c|}{$a$ Fit } \\
\hline & & $\begin{array}{r}\mathrm{T} \mathrm{MeV} \\
(\Delta \mathrm{T}) \\
\end{array}$ & Mean & $\begin{array}{l}\sigma_{\mathrm{ASYM}} / \sigma_{\mathrm{ne}} \\
\underline{(\Delta \sigma / \sigma)}\end{array}$ & Mean & $\begin{array}{c}a \mathrm{MeV}^{-1} \\
(\Delta a) \\
\end{array}$ & Mean & $\begin{array}{c}\sigma_{\mathrm{ASYM}} / \sigma_{\mathrm{ne}} \\
(\Delta \sigma / \sigma)\end{array}$ & Mean \\
\hline \multirow{5}{*}{ 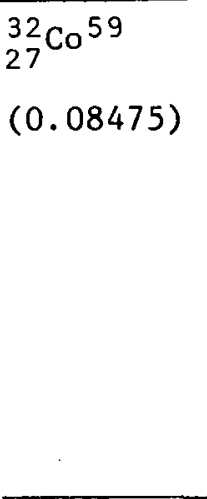 } & $\bar{D} 68$ & $\begin{array}{l}1.175 \\
0.037\end{array}$ & $\begin{array}{l}1.190 \\
0.014\end{array}$ & $\begin{array}{l}0.5411 \\
0.0083\end{array}$ & $\begin{array}{l}0.5599^{c} \\
0.0126\end{array}$ & $\begin{array}{l}8.697 \\
0.617\end{array}$ & $\begin{array}{l}8.622 \\
0.156\end{array}$ & $\begin{array}{l}0.5594 \\
0.0106\end{array}$ & $\begin{array}{l}0.5764^{c} \\
0.0142\end{array}$ \\
\hline & 067 & $\begin{array}{l}1.183 \\
0.122\end{array}$ & & $\begin{array}{l}0.8748^{d} \\
0.0487\end{array}$ & & $\begin{array}{l}8.385 \\
1.978\end{array}$ & & $\begin{array}{l}0.9254^{d} \\
0.0682\end{array}$ & \\
\hline & B 66 & $\begin{array}{l}1.124 \\
0.110\end{array}$ & & $\begin{array}{l}0.5703 \\
0.0282\end{array}$ & & $\begin{array}{l}9.609 \\
1.738\end{array}$ & & $\begin{array}{l}0.5883 \\
0.0291\end{array}$ & . \\
\hline & P 66 & $\begin{array}{l}0.896^{a} \\
0.087\end{array}$ & & $\begin{array}{l}0.5375 \\
0.0193\end{array}$ & & $\begin{array}{c}15.641^{a} \\
3.354\end{array}$ & & $\begin{array}{l}0.5475 \\
0.0238\end{array}$ & \\
\hline & P 65 & $\begin{array}{l}1.194 \\
0.015 \\
\end{array}$ & & $\begin{array}{l}0.5908 \\
0.0039 \\
\end{array}$ & & $\begin{array}{l}8.610 \\
0.163 \\
\end{array}$ & & $\begin{array}{r}0.6104 \\
0.0034 \\
\end{array}$ & . \\
\hline \multirow{4}{*}{$\begin{array}{l}3 \dot{ }^{30} \mathrm{Ni}^{58} \\
(0.03448)\end{array}$} & C 65 & $\begin{array}{l}2.158 \\
1.181\end{array}$ & $\begin{array}{l}1.407 \\
0.033\end{array}$ & $\begin{array}{l}0.1010^{\mathrm{l}} \\
0.0711\end{array}$ & $\begin{array}{l}0.0473^{\circ} \\
0.0071\end{array}$ & $\begin{array}{l}2.083 \\
2.893\end{array}$ & $\begin{array}{l}0.191 \\
0.294\end{array}$ & $\begin{array}{l}0.1354^{d} \\
0.1327\end{array}$ & $\begin{array}{l}0.0510^{c} \\
0.0074\end{array}$ \\
\hline & P 65 & $\begin{array}{l}1.367 \\
0.037\end{array}$ & & $\begin{array}{l}0.0472 \\
0.0009\end{array}$ & & $\begin{array}{l}6.990 \\
0.370\end{array}$ & & $\begin{array}{l}0.0502 \\
0.0010\end{array}$ & \\
\hline & $\mathrm{J} 63$ & $\begin{array}{l}2.136 \\
0.341\end{array}$ & & $\begin{array}{l}0.0350 \\
0.0036\end{array}$ & & $\begin{array}{l}2.940 \\
1.051\end{array}$ & & $\begin{array}{l}0.0386 \\
0.0052\end{array}$ & \\
\hline & P 61 & $\begin{array}{l}1.524 \\
0.072 \\
\end{array}$ & & $\begin{array}{l}0.0596 \\
0.0030 \\
\end{array}$ & & $\begin{array}{l}5.460 \\
0.552 \\
\end{array}$ & & $\begin{array}{l}0.0643 \\
0.0036 \\
\end{array}$ & \\
\hline \multirow{10}{*}{$\begin{array}{l}{ }_{2 y}^{34} \mathrm{Cu}^{63} \\
(0.07937)\end{array}$} & В 69 & $\begin{array}{l}1.565 \\
0.080\end{array}$ & $\begin{array}{l}1.767 \\
0.017\end{array}$ & $\begin{array}{l}0.6524 \\
0.0201\end{array}$ & $\begin{array}{l}0.7129 \\
0.0053\end{array}$ & $\begin{array}{l}4.847 \\
0.466\end{array}$ & $\begin{array}{l}3.544 \\
0.090\end{array}$ & $\begin{array}{l}0.7057 \\
0.0238\end{array}$ & $\begin{array}{l}0.7823 \\
0.0066\end{array}$ \\
\hline & L 65 & $\begin{array}{l}1.790 \\
0.020\end{array}$ & & $\begin{array}{l}0.7233 \\
0.0066\end{array}$ & & $\begin{array}{l}3.538 \\
0.111\end{array}$ & & $\begin{array}{l}11.811 .1 / \\
0.0115\end{array}$ & \\
\hline & R 63 & $\begin{array}{l}1.703 \\
0.038\end{array}$ & & $\begin{array}{l}0.5127^{\mathrm{a}} \\
0.0085\end{array}$ & & $\begin{array}{l}4.032 \\
0.238\end{array}$ & & $\begin{array}{l}0.5560^{\mathrm{a}} \\
0.0136\end{array}$ & \\
\hline & G 62 & $\begin{array}{l}1.741 \\
0.127\end{array}$ & & $\begin{array}{l}0.5934 \\
0.0414\end{array}$ & & $\begin{array}{l}3.432 \\
0.581\end{array}$ & & $\begin{array}{l}0.6980 \\
0.0638\end{array}$ & \\
\hline & K 62 & $\begin{array}{l}1.814 \\
0.106\end{array}$ & & $\begin{array}{l}0.6385 \\
0.0315\end{array}$ & & $\begin{array}{l}3.249 \\
0.619\end{array}$ & & $\begin{array}{l}0.7279 \\
0.0663\end{array}$ & \\
\hline & F 60 & $\begin{array}{l}2.036 \\
0.121\end{array}$ & & $\begin{array}{l}0.6821 \\
0.0394\end{array}$ & & $\begin{array}{l}2.526 \\
0.271\end{array}$ & & $\begin{array}{l}0.8064 \\
0.0473\end{array}$ & . \\
\hline & P 60 & $\begin{array}{l}1.687 \\
0.315\end{array}$ & & $\begin{array}{l}0.8683 \\
0.1553\end{array}$ & & $\begin{array}{l}3.676 \\
1.624\end{array}$ & & $\begin{array}{l}1.0125 \\
0.2407\end{array}$ & \\
\hline & A 59 & $\begin{array}{l}1.530^{\mathrm{a}} \\
0.066\end{array}$ & & $\begin{array}{l}0.7236 \\
0.0213\end{array}$ & & $\begin{array}{l}4.970^{\mathrm{a}} \\
0.151\end{array}$ & & $\begin{array}{l}0.7827 \\
0.0091\end{array}$ & \\
\hline & C 56 & $\begin{array}{l}0.951^{\mathrm{a}} \\
0.109\end{array}$ & & $\begin{array}{l}0.4041^{a} \\
0.0204\end{array}$ & & $\begin{array}{c}13.792^{a} \\
3.272\end{array}$ & . & $\begin{array}{l}0.4150^{\mathrm{a}} \\
0.0238\end{array}$ & \\
\hline & B 52 & $\begin{array}{l}1.643 \\
0.240 \\
\end{array}$ & & $\begin{array}{l}0.7003 \\
0.0539\end{array}$ & & $\begin{array}{l}4.802 \\
1.303\end{array}$ & & $\begin{array}{l}0.7384 \\
0.0601\end{array}$ & \\
\hline
\end{tabular}


TABLE I. (Contd.)

\begin{tabular}{|c|c|c|c|c|c|c|c|c|c|}
\hline \multirow{2}{*}{$\begin{array}{l}\mathrm{N} \times \mathrm{A} \\
\mathrm{Z} \\
\frac{\mathrm{N}-\mathrm{Z}}{\mathrm{A}} \\
\end{array}$} & \multirow[b]{2}{*}{ Ref. } & \multicolumn{4}{|c|}{$\mathrm{T}$ Fit } & \multicolumn{4}{|c|}{$a$ Fit } \\
\hline & & $\begin{array}{r}\mathrm{T} \mathrm{MeV} \\
(\Delta \mathrm{T}) \\
\end{array}$ & Mean & $\begin{array}{c}\sigma_{\mathrm{ASYM}} / \sigma_{\mathrm{ne}} \\
(\Delta \sigma / \sigma) \\
\end{array}$ & Mean & $\begin{array}{c}a \mathrm{MeV}^{-1} \\
(\Delta a) \\
\end{array}$ & Mean & 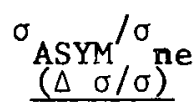 & Mean \\
\hline \multirow{8}{*}{$\begin{array}{l}{ }^{36} \mathrm{Cu}^{65} \\
(0.10769)\end{array}$} & В 69 & $\begin{array}{l}1.161^{a} \\
0.044\end{array}$ & $\begin{array}{l}1.305 \\
0.015\end{array}$ & $\begin{array}{l}0.7161 \\
0.0099\end{array}$ & $\begin{array}{l}0.7072^{c} \\
0.0181\end{array}$ & $\begin{array}{l}9.186^{\mathrm{a}} \\
0.661\end{array}$ & $\begin{array}{l}6.847 \\
0.212\end{array}$ & $\begin{array}{l}0.7322 \\
0.0107\end{array}$ & $\begin{array}{l}0.7247^{\circ} \\
0.0230\end{array}$ \\
\hline & C 69 & $\begin{array}{l}0.914^{a} \\
0.018\end{array}$ & & $\begin{array}{l}0.6708 \\
0.0017\end{array}$ & & $\begin{array}{c}16.397^{\mathrm{a}} \\
0.381\end{array}$ & & $\begin{array}{l}0.6745 \\
0.0011\end{array}$ & \\
\hline & S 66 & $\begin{array}{l}1.436^{a} \\
0.036\end{array}$ & & $\begin{array}{l}0.8115^{d} \\
0.0156\end{array}$ & & $\begin{array}{l}4.984^{a} \\
0.373\end{array}$ & & $\begin{array}{l}0.8955^{d} \\
0.0289\end{array}$ & \\
\hline & P 65 & $\begin{array}{l}1.330 \\
0.017\end{array}$ & & $\begin{array}{l}0.7755 \\
0.0052\end{array}$ & & $\begin{array}{l}6.717 \\
0.230\end{array}$ & & $\begin{array}{l}0.8082 \\
0.0081\end{array}$ & \\
\hline & B 63 & $\begin{array}{l}0.941 \\
0.145\end{array}$ & & $\begin{array}{l}0.6482 \\
0.0191\end{array}$ & . & $\begin{array}{r}15.309 \\
5.344\end{array}$ & & $\begin{array}{l}0.6514 \\
0.0229\end{array}$ & \\
\hline & R 63 & $\begin{array}{l}1.127 \\
0.068\end{array}$ & & $\begin{array}{l}0.7111 \\
0.0203\end{array}$ & & $\begin{array}{l}9.628 \\
1.376\end{array}$ & & $\begin{array}{l}0.7268 \\
0.0261\end{array}$ & \\
\hline & P 61 & $\begin{array}{l}1.249 \\
0.040\end{array}$ & & $\begin{array}{l}0.7218 \\
0.0124\end{array}$ & & $\begin{array}{l}7.500 \\
0.635\end{array}$ & & $\begin{array}{l}0.7550 \\
0.0193\end{array}$ & \\
\hline & P 60 & $\begin{array}{l}1.591 \\
0.265 \\
\end{array}$ & . & $\begin{array}{l}1.3699^{d} \\
0.1568\end{array}$ & & $\begin{array}{l}4.287 \\
1.653 \\
\end{array}$ & . & $\begin{array}{l}1.5111^{\mathrm{d}} \\
0.2336 \\
\end{array}$ & : \\
\hline \multirow{7}{*}{$\begin{array}{l}{ }_{34} \mathrm{Zn}^{64} \\
(0.06250)\end{array}$} & B 69 & $\begin{array}{l}2.476 \\
0.069\end{array}$ & $\begin{array}{l}2.307 \\
0.032\end{array}$ & $\begin{array}{l}0.4704 \\
0.0153\end{array}$ & $\begin{array}{l}0.4004 \\
0.0308\end{array}$ & $\begin{array}{l}1.633 \\
0.135\end{array}$ & $\begin{array}{l}1.888 \\
0.081\end{array}$ & $\begin{array}{l}0.6142 \\
0.0335\end{array}$ & $\begin{array}{l}0.4999 \\
0.0398\end{array}$ \\
\hline & P 65 & $\begin{array}{l}2.328 \\
0.042\end{array}$ & & $\begin{array}{l}0.4204 \\
0.0082\end{array}$ & & $\begin{array}{l}1.953 \\
0.112\end{array}$ & & $\begin{array}{l}0.5214 \\
0.0180\end{array}$ & \\
\hline & В 63 & $\begin{array}{l}1.750^{a} \\
0.149\end{array}$ & & $\begin{array}{l}0.2305^{d} \\
0.0141\end{array}$ & & $\begin{array}{l}4.205^{a} \\
0.934\end{array}$ & & $\begin{array}{l}0.2493^{d} \\
0.0221\end{array}$ & \\
\hline & R $63^{\circ}$ & $\begin{array}{l}2.045 \\
0.082\end{array}$ & & $\begin{array}{l}0.3257 \\
0.0119\end{array}$ & & $\begin{array}{l}2.686 \\
0.322\end{array}$ & & $\begin{array}{l}0.3816 \\
0.0238\end{array}$ & \\
\hline & K 60 & $\begin{array}{l}1.616^{a} \\
0.058\end{array}$ & & $\begin{array}{l}0.2710^{d} \\
0.0093\end{array}$ & . & $\begin{array}{l}4.469^{\mathrm{a}} \\
0.386\end{array}$ & & $\begin{array}{l}0.3047^{\mathrm{d}} \\
0.0139\end{array}$ & \\
\hline & A 59 & $\begin{array}{l}2.281 \\
0.182\end{array}$ & & $\begin{array}{l}0.3298 \\
0.0329\end{array}$ & & $\begin{array}{l}1.790 \\
0.434\end{array}$ & & $\begin{array}{l}0.4467 \\
0.0752\end{array}$ & \\
\hline & C 56 & $\begin{array}{l}1.913 \\
0.228 \\
\end{array}$ & & $\begin{array}{l}0.4556 \\
0.0406 \\
\end{array}$ & & $\begin{array}{l}3.085 \\
0.872 \\
\end{array}$ & & $\begin{array}{l}0.5357 \\
0.0690 \\
\end{array}$ & \\
\hline $\begin{array}{l}36 \mathrm{Zn}^{36} \\
30 \\
(0.09091)\end{array}$ & B 69 & $\begin{array}{l}1.427 \\
0.052\end{array}$ & & $\begin{array}{l}0.8333 \\
0.0153\end{array}$ & & $\begin{array}{l}6.326 \\
0.434\end{array}$ & & $\begin{array}{l}0.8758 \\
0.0173\end{array}$ & \\
\hline $\begin{array}{l}{ }^{38} \mathrm{Ga}^{69} \\
\mathrm{l}^{1} \\
(0.10145) \\
\end{array}$ & B 65 & $\begin{array}{l}1.401 \\
0.080\end{array}$ & & $\begin{array}{l}0.8458 \\
0.0267\end{array}$ & & $\begin{array}{l}6.192 \\
0.731\end{array}$ & & $\begin{array}{l}0.8856 \\
0.0321\end{array}$ & \\
\hline $\begin{array}{l}{ }^{40} \mathrm{Ga}^{71} \\
31 \\
(0.12676)\end{array}$ & D 71 & $\begin{array}{l}0.837 \\
0.085\end{array}$ & & $\begin{array}{l}0.7603 \\
0.0096\end{array}$ & & $\begin{array}{r}18.383 \\
4.070\end{array}$ & & $\begin{array}{l}0.7642 \\
0.0118\end{array}$ & \\
\hline
\end{tabular}


TABLE I. (Contd.)

\begin{tabular}{|c|c|c|c|c|c|c|c|c|c|}
\hline \multirow{2}{*}{$\begin{array}{l}\mathrm{N} \times A \\
\mathrm{Z} \\
. \frac{\mathrm{N}-\mathrm{Z}}{\mathrm{A}} \\
\end{array}$} & \multirow[b]{2}{*}{ Ref. } & \multicolumn{4}{|c|}{ T Fit } & \multicolumn{4}{|c|}{$a$ Fit } \\
\hline & & $\begin{array}{r}\mathrm{T} \mathrm{MeV} \\
(\Delta \mathrm{T}) \\
\end{array}$ & Mean & $\begin{array}{c}\sigma_{\mathrm{ASYM}} / \sigma_{\mathrm{ne}} \\
\underline{(\Delta \sigma / \sigma)}\end{array}$ & Mean & $\begin{array}{l}\alpha \mathrm{MeV}^{-1} \\
(\Delta a) \\
\end{array}$ & Mean & $\begin{array}{l}\sigma_{\text {ASYM }} / \sigma_{\text {ne }} \\
(\Delta \sigma / \sigma)\end{array}$ & Mean \\
\hline \multirow{2}{*}{$\begin{array}{l}{ }_{32}^{38} \mathrm{Ge}^{70} \\
(0.08571)\end{array}$} & B 72 & $\begin{array}{l}1.161 \\
0.071\end{array}$ & $\begin{array}{l}1.263 \\
0.034\end{array}$ & $\begin{array}{l}0.6318 \\
0.0151\end{array}$ & $\begin{array}{l}0.6404 \\
0.0114\end{array}$ & $\begin{array}{l}9.695 \\
1.131\end{array}$ & $\begin{array}{l}7.850 \\
0.452\end{array}$ & $\begin{array}{l}0.6549 \\
0.0174\end{array}$ & $\begin{array}{l}0.6689 \\
0.0136\end{array}$ \\
\hline & P 61 & $\begin{array}{l}1.292 \\
0.038 \\
\end{array}$ & & $\begin{array}{l}0.6520 \\
0.0175 \\
\end{array}$ & & $\begin{array}{l}7.499 \\
0.493 \\
\end{array}$ & & $\begin{array}{l}0.6906 \\
0.0216 \\
\end{array}$ & \\
\hline \multirow{2}{*}{$\begin{array}{l}{ }_{32}^{44} \mathrm{Ge}^{76} \\
(0.15789)\end{array}$} & S 70 & $\begin{array}{l}1.735 \\
0.102\end{array}$ & $\begin{array}{l}1.761 \\
0.100\end{array}$ & $\begin{array}{l}0.9595 \\
0.0589\end{array}$ & $\begin{array}{l}0.9595 \\
0.0589\end{array}$ & $\begin{array}{l}3.297 \\
0.509\end{array}$ & $\begin{array}{l}2.792 \\
0.434\end{array}$ & $\begin{array}{l}1.0862 \\
0.0946\end{array}$ & $\begin{array}{l}1.0862 \\
0.0946\end{array}$ \\
\hline & 067 & $\begin{array}{l}2.441 \\
0.518 \\
\end{array}$ & & $\begin{array}{l}1.2998^{\mathrm{d}} \\
0.2645 \\
\end{array}$ & & $\begin{array}{l}1.459 \\
0.827 \\
\end{array}$ & & $\begin{array}{l}1.6798^{\mathrm{d}} \\
0.5450 \\
\end{array}$ & \\
\hline \multirow{3}{*}{$\begin{array}{l}{ }_{33}^{42} \mathrm{As}^{75} \\
(0.12000)\end{array}$} & D 71 & $\begin{array}{l}1.269 \\
0.138\end{array}$ & $\begin{array}{l}1.286 \\
0.038\end{array}$ & $\begin{array}{l}0.8353 \\
0.0567\end{array}$ & $\begin{array}{l}0.8206 \\
0.0151\end{array}$ & $\begin{array}{l}7.280 \\
1.681\end{array}$ & $\begin{array}{l}7.034 \\
0.543\end{array}$ & $\begin{array}{l}0.8805 \\
0.0701\end{array}$ & $\begin{array}{l}0.8575 \\
0.0221\end{array}$ \\
\hline & B 68 & $\begin{array}{l}1.346 \\
0.063\end{array}$ & & $\begin{array}{l}0.8079 \\
0.0220\end{array}$ & & $\begin{array}{l}0.13 y \\
0.751\end{array}$ & & $\begin{array}{l}0.8416 \\
0.0298\end{array}$ & \\
\hline & P 61 & $\begin{array}{l}1.248 \\
0.052 \\
\end{array}$ & & $\begin{array}{r}0.8312 \\
0.0222 \\
\end{array}$ & & $\begin{array}{l}7.379 \\
0.889 \\
\end{array}$ & & $\begin{array}{l}0.8759 \\
0.0374 \\
\end{array}$ & \\
\hline \multirow{3}{*}{$\begin{array}{l}40 \mathrm{Se}^{1 / 4} \\
(0.08108)\end{array}$} & B 72 & $\begin{array}{l}1.741^{a} \\
0.049\end{array}$ & $\begin{array}{l}1.264 \\
0.058\end{array}$ & $\begin{array}{l}0.5304^{a} \\
0.0130\end{array}$ & $\begin{array}{l}0.4526 \\
0.0136\end{array}$ & $\begin{array}{l}3.928^{a} \\
0.213\end{array}$ & $\begin{array}{l}8.180 \\
0.803\end{array}$ & $\begin{array}{l}0.6018^{a} \\
0.0160\end{array}$ & $\begin{array}{l}0.4745 \\
0.0167\end{array}$ \\
\hline & A 69 & $\begin{array}{l}1.185 \\
0.153\end{array}$ & & $\begin{array}{l}0.4611 \\
0.0384\end{array}$ & & $\begin{array}{l}9.039 \\
2.644\end{array}$ & & $\begin{array}{l}0.4906 \\
0.0517\end{array}$ & \\
\hline & B 66 & $\begin{array}{l}1.277 \\
0.062 \\
\end{array}$ & . & $\begin{array}{l}0.4514 \\
0.0146 \\
\end{array}$ & . & $\begin{array}{l}8.093 \\
0.843 \\
\end{array}$ & & $\begin{array}{l}0.4726 \\
0.0177 \\
\end{array}$ & \\
\hline \multirow{3}{*}{$\begin{array}{l}\begin{array}{l}44 \\
35 \\
5^{19}\end{array} \\
(0.11392)\end{array}$} & B 67 & $\begin{array}{l}0.804^{\mathrm{a}} \\
0.054\end{array}$ & $\begin{array}{l}1.160 \\
0.044\end{array}$ & $\begin{array}{l}0.6275 \\
0.01 .43\end{array}$ & $\begin{array}{l}0.6155 \\
0.01104\end{array}$ & $\begin{array}{c}19.984^{\mathrm{a}} \\
3.021\end{array}$ & $\begin{array}{l}8.761 \\
0.825\end{array}$ & $\begin{array}{l}0.6347 \\
0.0174\end{array}$ & $\begin{array}{l}0.6304 \\
0.0137\end{array}$ \\
\hline & 067 & $\begin{array}{l}1.195 \\
0.087\end{array}$ & . & $\begin{array}{l}0.7454^{a} \\
0.0328\end{array}$ & & $\begin{array}{l}8.165 \\
1.291\end{array}$ & & $\begin{array}{l}0.7940^{\mathrm{a}} \\
0.0432\end{array}$ & \\
\hline & K 60 & $\begin{array}{l}1.148 \\
0.051 \\
\end{array}$ & & $\begin{array}{l}0.6023 \\
0.0150 \\
\end{array}$ & & $\begin{array}{l}9.172 \\
1.072 \\
\end{array}$ & & $\begin{array}{l}0.6235 \\
0.0221 \\
\end{array}$ & . \\
\hline $\begin{array}{l}46 \mathrm{Br}^{81} \\
35 \\
(0.13580) \\
\end{array}$ & 067 & $\begin{array}{l}1.389 \\
0.102\end{array}$ & & $\begin{array}{l}0.5781 \\
0.0264\end{array}$ & & $\begin{array}{l}5.827 \\
0.976 \\
\end{array}$ & & $\begin{array}{l}0.6239 \\
0.0377\end{array}$ & \\
\hline \multirow{5}{*}{$\begin{array}{l}49 \mathrm{Rb}^{85} \\
(0.12941)\end{array}$} & A 72 & $\begin{array}{l}0.998 \\
0.233\end{array}$ & $\begin{array}{l}1.124 \\
0.034\end{array}$ & $\begin{array}{l}0.7338 \\
0.0747\end{array}$ & $\begin{array}{l}0.7238 \\
0.0095\end{array}$ & $\begin{array}{r}12.415 \\
6.379\end{array}$ & $\begin{array}{l}9.517 \\
0.712\end{array}$ & $\begin{array}{l}0.7533 \\
0.0931\end{array}$ & $\begin{array}{l}0.7375 \\
0.0128\end{array}$ \\
\hline & B 72 & $\begin{array}{l}1.070 \\
0.057\end{array}$ & & $\begin{array}{l}0.7116 \\
0.0131\end{array}$ & . & $\begin{array}{r}11.340 \\
1.536\end{array}$ & & $\begin{array}{l}0.7235 \\
0.0183\end{array}$ & \\
\hline & B 67 & $\begin{array}{l}1.142 \\
0.049\end{array}$ & & $\begin{array}{l}0.7376 \\
0.0141\end{array}$ & & $\begin{array}{l}9.897 \\
1.029\end{array}$ & & $\begin{array}{l}0.7508 \\
0.0183\end{array}$ & \\
\hline & P 61 & $\begin{array}{l}1.232 \\
0.112\end{array}$ & & $\begin{array}{l}1.0861^{b} \\
0.0629\end{array}$ & & $\begin{array}{l}7.703 \\
1.545\end{array}$ & & $\begin{array}{l}1.1498^{b} \\
0.0817\end{array}$ & \\
\hline & T 60 & $\begin{array}{l}1.243 \\
0.209 \\
\end{array}$ & $\therefore$ & $\begin{array}{l}1.2677^{d} \\
0.1863 \\
\end{array}$ & & $\begin{array}{l}6.814 \\
2.473 \\
\end{array}$ & & $\begin{array}{l}1.4007^{\mathrm{d}} \\
0.2445 \\
\end{array}$ & 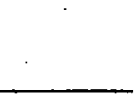 \\
\hline
\end{tabular}


TABLE I. (Contd.)

\begin{tabular}{|c|c|c|c|c|c|c|c|c|c|}
\hline \multirow{2}{*}{$\begin{array}{l}\mathrm{Z}^{\mathrm{N}} \mathrm{x}^{\mathrm{A}} \\
\frac{\mathrm{N}-\mathrm{Z}}{\mathrm{A}}\end{array}$} & \multirow[b]{2}{*}{ Ref. } & \multicolumn{4}{|c|}{$T$ Fit } & \multicolumn{4}{|c|}{$a$ Fit } \\
\hline & & $\begin{array}{r}\mathrm{T} \mathrm{MeV} \\
(\Delta \mathrm{T}) \\
\end{array}$ & Mean & $\begin{array}{c}\sigma_{\text {ASYM }} / \sigma_{\text {ne }} \\
(\Delta \sigma / \sigma)\end{array}$ & Mean & $\begin{array}{l}a \mathrm{MeV}^{-1} \\
(\Delta a) \\
\end{array}$ & Mean & $\begin{array}{c}\sigma_{\text {ASYM }} / \sigma_{\text {ne }} \\
(\Delta \sigma / \sigma) \\
\end{array}$ & Mean \\
\hline \multirow{4}{*}{$\begin{array}{l}{ }_{37}^{50} \mathrm{Rb}^{87} \\
(0.14943)\end{array}$} & A 72 & $\begin{array}{l}0.904 \\
0.274\end{array}$ & $\begin{array}{l}1.108 \\
0.057\end{array}$ & $\begin{array}{l}0.7484 \\
0.0564\end{array}$ & $\begin{array}{l}0.7739 \\
0.0207\end{array}$ & $\begin{array}{l}15.563 \\
10.351\end{array}$ & $\begin{array}{l}9.153 \\
1.094\end{array}$ & $\begin{array}{l}0.7571 \\
0.0696\end{array}$ & $\begin{array}{l}0.7950 \\
0.0309\end{array}$ \\
\hline & B 72 & $\begin{array}{l}1.162 \\
0.219\end{array}$ & & $\begin{array}{l}1.1365^{a} \\
0.0880\end{array}$ & & $\begin{array}{l}9.456 \\
4.155\end{array}$ & & $\begin{array}{l}1.1572^{a} \\
0.1126\end{array}$ & \\
\hline & P 61 & $\begin{array}{l}1.125 \\
0.074\end{array}$ & & $\begin{array}{l}0.7779 \\
0.0223\end{array}$ & & $\begin{array}{l}9.404 \\
1.631\end{array}$ & & $\begin{array}{l}0.8043 \\
0.0345\end{array}$ & \\
\hline & T 60 & $\begin{array}{l}1.091 \\
0.103 \\
\end{array}$ & & $\begin{array}{l}1.4624^{\mathrm{a}} \\
0.1047 \\
\end{array}$ & & $\begin{array}{l}8.715 \\
1.596 \\
\end{array}$ & & $\begin{array}{l}1.5706^{\mathrm{a}} \\
0.1200 \\
\end{array}$ & \\
\hline \multirow{2}{*}{$\begin{array}{l}{ }_{38}^{46} \mathrm{Sr}^{84} \\
(0.09524)\end{array}$} & В 66 & $\begin{array}{l}0.992 \\
0.030\end{array}$ & $\begin{array}{l}1.013 \\
0.029\end{array}$ & $\begin{array}{l}0.9444 \\
0.0167\end{array}$ & $\begin{array}{l}0.9444 \\
0.0167\end{array}$ & $\begin{array}{r}13.661 \\
1.104\end{array}$ & $\begin{array}{r}11.293 \\
0.833\end{array}$ & $\begin{array}{l}0.9640 \\
0.0239\end{array}$ & $\begin{array}{l}0.9640 \\
0.0239\end{array}$ \\
\hline & P 61 & $\begin{array}{l}1.232 \\
0.098 \\
\end{array}$ & & $\begin{array}{l}0.1805^{b} \\
0.0154\end{array}$ & & $\begin{array}{l}8.170 \\
1.268 \\
\end{array}$ & & $\begin{array}{l}0.1935^{b} \\
0.0168\end{array}$ & \\
\hline $\begin{array}{l}{ }_{38}^{48} \mathrm{Sr}^{86} \\
(0.11628) \\
\end{array}$ & B 72 & $\begin{array}{l}1.003 \\
0.044\end{array}$ & & $\begin{array}{l}0.4606 \\
0.0108\end{array}$ & & $\begin{array}{r}12.818 \\
1.072\end{array}$ & & $\begin{array}{l}0.4727 \\
0.0112\end{array}$ & \\
\hline \multirow{4}{*}{$\begin{array}{l}50 Y^{8 y} \\
39 \\
(0.12360)\end{array}$} & B 72 & $\begin{array}{l}1.157 \\
0.052\end{array}$ & $\begin{array}{l}1.148 \\
0.032\end{array}$ & $\begin{array}{l}0.7155 \\
0.0228\end{array}$ & $\begin{array}{l}0.6464 \\
0.0127\end{array}$ & $\begin{array}{l}9.277 \\
1.090\end{array}$ & $\begin{array}{l}8.460 \\
0.592\end{array}$ & $\begin{array}{l}0.7493 \\
0.0334\end{array}$ & $\begin{array}{l}0.6501 \\
0.0147\end{array}$ \\
\hline & A 69 & $\begin{array}{l}0.842^{\mathrm{a}} \\
0.026\end{array}$ & & $\begin{array}{l}0.6130 \\
0.0154\end{array}$ & & $\begin{array}{c}18.024^{\mathrm{a}} \\
1.156\end{array}$ & & $\begin{array}{l}0.6245 \\
0.0164\end{array}$ & \\
\hline & P 61 & $\begin{array}{l}1.129 \\
0.041\end{array}$ & & $\begin{array}{l}0.0107^{b} \\
0.0003\end{array}$ & & $\begin{array}{l}9.790 \\
0.828\end{array}$ & & $\begin{array}{l}0.0112^{h} \\
0.0004\end{array}$ & \\
\hline & T 60 & $\begin{array}{l}1.639 \\
0.252 \\
\end{array}$ & & $\begin{array}{l}0.8665 \\
0.1637 \\
\end{array}$ & & $\begin{array}{l}3.674 \\
1.350 \\
\end{array}$ & & $\begin{array}{l}1.0663 \\
0.2609 \\
\end{array}$ & \\
\hline \multirow{3}{*}{$\begin{array}{l}50 \mathrm{Zr}^{90} \\
{ }_{40} \\
(0.11111)\end{array}$} & K 72 & $\begin{array}{l}1.422 \\
0.576\end{array}$ & $\begin{array}{l}1.104 \\
0.025\end{array}$ & $\begin{array}{l}1.0294 \\
0.4914\end{array}$ & $\begin{array}{l}0.7183 \\
0.0152\end{array}$ & $\begin{array}{l}5.293 \\
5.103\end{array}$ & $\begin{array}{r}10.398 \\
0.433\end{array}$ & $\begin{array}{l}1.2172 \\
0.7453\end{array}$ & $\begin{array}{l}0.7534 \\
0.0152\end{array}$ \\
\hline & A 69 & $\begin{array}{l}1.161 \\
0.115\end{array}$ & & $\begin{array}{l}0.7675 \\
0.0458\end{array}$ & & $\begin{array}{l}9.814 \\
1.932\end{array}$ & & $\begin{array}{l}0.8020 \\
0.0521\end{array}$ & \\
\hline & P 61 & $\begin{array}{l}1.101 \\
0.026 \\
\end{array}$ & & $\begin{array}{l}0.7119 \\
0.0161 \\
\end{array}$ & & $\begin{array}{r}10.468 \\
0.446 \\
\end{array}$ & & $\begin{array}{l}0.7487 \\
0.0159 \\
\end{array}$ & \\
\hline \multirow{4}{*}{$\begin{array}{l}50 \mathrm{Mo}^{92} \\
42^{2} \\
(0.08696)\end{array}$} & B 72 & $\begin{array}{l}2.486 \\
0.203\end{array}$ & $\begin{array}{l}1.838 \\
0.084\end{array}$ & $\begin{array}{l}0.7339 \\
0.0712\end{array}$ & $\begin{array}{l}0.6702 \\
0.0277\end{array}$ & $\begin{array}{l}1.675 \\
0.388\end{array}$ & $\begin{array}{l}2.258 \\
0.344\end{array}$ & $\begin{array}{l}0.9709 \\
0.1497\end{array}$ & $\begin{array}{l}0.7661 \\
0.0598\end{array}$ \\
\hline & K 72 & $\begin{array}{l}0.799^{a} \\
0.086\end{array}$ & & $\begin{array}{l}0.1410^{a} \\
0.0132\end{array}$ & & $\begin{array}{c}20.038^{a} \\
4.653\end{array}$ & & $\begin{array}{l}0.1491^{\mathrm{a}} \\
0.0159\end{array}$ & \\
\hline & $\Lambda 69$ & $\begin{array}{l}1.600 \\
0.200\end{array}$ & & $\begin{array}{l}0.3396^{a} \\
0.0496\end{array}$ & & $\begin{array}{l}4.689 \\
1.371\end{array}$ & & $\begin{array}{l}0.3886^{a} \\
0.0708\end{array}$ & \\
\hline & B 52 & $\begin{array}{l}1.734 \\
0.103 \\
\end{array}$ & & $\begin{array}{l}0.6588 \\
0.0301 \\
\end{array}$ & & $\begin{array}{l}4.294 \\
0.889 \\
\end{array}$ & & $\begin{array}{l}0.7273 \\
0.0652 \\
\end{array}$ & \\
\hline $\begin{array}{l}{ }_{44}^{52} \mathrm{Ru}^{96} \\
(0.08333) \\
\end{array}$ & B 70 & $\begin{array}{l}1.191 \\
0.059\end{array}$ & & $\begin{array}{l}0.5825 \\
0.0141\end{array}$ & & $\begin{array}{l}8.745 \\
1.062\end{array}$ & & $\begin{array}{l}0.6015 \\
0.0194\end{array}$ & \\
\hline
\end{tabular}


TABLE I. (Contd.)

\begin{tabular}{|c|c|c|c|c|c|c|c|c|c|}
\hline \multirow{2}{*}{$\begin{array}{l}\mathrm{N}_{\mathrm{Z}} \mathrm{A} \\
\frac{\mathrm{N}-\mathrm{Z}}{\mathrm{A}} \\
\end{array}$} & \multirow[b]{2}{*}{ Ref. } & \multicolumn{4}{|c|}{ T Fit } & \multicolumn{4}{|c|}{$a$ Fit } \\
\hline & & $\begin{array}{r}\mathrm{T} \mathrm{MeV} \\
(\Delta \mathrm{T}) \\
\end{array}$ & Mean & $\begin{array}{l}\sigma_{A S Y M} / \sigma \\
(\Delta \sigma / \sigma) \\
(\Delta \sigma / \sigma\end{array}$ & Mean & $\begin{array}{l}a \mathrm{MeV}^{-1} \\
(\Delta a) \\
\end{array}$ & Mean & $\begin{array}{l}{ }_{\mathrm{ASYM}} / \sigma \\
\left(\Delta_{\sigma / \sigma}\right)^{\mathrm{ne}}\end{array}$ & Mean \\
\hline $\begin{array}{l}{ }_{44}^{60} \mathrm{Ru} 104 \\
(0.15385)\end{array}$ & B 70 & $\begin{array}{l}1.072 \\
0.089\end{array}$ & & $\begin{array}{l}0.8550 \\
0.0205\end{array}$ & & $\begin{array}{r}10.144 \\
1.867\end{array}$ & & $\begin{array}{l}0.8727 \\
0.0268\end{array}$ & \\
\hline${ }_{45}^{58} \mathrm{Rh}^{103}$ & P 70 & $\begin{array}{l}0.938 \\
0.067\end{array}$ & $\begin{array}{l}1.142 \\
0.033\end{array}$ & $\begin{array}{l}0.5636 \\
0.0097\end{array}$ & $\begin{array}{l}0.5115^{c} \\
0.0521\end{array}$ & $\begin{array}{r}12.990 \\
1.899\end{array}$ & $\begin{array}{l}6.960 \\
0.491\end{array}$ & $\begin{array}{l}0.5731 \\
0.0117\end{array}$ & $\begin{array}{l}0.5371^{c} \\
0.0360\end{array}$ \\
\hline$(0.12621)$ & T 60 & $\begin{array}{l}1.208 \\
0.038 \\
\end{array}$ & & $\begin{array}{l}0.4594 \\
0.0119 \\
\end{array}$ & & $\begin{array}{l}6.528 \\
0.508 \\
\end{array}$ & & $\begin{array}{l}0.5011 \\
0.0177 \\
\end{array}$ & \\
\hline $\begin{array}{l}{ }_{46}^{56} \mathrm{Pd}^{102} \\
(0.09804) \\
\end{array}$ & B 70 & $\begin{array}{l}1.082 \\
0.073\end{array}$ & & $\begin{array}{l}0.621 .5 \\
0.0183\end{array}$ & & $\begin{array}{r}10.594 \\
1.621\end{array}$ & & $\begin{array}{l}0.6358 \\
0.0229\end{array}$ & \\
\hline $\begin{array}{l}{ }_{46}^{64} \mathrm{Pd}^{110} \\
(0.16364) \\
\end{array}$ & В 70 & $\begin{array}{l}1.186 \\
\text { U. U9/ }\end{array}$ & & $\begin{array}{l}0.8510 \\
0.0275\end{array}$ & & $\begin{array}{l}7.854 \\
1.271\end{array}$ & & $\begin{array}{l}0.8833 \\
0.0332\end{array}$ & \\
\hline${ }_{48}^{58} \mathrm{Cd}^{106}$ & B 68 & $\begin{array}{l}1.017 \\
0.085\end{array}$ & $\begin{array}{l}1.083 \\
0.074\end{array}$ & $\begin{array}{l}0.8587 \\
0.0333\end{array}$ & $\begin{array}{l}0.7281^{c} \\
0.1306\end{array}$ & $\begin{array}{r}12.464 \\
2.261\end{array}$ & $\begin{array}{l}9.271 . \\
1.417\end{array}$ & $\begin{array}{l}0.8719 \\
0.0385\end{array}$ & $\begin{array}{l}0.7522^{C} \\
0.1196\end{array}$ \\
\hline$(0.09434)$ & R 63 & $\begin{array}{l}1.286 \\
0.149 \\
\end{array}$ & & $\begin{array}{l}0.5976 \\
0.0504 \\
\end{array}$ & & $\begin{array}{l}7.206 \\
1.818 \\
\end{array}$ & & $\begin{array}{l}0.6326 \\
0.0630 \\
\end{array}$ & \\
\hline $\begin{array}{l}{ }_{48}^{68} \mathrm{Cd}^{116} \\
(0.17241) \\
\end{array}$ & P 61 & $\begin{array}{l}0.933 \\
0.076\end{array}$ & & $\begin{array}{l}0.8685 \\
0.0121\end{array}$ & & $\begin{array}{r}13.224 \\
2.362\end{array}$ & & $\begin{array}{l}0.8795 \\
0.0160\end{array}$ & . \\
\hline $\begin{array}{l}6 ! \cdot \ln ^{113} \\
49 \\
(0.13274) \\
\end{array}$ & G 70 & $\begin{array}{l}1.159 \\
0.220\end{array}$ & & $\begin{array}{l}0.8777 \\
0.0427\end{array}$ & & $\begin{array}{l}9.254 \\
3.936\end{array}$ & & $\begin{array}{l}0.8962 \\
0.0582\end{array}$ & \\
\hline $\begin{array}{l}b b \ln 115 \\
49 \\
(0.14783)\end{array}$ & $G 70$ & $\begin{array}{l}1.021 \\
0.161\end{array}$ & & $\begin{array}{l}0.9236 \\
0.0294\end{array}$ & & $\begin{array}{r}12.047 \\
4.27 .3\end{array}$ & & $\begin{array}{l}0.9331 \\
0.0376\end{array}$ & \\
\hline${ }_{50}^{62} \mathrm{Sn}^{112}$ & В 68 & $\begin{array}{l}0.945 \\
0.043\end{array}$ & $\begin{array}{l}0.991 \\
0.035\end{array}$ & $\begin{array}{l}0.6796 \\
0.0131\end{array}$ & $\begin{array}{l}0.6837 \\
0.0124\end{array}$ & $\begin{array}{r}14.267 \\
1.605\end{array}$ & $\begin{array}{r}10.798 \\
0.894\end{array}$ & $\begin{array}{l}0.6894 \\
0.0175\end{array}$ & $\begin{array}{l}0.6952 \\
0.0164\end{array}$ \\
\hline$(0.10714)$ & R 63 & $\begin{array}{l}1.172 \\
0.075\end{array}$ & & $\begin{array}{l}1.0294^{\mathrm{a}} \\
0.0388\end{array}$ & & $\begin{array}{l}8.779 \\
1.115\end{array}$ & & $\begin{array}{l}1.0739^{a} \\
0.0439\end{array}$ & \\
\hline & P 61 & $\begin{array}{l}0.900 \\
0.111 \\
\end{array}$ & & $\begin{array}{l}0.7218 \\
0.0397 \\
\end{array}$ & & $\begin{array}{r}15.480 \\
4.110 \\
\end{array}$ & & $\begin{array}{l}0.7387 \\
0.0478 \\
\end{array}$ & \\
\hline${ }_{51}^{70} \mathrm{Sb}^{121}$ & B 68 & $\begin{array}{l}1.354 \\
0.078\end{array}$ & $\begin{array}{l}1.325 \\
0.069\end{array}$ & $\begin{array}{l}0.9579 \\
0.0239\end{array}$ & $\begin{array}{l}0.8915 \\
0.0193\end{array}$ & $\begin{array}{l}6.281 \\
0.742\end{array}$ & $\begin{array}{l}6.463 \\
0.701\end{array}$ & $\begin{array}{l}0.9941 \\
0.0297\end{array}$ & $\begin{array}{l}0.9330 \\
0.0245\end{array}$ \\
\hline$(0.15702)$ & P 60 & $\begin{array}{l}1.215 \\
0.151 \\
\end{array}$ & & $\begin{array}{l}0.7773 \\
0.0326 \\
\end{array}$ & & $\begin{array}{l}7.958 \\
2.129 \\
\end{array}$ & & $\begin{array}{r}0.8030 \\
0.0433 \\
\end{array}$ & \\
\hline${ }_{51}^{72} \mathrm{Sb}^{123}$ & B 68 & $\begin{array}{l}1.220 \\
0.103\end{array}$ & $\begin{array}{l}1.163 \\
0.087\end{array}$ & $\begin{array}{l}0.7030 \\
0.0206\end{array}$ & $\begin{array}{l}0.6846 \\
0.0152\end{array}$ & $\begin{array}{l}7.783 \\
1.469\end{array}$ & $\begin{array}{l}8.228 \\
1.369\end{array}$ & $\begin{array}{l}0.7244 \\
0.0278\end{array}$ & $\begin{array}{l}0.7016 \\
0.0205\end{array}$ \\
\hline$(0.17073)$ & P 61 & $\begin{array}{l}1.025 \\
0.161\end{array}$ & & $\begin{array}{l}0.6624 \\
0.0226 \\
\end{array}$ & & $\begin{array}{r}11.155 \\
3.770\end{array}$ & & $\begin{array}{l}0.6748 \\
0.0302\end{array}$ &. \\
\hline
\end{tabular}


TABLE I. (Contd.)

\begin{tabular}{|c|c|c|c|c|c|c|c|c|c|}
\hline \multirow{2}{*}{$\begin{array}{l}\mathrm{N}^{\mathrm{A}} \mathrm{X}^{\mathrm{A}} \\
\frac{\mathrm{N}-\mathrm{Z}}{\mathrm{A}} \\
\end{array}$} & \multirow[b]{2}{*}{ Ref. } & \multicolumn{4}{|c|}{$\mathrm{T}$ Fit } & \multicolumn{4}{|c|}{$a$ Fit } \\
\hline & & $\begin{array}{r}\mathrm{T} \mathrm{MeV} \\
(\Delta \mathrm{T}) \\
\end{array}$ & Mean & $\begin{array}{l}\sigma{ }_{\mathrm{ASYM}} / \sigma \\
\underline{(\Delta \sigma / \sigma)} \\
\underline{\underline{n}}\end{array}$ & Mean & $\begin{array}{l}a \mathrm{MeV}^{-1} \\
(\Delta a) \\
\end{array}$ & Mean & $\begin{array}{l}\sigma_{\mathrm{ASYM}} / \sigma \\
\underline{(\Delta \sigma / \sigma)^{\circ}} \\
\end{array}$ & Mean \\
\hline $\begin{array}{l}{ }_{52}^{76} \mathrm{Te}^{128} \\
(0.18750) \\
\end{array}$ & B 70 & $\begin{array}{l}1.462 \\
0.122\end{array}$ & & $\begin{array}{l}1.0101 \\
0.0465\end{array}$ & & $\begin{array}{l}4.903 \\
1.052\end{array}$ & & $\begin{array}{l}1.0824 \\
0.0758\end{array}$ & \\
\hline $\begin{array}{l}78 \mathrm{Te}^{130} \\
52 \\
(0.20000) \\
\end{array}$ & B 70 & $\begin{array}{l}1.271 \\
0.159\end{array}$ & & $\begin{array}{l}0.9582 \\
0.0461\end{array}$ & & $\begin{array}{l}6.811 \\
2.042\end{array}$ & . & $\begin{array}{l}0.9939 \\
0.0676\end{array}$ & \\
\hline $\begin{array}{l}74 \\
53\end{array}$ & B 72 & $\begin{array}{l}1.530 \\
0.187\end{array}$ & $\begin{array}{l}1.306 \\
0.064\end{array}$ & $\begin{array}{l}0.8286 \\
0.0601\end{array}$ & $\begin{array}{l}0.7028 \\
0.0085\end{array}$ & $\begin{array}{l}4.638 \\
1.200\end{array}$ & $\begin{array}{l}5.696 \\
0.716\end{array}$ & $\begin{array}{l}0.8873 \\
0.0783\end{array}$ & $\begin{array}{l}0.7288 \\
0.0160\end{array}$ \\
\hline$(0.16535)$ & В 62 & $\begin{array}{l}1.065 \\
0.118\end{array}$ & & $\begin{array}{l}0.6770 \\
0.0192\end{array}$ & & $\begin{array}{r}10.736 \\
2.887\end{array}$ & & $\begin{array}{l}0.6883 \\
0.0274\end{array}$ & \\
\hline & M 53 & $\begin{array}{l}1.383 \\
0.084 \\
\end{array}$ & & $\begin{array}{l}0.7061 \\
0.0096 \\
\end{array}$ & & $\begin{array}{l}5.811 \\
0.937 \\
\end{array}$ & & $\begin{array}{l}0.7405 \\
0.0204 \\
\end{array}$ & \\
\hline $\begin{array}{l}78 \\
55\end{array}$ & B 72 & $\begin{array}{l}1.687 \\
0.065\end{array}$ & $\begin{array}{l}1.687 \\
0.065\end{array}$ & $\begin{array}{l}0.7909 \\
0.0192\end{array}$ & $\begin{array}{l}0.6921^{c} \\
0.0988\end{array}$ & $\begin{array}{l}3.688 \\
0.254\end{array}$ & $\begin{array}{l}3.688 \\
0.254\end{array}$ & $\begin{array}{l}0.8632 \\
0.0219\end{array}$ & $\begin{array}{l}0.7282^{\circ} \\
0.1350\end{array}$ \\
\hline$(0.17293)$ & B 62 & $\begin{array}{l}0.654 \\
3.530 \\
\end{array}$ & & $\begin{array}{l}0.5933 \\
0.0463 \\
\end{array}$ & & $\begin{array}{l}11.664 \\
542.5 \\
\end{array}$ & & $\begin{array}{l}0.5932 \\
0.0470 \\
\end{array}$ & ${ }^{\prime}$ \\
\hline $\begin{array}{l}82 \mathrm{Ce}^{140} \\
(0.17143) \\
\end{array}$ & B 68 & $\begin{array}{l}1.232 \\
0.079\end{array}$ & & $\begin{array}{l}0.9550 \\
0.0213\end{array}$ & & $\begin{array}{l}7.893 \\
1.139\end{array}$ & & $\begin{array}{l}0.9808 \\
0.0282\end{array}$ & \\
\hline $8 \% \mathrm{Pr}^{141}$ & B 68 & $\begin{array}{l}1.228 \\
0.106\end{array}$ & $\begin{array}{l}1.188 \\
0.063\end{array}$ & $\begin{array}{l}0.8886 \\
0.0277\end{array}$ & $\begin{array}{l}0.8735 \\
0.0186\end{array}$ & $\begin{array}{l}7.894 \\
1.348\end{array}$ & $\begin{array}{l}8.194 \\
0.929\end{array}$ & $\begin{array}{l}0.9145 \\
0.0323\end{array}$ & $\begin{array}{l}0.8976 \\
0.0227\end{array}$ \\
\hline$(0.16312)$ & F 60 & $\begin{array}{l}1.199 \\
0.139\end{array}$ & & $\begin{array}{l}0.8069 \\
0.0371\end{array}$ & & $\begin{array}{l}8.135 \\
1.976\end{array}$ & & $\begin{array}{l}0.8302 \\
0.0448\end{array}$ & \\
\hline & K 60 & $\begin{array}{l}1.151 \\
0.094 \\
\end{array}$ & & $\begin{array}{l}0.9066 \\
0.0339 \\
\end{array}$ & & $\begin{array}{l}8.703 \\
1.683 \\
\end{array}$ & & $\begin{array}{l}0.9332 \\
0.0452 \\
\end{array}$ & \\
\hline $\begin{array}{l}82 \mathrm{Nd}^{142} \\
(0.15493) \\
\end{array}$ & B 70 & $\begin{array}{l}1.282 \\
0.055\end{array}$ & & $\begin{array}{l}0.8618 \\
0.0156\end{array}$ & & $\begin{array}{l}7.339 \\
0.655\end{array}$ & & $\begin{array}{l}0.8922 \\
0.0192\end{array}$ & \\
\hline$\frac{82}{62} \mathrm{Sm}^{144}$ & В 68 & $\begin{array}{l}1.370 \\
0.061\end{array}$ & $\begin{array}{l}1.405 \\
0.057\end{array}$ & $\begin{array}{l}0.8843 \\
0.0231\end{array}$ & $\begin{array}{l}0.8937 \\
0.0220\end{array}$ & $\begin{array}{l}6.462 \\
0.706\end{array}$ & $\begin{array}{l}5.617 \\
0.570\end{array}$ & $\begin{array}{l}0.9259 \\
0.0328\end{array}$ & $\begin{array}{l}0.9395 \\
0.0314\end{array}$ \\
\hline$(0.13889)$ & R 63 & $\begin{array}{l}1.667 \\
0.168 \\
\end{array}$ & & $\begin{array}{l}0.9856 \\
0.0723 \\
\end{array}$ & & $\begin{array}{l}4.042 \\
0.964 \\
\end{array}$ & & $\begin{array}{l}1.0857 \\
0.1074 \\
\end{array}$ & \\
\hline $\begin{array}{l}100 \mathrm{Tm}^{169} \\
69 \\
(0.18343) \\
\end{array}$ & $\mathrm{T} 60$ & $\begin{array}{l}1.122 \\
0.066\end{array}$ & & $\begin{array}{l}0.4501 \\
0.0163\end{array}$ & & $\begin{array}{l}7.225 \\
1.065\end{array}$ & & $\begin{array}{l}0.4751 \\
0.0240\end{array}$ & \\
\hline $\begin{array}{l}120 \mathrm{Pt}^{198} \\
(0.21212)\end{array}$ & В 70 & No & Fit & No & Fit & $\begin{array}{l}6.089^{\circ} \\
0.373\end{array}$ & & $\begin{array}{l}1.0124 \\
0.0121\end{array}$ & \\
\hline
\end{tabular}


TABLE I. (Contd.)

\begin{tabular}{|c|c|c|c|c|c|c|c|c|c|}
\hline \multirow{2}{*}{$\begin{array}{l}Z^{N} X^{A} \\
\frac{N-Z}{A} \\
\end{array}$} & \multirow[b]{2}{*}{ Ref. } & \multicolumn{4}{|c|}{ T Fit } & \multicolumn{4}{|c|}{ a Fit } \\
\hline & & $\begin{array}{c}\mathrm{T} \mathrm{MeV} \\
(\Delta \mathrm{T}) \\
\end{array}$ & Mean & $\begin{array}{c}\sigma_{\mathrm{ASYM}} / \sigma_{\mathrm{ne}} \\
(\Delta \sigma / \sigma)\end{array}$ & Mean & $\begin{array}{l}a \mathrm{MeV}^{-1} \\
(\Delta a) \\
\end{array}$ & Mean & $\begin{array}{c}\sigma_{\text {ASYM }} / \sigma_{\text {ne }} \\
(\Delta \sigma / \sigma) \\
\end{array}$ & Mean \\
\hline $\begin{array}{l}118 \mathrm{Au} 197 \\
79 \\
(0.19797)\end{array}$ & $\mathrm{T} 60$ & $\begin{array}{l}1.787 \\
0.149\end{array}$ & & $\begin{array}{l}1.1051 \\
0.0928\end{array}$ & & $\begin{array}{l}2.215 \\
0.524\end{array}$ & & $\begin{array}{l}1.3910 \\
0.1910\end{array}$ & \\
\hline $\begin{array}{l}122 \mathrm{~T}^{203} \\
81 \\
(0.20197) \\
\end{array}$ & T 60 & $\begin{array}{l}2.283 \\
0.270\end{array}$ & & $\begin{array}{l}0.8284 \\
0.1113\end{array}$ & & $\begin{array}{l}1.155 \\
0.421\end{array}$ & & $\begin{array}{l}1.1842 \\
0.2852\end{array}$ & \\
\hline$\frac{122}{82} \mathrm{~Pb}^{204}$ & I 65 & $\begin{array}{l}1.027 \\
0.156\end{array}$ & $\begin{array}{l}1.584 \\
0.106\end{array}$ & $\begin{array}{l}0.6979 \\
0.0432\end{array}$ & $\begin{array}{l}0.8086^{c} \\
0.1107\end{array}$ & $\begin{array}{l}9.331 \\
2.937\end{array}$ & $\begin{array}{l}1.827 \\
0.250\end{array}$ & $\begin{array}{l}0.7272 \\
0.0548\end{array}$ & c \\
\hline$(0.19608)$ & T 60 & $\begin{array}{l}2.059 \\
0.144 \\
\end{array}$ & & $\begin{array}{l}0.9193 \\
0.0500 \\
\end{array}$ & & $\begin{array}{l}1.772 \\
0.251 \\
\end{array}$ & & $\begin{array}{l}1.1769 \\
0.0839 \\
\end{array}$ & \\
\hline $\begin{array}{l}142 \\
90\end{array} \mathrm{Th}^{232}$ & BU 61 & $\begin{array}{l}0.703 \\
0.027\end{array}$ & $\begin{array}{l}0.703 \\
0.027\end{array}$ & $\begin{array}{l}0.7392 \\
0.0205\end{array}$ & $\begin{array}{l}0.7287 \\
0.0192\end{array}$ & $\begin{array}{r}11.051 \\
1.410\end{array}$ & $\begin{array}{r}14.080 \\
1.389\end{array}$ & $\begin{array}{l}0.7747 \\
0.0303\end{array}$ & $\begin{array}{l}0.7567 \\
0.0276\end{array}$ \\
\hline$(0.22414)$ & $\mathrm{T} 60$ & $\begin{array}{l}0.710 \\
0.191 \\
\end{array}$ & & $\begin{array}{l}0.6507 \\
0.0558 \\
\end{array}$ & & $\begin{array}{r}15.048 \\
8.133 \\
\end{array}$ & & $\begin{array}{l}0.6683 \\
0.0671 \\
\end{array}$ & \\
\hline $\begin{array}{l}146 \mathrm{U}^{238} \\
92 \\
(0.22689) \\
\end{array}$ & K 66 & $\begin{array}{l}0.770 \\
0.051\end{array}$ & & $\begin{array}{l}0.6454 \\
0.0394\end{array}$ & & $\begin{array}{r}10.602 \\
1.685\end{array}$ & & $\begin{array}{l}0.6978 \\
0.0542\end{array}$ & \\
\hline
\end{tabular}

${ }^{a}$ Not included in mean. Greater than $3 \sigma$ from mean for either $T$ or a fit.

b NuL lucluded in mean. Relative measurement only.

"Simple mean used. Measurements not consistent with weighted mean.

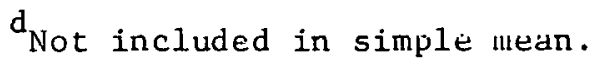

adopted is to use the initial letter of the first author and the last two digits of the year of publication for easy reference.

In Table I, we list each individual, measurement of the two output pararrieters for both the ' $\mathrm{T}$ and $\alpha$ ' fits, and where there is more than one measurement, we have generally derived a best-meall value for each isotope. As far as possible, we have attempted to derive weighted mean values using the reciprocals of the squares of derived errors as weights. We have also attempted to use objective, statistical judgriento on acceptance or refection of an individual measurement on the basis of deviation by less or more than three standard deviations from the weighted mean of the remainder of the data. These attempts have met with reasonable, but not completc, success, and we should state clearly that the error assessment and selection of the best values is not, and cannot, be made on a completely objective basis. Some subjective judgments are inevitable because of inconsistencies between quoted errors and spreads of data, but we believe that these are of minor importance in the overall picture. 
Where the quoted eirors are not consistent with a weighted mean, and there is no obvious correction by rejection of a measurement, we have usually adopted a simple arithmetic mean and assessed the error on the basis of the spread of the measurements. This is a conservative measure, since the error on the mean is usually larger than where a weighted mean is used. In general, we find that the spreads of $\mathrm{T}$ and $\alpha$ are reasonably consistent with the individual errors, and weighted means can be used. This is expected, since it is reasonable that the shapes of the cross-section curves would not be subject to great error. By contrast, this is less true for the cross-section ratio, $\sigma_{\text {ASYM }} / \sigma_{\text {ne, }}$ and again this is as expected, since the accuracy of these data depends upon the more difficult absolute measurement of cross sections.

\section{SYSTEMATICS OF $\sigma_{\text {ASYM }} / \sigma_{\text {ne }}$}

As discussed in Sec. II, Barr, Browne, and Gilmore discovered that the ratio of the asymptotic $(n, 2 n)$ cross section to the nonelastic cross section $\left(\sigma_{\text {ASYM }} / \sigma_{\text {ne }}\right)$ was smoothly dependent upon the neutron asymmetry parameter $(N-Z) / A$ and was well represented by a function of the form

$$
\sigma_{A S Y M} / \sigma_{n e}=1-A \exp \left[-B\left(\frac{N-Z}{A}\right)\right]
$$

shown in Fig. 3. Accordingly, we have examined the data derived in the present work to see if they support this conclusion.

In Table II we have summarized the relevant data of Table I, ordered in terms of increasing values of $(\mathrm{N}-\mathrm{Z}) / \mathrm{A}$. In addition to the data taken from Table I, we have also listed the actual number of individual measurements used in obtaining the quoted value together with an "effective" number. 'l'he latter is the actual number when all the measurements contribute approximately equally toward the mean, but where measurements are of widely varying accuracy, it is the smaller number of values whose relative weight is sufficiently high that they alone contribute effectively to determining the mean. These "effective" numbers are only approximate quantities, but since they are only used as weighting parameters for certain fitting procedures, exact values are not of great importance.

These experimental data are shown in Figs. 7 and 8 , and it can be seen that they do indeed follow curves of the general form of Eq. 7. Some of the data lie well away from the general trend, and these data points can reasonably be considered to be probably in error, due to the difficulty in making the necessary absolute cross-section measurements. In some instances (but not all), good supportive evidence for this contention can be made. For example, some relevant measurements were made at energies near $14 \mathrm{MeV}$ by Mather et al. ${ }^{10}$ These are of the direct neutron-emission cross section (and thus not subject to decay-scheme uncertainties in the active isotope) and have good internal consistency, and they indicate that the $\mathrm{Rh}^{103}$ and $\mathrm{Tm}^{169}$ data given in Table II are too low and should be scaled up to values in the range $0.8-0.9$. 
TABLE II. $\sigma_{\mathrm{ASYM}} / \sigma_{\text {ne }}$ vs $(\mathrm{N}-\mathrm{Z}) / \mathrm{A}$ for $\mathrm{T}$ and $\alpha$ Fits

\begin{tabular}{|c|c|c|c|c|c|c|c|c|}
\hline \multirow[b]{2}{*}{$\frac{N-Z}{A}$} & \multirow[b]{2}{*}{ Isotope } & \multicolumn{3}{|c|}{ T Fit Data } & \multicolumn{3}{|c|}{ a Fit Data } & \multirow[b]{2}{*}{$\begin{array}{c}\text { Comment } \\
\text { (See } \\
\text { Footnotes) }\end{array}$} \\
\hline & & $\sigma / \sigma$ & Error & $\begin{array}{c}\text { Number } \\
\text { Meas. } \\
\text { Actual/Eff. } \\
\end{array}$ & $\sigma / \sigma$ & Error & $\begin{array}{c}\text { Number } \\
\text { Meas. } \\
\text { Actual/Ef f. }\end{array}$ & \\
\hline 0.00000 & $c^{12}$ & 0.0479 & 0.0038 & $3 / 1$ & 0.0529 & 0.0067 & $3 / 1$ & \\
\hline 0.00000 & $\mathrm{~N}^{14}$ & 0.0182 & 0.0006 & $4 / 3$ & 0.0199 & 0.0009 & $4 / 3$ & \\
\hline 0.00000 & $0^{16}$ & 0.0666 & 0.0214 & $1 / 1$ & No & Fit & $0 / 0$ & \\
\hline 0.02564 & $\mathrm{~K}^{39}$ & 0.0312 & 0.0030 & $2 / 1$ & 0.0389 & 0.0048 & $2 / 1$ & \\
\hline 0.03226 & $\mathrm{p}^{31}$ & 0.0721 & 0.0048 & $1 / 1$ & 0.0816 & 0.0063 & $1 / 1$ & \\
\hline 0.03448 & $\mathrm{Ni}{ }^{58}$ & 0.0473 & 0.0071 & $3 / 3$ & 0.0510 & 0.0074 & $3 / 3$ & \\
\hline 0.03704 & $\mathrm{Fe}^{54}$ & 0.0538 & 0.0034 & $2 / 1$ & 0.0577 & 0.0043 & $2 / 1$ & \\
\hline 0.04000 & $\mathrm{Cr}^{50}$ & 0.0850 & 0.0045 & $1 / 1$ & 0.0949 & 0.0053 & $1 / 1$ & \\
\hline 0.04348 & $\mathrm{Na}^{23}$ & 0.1626 & 0.0661 & $3 / 3$ & 0.1828 & 0.0779 & $3 / 3$ & \\
\hline 0.04348 & $\mathrm{Ti}^{46}$ & 0.2626 & 0.0319 & $3 / 3$ & 0.3121 & 0.0501 & $3 / 3$ & \\
\hline 0.05263 & $\mathrm{~F}^{19}$ & 0.1636 & 0.0061 & $4 / 3$ & 0.21 .91 & 0.01 .47 & $4 / 3$ & \\
\hline 0.06250 & $\mathrm{Zn}^{64}$ & 0.4004 & 0.0308 & $5 / 3$ & 0.4999 & 0.0398 & $5 / 3$ & \\
\hline 0.06667 & $S c^{45}$ & 0.4267 & 0.0743 & $2 / 2$ & 0.4598 & 0.0947 & $2 / 2$ & \\
\hline 0.07692 & $\mathrm{Cr}^{52}$ & 0.4194 & 0.0186 & $1 / 1$ & 0.4330 & 0.0248 & $1 / 1$ & \\
\hline 0.07937 & $\mathrm{Cu}^{63}$ & 0.7129 & 0.0053 & $8 / 3$ & 0.7823 & 0.0066 & $8 / 3$ & \\
\hline 0.08108 & $\mathrm{Se}^{74}$ & 0.4526 & 0.0136 & $2 / 2$ & 0.4745 & 0.0167 & $2 / 2$ & \\
\hline 0.08333 & $\mathrm{Ru}^{96}$ & 0.5825 & 0.0141 & $1 / 1$ & 0.6015 & 0.0194 & $1 / 1$ & \\
\hline 0.08475 & $\mathrm{Co}^{59}$ & 0.5599 & 0.0126 & $4 / 4$ & 0.5764 & 0.0142 & $4 / 4$ & \\
\hline 0.08571 & $\mathrm{Ge}^{70}$ & 0.6404 & 0.0114 & $2 / 2$ & 0.6689 & 0.0136 & $2 / 2$ & \\
\hline 0.08696 & $\mathrm{Mo}^{92}$ & 0.6702 & 0.0277 & $2 / 2$ & 0.7661 & 0.0598 & $2 / 2$ & \\
\hline 0.09091 & $\mathrm{Mn}^{55}$ & 0.6855 & 0.0124 & $2 / 2$ & 0.7043 & 0.0158 & $2 / 2$ & \\
\hline 0.09091 & $\mathrm{Zn}{ }^{66}$ & 0.8333 & 0.0153 & $1 / 1$ & 0.8758 & 0.0173 & $1 / 1$ & \\
\hline 0.09434 & $\mathrm{Cd} 106$ & 0.7281 & 0.1306 & $2 / 2$ & 0.7522 & 0.1196 & $2 / 2$ & \\
\hline 0.09524 & $5 r^{84}$ & 0.9444 & 0.0167 & $1 / 1$ & 0.9640 & 0.0239 & $1 / 1$ & \\
\hline 0.09804 & $\mathrm{Pd}$ & 0.6215 & 0.0183 & $1 / 1$ & 0.6358 & 0.0229 & $1 / 1$ & \\
\hline 0.10145 & $\mathrm{Ga}^{69}$ & 0.8458 & 0.0267 & $1 / 1$ & 0.8856 & 0.0321 & $1 / 1$ & \\
\hline 0.10714 & $\mathrm{Sn}^{112}$ & 0.6837 & 0.0124 & $2 / 2$ & 0.6952 & 0.0164 & $2 / 2$ & \\
\hline 0.10769 & $\mathrm{Cu}^{\mathrm{bS}}$ & 0.7072 & 0.0181 & $6 / 6$ & 0.7247 & 0.0230 & $6 / 6$ & \\
\hline 0.11111 & $2 r^{90}$ & 0.7183 & 0.0152 & $3 / 2$ & 0.7534 & 0.0152 & $3 / 2$ & \\
\hline 0.11392 & $\mathrm{Br}^{79}$ & 0.6155 & 0.0104 & $2 / 2$ & 0.6304 & 0.0137 & $2 / 2$ & . \\
\hline 0.11628 & $\mathrm{Sr}^{86}$ & 0.4606 & 0.0108 & $1 / 1$ & 0.4727 & 0.0112 & $1 / 1$ & \\
\hline 0.12000 & $\mathrm{As}^{75}$ & 0.8206 & 0.0151 & $3 / 2$ & 0.8575 & 0.0221 & $3 / 2$ & \\
\hline
\end{tabular}


TABLE II. (Contd.)

\begin{tabular}{|c|c|c|c|c|c|c|c|c|}
\hline \multirow[b]{2}{*}{$\frac{N-Z}{A}$} & \multirow[b]{2}{*}{ Isotope } & \multirow[b]{2}{*}{0} & T Fit 1 & Data & \multicolumn{3}{|c|}{$a$ Fit Data } & \multirow{2}{*}{$\begin{array}{c}\text { Comment } \\
\text { (See } \\
\text { Footnotes) }\end{array}$} \\
\hline & & & Error & $\begin{array}{c}\begin{array}{c}\text { Number } \\
\text { Meas. }\end{array} \\
\text { Actual/Eff. } \\
\end{array}$ & $\sigma / \sigma$ & Error & $\begin{array}{c}\begin{array}{c}\text { Number } \\
\text { Meas. } \\
\text { Actual/Eff. }\end{array} \\
\end{array}$ & \\
\hline 0.12360 & $\mathrm{Y}^{89}$ & 0.6464 & 0.0127 & $3 / 2$. & 0.6501 & 0.0147 & $3 / 2$ & \\
\hline 0.12621 & $\mathrm{Rh}^{103}$ & 0.5115 & 0.0521 & $2 / 2$ & 0.5371 & 0.0360 & $2 / 2$ & a \\
\hline 0.12676 & $\mathrm{Ga}^{7 \cdot 1}$ & 0.7603 & 0.0096 & $1 / 1$ & 0.7642 & 0.0118 & $1 / 1$ & \\
\hline 0.12941 & $\mathrm{Rb}^{85}$ & 0.72 .38 & 0.0095 & $3 / 2$ & 0.7375 & 0.0128 & $3 / 2$ & \\
\hline 0.13274 & In 113 & 0.8777 & 0.0427 & $1 / 1$ & 0.8962 & 0.0582 & $1 / 1$ & $\therefore$ \\
\hline 0.13580 & $\mathrm{Br}^{81}$ & 0.5781 & 0.0264 & $1 / 1$ & 0.6239 & 0.0377 & $1 / 1$ & \\
\hline 0.13889 & $\mathrm{sm}^{144}$ & 0.8937 & 0.0220 & $2 / 1$ & 0.9395 & 0.0314 & $2 / 1$ & \\
\hline 0.14783 & $\operatorname{In}^{115}$ & 0.9236 & 0.0294 & $1 / 1$ & 0.9331 & 0.0376 & $1 / 1$ & \\
\hline 0.14943 & $\mathrm{Rb}^{87}$ & 0.7739 & 0.0207 & $2 / 1$ & 0.7950 & 0.0309 & $2 / 1$ & \\
\hline 0.15385 & $\mathrm{Ru}^{104}$ & 0.8550 & 0.0205 & $1 / 1$ & 0.8727 & 0.0268 & $1 / 1$ & \\
\hline 0.15493 & $\mathrm{Nd}^{142}$ & 0.8618 & 0.0156 & $1 / 1$ & 0.8922 & 0.0192 & $1 / 1$ & \\
\hline 0.15702 & $\mathrm{Sb}^{121}$ & 0.8915 & 0.0193 & $2 / 2$ & 0.9330 & 0.0245 & $2 / 2$ & \\
\hline 0.15789 & $\mathrm{Ge}^{76}$ & 0.9595 & 0.0589 & $1 / 1$ & 1.0862 & 0.0946 & $1 / 1$ & \\
\hline 0.16312 & $\operatorname{Pr}{ }^{141}$ & 0.8735 & 0.0186 & $3 / 3$ & 0.8976 & 0.0227 & $3 / 3$ & \\
\hline 0.16364 & $\mathrm{Pd}^{110}$ & 0.8510 & 0.0275 & $1 / 1$ & 0.8833 & 0.0332 & $1 / 1$ & \\
\hline 0.16535 & $I^{127}$ & 0.7028 & 0.0085 & $3 / 2$ & 0.7288 & 0.0160 & $3 / 2$ & \\
\hline 0.17073 & $\mathrm{Sb}^{123}$ & 0.6846 & 0.0152 & $2 / 2$ & 0.7016 & 0.0205 & $2 / 2$ & \\
\hline 0.17143 & $\mathrm{Ce}^{140}$ & 0.9550 & 0.0213 & $1 / 1$ & 0.9808 & 0.0282 & $1 / 1$ & \\
\hline 0.17241 & $\mathrm{Cd}^{116}$ & 0.8685 & 0.0121 & $1 / 1$ & 0.8795 & 0.0160 & $1 / 1$ & \\
\hline 0.17293 & $\mathrm{Cs}^{133}$ & 0.6921 & 0.0988 & $2 / 2$ & 0.7282 & 0.1350 & $2 / 2$ & \\
\hline 0.18343 & $\operatorname{Tm} 169$ & 0.4501 & 0.0163 & $1 / 1$ & 0.4751 & 0.0240 & $.1 / 1$ & a \\
\hline 0.18750 & $\mathrm{Te} \mathrm{e}^{128}$ & 1.0101 & 0.0465 & $1 / 1$ & 1.0824 & 0.0758 & $1 / 1$ & \\
\hline 0.19608 & $\mathrm{~Pb}^{204}$ & 0.8086 & 0.1107 & $2 / 2$ & 0.9520 & 0.2249 & $2 / 2$ & \\
\hline 0.19797 & $\mathrm{Au}^{197}$ & 1. 1051 & 0.0928 & $1 / 1$ & 1. 3910 & 0.1910 & $1 / 1$ & \\
\hline 0.20000 & $\mathrm{Te}^{130}$ & 0.9582 & 0.0461 & $1 / 1$ & 0.9939 & 0.0676 & $1 / 1$ & \\
\hline $0.20197^{\circ}$ & $\mathrm{Tl}{ }^{203}$ & 0.8284 & 0.1113 & $1 / 1$ & 1.1842 & 0.2852 & $1 / 1$ & \\
\hline 0.21212 & $\mathrm{Pt}^{198}$ & No & Fit & $0 / 0$ & 1.0124 & 0.0121 & $1 / 1$ & \\
\hline 0.22414 & $\operatorname{Th}^{232}$ & 0.7287 & 0.0192 & $2 / 1$ & 0.7567 & 0.0276 & $2 / 1$ & $b$ \\
\hline 0.22689 & $u^{238}$ & 0.6454 & 0.0394 & $1 / 1$ & 0.6978 & 0.0542 & $1 / 1$ & b \\
\hline
\end{tabular}

${ }^{a}$ Direct neutron-emission measurements near $1.4 \mathrm{MeV}$ indicate that these activation measurements are too low and should be disregarded (see Text).

$b$ The asymptotic cross section does not include the competitive $\left(n, n^{\prime} f\right)$ reaction and the ratios rise to about 0.9 if these are added (see Text). 


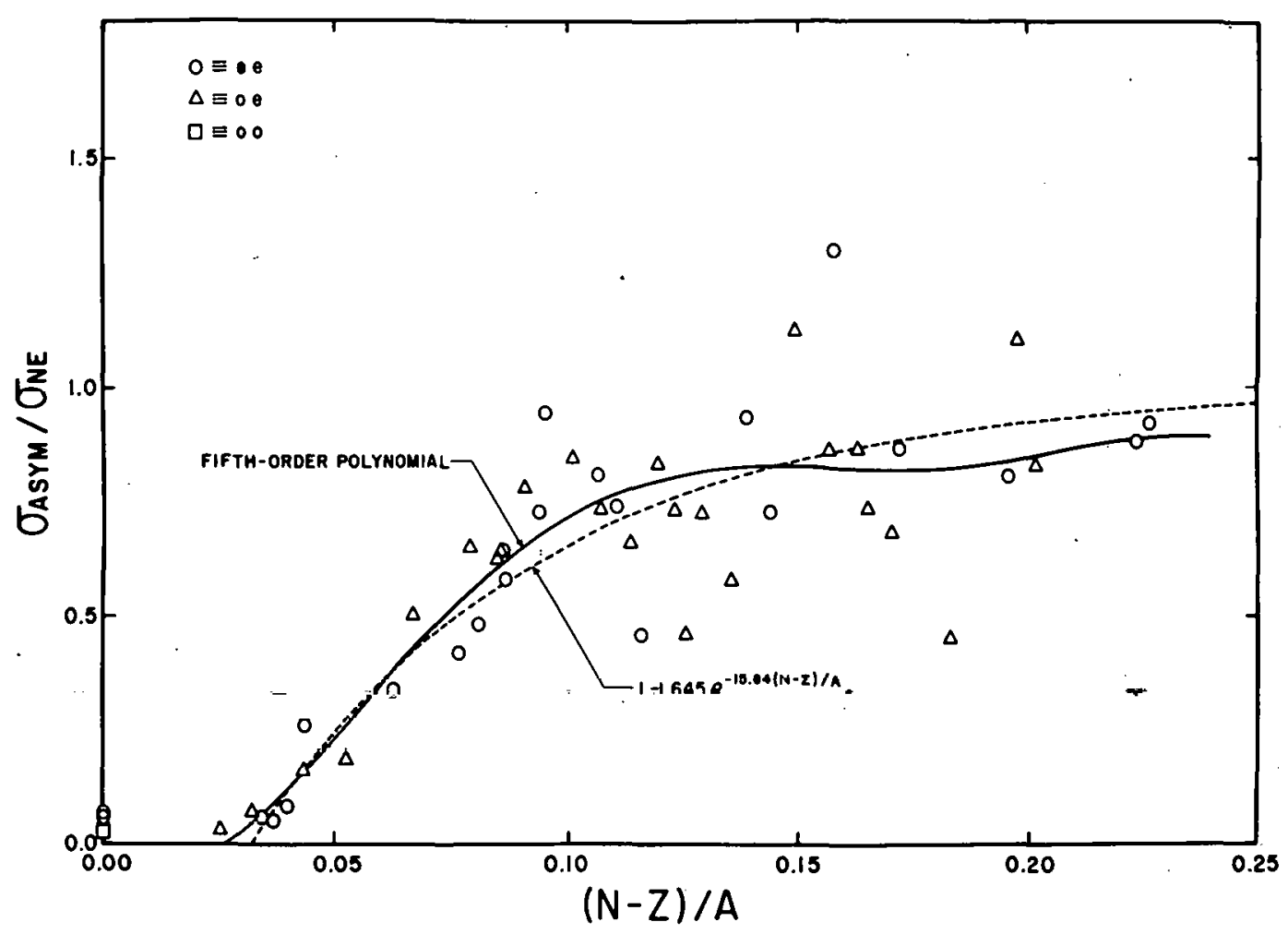

Fig. 7. $\sigma_{A S Y M} / \sigma_{\text {ne }}$ vs $(N-Z) / A$ for $T$ Fit. ANL Neg. No. 103-B11675.

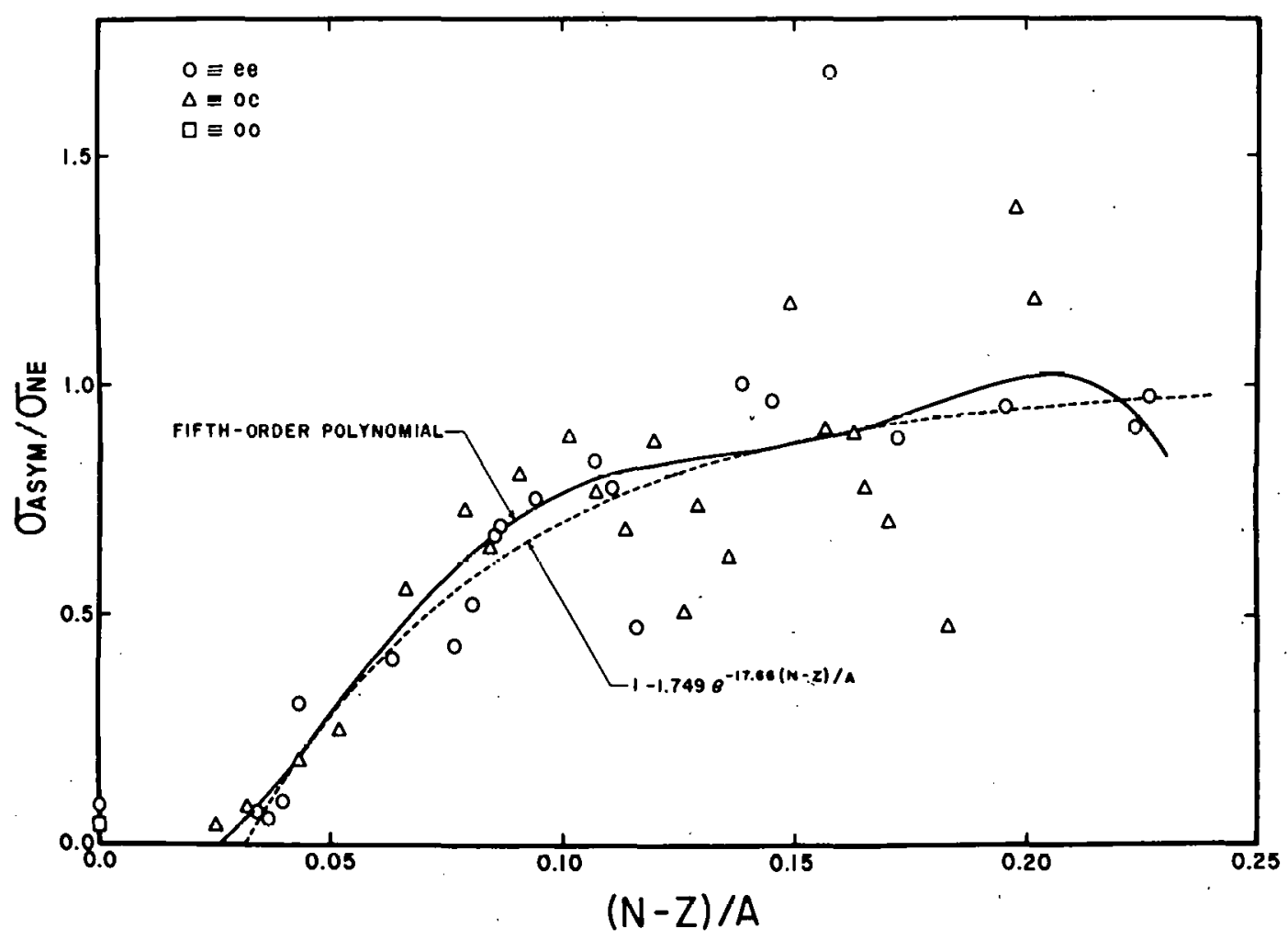

Fig. 8. $\sigma_{A S Y M} / U_{n e}$ vs $(N-Z) / A$ for $\alpha$ Fit, ANI. Neg. No. 103-B116 14 . 
In addition, for the fissionable isotopes $\mathrm{Th}^{232}$ and $\mathrm{U}^{238}$, the data quoted in Table II are exclusively for the $(n ; 2 n)$ reaction and do not allow for the effect of the competitive ( $n, n^{\prime} f$ ) reaction (which, of course, does not occur in the other isotopes). The magnitude of the cross sections for these reactions cannot be obtained accurately, but an estimate can be made by extrapolating the $(n, f)$ reaction data below the ( $\left.n, n^{\prime} f\right)$ threshold and subtracting this from: the total fission cross section. In this way, $\sigma\left(n, n^{\prime} f\right)$ for $T h^{232}$ and $U^{238}$ were estimated to be about $0.5 \mathrm{~b}$ and $0.75 \mathrm{~b}$, respectively. Addition of these values to $\sigma(n, 2 n)$ gives $\sigma$ ASYM $/ \sigma_{\text {ne }}$ ratios of about 0.9 for both isotopes.

The "best" variation of $\sigma_{\text {ASYM }} / \sigma_{\text {ne }}$ with $(N-Z) / A$ was obtained for both $T$ and $\alpha$ fits using both polynomial functions and the form of $\mathrm{Eq}$. 7 . The polynomial form was used first because it is the most objective fit to the data, but it has the disadvantage of possibly introducing fluctuations in the fitted curve that are not real. In all instances, the cases that were believed to be inapplicable (that is, $\mathrm{Rh}^{103}, \mathrm{Tm}^{169}, \mathrm{Th}^{232}$, and $\mathrm{U}^{238}$ ) were excluded from the fits.

Two forms of weighting the data were used: first, the assigned errors, and second, the effective number of measurements that contributed to each point. This procedure was adopted because the assigned errors are frequently likely to be inaccurate, and the alternative weighting assumes that all individual measurements are of equal accuracy. Hopefully, the choice of weights is not too important, and this is seen to be the case here. The final fits chosen here were made on the basis of the assigned errors.

As can be seen from Figs. 7 and 8 , the data are consistent with a constant value of $\sigma_{\text {ASYM }} / \sigma_{\text {ne }}$ for $(N-Z) / A$ values below about 0.035 , but the lack of data between 0.00 and 0.025 does not allow the curve to be defined in this region. Also, as discussed in Sec. VII, the correction for the decrease in $\sigma_{n e}$ with increasing energy is so large for the nuclei of low mass that the data for $\mathrm{C}^{12}, \mathrm{~N}^{14}$, and $\mathrm{O}^{16}$ are not believed to be accurate, although there is little doubt that the values given in Table II for these isotopes are approximately correct. For this reason, the data were fitted excluding the values at zero $(N-Z) / A$.

Significantly better fits were obtained when the one additional lowest $(\mathrm{N}-\mathrm{Z}) / \mathrm{A}$ point $\left(\mathrm{K}^{39}\right)$ was also rejected; this is some indication that the smooth correlation deviates at the very lowest values of the neutron excess parameter. The data for $\mathrm{K}^{39}$ were not included in the best fits. Polynomials of increasing order were fitted, and the fit improved up to the fifth order, at which a good fit was obtained. Even with the fifth-order fit, some fluctuations are observed at high $(\mathrm{N}-\mathrm{Z}) / \mathrm{A}$ that are attributable to only a few experimental points, and are probably not real, while higher-order fits produced even larger effects.

The best fits of the form of Barr, Browne, and Gilmore were 


$$
\frac{\sigma_{\text {ASYM }}}{\sigma_{\text {ne }}}=1-(1.645 \pm 0.084) \exp \left[-(15.64 \pm 1.09) \frac{\mathrm{N}-\mathrm{Z}}{\mathrm{A}}\right]
$$

for the $T$ fit, and

$$
\frac{\sigma_{\text {ASYM }}}{\sigma_{\text {ne }}}=1-(1.749 \pm 0.104) \exp \left[-(17.66 \pm 1.33) \frac{\mathrm{N}-\mathrm{Z}}{\mathrm{A}}\right]
$$

for the $\alpha$ fit. The coefficients for the latter fit are close to those obtained for Barr, Browne, and Gilmore (Eq. 3).

These are in good agreement with the polynomial fits (Figs. 7 and 8) and are, we believe, the best definitions of the variation of $\sigma_{\text {ASIM }} / \sigma_{11} n h=$ tainable from the existing data. We believe that the experimental points that deviate greatly from these curves are most probably the result of experimental errors, but the only way to determine this is to obtain more ar.urate. e.xperimental data. Clearly, the accuracy of the fittcd curves cannot be estimated with any reliability, but we believe there is no strong evidence that deviations from the smooth variation of $\sigma_{A S Y M} / \sigma_{n e}$ with $(N-Z) / A$ are larger than the experimental errors.

Some indication of the relative quality of the $T$ and $\alpha$ fits can be inferred from these data. Examination of the $\sigma_{\text {ASYM }} / \sigma_{n e}$ data in Tables I and II shows that, when more than one measurement has been made, the spread of these values is always larger for $\alpha$ fits than for $T$ fits. Similarly, the as signed errors for $\alpha$ fits. in Table II are always larger than for $T$ fits. The clear implication is that the constant-temperature model gives a better fit than the level-density formulation used here, but both functions fit the experimental data within the errors.

\section{SYSTEMATICS OF T AND $\alpha$ DAT A}

In order to examine the systematics of the $\mathrm{T}$ and $\alpha$ parameters, we have assembled the best values of these data in Table III. These a re taken from Table I and are the weighted or a rithmetic means where more than one measurement is applicable, and are the single result where this is all that is available.

The derived quantities $T \sqrt{\mathrm{A}}$ and $\alpha / \mathrm{A}$ (where $\mathrm{A}$ is the mass number of the target nucleus) are also given in Table III, since these quantities might be expected to be constant if statistical models of the nuclei are applicable.

Data for the lightest nuclei-- $\mathrm{C}^{12}, \mathrm{~N}^{14}$, and $\mathrm{O}^{16}$ - -have not been included because we believe that the allowance for the energy variation of the nonelastic cross section is so large that the derived parameters are poorly established. 
TABLE III. Systematics of $T$ and $\alpha$ Parameters ${ }^{a}$

\begin{tabular}{|c|c|c|c|c|c|c|c|c|c|c|}
\hline \multirow{2}{*}{$\begin{array}{l}\text { Isotope } \\
\mathrm{N} \times \mathrm{A} \\
\mathrm{Z}\end{array}$} & \multirow{2}{*}{\multicolumn{2}{|c|}{$\begin{array}{l}\text { Magic } \\
\text { Number } \\
(\mathrm{N} \text { or } \mathrm{Z}) \\
\end{array}$}} & \multicolumn{4}{|c|}{$T$ Fit } & \multicolumn{4}{|c|}{$a$ Fit } \\
\hline & & & $\mathrm{T}(\mathrm{MeV})$ & $\Delta \mathrm{T}$ & $\mathrm{T} \sqrt{\mathrm{A}}$ & $\Delta \mathrm{T} \sqrt{\mathrm{A}}$ & $a\left(\mathrm{MeV}^{-1}\right)$ & $\Delta a$ & $a / A$ & $\Delta a / A$ \\
\hline${ }_{9}^{10} F^{19}$ & & & 2.770 & 0.084 & 12.07 & 0.37 & 1.063 & $0: 104$ & 0.0559 & 0.0055 \\
\hline$\frac{12}{1} \mathrm{Na}^{23}$ & & & 1.854 & 0.057 & 8.89 & 0.27 & 3.463 & 0.252 & 0.1505 & 0.0109 \\
\hline${ }_{15}^{16} \mathrm{P}^{31}$ & & . & 1.909 & 0.133 & 10.63 & 0.74 & 3.439 & 0.506 & 0.1109 & 0.0163 \\
\hline${ }_{19}^{20} K^{39}$ & $\mathrm{~N}$ & 20 & 2.263 & 0.196 & 14.13 & 1.22 & 2.061 & 0.423 & 0.0528 & 0.0108 \\
\hline $2{ }_{2}^{4} \mathrm{Sc}^{45}$ & & & 1.420 & 0.358 & 9.53 & 2.40 & .7 .424 & 3.678 & 0.1650 & 0.081 .7 \\
\hline${ }_{22}^{2}{ }_{2}^{4} \mathrm{Ti}^{46}$ & & & 2.050 & 0.314 & 13.90 & 2.13 & 3.593 & 1.378 & 0.0781 & 0.0300 \\
\hline $26{ }_{4} \mathrm{Cr}^{50}$ & & . & 1.778 & 0.111 & 12.57 & 0.78 & 4.129 & 0.493 & 0.0826 & $0: 0099$ \\
\hline $2 \frac{28}{4} \mathrm{Cr}^{52}$ & $\mathrm{~N}$ & 28 & 1.131 & 0.075 & 8.16 & 0.54 & 1.0 .374 & 1.688 & 0.1995 & .0 .0325 \\
\hline $\begin{array}{l}30 \\
25 \\
\mathrm{Mn}^{55}\end{array}$ & & & 1.279 & 0.024 & 9.49 & 0.18 & 7.341 & 0.273 & 0.1334 & 0.0050 \\
\hline${ }_{26}^{28} \mathrm{Fe}^{54}$ & $\mathrm{~N}$ & 28 & 1.284 & 0.088 & 9.44 & 0.65 & $4.77 \cdot 3$ & 0.912 & 0.0884 & 0.0169 \\
\hline${ }_{27}^{32} \mathrm{Co}^{59}$ & & & 1.190 & 0.014 & 9.14 & 0.11 & 8.622 & 0.156 & 0.1461 & 0.0026 \\
\hline${ }_{28}^{3} \mathrm{Ni}^{58}$ & $Z$ & 28 & 1.407 & 0.033 & 10.72 & 0.25 & 6.191 & 0.294 & 0.1067 & 0.0051 \\
\hline${ }_{29}^{34} \mathrm{Cu}^{63}$ & & · & 1.767 & 0.017 & 14.03 & 0.13 & 3.544 & 0.090 & 0.0563 & 0.0014 \\
\hline${ }_{29}^{36} \mathrm{Cu}^{65}$ & & & 1.305 & 0.015 & 10.52 & 0.12 & 6.847 & 0.212 & 0.1053 & 0.0033 \\
\hline${ }_{30}^{34} \mathrm{Zn}^{64}$ & & & 2.307 & 0.032 & 18.46 & 0.26 & 1.888 & 0.081 & 0.0295 & 0.0013 \\
\hline${ }_{30}^{36} \mathrm{z}_{\mathrm{n}} 66$ & & & 1.427 & 0.052 & 11.59 & 0.42 & 6.326 & 0.434 & 0.0958 & 0.0066 \\
\hline${ }_{31}^{38} \mathrm{Ga}^{69}$ & & & 1.401 & 0.080 & 11.64 & 0.66 & 6.192 & 0.731 & 0.0897 & 0.0106 \\
\hline${ }_{31}^{40} \mathrm{Ga}^{71}$ & & & 0.837 & 0.085 & 7.05 & 0.72 & 18.383 & 4.070 & 0.2589 & 0.0573 \\
\hline${ }_{32}^{38} \mathrm{Ge}^{70}$ & & & 1.263 & 0.034 & 10.57 & 0.28 & 7.850 & 0.452 & 0.1121 & 0.0065 \\
\hline${ }_{32}^{44} \mathrm{Ge}^{76}$ & & & 1.761 & 0.100 & 15.35 & 0.87 & 2.792 & 0.434 & 0.0367 & 0.0057 \\
\hline${ }_{3}^{4} \mathrm{As}^{75}$ & & & 1.286 & 0.038 & 11 & 0.33 & 7.034 & 0.543 & 0.0938 & 0.0072 \\
\hline $34 \mathrm{Se}^{71}$ & & & 1.264 & 0.058 & 10.87 & 0.50 & 8.180 & 0.803 & 0.1105 & 0.0109 \\
\hline $35 \mathrm{Br}^{79}$ & & & 1.160 & 0.044 & 10.31 & 0.39 & 8.761 & 25 & 0.1109 & 0.0104 \\
\hline $36 \mathrm{Br}^{81}$ & & & 1.389 & 0.102 & $12.50^{\circ}$ & 0.92 & 5.827 & 0.976 & 0.0719 & 0.0120 \\
\hline${ }_{37}^{48} \mathrm{Rb}^{85}$ & & & 1.124 & 34 & 36 & .0 .31 & 17 & 0.712 & 0.1120 & 0.0084 \\
\hline${ }_{37}^{50} \mathrm{Rb}^{87}$ & $\mathrm{~N}$ & 50 & 1.108 & 0.057 & 10.33 & 0.53 & 9.153 & 1.094 & 0.1052 & 0.0125 \\
\hline${ }_{38}^{46} \mathrm{Sr}^{84}$ & & & 1.013 & 0.029 & 9.28 & 0.27 & 11.293 & 0.833 & 0.1344 & 0.0099 \\
\hline${ }_{38}^{48} \mathrm{Sr}^{86}$ & & & 1.003 & 0.044 & 9.30 & 0.41 & 12.818 & 1.072 & 0.1490 & 0.0125 \\
\hline${ }_{39}^{50} Y^{89}$ & N & 50 & 1.148 & 0.032 & 10.83 & 0.30 & 8.460 & 0.592 & 0.0951 & 0.0067 \\
\hline${ }_{1,0}^{50} \mathrm{Zr}^{90}$ & $\mathrm{~N}$ & 50 & 1.104 & 0.025 & 10.47 & 0.24 & 10.398 & 0.433 & 0.1155 & 0.0048 \\
\hline${ }_{42}^{50} \mathrm{Mn}^{92}$ & $\mathrm{~N}$ & 50 & 1.838 & 0.084 & 17.63 & 0.81 & 2.258 & 0.344 & 0.0245 & 0.0037 \\
\hline
\end{tabular}


TABLE III. (Contd.)

\begin{tabular}{|c|c|c|c|c|c|c|c|c|c|}
\hline \multirow{2}{*}{$\begin{array}{c}\text { Isotope } \\
\mathrm{N} \text { X } \\
\mathrm{Z}\end{array}$} & \multirow{2}{*}{$\begin{array}{l}\text { Magic } \\
\text { Number } \\
(\mathrm{N} \text { or } \mathrm{Z}) \\
\end{array}$} & \multicolumn{4}{|c|}{ T Fit } & \multicolumn{4}{|c|}{$a$ Fit } \\
\hline & & $\mathrm{T}(\mathrm{MeV})$ & $\Delta \mathrm{T}$ & $\mathrm{T} \sqrt{\mathrm{A}}$ & $\Delta \mathrm{T} \sqrt{\mathrm{A}}$ & $\underline{a}\left(\mathrm{MeV}^{-1}\right)$ & $\Delta a$ & $a / A$ & $\Delta a / A$ \\
\hline${ }_{44}^{52} \mathrm{Ru}^{96}$ & & 1.191 & 0.059 & 11.67 & 0.58 & 8.745 & 1.062 & $0.0911^{\circ}$ & 0.0111 \\
\hline${ }_{44}^{60} \mathrm{Ru} 104$ & & 1.072 & 0.089 & 10.93 & 0.91 & 10.144 & 1.867 & 0.0975 & 0.0180 \\
\hline $\begin{array}{l}58 \\
45\end{array}$ & & 1.142 & 0.033 & 11.59 & 0.33 & 6.960 & 0.491 & 0.0675 & 0.0048 \\
\hline${ }_{46}^{36} \mathrm{Pd} 102$ & & 1.082 & 0.073 & 10.93 & 0.74 & 10.594 & 1.621 & 0.1039 & 0.0159 \\
\hline${ }_{46}^{64} \mathrm{Pd} 110$ & & 1.186 & 0.097 & 12.44 & 1.02 & 7.854 & 1.271 & 0.0714 & 0.0116 \\
\hline${ }_{48}^{58} \mathrm{Cd}^{106}$ & & 1.083 & 0.074 & 11.15 & 0.76 & 9.271 & 1.417 & 0.0875 & 0.0134 \\
\hline${ }_{48}^{6} \mathrm{Cd}^{116}$ & & 0.933 & 0.076 & 10.05 & 0.82 & 13.224 & 2.362 & 0.1140 & 0.0204 \\
\hline${ }_{49}^{64} I^{1} 13$ & & 1.159 & 0.220 & 12.32 & 2.34 & 9.254 & 3.936 & 0.0819 & 0.0348 \\
\hline${ }_{44}^{66} \operatorname{In}^{115}$ & & 1.021 & 0.161 & 10.95 & 1.73 & 12.047 & 4.273 & 0.1048 & 0.0372 \\
\hline${ }_{50}^{6} \mathrm{Sn} 112$ & 250 & 0.991 & 0.035 & 10.49 & 0.37 & 10.798 & 0.894 & 0.0964 & U. $0080^{\circ}$ \\
\hline${ }_{51}^{70} \mathrm{Sb}^{121}$ & & 1.325 & 0.069 & 14.58 & 0.76 & 6.463 & 0.701 & 0.0534 & 0.0058 \\
\hline $72 \frac{2}{1} \mathrm{Sb}^{123}$ & & 1.163 & 0.087 & 12.90 & 0.96 & 8.228 & 1.369 & 0.0669 & 0.0111 \\
\hline${ }_{52}^{16} \mathrm{Te}^{128}$ & & 1.462 & 0.122 & 16.54 & 1.38 & 4.903 & 1.052 & 0.0383 & 0.0082 \\
\hline${ }_{52}^{78} \mathrm{Te}^{130}$ & & 1.271 & 0.159 & 14.49 & 1.81 & 6.811 & 2.042 & 0.0542 & 0.0157 \\
\hline $\begin{array}{l}74 \\
53\end{array}$ & & 1.306 & 0.064 & 14.72 & 0.72 & 5.696 & 0.716 & 0.0449 & 0.0056 \\
\hline${ }_{55}^{18} \mathrm{Cs}^{133}$ & & 1.687 & 0.065 & 19.46 & 0.75 & 3.688 & 0.254 & 0.0277 & 0.0019 \\
\hline${ }_{58}^{82} \mathrm{Ce}^{140}$ & N 82 & 1.232 & 0.079 & 14.58 & 0.93 & 7.893 & $1.13 y$ & 0.0564 & 0.0081 \\
\hline${ }_{59}^{82} \operatorname{Pr}^{141}$ & N 82 & 1.188 & 0.063 & 14.11 & 0.75 & 8.194 & 0.929 & 0.0581 & 0.0066 \\
\hline $\begin{array}{l}02 \mathrm{Nd}^{1 / 2} \\
60^{1 / 2}\end{array}$ & IN 82 & 1.282 & 0.055 & 15.28 & 0.66 & $\% .339$ & ก.65.5 & 0.0517 & 0.0046 \\
\hline${ }_{62}^{82} \mathrm{Sm}^{144}$ & N 82 & 1.405 & 0.057 & 16.86 & 0.68 & 5.617 & U.נ & 0.0390 & 0.0040 \\
\hline${ }_{6 y}^{100} \operatorname{Tm} 169$ & & 1.122 & 0.066 & 14.59 & 0.86 & 7.225 & 1.065 & 0.0428 & 0.0063 \\
\hline $1{ }_{7}^{0}{ }_{8} \mathrm{Pt}^{198}$ & & No & Fit & No & Pit & 6.089 & 0.373 & 0.0308 & 0.0019 \\
\hline $118 \mathrm{Au} 197$ & & 1.787 & 0.149 & 25.08 & 2.09 & 2.215 & 0.524 & 0.0112 & 0.0027 \\
\hline $122 \mathrm{~T}^{203}$ & & 2.283 & 0.270 & 32.53 & 3.85 . & 1.155 & 0.421 & 0.0057 & 0.0021 \\
\hline $12 \frac{2}{82} \mathrm{~Pb}^{204}$ & Z 82 & 1.584 & 0.106 & 22.62 & 1.51 & 1.827 & 0.250 & 0.0090 & 0.0012 \\
\hline
\end{tabular}

${ }^{\mathrm{a}} \mathrm{C}^{12}, \mathrm{~N}^{14}, \mathrm{O}^{16}, \mathrm{Th}^{232}$, and $\mathrm{U}^{238}$ data are excluded; see Text.

Data have also been excluded for $T^{232}$ and $U^{238}$, since the $\left(n, n^{\prime} f\right)$ reaction is competitive with the $(n, 2 n)$ reaction for these nuclei; thus the analys is of the $(n, 2 n)$ reaction alune for these nuclei cannot be expected to yield parameters consistent with those for nuclei where the fission reaction does not occur.

The data of Table III are displayed in different ways in the graphs of Figs. 9 and 10 and the histograms of Figs. 11 and 12 . In Figs. 9 and 10 , the errors have been omitted for clarity, but are generally smaller than the spread of the data points (see Table III). 


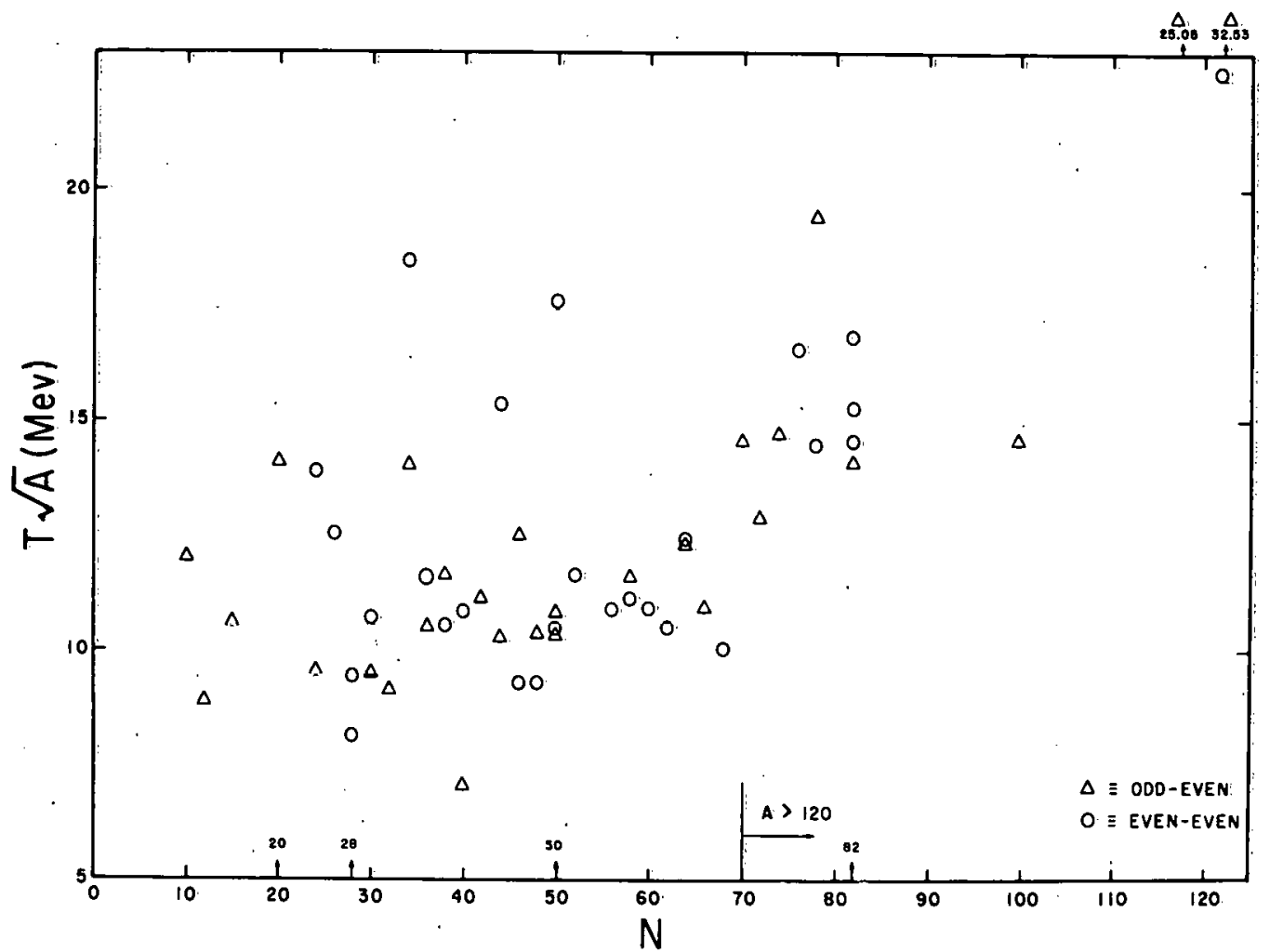

Fig. 9. $T \sqrt{\mathrm{A}}$ vs N. ANL Neg. No. 103-B11670.

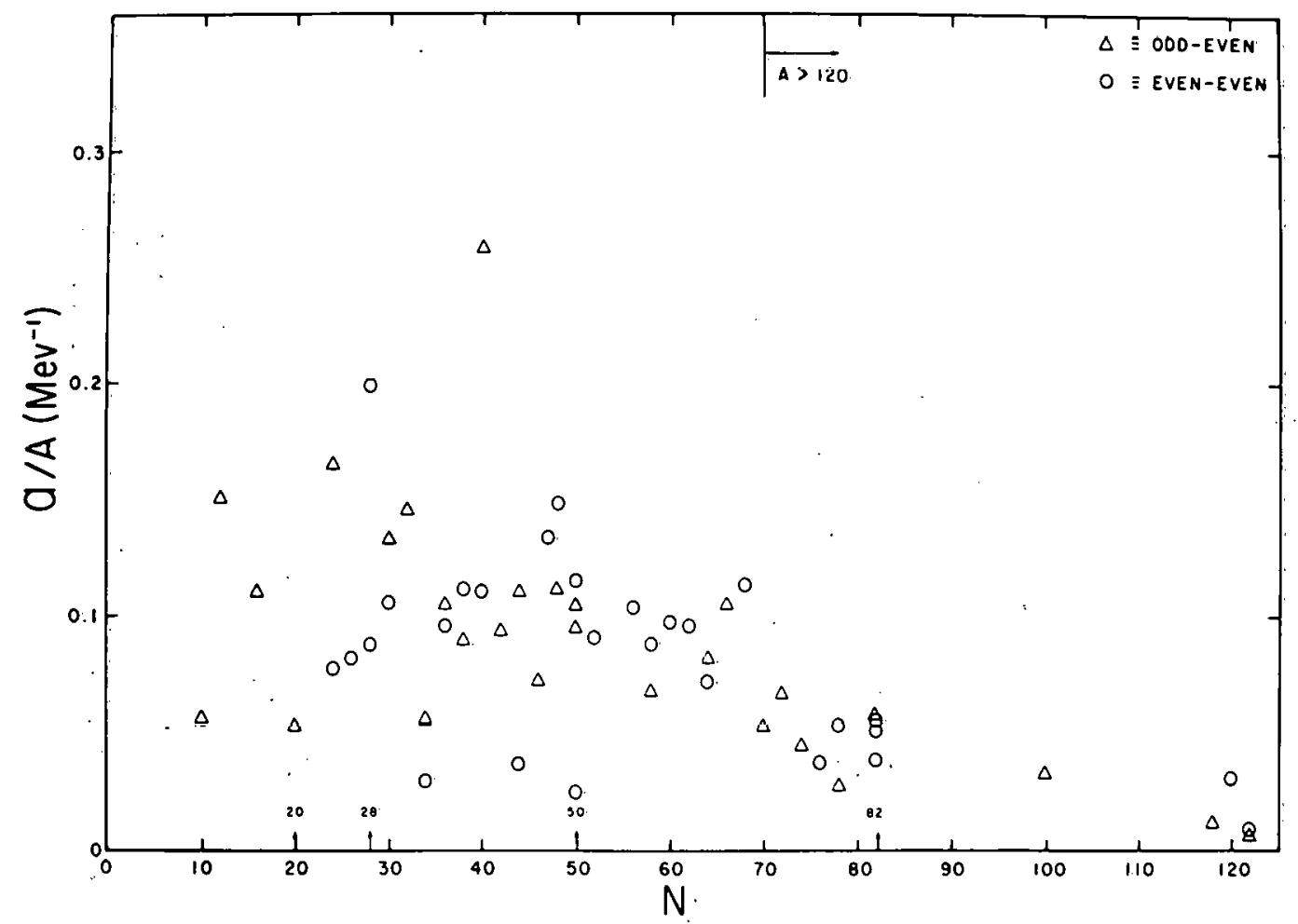

Fig. 10. $\alpha /$ A vs N. ANL Neg. No. 103-B11671. 
$\underline{A<120}$
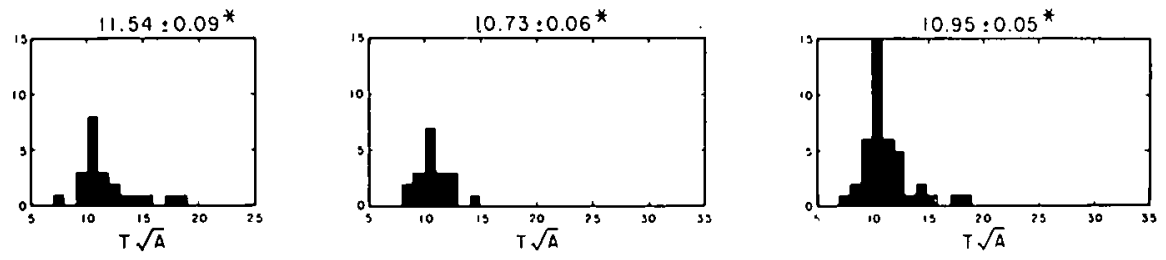

$\underline{A}>120$

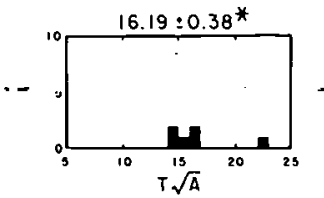

EVEN-EVEN NUCLE I

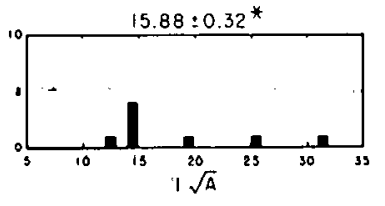

ODD-EVEN NUCLE!

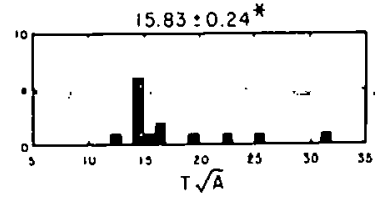

ALL NUCLEI

* weighted means

Fig. 11. Distribution of $T \sqrt{A}$ for Nuclei with $A \gtrless 120$. ANL Neg. No. 103-B11673.

$$
\underline{A}<120
$$
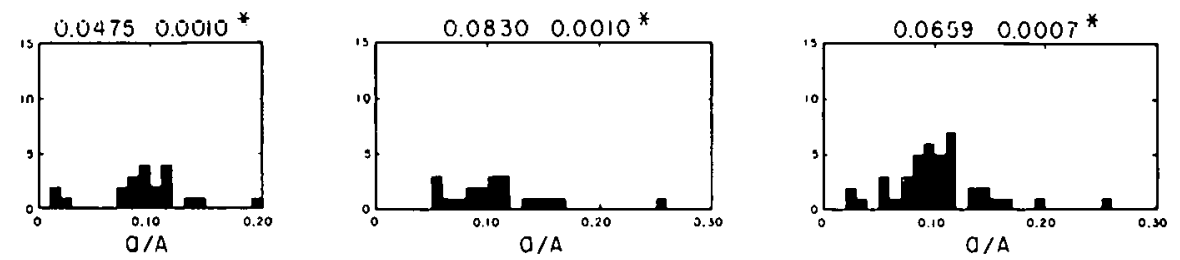

$\underline{A}>120$
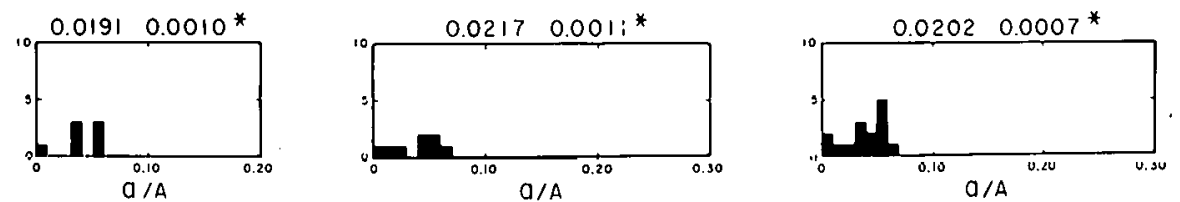

ALL NUCLEI

* weighted means

Fig. 12. Distribution of $\alpha / A$ for Nuclei with $A \gtrless 120$. ANL Neg. No. 103-B11672. 
These four figures are largely self-explanatory, but we will list the major inferences from these data.

1. There is no evidence of differences in the systematics of odd-even and even-even nuclei.

2. As anticipated, there is a reasonable trend to constancy of $T \sqrt{\mathrm{A}}$ and $\alpha / \mathrm{A}$, and this is much more clearly defined if the results are divided into those for nuclei less than and greater than mass 120 . These trends are more clearly seen in the histograms (Figs. 11 and 12).

3. The spread of data for the constant-temperature fit is smaller than for the $\alpha$ fit; this supports the conclusion reached from the $\sigma_{\mathrm{ASYM}} / \sigma_{\text {ne }}$ data (Sec. VI) that the constant-temperature model is a better fit.

4. For $\mathrm{A}<120$, the approximate constancy of $\mathrm{T} \sqrt{\mathrm{A}}$ is clear. The distribution appears to be somewhat asymmetric about a weighted mean value of $10.95 \pm 0.05$ (where the errors in the separate values are used to determine the error), and about two-thirds of the data points lie in the range $11.0 \pm 1.5$. This spread in $\mathrm{T} \sqrt{\mathrm{A}}$ probably principally represents the real spread in this parameter for different nuclei, rather than the consequences of experimental errors. Thus, if precise data are needed for a given nucleus, they must be obtained by measurement rather than from the systematics.

5. For $\mathrm{A}>120$, the values of $\mathrm{T} \sqrt{\mathrm{A}}$ are again approximately constant, but at a higher value than for $A<120$. The statistics, however, are poor, and

TABLE IV. Systematics of $T \sqrt{A}$ and $\alpha / A$ for Magic-number Target Nuclei

\begin{tabular}{|c|c|c|c|c|c|c|}
\hline $\begin{array}{l}\text { Isotope } \\
\mathrm{N} \times A \\
\mathrm{Z}\end{array}$ & $\mathrm{N}$ or $\mathrm{Z}$ & $\begin{array}{l}\text { Magic } \\
\text { Number }\end{array}$ & $\mathrm{T} \sqrt{\mathrm{A}}$ & Error & $a / A$ & Error \\
\hline${ }_{1}^{2}{ }_{y} K^{39}$ & $\mathrm{~N}$ & 20 & 14.13 & 1.22 & 0.0528 & 0.0108 \\
\hline${ }_{24}^{28} \mathrm{Cr}^{52}$ & $N$ & 28 & 8.16 & 0.54 & 0.1995 & 0.0325 \\
\hline${ }_{26}^{28} \mathrm{Fe}^{54}$ & $\mathrm{~N}$ & 28 & $9 . \dot{4} 4$ & 0.65 & 0.0884 & 0.0169 \\
\hline${ }_{28}^{30} \mathrm{Ni}^{58}$ & $z$ & 28 & 10.72 & 0.25 & 0.1067 & 0.0051 \\
\hline${ }_{37}^{50} \mathrm{Rb}^{8 \%}$ & $\mathrm{~N}$ & 50 & 10.33 & 0.53 & 0.1052 & 0.0125 \\
\hline $\begin{array}{l}50 Y^{89} \\
39\end{array}$ & $\mathrm{~N}$ & 50 & 10.83 & 0.30 & 0.0951 & 0.0067 \\
\hline${ }_{40}^{50} \mathrm{Zr}^{90}$ & $\mathrm{~N}$ & 50 & 10.47 & 0.24 & 0.1155 & 0.0048 \\
\hline $\begin{array}{l}50 \mathrm{Mo}^{92} \\
42^{2}\end{array}$ & $N$ & 50 & 17.53 & 0.81 & 0.0245 & 0.0037 \\
\hline${ }_{50}^{62} \mathrm{Sn}^{112}$ & $z$ & 50 & 10.49 & 0.37 & 0.0964 & 0.0080 \\
\hline${ }_{58}^{82} \mathrm{Ce}^{140}$ & $N$ & 82 & 14.58 & 0.93 & 0.0564 & 0.0081 \\
\hline${ }_{59}^{82} \mathrm{Pr}^{141}$ & $N$ & 82 & 14.11 & 0.75 & 0.0581 & 0.0066 \\
\hline${ }_{60}^{82} \mathrm{Nd}^{142}$ & $N$ & 82 & 15.28 & 0.66 & 0.0517 & 0.0046 \\
\hline${ }_{62}^{82} \mathrm{Sm}^{144}$ & $\mathrm{~N}$ & 82 & 16.86 & 0.68 & 0.0390 & 0.0040 \\
\hline $\begin{array}{r}122 \\
82\end{array}$ & $z$ & 82 & 22.62 & 1.51 & 0.0090 & 0.0012 . \\
\hline
\end{tabular}

there is some evidence from the heaviest nuclei of an increase of $\mathrm{T} \sqrt{\mathrm{A}}$ with increasing $\mathrm{A}$; examination of the data in Table $I$ for these nuclei will show that the confidence that can be placed in the experiments for the heaviest nuclei is not large. In general, the scarcity of data for $A>145$ makes any conclusions hazardous for this mass range.

6. The trends indicated for $\mathrm{T} \sqrt{\mathrm{A}}$ are roughly reproduced for the $\alpha / A$ data, but the greater spread in these latter makes them much less clear.

7. The $T \sqrt{\mathrm{A}}$ and $\alpha / \mathrm{A}$ data for magic-number nuclei collected in Table IV show that there is no significant indication of shell effects in the $(n, 2 n)$ data. The values of these quantities and their spread for

a given magic number is similar to that exhibited by non-magic-number nuclei, and even if it is assumed that some effects are present, it is clear that magicnumber nuclei only sometimes show shell effects. 


\section{SUMMARY OF CONCLUSIONS}

1. Analysis shows that all the currently available energy-dependent measurements of $(n, 2 n)$ cross sections can be described within the experimental errors by the ratio of the asymptotic cross section to the nonelastic cross section, which is dependent upon the neutron-asymmetry parameter, and a level-density parameter (temperature), which is dependent on the nuclear mass.

2. For values of the neutron-asymmetry parameter (N - Z)/A greater than about 0.03 , the best description of the asymptotic cross section is given by

$$
\frac{\sigma_{\text {ASYM }}}{\sigma_{\text {ne }}}=1-(1.645 \pm 0.084) \exp \left[-(15.64 \pm 1.09) \frac{\mathrm{N}-\mathrm{Z}}{\mathrm{A}}\right]
$$

for the constant-temperature model and

$$
\frac{\sigma_{\text {ASYM }}}{\sigma_{\text {ne }}}=1-(1.749 \pm 0.104) \exp \left[-(17.66 \pm 1.33) \frac{N-Z}{A}\right]
$$

for a simple level-density formulation.

3. Both models fit the experimental data adequately, but the constanttemperature model is significantly better since it gives less spread in the derived parameters.

4. The mass dependence of the nuclear temperature $T$ is well described by a nominally constant value of $T \sqrt{\mathrm{A}}$ of 11.0 for nuclei of mass $<120$, but the spread of this parameter is significant. The distribution is probably asymmetric, but two-thirds of the data points lie in the range $11.0 \pm 1.5$. This spread probably indicates the real variation in $T \sqrt{\mathrm{A}}$ for different nuclei rather than the experimental errors in the cross-section measurements.

5. For nuclei of $\mathrm{A}>120$, the mean value of $\mathrm{T} \sqrt{\mathrm{A}}$ is clearly higher, and the weighted mean is about 16 for the cases studied. There is some indication that $\mathrm{T} \sqrt{\mathrm{A}}$ increases with increasing $\mathrm{A}$ (for $\mathrm{A}>120$ ), but the evidence is not good, and in general, data are very limited for $A>145$.

6. There is no evidence of different systematics for odd-even and even-even nuclei.

7. There is no evidence for any significant magic-number effects. 


\section{APPENDIX A}

\section{List of Data References}

A 59 ARGMA-TN-ICIN-23 (1959)

U. S. Army Rocket \& Guided Missile Division.

A 64 D. M. Arnold and L. A. Rayburn, Bull. Am. Phys. Soc. 9,352 (1964).

A 65 D. M. Arnold, Dis. Abs. 26, 3425 (1965).

A 68 M. F. Andreev and V.I. Serov, Soviet J. Nucl. Phys. 7; 454455 (1968).

A 69 A. Abboud, P. Decowski, W. Grochulski, A. Marcinkowski, J. Piotowski, K. Siwek, and Z. Wilhelmi, Nucl. Phys. 139, $42-56$ (1969).

A. Abboud, P. Decowski, W. Grochulski, A. Marcinkowski, K. Siwek, I. Turkiewitz, and Z. Wilhelmi, INR-1147/I/PL (1969).

A 72 W. Augustyniak, J. Wierth, and A. Marcinkowski, INDC(sec)28/L, 170 (1972).

A 73 B. Anders, M. Bormann, and W. Scobel, EANDC(E)157U (1973) and private communication.

B 52 J. E. Brolley, Jr., J. L. Fowler, and L. K. Schlacks, Phys. Rev. 88, 618 (1952).

B 61, BU 61 J. P. Butler and D. C. Santry, Can. J. Chem. 39, 689 (1961).

O. D. Brill, N. A. Vlasov, S. P. Kalinin, and L. S. Sokolov, Soviet Phys. Doklady $\underline{6}, 24$ (1961).

B 62 M. Bormann, S. Cierjacks, R. Langkau, and H. Neuert; Z. Phys. 166, 477 (1962).

B 63 M. Bormann, S. Cierjacks, E. Fretwurst, K. J. Giesecke, H. Neuert, and H. Pollehn, Z. Phys. 174, l (1963).

B 65 M. Bormann, E. Fretwurst, P. Schehka, G. Wrege, H. Buttne, A. Lindner, and H. Meldner, Nucl. Phys. 63, 438 (1965).

M. Bormann, F. Dreyer, E. Fretwurst, and P. Schehka, EANDC (E)-57U, p. 17 (1965).

B 66 M. Bormann, F. Dreyer, P. Jessen, and P. Schehka, Nucl. Data 1,171 (1966).

M. Bormann, F. Dreyer, U. Seebeck, and W. Voigts, Z. Naturforsch. 21,988 (1966).

M. Bormann, F. Dreyer, and U. Zielinski, EANDC(E)-66U (1966). 


\author{
B 67 M. Bormann, C. Abels, W. Carstens, and I. Riehle, EANDC (E)- \\ 76U, p. 51 (1967); Nucl. Phys. Al15, 309-320 (1968). \\ $\mathrm{BO} 67$ \\ B 68 \\ B 69 \\ B 70 \\ B 72 \\ C 56 \\ C 61 \\ C 65 \\ C 69 \\ D 68 \\ D 70 \\ D 71 . \\ E 68 \\ F 57 \\ F 60 \\ G 62 \\ G 70 \\ H 69 \\ HO 69 \\ I 65 \\ M. Bormann and I. Riehle, Z. Phys. 207, 64 (1967). \\ M. Bormann, A. Behrendt, and O. Vogel, EANDC $(E)-89$ U, p. 59 \\ (1968); Nucl. Phys. A115, 309 (1968). \\ M. Bormann and B. Lanner, Nucl. Phys. Al30, 195-208 (1969). \\ M. Bormann, H. H. Bissen, E. Magiera, and R. Warnemunde, \\ Nucl. Phys. Al57, 48l-496 (1970). \\ M. Bormann, H. K. Fedderson, H. H. Holsche, H. Wagner, \\ and W. Scobel, EANDC(E)-150U (1972). \\ A. V. Cohen and P. H. White, Nucl. Phys. 1, 73 (1956). \\ H. C. Catron, M. D. Goldburg, R. W. Hill, J. M. LeBlanc, \\ J. F. Stoering, C. .J. Taylor, and M. A. Williamson, Phys. \\ Rev. 123,218 (1961). \\ S. Chojnacki, P. Decowski, E. Gierlik, W. Grochulski, \\ A. Marcinkowski, K. Siwek, I. Sledzinska, and Z. Wilhelmi, \\ INR $-680 / \mathrm{I} / \mathrm{PH}$ (1965). \\ I. G. Clator, Dis. Abs/B 30, 2850 (1969). \\ P. Decowski, W. Grochulski, A. Marcinkowski, K. Siwek, \\ I. Sledzinska, and Z. Wilhelmi, Nucl. Phys. 112, 513 (1968). \\ P. Decowski, W. Grochulski, A. Marcinkowski, A. Kerelyi, \\ J. Piotowski, E. Saad, K. Siwek-Wilesyski, J. M. Turkiewitz, \\ and Z. Wilhelmi, INR-1197, 18-25 (1970). \\ P. Decowski, S. El-Konsol, W. Grochulski, A. Marcinkowski, \\ J. M. Turkiewitz, and Z. Wilhelmi, INDC(sec)-18L, 199 (1971). \\ J. R. P. Eaton and J. Walker, Proc. Conf. Neutron Cross \\ Sections and Tech., Washington, D.C., NBS Spec. Pub. 299, 1, \\ 169 (1968). \\ C. J. Fisher, Phys, Rev. 108, 99 (1957). \\ W. E. Thompson and J. M. Ferguson, Phys. Rev. 118, 228 \\ (1960). \\ R. N. Glover and E. Weigold, Nucl. Phys. 29, 309 (1962). \\ W. Grochulski, J. Karelzi, A. Marcinkowski, J. Piotowski, \\ E. Saad, K. Siwek, and Z. Wilhelmi, INR-1197, 10-17 (1970). \\ M. Holmberg and J. Hansen, Nucl. Phys. Al29, 305,326 (1969). \\ M. Holmberg, Nucl. Phys. Al29, 327-330 (1969). \\ W. L. Imhoff, R. G. Johnson, and F. S. Vaughn, private com- \\ munication (1965).
}


J. 63

K 58

K 60, K 62

K 66

K 72

L 65

L 65

L 65

M 53

M 67

067

P 60

P 61

PI 65, P 65

P 65

P 65

P 66

P 70

R 63

J. H. F. Jeronymo, G. S. Mani, O. Olkowsky, A. Sadeghi, and C. F. Williamson, Núcl. Phys. 47, 157 (1963); private communication, H. D. Lemmel, IAEA, Vienna (Jüne 1969).

J. D. Knight, R. K. Smith, and B. Warren, Phys. Rev. 112, 259-261 (1958).

D. R. Koehle and W. L. Alford, Phys Rev. 119, 311 (1960), Phys. Rev. 123, 1365 (1961), ADMC-RR-TR-62-1 (1962).

J. D. Knight, private communication (1966).

Y. Kanda, Nuc1. Phys. A185, $177-195$ (1972).

A. Paulsen and H. Liskien, Nukleonik 7, 117 (1965).

H. Liskien and A. Paulsen, Nucl. Phys. 63, 39.3 (1965); private communication via BNL SIGMA Center at $\mathrm{E}_{\mathrm{N}}>17 \mathrm{MeV}$.

H. Liskien and A. Paulsen, J. Nucl. Energy A/B 19, 73. (1965).

H. C. Martin and R. F. Taschek, Phys. Rev. 89, 1302 (1953).

H. O. Menlove, K. L. Coop, and H. A. Grench, Phys. Rev. 163, 1308 (1967).

S. Okumura, Nucl. Phys. A93, 74-80 (1967).

J. T. Prud'homme, I. L. Morgan, J. H. McCrary, J. B. Ashe, and O. M. Mudson, Jr., AFSWC-TR-60-30, Bull. Am. Phys. Soc. $\underline{5}, 246$ (1960).

R. J. Prestwood and B. P. Bayhurst, Phys. Rev. 121, 1438 (1961).

J. Picard and C. F. Williamson, Nucl. Phys. 63, 673 (1.965).

J. Picard and C. F. Williamson, Nukleonik 2, 117 (1965).

A. Paulsen and H. Liskien, J. Nucl. Energy Parts A/B 19, 907 (1965).

H. L. Pai, Can. J. Phys: 44, 2337 (1966).

P. Decowski, W. Grochulski, H. Marcinkowski, K. Siwek, I. Sledzinska, and Z. Wilhelmi, INR-668/I/PH (1965).

A. Paulsen and R. Widera, Z. Phys. 238, 23-34 (1970).

L. A. Rayburn, private communication to BNL SIGMA Center (1963); Bull. Am. Phys. Soc. 7, 335 (1962).

L. A. Rayburn, Phys. Rev. 130, 731 (1963).

L. A. Rayburn, Bull. Am. Phys. Soc. 8, 121 (1963).

L. A. Rayburn, Bull. Am. Phys. Soc. 8, 121 (1963).

S 66

D. C. Santoy and J. P. Butler, Can. J. Phys. 44, 1183 (1966). 
S 70 E. Steiner, P. Huber, W. Salathe, and R. Wagner, Helv. Phys. Act. $43,7(1970)$.

T 60

H. A. Tewes, A. A. Caretto, A. E. Miller, and D. R. Nethaway, UCRL-6028-T. (1960).

V 68

H. K. Vonach, W. E. Vonach, H. Munze, and P. Schramel, Proc. Conf. Neutron Cross Sections and Tech., Washington, D.C., NBS Spec. Pub. 299, 2, 885 (1968).

W 61

C. Williamson and J. D. Picard, J. Phys. Radium.22, 651 (1961).

W 65 R. Wagner, W. M. Good, and D. Paya, Nuclear Structure Study with Neutrons, Antwerp, P/99 (1965).

Z 61 Yu. G. Zubov, N. S. Lebedeva, and M. Morozov, Soviet Prog. Nucl. Phys., p. 219 (1961). 
APPENDIX B

(n, 2n) Cross - section Data, Fitted to Constanttemperature Model and to Level-density Model 


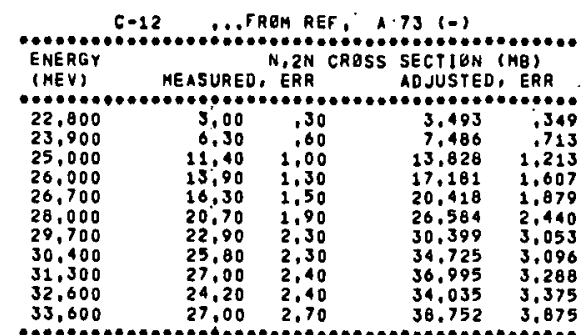

\section{FITTED PARAMETERS}

NUCLEAR TEMP. 6.173 PLUS-OR-HINUS, 750 MEV

ASYMPTBTIC (N, 2N) CROSS SECTION : 66,53 PLUS-RR-MINISS 10,52 ME

RELATED DATA

NON-ELASTIC CROSS SECTION AT 14,2 MEY * 660.31 MB

$(N, 2 N)$ THRESHELD: 20,28 MEV
$(N, 3 N)$ THRESHELD 34,50 MEV

THIS ISOTOPE HAS 6 NEUTRONS, G PRBTUNS, (MASS, 12)

NEUTRON EXCESS PARAMETER - .00000

RATIO OO ASYMPTOTIC (N,2N) TO 14,2 MEV NON-ELASTIC , 1000 PLUSABK-HINUS , 0150

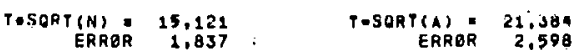

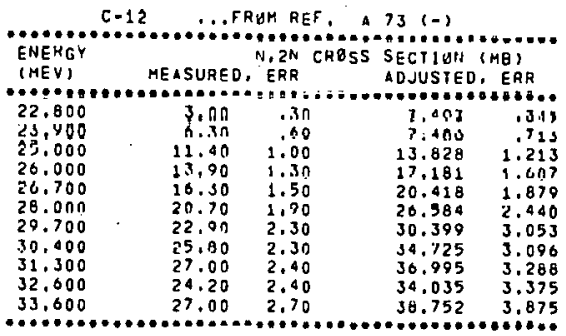

TITTED PARAMETERS
LEVEL SPACING
LOEYO . 339 PLUS-6R-MINUS .137PER MEV

ASYMPTOTIC (N, ZN, CHESS SECPION = 111.29 PLUS-ER-MINUS 33.55 MG

RELATED DATA

NÖN-ELASPIC CFASS SECTION AT 14.2 MEV $=660.31 \mathrm{MB}$

$(N, 2 M)$ THFESHQLD $=20,28 \mathrm{MEV}$

(N, $3 N)$ THEESHPLD - 34,50 MEV

THIS ISOTGPE MAS O NEUTRENS, G PROTUNS, (MASS = 121

NEUTRON EXCESS PARAMETER ; .00000

RATIO UF ASYAPIOTIC (N.2A) TO 14,2 MEV NON-ELASTIC 1885 PLUS-DR-MINUS , OADA

N/SPACING $=$
ERALR
7.699
7.153
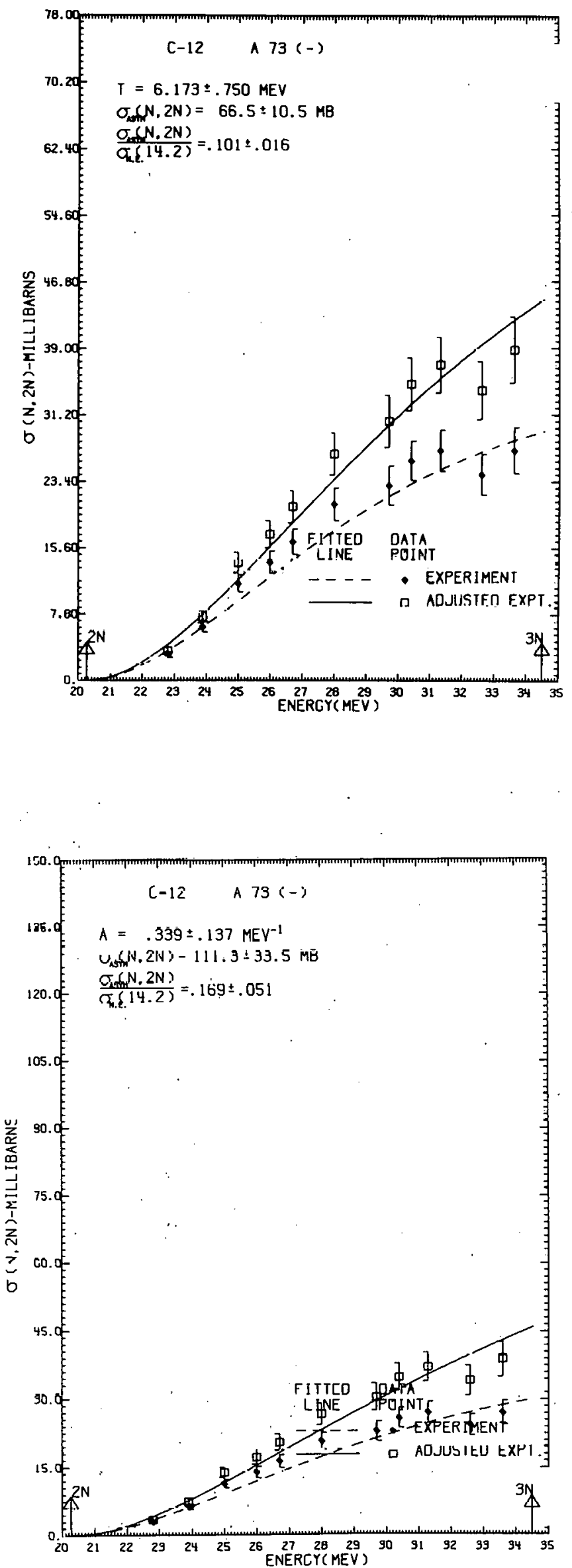
C-12 ‥FROM REF, $\theta$ O1 (808)

ENERG

ENERGY N, $2 N$ CRESS SECTION (MB)

(MEV) MEASURED, ERR ADUUSTED, ERR

$25.000010 .00 .1 .50 \quad 12.130 \quad 1.819$

$\begin{array}{lllll}27.800 & 12,30 & .50 & 15.735 & .640 \\ 30.400 & 15.30 & .30 & 20.862 & .404\end{array}$

30.400

34,200

17,50

20.862

25,034

.719

FITTED PARAMETERS

NUCLEAR TEHP 4,409 PLUS-DR-MINUS, 541 MEV

ASYMPTETIC (N,2N) CRESS SECIION: 31,05 PLUS-BR-MINUS $2.82 \mathrm{MB}$

RELATED DATA

NEN-ELASTIC CRESS SECTION AT 14.2 MEV. 660.31 ME

$(N, 2 N)$ THAESHaLT $\# 20.28$ MEY

$(N, S N)$ THRESHQLD $=34,50 \mathrm{MEV}$

THIS ISOTOPE HAS 6 NEUTRONS, G PRETONS, (MASS - 121

NEUTRON EXCESS PARAMETER * .00000

RATIO OF ASYMPTETIC IN, 2N, TO 14,2 MEV NEN-ELASTIC .0479 PLUSABR-MINUS .0043

TOSORT(N) $=10.800 \quad$ TESORT(A) $=15.273$

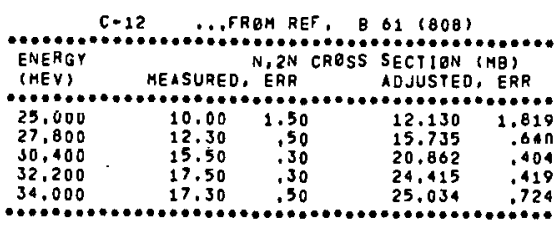

FITTED PARAMETERS

LEVEL SPACING 1.091 PLUS-QR-MINUS, 335PER MEV

ASYMPIOTIC (N, ZN, CROSS SECTIBN = 30.92 PLUS=GR-MINUS 5.05 MB

RELATEO DATA

NON-ELASTIC CRESS SEETION AT $14.2 \mathrm{MEV}=600.31 \mathrm{MB}$

(N.2N) THRESHPLD $=20,26$ MEV

(N.2N) THRESHRLD $=20,26 \mathrm{MEV}$
(N,3H) THRESTRLD $=34,50 \mathrm{MEV}$

THIS ISOTOPE HAS G NEUTRONS, G PROTONS, CMASS $=12$,

NEUTRON EXCESS PARAMETER $=.00000$

RATIO OF ASYMPTATIC (N, 2N) TO 14.2 MEV NON-ELASTIC , ASTO PLUS-GD-MINUS .0070

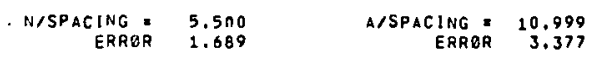
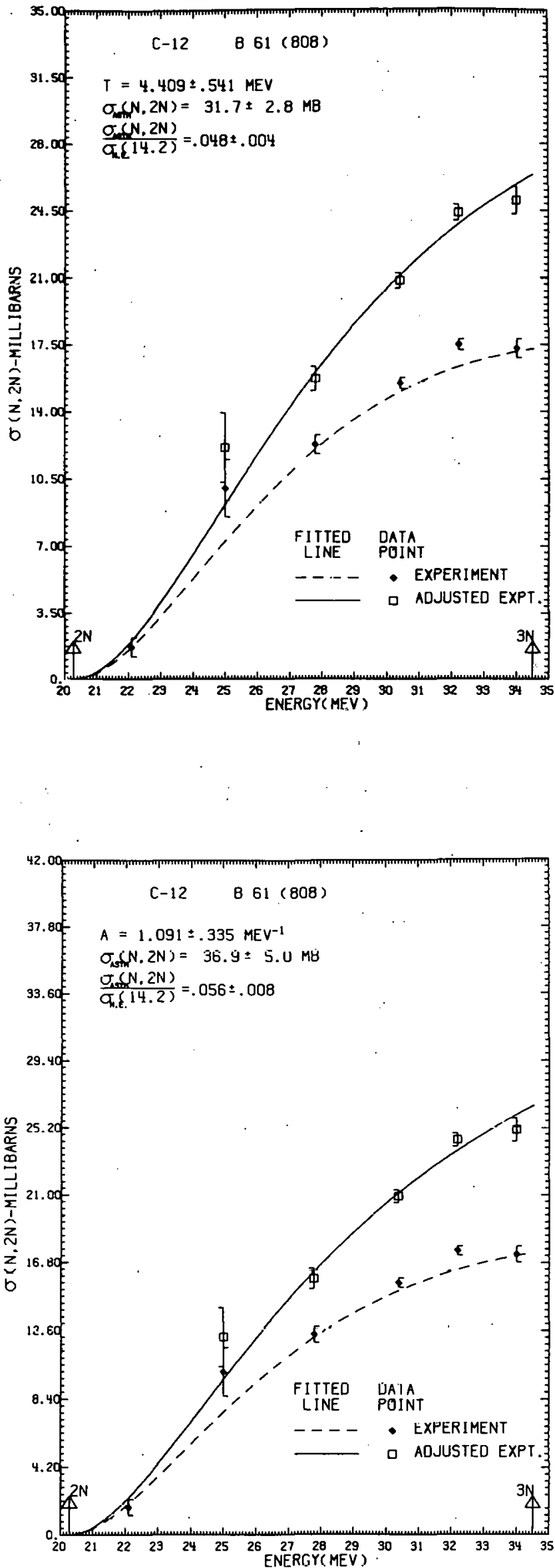


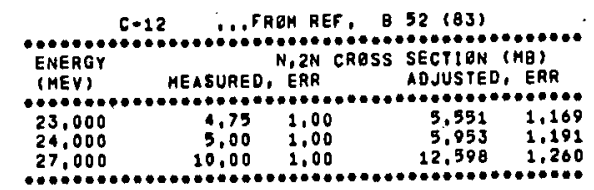

FITTED PARAMETERS

NUCLEAR TEMP

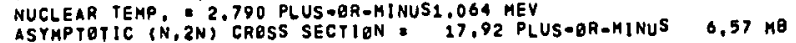

RELATED DATA

NON-ELASTIC CROSS SECTION AT 14,2 MEV = 600,31 MB (N,ZN) THRESHELD: $20,28 \mathrm{MEV}$
(N, 3N) THRESHOLD: $34,50 \mathrm{MEV}$

THIS ISOTOPE has O MEUTRONS, O PROTONS, (MASS - 12)

NEUTROA EXCESS PARAMETER: .00000

RATIE OF ASYMPTBYIC (N, 2N) TO 14,2 MEV NON-ELASTIC ,0271 PLUS-gR-MINUS .0100

$\begin{array}{rrr}\text { TOSORT(N) } & 0.834 \\ \text { ERROR } & 2.600 & \text { TOSORT(A) } \\ & & 9.605 \\ & \end{array}$

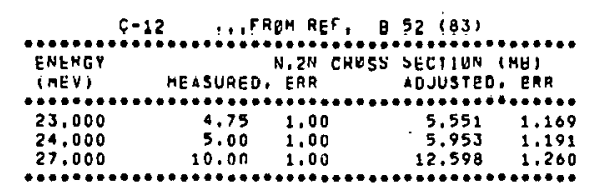

FITTED PARAMETERS

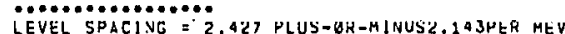

LEVEL SPACINC $=2.427$ PLUS-OH-MINUSZ, $143 \%$ ER MEV
ASYMPTOTIC IN.2NI CROSS SECTIGN $=20.78$ PLUS-OR-MINUS $9.85 \mathrm{MB}$

HELAIED TATA

VUN-ELASTIC CROSS SECTION AT 14.2 MEV $=660.31 \mathrm{MO}$ NUN-ELASTIC CRESS SECTION AT
$(N, 2 N)$ THRESHOLD $=20.28$ MEV

$(\mathrm{N}, 2 \mathrm{~N})$ THRESHALD $=20.28 \mathrm{MEV}$
$(\mathrm{i}, 3 \mathrm{H})$ THHESHPLD $=34.50 \mathrm{MEV}$

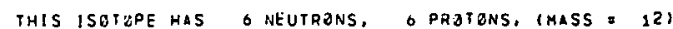

NeUTRIS EXCESS PARAMETER $=.00000$

RATIV OF ASYMPTOTIC IN.ZN TE 14.2 MEV NON-ELASTIC

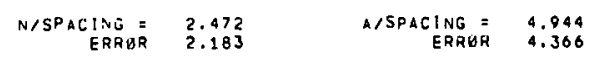
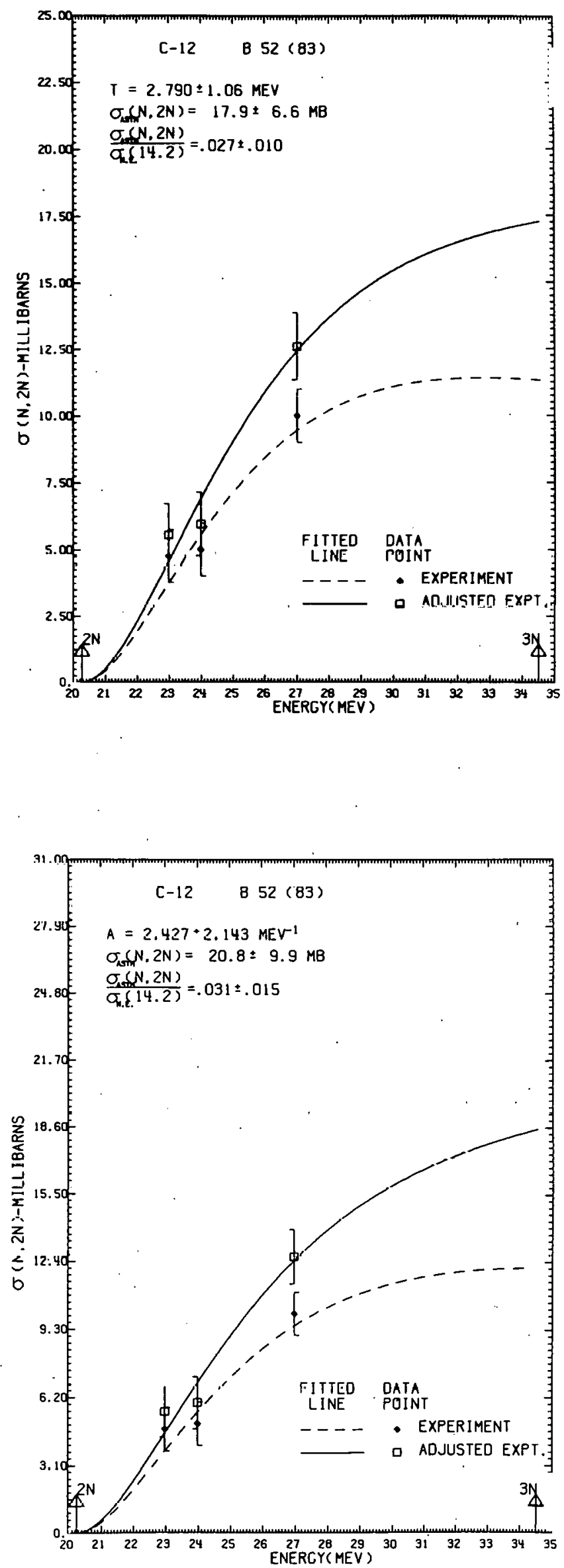


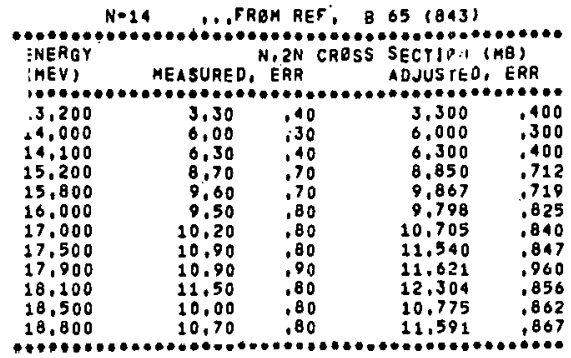

TITTED PaRAMETERS

NUCLEAR TEMP, 1.729 PLUS $\bullet 6 R-H I N U S, 075$ MEV
ASYMPTOTIC $($ N, $2 N)$ CROSS SECTION 12.80 PLUS-QR-MINUS .43 MB

RELATED DATA

NGN-ELASTIC CROSS SECTION AT 14,2 MEV $713.92 \mathrm{MB}$ (N, 2N) THRESHELD: $11,31 \mathrm{HEV}$
$(\mathrm{N}, 3 \mathrm{~N})$ THRESHELD: $32,81 \mathrm{MEV}$

THIS ISOTOPE HAS 7 NEUTRONS, 7 PROTONS, (HASS - I4)

NEUTRON EXCESS PARAMETER . .00000

RAT1O OF ASYMPTOTIC (N.2N) TO 14,2 MEV NEN-ELASTIC .0181 PLUS-BR-MINUS .0008

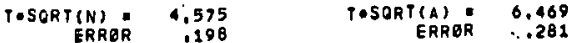

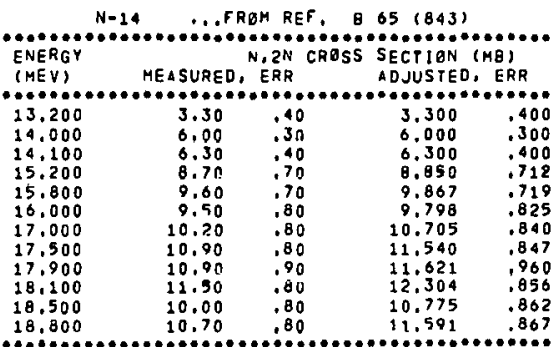

FITIED PARAMETERS

LEVEL SPACING 4.005 PLUS-OH-RINUS 903 PER MEV
ASYMPTOTIC (N, ZN) CRESS SECTIGN $=$ 14,12 PLUS-OR-MINUS ,70 MU

RELATED DATA

NON-ELASTIC CROSS SECTION AT 14.2 MEV $=713.92 \mathrm{MB}$

(N.ZN) THRESHBLD $=11.31$ MEV
(N,3N) THRESHYLD $=32.81$ HEV

THIS (SBTORC WAE, NEUTRONS, PHOTONS, (MASS: 14 )

NEUTRON EXCESS PARAMETER * .00000

RATIO OF ASYMPTOTIC (N,ZN) TO 14.2 MEV NON-ELASTIC .0198 PLUS-OR-MINUS ,0010

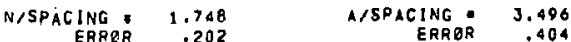
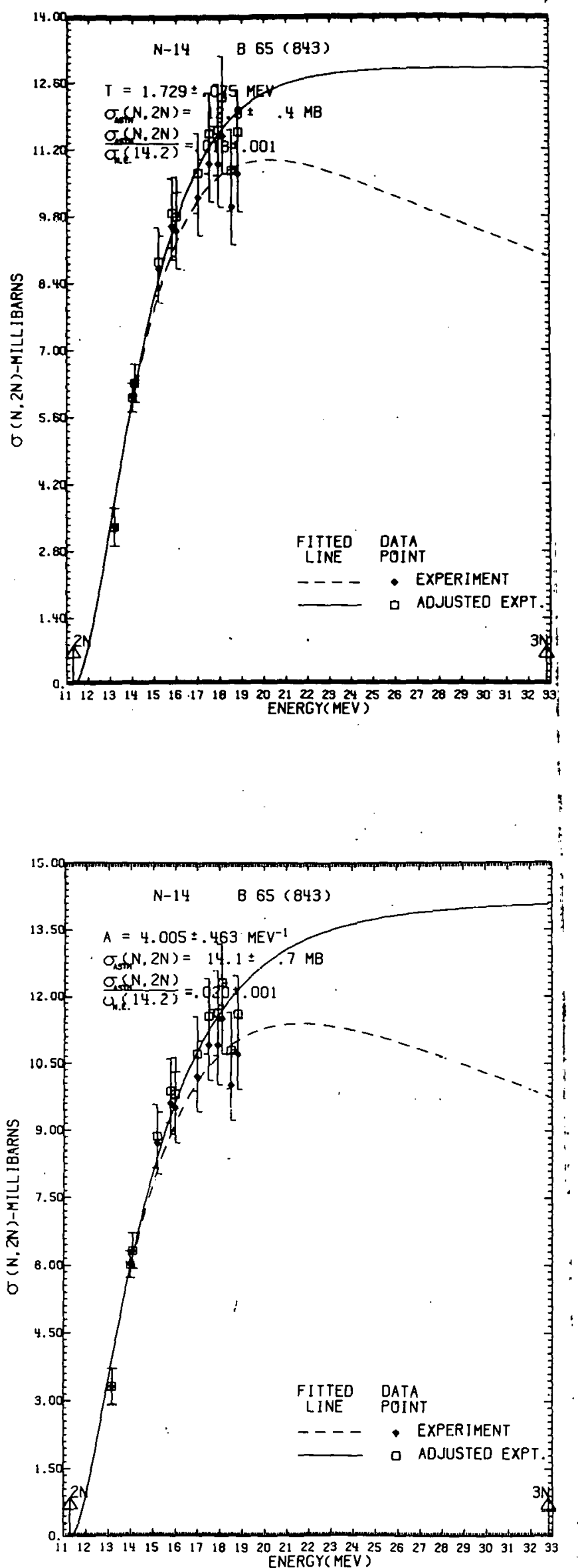


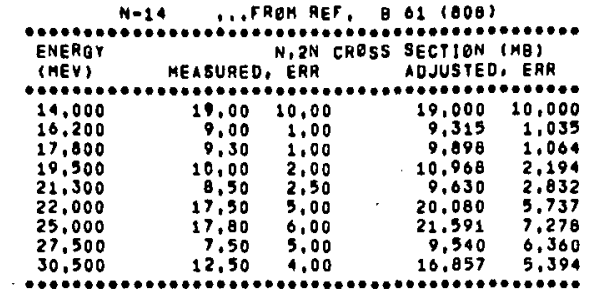

FITTED PARAMETERS

NUCLEAR TEMP, 11.805 PLUS-ORR-MINUS
ASYMPTETIC $(N, 233$ MEV
CROSS SECTION

\section{RELATED DATA}

NON-ELASTIC CRESS SECTION AT 14,2 MEV O $713.92 \mathrm{MB}$

$(N, 2 N)$ THRESHELD : 11,31 MEV

$(N, 3 N)$ PHRESHEL $=32.81$ ME

THIS ISOTOPE HAS 7 NEUTRONS, 7 PROTONS, (HASS : 14 )

WEUTRON EXCESS PARAHETER . .00000 RATIB OF ASYMPTETIC (N,2N) TO 14,2 MEV NON-ELASTIC
.0171 PLUSOOR-MINUS, 0028

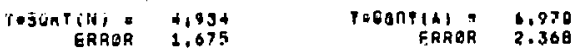

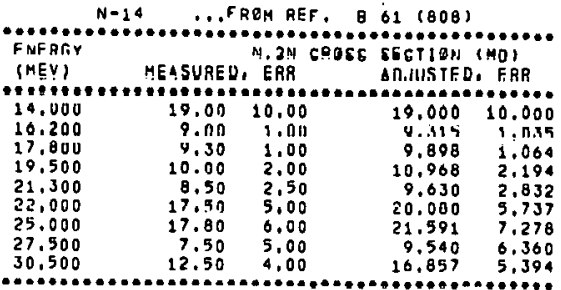

FITIEU HAHAHETEHS

LEVEL SPACING OJ,914 PLUS-GR-MINUS2,723PER HEV

ASYMPTOTIC $(N, 2 N)$ CRBSS SECYIGN $=12.94$ PLUS-OR-MINUS $2.59 \mathrm{MB}$

RELATED DATA

NAN-ELASTIC CEOSS SECTION AI $14,2 \mathrm{MEV}=713.92 \mathrm{MB}$

(N.2N) THRESHQLD: 11,31 MEV

THIS ISOTGPE HAS 7 NEUTRONS, 7 PKUTANS, (MASS: 14)

NEUTRON EXCESS PARAMETER $=.00000$

RATIO OF ASYMPTETIC (N, 2N) TA $14, Z$ MEV NON-FLASTIC .0181 PLUS-OR-MINUS .0036

$\begin{array}{rrr}\text { N/SPACING }= & 1.788 \\ \text { ERRER } & 1.244\end{array} \quad$ AISPACING $=\quad 3.577$
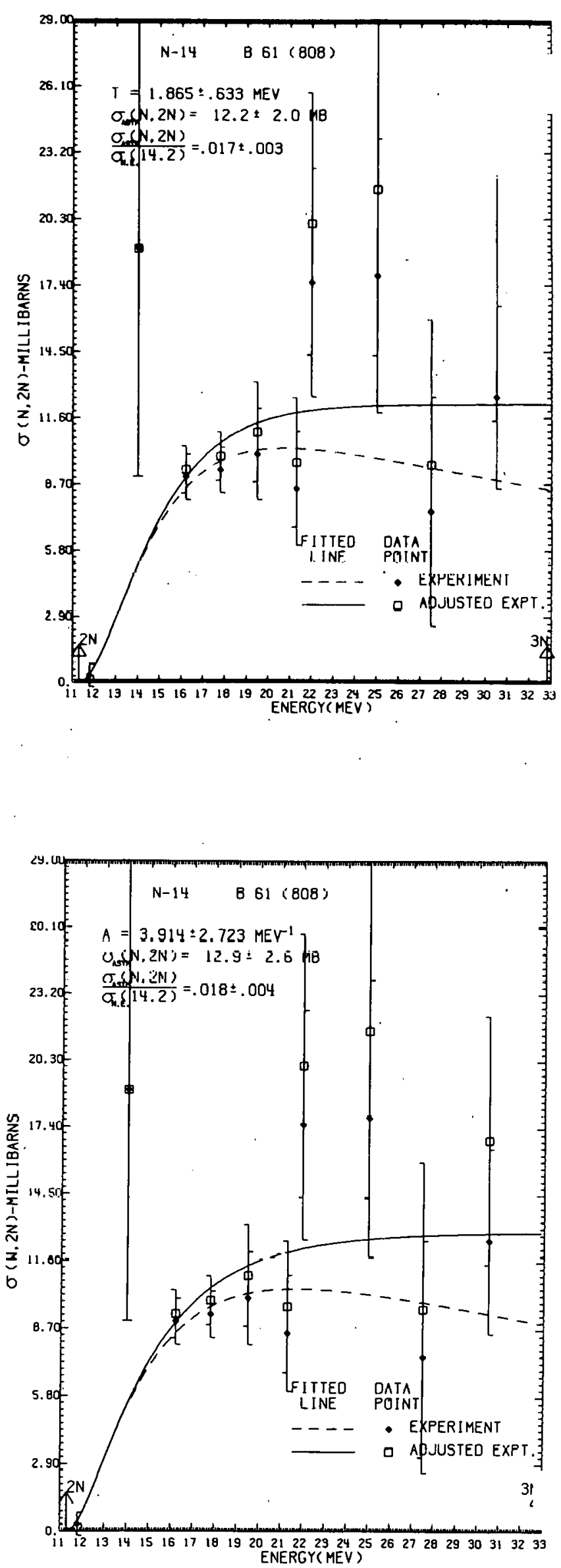


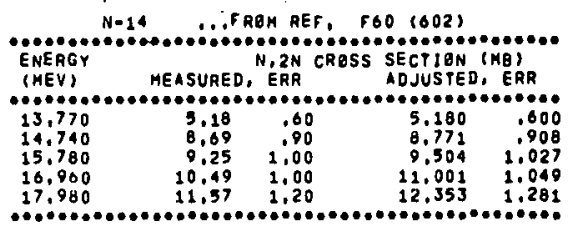

FITTED PARAMETERS

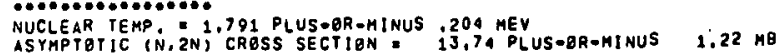

\section{RELATEO DATA}

NON-ELASTIC CROSS SECTION AT 14,2 MEV $=113,92$ MB

(N,2N) THRESHRLD: 11,31 MEV

THIS ISOTOPE HAS 7 NEUTRONS, 7 PRETONS, (MASS 14 )

NEUTRON EXCESS PARAMETER = .00000

RATIP OF ASTMPTETIC IN, 2N) TO 14,2 MEV NGNELLASTIC .0192 PLUS-BRTHINUS .0017

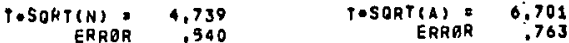

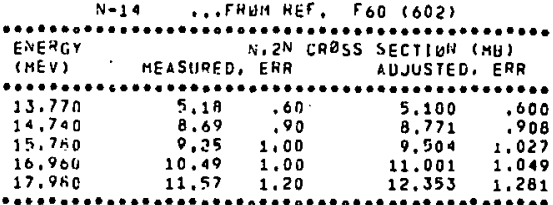

FITTER PAHATETFRS

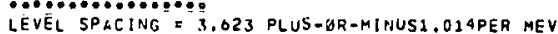

LEYHPTETIC (N,2N) CRESS JECTIGN $=$ IS.36 PLUS =QR-MINUS 1.91 ME

RELATEL LIATA

mo.........

YATI-ELASTIC CHESS SECIIJY AT 14.2 MEV = $713.92 \mathrm{MB}$

(H, 2N) TWir GHVLC $=11,31$ MEV

THIJ ISUTPPE HAS 7 NEUTHUNS, 7 PRUTONS, (MASS $=14$ )

NEUTRZIS EXCFSS PAPAIETEN = .000OC

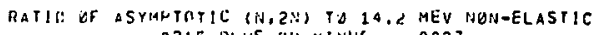
.0215 PLUS-EK-MINUS .002?

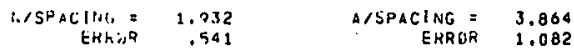
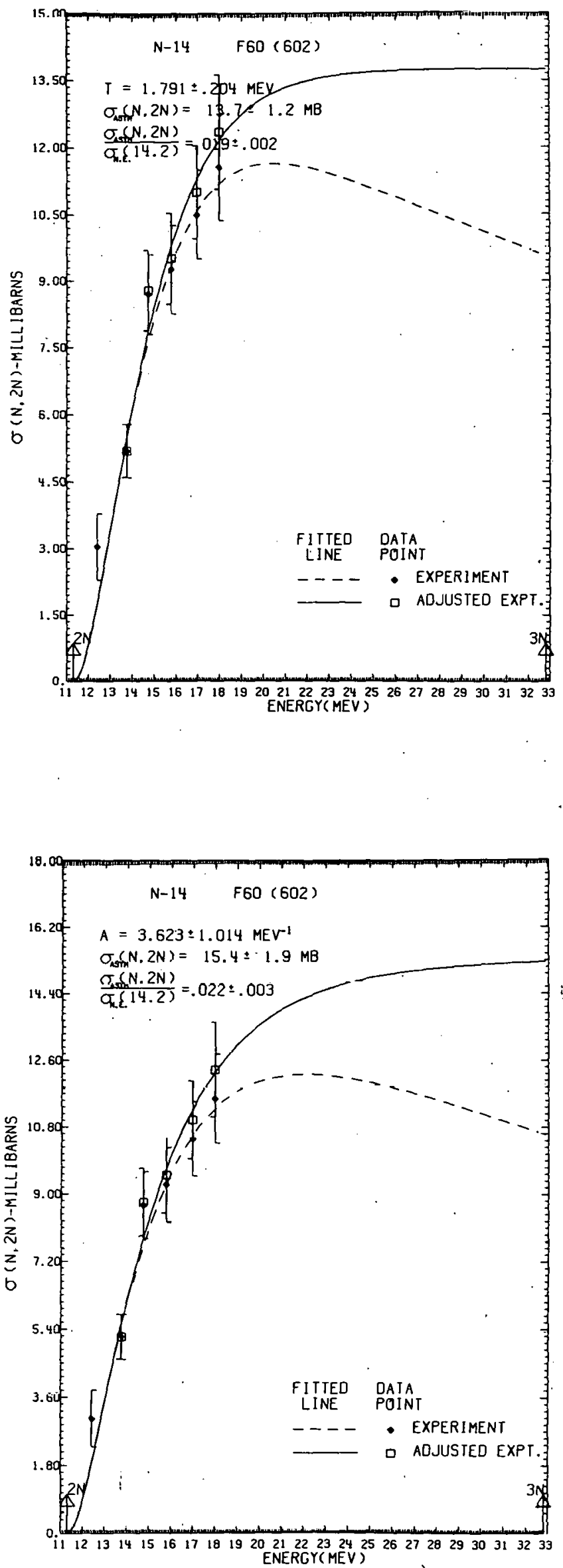


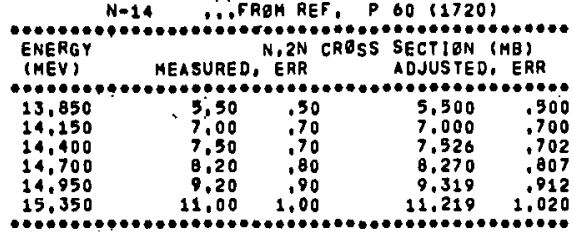

FITTED PARAHETERS

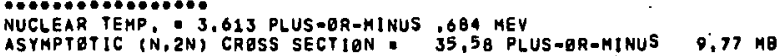

ASYAPTBTIC (N,2N) CRESS SECTION - 35,5B PLUS-gR-MINUS

RELATED DATA

NBN-ELASTIC CROSS SECTION AT 14.2 MEV = $713.92 \mathrm{MB}$

(N,2N) THRESHELD $=11,31$ MEV
(N,JN) THRESHELD $=32,81$ MEV

THIS ISOTGPE HAS 7 NEUTRENS, 7 PROTONS, (MASS 14)

NEUTHON EXCESS PARAMETER = .00000

RATIO OF ASYMPTBTIC (N,2N) TO 14.2 MEV NON-ELASTIC

.049B PLUS-ER-MINUS , 0137

$\begin{array}{rrr}T \text { SORTIN) } & 9.559 & \text { TESORT (A) } \\ \text { ERRBR } & 1,810 & 13.519 \\ \text { ERRER } & 2,559\end{array}$

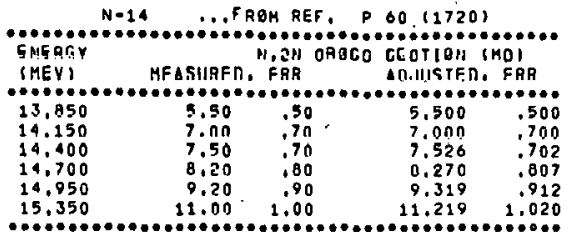

FITTEO PARAMETERS

LEVGL SPACING . 473 PLUS-OR-MINUS .267PER MEV

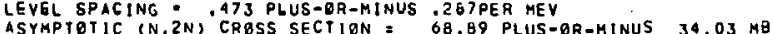

RELATED DATA

NUN-ELASTIC. CRQSS SECTION AT $14.2 \mathrm{MEV}=713.92 \mathrm{MB}$

(N,2N) THRESHQLO: 11.31 MEN

THIS ISETJPE HAS 7 NEUTRONS, T PRUTUNS, (MASS 14 )

NEUTRQN EXCESS PARAMETER $=.00000$.

RATIO OS ASYMPTOTIC (N,2N) TQ 14,2 MEV NON-ELASTIC

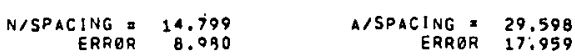
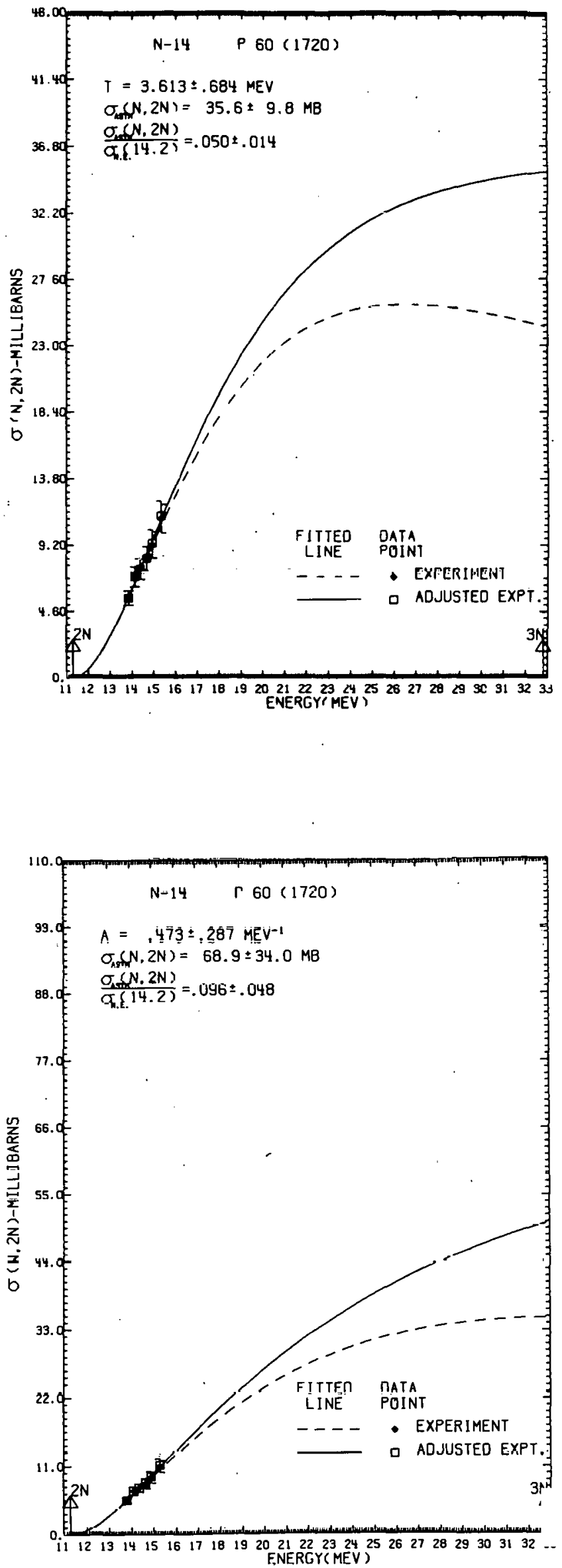


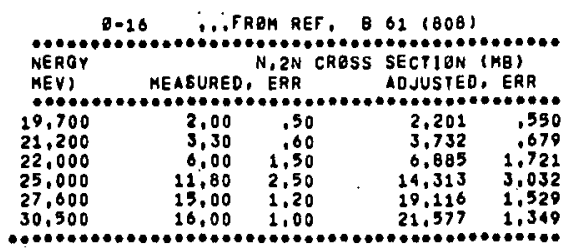

FITTED PARAMETERS

NUCLEAR IEMP

NUCLEAR TENP, 9,194 PLUSOBR-MINUS2,307 MEV
ASYMPIBTIC (N.2N) CROSS SECTION

\section{RELATED DATA}

NBN-ELASTIC CRESS SECTIEN AT 14.2 HEV * 763.26 MO (N,2N) THRESHELD $=16,65 \mathrm{MEV}$
$(N, 3 N)$ THRESHOLO $=30,69 \mathrm{MEV}$

THIS ISETEPE HAS 8 NEUTRENS, 8 PROTONS, (MASS 16 )

NEUTRON EXCESS PARAMETER = .00000

RATIO OF ASYMPTOTIC (N,2N) TO 24,2 MEV NEN-ELASTIC .0066 PLUE-BR-MINUS 2 MEN

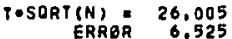
TOSURT(A) $\quad 36: 776$

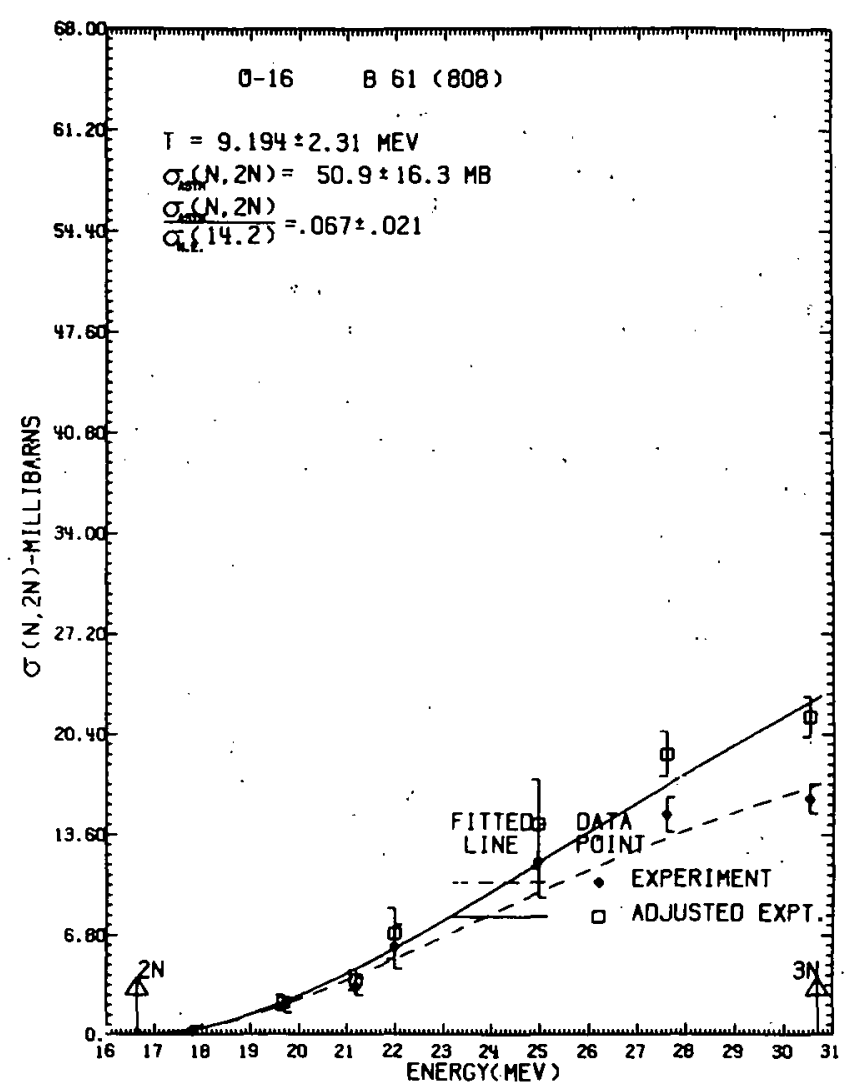




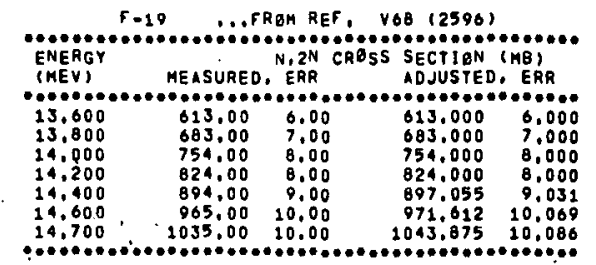

FITIED PARAMETERS

NUCLEAR TEMP, 3.689 PLUS-OR-MINUS 323 ME

ASYMPTOTIC (N, $2 N$ ) CROSS SECTION 3818.90 PLUS-OR-MINUS 489.77 MB

RELATED DATA

NON-ELASTIC CRESS SECTION AT 14,2 MEV $=830,00 \mathrm{MB}$

(N,2N) THRESHOLD : 10,98 MEV
(N,3N) THRESHOLD a 20.61 MEV

THIS ISUTOPE HAS 10 NEUTRENS, Q PRETONS, (MASS = 10 )

NEUTRQN EXCESS PARAMETER *, 05203

RATIO OF ASYMPTOTIC (N,2N) TO 14,2 MEV NBN+ELASTIC

4.5961 PLUS $-E R \rightarrow H I N U S$
4.5

TOSORT (N) 11.606

TOSORTCA) $=16,080$

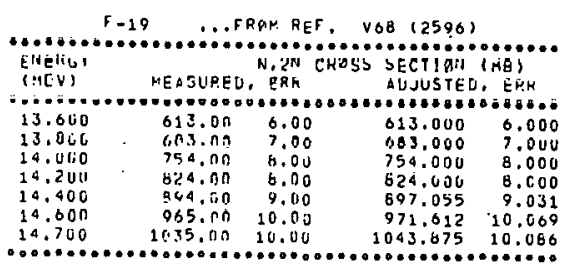

TITIED PAKATETSRS

LEVEL SHACIVIF = .414 PLUS-DST-HINUS .117PER MEY

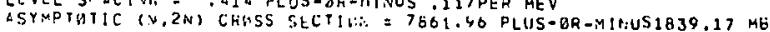

iithate

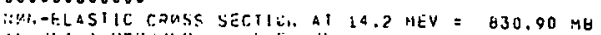

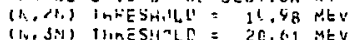

THIS ISATGOE HAS III NEUTRIIUS, Y PHATUNS, (MASS $=19$ )

SEUTRE:A EXCESS PAOAMETEK = .0520.3

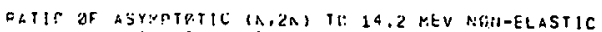

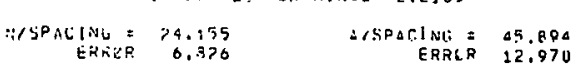
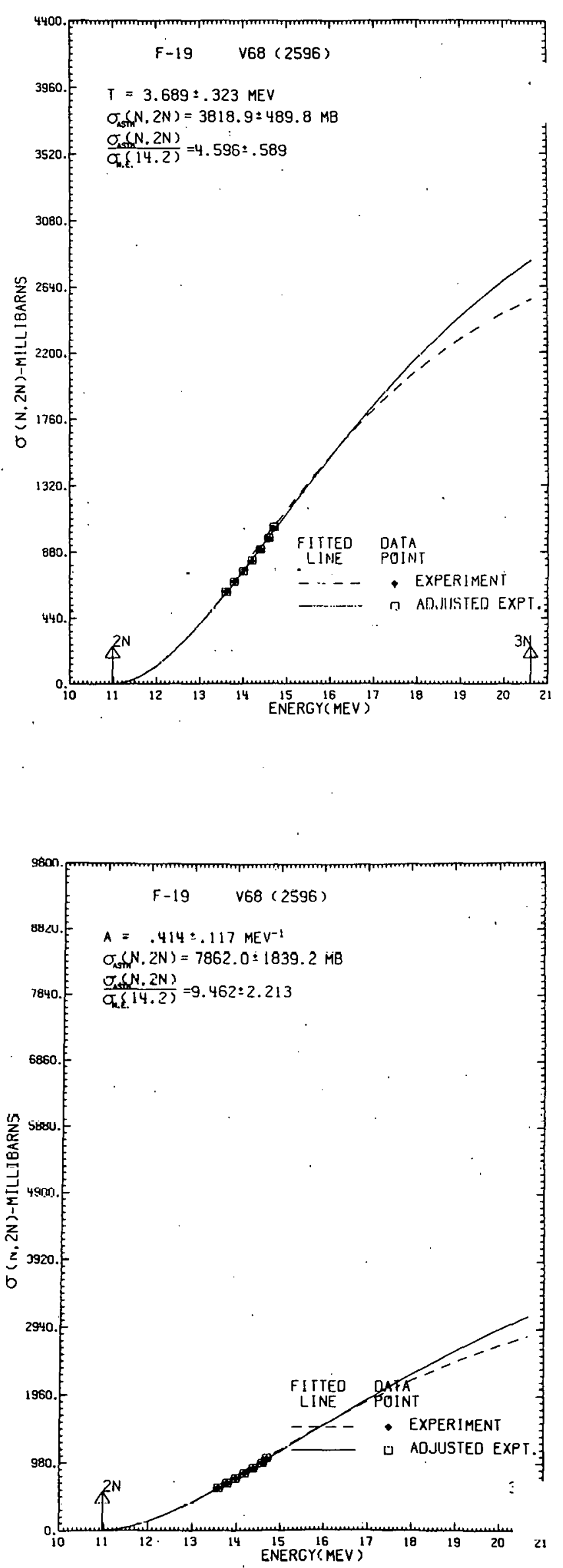


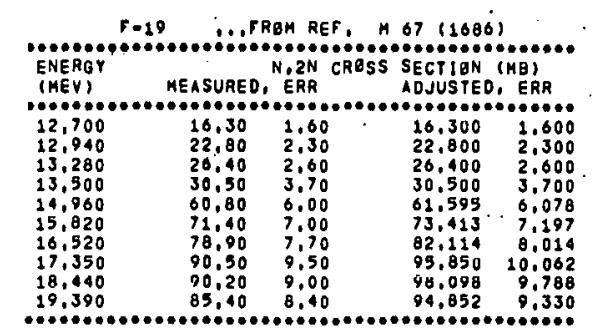

FITTED PARAMETERS

NUCLEAR TEAP, 2.062 PLUS - GR-MINUS .157 MEV

ASYMPTOTIC $(\dot{N}, 2 N)$ CROSS SECTION $1.28,15$ PLUS-OR-MINUS $8.60 \mathrm{MB}$

RELATED DATA

NON-ELASTIC CROSS SECTION AT 14,2 MEV = 830,90 MB

(N,2N) THRESHOLD: 10,98 MEV

THIS ISOTOPE has 10 NEUTKENS, 9 PHDTUNS, IMASS .191

NEUIREN EXCESS PARAKETER = .05263

RATIO OF ASYMPTOTIC $\{N, 2 N$, TO 14,2 MEV NBNEELASTIC .1542 PLUS $-B R=$ MINUS .0105

TESORT(N): 8.418 TERRER TOSORT(A) 11.603

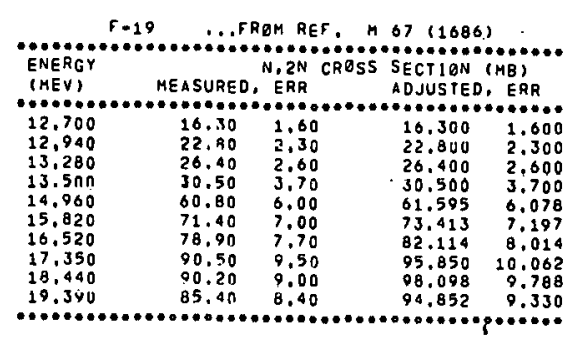

FITTED PAKA YETERS

LEVEL SPACING $=1$, J09 PLUS-OR-MINUS .245PER MEV

ASYMPTOTIC (N, 2N) CROSS SECIION $=167.77$ PLUS-OR-HINUS $20.09 \mathrm{MB}$

RELATED UATA

NEN-ELASTIC CRASS SECTION AT $14.2 \mathrm{MEV}=830.90 \mathrm{MB}$

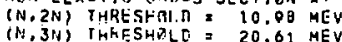

THIS ISGTHPE HAS 10 NEUTRONS, O PRETONS, (MASS $=19$ )

HEUTION EALESS PAKAMETER $=.05263$

RATIO UF ASYTPTATIC (N.2N) TO 14.2 MEV NON-ELASTIC

$$
\begin{aligned}
& .2019 \text { PLLUS-OR-MINUS } 20242 \\
& \text { :02 NON-ELASTIC }
\end{aligned}
$$

$\begin{aligned} N / S P A C I N G= & 7.639 \\ \text { ERRER } & 1.412\end{aligned} \quad$ ALSPACING $=14.515$
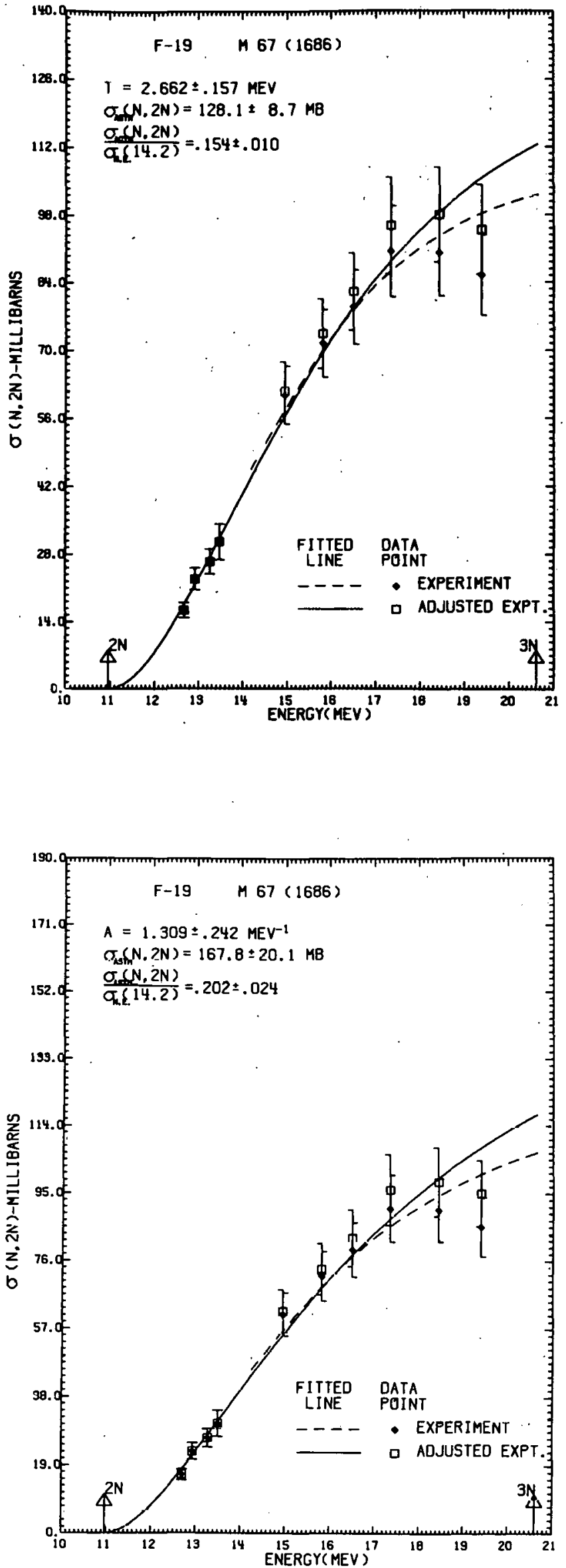


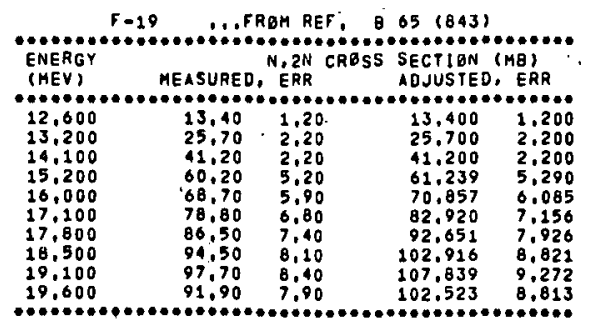

FITTED BARAMETERS

NUCLEAR TEMP." 2.095 PLUS-OR-MINUS .127 MEY

ASYMPTOTIC $(N$, ?N) CROSS SECTIIUN 136,67 PLUS-OR-MINUS 6,73 MB

RELATED DATA

NBN-ELASTIC CROSS SECTIBN AT 14,2 MEV $=030.90 \mathrm{MB}$

$(N, 2 N)$ THRESHOLD: 10,98 MEV
(N,3N) THRESHELD $=20.61$ HEV

THIS ISOTOPE HAS 10 NEUTRONS, 9 PRBTONS, (MASS 19 )

NEUTREN EXCESS PARAMETER ₹ .05263

RATIO OF ASYMPTETIC (N,2N) TO \$4,2 MEV NON-ELASTIC

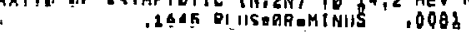

$\begin{array}{rr}\text { TOSORT(N) } & 9.155 \\ \text { ERRQR } & .402\end{array} \quad$ TOSUKTIAA) $=12,019$

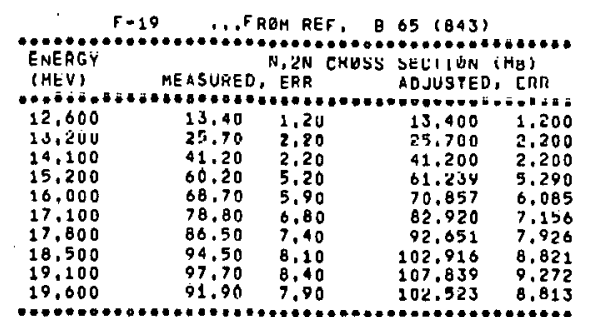

FITTED PARAKETERS

LEVEL SPACING 1.068 PLUS-EK-MINUS 15TPER MEV

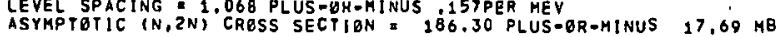

RELATEO DATA

NON-ELASTIC CROSS SECTION AT 14.2 MEV $=830.90 \mathrm{MB}$

(N,2N) THRESHQLD $\equiv 10,98 \mathrm{MEV}$
$(\mathrm{N}, 3 \mathrm{~N})$ THRESHOLO $=20.61 \mathrm{MEV}$

THIS ISGTOPE HAS 10 NEUTRONS, O PROTENS, (MASS = 19)

NEUTRAN EXCESS PARAMETER $=.05263$

RATIO OF AGYMTIOTIC (N, $3 N$ ) IO 14,2 MEV NAN-ELASTIC .2242 PLUSARR-MINUS .0213

N/SPACING $=9.363 \quad$ A SPACING $=17,790$
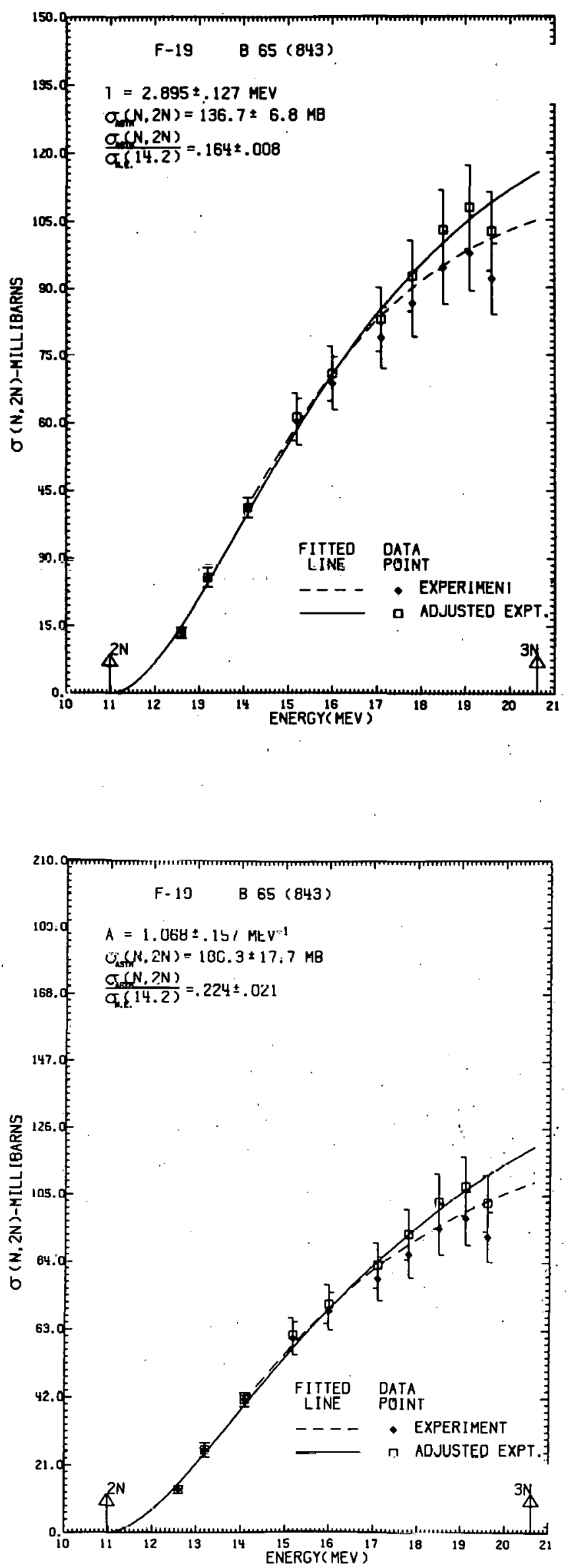


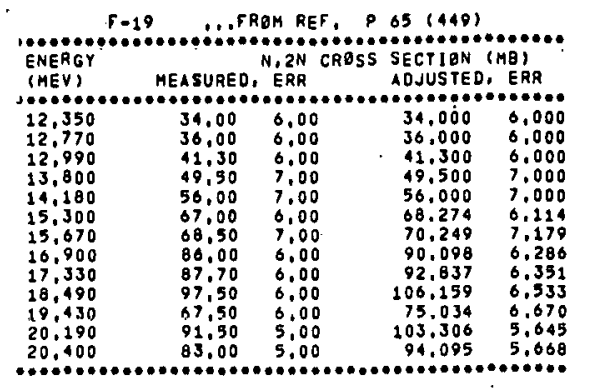

FITTED PARAMETERS

NUCLEAR TEMP,
ASYMPTETIC (N, $2 N)$ CRESS SECTIQN

\section{RELATED OATA}

NUN-ELASIIC CROSS SECTION AT 14,2 MEV $=830.90 \mathrm{MB}$

(N,2N) THRESHQLD: 10.98 MEV

$(N, 3 N)$ THRESHQLD: 20.61 HEV

THIS ISETOPE HAS 10 NEUTRONS, 9 PROTONS, (MASS 191

NEUTRON EXCESS PARAMETER $=.05263$

RATIO OF ASYMPTOIIC (N,ZN) TO 14,2 MEV NON-ELASTIC

, 1160 PLUS-QR-MINUS .0057

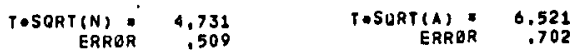

RELATED CATA

AO........

NON-ELASTIC CRESS SECTION AT
(N,2N) THRESHELD: 20,98 MEY
(N,3N) THRESHALD: 20.61 HEV

THIS ISGTOPE haS 10 NEUTRaNS. Q PRgtONS. (HASS = 191

NEUTRON EXCESS PATMAHETEK = .0S263

RATIO OF ASYMPTOTIC (N, 2N) TO 14.2 MEV NON-ELASTIC

RATIO OF ASYMPTETIC LN, IN T TO 14,2 MEV NON

$\begin{array}{rrrr}\text { N/SPACING } & 1.739 & \text { A/SPACING } & 3.303 \\ \text { ERRBR } & .387 & .736\end{array}$

$\therefore$

4
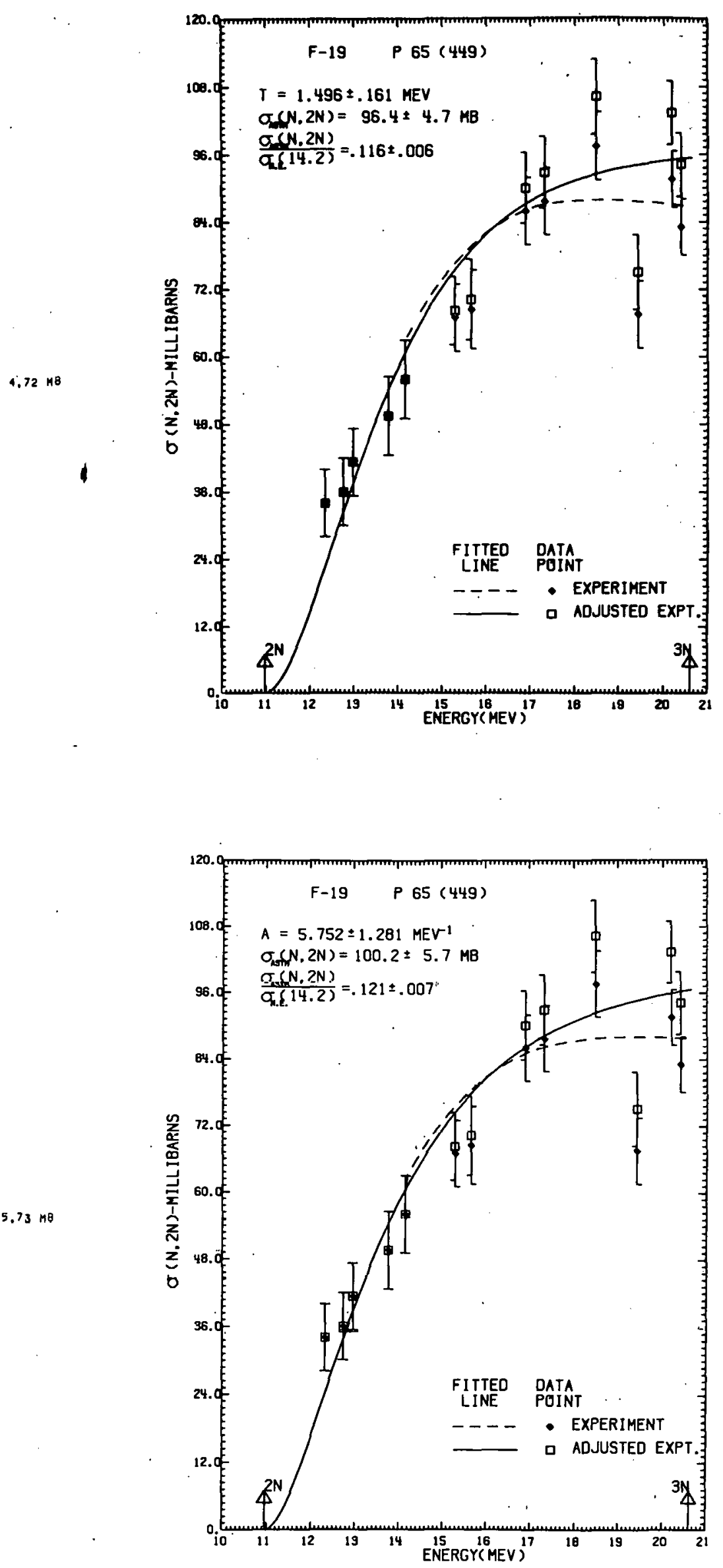


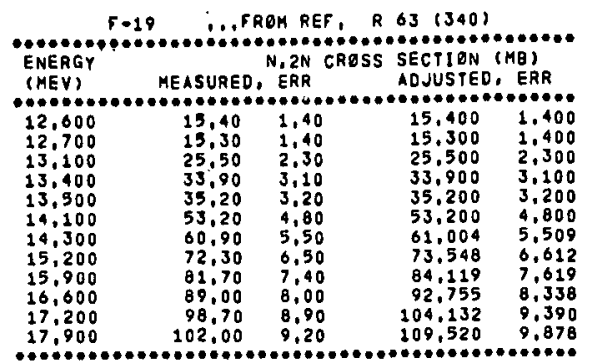

FITTED PARAMEIERS

NUCLEARTEP

ASYMPTETIC (N,2N) CRESS SECTIEN 194,27 PLUS-BR-MINUS 28,40 HB

\section{RELATED DATA}

NON-ELASTIC CROSS SECTIUN AT $14.2 \mathrm{MEV}=830.90 \mathrm{MB}$

(N,2N\} THRESHOLD: $10,98 \mathrm{MEV}$

THIS ISBTOPE haS 10 NEUTRONS, 9 PRGTONS, (MASS 19 )

MLUTRON EXEESE PARAMETEP = .057.63 RATIO OF ASYMPTOTIC (N,2N) TO 14,2 MEY NON-ELASTIC
.2338 PLUS=DR-MINUS, 0342

TOSORT (N):: 10.660

TOSORT(A)= 14.694

\section{FITTED PARAMETERS}

LEVEL SPACING .610 PLUS-QR-MINUS .213PER MEV

ASYMPTETIC (N, 2N) CROSS SECTION $=329.01$ PLUS-OR-MINUS $89.04 \mathrm{MG}$

RELATED DATA

NQN-ELASTIC CRESS SECTION AT 14.2 MEV $=830.90 \mathrm{MB}$ $(N, 2 N)$ THRESHGLD $=10,98 \mathrm{MEV}$
$(N, 3 N)$ THRESHOLO $=20.61 \mathrm{MEV}$

THIS ISUTUPE HAS 10 NEUTRONS, Q PROTONS, (MASS $=191$

NEUTRAN EXCESS PARAMETER $=.05263$

RATIO OF ASYMPYOTIC (N.2N) TO 14.2 MEV NON-ELASTIC

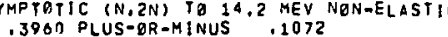

$$
\begin{aligned}
& \begin{array}{rrr}
\text { NISPACING }= & 16.393 \\
\text { ERRBR } & 5.724
\end{array}
\end{aligned}
$$
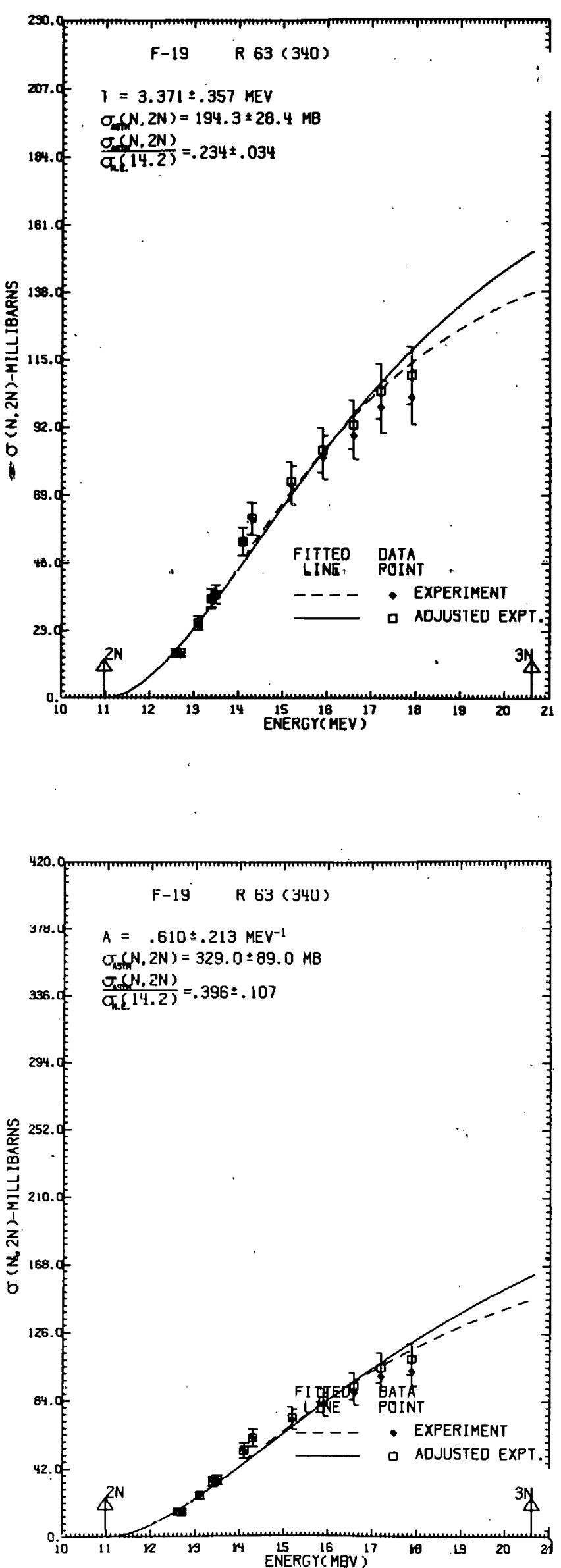


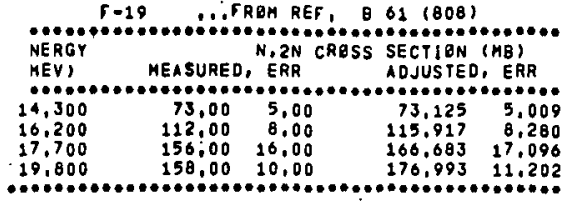

\section{FITTED PARAMETERS}

NUCLEAF TEMP, 2.794 PLUS-GR-HINUS 260 MEV

ASYMPTETIC (N, 2N) CRESS SECTION $=216,92$ PLUS-BR-MINUS 19,50 MB

\section{RELATED DATA}

NON-ELASTIC CRESS SECTION AT 14,2 MEV $=830,80 \mathrm{MB}$

(N, 2N.) THRESHQLD: $10,98 \mathrm{MEN}$

THIS' ISOTOPE HAS 10 NEUTRONS, O PRUTONS, (HASS 19 )

NEUTRON EXCESS. PARAMETER : 05263

RATIO OF ASYMPTBTIC (N,2N) TO 14,2 MEV NON-ELASTIC

$\begin{array}{rrr}\text { TESORT(N) } & 8.835 \\ \text { ERROR } & .851 & \text { TOSORT(A) } \\ \text { ERRQR } & 12.179 \\ 1.173\end{array}$

FITEU PARAMETERS

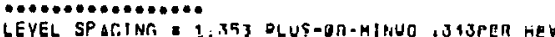

ASYMPTETIC (N, 2N) CRBSS SECTION $=268,03$ PLUS-QR-MINUS 37,19 MB

\section{RELATED DATA}

NON-ELASTIC CRESS SECTION AT $14.2 \mathrm{MEV}=830.90 \mathrm{MB}$

(N,2N) TRRESHULD = 10.93 MEV
(N,3N) THRESHWLU $=20,61$ MEV

THIS ISUIUPE HAS 10 NEUTRONS, 9 PRgTONS, (MASS 19

NFUTRON GXCESS PARAHCTEN :.0D2O3 RATIO OF ASYMPTOTIC (N, 2N) TE 14,2 MEV NON-ELASTIC
.3226 PLUS-OR-MINUS .0448

$\begin{array}{rrr}\text { NASPACING } & 7.391 & \text { A/SPACING } \\ \text { ERRER } & 1.874 & 14.043 \\ \text { ERRER } & 3.560\end{array}$
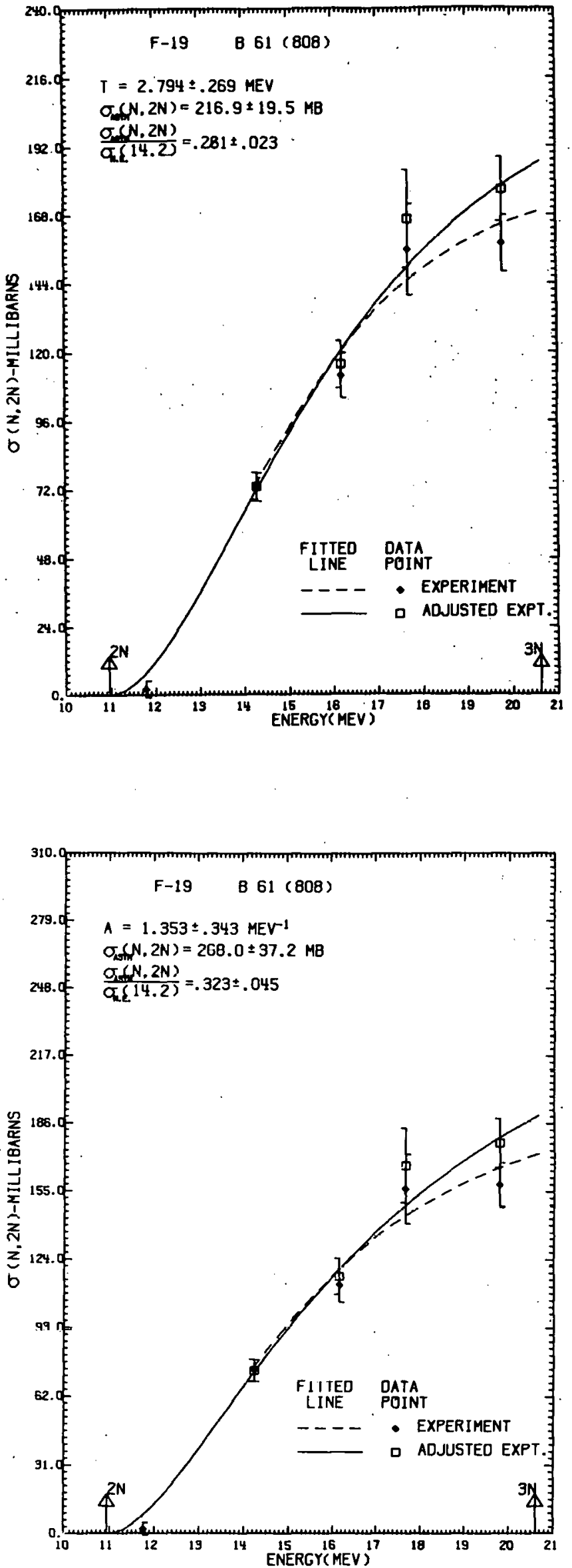


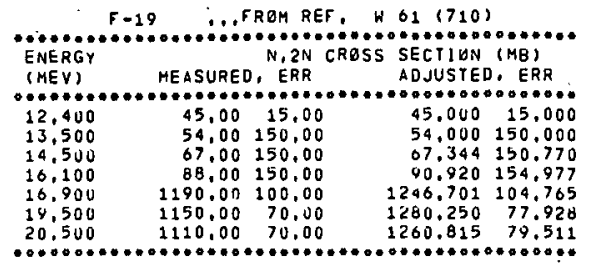

\section{FITTED PARAMETERS}

NUCLEAR TEMP $=6.674$ PLUS - UR-MINUS5.374 MEV

ASYMPIOTIC (N.2N) CRESS SECTIUN $=3306.64$ PLUS-OR-MINUSJ365.29 ME

RELATED DATA

NBN-ELASTIC CABSS SECTION AT 14,2 MEV = 830.90 MB (N,2N) THRESHULD $=10,90 \mathrm{MEV}$

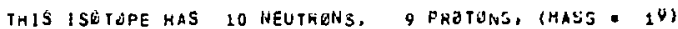

NËUTRGN EXCESS PARAMETEK $=.05203$

RATIO UF ASYMPTOTIC (N,2N) TUL 14.2 MEV HON-ELASTIC

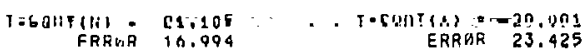

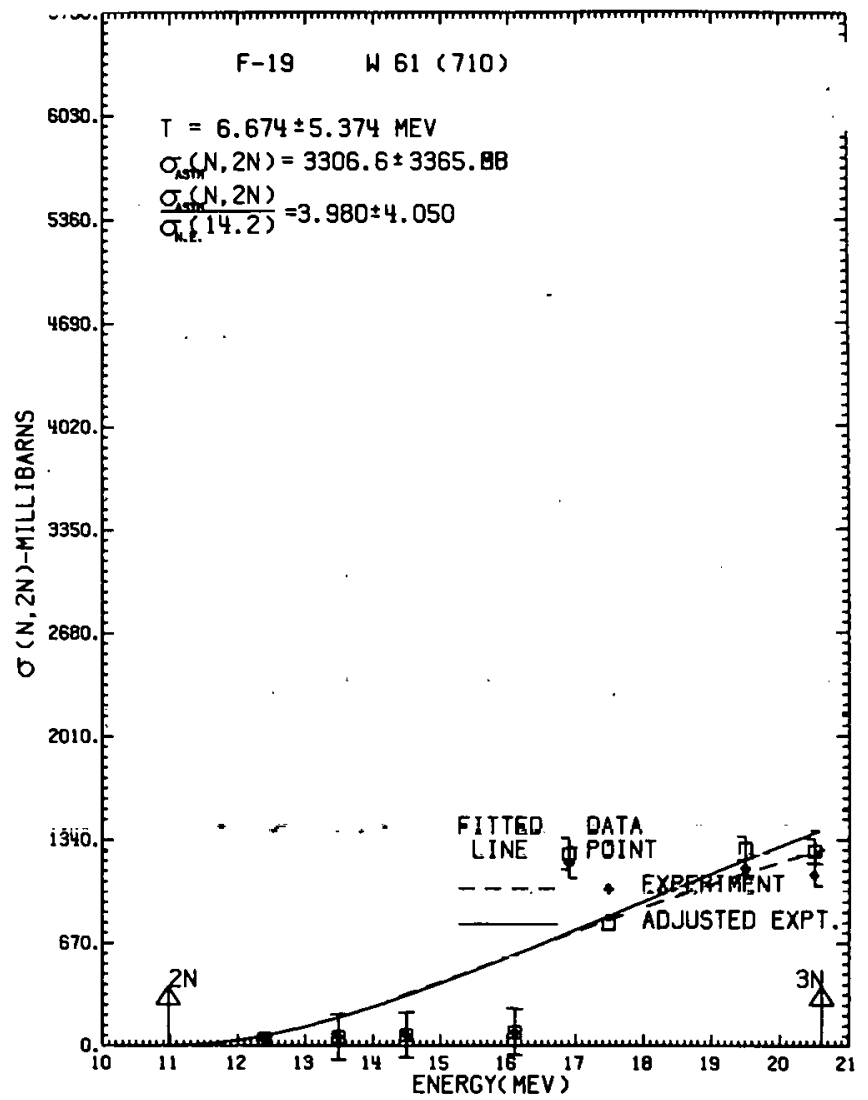




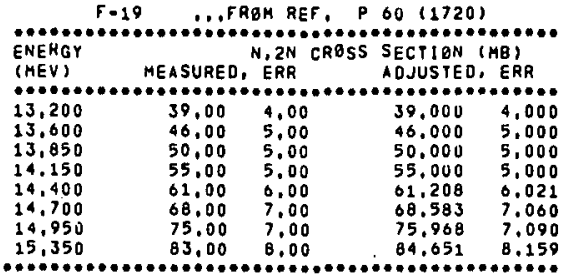

FITTEU PARAMETERS

NUCLEAR TEMP, 2,252 PLUS-BR-HINUS ,248 MEV

ASYMPTOTIC (N, $2 N$ ) CROSS SECTIUN $=140,77$ PLUS-OR-MINUS 17.99 MB

RELATED UATA

NON-ELASTIC CROSS SECTIUN AT 14,2 MEV $=830.90 \mathrm{MB}$

(N,2N) THKESHQLO $=10,98$ MEV

THIS ISOTOPE HAS 10 NEUTRQNS, Q PRQTANS, (MASS a 20 )

NEUTRUN EXCESS PARAHETER = .05263

RATIE OF ASYMPTOTIC (N,2N) TU 14.2 MEV NON-ELASTIC .1694 PLUS-OR-MINUS
.0216

TOSORT(N): T.121 TOSORTIA) $=9.816$

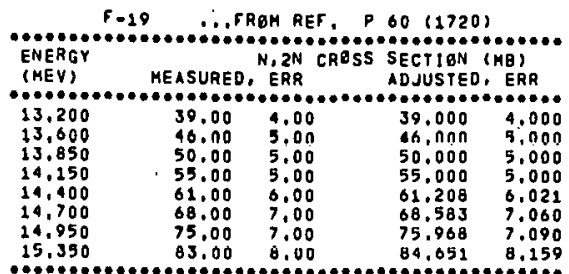

FITTED PARAMETERS

LEVEL SPACING 1,786 PLUS -QR-HINUS, 484 PER MEV

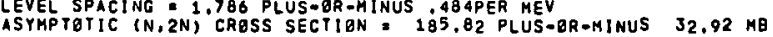

RELATED DATA

NON-ELASTIC CAOSS SECTION AT 14.2 MEV $=830.80 \mathrm{MB}$

(N,2N) THRESHAI.D: $10 . P B$ MEV

(N,3N) THRESHOLD: 20.01 MEV

THIS ISOTUPE haS 10 NEUTRGNS, O PROTONS, (HASS = 19 )

NEUTTEON EXCESS PARAHETER, .0526S

RATID OF ASYMPTOTIC (N, 2N) TO 14,2 MEV NON-ELASTIC .2236 PLUS-DR=MINUS .0396

$\begin{array}{rrr}\text { N/SPACING } & 5.599 \\ \text { ERRQR } & 1.517\end{array} \quad$ A/SPACING $=\begin{array}{r}10.638 \\ \text { ERRER }\end{array}$
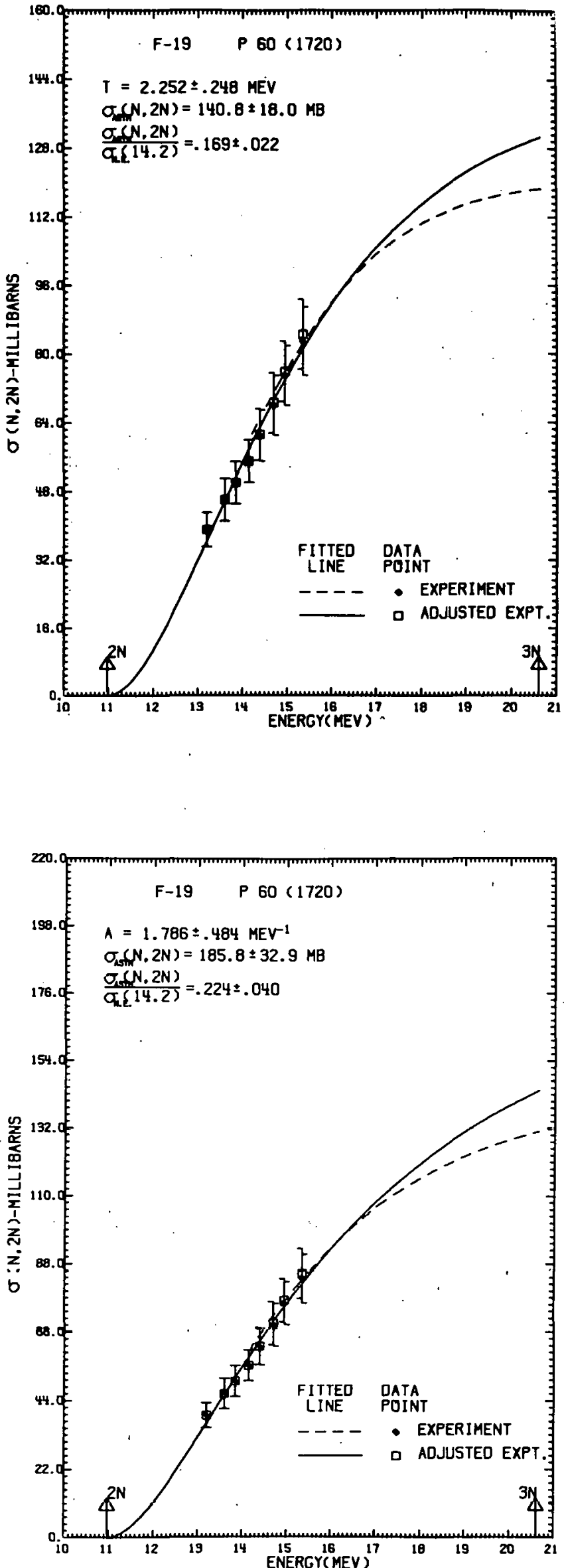


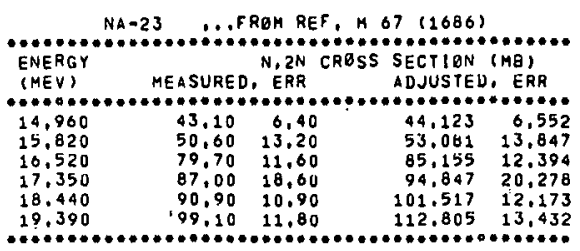

FIITEU PARAMETERS

AUCLEAR TEMP. $=1.021$ PLUS-ER-MINUS 151 MEV
ASYMPTOTIC (N.2N) CRUSS SECTIMN $=122,73$ PLUS-BR-MINUS 8.59 MB

RELATED DATA

NON-ELASTIC CRESS SECTION AT 14.2 MEV $=911.64 \mathrm{MB}$ (N, 2N) THRESHBLD $=12,96 \mathrm{MEV}$
(N,3N) THRESHQLD $=24,51 \mathrm{MEV}$

THIS ISOTUPE HAS 12 NEUTRONS, 11 PRDTENS, (MASS, 23 )

NEUTRGN EXCESS PARAMETER $=.04348$

RATIE UF ASYMPTBTIC (N,ZN) TO 14,2 MEV NUN-ELASTIC .1346 PLUS-OA-MINUS, 0094

$\begin{array}{rrrr}\text { TOSOHT(N) } & 5.615 & \text { TOSURTIA)E } & 7.774 \\ \text { ERRER } & .523 & .724\end{array}$

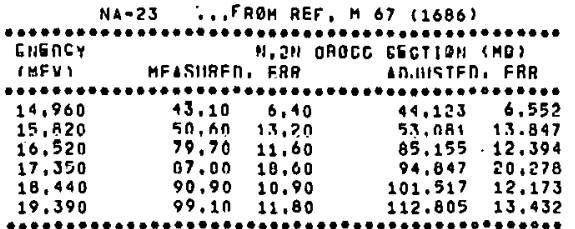

\section{FITTED PARAMETERS}

LEVEL SPACING 5.083 PLUE-OR-NINUS1, 077PER MEV

ASYMPTOTIC (N,2N) CRASS SECTION=133.26 PLUS-GR-MINUS 11.79 MO

RELATED DATA

NON-ELASTIC CROSS SECTION AT $14.2 \mathrm{MEV}=911.84 \mathrm{MB}$

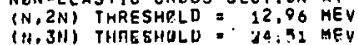

THIS ISGTUPE HAS 12 NEUTRONS, 11 PRQTENS, (MASS = 23 )

NEUTRON EXCESS PARAMETER $=.04348$

RATIO OF ASYMPTOTIC (N.2N) TO $14 ! 2$ MEV NON-ELASTIC .1461 PLUS-BR-MINUS .0129

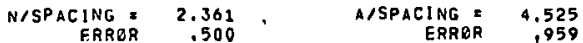
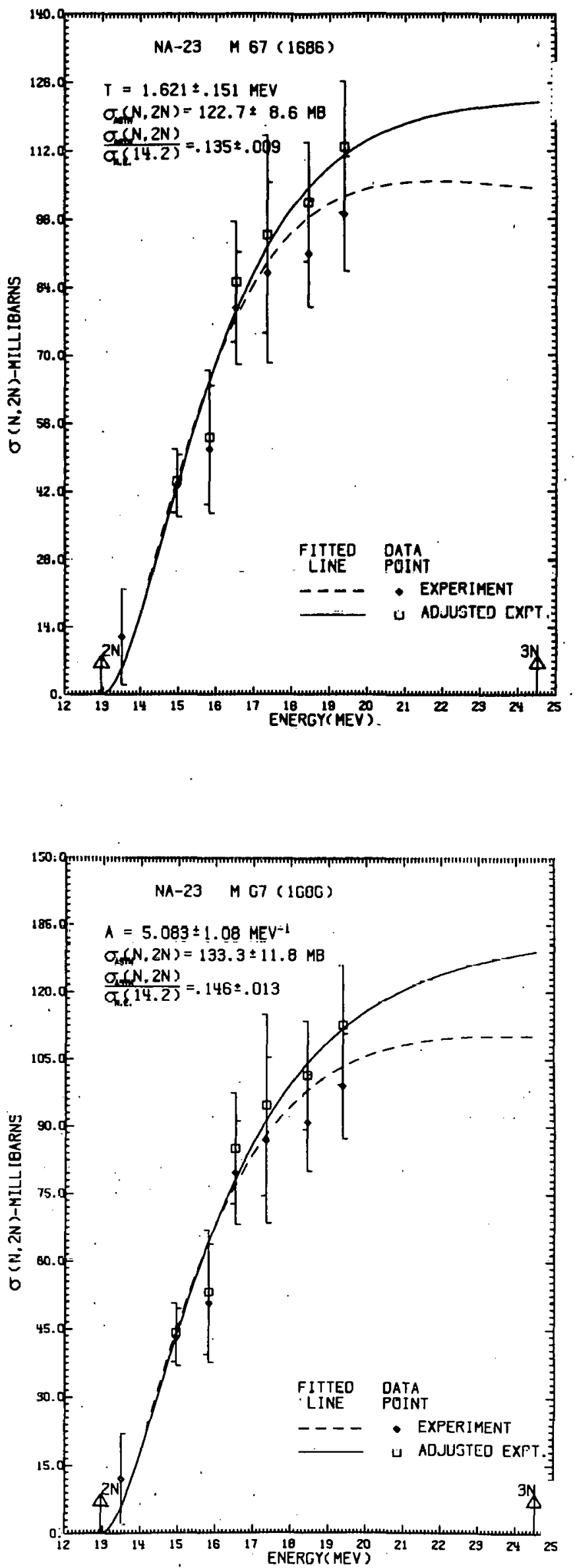


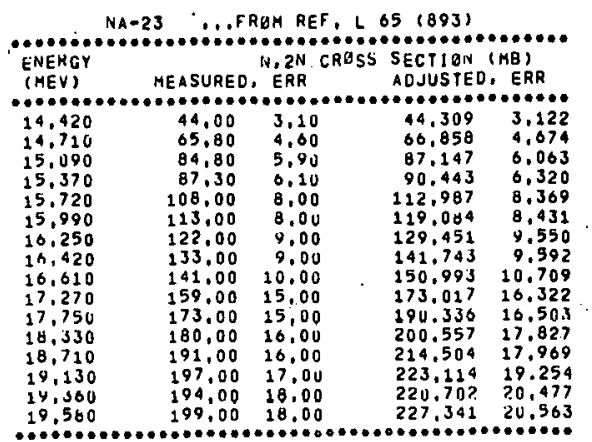

FITTED PARAMETERS

AUCLEAR TEMP

ASYMPTQTIC (N,2N) CRESS SECTION $=263.03$ PLUS-BR-MINUS $9.02 \mathrm{MO}$

\section{RELATED DATA}

NON-ELASTIC CROSS SECTIGN AT 14,2 MEV $=911.84 \mathrm{MB}$

(N,2N) THRESHOLD $=12.96 \mathrm{MEV}$

(N, 2N) THRESHBLD $=12,96 \mathrm{MEV}$

THIS ISOTUPE haS 12 NEUTRANS, 11 PRGTONS, (HASS . 23)

NEUTRON EXCESS PARAMETER $=.04340$

RATIU DF ASYMPTOTIC (N, 2N) TO 14.2 MEV NGN-ELASTIC .2885 PLUS-DR-MINUS .0099

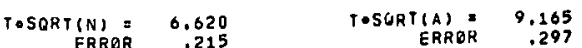

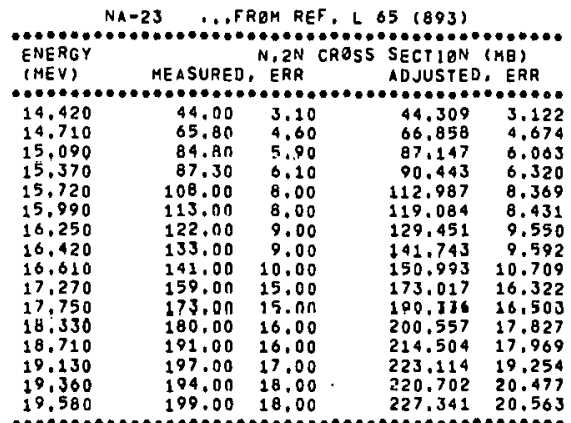

\section{FITTED PARAMETERS}

LEVEL SPACING 3.363 PLUS-OR-MINUS 259PER MEV

ASTHFTOTIC (N.2N) CRESS SECTION O 303.00 PLUS-OR-MINUS 13.35 ME

RELATED DATA

NEN-ELASTIC CRQSS SECTION AT $14.2 \mathrm{MEV}=911.84 \mathrm{MB}$

(N,2N) THRESHOLO = $12,96 \mathrm{MEV}$

THIS ISOTOPE HAS 12 NEUTRENS, 11 PROTUNS, (MASS = 23)

NEUTRON EXCESS PARAMETER $=.04340$

RATIE OF ASYMPTOTIC (N.2N) TO 14.2 MEV NON-ELASTIC

$$
.3323 \text { PLUS-OR-MINUS .0146 }
$$

N/SPACING $=3.568 \quad$ A/SPACING $=0.839$
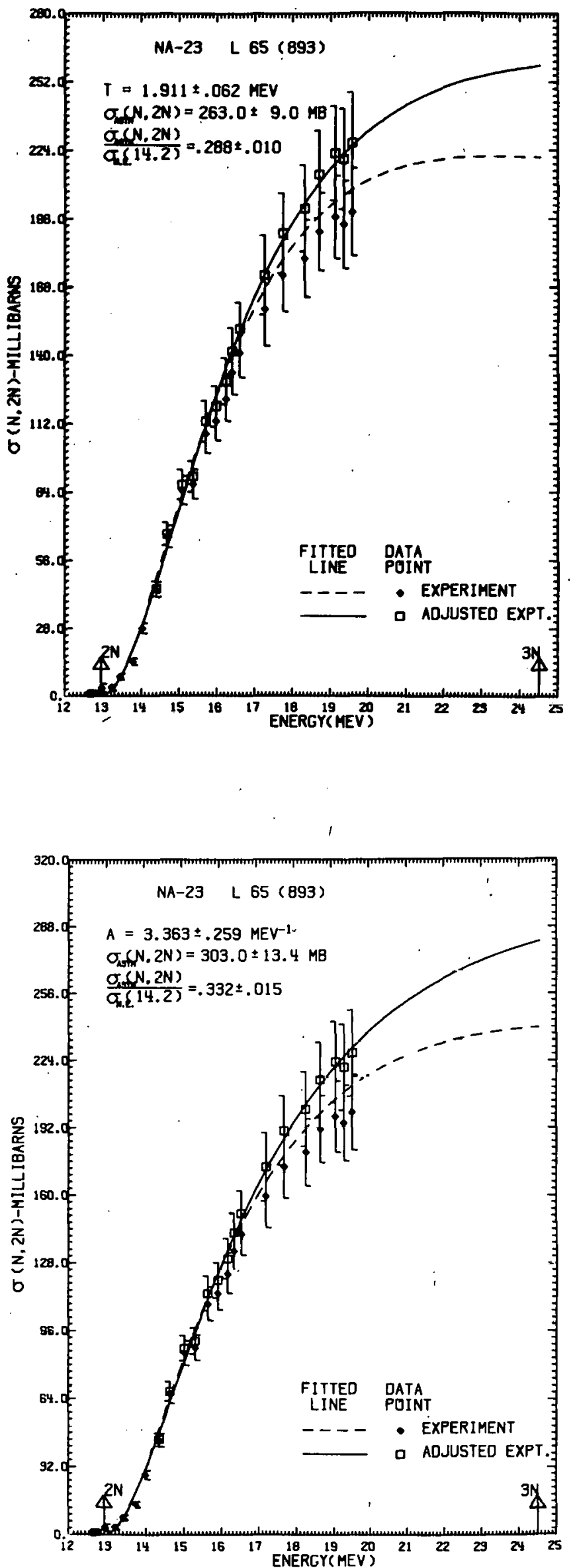


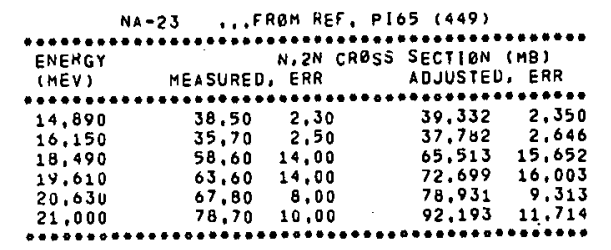

FITTEU PARAMETERS

NUCLEAR ITMP = 1.027 PLUS-OF-MINUS .916 MEV

ASYMPTOTIC (N,2N) CRESS SECTIDN $=\$ 8.94$ PLUS-OR-MINUS $15.95 \mathrm{MB}$

RELATED DATA

NON-ELASTIC CRESS SECTION AT 14,2 MEV $=911.84 \mathrm{MB}$ $(N, 2 N)$ THRESHALD $=12,90$ MEV
$(N, 3 N)$ THRESHOLD $=24,51$ MEV

thIS ISETUPE has 12 MeUTKONS, 11 PRDTUNS, (MASS = 23 )

NEUTRGN EXCESS PARAMETER $=.04348$

KATIS OF ASYMPTOTIC (N,2N) TU 14.2 MEY NON-ELASTIC
,064G PLUS-DR-MINUS
.0175

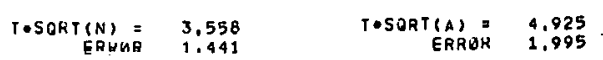

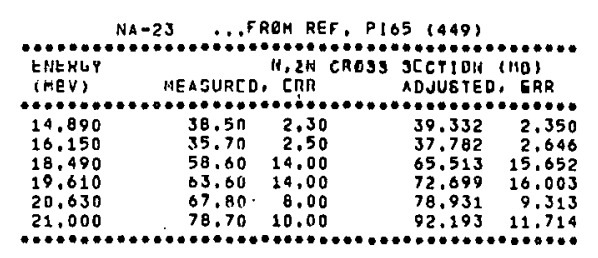

\section{FITTED PARAMETEPS}

LEVEL SPALING 11.353 PLUS-OR-MINUS8,940PER MEV

ASYMPTBTIC (N, ZN) CRASS SECTION = 63.92 PLUS-OR-MINUS $18.51 \mathrm{MB}$

\section{RELATED DATA}

NGN-ELASTIC CRASS SECTIEN AT 14.2 MEV $=911.84 \mathrm{MB}$ $(N, 2 N)$ THRESHQL D $=12.96$ MEV

THIS. ISOTGPE HAS 12 NEUTRONS, 11 PROTONS, (MASS $=23$ )

NEUTRON EXCESS PARAMETER $=.04348$

RATIO OF ASYMPTETIC (N,2N) TO $14: 2$ MEV NON-ELASTIC

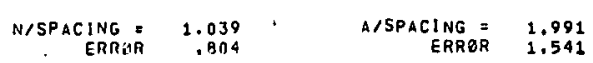
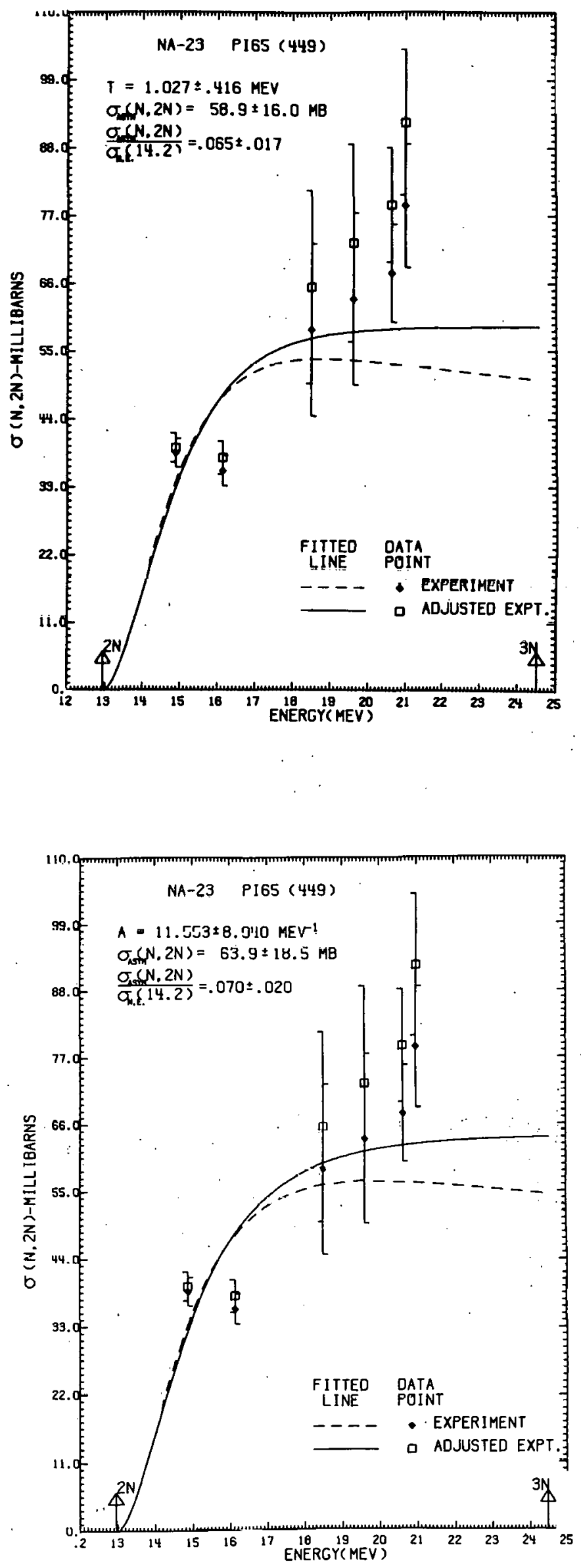


\begin{tabular}{|c|c|c|c|c|}
\hline $\begin{array}{l}\text { ENERGY } \\
\text { (MEV) }\end{array}$ & MEASURED & $,{ }^{N}, 2 N$ & $\begin{array}{l}\text { IOSS SECTION } \\
\text { AOJUSTED }\end{array}$ & $\begin{array}{l}(M B) \\
\text { ERR }\end{array}$ \\
\hline $\begin{array}{l}10000 \\
14,100 \\
15,200 \\
16,000 \\
17,200 \\
18,800 \\
19,700\end{array}$ & $\begin{array}{l}12,50 \\
29,00 \\
34,50 \\
47,00 \\
58,00 \\
61,50\end{array}$ & $\begin{array}{l}3.00 \\
3.00 \\
2.00 \\
3,50 \\
1.00 \\
0.00 \\
7.50\end{array}$ & $\begin{array}{l}12.500 \\
29,577 \\
36,120 \\
50.470 \\
64,173 \\
69,055\end{array}$ & $\begin{array}{l}3.000 \\
3.000 \\
2.054 \\
3.003 \\
4.296 \\
0.039 \\
8.421\end{array}$ \\
\hline
\end{tabular}

\section{F. ITTED PARAMETERS}

NUCLEAR TEMP, $=1.909$ PLUS-DR-NINUS, 133 MEV

ASYMPTOTIC $(\dot{N}, 2 N)$ CROSS SECTION = 35,80 PLUS-OR-MINUS 5.07 MB

RELATED UATA

NON-ELASTIC CROSS SECTIUN AT 14,2 MEV = 1051.31 MB,

(N,2N) THKESHOLD: 12,70 MEY

THIS ISUTEPE haS 16 NEUTRQNS, 15 PRUTONS, (MASS 31 )

NEUTRUN EXCESS PARAMETER $=.03226$

RATIO OF ASYMPTOTIC (N,2N) TO 14,2 MEV NON-ELASTIC

$\begin{array}{rrr}\text { TOSORT(N) }= & 7.636 \\ \text { ERROR } & .532\end{array}$

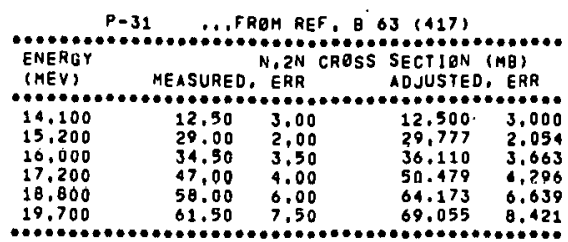

\section{fitTED paramepers}

LEVEL JHACING I 3,430 DLUS-OR-HINUS, SOGPER MEV

ASYMPTOTIC (N,2N) CRESS SECTION = 85.81 PLUS-QR-MINUS $6.66 \mathrm{MB}$

\section{RELATED DATA}

NON-ELASTIC CROSS SECTION AT 14.2 MEV = 1051.31 MB

(N,2N) THRESHOLD: $12,70 \mathrm{MEV}$
(N.3N) THRESHELD : $24,39 \mathrm{MEV}$

THIS ISOTOPE HAS 16 NEUTRQNS, 15 PROIONS, (MASS : 31)

NEUTRON EXEESSS PAËAMEIEÄ $=.03226$

RATIO OF ASYMPTETIC (N, 2N) TE 14.2 MEV NEN-ELASTIC
.0816 PLUS-ER-MINUS .0063

$\begin{array}{rrrr}\text { NSPACING } & 4.653 \\ \text { ERRGR } & .685 & \text { NSPACING } & 9.014 \\ \text { ERRER } & 1.326\end{array}$
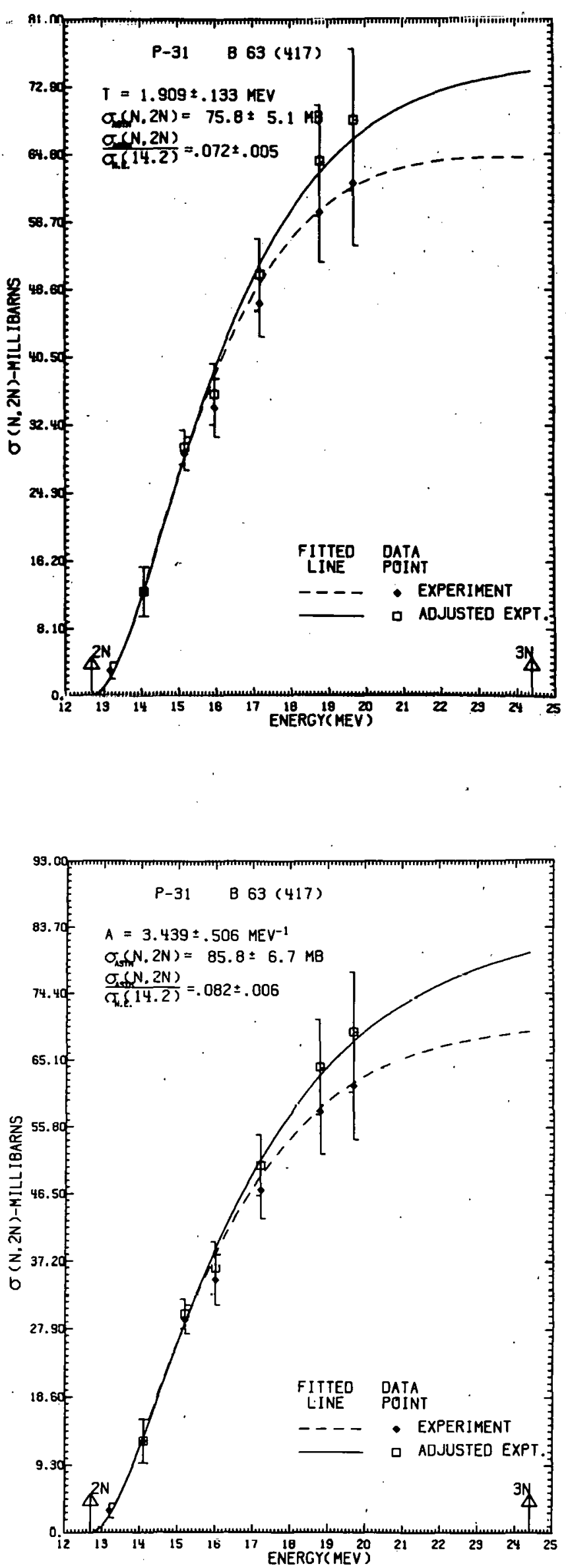


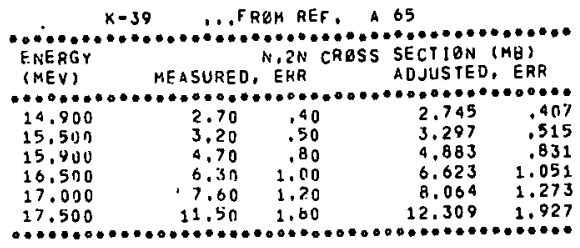

FITTED PARAMETERS

UUCLEAR TEMP. $=3.338$ PLUS-0R-MINUS1.067 MEV

A5YMPTETIC (N, $2 N$ ) CRGSS SECTIRN $=29.48$ PLUS-OR-MINUS $22.03 \mathrm{MH}$

RELATED DATA

NON-ELASTICC CROSS SECTISN AT 14,2 MEV $=1170.31 \mathrm{MB}$

NON-ELASTIC CRDSS SECTITN AT

$(N, 2 N)$ THRESHPLD $=13,42$ MEV
$(\mathrm{N}, 3$ SH) THRESHILD $=25,79 \mathrm{MEV}$

THIS ISRTIPPE HAS 20 NEUTRUNS, 19 PRETONS, (MASS $=39$ )

NEUTROA EXCESS PARAMETEP $=.02564$

RATII OF ASYMOTOTIS IM,PNI TU 14,2 MEV NON-ELASTIC

$\begin{array}{rr}\text { TOSORT(N) } & 14.928 \\ \text { ERRIOR } & 7.455\end{array}$

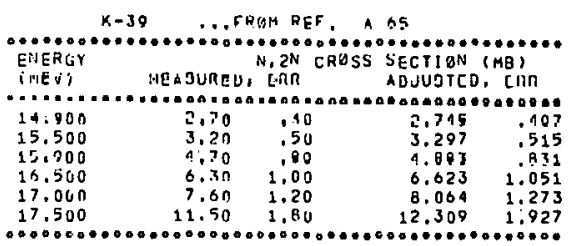

PIIIEU MARAMETFRS

LEVEL SPACING $=$ 761 PLUS-ZZK-11LNUS1.071PER MEV

ASYMPTQTIC $(M, 2 N)$ CRQSS SECTIBN $=48.67$ PLUS-פR-MINUS 55.74110

PELATED DATA

MCN-ELASTIC CRQSS SECTIGN AT 14.2 MEV $=1170.31 \mathrm{MB}$

$(N, 211)$ THRESHVLD $=13,42$ MEV

(N.2Hi) THRESHVLD $=13.42$ MEV
(N,3H) THKESHILD $=25,79 \mathrm{MEV}$

THIS ISHTEPE HAS 20 MEUTR:ANS, 29 PROTENS, (MASS $=39$ )

REUTHGN EXCESS PAPAMETER $=.02564$

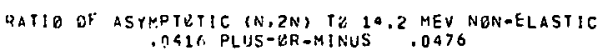

$\begin{aligned} \text { ASPACING }= & 20.281 \\ \text { ERRYR } & 36.997\end{aligned}$
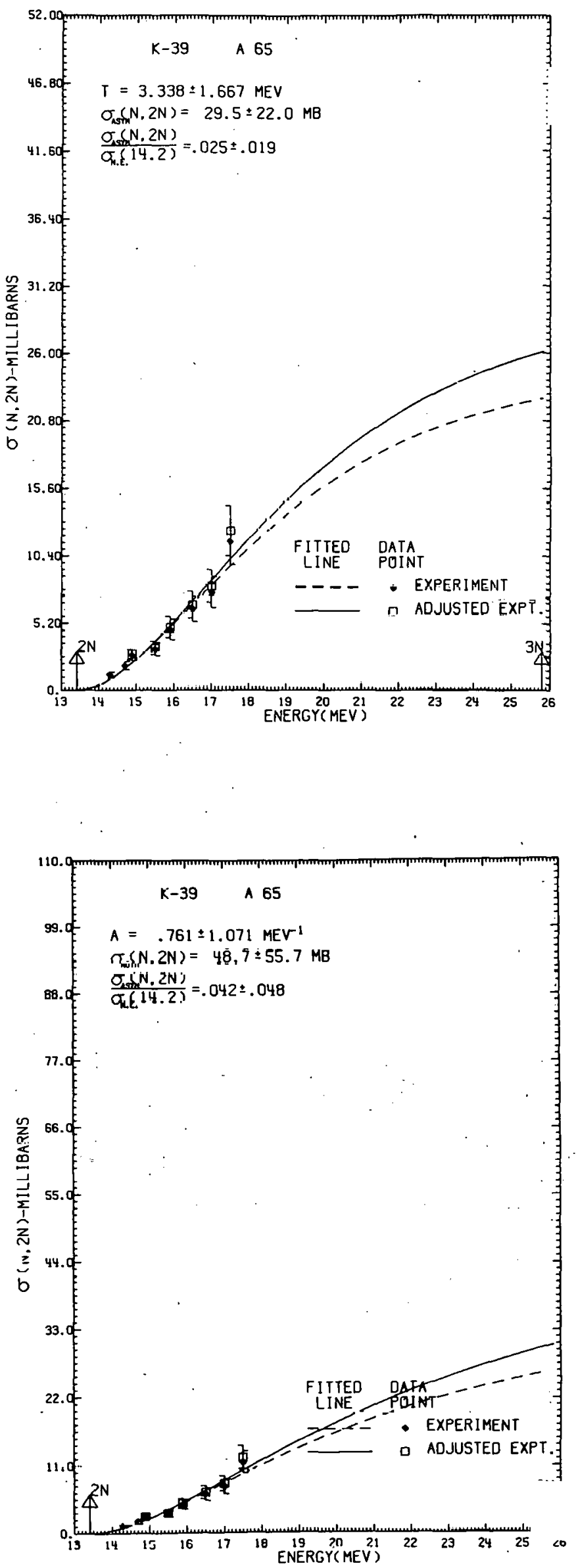


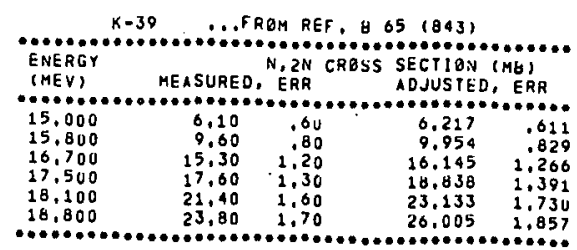

FITIEU PARAMETERS

WUCLEAR TEMP. 2.248 PLUS-OR-MINUS, 147 MEV

ASYMPTUTIC (N, 2N) CROSS SECTION

\section{RELATED DATA}

NON-ELASTIC CROSS SECTIUN AT 14.2 MEV $=1170.31 \mathrm{MB}$

$(N, 2 N)$ THKESHQLD: 13,42 MEV
$(N, 3 N)$ THKESHIALD: 25,79 MEV

THIS ISUTOPE HAS 20 NEUTRONS, 19 PRUTENS, (MASS $=39$ )

NEUTHON EXCESS PARAMETER = .02504

RATIU OF ASYMPTOTIC (N,2N) TO 14.2 MEV NUNEELASTIC .0314 PLUS-DR-MINUS , OOSO

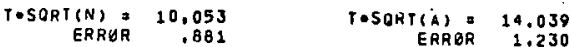

LEVEL SPACING 2.301 PLUS-BR-MINUS 460PER MEV

ASYMPTOTIC (N, 2N) CROSS SECTION a 45.52 PLUS-OR-MINUS $5.57 \mathrm{H}$

RELATED DATA

NON-ELASTIC CAOSS SECTION AT 14.2 MEV $=1270,31 \mathrm{MB}$

(N,2N) THHESHQLD : 13,42 MEV

THIS ISGTUPE HAS 20 NEUTRONS, 19 PRQTONS, IMASS $=39$

NEUTKON EXCESS PARAMETER $=.02564$

RATIR OF ASYMPTGTIC $(N, 2 N)$ TO 14.2 MEV NAN-ELASTIC.

.0389 PLUS-OR-HINUS .0048

$\begin{array}{rrr}\text { NISPACING } & 8.692 \\ \text { ERRUR } & 1.738\end{array} \quad$ A/SPACING $=\begin{array}{r}16.949 \\ 3.380\end{array}$
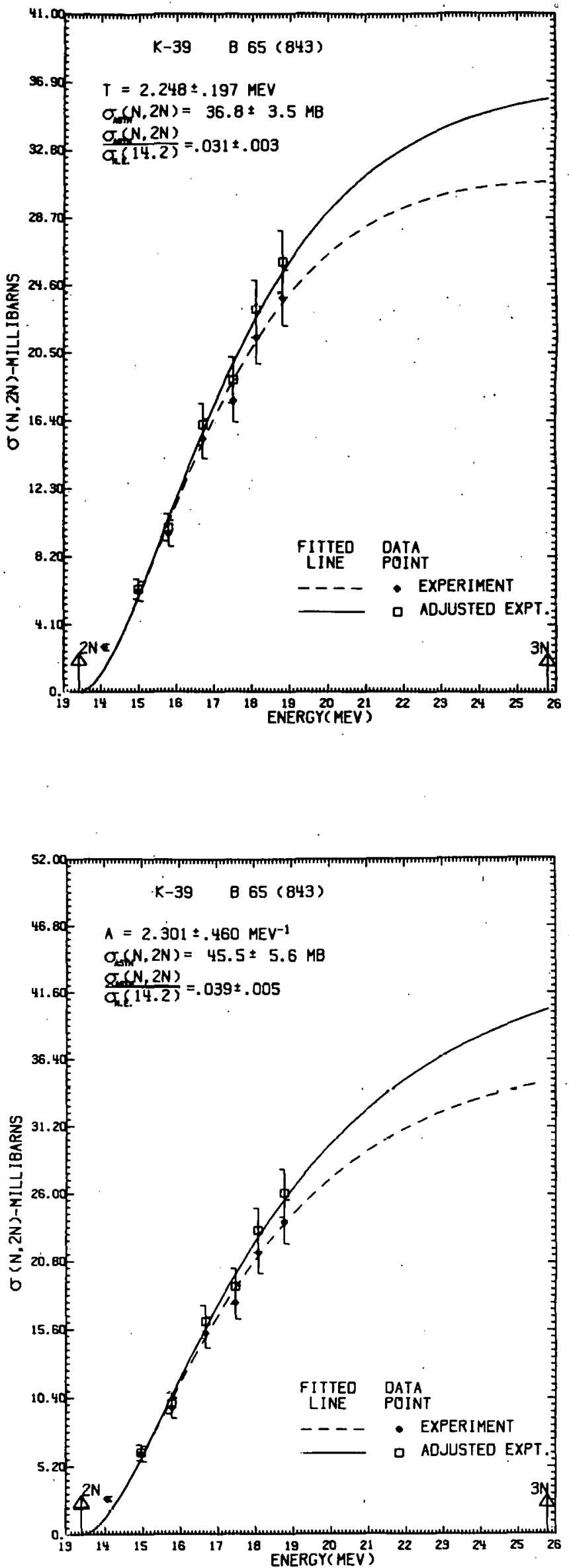


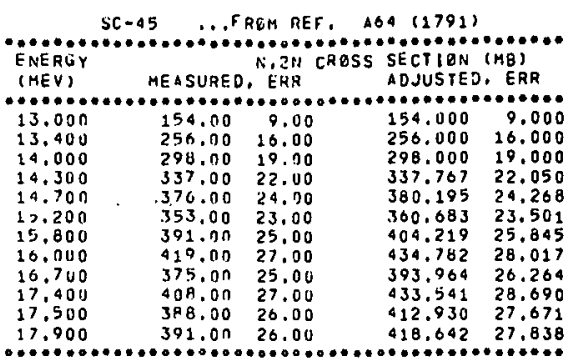

FITTEI PAHAMFTERS

AOCLEAR TEMP. = 1.063 PLUS-QR-11INUS .059 MEV

ASYMPTATIC (II, $2 N$ ) CRESS SECTION $=440.51$ PLUS-OR-MINUS $15.64 \mathrm{HB}$

RELATED TATA

NDÄ-ELASTIC CRUSS SECTISN AT $14.2 \mathrm{MEV}=1250.12 \mathrm{MB}$

(H. ZN) THRESURL $19=11$, ST MEV

THIS ISZTGPE HAS 24 NËHAONS, 21 PHOTONS, SMASS $=451$

NEUTHAN EXCESS PARAMETEK $=.00067$

AATIV OH ASYMPTITIC (N,ZN) TE 14,2 MEV NON-ELASTIC

T.SORTEN = 5.20R TOSOKTIA) $=7.131$

FITTED PARAMETERS

LEVEL SPACING E11, 102 PLUS-UR-MINUS1, 434 PER MEV

ASYMPTETIC (N.2N) CRASS SECTION 456.46 PLUS-BR-MINUS 20.12 MB

RELATED DATA

HON-ELASTIC CROSS SECTION AT 14,2 MEV $=1250,12 \mathrm{MB}$

(N, $2 N$ ) THRESHQLD: 11,57 MEV

THIS ISGTEPE HAS 24 NEUTRONS, 21 PROTONS, (MASS 451

NEUTRUN EXCESS PARAMETER $=.06667$

RATIO OF ASYMPTETIC (N,2N) TO 14,2 MEV NON-ELASTIC .3651 PLUS-BR-MINUS .0161

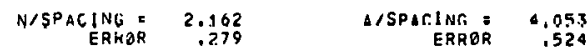
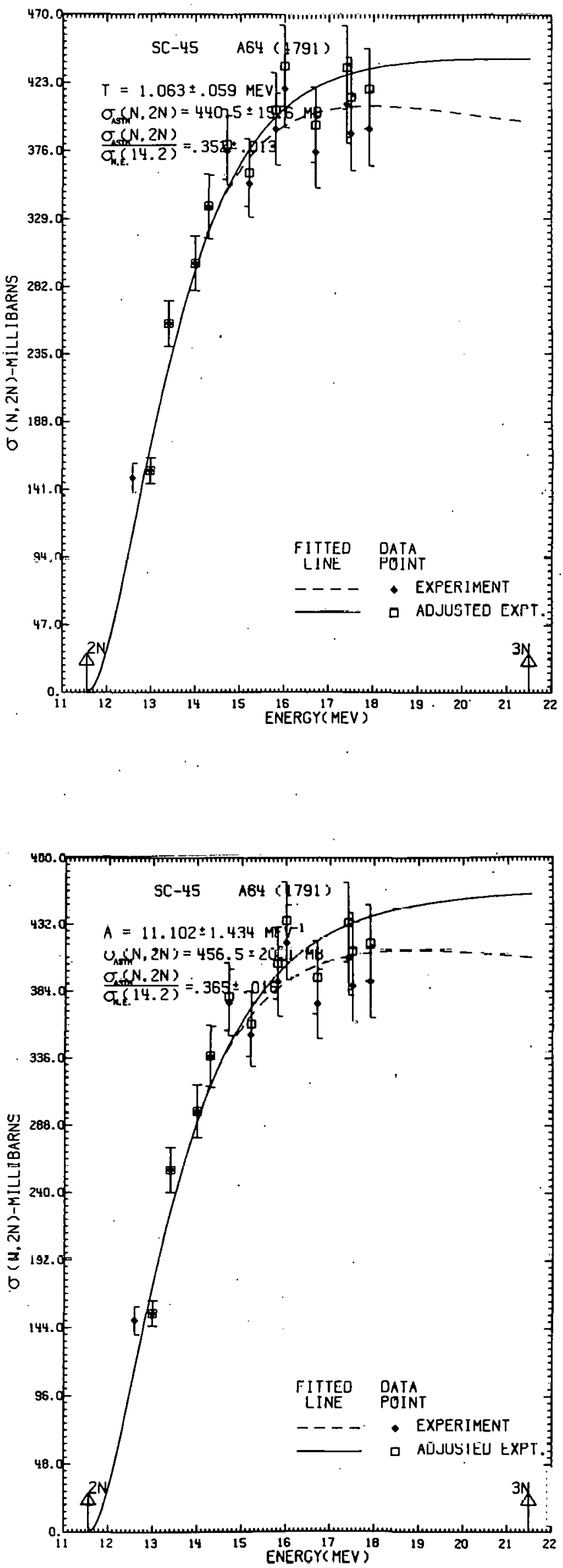


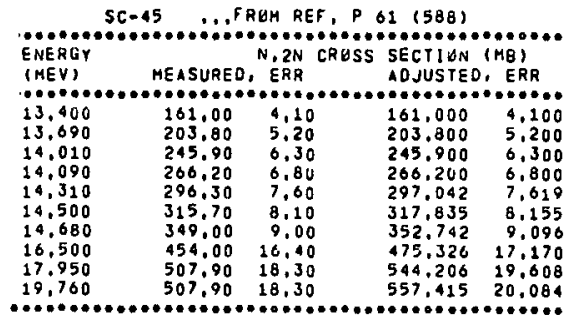

\section{FITTED PARAMETERS}

NUCLEAR TEMP. 1.778 PLUS-DR-MINUS 004 MEV
ASYMPTETIC (N, $2 N$ I CROSS SECTION 626.48 PLUS-BR-MINUS 32,49 MB

\section{RELATED DATA}

NUN-ELASTIC CROSS SECTIUN AT 14,2 MEV $=1250.12 \mathrm{MB}$ $(N, Z N)$ THKESHOLD $=11,57$ MEV

THIS ISOTUPE HAS 24 NEUTRUNS, 21 PRUTMNS, (MASS 45 )

NEUTRUN EXCESS PARAMETER $=.06667$

RATIL OF ASYMPTOTIC (N,2N) TO 14,2 MEV NUN-ELASTIC .5011 PLUS-UR-MINUS .0260

T.SORTIN) = $0.710 \quad$ TOSORT (A) $=11.927$

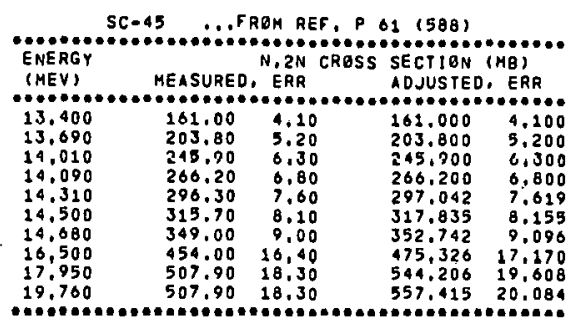

\section{FITTED PARAMETERS}

LEVEL SPACING 3.746 PLUS-OR-MINUS $500 P E R$ MEV
ASYMPTOTIC (N, 2N) CRESS SECTION 693.32 PLUS=-BR-MINUS 53.53 MO

\section{RELATED DATA}

NQN-TLAETIO CROEE SECTION AT 24, I HEV - 1250,18 MO (N, 2N) THRESHOLD: 11,57 MEV

THIS ISGTEPE HAS 24 NEUTRONS, 22 PROTONS, (HASS : 45)

NEUTRGN EXCESS PARAMETER : .06667

RATIO OF ASYMPTOTIC (N,2N) TO 14.2 MEV NON-ELASTIC

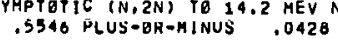

N/SPACING: 6.407

$$
\begin{array}{rr}
\text { A/SPACING } & 12,013 \\
\text { ERRER } & 1,603
\end{array}
$$
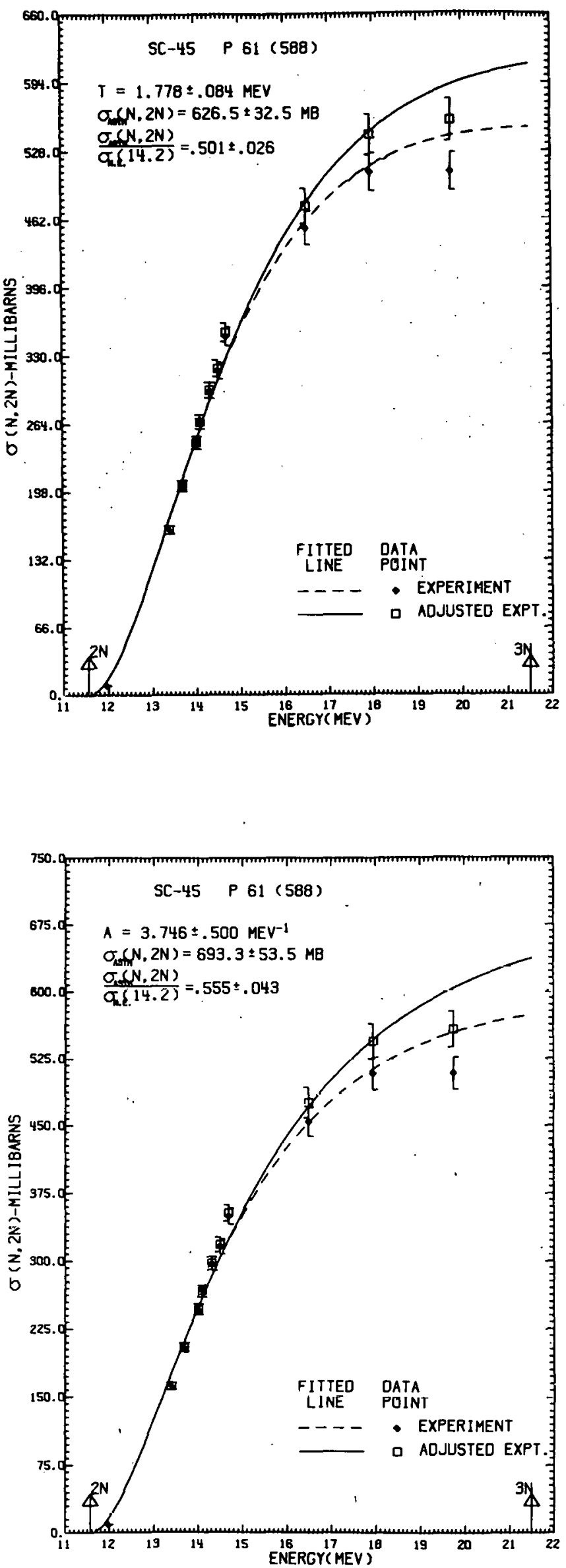


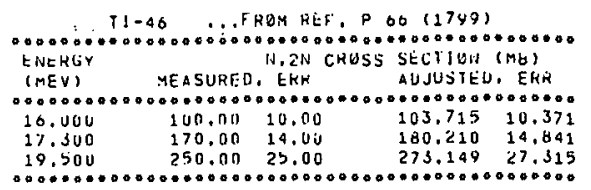

FIITEJ PAFAMETERS

NUCLEAH TFMP. $=2.546$ PLUS-OUN-HINUS .112 MEV

ASYMPTQTIL (D:EN) CRUSS SECTILN = 40K.0O PLUS-OR-MINUS 19.99 MA

KCLLATED UATA

NEN-ELASTIC COQSS SECIIUR AT 24.2 MEV $=1262.79 \mathrm{MB}$

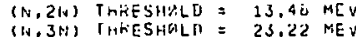

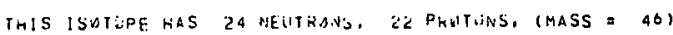

NEUTREAM ERCESS PARAMETEK = .64340

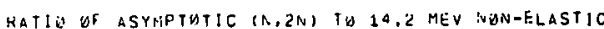
.3187 PLUS $-4.1 \%=$ MIN.JS , 0150

$\begin{array}{rrr}\text { TOSOHTRN } & 12.483 \\ \text { ERRLR } & .549 & \text { TOSONT(A) }=17.281 \\ \text { ERRLF } & .760\end{array}$

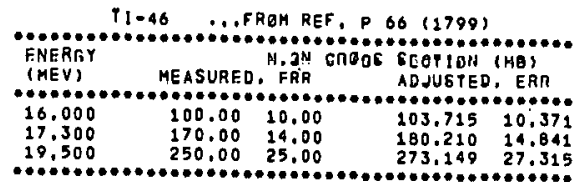

FITTED PARAMETERS

LEVH SPACING

LEVFL SPACING 1.917 PLUSNOR-MINUS JOOPER MEY

ASYMPTOTIC (N.2N) CRESS SECTIEN E 503.83 PLLUS-AR OMINUS 52.35 ME

KELATEU UATA

NON-ELASTIC CRESS SECTION AT 14.2 MEV * 1262:79 MO

$(N, 2 N)$ THRESHOLD $: 13,48 \mathrm{MEV}$

THIS ISOTEPE HAS 24 NEUTRENS, 22 PROTONS, (MASS a 46)

NEUTRON EXCESS PARAMETER = .04348

RATIO OF ASYMPTOTIC (N.2N) TO 14.2 MEV NGN-ELASTIC

.3900 PLUS-QR-MINUS .0415

N/SPACING $=13.209$

A/SPACING: 25,316
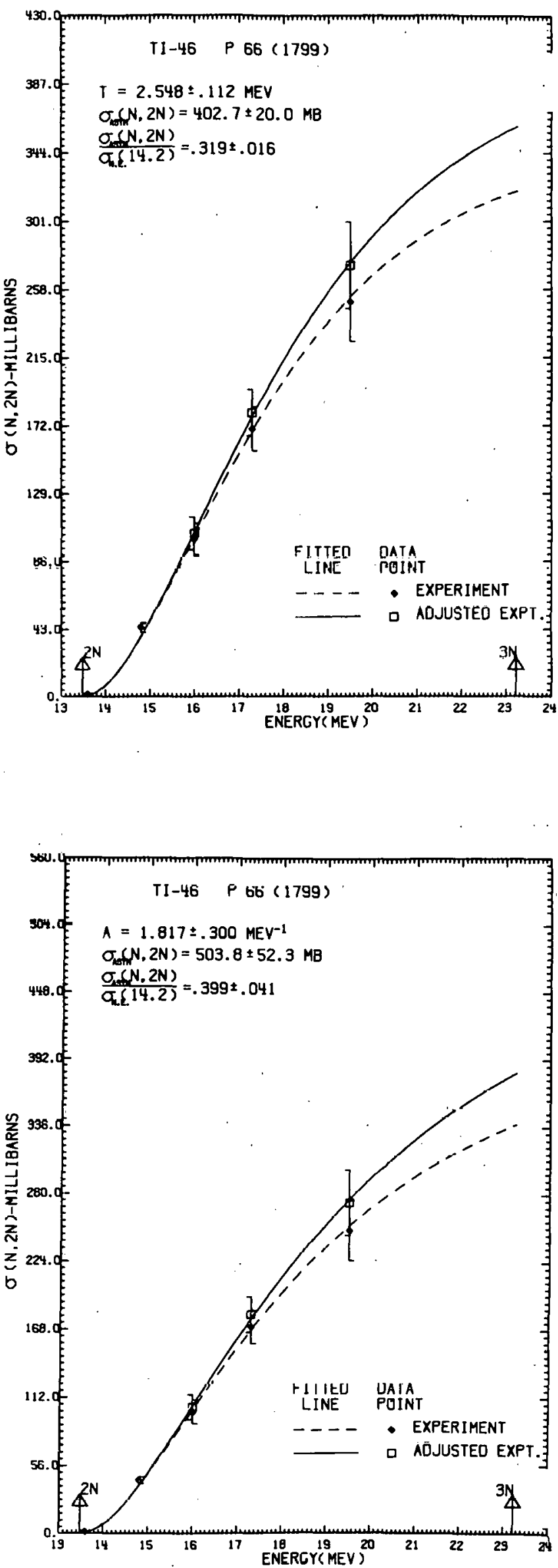


\begin{tabular}{|c|c|c|c|c|}
\hline \multicolumn{5}{|c|}{ T1-46 WFKGM HEH, G OS $(1600)$} \\
\hline E:AERGY & & $0,2 N$ & CKÄSS SECTIOH & \\
\hline (IFE) & $\begin{array}{l}\text { MEASURED } \\
\text { OO...... }\end{array}$ & $\begin{array}{l}1, E R K \\
\ldots, D \in 0\end{array}$ & AUJUSTE & ERR \\
\hline 15.000 & 69.50 & 8.60 & 70.706 & 0.134 \\
\hline 16.000 & $137 . n 0$ & 17.00 & $142.06 y$ & \\
\hline $1 \% .600$ & 173.00 & 22.00 & 162.521 & 23.211 \\
\hline $1 E .040$ & 202.10 & 25.00 & 216.369 & $<6.700$ \\
\hline $10.60 \mathrm{n}$ & 213.00 & 20.04 & 230.073 & 20.004 \\
\hline 19.600 & 214.07 & 20.00 & 234.097 & 26.442 \\
\hline
\end{tabular}

FIITHU PARAHETERS

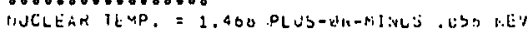

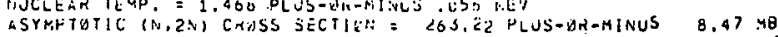

KELATED LATA

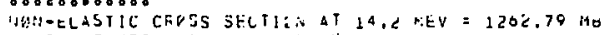

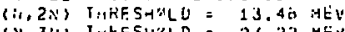

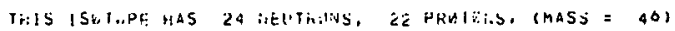

DEUTMAN LXCESS PARAMETEH $=.04340$

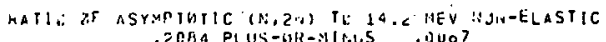

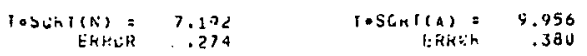

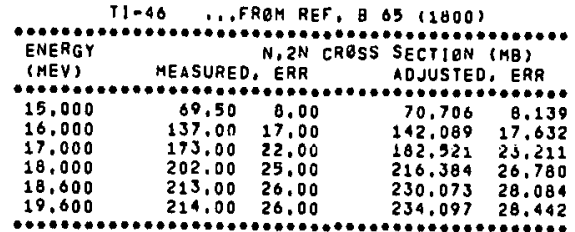

\section{FitTED ramani tent}

LEVEL SPACING O. 306 PLUS-OR-MINUS .679PER MEV

ASYMPTOTIC (N.2N) CROSS SECTIBN= 284.56 PLUS-OR-MINUS 13.99 ME:

\section{RELATED DATA}

NON-ELASTIC CROSS SECTION AT 14.2 MEV $=1262.79 \mathrm{MB}$

$(N, 2 N)$ THRESHQLD: $13.48 \mathrm{MEV}$
(N,3N) THRESHOLD: $23.22 \mathrm{MEV}$

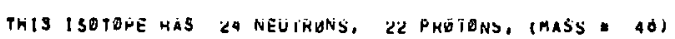

NEUTRON EXCESS PARAMETER = .04348

RATI OF ASYMPTATIC. (N, ZN) TO 14.3 MEV NON-FLASTIC .2253 PLUS-OR-MINUS .0111

$\begin{array}{rrrr}\text { N/SPACING } & 3.806 & \text { A/SPACING: } & 7,295 \\ \text { ERRBR } & .410 & \text { ERROR } & 789\end{array}$
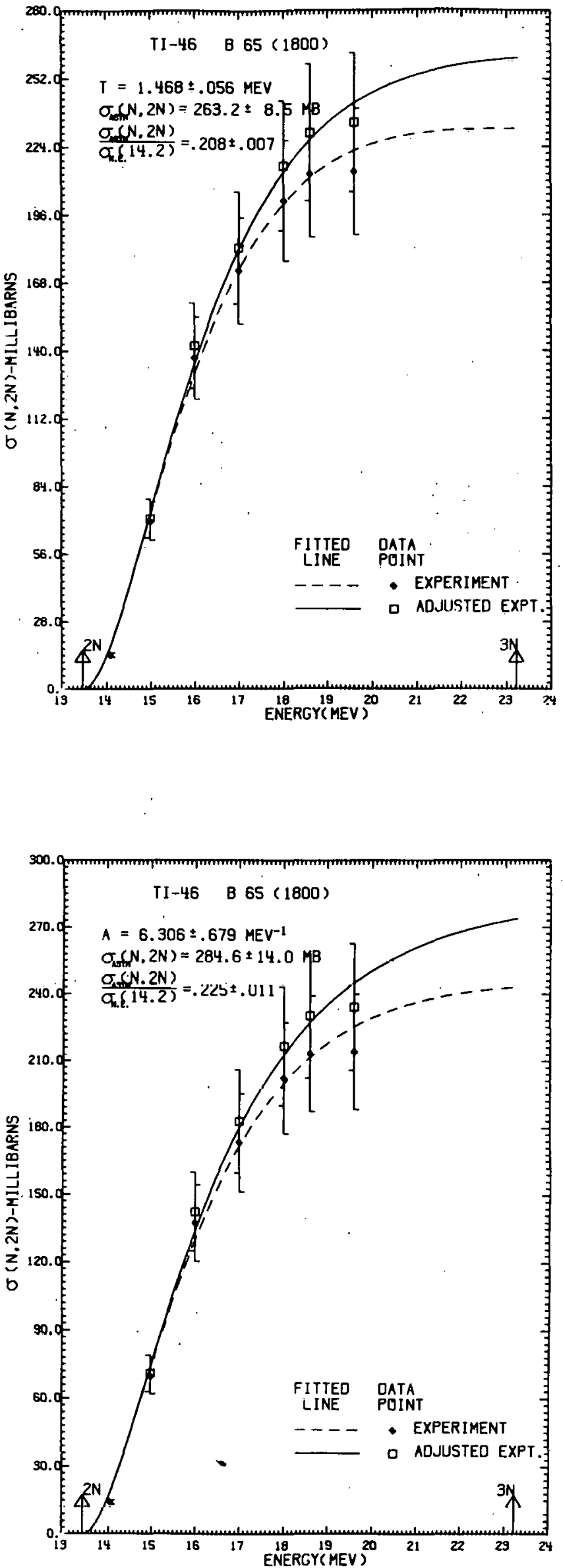


\begin{tabular}{|c|c|c|c|c|}
\hline $\begin{array}{l}\text { ENERLYY } \\
\text { (MEV) }\end{array}$ & & $\begin{aligned} N, 2 N \\
E R H \\
B\end{aligned}$ & $\begin{array}{r}\text { CHOSS SECTIDIN } \\
\text { AUJUSTE }\end{array}$ & (HO) \\
\hline & & & & \\
\hline $\begin{array}{l}14.930 \\
16.500\end{array}$ & $\begin{array}{r}44,50 \\
145,00\end{array}$ & $\begin{array}{l}3.00 \\
7.00\end{array}$ & $\begin{array}{r}45.267 \\
151.716\end{array}$ & $\begin{array}{l}3.048 \\
7.3<4\end{array}$ \\
\hline 17.950 & 185.00 & 9,00 & 190.031 & 9.034 \\
\hline 19.700 & 233.90 & 12,00 & 256.351 & 13.152 \\
\hline
\end{tabular}

FITTED PARAMETERS

NUCLEAK TEMP. = 2.133 HLUS-AR-MINUS RQY MEV

ASYMPTETIC (N,?N) CRUSS SECTIAT: = 324, 1 S PLUS-ER-i1INUS 47,3240

RELATED NAT

ACN-GLASTIC CRESS SECTIR: AT 14,2 MEV = $1262.79 \mathrm{MB}$ $(N, 2 N)$ THKESHRLU $=13,40: 4$ :

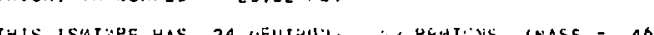

REUTHON EXCLSS PARAMETER $=.04040$

RATIZ UF ASYMPTETIC (N,ZN) IE 14.2 HEV NON-ELASTIC

$\begin{array}{rrr}\text { T.SOHT N N }= & 10.450 \\ \text { ERHAH } & 1.431\end{array} \quad$ T.SURT(A) $=14.467$

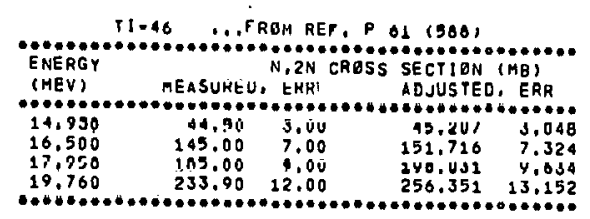

FITTED PARAMETERS

LEVEL SPACING 2.855 PLUS-OR-MINUS .971PER MEV

ASYMPTOTIC (N, 2N) CRQSS SECTION 394.02 PLUS-OR-MINUS 83,98 MO

KELATEU UATA

-..............

NON-ELASIIC CROSS SECTION AT $14.2 \mathrm{MEV}=1202.79 \mathrm{mB}$

$(N, 2 N)$ THRE SHELD: 13,48 MEV
$(N, 3 N)$ THRESHOLD 23,22 MEY

THIS ISOTOPE HAS 24 NEUTRONS, 22 PROTONS, (MASS: 46)

NEUTRON EXCESS PARAMETER $=.04348$

RATIO OF ASYMPTOTIC. (N,2N) 1014.2 MEV NEN-ELASTIC .3120 PLUS-BR-MINUS .0665

$\begin{array}{rrrr}\text { N/SPACING } & 9.040 & \\ \text { ERRER } & 3.306 & \text { A/SPACING } & 17.326 \\ \text { ERROR } & 6.336\end{array}$
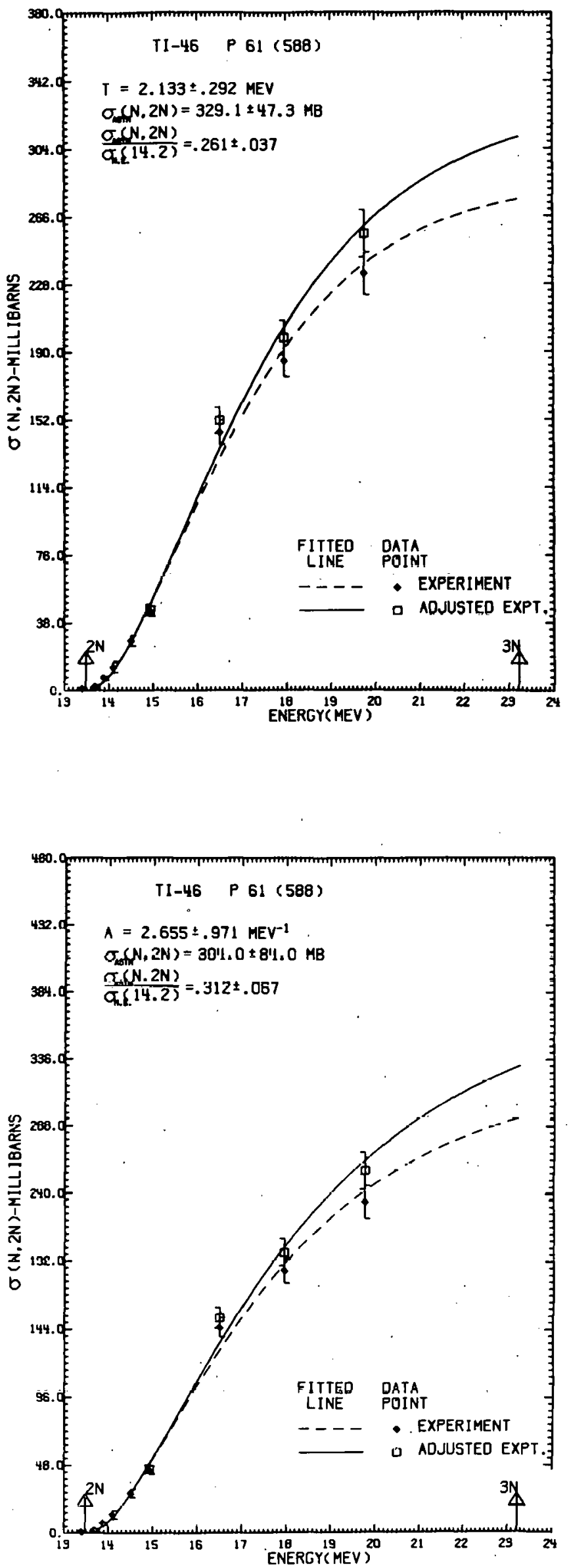


\begin{tabular}{|c|c|c|c|c|}
\hline \multicolumn{5}{|c|}{ 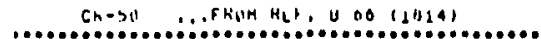 } \\
\hline $\begin{array}{l}\text { AERTYY } \\
\text { AEVI }\end{array}$ & YEA A SURE: & 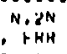 & $\begin{array}{l}\text { CHOSS SI.CTION } \\
\text { AIIJUSTH:D }\end{array}$ & MULR \\
\hline$\ngtr 00$ & 70 & 2.50 & 24 & 36 \\
\hline 15.800 & & & & \\
\hline 10.000 & 50. & 4,3 & 62. & 4.496 \\
\hline 40 & & & 71. & 5,292 \\
\hline 18.200 & 78.40 & 3.40 & 85.895 & 5.778 \\
\hline 16.90 & 84.40 & 0, & 41,110 & 7.233 \\
\hline & 96 , & & 104 & 6 \\
\hline
\end{tabular}

DIIEU PAHAMETELS

VULLEAR TEMP. = 1.778 PLUS-UK-MINUS, 111 IIEV

ASYMPTOTIC $(N, 2 N)$ CRESS SECTION.= 111,40 PLUS-OR-MINUS 5.00 ME

FELATED DATA

MEN-ELASTIC CROSS SECTIUN AT 14.2 MEV $=1311.87 \mathrm{MB}$ $(N, 2 N)$ THRESHQLD. = 13,20 MEV

IHIS ISUTEPE HAS 20 NEUTHONS, 24 PROTONS, (MASS a 50 )

HEUTRGA EXCESS PARAMETER $=.04000$

RATIS OF ASYMPTETIC (N,2N) TU 14.2 MEV NEN-ELASTIC
.OUSO PLUS-BH-MINUS .0O4S

$\begin{array}{rrr}\text { T.SUPT (N) }= & 9.066 & \text { TOSURT(A) } \\ \text { EKRDR } & .566 & 12.572 \\ \text { ERRER } & .785\end{array}$

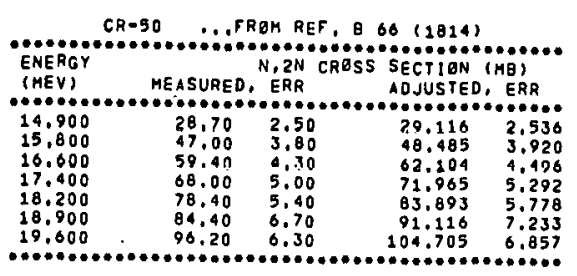

\section{FITTED PARAMEFERS}

LEVEL SPACING 4.129 PLUS-OR-MINUS ,493PER MEY

ASYMPTOTIC IN, $2 N$ I CRGSS SECTION 124.55 PLUS-OR-MINUS $7,02 \mathrm{MB}$

\section{RELATED DATA}

NON-ELASTIC CRESS SECTION AT 14.2 MEV $=1311.87 \mathrm{MB}$

(N, 2N) THRESHOLD: $13,20 \mathrm{MEV}$
(N,3N) THRESHOLD: $24.05 \mathrm{MEV}$

PHIS ISOTOPE HAS 26 NEUTRONS, 24 PROTENS, (MASS = 50 )

NEUTRON EXCESS PARAMETER = .04000

. MATIO OF ASTHPTOTIC IN,ZN) IO 14,2 MEV NON-ELASTIC
.0949 PLUS-OR-MINUS .0053

$\begin{array}{rr}\text { N/SPACING } & 6.297 \\ \text { ERRER } & .752\end{array}$

$\begin{array}{rr}\text { A/SPACING }= & 12,109 \\ \text { ERRER } & 1,446\end{array}$
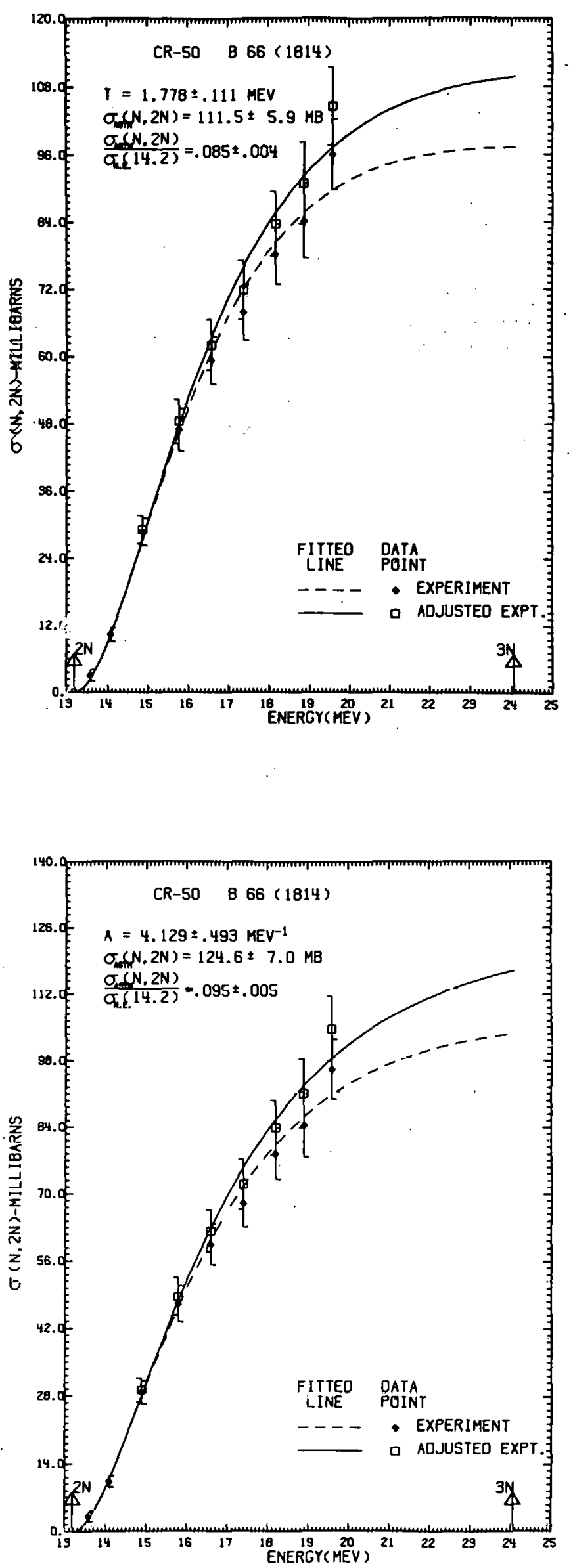


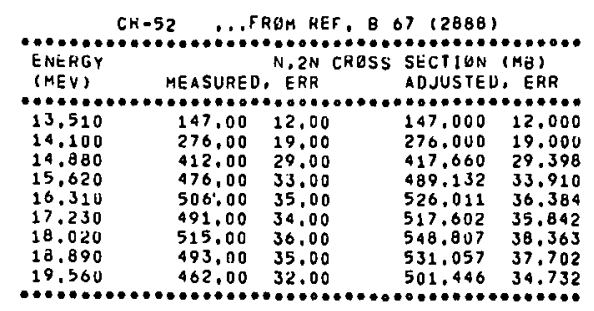

FIITED PARAMETERS

NUCLEAR TEMP. = 1.131 PLUS-ORK-MINUS .075 MEV

ASYMPIGTIC (N.2N) CRUSS SECTION = 500.19 PLUS-GR-MINUS 24.88 MB

RELATED DATA

NON-ELASTIC CRESS SECTIEN AT 14.2 MEV $=1335.54 \mathrm{MB}$ (N,2N) THRESHELD $=22.27$ MEV

THIS ISOTAPE HAS 28 NEUTRENS, 24 PRDTONS, (MASS $=52$ )

NEUTHUN EXCESS FARAMETER $=.07692$

HATIS OF ASYMPTBTIC (N, 2N) TU 14,2 MEV NBN-ELASTIC

.4194 PLUS-GH-MINUS .0186

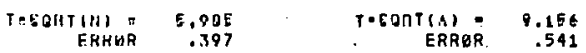

DITTED PARAMETERS

LEVEL SPACING 10.374 PLUS-gR-MINUS1, OBQPER MEV

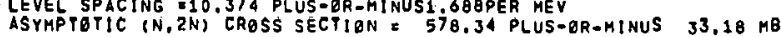

RELATED DATA

NON-ELASTIC CRESS SECTIEN AT 14.2 MEV $=1335.54 \mathrm{MB}$

$(N, 2 N)$ THRESHQLD $=.12,27$ MEV
$(N, 3 N)$ THRESHOLD $=21,71$ : MEY

THIS ISOTOPE HAS 28 NEUTRENS, 24 PROTONS, IMASS 52 ,

NEUTRON EXCESS PARAMETER $=.07692$

RATIO OF ASYMPTOTIC (N,2N) TO 14,2 MEV NON-ELASTIC .4330 PLUS-OR-MINUS .0248

$\begin{array}{rrrr}\text { N/SPACING: } & 2.699 \\ \text { ERRER } & .439 & \text { A/SPACING: } & 5.013 \\ & .816\end{array}$
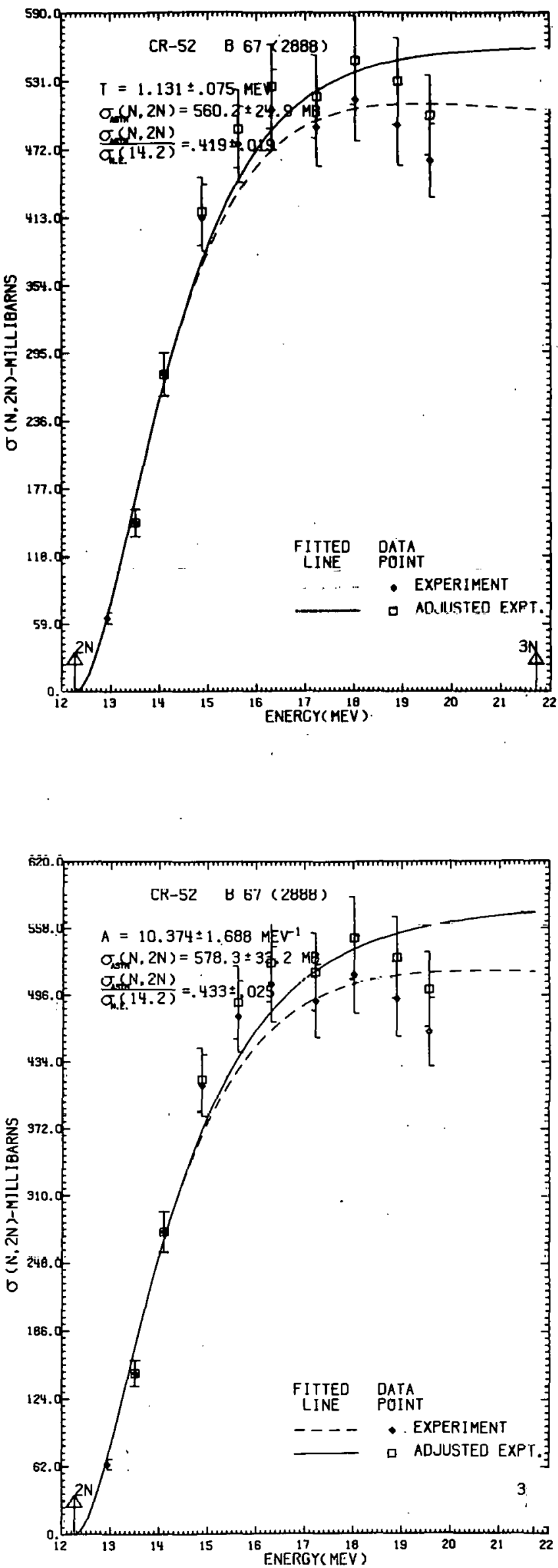


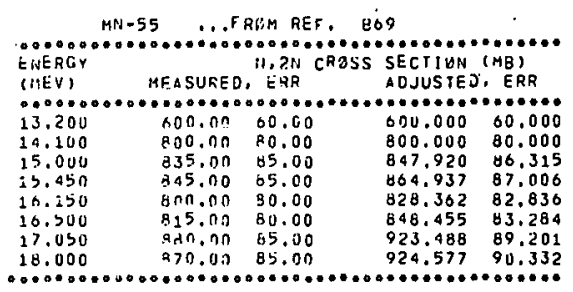

FITTEU PAhAMFTERS

NULLFAK TFMP. $=1.197$ PLULS-MR-MIIUUS .087 MFV

ASYMPTOTIC (N, ?N) CROSS SECTIUN $=920.90$ PLUS-GR-MINUS 25.79 MU

RFLATED DATA

NGN-ELASTIC CEASS SECTIEN AT 14.2 MEV $=1370.05$ MB

(N.ZN) THEESHOLD $=10.41 \mathrm{MEV}$
(N, ZH) THEESHOLD $=19.52 \mathrm{MEV}$

THIS ISUTOPE HAS 30 NEUTRINS, 25 PRQTIONS. (MASS : 55 )

MEUTRGN EXCESS PARAMETER $=.09091$

RATIG OT ASYMPIOTIC (N.2N) IM 14.2 MEV NON-ELASTIC

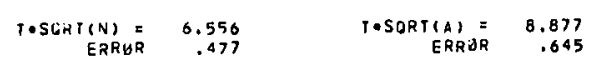

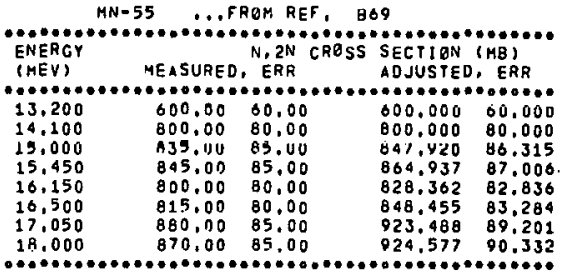

\section{FITTED PARAMETERS}

LEVEL SPACING $=8,729$ PLUS-BKAMINUS1, 440 PEH MEV

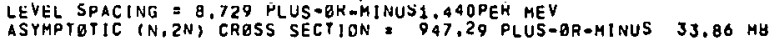

\section{RELATED DATA}

NON-ELASTIC CRASS SECTIUN AT 14,2 MEV. $=1370.05$ MB (N,2N) THHESHQLD, 10.41 MEV

THIS ISETUPE HAS 30 NEUTRONS, 25 PRETONS, (MASS = 55)

NEUTRQN FXTESS PARAMFIFA = , חQNQ

RATIO OF ASYMPTOTIC (N,2N) IO 14.2 MEV NON-ELASIIC

RATID OF ASYMPTOTIC (N,2N) TO 14.2 MEV NON

$\begin{array}{rrrr}\text { N/SPACING } & 3.437 \\ \text { ERHER } & .567 & \text { A/SPACING }= & 6.301 \\ \text { ERRER } & 1.030\end{array}$
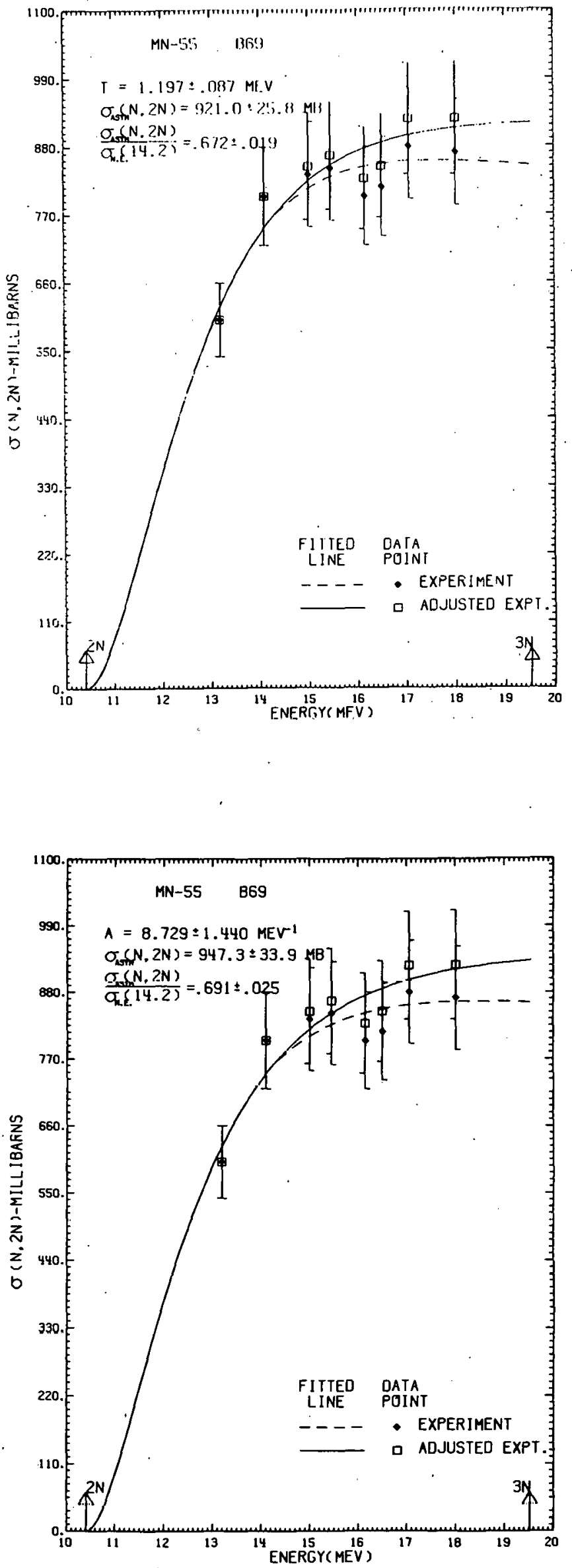


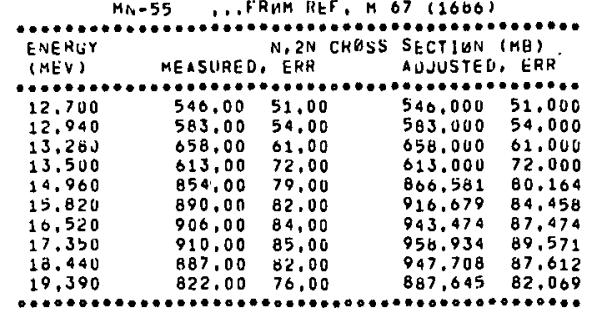

FITTED PARAMETERS

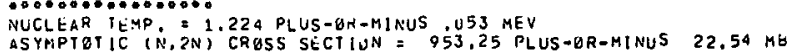

RELATEU UATA

NON-ELASTIC CRESS SECTIBN AT $14.2 \mathrm{MEV}=1370.05 \mathrm{MB}$

(IN.2N) THEESHOLD $=10.41 \mathrm{MEV}$

THIS ISUTUPE HAS 30 NEUTRONS, 25 PROTBHS, (MASS = 5H)

NEUTHON EXCESS PARAMETEF $=.09091$

RATIO OT ASYMPTOTIC (N,2N) TI 14.2 MEV NEN-ELASTIC 6950 PLUS-BA-MINUS, 0165

$\begin{array}{rrr}1.5 U H I N)=0.704 & \text { T.SURT(A) } & 9.077 \\ \text { ERRER } & , 393\end{array}$

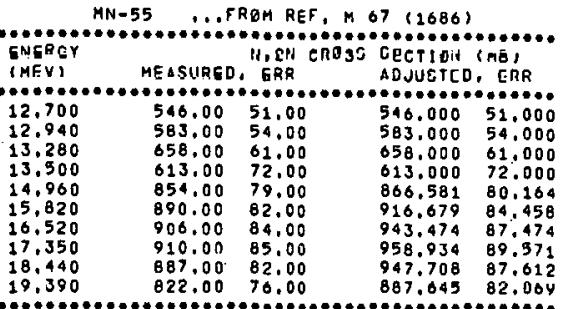

FITTED PARAMETERS

LEVEL GPACING

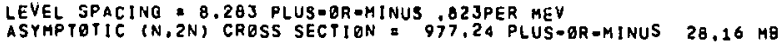

HELTTEO DATA.

NON-ELASTIC CROSS SECTION AT 14.2 MEV $=1370^{\circ} .05$ MB

(N,2N) THRESHOLD = $10.41 \mathrm{MEV}$
$(\mathrm{N}, 3 \mathrm{~N})$ THRESHQLD $=19.52 \mathrm{MEV}$

THIS ISOTEPE HAS 30 NEUTRONS, 25 PROTONS, (HASS: 55)

NEUTREN EXCESS PARAMETER $=.09091$

RATIG OF ASYMPTATIC (N,ZN) TG 10.2 MEV NON-ELASTIC .7133 PLUS-GR-MINUS 2 MEN NO

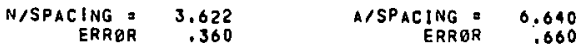
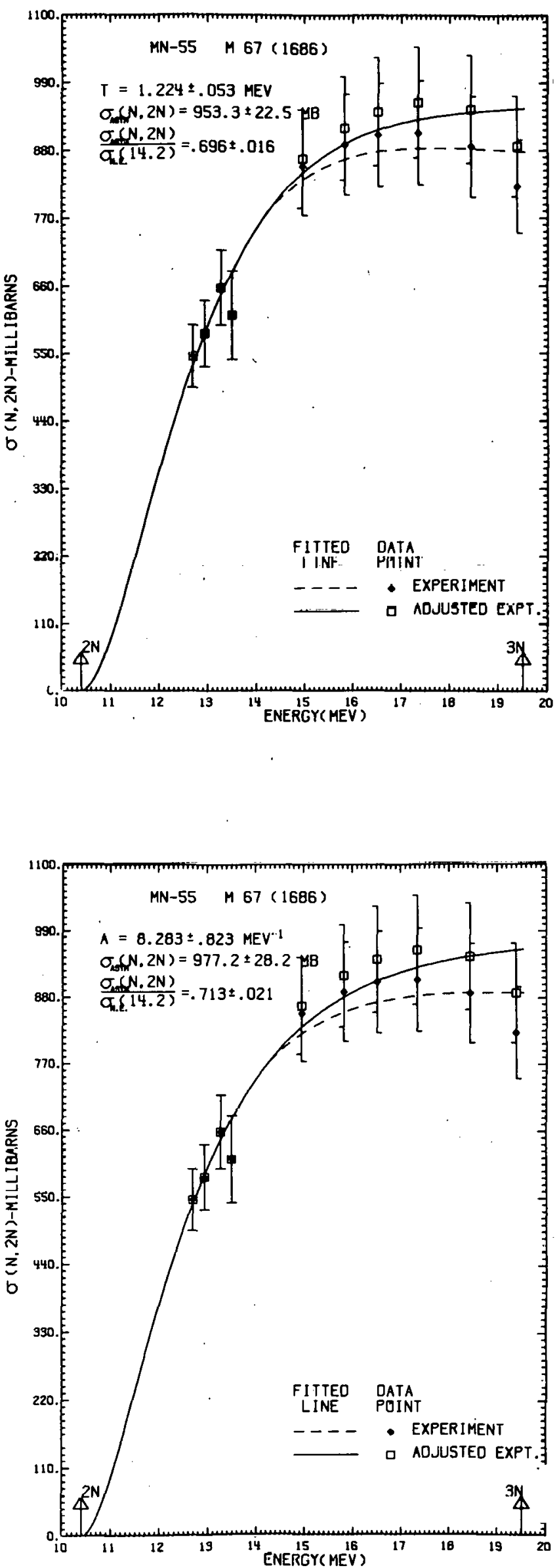


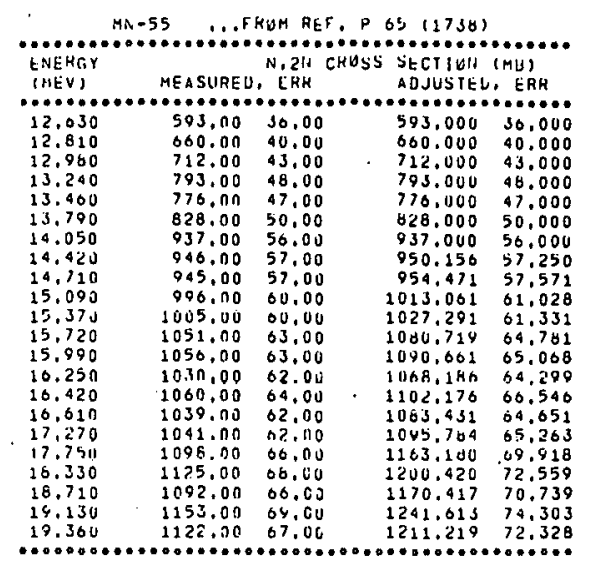

FITIED PASALETERS

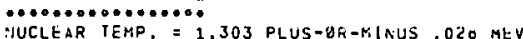

ASYMPTUTIC (N.2N) CRESS SECTINH = 1177.09 PLUS-OR-MINUS 13.58 YE

RELATED UATA

NON-ELASTIC COUSS SECTIUN AT $14.2 \mathrm{MEV}=1370.05 \mathrm{MB}$

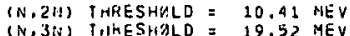

THIS ISZTLPE has 30 NeUTHans, 25 PHuTHNS, (MASS - 53)

NEUTRLiN EXCESS PAHAMETER $=.09091$

RATIO OF ASYMPTUTIC (N.2N) TU 14,2 MEV NUN-ELASTIC 08592 PLUS-ËR-MINUS .0099

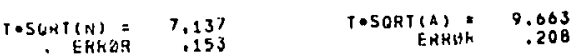

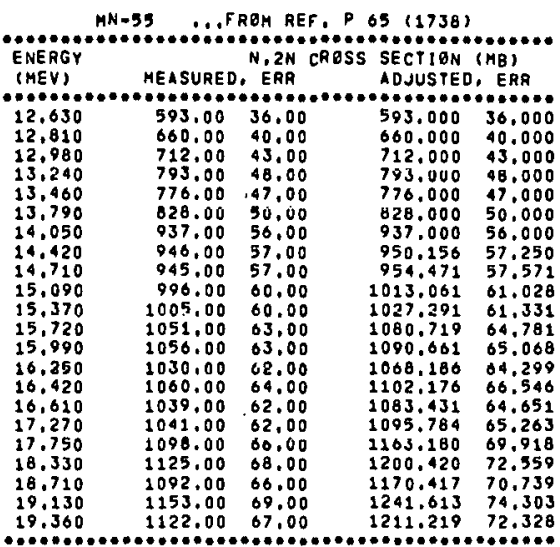

FI'TtEo Parameters

LEVEL SPACING, 162 PLUS-ER-MINUS .295PER MEV

ASYMPTOTIC (N.2N) CAOSS SECTION a 1221.76 PLUS-OR-MINUS 14.58 MB

RELATED DATA

MON-ELASTIC CROSS SECTION AT 14,2 MEV = 1370,05 ME

NON-ELASTIC CROSS SECTION AT 14

(N,2N) THRESHOLD 10,41 MEV

THIS ISGTOPE HAS 30 NEUTRONS, 25 PRETONS, (MASS - 55)

IEUTRON EXCESS PARAMETER - .09091

IATIE OF ASYMPTETIC (N, 2N) TO 14.2 MEV NON-ELASTIC .8Y1B PLUSAR-MINUS .0106

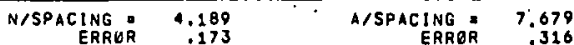
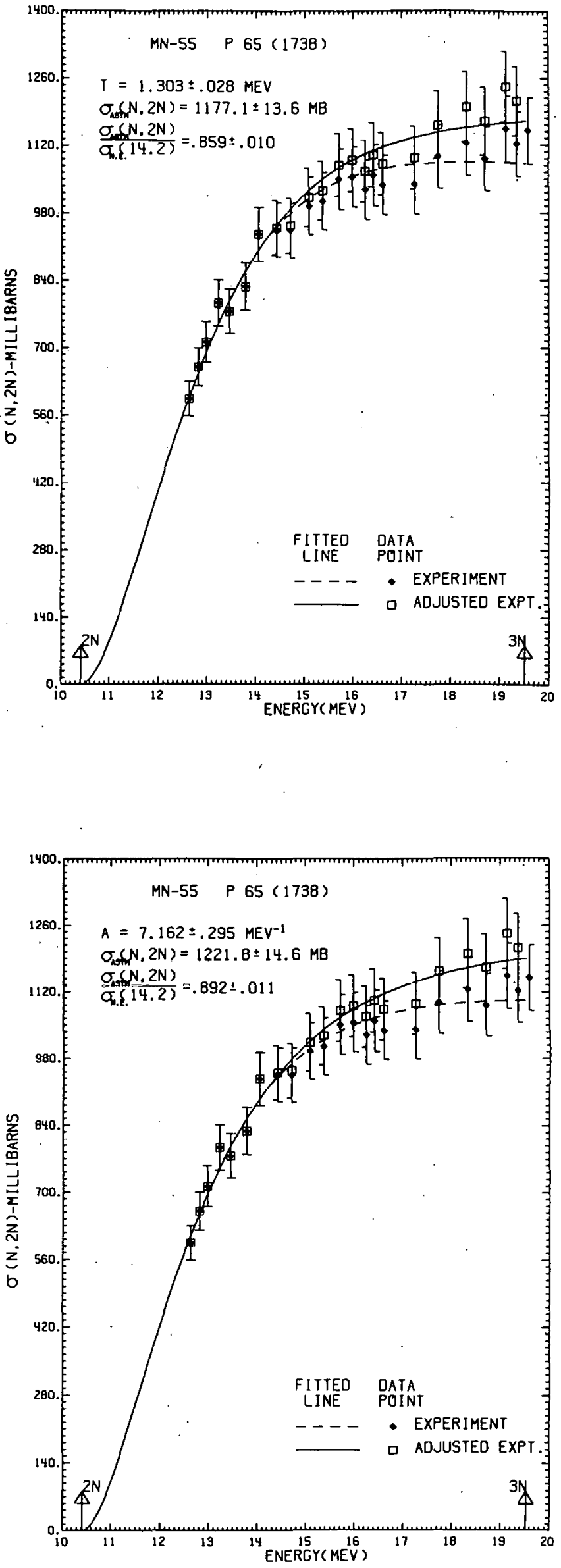


\begin{tabular}{|c|c|c|c|c|}
\hline \multicolumn{5}{|c|}{$F_{E-54}$...FRUM REF, a 72} \\
\hline $\begin{array}{l}\text { OOÖOO } \\
\text { EIVEHGY } \\
\text { (MEV) }\end{array}$ & & 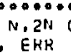 & $\begin{array}{l}\text { CROSS SECTIUN } \\
\text { ADJUSIEO }\end{array}$ & ERR \\
\hline$\infty \ldots+\infty$ & me & & & \\
\hline 15,080 & 23.60 & 1. & 24.005 & 526 \\
\hline 15.350 & 29.00 & & 29.0 & 8 \\
\hline Hir & 29.50 & & 30.208 & \\
\hline 15,920 & 37.00 & 2,10 & 36.186 & 2.107 \\
\hline 16.430 & 45,50 & 2.40 & 47.341 & 97 \\
\hline 16.940 & 56.00 & 3,00 & 58.711 & 3.145 \\
\hline 17.560 & 50. & 3. & 59.432 & 3,2 \\
\hline & 58.10 & 3.00 & 01.973 & 3.200 \\
\hline & & & & \\
\hline
\end{tabular}

FitTLu PARAMETERS

NUCLEAR TEMP. = 1.268 PLUS-UK-H1NUS, 089 MEV

ASTMPTOTIC (N, $2 N)$ CFUSS SECTIEN $=72,07$ PLUS-GR-MINUS $4.57 \mathrm{MO}$

RELATED DATA

NUN-ELASFIC CRUSS SECTIMN AT $14.2 \mathrm{MEV}=1358.07 \mathrm{MU}$

(N.2N) THRESHOLO $=13.63$ MEV

THIS ISOTSPE HAS 20 HEUTKONS, 20 PHOTHNS, (MASS $=54$ )

MHUTHGN EXTESS PARAMETER = .03\%4

FATIB EF ASYMPTRTIC (M,2N) TD 14,2 MEV NUN-ELASTIC .0536 PLUS-OR-AIINUS .0U34

$\begin{array}{rrr}\text { TOSORTSN) }= & 6,710 \\ \text { FRHMR } & .471 & \text { TOSUHT(A) }\end{array}$

FE-54 W. TREH REF, B 78

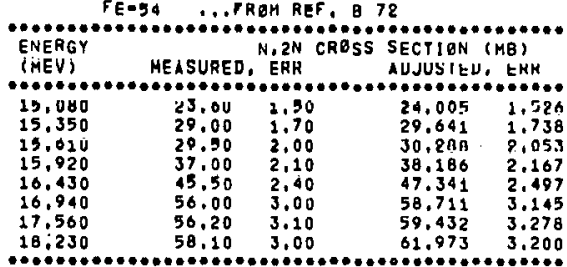

FitTed parahetérs

LEVEL SPACING B.

ASYMPTETIC (N,2N) CRESS SECTIONE ;B.24 PLUS-QR-MINUS $5.88 \mathrm{MB}$

\section{RELATED DATA}

NGN-GLASTIC CPBSS SECTIEN AT 14.2 MEV = 1358.67 MB

$(N, 2 N)$ THRESHOLD: $15,63 \mathrm{MEV}$

(N,2N) THRESHOLD: $13,63 \mathrm{MEV}$
(N,3N) THRESHOLO: $24,51 \mathrm{MEV}$

THIS ISOTOPE HAS 28 NEUTRONS, 26 PROTONS, (MASS = 54)

NEUTRON EXCESS PARAKETER = .03704

RATIO OF ASYMPTOTIC (N,2N) TO 14.2 MEV NGN-ELASTIC
.0570 PLUS-OR-MINUS .0043

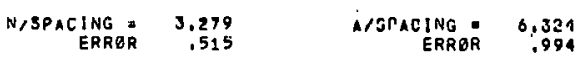
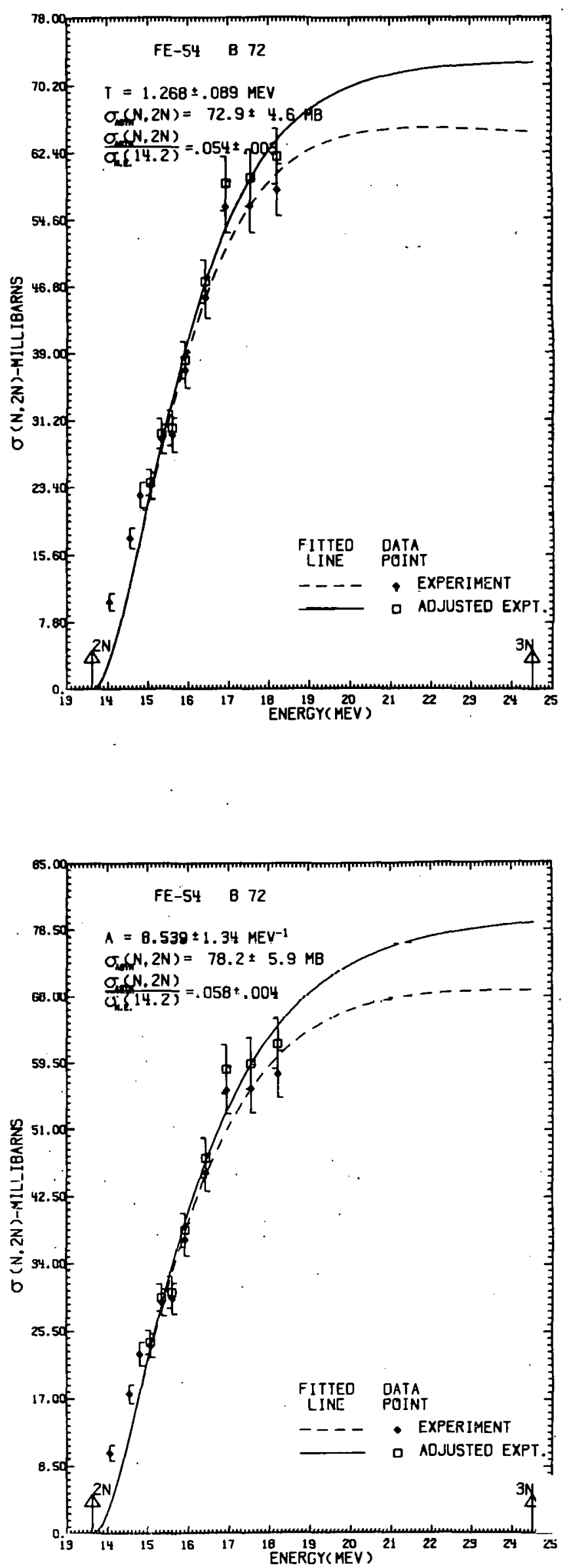


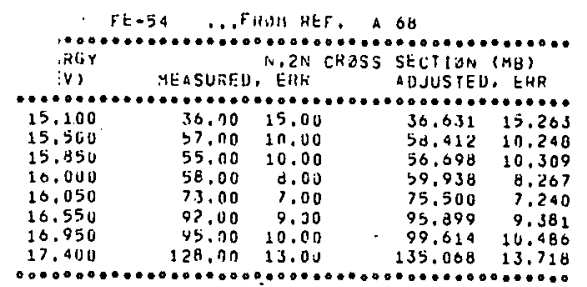

FITIED PANAMETERS

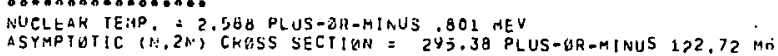

RELATET DATA

NGN-ELASTIC CRUSS SECTIGN AT 14.2 NEV = $1358.67 \mathrm{MB}$ (N, 2il) THRESH.:LO $=13.63 \mathrm{MEV}$
(N, BN) THRESHULD $=24.51 \mathrm{MEV}$

THIS ISOTJPE HAS 20 NEUTRUNS, 26 PHITENS, (MASS a 54 )

HEUTRUN EXCESS PARAMETHE $=.03704$

RATIU OF ASYMPTUTIC (N,Z̈N, TE 14.2 MEV NEN-ELASTIC 3174 PLUS-6R-MINUS .0903

$\begin{array}{rrr}\text { TOSOFT(M) } & 13.604 \\ \text { ERHAR } & 4.230\end{array} \quad$ TOSORT(A) $=\begin{array}{r}19.018 \\ \text { ERROR }\end{array}$

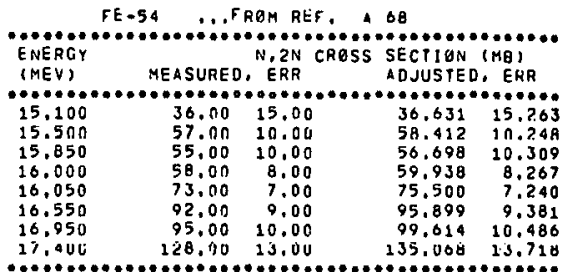

\section{FIITED PARAMETERS}

LEVEL SPACING I. 548 PLUS-QR-MINUS1.242PER MEV

LEVEL SPACING 1.548 PLUS-OR-MINUS1.242PER MEV
ASYMPIOTIC (N.2N) CROSS SECTION $=808.10$ PLUS-OR-KINUS $239.90 \mathrm{MB}$

RELATED UATA

NBN-ELASTIC CRESS SECTION AT 14.2 MEV $=1358.67 \mathrm{MB}$

(N.2H) THRESHALD $=13.63$ MEV
(N.3N) THFESHLLD $=24.51 \mathrm{MEV}$

THIS ISOTOPE HAS 28 NEUTRONS, 26 PRDTENS, (MASS: 54)

NEUTHUA EACESS PAFAHETER = .0370

FATIO OF ASYMPTOTIC (N.CN) TU 14.2 MEV NEN-ELASTIC $3 C C_{4}$ PLUS-ER-MI NUS, 1760

NSPACING $=18.088$
ERHOR
14.512
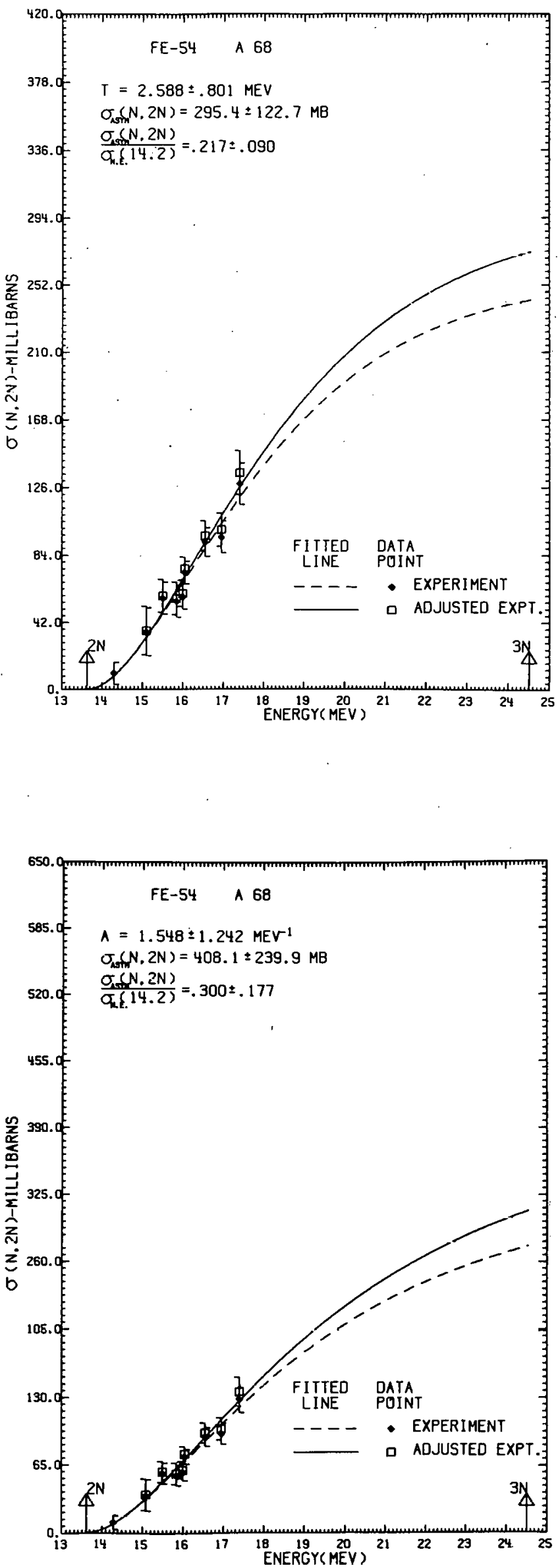


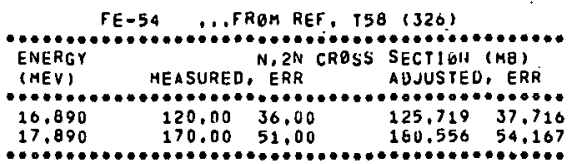

FITTED PARAMETERS

HUCLEAR TEMP. $9=15.68$ PLUS-UK-MINUS ,000 MEV

$.00 \mathrm{mb}$

RELATED UATA

NON-ËLASTIC CROSS SECTIDN AT 14,2 MEV = $1358.67 \mathrm{ME}$

(N.2N) TARESHULD $=11,40$ MEV

THIS ISUTEPE HAS 28 NEUTHONS, 20 PRUTUNS, (MASS $=54$ )

NEUTRON EXCESS FARAMETER = .037U4

RATIO OF ASYMPTETIC (N.2N) TO 14.2 MEV NUN-ELASTIC .7621 PLUS-BR-MINUS, 0000

T.SOKTIN) $=-84.034 \quad$ TOSURT(A) $=-116.701$

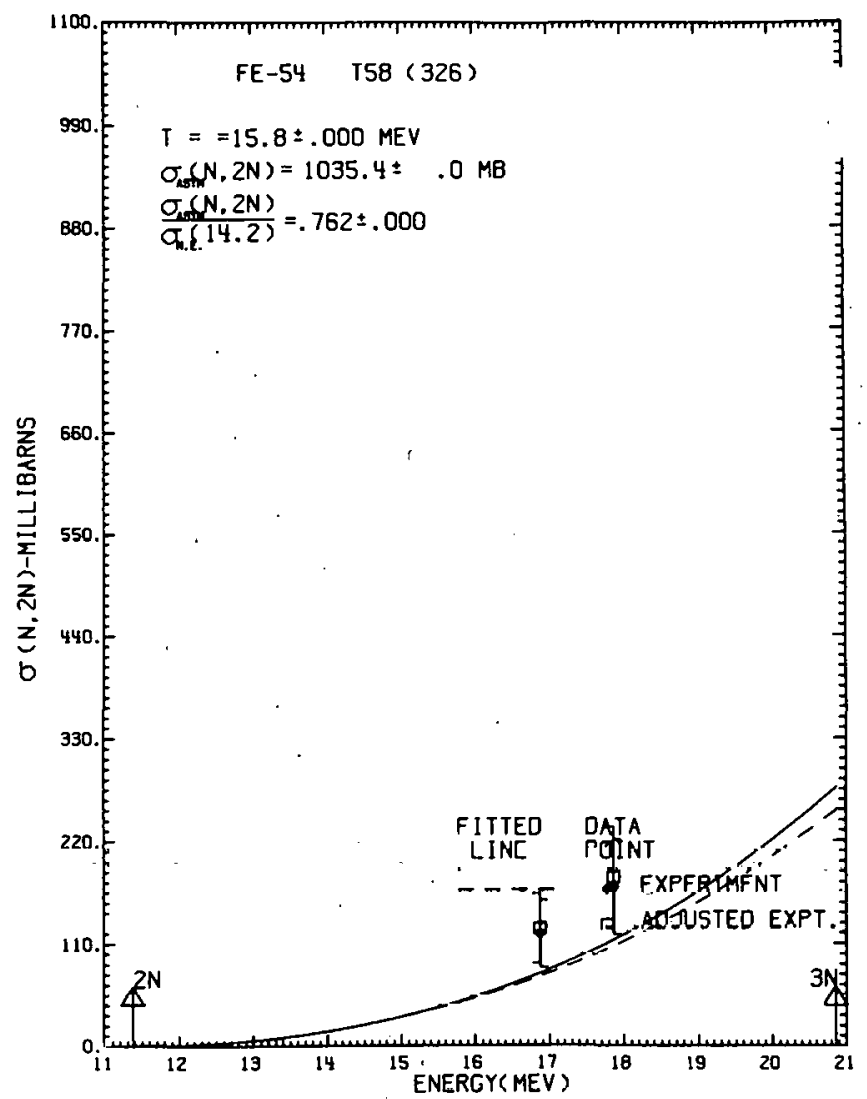

NO "A" FIT POSSIBLE 


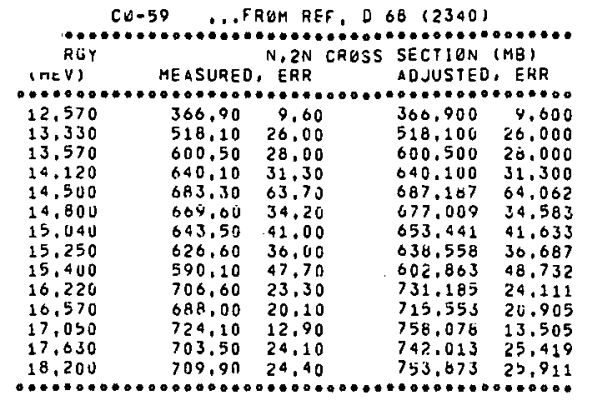

FitTEu PaRameteks

MUCLEAR TEMP, E1.175 PLUS-2R-MINUS, 037 MEV

MUCLEAR TEMP, E 1.175 PLUS-2R-MINUS, 637 MEV

FELATED LATA

WQAN- ELASIIC CROSS SECTIEN AT 14,2 MEV = $1414,36 \mathrm{MB}$ (N, ZL) THRESHZLD $=10,64 \mathrm{MEV}$
$($ iN, 3N) THRESHRLD $=19.36 \mathrm{MEV}$

THIS ISUTAPE HAS 32 NEUTKBNS, 27 PROTONS, (HASS = 59 )

NEUTRUN EXCESS PARAMETER $=.08475$

TATIV UF ASYMPTRTIC (N, 2N) TD 14.2 MEV NUN-ELASTIC 5411 PLUS-GK-MINUS .0003

TOSURT(N) $=0.647$ TOSURT(A) $=9.025$

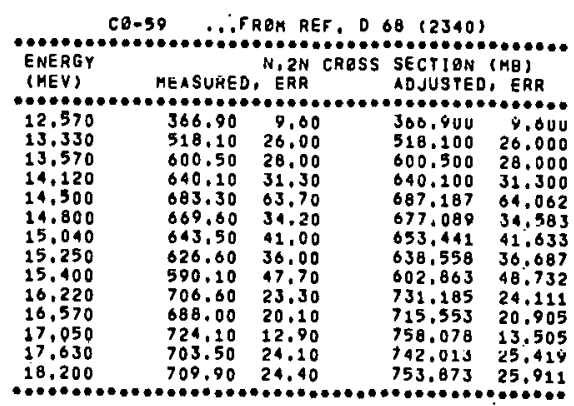

FITTED PARAMETERS

LEVEL SPACING B. 697 PLUS-OR-HINUS .617PER MEV

ASYMPTOTIC IN,2N) CROSS SECIION 791.27 PLUS-OR-HINUS $15.04 \mathrm{MB}$

RELATED DATA

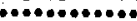

NEN-ELASTIC CROSS SECTION AT 14.2 MEV - 1414.38 AB

$(N, 2 N)$ THRESHELD: 10.64 NEV

PHIS ISOTOPE HAS 32 NEUTRENS, 27 PROTONS, (MASS 59 )

NEUTREN EXCESS PARAMETER : .08475

RATIO OF ASYMPTOTIC (N,2N) TO 14,2 MEV NON-ELASTIC

9594 PLUS-OR-MINUS .0106

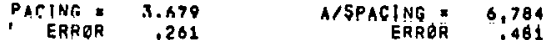
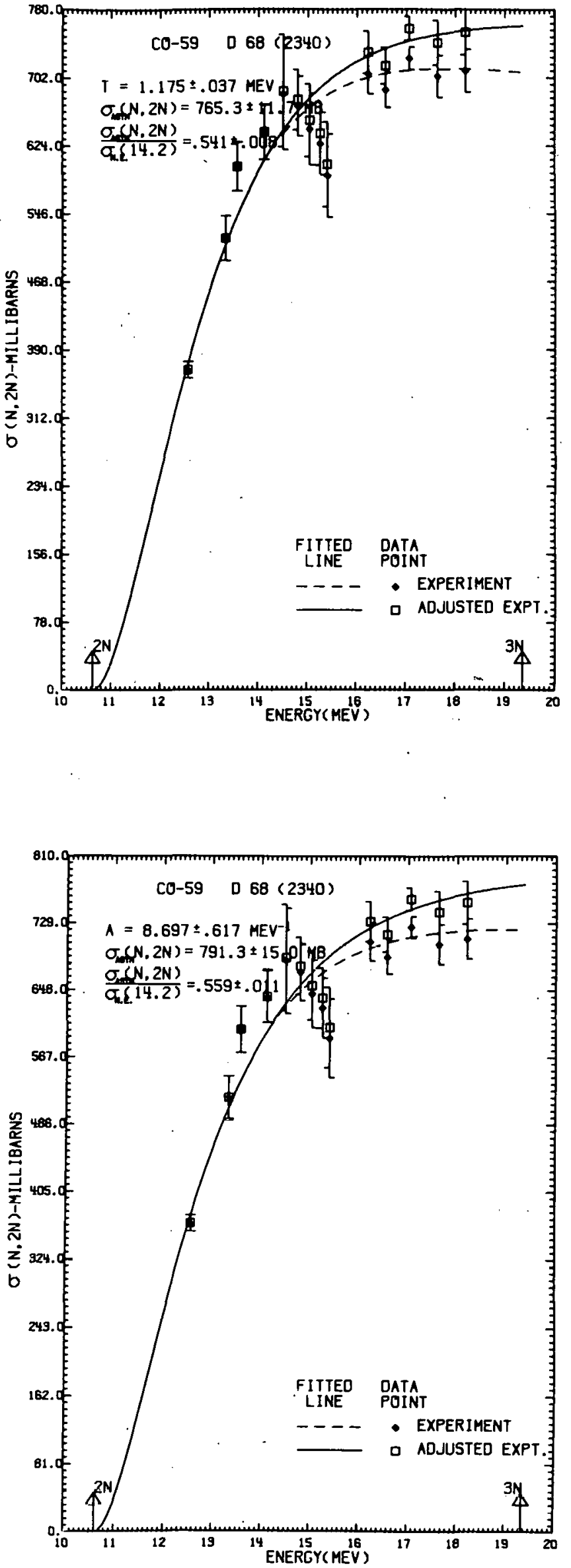


CG.59
$\ldots \ldots F R O M$

FI TTED PARAMETERS

NUCLEAR TEMP. = 1,183 PLUS-GR-MINUS , $12 \angle$ MEV

ASYMPTUTIC (N.2N) CRUSS SECT1UN = 1237,35 PLUS-UR-MINUS 68.91 ME

RELATED UATA

NGN-ELASTIC CFOSS SECTION AI 14,2 MEV $=1414.38 \mathrm{MH}$

(N.2N) THAESHALD $=10,64 \mathrm{MEV}$
$(N, 3 N)$ THKESHQLD $=19,36 \mathrm{MEV}$

THIS ISQTIDE HAS 32 NEUTHQNS, 27 PHOTWNS, (MASS = 59 )

NEUTHUN EXCESS PARAMETER $=.08475$

RATIO OF ASYMPTOTIC (N,2N) TI 14,2 MEV NGN-ELASTIC

$$
\begin{aligned}
& \text { MPTOTIC }(N, 2 N) \text { TI } 14,2 \text { MEV NGN-ELASTIC } \\
& .8748 \text { PLUS-ER-MINUS } 0487
\end{aligned}
$$

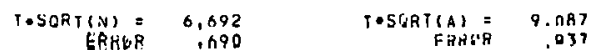

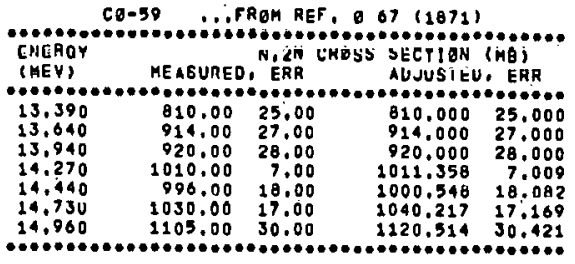

FITTED PARAMETERS

LEVEL SPACING 8.385 PLUS-gR-HINUS1, 978PER MEV

ASYMPTOTIC (N,2N) CROSS SECTIGN 1300.92 PLUS=GR-MINUS $96.42 \mathrm{HB}$

RELATED DATA

NON-ELASTIC CROSS SECTION AT 14.2 MEV - 1414;38 HQ

(N,2N) FIIRESHOLD: IO:OQ MEV

THIS ISOTOPE HAS 32 NEUTRONS, 27 PROTONS, (MASS. 59 )

NEUTRON EXCESS PARAMETER : .08475

RATIO OS ASYMPTETIC (N,2N) TO 14.2 MEV NGN-ELASTIC .9254 PLUS-BR=MINUS .0682

N/SPACINC $=3.810$

A/SPACINGO T,OSB
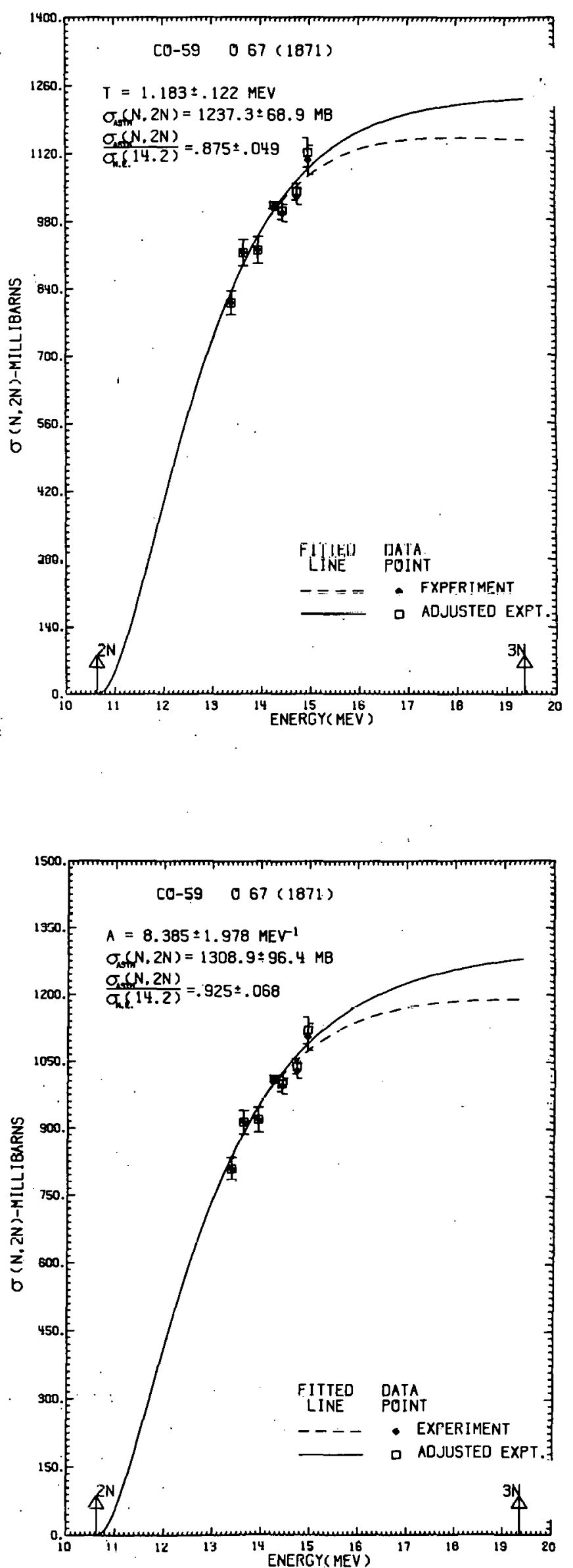


CQ-59 $\ldots$ FROM REF, O O6 12894$)$
NERGY
MEV

FITTED PAHAMETERS

NUCLEAR TEMP, 1,124 PLUS-2R-MINUS .110 MEV

ASYMPTUTIC (N, 2N) CROSS SECTIUN $=800.69$ PLUS-BR-HINUS $39.84 \mathrm{ME}$

RELATED DATA

NEN-ELASTIC CRQSS SECTIEN AT 14,2, MEV $=2419,30 \mathrm{MQ}$

(N.ZN) INKESHELU $=10.64$ MEV

(N,3N) IHKESHZLD $=19,36 \mathrm{HEV}$

THIS ISUTHPE HAS 32 NEUTRUNS, 27 PRUTENS, (MASS $=57$ )

NEUTREN EXCESS PARAMETER $=.08475$

RATIOS OF ASYMPTRTIC (N,2N) TU 24.2 MEV NON-ELASTIC .5703 PLUS-OR-MINUS .0282

TESOHT(N) $=6.358 \quad T$ TORT (A) $=0 . A 34$

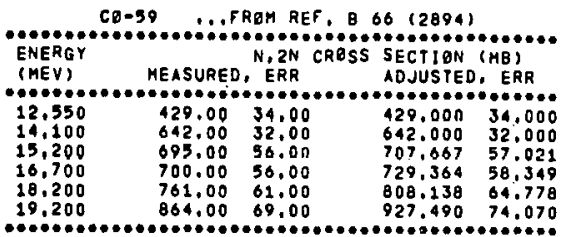

\section{FITTED PARAMETERS}

LEVEL SPACING

ASYMPTETIC (N. 2N) CRESS SECTION. B32.03 PLUS-GR-RINUS 41.22 ME

RELATED DATA

NON-ELASTIC CRESS SECTIEN AT 14,2 MEV 1414,38 MU

(N.2N) THRESHELD: 10.64 MEV

THIS ISOTEPE HAS 32 NEUTRENS, 27 PROTONS, (MASS 59

NEUTRON EXCESS PARAMETER = .08475

RATIO OF ASYAPTOTIC (N,2N) TO 24.2 MEV NON-ELASTIC .5885 fLUS-BH-MINUS .0291

N/SPACING: 3.330 A/SPACING: 0.140
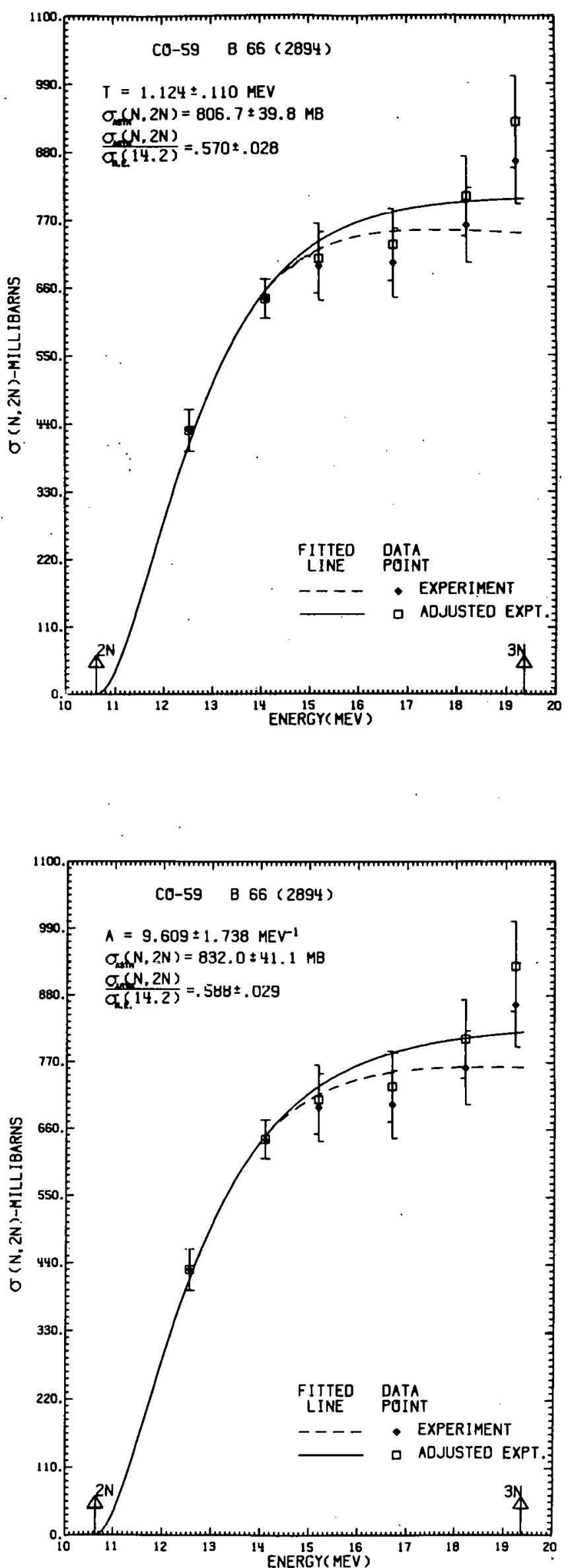


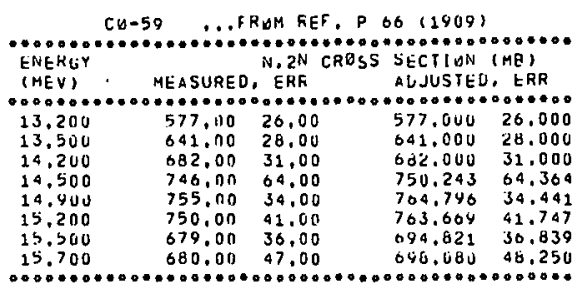

FITTED PAKALETERS

NUCLEAR TEMP. = .696 PLUS-UR-11!NUS, 007 MEV

ASYMPTOTIC (N, $2 N$ ) CROSS SECTION $=760,29$ PLUS-BR-MINUS $27,20 \mathrm{MB}$

RELATED JATA

HON-ELASTIC CRQSS SECTIC: AT 14.2 HEV $=1414.32 \mathrm{MB}$

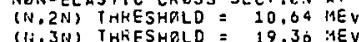

THIS ISOTJPE HAS 32 NEUTHENS, 27 PHOTCAS, (HASS $=59$ )

HEUTRGN EXCESS PAPAMETEK = .06475

RATIZ GF ASYMPTOTIC (N,2N) TH 14,? HEV NGN-ELASTIC

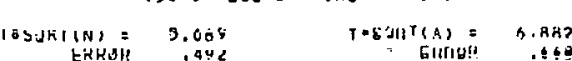

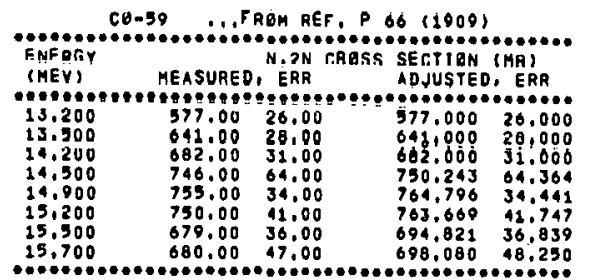

FITICD TARAMETERE

LEVEL SPACING 15,641 PLUS-OR-MINUSJ, 354PER MEV

ASYMPTOIIC (N,2N) CAOSS SECTION Ti4.31 PLUS-BR-MINUS 33.64 HB

\section{RELATED DATA}

MUM-ELASTIC TRASR SFETION AT 14,2 MEV = 1414:38 MO (N,2N) THRESHOLO $=10,64$ MEV
(N,JN) THRESHOLO 19,36 MEV

THIS ISOTOPE HAS, 32 NEUTRONS, 27 PROTONS, (MASS = 59 )

NEUTRQN EXCESS PARAMETER = .08475

RATIO BF ASYMPTETIC (N,2N) TO 14.2 MEV NON-ELASTIC

$$
.5475 \text { PLUS-QR-MINUS } .0238
$$

$\begin{array}{rrr}\text { N/SPACING } & 2.046 \\ \text { ERRER } & .430\end{array}$ A/SPACING $=\begin{array}{r}3.772 \\ \text { ERROR }\end{array}$
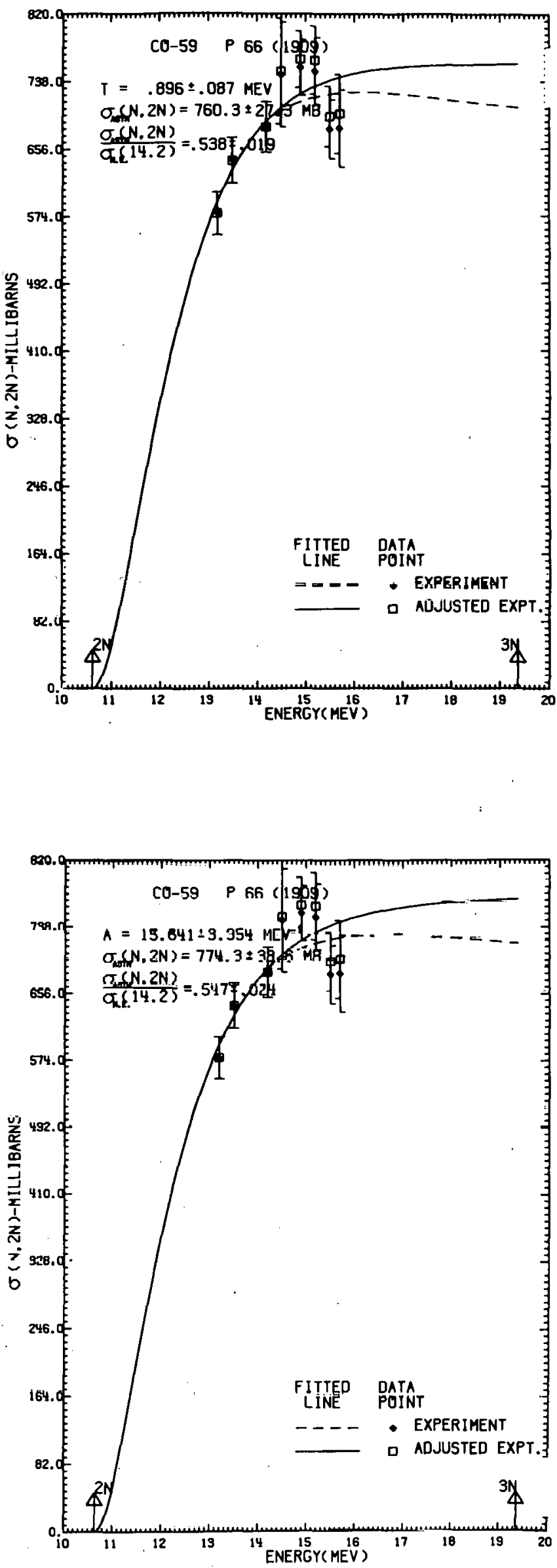


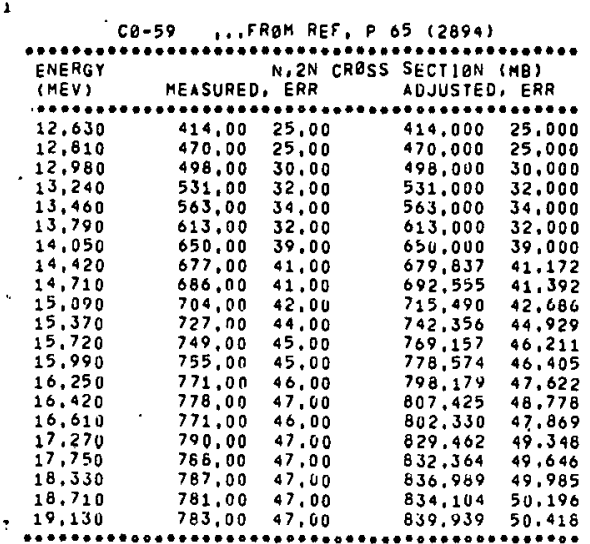

TITTED PARAMETERS

NUCLEAR TEMP, = 1.194 PLUS-OK-MINUS 015 MEV

ASYMPTUTIC $(\dot{N}, 2 N)$ CKUSS SECTION $=835.61$ PLUS-OR-MINUS $5.55 \mathrm{MB}$

HELATED JATA

NON-ELASTIC CRESS SECTIUN AT 14,2 MEV $=1414,38 \mathrm{MB}$

$(N, 2 H)$ THRESHOLD $=10.64$ MEV

(N,jN) THKESHQLD $=19.36 \mathrm{MEV}$

THIS I5OTEPE HAS 32 NEUTKGNS, 27 PRGTUNS, IMASS = 59

NEUTHUN EXCESS PARAMETER $=.08475$

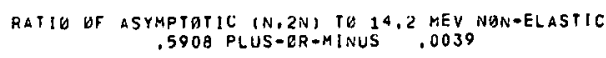

TOSOHTIN) $=0.754 \quad$ T.SORT(A) $=9.171$

ERHOR $\quad .085$

ERRUK .115

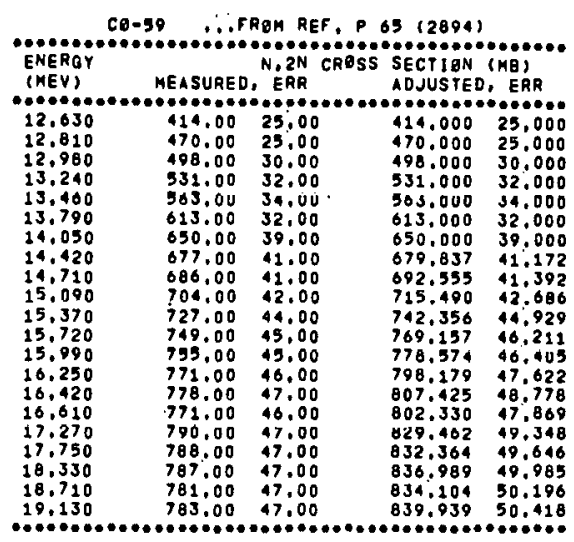

FitTED PaRAMETERS

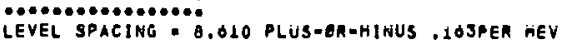

ASYMPTOTIC (N,2N) CRESS SECTION E 863.36 PLUS-gR-MINUS 1.82 MB

RELATED DATA

NON-ELASTIC CROSS SECTION AT 14.2 MEV - 1414.30 MB (N,2N) THRESHOLD $=10,04 \mathrm{MEV}$

THIS ISOTGPE HAS 32 NEUTRONS, 27 PROTONS, (MASS. 50 )

NEUTRON EXCESS PARAMETER ॥.08475

10 OF ASYMPTETIC (N:2N) TE 14,2 MEV NON-ELASTIC
.6104 PLUS-OR-MINUS .0OJ4

...'ACING 3.717 A/SPACING 6.852.

EARER $\quad .070$

E'HRER .130
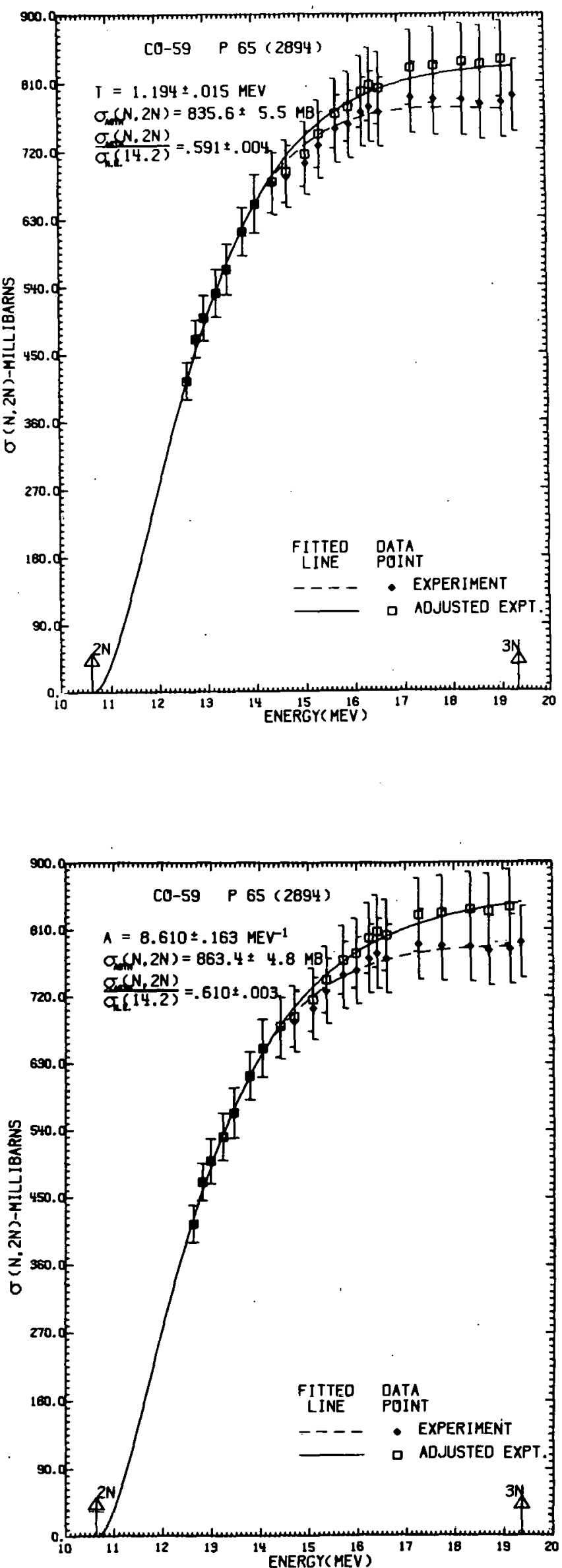


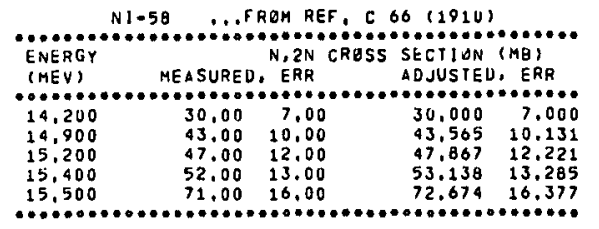

FITTED PARAMETERS

NUCLEAH TEMP. $=2,158$ PLUS-OR-MINUS1,181 HEV

ASYMPTETIC (N, 2N) CRESS SECTIUN $=141.69$ PLUS-IBR-MINUS $99.78 \mathrm{MB}$

RELATED DA TA

NON-ELASTIC CRASS SECTIBN AT 14,2 MEV $=1403.47 \mathrm{MB}$

$(N, 2 N)$ THRESHQLD $=12,41$ MEV
$(N, 3 N)$ THRESHQLD $=22,86$ MEV

THIS ISOTBPE HAS 30 NEUTRONS: 28 PRIIONS, (MASS $=58$ )

NEUTRUN EXCESS PARAMETEK $=.03448$

RATIO OF ASYMPTOTIC (N.2N) TE 14.2 MEV NON-ELASTIC

$\begin{array}{rrr}\text { T.SORT (N) }= & 11,820 \\ \text { ERRQR } & 6.469\end{array} \quad$ T.SORT(A) $=\begin{array}{r}16.435 \\ \text { ERRRQR }\end{array}$

NI-58 $\therefore$ FARM AEF, C OB $(1910)$

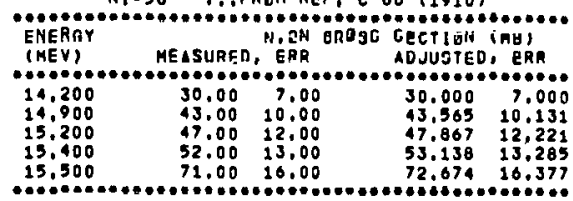

FITTED PARAMETERS

LEVEL SPACING 2.0B3 PLUS-OR-MINUS2, B93PER MEV

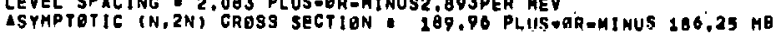

RELATED DATA

NQN-ELASTIC CRESS SECT1ON AT 14.2 MEV - 1403,47 MB

(N.ZN) PHRESHELD = 12,41 MEV

(N,3N) THRESHQLO - $22.86 \mathrm{KEV}$

PHIS ISBBTEPE HAS 30 NEUTRONS, 26 PROTONS, (HASS, 58)

NEUTRON EXCESS PARAMETER, .03448 RATIO OF ASYMPTETIC (N.2N) TO 14 I2 MEV NON-ELASTIC
.1354 PLUS-BR-MINUS ,1327

N/SPACING 14,402

A/SPACING 27.844
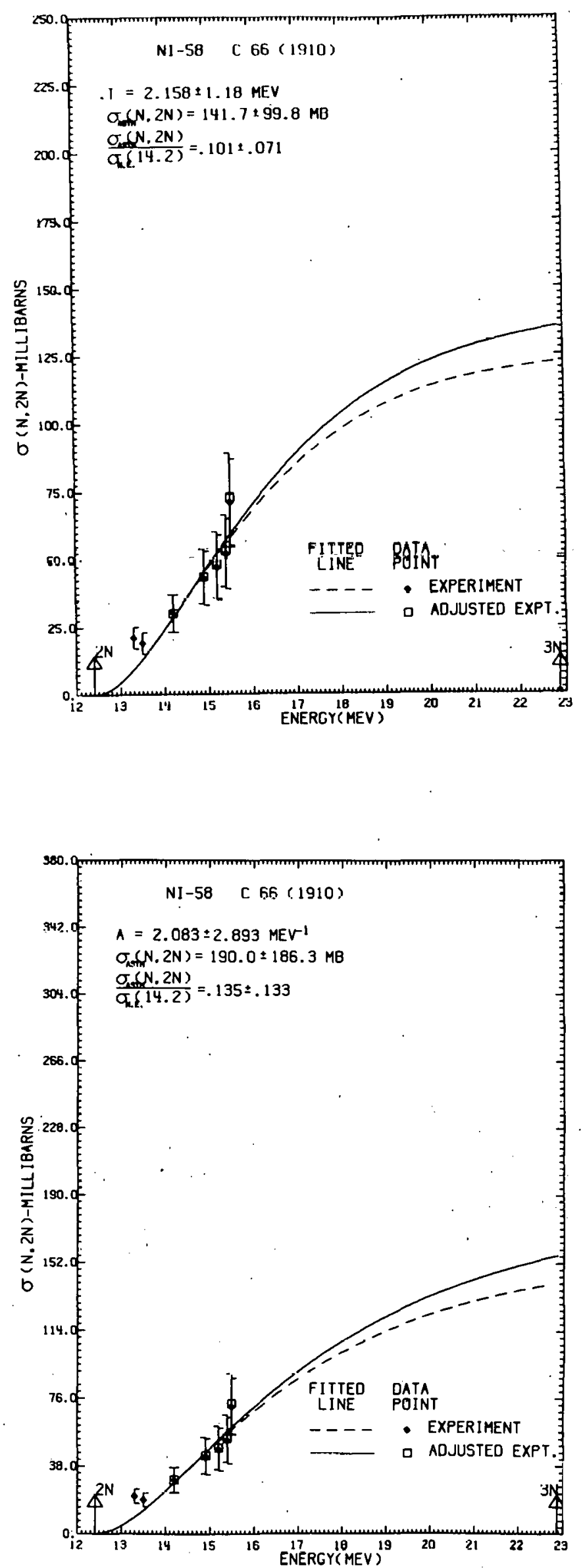


\begin{tabular}{|c|c|c|c|c|}
\hline \multicolumn{5}{|c|}{ NI-58 $\quad$ (1) FRUM KEF, $P$ 65 $(892)$} \\
\hline $\begin{array}{l}\text { VERGY } \\
\text { MEVY }\end{array}$ & MEASURED & $\begin{array}{l}\text { N, } 2 \mathrm{~N} \\
\text { ERR }\end{array}$ & $\begin{aligned} \text { CRESS SECIIUN } \\
\text { ADJUSTED }\end{aligned}$ & (ME) \\
\hline 3.880 & & & & 1,40 \\
\hline 14,050 & 22,00 & $\begin{array}{l}1,20 \\
1,50\end{array}$ & 22,000 & $\begin{array}{l}1,40 \\
1,50\end{array}$ \\
\hline 14,420 & $29,4 \pi$ & 2,10 & 29.525 & 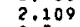 \\
\hline 14.014 & 33,40 & 2,30 & 1 & \\
\hline 14.990 & 38.00 & 2,70 & 38. & 2.740 \\
\hline 15.100 & 39.50 & 2,80 & 40. & 2.85 \\
\hline & 0 & & 44. & 3.073 \\
\hline 15.710 & 44,50 & 3.10 & 45.705 & 3.184 \\
\hline 16.030 & 46.10 & 3.20 & 47.587 & 3.303 \\
\hline 16.240 & 47.10 & 3,30 & 48.7 & 3.417 \\
\hline 590 & 50. & & 52.459 & 3.643 \\
\hline 16.930 & 0 & 3.50 & 52. & $\begin{array}{l}3.660 \\
3.762 .\end{array}$ \\
\hline $\begin{array}{l}17.290 \\
17.590\end{array}$ & $\begin{array}{l}51.20 \\
55.10\end{array}$ & $\begin{array}{l}3.60 \\
3.90\end{array}$ & & $\begin{array}{l}3,762 \\
4,114\end{array}$ \\
\hline $\begin{array}{l}17.590 \\
17,900\end{array}$ & $\begin{array}{l}55,10 \\
55,00\end{array}$ & $\begin{array}{l}3.90 \\
3.90\end{array}$ & $\begin{array}{l}38,127 \\
58,244\end{array}$ & 4.130 \\
\hline $16.1 \% 0$ & 30.40 & 4,00 & 54.935 & 4.251 \\
\hline 18.470 & 58.40 & 4.10 & 62.259 & 4.371 \\
\hline 18.710 & 60. & 4.20 & 64.503 & 4.469 \\
\hline 18.940 & 60. & & 04.830 & \\
\hline 19.240 & 03.80 & 4.50 & 68.616 & 4.840 \\
\hline 19.580 & 66.50 & 4.70 & 71.728 & 5,06 \\
\hline
\end{tabular}

FITTEO PAHAMETERS

MUCLER TEMP : 367 FLUS-GR-MINUS .037 MEV

ASYMPTKTIC (N, ?R) CROSS SECTISN $=$ OO.27 PLUS-OR-MINUS $1,30 \mathrm{HB}$

RELATEU UATA

NEM-ELASTIC CFASS SECTIEN AT 14.2 MEV $=1403.47 \mathrm{ME}$

$(N, 2 H)$ THAESHALO $=12,41$ MEV

(N, 3N) THMESHADLO = 23,86 MEN

THIS ISUTUPE MAS 30 NEUTHONS, 26 PHOTONS, IMASS $=56$

NEUTRON EACESS PARAMETER $=.03448$

RATIO OR ASYMPTOIIC $(N, 2 N)$ IO 14.2 MEV NEN-ELASTIC

0472 PLUS-GR-MINUS ,0009

$\begin{array}{rrr}\text { T.SUHT(N) }=7.487 & \text { TOSOHTCA }= & 10.411 \\ \text { ERHER } & .203 & .282\end{array}$

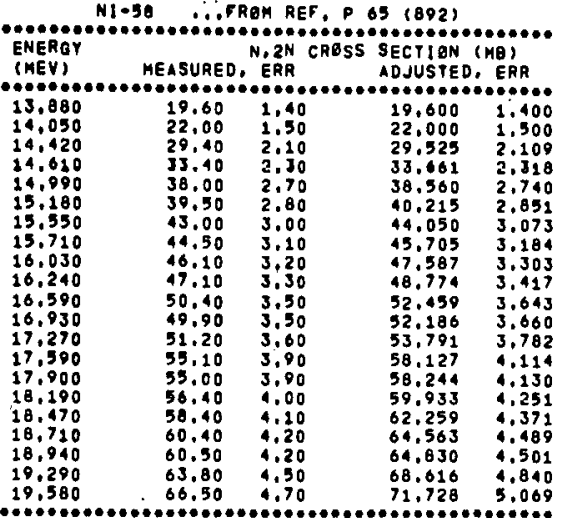

FITTED PARAMETERS

LEVEL SPACING 6.990 PLUS-BR-MINUS, J7OPER MEV

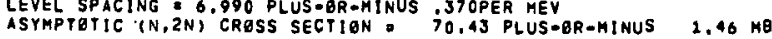

\section{RELATED DATA}

NQN-ELASTIC CRESS SECTION AT 14.2 MEV = 1403,47 MO

(N,ZN) THRESHQLD: 12,41 MEV

THIS ISETOPE HAS 30 NEUTRONS, 28 PROTENS, (MASS 58 )

UTRON EXCESS PARAMETER * .03448

FIO OF AgYMPYOTIO (N,EN) TO 24,E HEV NON-ELAOTIO .0502 PLUS-GR-MINUS .0010

N/SPACING. 4.292

A/SPACING = 8,298

ERRGR $\quad .227$

ERRER .439
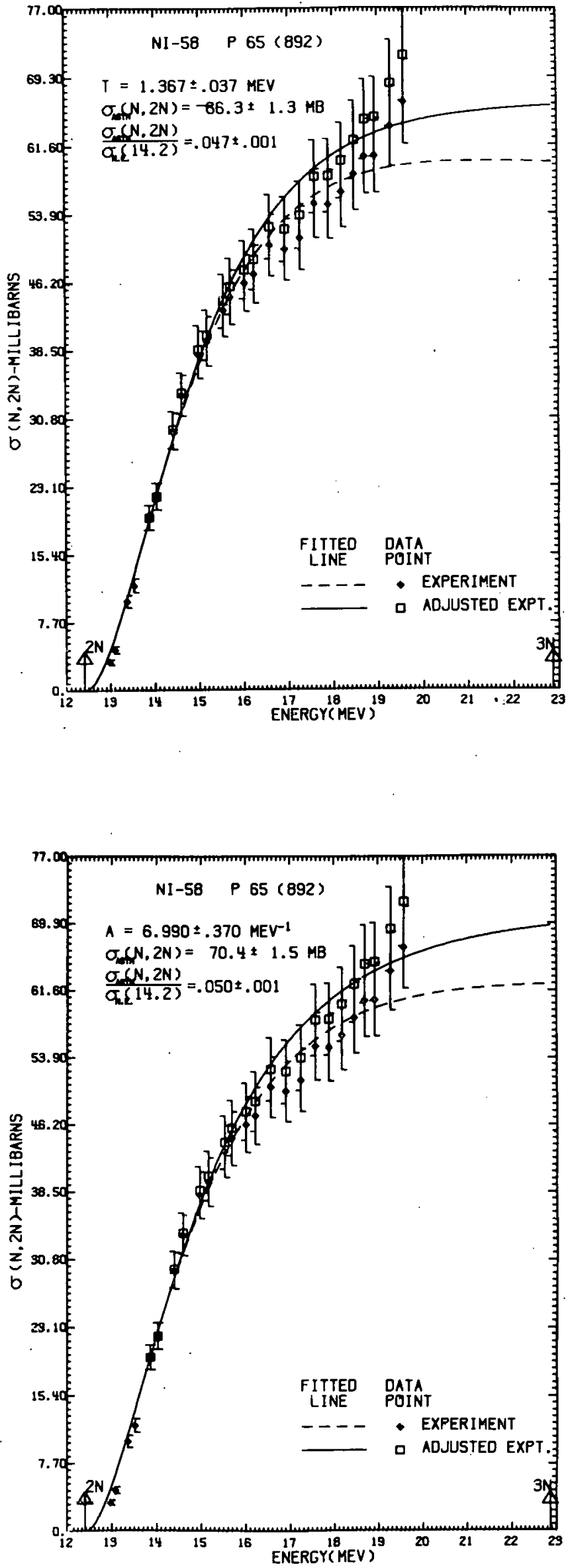


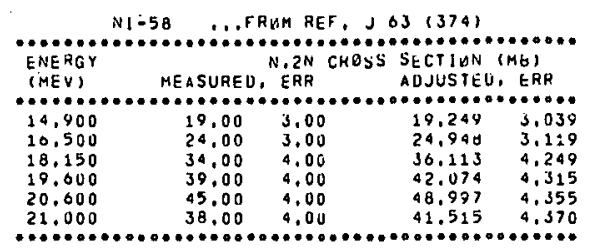

FITTEU PARAMETERS

NUCLEAK TEMP, = 2,130 PLUS-DK-HINUS .341 MEV

ASYMPTUTIC (N, 2N) CRBSS JECTIUN $=.49 .16$ PLUS-UR-MINUS $4.99 \mathrm{Mb}$

RELATED UATA

NON-ELASTIC CROSS SECTION AT 14,2 MEV $=1403.47 \mathrm{MB}$

(N, NN) THRESHOLO = 12,42 MEV

THIS ISUTEPE HAS 30 NEUTRONS

NEUTRUN EXCESS PARAMETER = .03448

FATIO OF ASYMPTOTIC (N.2N) TE 14.2 MEV NUN-ELASTIC

$\begin{array}{rrr}\text { TOSUHTIN) }= & 11.699 \\ \text { ERROR } & 1.868\end{array} \quad$ TOSURT(A) $=\begin{array}{r}16.267 \\ 2.597\end{array}$

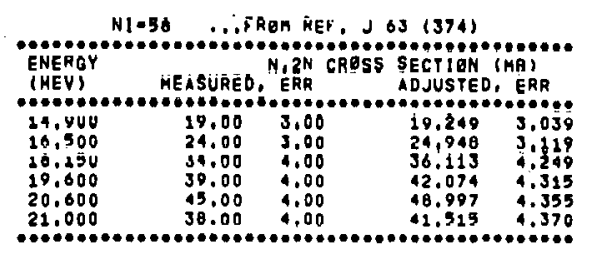

FITTED PARAMETERS

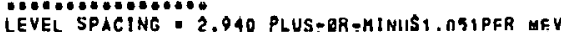

ASTMPTOTIC (N,2N) CRESS SECTION E S4,22 PLUS-GR-MINUS 7,30 MB

RELATED DATA

NON-ELASTIC CRESS SECTION AT 14,2 MEV - 1403.47 MB

(N.2N) THRESHELD: $12,41 \mathrm{MEV}$
(N,3N) THRESHQLD : $22,86 \mathrm{HEV}$

THIS ISUTOPE HAS JO NEUTRONS, 28 PROTONS, (MASS - 58)

NEUTRON EXCESS PARAMETER: .0344B

RATIO BF ASYMPTOTIC (N.2N) TO 14.2 MEV NON-ELASTIC

.0386 PLUS-OR-MINUS , 0052

N/SPACING 10.204, A/SPACING. 19.728
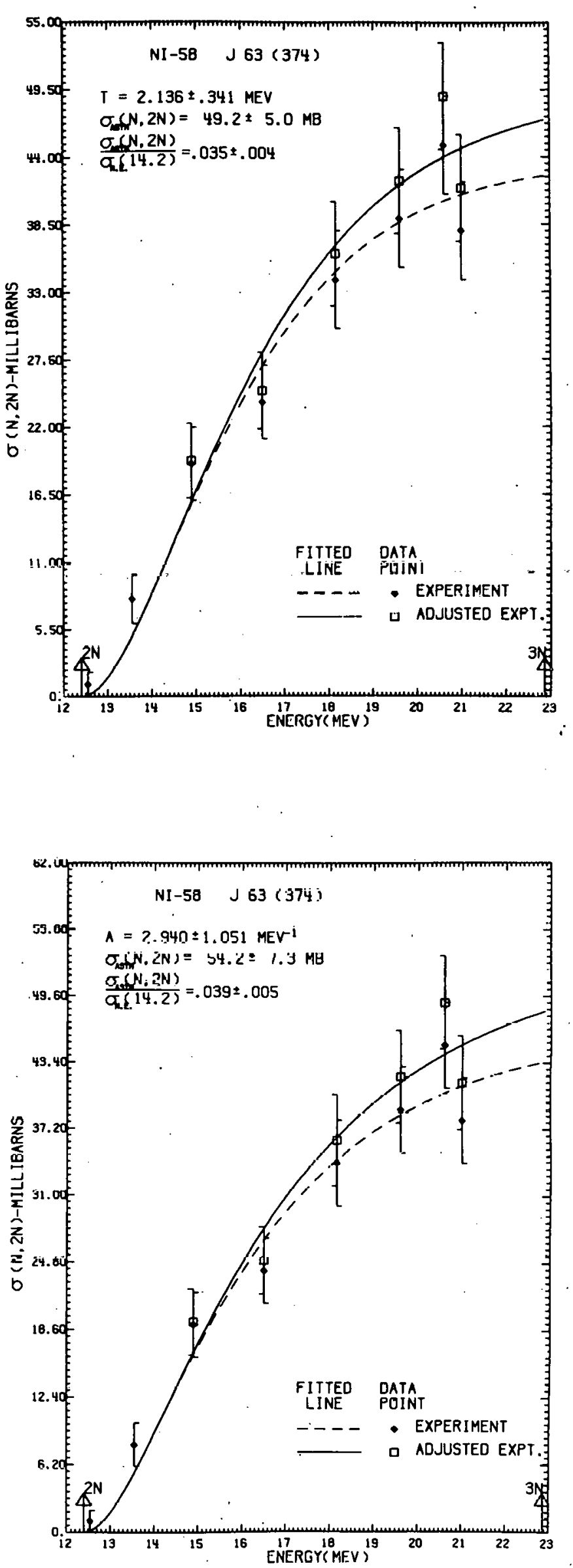


\begin{tabular}{|c|c|c|c|c|}
\hline $\begin{array}{l}\text { ERGY } \\
(M E V)\end{array}$ & ME ASURED & $\begin{array}{l}N, 2 N \\
E R R\end{array}$ & $\begin{array}{l}\text { CROSS SECTION } \\
\text { AOJUSTE }\end{array}$ & \\
\hline $\begin{array}{l}13,800 \\
14,090 \\
14,310 \\
14,500 \\
14,810 \\
10,500 \\
17,950 \\
19,960\end{array}$ & $\begin{array}{l}21,40 \\
23,50 \\
31,10 \\
34,30 \\
39,30 \\
53.30 \\
67.60 \\
77,40\end{array}$ & $\begin{array}{l}1,10 \\
1,20 \\
1,60 \\
1,70 \\
2,00 \\
4,30 \\
3,40 \\
3,90\end{array}$ & $\begin{array}{l}21.400 \\
23.500 \\
31.166 \\
34.497 \\
39.752 \\
55.406 \\
71.631 \\
83.631\end{array}$ & $\begin{array}{l}1,100 \\
1,200 \\
1,603 \\
1,710 \\
2,023 \\
4.470 \\
3.603 \\
4.214\end{array}$ \\
\hline
\end{tabular}

FITTED PARLMETERS

NUCLEAR TEMP. 1.524 PLUS-gR-MLNUS, 072 MEV

ASYMPTETIC (N, 2N) CROSS SECTIUN $=33.60$ PLUS-OR-MINUS 4.19 ME

\section{RELATED DATA}

NGN-ELASTIC CRESS SECTION AT 14,2 MEV $=1403,47 \mathrm{MB}$

(N, 2N) THRESHQLD $=12,41$ MEV

$(N, 3 N)$ THRESHOLD $=22,86$ MEV

THIS ISBTUPE haS 30 NEUTRONS, 28 PROTENS, (MASS: $\$ 581$

NEUTRON EXCESS PARAMETER $=.03448$

RATIO BF ASYMPTOTIC (N,2N) TO 14,2 MEV NBN-ELASTIC .0596 PLUS=BR-MINUS .0030

$\begin{array}{rrr}\text { TOSORT(N) } & 8,347 & \text { TESORT(A) } \\ \text { ERRBR } & 11.606 \\ & .548\end{array}$

NI.58 _., FREM REF, P 61 (588)

MEASUPED N.2N CRESS SECTION (MB)

ADJUSTED, ERR

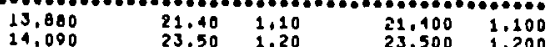

$\begin{array}{lllll}14.310 & 33.50 & 1.20 & 23.500 & 1.200 \\ 14.3100 & 31.10 & 1.60 & 31.160 & 1.803\end{array}$

$\begin{array}{lllll}14.300 & 34.30 & 1.70 & 34.497 & 1.710 \\ 14.810 & 39,30 & 2.00 & 39.752 & 2.023\end{array}$

$\begin{array}{lllll}14.810 & 39.30 & 2.00 & 39.752 & 2.023 \\ 16.500 & 53.30 & 4.30 & 55.400 & 4.470\end{array}$

$\begin{array}{lllll}17.950 & 67.60 & 3.40 & 7.631 & 3.603\end{array}$

$19.760 \quad 77,40 \quad 3.90 \quad 83.631 \quad 4.214$

FITIED PARAHETERs

OE..................

LEVEL SPACING 5,460 PLUS-QRE-HINUS 552PER MEV

ASYMPTETIC (N,2N) CRESS SECTION 90.24 PLUS-ER-MINUS 5.05 MB

RELATED DATA

NEN-ELASTIC CROSS SECTIBN AT 14,2 HEV $=1403,47 \mathrm{MB}$

(N,2N) THRESHOLD: 12,41 MEV

THIS ISOTQPE HAS 30 NEUTRONS, 28 PRBTONS, (MASS = 38)

NEUTRQN EXCESS PARAMETER = .03448

RATIO OF ASYMPTETIC (N,2N) TO 14.2 MEV NON-ELASTIC .0043 PLUS $=0 R+H ! N U S$, 0036

N/SPACING
EHHOR
5.495
555
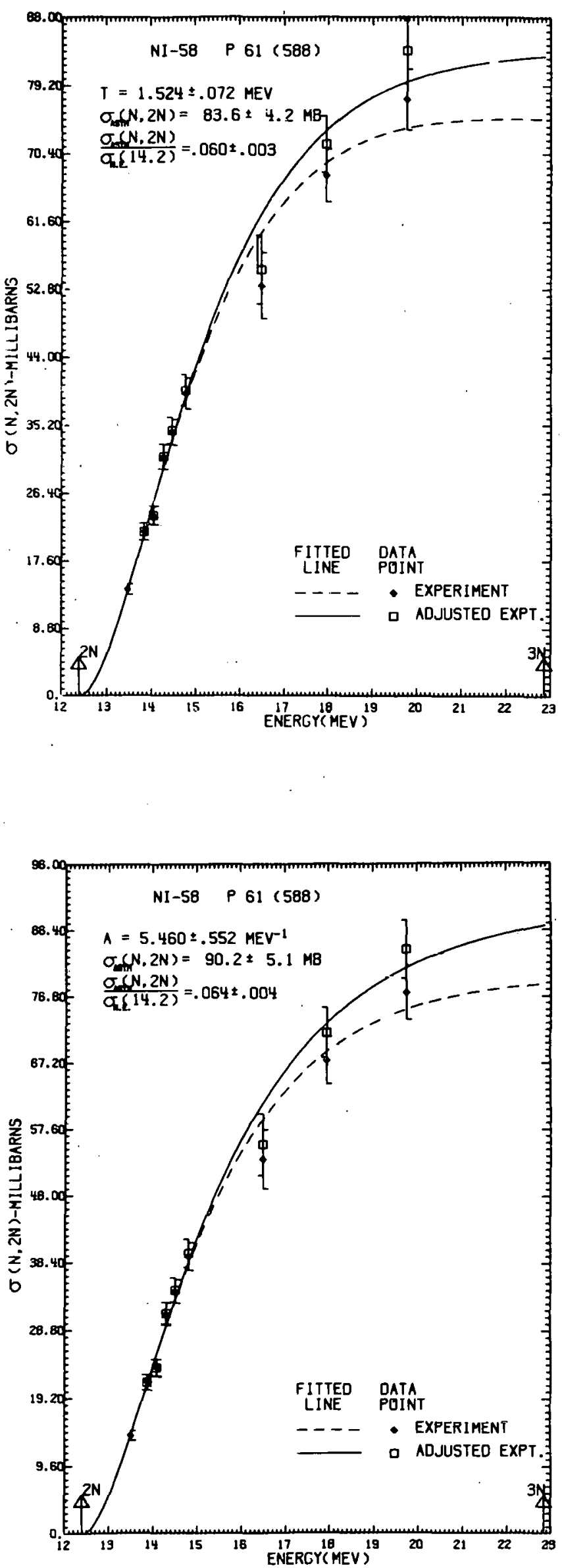


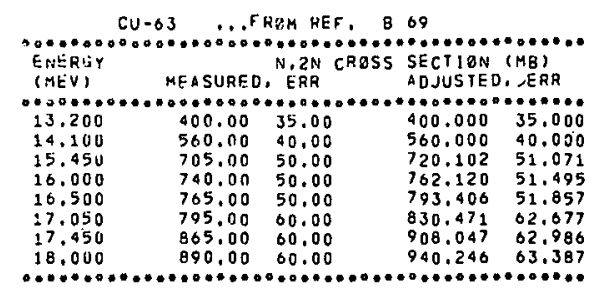

FITIED HARAMETERS

NUCLEAR TEMP : 1 SO5 RLUS-RR-MINUS, 080 MEV

ASYMPTUIIC $(N, 2 N)$ CRESS SECTIEN $=950.62$ PLUS-BR-MINUS $29.29 \mathrm{MB}$

\section{RELATED DATA}

NON-ELASTIC CRESS SECTION AT 14,2 MEV $=1457.00 \mathrm{MB}$

NON-ELASTIC CRQSS SECTION AT
$(N, 2 N)$ THRESHOLD $=11.02 \mathrm{MEV}$
$(N, 3 N)$ THRESHOLD $=20.06 \mathrm{MEV}$

THIS ISUTEPE haS 34 NEUTRaNS, 29 PRBTONS, (MASS $=63$ )

MEUTRON EXCESS PARAMETER $=.07937$

RATIO OF ASYMPTETIC (N, 2N) TO 14.2 MEV NON-ELASTIC

.6524 PLUS-UR-HINUS .0201

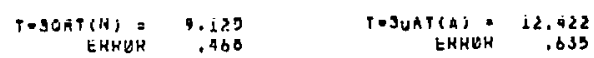

F!TTFD DQTQMETGRE

LEVEL SPACING $=4.847$ PLUS-gR-MINUS .466PER MEV

ASYMPTOTIC (N, $2 N)$ CRESS SECTION $=1028.25$ FLUS-OR-MINUS 34.63 MR

RELATED DATA

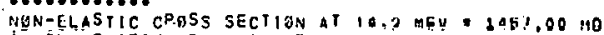

(N), $2 N)$ THRESHPLD $=11.02$ MEV
$(N, 3 N)$ THRESHALD $=20.06$ MEV

IHIS ISOTUPE HAS 34 NEUTRONS, 29 PRDTONS, (MASS a 63)

NEUTKON EXCESS PARAMETER $=.07937$

FATIO OF ASYMPTETIC (N, $2 H$ II 14.2 MEV NON-ELASTIC .7057 PLUS-gR=MINUS 14.2 MEV .0238

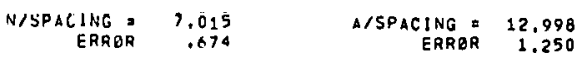
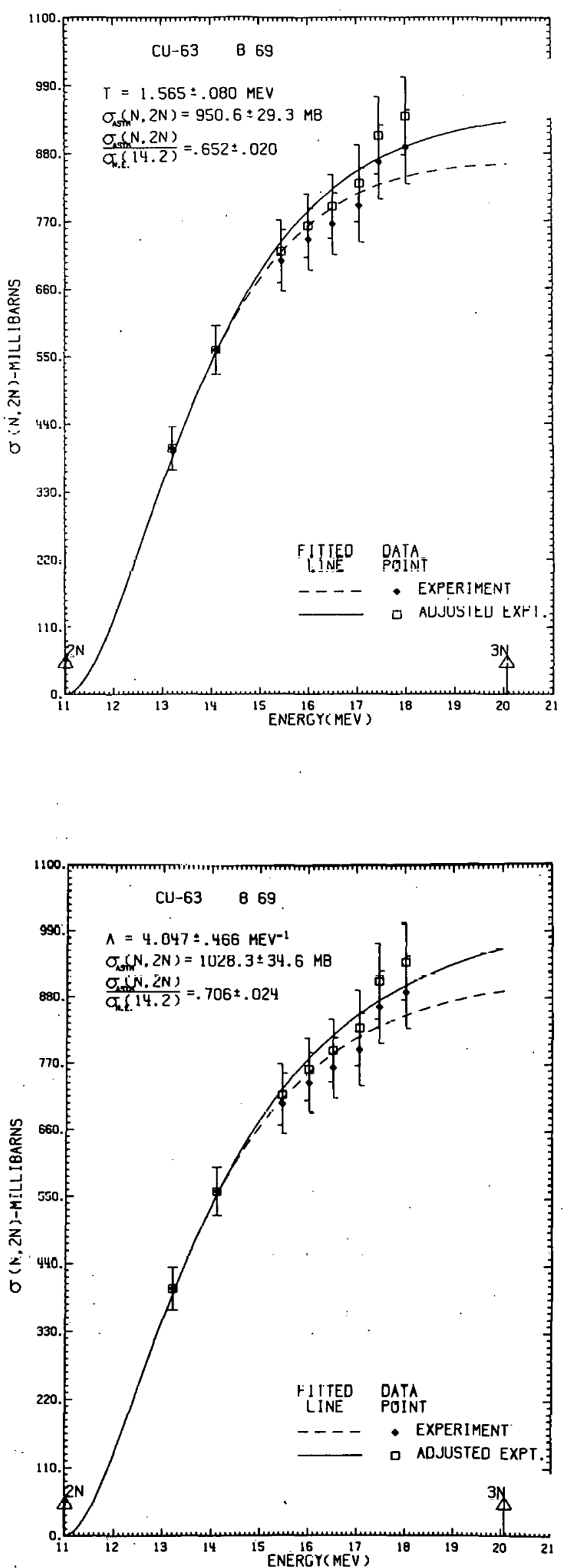


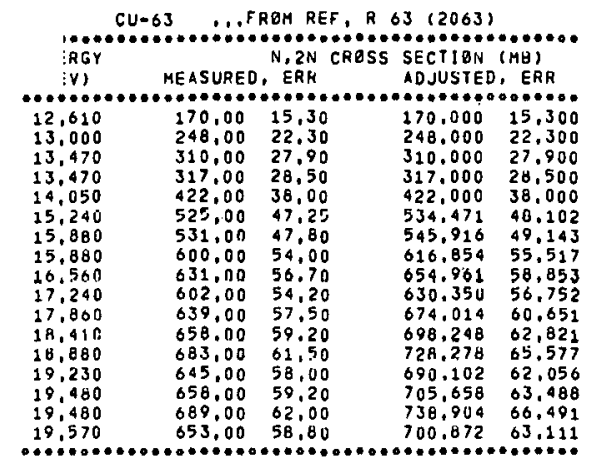

FITTEU PARAMETERS

NUCLEAR TEMP. $x 1.703$ PLUS-GR-MINUS, 038 MEV
ASYMPTOTIC $(N, 2 N)$ CROSS SECTION $=740,96$ PLUS-BR-MINUS 12,32 ME

RELATED DATA

NON-ELASTIC CROSS SECTION AT 14.2 MEV $=1457,00 \mathrm{MB}$

$(N, 2 N)$ THKESHOLD $=11,02 \mathrm{ME}$

$(N, 3 H)$ THKESHEL $=20,06 \mathrm{MEV}$

THIS ISGTGPE HAS 34 MEUTRONS, 29 PROTENS, (MASS - 63)

NEUTRDN EXCESS PARAMETER : .07937

RATIO OF ASYMPTOTIC (N,2N) TO 14.2 MEV NON-ELASTIC

$$
\begin{aligned}
& .5127 \text { PLUS }=E R-M I N U S \text { T } 14.2 \text { MEV } \\
& .0065
\end{aligned}
$$

TESOKTIN)= $9.930 \quad$ TOSURT(A) $=13,517$

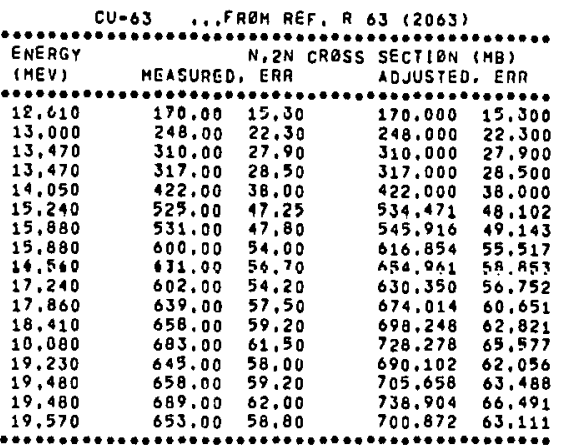

FITTED PARAMETERS

LEVEI SPACING

ASYMPTEIIC (N,2N) CRDSS SECTION= BiO.04 PLUS-ER-MINUS 19.85 MB

RELATED DATA

NUN-ELASIIC CROSS SECTION AT 14.2 MEV $1459,00 \mathrm{MB}$

(N,2N) THRESHQLD $=11,02 \mathrm{MEV}$

$0=20,06$ MEV

THIS ISUTGPE HAS 34 NEUTRQNS, 29 PROTENS, (MASS = 63)

NEUTRON EXCESS PARAMETER $=.0793$ :

O OF ASYMPTETIC (N,2N) TO 14,2 MEV NGN-ELASTIC

.5560 PLUS-OR-MINUS 10136

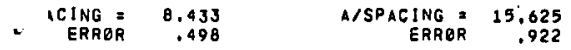
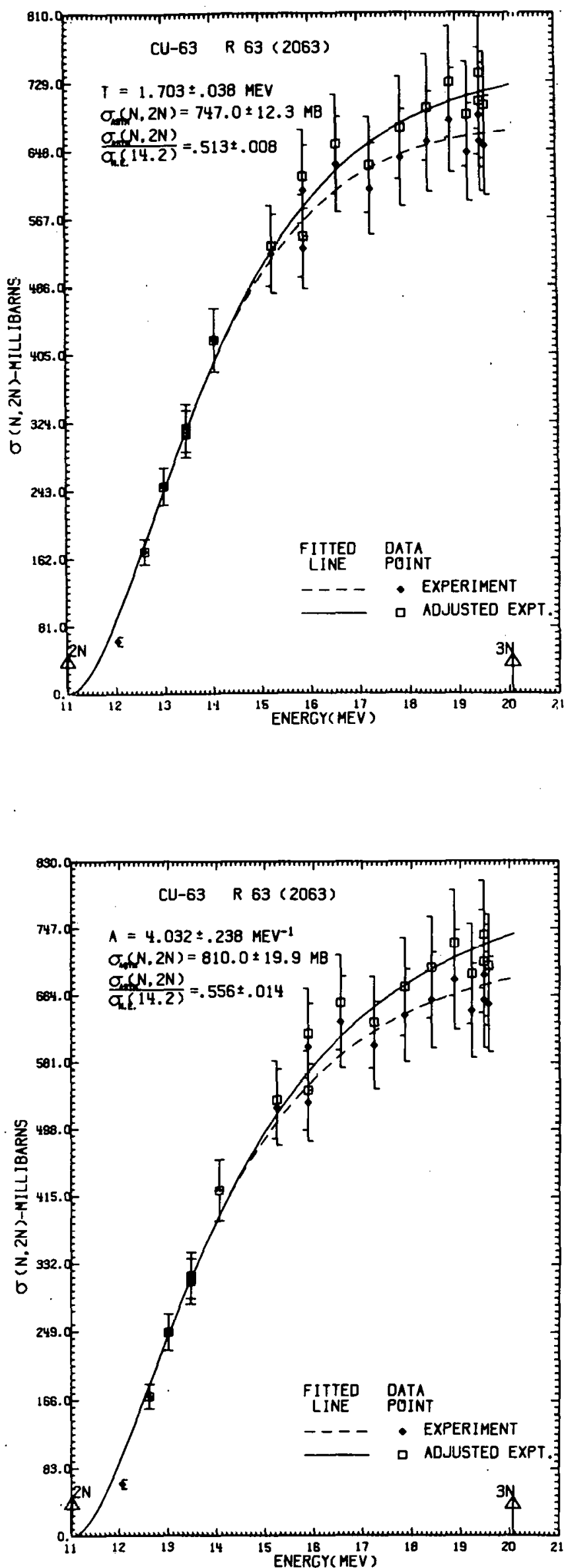


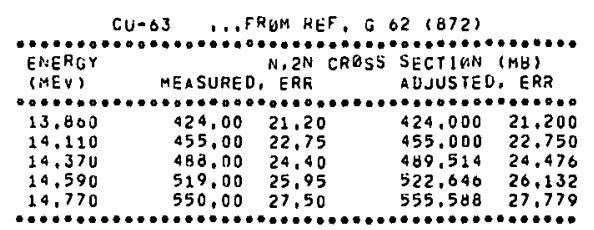

- FITTEL parameters

NUCLEAR TEMP, 1,741 PLUS-gR-MINUS, 127 MEV

ASYMPTBTIC IN,2N) CRESS SECTIUN $=864.61$ PLUS-UR-MINUS $60.29 \mathrm{Md}$

RELAIED UATA

NON-ELASTIC CAOSS SECTION AT 14,2 MEV $=1457,00 \mathrm{MB}$

(N,2N) THRESHQLD $=11.02$ MEV
$(N, 3 N)$ THRESHOLD $=20.05$ MEV

THIS ISOTUPE HAS 34 WEUTRUNS, 29 PRUTONS, (MASS $=63$ )

NEUTRELI EXCESS PARAMETER $=.07937$

RATII) LF ASYMPTETIC (N,2N) TO 14,2 MEV NON-ELASTIC

.5034 PLUS-DR-MINUS, 0414

TOSORT(N) $=10.152 \quad$ TOSORT(A) $=13.818$

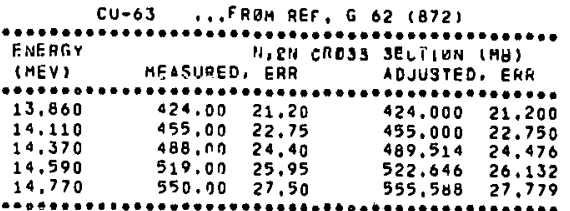

TITTED PARAMETEHS

LEVEL SPACING 3.435 PLUS-GH-MINUS 581 TER MEV

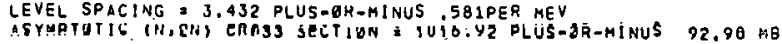

RELATLD DATA

NON-ELASTIC COASS SECTION AT 14.2 MEV = $1457.00 \mathrm{Mg}$

(N,2N) THRESHRLD $=11,02$ MEV
$(N, 3 N)$ THRESHOLD $: 20,06$ MEV

FHIS 1SUTDPE HAS 34 NEUTRgNS, 29 PROTONS, (MASS 63 )

NEUTRGN EXCESS PARAMETER: .07937

RATIO OF ASYMPTOTIC (N, ZN) TO 14,2 MEV NON-ELASTIC

.6980 PLUS $=$ DR-HINUS .0638

$\begin{array}{rrr}\text { N/SPACING }= & 9.907 \\ \text { ERRUR } & 1.677\end{array} \quad$ A/SPACING $=\begin{array}{r}18.357 \\ 3.108\end{array}$
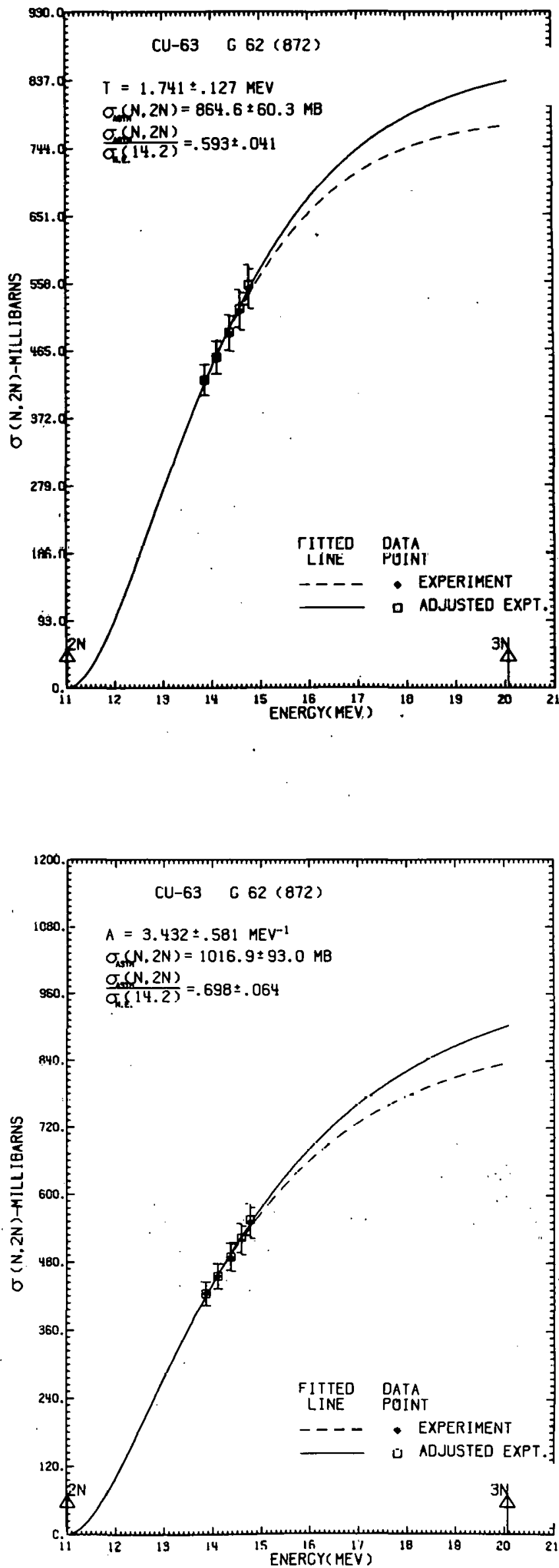


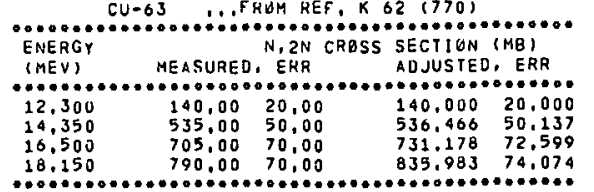

FITTED PARAMETERS

NUCLEAR TEMP. 1.0.14 PLUS-OR-MINUS, 106 MEV

NUCLEAR TEMP, 1.814 PLUS-OR-MINUS 106 MEV
ASYMPTOIIC (N,2N) CRESS SECTION $=930.25$ PLUS-OR-MINUS $45.91 \mathrm{MH}$

RELATED DATA

NUH-ELASTIC CROSS SECT1ON AI 14.2 MEV = $1457.00 \mathrm{MB}$

(H.2N) THRFSHQLD $=11,02$ MEV

THIS ISOTOPE HAS 34 NEUTRONS, 29 PRHTONS, (MASS a 63 )

NEUTRON EXCESS PARAMEIER $=.07937$

RATIO OF ASYMPTOTIC (N,2N) IO 14.2 MEV NEN-ELASTIC .0385 PLUS-UR-MINUS .0315

TOSURT(N) 10.577 TOSORT(A) $=14.398$

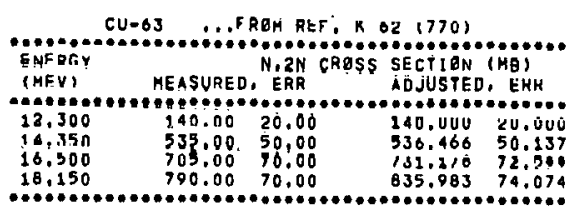

FITTED PARAHETERS

LEVEL SPACING 3.249 PLUS-UR-MINUS . G19PEH HEV

ISYMPTOTIC (N, 2N) CRESS SECTION O 1060.57 PLUS-OR-MINUS 96.62 MB

RELATED DATA

NON-ELASTIC CROSS SECTION AT 14,2 MEV = 1457,00 MB

(N,2N) THRESHEL D 11,02 MEV

THIS ISOTOPE HAS 34 NEUTRENS, 29 PROTONS, (HASS - 63)

NEUTREN EXCESS PARAMETER = .07937

RATIO OF ASYMPTETIC (N.2N) TE 94.2 MEV NON-ELASTIC

$\begin{array}{rr}\text { NISPACING } & 10.465 \\ \text { ERROA } & 1.094\end{array} \quad$ A/SPACING 19.391
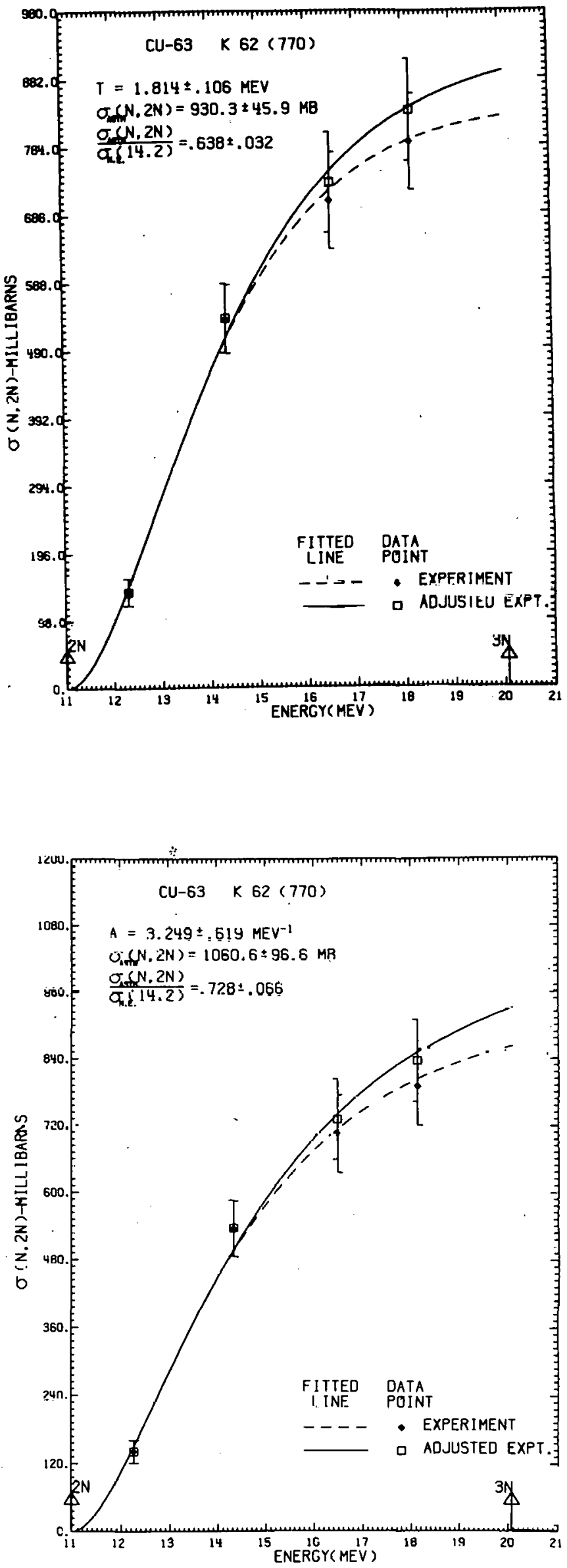


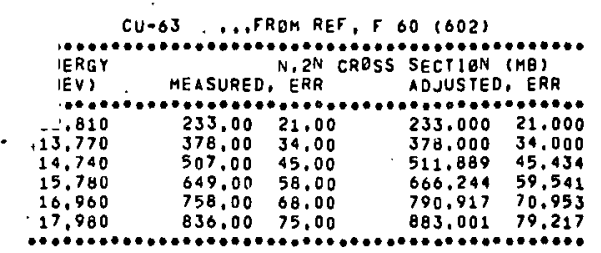

\section{FITTED PARAMETERS}

NUCLEAR TEMP, E2.036 PLUS-GR-MINUS 121 MEV
ASYMPTOTIC (N, 2N), CROSS SECTION $=993,75$ PLUS-OR-MINUS $57,41 \mathrm{ME}$

\section{RELATED DATA}

NON-ELASTIF TROSS SECTION AT 14.2 MEV $=1457.00 \mathrm{MO}$

(N,2N) IHRESHALD: 11.02 MEV

(N, JN) THRESHQLD 20.06 MEV

THIS ISOTOPE HAS 34 NEUTRQNS, 29 PROTONS, (MASS = 63)

NEUTRBN EXCESS PARAMETER = .07937 RATIG GF ASYMPTOTIC (N,2N) TO 14,2 MEV NON-ELASTIC
.6821 PLUS-OR-HINUS . O394

$\begin{array}{rrr}\text { TOSORT(N) } & 11.872 & \text { T.SORT(A) } \\ \text { ERRER } & .706 & 16.160 \\ \text { ERRER } & .960\end{array}$

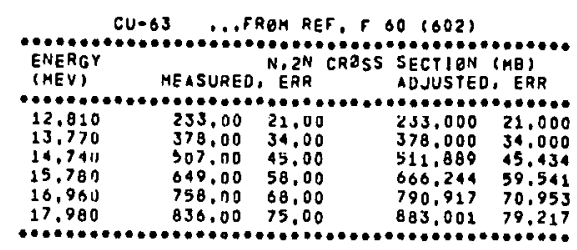

FITTCD PARAHCTCR3

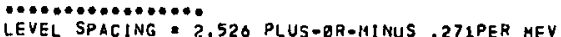

ASYHOTOTIC (N, 2N) CROSS SECTION 1174,96 PLUS-OR-MINUS OB.85 MB

RELATED DATA

NGN-ELASTIC CRGSS SECTION AT $14.2 \mathrm{MEV}=1457.00 \mathrm{MB}$

(N, ZN) THEESHQLD $=11.02$ MEV
$(N, 3 N)$ THFESHOLD, 20.06 MEV

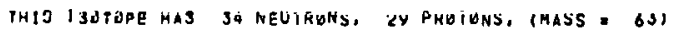

NEUTRON EXCESS PARAMETER = .07937

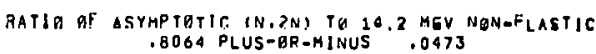

$\begin{array}{rrr}\text { N/SPACING } & 13.460 \\ \text { ERRBR } & 1.444\end{array} \quad$ A/SPACING $=\begin{array}{r}24.941 \\ \text { ERRQR }\end{array}$
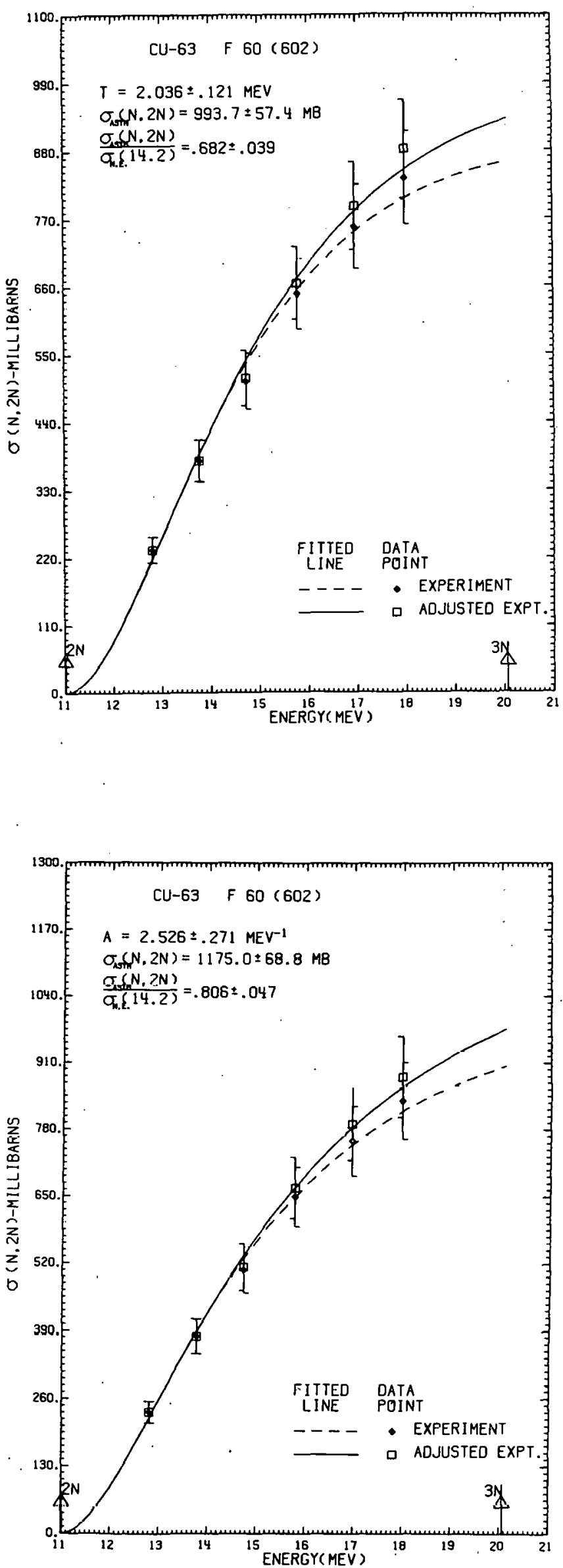


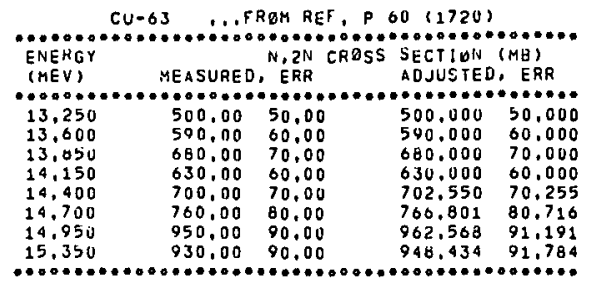

FITTED PARAMEIEFS

NUCLEAR TEMP $=1$, 6a7 PLUS-GH-MINUS, $315 \mathrm{MEV}$

ASYMPTOTIC $(N, 2 N)$ CKOSS SECTION $=1265,15$ PLUS-OR-MINUS 226,26 MG

RELATED UATA

NON-ELASTIC CROSS SECTIUN AT $14,2 \mathrm{MEV}=1457.00 \mathrm{MB}$

(N, 2N) THRESHOLD $=11,02$ MEV

$(N, 3 N)$ THRESHOLD $=20,00$ MEV

THIS 1 SOTOPE HAS 34 NEUTRONS, 29 PRUTENS, (MASS $=63$ )

NEUTRGN EXCESS PARAMETER = .07937

RATID OF ASYMPTETIC (N.2N) TE 14.2 MEV NGN-ELASTIC
.86B3 PLUS-OR-MINUS 1553

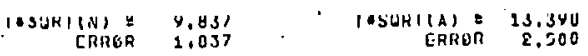

\section{FITTED PaRameters}

LEVEL SPACING 3.676 PLUS-QR-MINUS1. O24PER MEY

ASYMPTOTIC (N, $2 N$ ) CRESS SECTION = 1475.17 PLUS-OR-MINUS $350.66 \mathrm{ME}$

\section{RELATED DATA}

NON-ELASTIC CRESS SEC ION AP 14.2 MEV $1457.00 \mathrm{MB}$

(N,2N) THRESHALD: 11,02 MEV

(N.SN) THRESHOLD \& 20.06 MEV

THIS ISOTIPE HAS 34 NEUTRENS, 29 PROTONS, (MASS = 63)

NEUTRON EXCESS PARAMETER = .07937

RATIO OF ASYMPTETIC (N, 2N) TE 14,2 MEV NON-ELASTIC

$$
1.0125 \text { PLUS }-Q R-H ! N U S \text { S }, 2407
$$

N/SPACING
9 ERRER
4.249
4.086 $\quad$ A/SPACING $=17.138$
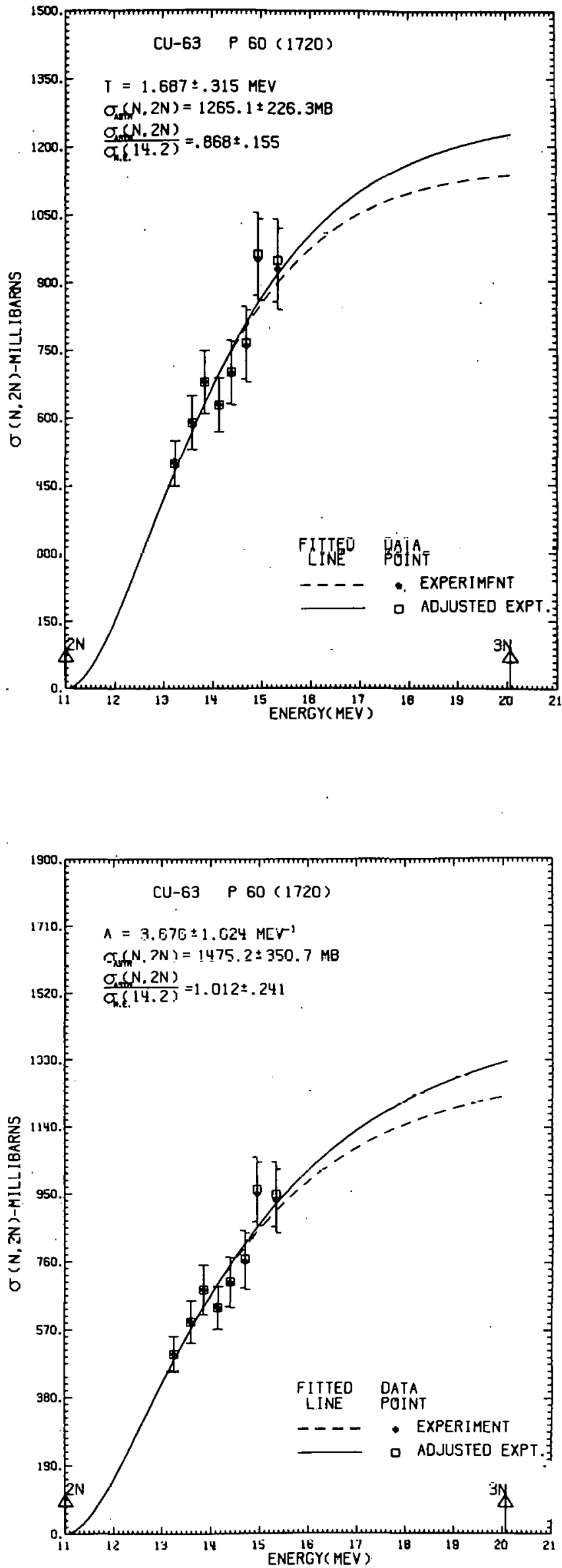


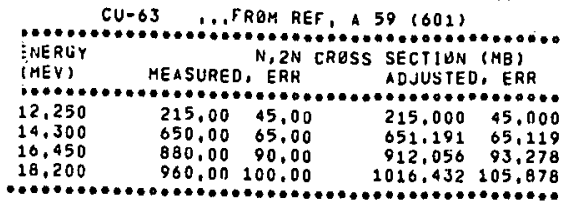

FITTED PARAMETERS

NUCLEAR TEMP, 1.030 PLUS-GR-MINUS 006 MEY

ASYHPTOTIC (N, ZN) CRUSS SECTION $=1054,35$ PLUS-OR-MINUS $30,98 \mathrm{MB}$

\section{RELATED DATA}

NON-ELASTIC CROSS SECT1ON AT 14.2 MEV $=1457.00 \mathrm{MB}$

(N, ZN) THRESHOLD $=11.02$ MEV
(N,3N) THRESHPLD $=20.00$ MEV

THIS ISETUPE HAS 34 NEUTRÚNS, 29 PRUTONS, (MASS = 63)

NEUTRBN EXCESS PARAMETER $=.07937$

RATIO OF ASYMPTOTIC (N, 2N) TO 14,2 HEV NON-ELASTIC

$S=6 R-M ! I N U S \quad .0213$

$\begin{array}{rrr}\text { TOSORT(N) } & 8.921 & \text { T.SORT(A) } \\ \text { ERRIR } & .385 & 12.144 \\ \text { ERROR } & .524\end{array}$

CU 63 3. . FREM REF, A 3916012

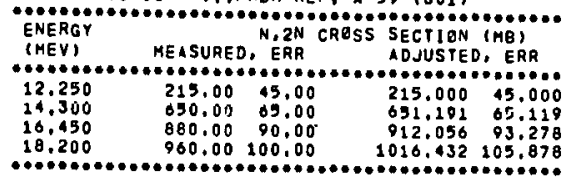

FITTED PARAMETERS

LEVEL SPACING: 4.970 PLUS-GR-MINUS, 151PER MEV

ASYMPTOTIC (N, ZN) CRESS SECTION : 1140.36 PLUS-QR-MINUS 13,31 HB

RELATED DATA

NON-ELASTIC CRESS SECTION AT 14.2 MEV $=1457.00 \mathrm{MB}$

(N, $2 N)$ THRESHOLD 11.02 MEV

THIS ISOTBPE HAS 34 NEUTRONS, 29 PROTONS, (MASS, 63 )

NEUTREN EXCESS PARAMETER = .07937 RATIO OF ASYMPTETIC (N, 2N) TO 24,2, MEV NON-ELASTIC
,7027 PLUS-GR-MINUS ,0091

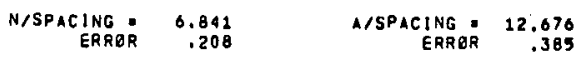
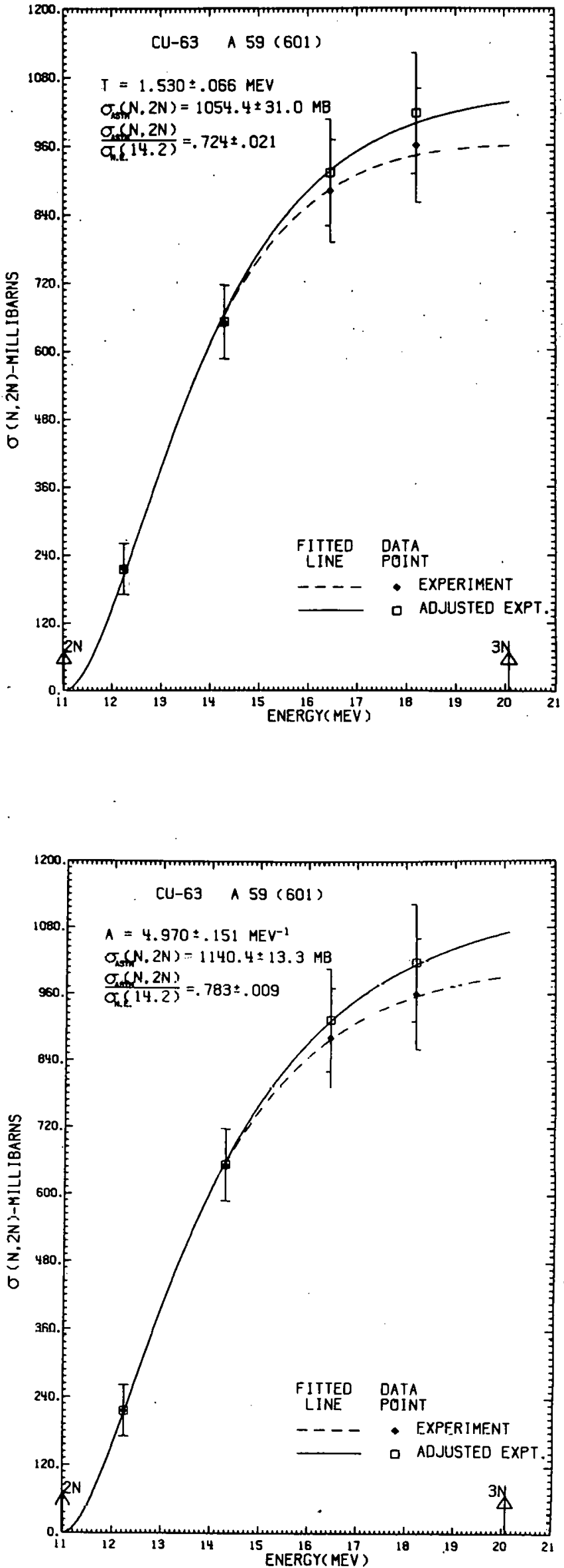


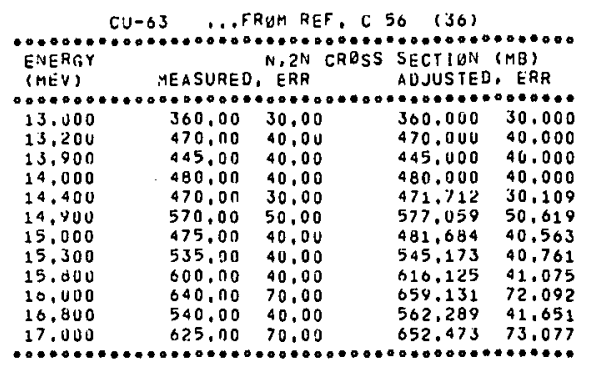

FITTEU PAKAMETERS

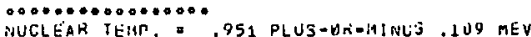

ASYMPTOTIC (N.2N) CRBSS SECTIUH $=580.70$ PLUS-OR-MINUS $29.75 \mathrm{MB}$

FELATED JATA

TUENELASTIC CFUSS SECIION AT 14,2 MEV - 1457,00 MB

(iv, LN) THRESHLLD = 11,02 MEV

iN, JNI THR उHYLU

THIS ISDTOPE HAS 34 NEUTRQNS, 29 PRDTHNS, (MASS $=63$ )

NEUTRON EXCESS PARAMETER $=.07937$

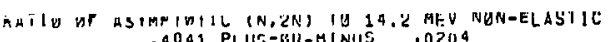

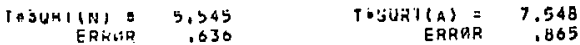

\section{TITTED PARAMETER:}

LEVEL SPACING I3. 792 PLUS-GR-AINUS3,272PER MEV

LGYAPTOTIC (N, 2N) CROSS SECTION $=604,68$ PLUS-OR.MINUS $34,72 \mathrm{MB}$

\section{RELATED DATA}

NON-ELASTIC CROSS SECTION AT 14,2 MEV - 2457.00 ME

(N,2N) THRESHQLD: $11.02 \mathrm{MEV}$

THIS ISOTUPE HAS 34 NEUTRONS, 29 PROTENS, (MASS, 63 )

NEUTRON EXCESS PARAMETER = .07037 RATIO OF ASYMPTBTIC (N,2N) TO 14,2 MEV NON-ELASTIC
.41SO PLUS-QR-MINUS .0238

$\begin{array}{rrrr}\text { N/SPACING } & 2.485 \\ \text { ERROR } & .585 & \text { LSPACING } & 1.568 \\ & & \text { ERROR } & 1.084\end{array}$
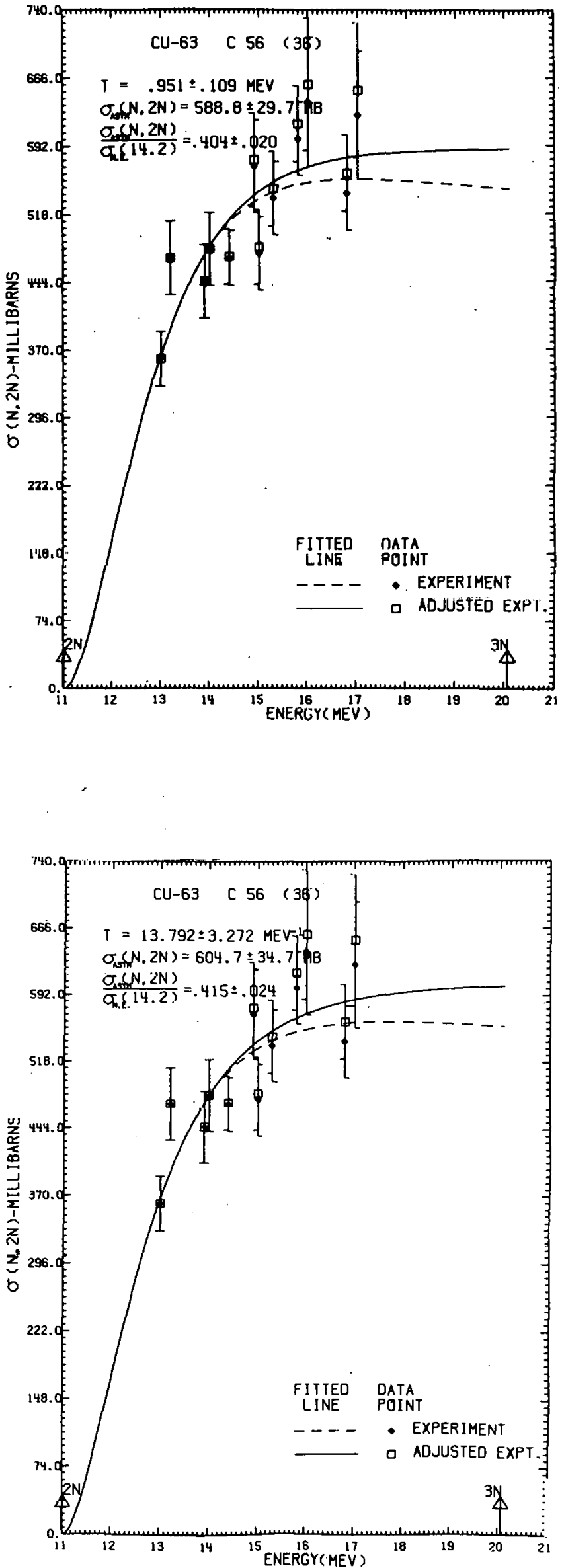


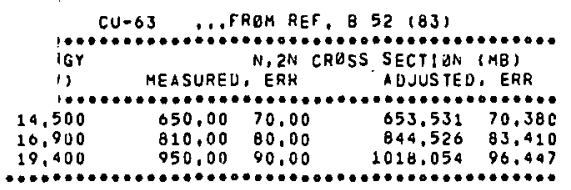

FitTED PARAMETERS

MUCLFAR TEMP. $=1.643$ PLUS-ER-MINUS 240 MEV

NUCLFAR TEMP, 2 1.643 PLUS-ER-MINUS, 240 MEV

RELATEO DATA

MUN-ELASTIC CRQSS SECTIUN AT 14,2 MEV $=1457.00 \mathrm{mB}$

(N,2H) THRESHOLL $=11,02$ MEV

(N,BII) THRESHALL $=20.06 \mathrm{MEY}$

THIS ISOTUPE HAS 34 NEUTHONS, 29 PRUTGNS, (MASS $* 63$ )

NEUTRUN EXCESS FARAHETER $=0.07937$

RATHO OF ASYMPTETIC (N,2N) TL 14,2 MEV NON-ELASTIC

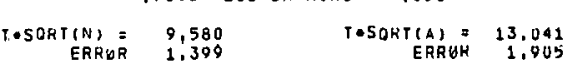

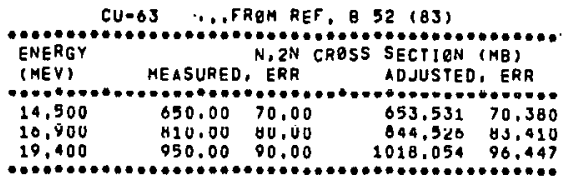

FITTED PARAMETERS

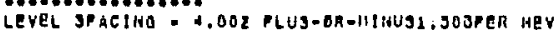

ASYMPTBTIC $(N, 2 N)$ CRESS SECTION = 1075.80 PLUS-OR-MINUS 87,54 MB

\section{RELATED DATA}

NBN-ELASTIC CROSS SECTION AT 14.2 MEV = 1457,00 MO

(N,2N) THRESHELD: 11.02 MEV
$(N, 3 N)$ THRESHBLD 20.06 MEV

IHIS ISOTOPE haS 34 NEUTRENS, 29 PRUTONS, (MASS : 63)

NEUTAUN EXEESS PARAMETER = .07937

RATIO BF ASYMPTETIC (N, ZN) TO 14,2 MEV NEN-ELASTIC .7384 PLUS-OR=M!NUS 0601

N/SPACING 7.080 AISPACING 13.120
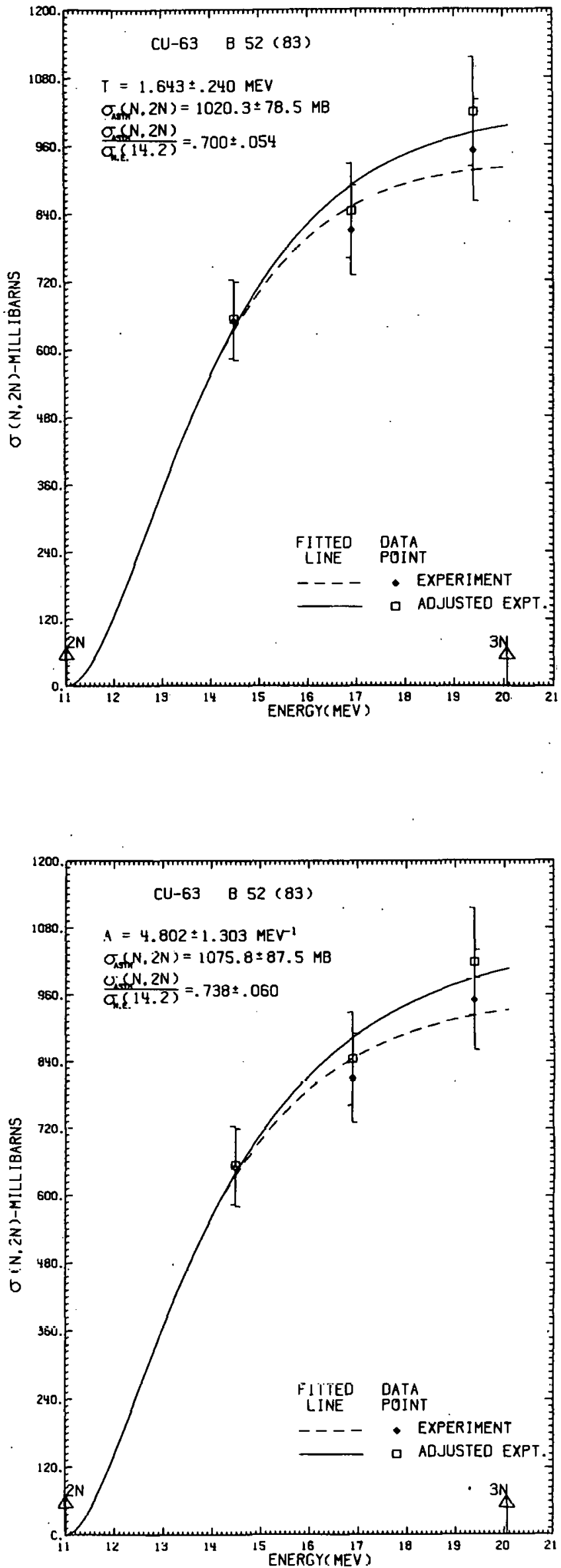


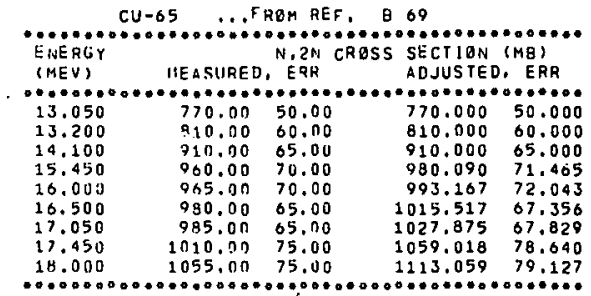

FITTED PARAMETERS

NUCLEAH TEMP. = 1.161 PLUS-DR-MINUS .044 MEV

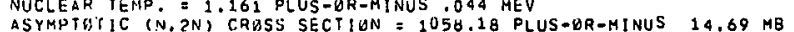

RELATED DATA

NUN-ELASTIC CRQSS SECTISN AT 14.2 MEV $=1477.72 \mathrm{MB}$

(N.2N) THKESHOLD $=10.06$ MEV
(N.3N) THRESHOLO $=18,10 \mathrm{MEV}$

THIS ISUTGPE HAS 36 NEUTRONS, 29 PROTONS, (MASS: 65)

NEUTHAN EXCESS PARAMETER $=.10764$

RAYIG GH ASYMPTRTIC (N, ?N) TU 14.2 MEV NDN-ELASTIC

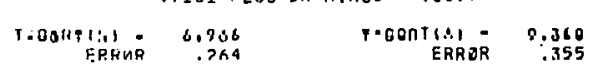

\section{Fi TTED PAFAMETERS}

LEVEL SPACING $=9,180$ PLUS-BR-MINUS $9001 P E R$ MEV
ASYMPTOTIC (HI, 2N) CRESS SECTION 1081.99 PLUS-OR-MINUS $15.76 \mathrm{MB}$

\section{RELATED UATA}

NEN-ELASTIC CROSS SECTION AT 14,2 MEV = 1477,72 MB

(N,2N) THRESHQLD $=10,00 \mathrm{MEV}$
(N,3N) THKESHPLD $=18,10 \mathrm{MEV}$

THIS ISUTGPE HAS 36 NEUTRONS. 29 PRETONS, MASS = 651

NEUTREN EXCESS PARAMETER $=.10769$

RATIQ OF ASYMPTETIC (N,2N) TO 14,2 KEV NON-ELASTIC

$\begin{array}{rrr}\text { N/SPACING }= & 3.919 \\ \text { ERRKR } & .282 & \text { A/SPACING }=7.076\end{array}$
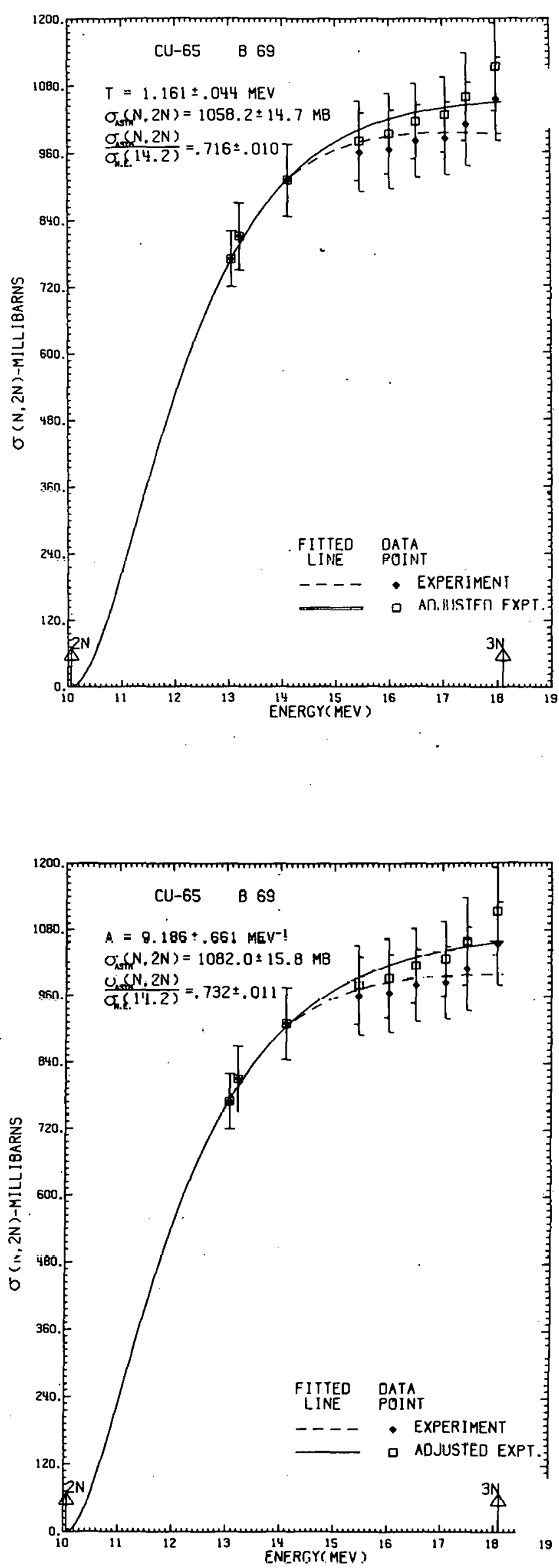


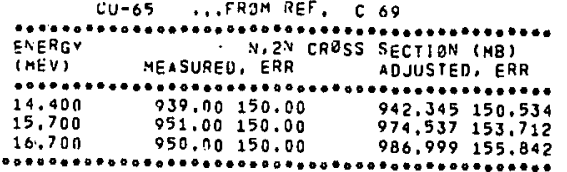

FITTED PAFAMETERS

-...................

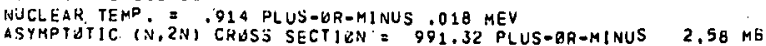

RELATED DATA

nonomono

N:JN-ELASTIC CRESS SECIIJN AY $14.2 \mathrm{MEV}=1477,72 \mathrm{MB}$

(W, 2W) THRESHBLD = $10.90 \mathrm{MEV}$

SN) IHRFSHFLD $=18.10 \mathrm{MEV}$

THIS ISUIEPF HAS 30 NEUTRONS, 29 PRGTINS. (MASS $=65$ )

INEUTRGIS EXCESS PARAMEISK $=.10769$ FATIE JF ASY:PTGTIC (N, 2N) TO 14:2 MEV NUN-ELASTIC

TUSORT(H)E $5.4 \mathrm{AA} \quad$ TOSORTLA) $=7.369$

CU-65 W. TRRAM REF, C $\triangle 9$

ENERGY

(MEV) MEASURED. N, LN CROSS SECTION (ME)
IDJUSTED, ERR

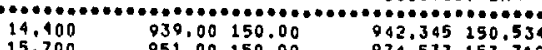

951.00150 .00

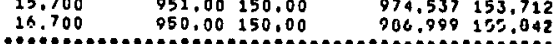

\section{FITTED PARAMETERS}

LEVEL SPACING:116.397 PLUS-gR-MINUS J81PER MEV

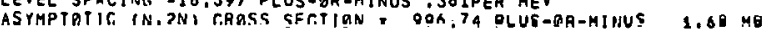

\section{RELATED DATA}

NON-ELASTIC CRESS SECTION AT 14.2 MEV $=1477,72 \mathrm{MB}$

$(N, 2 N)$ THRESHOLD $=10.06$ MEV

$(N, 3 N)$ THRESHOLD $=18,10$ MEV

THIS ISOTOPE HAS 36 NEUTRONS, 29 PROTONS, (HASS = 65)

NEUTRAN EXCESS PARAMETER $=.10760$

RATIG OF. ASYMPTATIC (N, 2N) TO 14,2 MEV NON-ELASTIC .6745 PLUS-QR-MINUS .0011

N/SPACING $=2.196 \quad$ A/SPACING 3.904
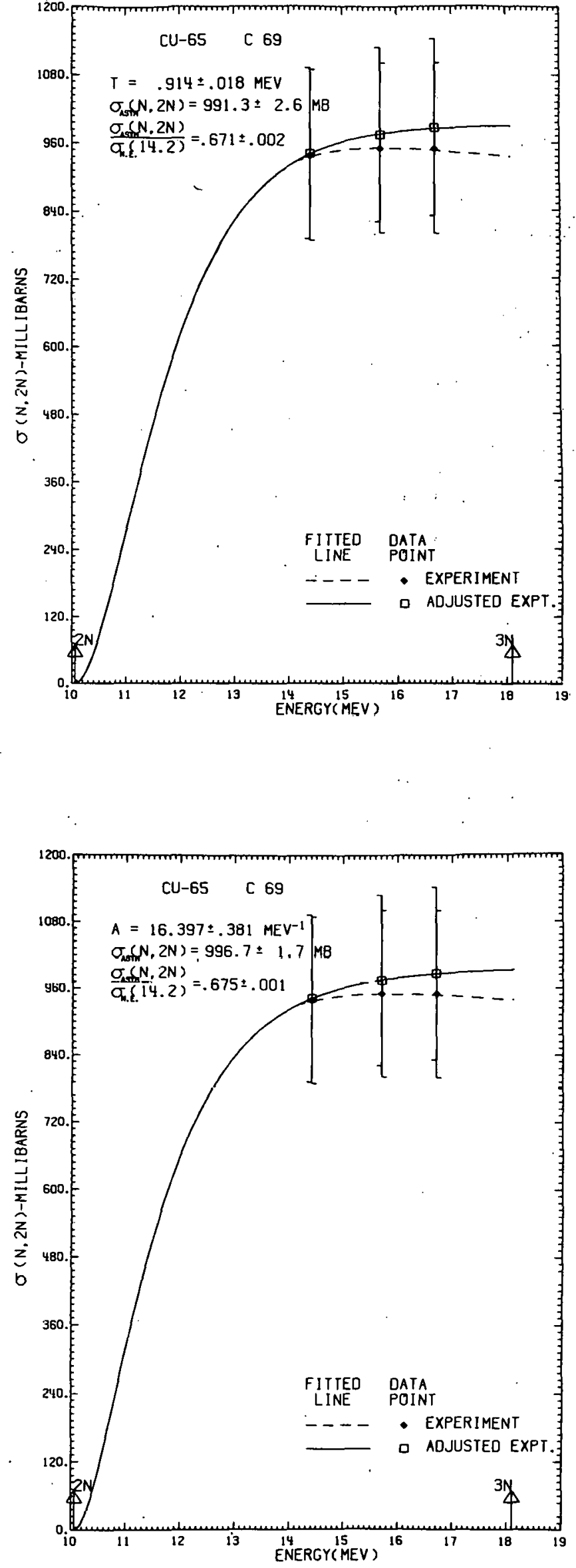


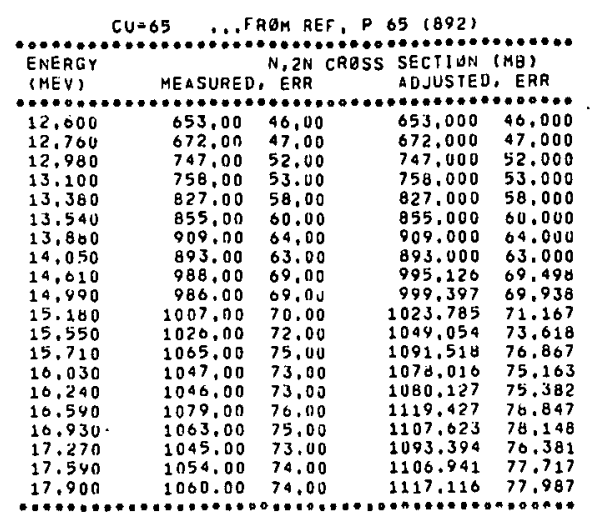

FITTED PAHAMFTERS

IACLEAR TEMP $=1.330$ PLUS-OR-MINUS .017 MEY

ASYMPTUTIC $(\dot{N}, 211)$ CRUSS SECTIUN $=1146.05$ PLUS-OR-MINUS $7.07 \mathrm{MU}$

RELATED DATA

NGN-ELASIIC CALSS SECTIEN AT 14.2 MEV $=1477.72 \mathrm{MB}$

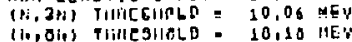

THIS ISGTEPE HAS 36 NEUTHENS, 29 PKUTUNS, (MASS = 65)

NEUTKUN EXCESS PARAMETER $=.10709$

HATIO DF ASYMPTRTIC (N, 2N) TO 14.2 MEV NON-ELASTIC

,7755 PLUS- 6 A-MINUS .0052

$\begin{array}{rrr}\text { TOSORTIN) } & 7.980 & \text { TOSURT(A) } \\ \text { ERRDR } & .102 & 10.723 \\ \text { EKRBR } & .137\end{array}$

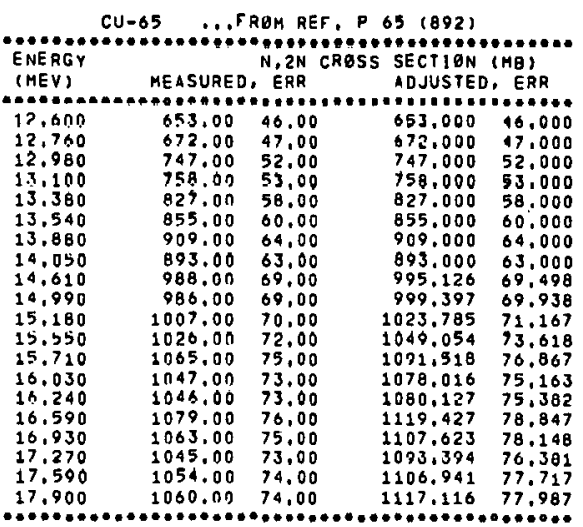

FITTED PARAMETERS

LEVEL SPACING 717 PLUS-OR-MINUS $2308 E R$ MEV

ASYMPTOTIC (N,2N) CRESS SECTION = 1194,28 PLUS-GR-MINUS 11,95 ME

RELATED DATA

HON-ELASIIC CROSS SECTION AT 14,2 MEV $=1477.72 \mathrm{MB}$

(N, 2N) THRESHRLD $=10,05$ MEV

(N, $(N, 3 N)$ THRESHRLD : 10,06 MEV

THIS ISUTGPE HAS 36 NEUTRENS, 29 PRETONS, (MASS : 65)

NEUTRON EXCESS PARAMETER $=.10760$

RATIG GF ASYMPTGTIC (N,2N) TO 14.2 MEV NGN-ELASTIO

$$
\text { .8082 PLUS-GR GMINUS } 14,2 \text { MEV NGN-ELAETIO }
$$

$\begin{array}{rrr}\text { N/SPACING }= & 5.380 & \text { A/SPACING } \\ \text { ERKER } & .184 & 9.677 \\ \text { ERRER } & .331\end{array}$
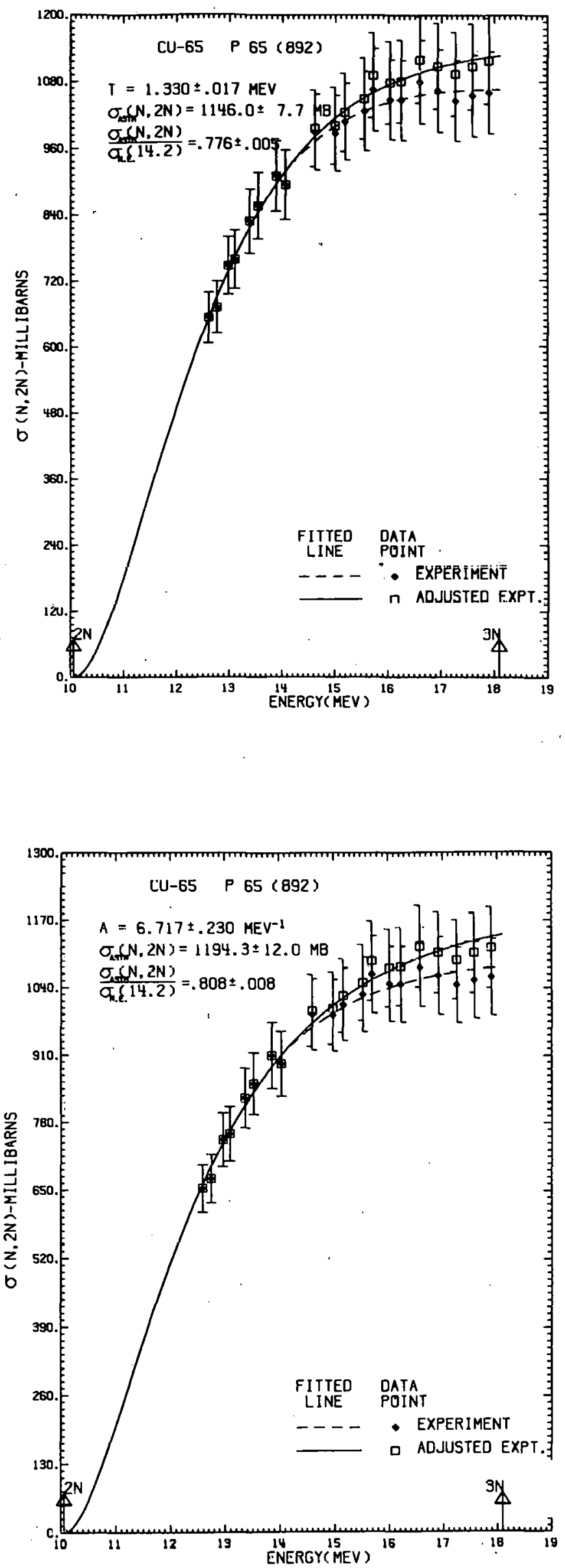


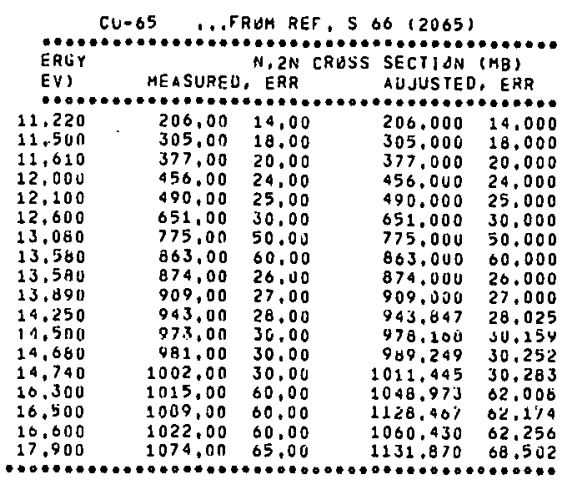

FITTED FARAHETERS

NUCLEAR TEMP. $=1.436$ PLUS-UR-MINUS .030 MEV

ASYMPTOTIC (N, ZN) CRGSS SECTIBN $=1199,19$ PLUS-OR-MINUS 23.04 ME

\section{RE(LATES DOTA}

NON-ELASTIC CRESS SECTION AT 14,2 MEV $=1477,72 \mathrm{MB}$

(N, $2 \mathrm{M})$ THRESHGL $=10.06 \mathrm{MF}$

(N,3N) THKESHOL $=18,10 \mathrm{MEV}$

IHIS ISOTUPE HAS 36 NEUTRIBNS, 29 PRETONS, (MASS $=651$

NEUTRGN EXCESS PARAMETER $=.10769$

RATIO UF ASYMPTOTIC (N.2N) TU 14.2 MEV NON-ELASTIC

(

$\begin{array}{rrr}\text { T.SORT }(N)= & 0.616 & \text { TOSORT(A) } \\ \text { ERRER } & .216 & 11.577 \\ \text { ERHEK } & .290\end{array}$

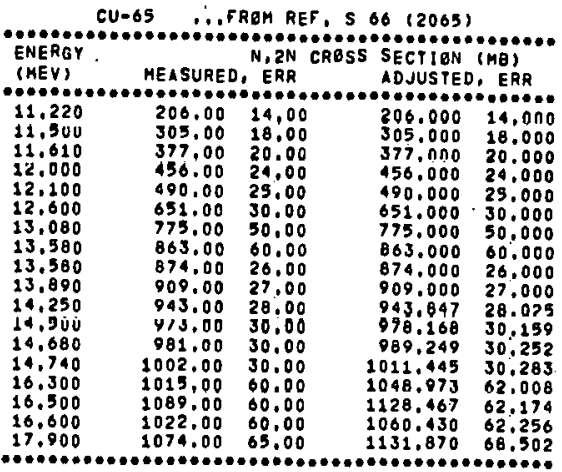

\section{FITTED PARAHETERS}

LEVEL SPACING 4,984 PLUS-BR-HINUS . J73PER MEV

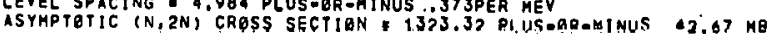

RELATED DATA

NON-ELASTIC CRESS SECTION AT 14.2 MEV = $1477.72 \mathrm{MB}$

$(N, 2 N)$ THRESHELD 10.06 MEV

(N,3N) THRESHELD: $10,10 \mathrm{MEV}$

THIS ISOTOPE HAS 36 NEUTRENS, 29 PROTONS, (MASS : 65)

NEUTREN EXCESS PARAMETER: 10769

1 of ASYMPTETIC (N.2N) TO 14.2 MEV NGN-ELASTIC
.0055 PLUS-DR-MINUS .0289

$\begin{array}{rrr}\text { ICING: } 7.223 & .541 \\ \text { ERROR } & .5 / S P A C I N G & 13.042 \\ \text { ERROR } & .976\end{array}$
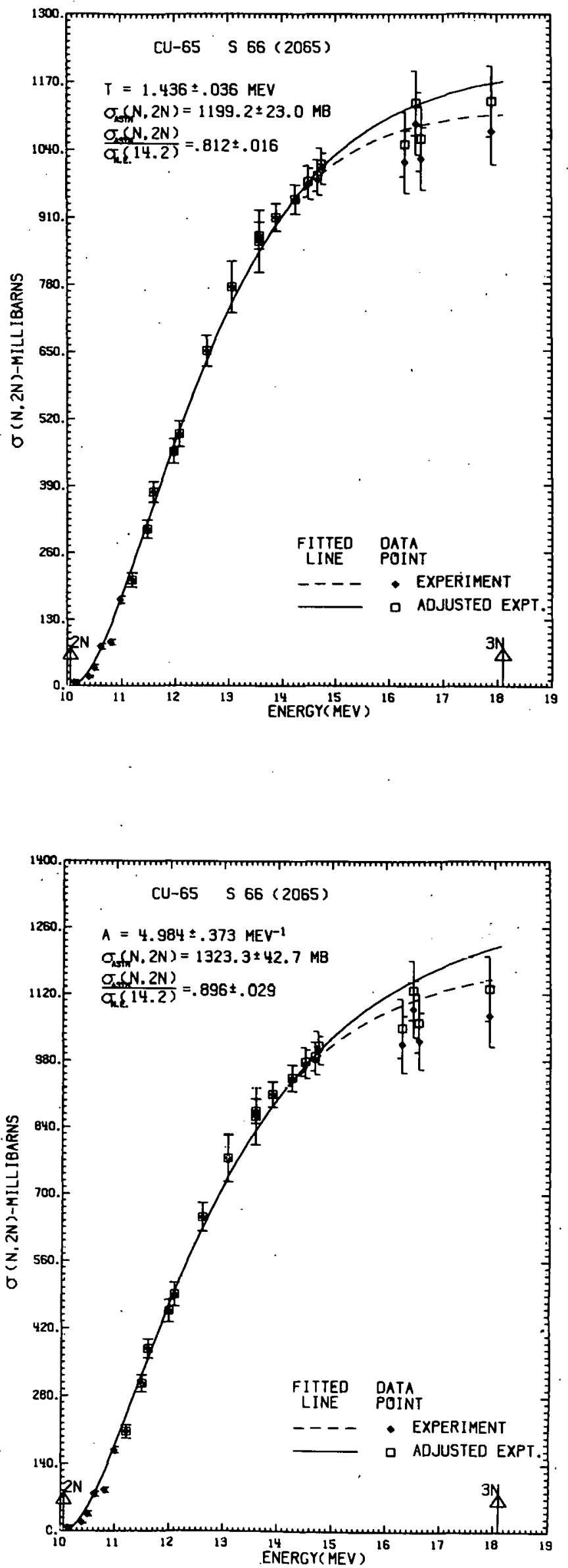


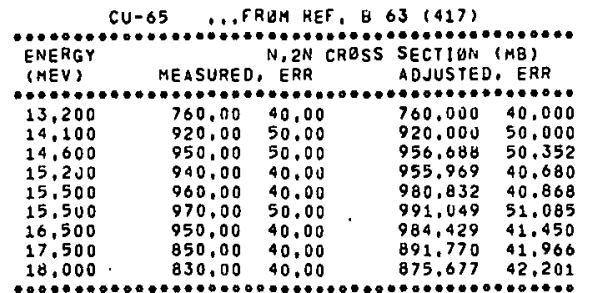

\section{FITTEU PARAMETERS}

NUCLEAR TEMP. $=941$ PLUS-QR-MINUS .145 MEV

ASYMPTOTIC (N, $2 H)$ CRDSS SECTION $=957.93$ PLUS-DR-MINUS 28,25 MO

\section{RELATED DATA}

MGN-ELASTIC CRESS SECTIOÁ AT 14,2 MEV $=1417,72 \mathrm{MB}$

(N,2N) THRESHELD $=10,06$ MEV
$(N, 3 N)$ THRESHRLD $=18.10 \mathrm{MEV}$

THIS ISUTUPE HAS 36 NEUTRUNS, 29 PROIGNS, (MASS $=65$

NEUTRGN EXCESS PARAMETER = .10769

HATIU UF ASYMPTOTIC (N, $2 N$ ) TO 14,2 MEY NON-ELASTIC 6482 PLUS-GR-MINUS .0191

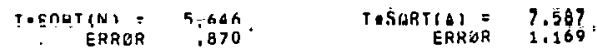

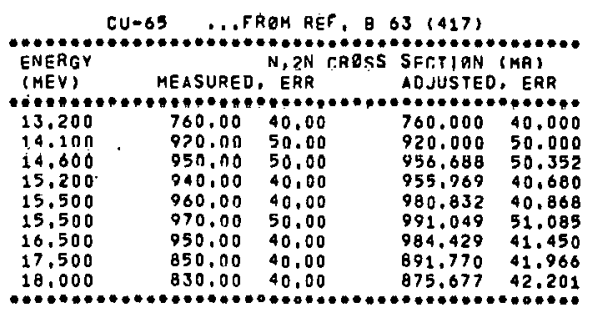

\section{FITTED PARAMETERS}

IEVEL SPACING 15 ; 300 PLUS-QR-MINUSS 344 PER MEV

ASYMPTOTIC (N, $2 N$ I CROSS SECTIION
REI,ATED OÄTA

A

(N,2N) THRESHQLD: 10.06 MEV

THIS ISOTOPE HAS 36 NEUTRONS, 29 PROTONS, IMASS : 651

NEUTRON EXCESS PARAMETER = .10769

RATIO OF ASYMPTOTIC (N,2N) TO 14,2 MEV NON-ELASTIC

$$
.6514 \mathrm{VLUS-UH-HINUS \text {, }} \text {. U2Z9 }
$$

N/SPACING $=2.352$

$$
\text { ASPACING }=4.246
$$
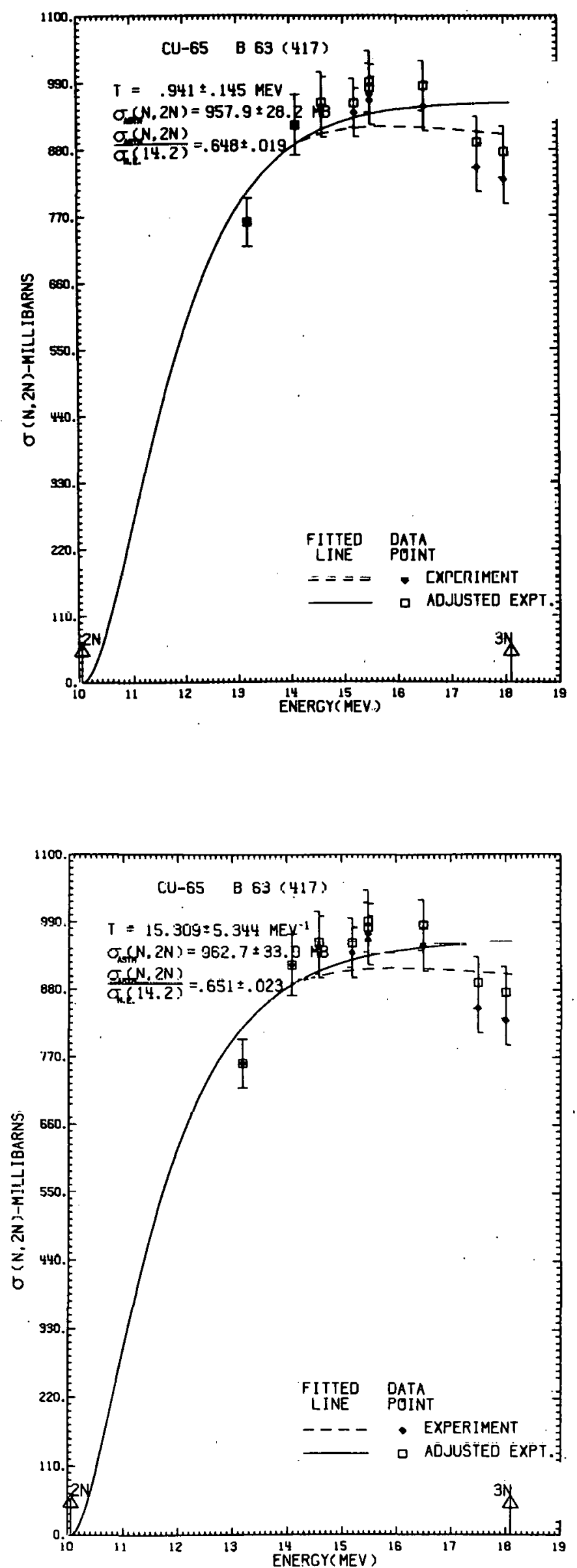


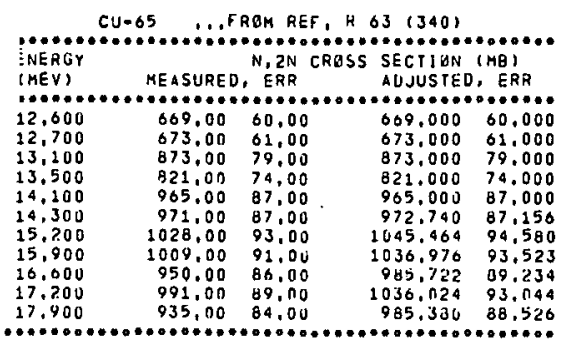

FITIED PATAMETERS

NUCLEAR TEMP $=1.127$ PLUS $-Q R-H 1$ NUS 008 MEV

ASYMPTOTIC $(N, 2 N)$ CROSS SECTIUN = 1050.8G PLUS-OR-MINUS 29.94 MO

HELATED DATA

NGN-ELASTIC CRQSS SECTION AT 14.2 MEV $=1477.72 \mathrm{MB}$

(N, 2N) THRESHQLD $=10.06 \mathrm{MEV}$

THIS ISUTLPE HAS 36 NEUTRGNS, 29 PRUTONS, (MASS a 63 )

NEUTFION EXCESS PARAMETER $=.10769$ RAT10 OF ASYMPTOTIC (N,2N) TO 14,2 MEV NON-ELASTIC

TOSURTIN) $=6.762 \quad$ TESLRT(A) $=9.086$

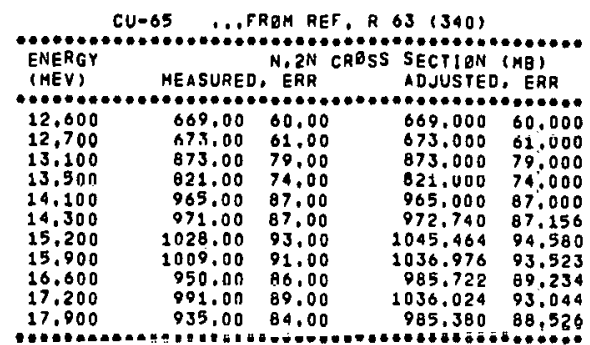

FITTED PARAMETERS

LEVEL SPACING 9.028 PLUS-QR-MINUSI 37OPER MEV

ASYMPTETIC (N,2N) CRESS SECTION = 1073.85 PLUS-DR-MINUS $38,52 \mathrm{HB}$

RELATED DATA

NON-ELASTIC CAOSS SECTION AT 14.2 MEV $=1477.72 \mathrm{MB}$

(N.2N) THRESHQLD $: 10.06$ MEV

(N.3N) THRESHOLD 18,10 MEV

THIS IGOTOFE HAS 36 NEUTRONS, 29 PROTONS, (MASS * 65)

NEUTRON EXCESS PARAMETER = .10709

RATIO OF ASYMPTETIC (N,2N) TO 14,2 HEV NGN-ELASTIC .7268 PLUS-OR-MINUS
0201

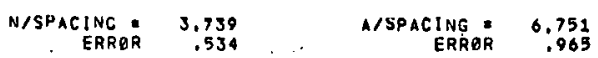
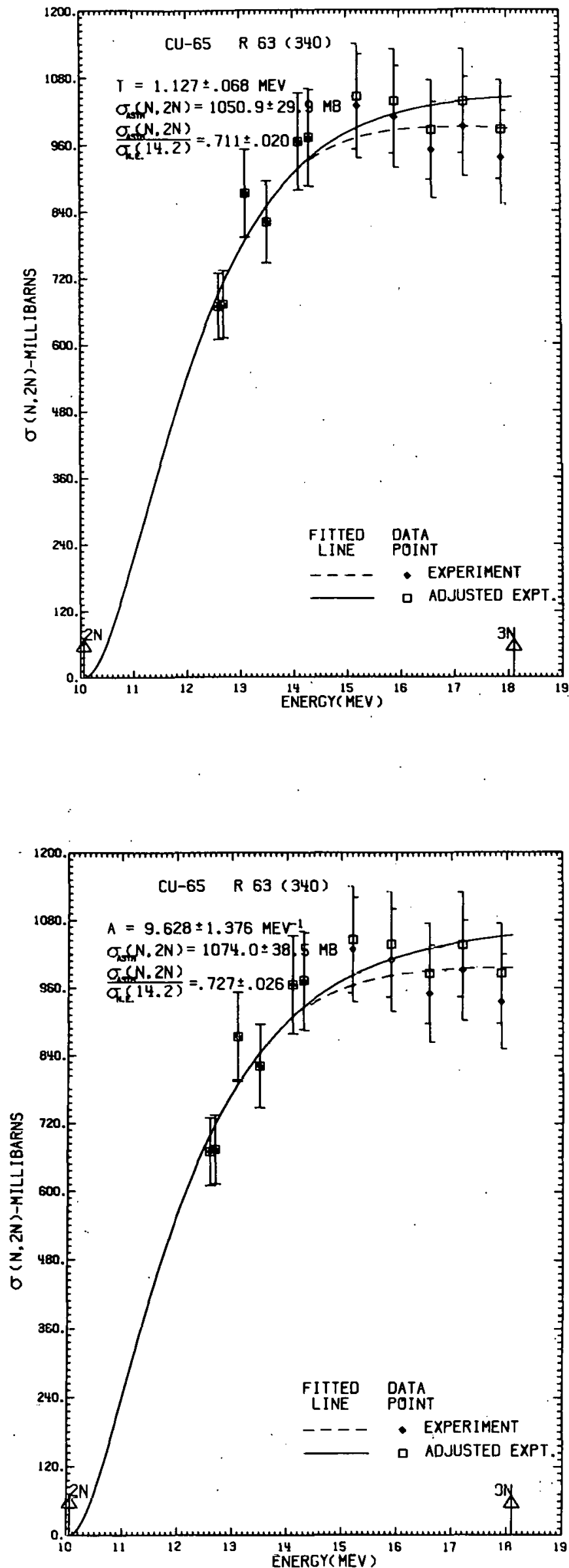


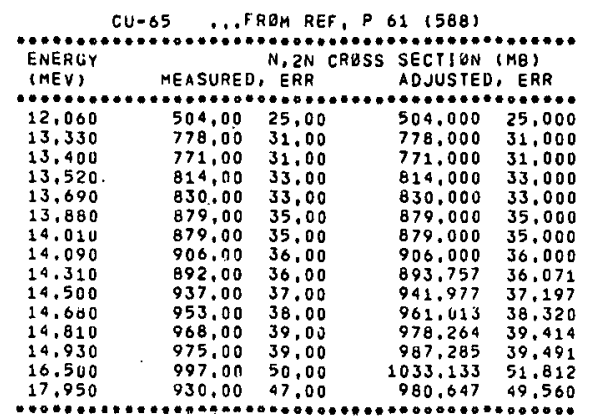

\section{FITTED HAKAMETERS}

NUCLEAR TEMP. 1.249 PLUS-OM-HINUS .040 ME

ASYMPTOTIC $(N, 2 N)$ CROSS SECTION $=1066.59$ PLUS-OR-MINUS 18.35 MH

RELATED DATA

NQN-ELASTIC CRQSS SECTION AT 14.2 MEV $=1477,72 \mathrm{MB}$

(N, $N$ N ) THRESHQLD $=10.00$ MEV

THIS ISUTUPE HAS 36 NEUTRENS, 29 PROTUNS, (MASS $=63$ )

NEUTRUN EXLESS PARAFETER = 10784

FATIO UF ASYMPTOTIC (N,2N) TU 14,2 MEV NON-ELASTIC

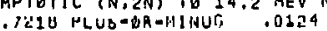

TOSORTIN) = $7.494 \quad$ TOSURT(A): 10.070

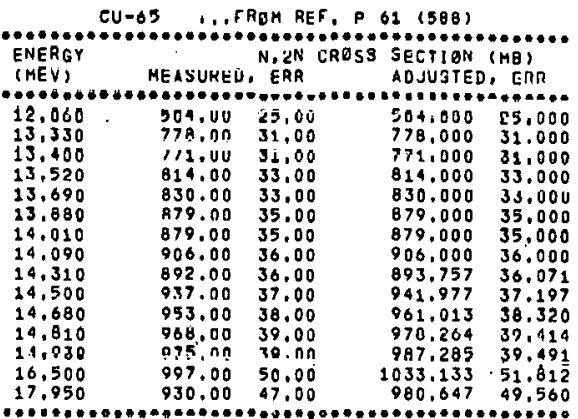

\section{FITTED PARAMETEPS}

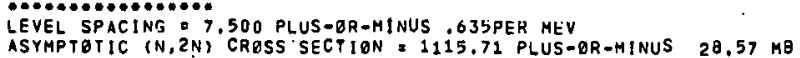

RELATED DATA

NON-ELASTIC CAOSS SECTION AT 14,2 MEV $=2477,72$ MB

$(N, 2 N)$ THRESHBLO 10,06 MEV

THIS ISOTOPE HAS 36 NEUTRONS, 29 PROTONS, (HASS $=65$ )

NEUTREN EXCESS PAPAHETER = .10769

RATIO OF ASYMPTETIC (N, 2N) TO 14.2 MEV NON-ELASTIC .7590 PLIJS-GR-MINUS .0193

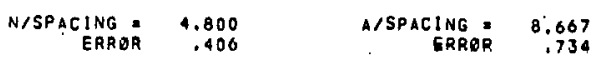
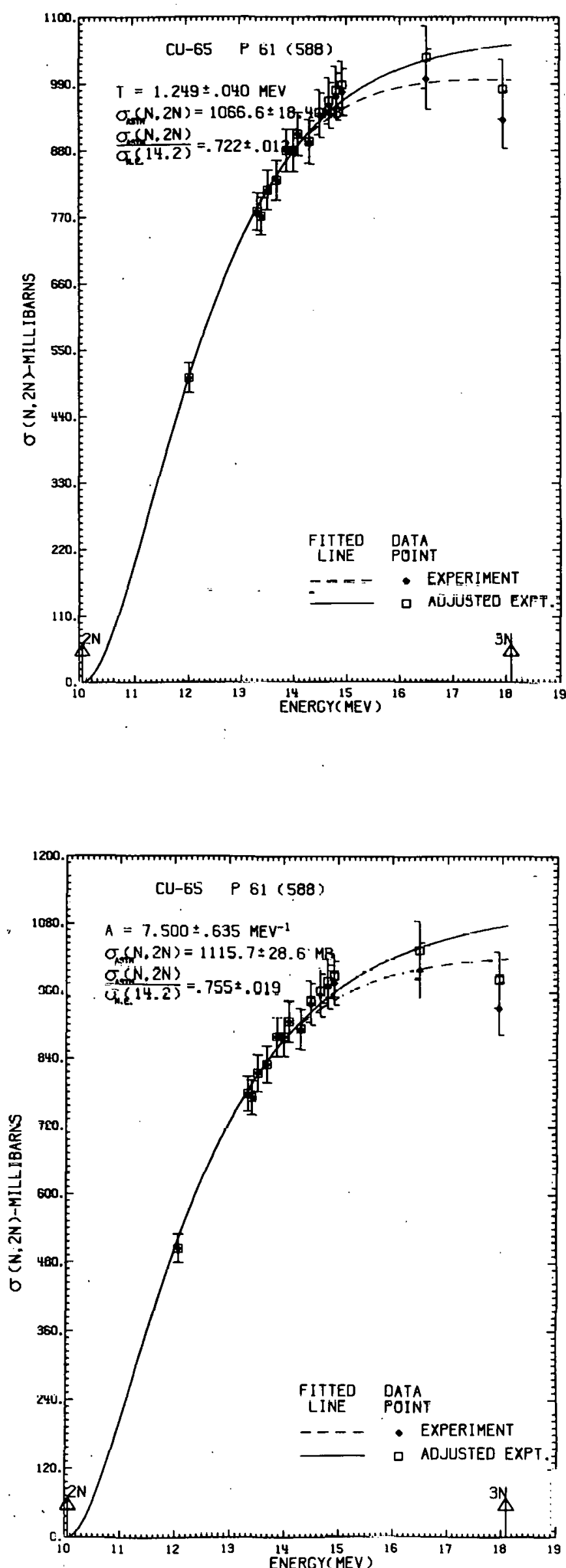


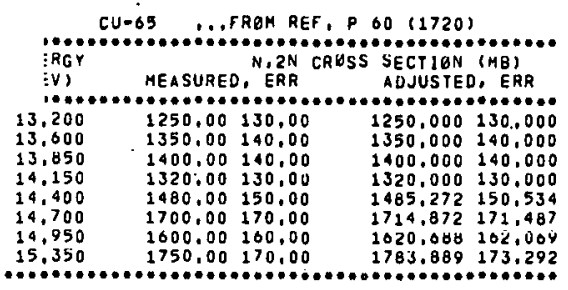

FITTED PARAMETERS

NUCLEAR TEMP, $=1.591$ PLUS-OHH-HINUS 265. MEV

ASYMPIOTIC (N, 2N) CRBSS SECTIUN $=2024,35$ PLUS-BR-HINUS $231.69 \mathrm{MB}$

RELATEO DATA

-.o.........

NON-ELASTIC CAOSS SECTIEN AT $14.2 \mathrm{MEV}=1477.72 \mathrm{MB}$

$(N, 2 N)$ THHESHOLD $=10,00 \mathrm{MEV}$

(N, SN) THRESHALD $=18,10 \mathrm{MEV}$

THIS ISOTUPE HAS 30 NEUTRENS, 29 PRGTINS, (MASS = 65)

NEUTHGN EXXFFS PARAMETER = .1967G9

RATID UF ASYMPTOTIC (N,2N) TU 14.2 MEV NON-ELASIIC

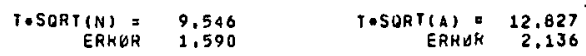

CU-65 W. FROH REF, P $60(1720)$

\begin{tabular}{|c|c|c|}
\hline $\begin{array}{l}\text { ENERGY } \\
\text { (MEY) }\end{array}$ & MEASURED. ERR & $\begin{array}{l}\text { SECTIQN (AB) } \\
\text { ADJUSTED, ERR }\end{array}$ \\
\hline $\begin{array}{l}13,200 \\
13,600 \\
13.850 \\
14,150 \\
14,400 \\
14,700 \\
14,950 \\
15.350\end{array}$ & 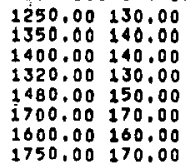 & 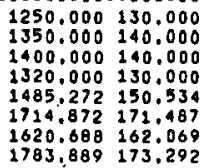 \\
\hline
\end{tabular}

\section{FITTED PARAMETERS}

LEVEL SPACING 4,287 PLUS-GR-MINUS1, 653PER MEV

ASYMPTETIC (N.2N) CRESS SECTIUN $=2233.04$ PLUS-ER-MINUS 345,25 MB

RELATED UATA

MON-ELASTIC CAOSS SECTION AT $14.2 \mathrm{MEV}=1477.72 \mathrm{MB}$ $(N, 2 N)$ THRESHELD $=10,06 \mathrm{MEV}$
$(N, 3 N)$ THRESHELD $=18,10 \mathrm{MEV}$

THIS ISOTOPE HAS 30 NEUTRONS, 29 PROTONS, (MASS D 65)

MEUTRON EXEESS PARAMETER = .10760 RATIO OF ASYMPTOTIC (N,2N) TO 14,2 MEV NON-ELASTIC
1.5111 PLUS-OR-MINUS

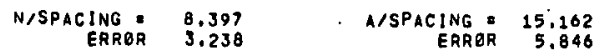
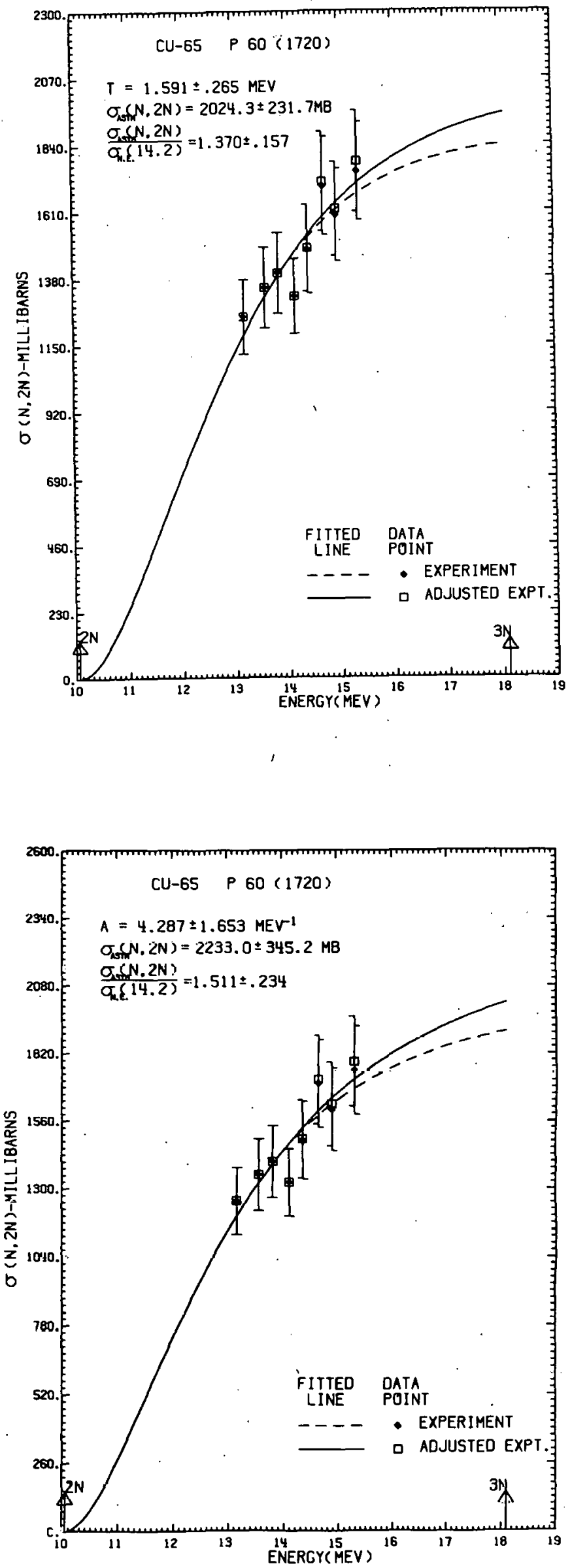


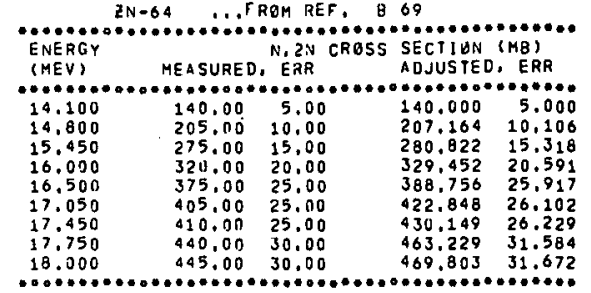

SITTED PARAMETERS.

NUCLEAR IEMP. $=? .476$ PLUS-BR-MINUS .069 MEV

ASYMPTQTIC (N, 2N) CROSS SECTION $=690.33$ PLUS-OR-MINUS $22.50 \mathrm{MB}$

RELATED JATA

NGN-ELASTIC CRESS SECTIUN AT 14,2 MEV $=1467,41 \mathrm{MB}$ (N.2N) THRESHRIO = 12.04 MEV

(N, $2 N)$ THRESHOLO $=12.04 \mathrm{MEV}$
(N.3N) THKESHELD $=21.36 \mathrm{MEV}$

THIS ISDTDPE HAS 34 NEUTRONS, 30 PROTJNS, (MASS $\approx 64$ )

REUTRUV EXCESS PARAMETEN $=.06250$

RATIG MF ASYMPTETIC IN, $2 N$ T TU 14.2 MEV NON-ELASTIC

TOSUNIYY $=14.451$
ERROT

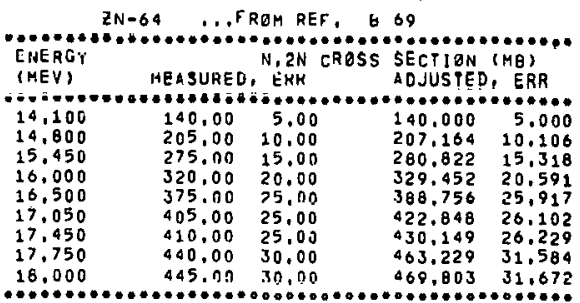

FItTED PARAMETERS

LEVEL SPACING " 1 , O33 PLUS-JH-MINUS .135PER MEV

ASYMPTOTIC (N, ZN) CRESS SECTION $=901,35$ PLUS-OR-MINUS $49,17 \mathrm{MB}$

RELATEN TATA

NEN-ELASTIC CROSS SECTION AT 14.2 MEV $=1407.41 \mathrm{MB}$

NEN-ELASTIC CRESS SECTION AT 14

(N, $2 N)$ THRESHRLD $=12,04 \mathrm{MEV}$
(N,3N) THRESHQLD $=21,36 \mathrm{MEV}$

THIS ISETUPE HAS. 34 NEUTRONS, 30 PRETONS, (HASS : 64)

"IEUTRON EXCESS PARAMETER $=.06250$

RATIU BF ASYMPTATIC (N,2N) TE 14,2 MEV NON-ELASTIC

NSPACING $=$
ERROR
20.821
1.721 $\quad$ A/SPACING $=39.192$
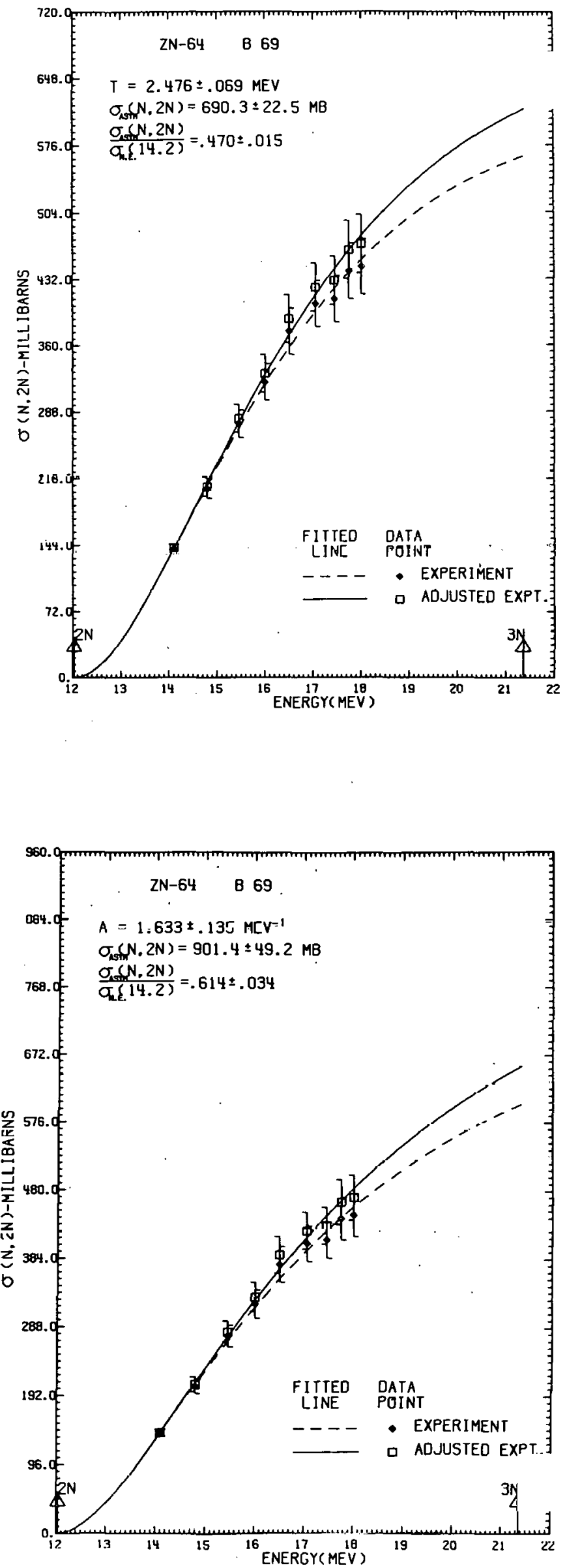


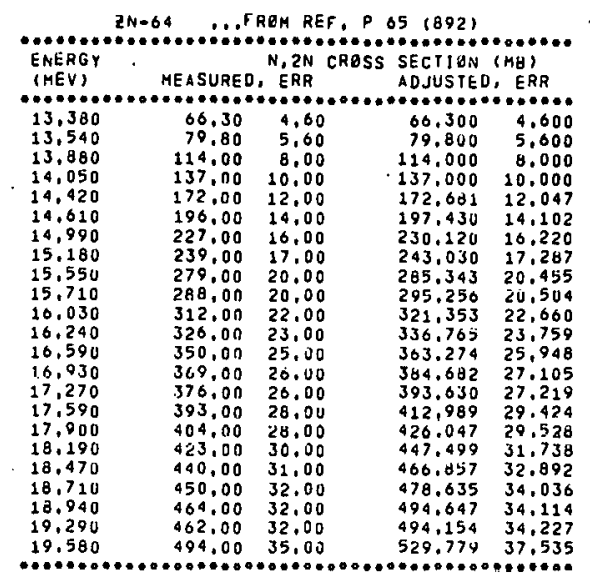

FITTED PAHAMETERS

NUCLEAR TEMP. = 2,328 PLUS-OR-MINUS .042 MEY

ASYMPTUTIC (N.2N) CRUSS SECTIUN $=616.91$ PLUS-GR-MINUS $12.03 \mathrm{MB}$

RELATED UATA

NGÄ-ELASTIC CRASS SECTIUN AT 14,2 MEV $=1467,41 \mathrm{MB}$

(N, $2 N$ ) THRESHELD $=12.04$ MEV

THIS ISOTUPE HAS 34 NEUTRONS,

IEUTRUN EXCESS PARAHETER $=.06250$

RATID OF ASYHPTOTIC (N,ZN) TU 14,2 MEV NON-ELASTIC
.4204 PLUS-UR-MINUS .0082

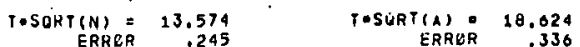

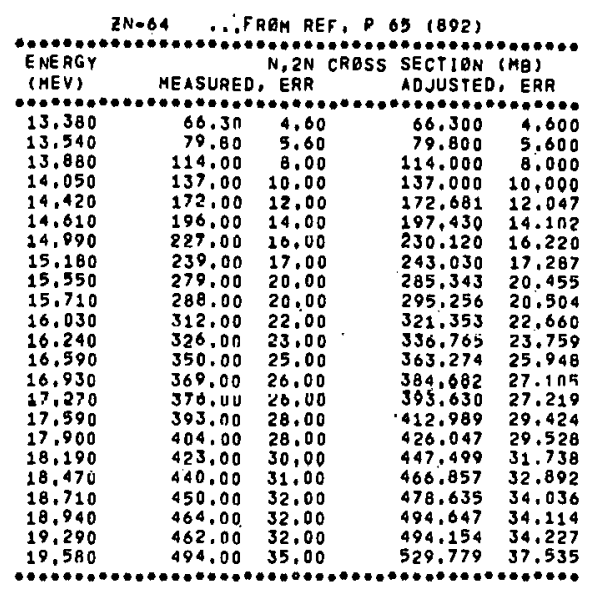

FITTED PARAMETERS

LEVEL SPACING " T.953 PLUS-OR-MINUS .112PER MEV

ASYMPTOTIC (N,2N) CROSS SECTIEN T65.06 PLUS-OR-MINUS 26.45 MO

\section{RELATED DATA}

NON-ELASTIC CROSS SECTION AT 14.2 MEV = 1467,41 ME

(N, $2 N$ ) THRESHELD $=12,04 \mathrm{MEV}$

(N,JN) THRESHELD : 21,36 MEV

.TMIS ISOTOPE haS 34 nEUTRONS, 30 PRETONS, (MASS : 64).

ZRON EXCESS PARAMETER = .06250

O or aSTMPTEIIC (N,2N) TË 14,2 MEV NON-ELASTIC

$$
, 5214 \text { PLUS-OR=MINUS } 0180
$$

$\begin{array}{r}\text { N/SPACING } \\ \text { ERRDR } \\ \quad 17.409 \\ \hline 998\end{array}$

$$
\text { ASPACING } 32,770
$$
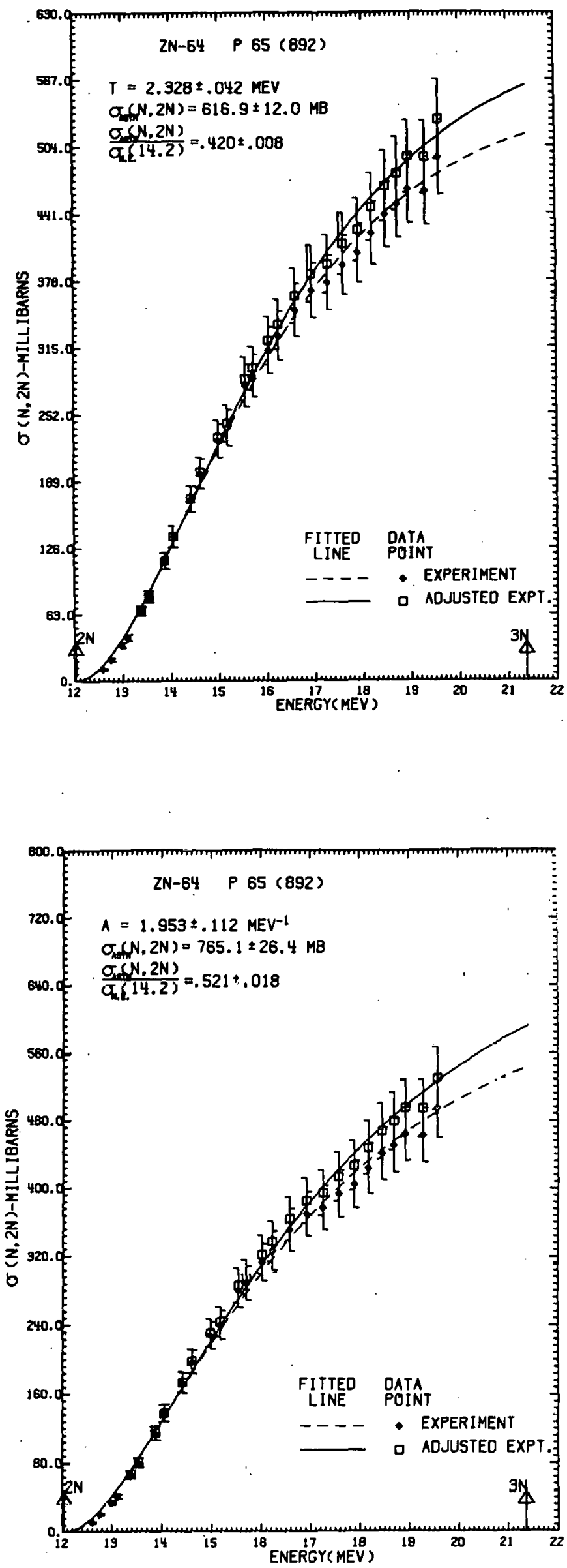


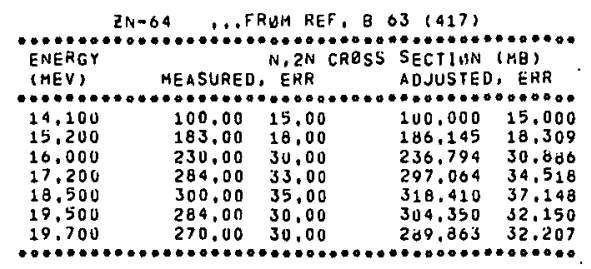

FITTEU PARAMETERS

IVUCLEAR TEMP, = 750 PLUS-UR-MINUS 149 MEV

ASYMPTETIC (N, 2N) CKDSS SECTIUN = 336.19 PLUS-DR-MINUS 20.04 MO

RELATED DATA

HWN-ELASIIC CROSS SECIICN AT 14,2 MEV $=1467.41 \mathrm{MB}$

(N, 2N) TRRESHELD $=12,04 \mathrm{MEV}$

(N, $2 N)$ THRESHELD $=12,04 \mathrm{MEV}$
(N,3N) THHESHQLO $=21,36 \mathrm{MEV}$

THIS ISOTDPE HAS 34 INEUTRENS, 3O PRETONS, (MASS $=64$ )

NEUTRUN EXCESS PARAMETER $=.06250$

HATHO OF ASYMPTATIC (N, 2N) TO 14.2 MEV WON-ELASTIC

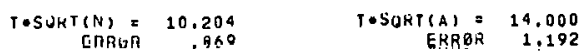

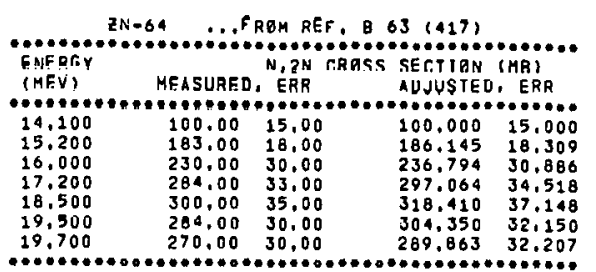

FITTED PARAMETERS

OEVE \$ABQ

LEVEL SPACING 4.205 PLUS- OR-MINUS 934 PER MEV
ASYMPTOTIC (N.2N) CRGSS SECTIBN = 365.77 PLUS-QR-MINUS $32.49 \mathrm{MB}$

RELATED DATA

NGN E

(N, 2N) PHRESHOLD: 12.04 MEV

(N,3N) THRESHOLD: 21,36 MEV

THIS ISOTOPE HAS 34 NEUTRONS, 3O PRETONS, (MASS, 64)

NEUTREN EXCESS PARAMETER $=.06250$

RATIO OF ASYMPTOTIC (N.2N) TO 14.2 MEV NEN-ELASTIC

.2493 PLUS-DR-MINUS .0221

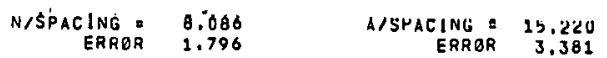
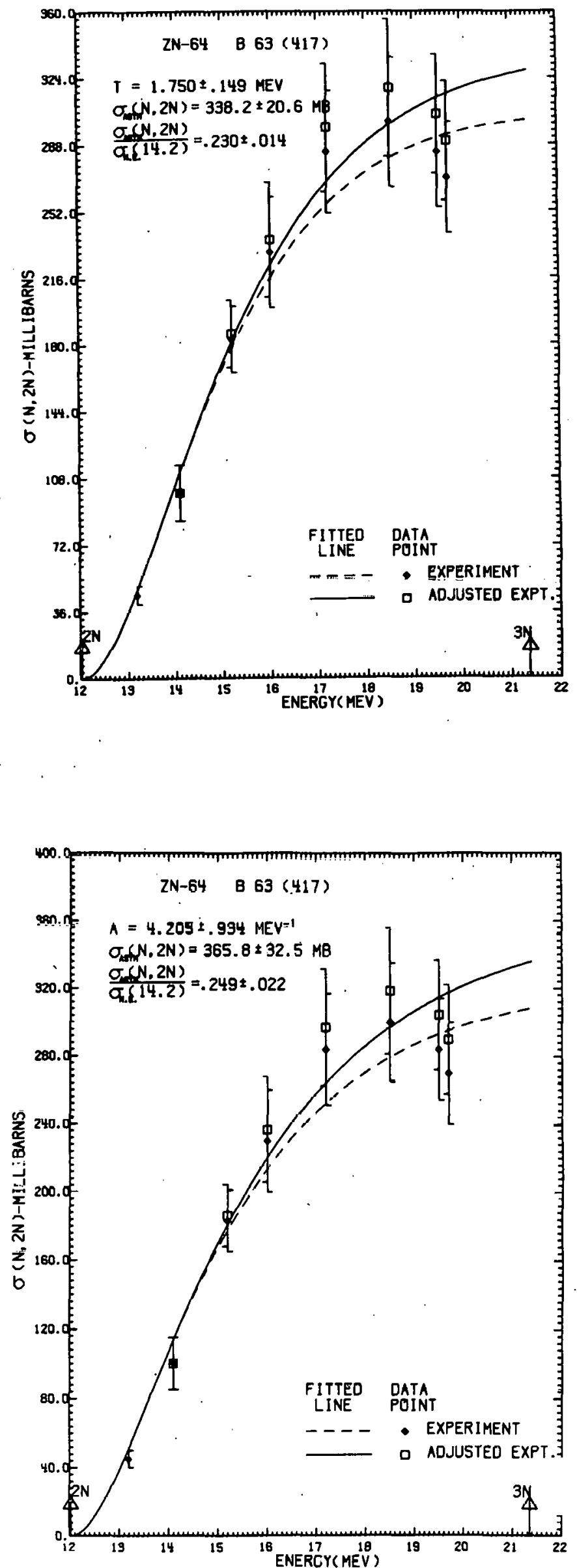


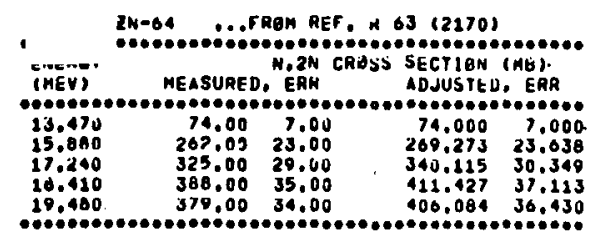

\section{FITTED PAKAMETERS}

MUELEAR TEMP. 2.045 PLUS-OR-HINUS OBE MEV

ASYMPTETIC (N.2N) CRESS SECTIUN $=477,09$ PLUS-gR-MINUS 17.49 NH

NELATEU UATA

MEN-ELASTIC CRESS SECTION AT 14,2 MEV = 1467.41 MB

NBN-ELASTIC CROSS SECTION AT

(N,2N) TWKESHELD : $12,04 \mathrm{NEV}$
$(\mathrm{N}, J N)$ THKESHELD $21,36 \mathrm{MEV}$

THIS ISOTOPE HAS JA NEUTRONS, JO PRGIGNS, (MASS $=64$ )

MEUTRGN EXCESS PARAMETER : .00250

HATIO GF ASYMPTgTIC (N.2N) TOD 14.2 MEV NONGELASTIC 3257 PLUS-BH-M!NUS .0119

TESUKT(A) 11.924
ERRER TESOAT(A)
.978

2N-O4., FREM REF R G3 12170$)$
ENERGY
(NEV)

FITTED PARAMETERS

LEVEL SPACING 2.086 PLUS-ZR-HINUS 322PER HEV

ASYMPTETIC (N,2N) CRESS SECTION 559.93 PLUS-OR-NINUS 34.8B RE

RELATED DATA

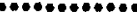

NQN-ELASTIC CROSS SECTION AT 14.2 MEV - 1467.41 MB

(N.2N) THRESHQLO $12,04 \mathrm{MEV}$

THIS ISOTOPE HAS 34 NEUTRONS, 30 PROTONS, (MASS: 041

NEUTRAN EXCESS PARAMGTGR - .06250

RATIO OF ASYMPTOPIC (N,2N) TO 14,2 MEV MON-ELASTIC .3616 PLUS-QR-MINUS, 0230

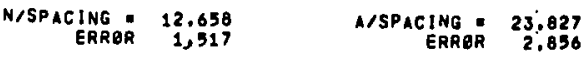
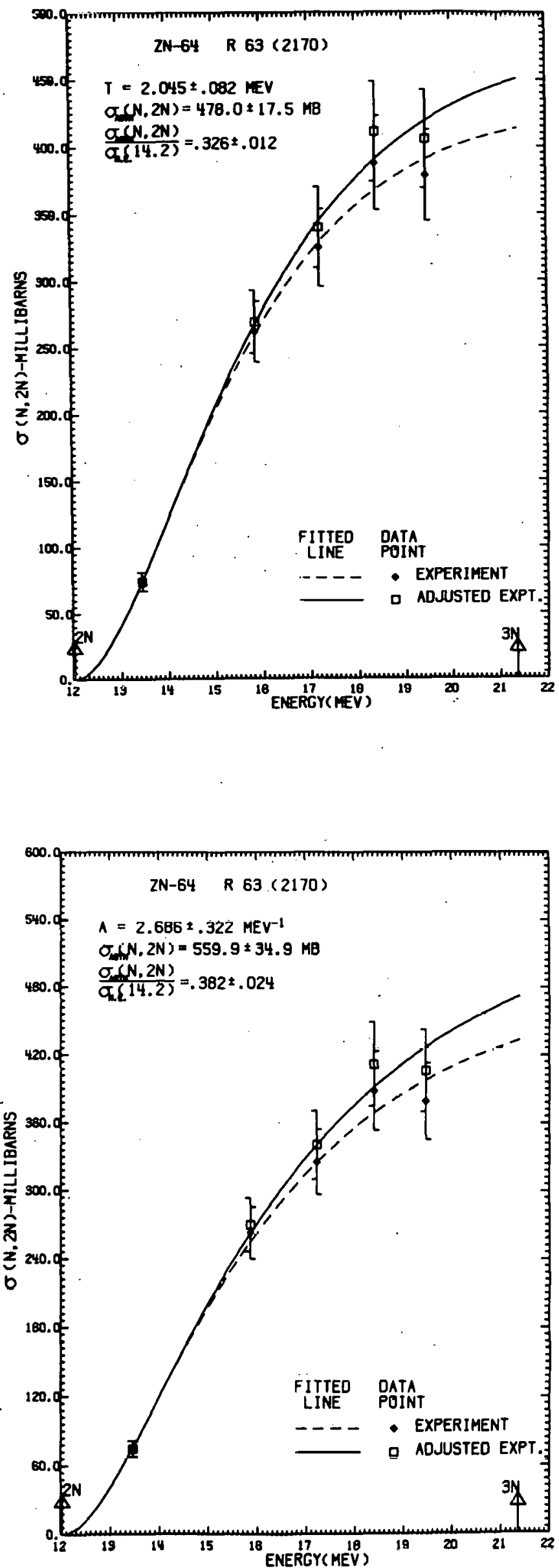


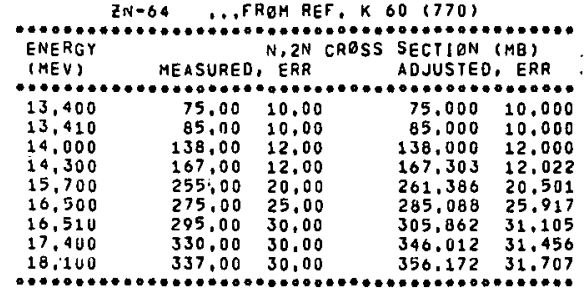

\section{FITTED PARAMETERS}

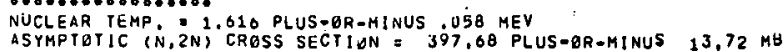

RELATED DATA

NON-ELASIIC CROSS SECTION AT 14,2 MEV $=1467,41 \mathrm{MB}$

$(N, 2 N)$ THRESHOLD $=12,04 \mathrm{MEV}$

$(N, 3 N)$ THRESHQLD $=21,36 \mathrm{MEV}$

THIS ISOTOPE HAS 34 NEUTRONS, 30 PROTOHS, (MASS 64 )

NEUTRONI EXCESS PARAMETER $=.06250$

RATIO OF ASYMPTETIC (N,2N) TO 14.2 MEV NEN-ELASTIC

TESORTINI a $9.42 \pi$
ERRER
.338

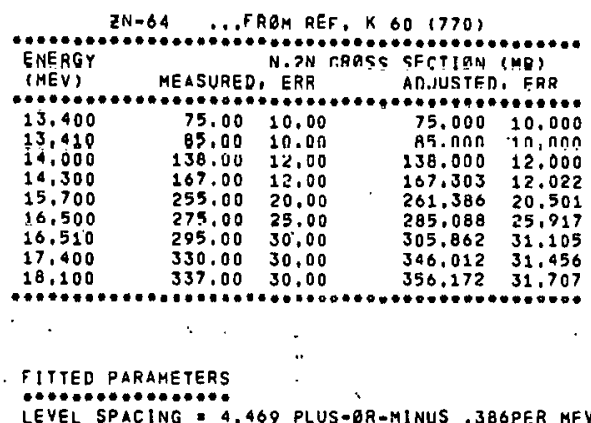

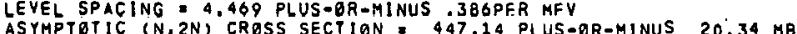

RELATED DATA

NON-ELASTIC CROSS SECTION AT 14.2 MEV $=1467.41 \mathrm{MB}$

$(N, 2 N)$ THRESHELD $=12.04$ MEV

a $21.36 \mathrm{MEV}$

THIS ISOTEPE HAS 34 NEUTRENS, 30 PROTONS, (MASS : 64)

NEUTRQN EXCESS PARAMETER ¿ .06250

RATIO OF ASYMPTOTIC (N,2N) TO 14,2 MEV NON-ELASTIC

N/SPACING $=7.608 \quad$ A/SPACING $=14.321$
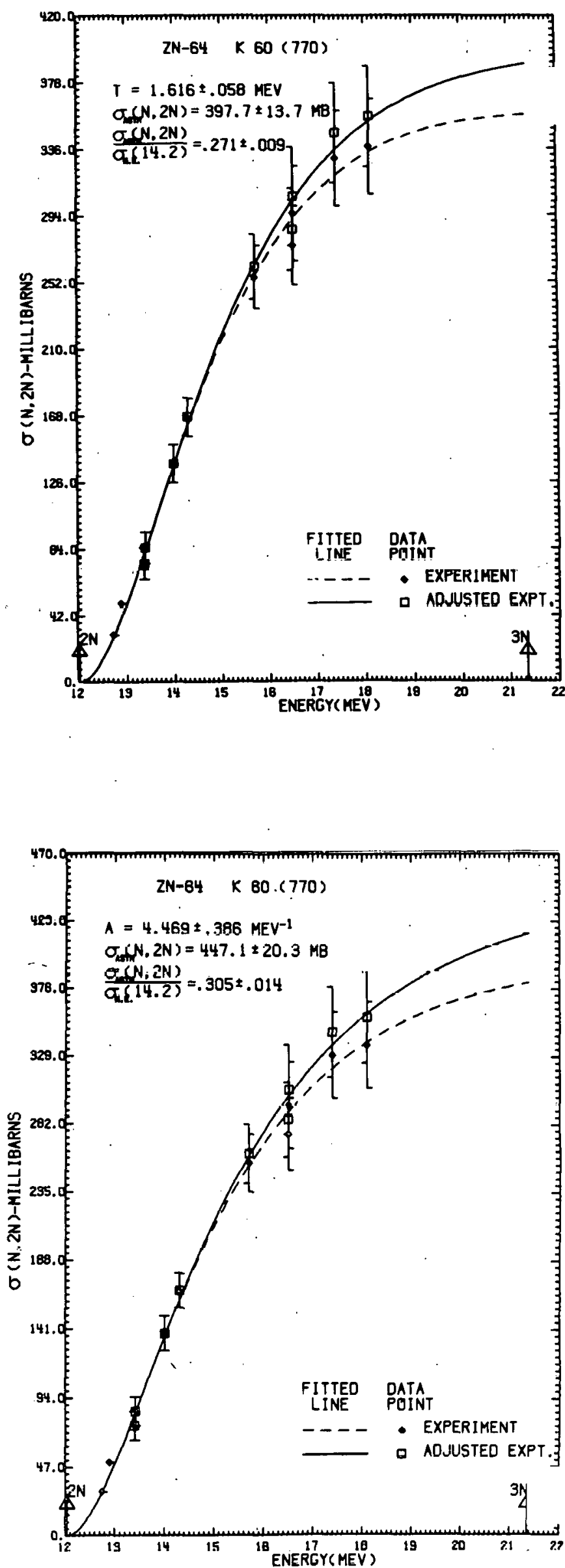


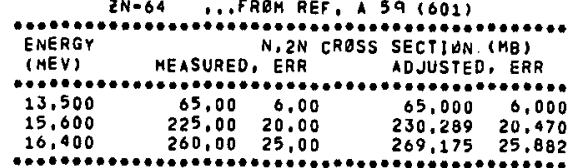

FITTED PARAMETERS

NUCLEAB TEMP.

ASYMPIUTIC (N, $2 N)$ CRESS SECTION $=483,89$ PLUS-OR-NINUS 48,32 MB

RELATED DITA

NEN-ELASTIC CRESS SECTION AT 14,2 MEV = $1467.41 \mathrm{HB}$

$(N, 2 N)$ THKESHALD $=12,04$ MEV
(N,JN) IHRESHQLD $=21,36$ MEV

THIS ISOTEPE. MAS 34.NEUTRONS, 30 PRÉTONS, (MASS = 64)

WEUTRON EXCESS PARAMETEK $=.06250$

RATIO OF ASYMPTOTIC (N,2N) TB 14.2 MEV NEN-ELASTIC .3598 PLUS $-6 R^{-M I N U S}, 0350$

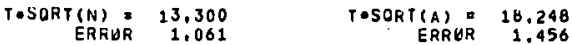

ZN-64 .. FROM REF, A $50(601)$

\begin{tabular}{|c|c|c|c|c|}
\hline $\begin{array}{l}\text { ENERGY } \\
\text { (MEV) } \\
\text { (ME..... }\end{array}$ & & $\begin{array}{l}N, 2 N \\
\text { ERR } \\
B . . .\end{array}$ & $\begin{array}{l}\text { CROSS SECTIUN } \\
\text { ADJUSTE }\end{array}$ & $\begin{array}{l}\text { (MB) } \\
\text { OERR } \\
A B \text { B }\end{array}$ \\
\hline $\begin{array}{l}13,500 \\
15,600 \\
16,400\end{array}$ & $\begin{array}{r}65.00 \\
225.00 \\
260.00\end{array}$ & $\begin{array}{r}6.00 \\
20.00 \\
25.00\end{array}$ & $\begin{array}{r}65.000 \\
230.289 \\
209.175\end{array}$ & $\begin{array}{r}6.000 \\
20.470 \\
25,882\end{array}$ \\
\hline
\end{tabular}

FITIED PARAHETERS

LEVEL SPACING 1.790 PLUS-BR-MINUS .434PER MEV

ASYMPTOTIC (N, $2 N$ ) CRDSS SECTION 655,55 PLUS-OR-MINUS $110.40 \mathrm{MB}$

\section{RELATEO dATA}

WON-ELASTIC CRESS SECTION AT 14.2 MEV = 1467.41 ME

$(N, 2 N)$ THRESHOLD: $12.04 \mathrm{MEV}$

THIS ISOTOPE HAS 34 NEUTRONS, JO PAETONS, (MASS a 64)

NEUTRON EXTESS PARAMETER = .06230

RATIO OF ASYMPTEPIC (N, 2N) IO 14.2 MEV NON-ELASTIC .4467 PLUS- $\triangle R-M I N U S$ T .0752

$\begin{array}{rrr}\text { N/SPACING } & 18.994 \\ \text { ERRER } & 4.605 & \text { A/SPACING } \\ & \text { ERRER } & 35.754 \\ 8.6 R 9\end{array}$
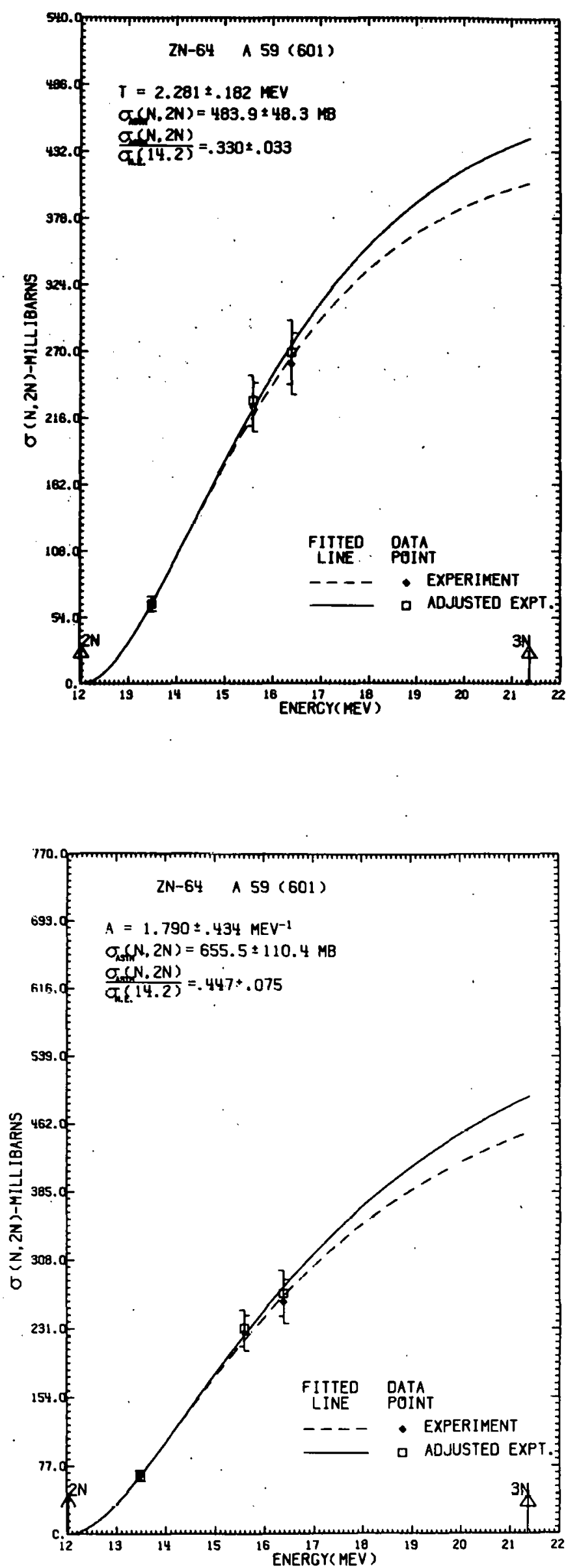


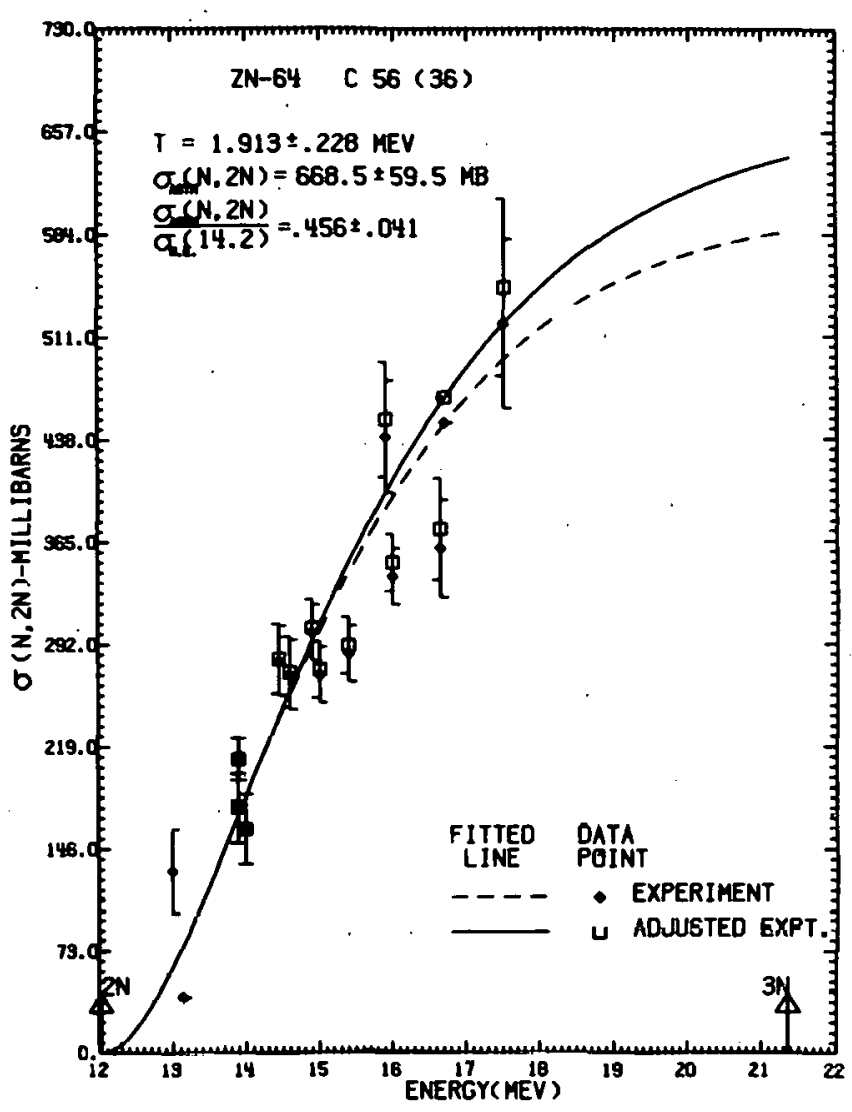

RELATED DATA

NGN-ELASTIC CRASS SECTION AT 14.2 MEV = $2487.41 \mathrm{MB}$

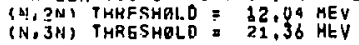

THIS ISOTOPE haS 34 NEUTRONS, 30 PRUTENS, (HASS = 64)

NEUTRON EXGEȘS PARAMETER $=.06250$

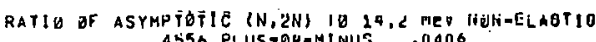

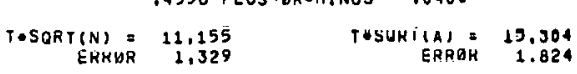

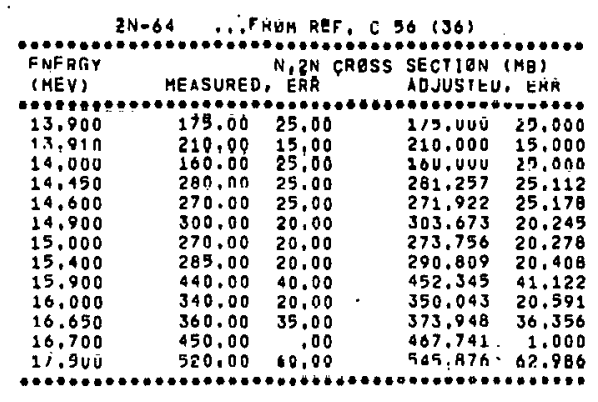

FITTED PARAMETERS

LEVEL SPACING 3.085 PLUS-6R-MINUS .872PER MEV

ASYMPTBTIC (N.2N) CRASS SECTION $=786,05$ PLUS-OR-MINUS 101,32 MB

\section{RELATED DATA}

NON-ELASTIC CRESS SECTION AT 14.2 MEV a $1467.41 \mathrm{MB}$

(N.2N) THRESHOLD : 12.04 MEV
$(N, 3 N)$ THRESHOLD : 21,36 MEV

THIS ISBTUPE HAS 34 NEUTRENS, 30 PROTBNS, (MASS - 641

NEUTRBN EXCESS PARAMETER $=.06250$

RATIO OF ASYMPTETIC (N, ZN) TO 14,2 MEV NEN-ELASTIC

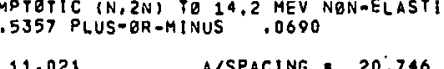

N/SPACING $=11.021 \quad$ A/SPACING 20.746 


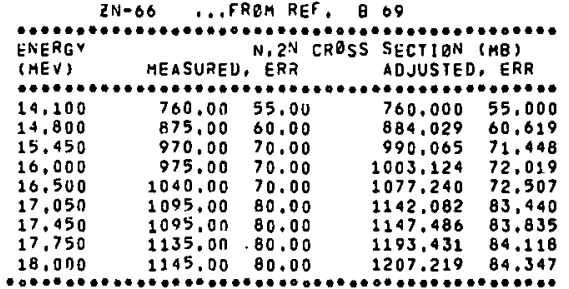

FITTED PATLALTEHS

NUCLEAR TEMP. $=1.427$ PLUS-OR-MINUS .052 MEV

ASYMPTBTIC IN, 2NI) CRASS SECTION = 1239.85 PLUS-GR-MINUS 22.70 KE

RFLATED UATA

NGN-EIASTIC CARSS SECTION AT 14,2 MEV $=1487.95 \mathrm{MB}$

(N,2N) THAESHOLD $=11.22$ MEV

THIS ISDTUPE haS 36 NEUTRONS, 30 PROTUNS, (MASS 60 )

HEUTRGH EXCESS PARAHETER = .09091

RATIO UF ASYMPTETIC (N.2N) TR 14.2 MEV NON-ELASTIC

$\begin{array}{rrr}\text { TOSOATIN) }= & 8.562 & \text { TOSORT(A) } \\ \text { ERRGR } & .312 .593 \\ \text { ERRQR } & .422\end{array}$

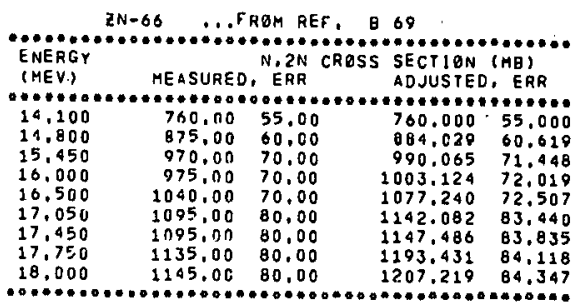

\section{FITTED PARAMETERS}

LEVEL SPACING $=6.326$ PLUS-QR-KIINUS 434 PER MEV

ASYMFTOTIC (N, 2N) CRESS SECTION 1303,11 PLUS-OR-MINUS $25,72.48$

\section{RELATEL DATA}

NEN-ELASIIC CHASS SECTIKN AT 14.2 MEV $=1467.93 \mathrm{HB}$

(11,2H.) THRESHQLO $=11,22$ MEV
(1i,3A) THKESHBLO $=19,32$ MEV

TIHE IEBTURE HAS 36 NEUTHONS, 30 PROTHNS, (HASS $=96$ )

NEUUREN EXCESS PARAMETEH = .09091

RATIB QF ASYMPTHTIC (N.?N) TG 14,? MEV NON-ELASTIC

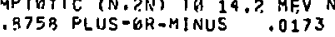

H/SPACING $=5.691$

A/SPACING 100,433
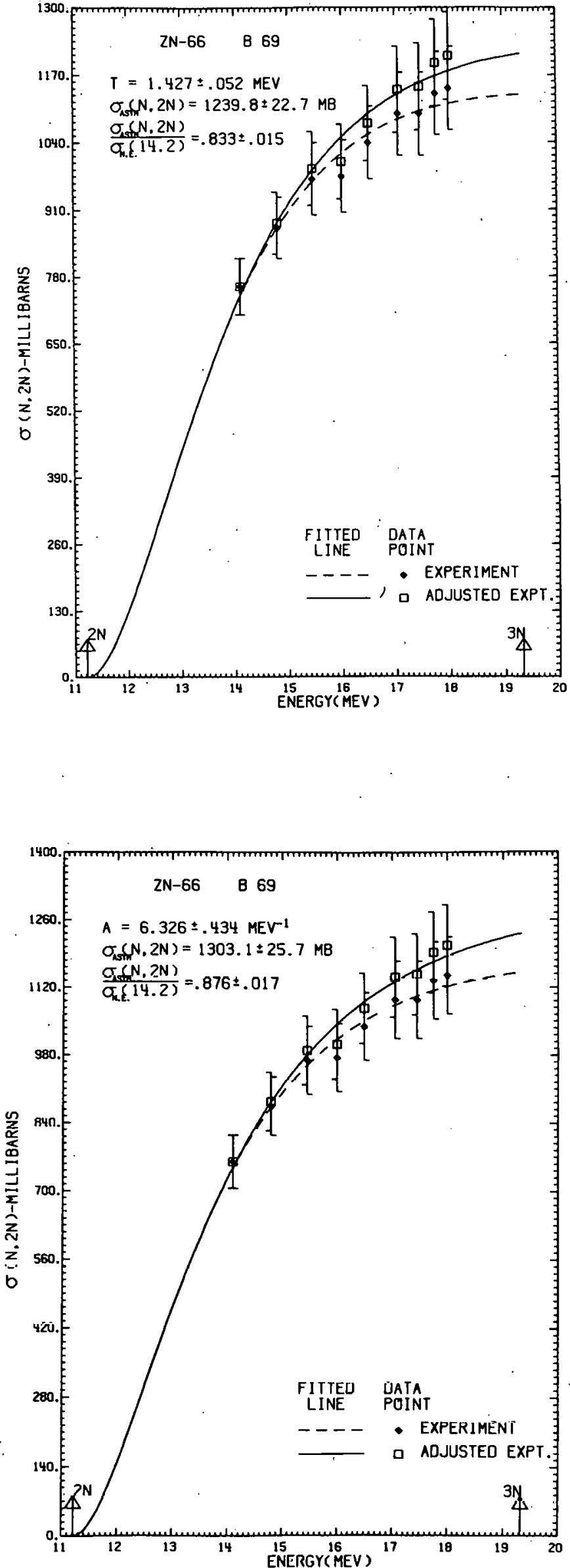


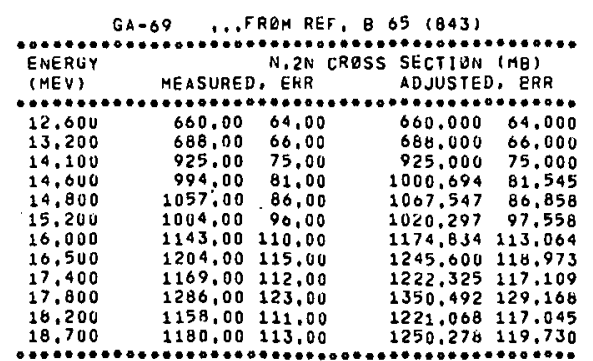

FITTEL PARAMETERS

NUCLEAR TEMP, : 1.402 PLUS-GH-MINUS .OBU MEV

ASYMPTOTIC $\{11,2 N$ ) CHOSS SECTIUN $=1284.03$ PLUS-BR-MINUS $40.48 \mathrm{MB}$

RELATED DATA

NON-ELASTIC CRESS SECTION AT 14,2 MEV $=1510.11 \mathrm{MB}$ (N, $2 N$ ) THKESHOLD $=10,46 \mathrm{MEV}$

(N,2N) THKESHBLD $=10,46$ MEV

THIS 150 TUPE HAS 30 NEUTRONS, 31 PROTONS, (MASS $=691$

NEUTRON EXCESS PARAMETER $=.10145$

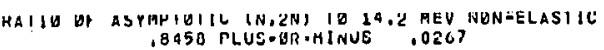

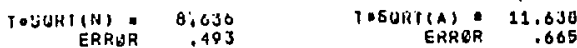

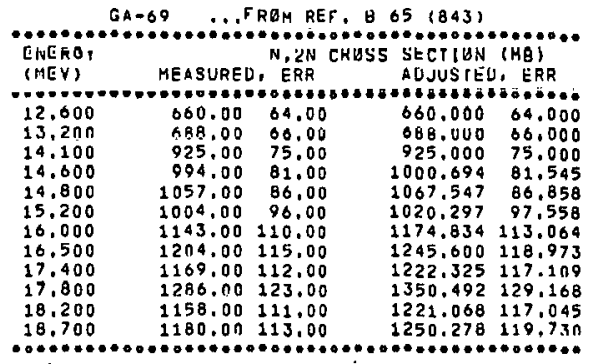

FITTED PARAMETERS

LEVEL SPACING $=6.192$ PLUS-BR-MINUS, 731 PER MEV

ASYMPTOTIC (N.2N) CROSS SECTION $=1344,45$ PLUS-OR-MINUS 48.73 MB

\section{RELATED DATA}

NON-ELASTIC CRESS SECTION AT 14.2 MEV = $1518.11 \mathrm{MB}$

$(N, 2 N)$ THRESHPLD $=10.46 \mathrm{MEV}$

(N, JN) THRESHOL $=18.86$ MEV

THIS ISOTGPE HAS 38 NEUTRONS. 31 PROTONS, IMASS $=691$

NEUTRGN EXCESS PARAMETER $=.10145$

RATIS UF ASYMPTETIC (N.ZN) TO 14,2 MEV NON-ELASTIC .8856 PLUS- $0 R-M I N U S$. .0321

$\begin{array}{rrr}\text { N/SPACING } & 6.137 \\ \text { ERFOR } & .725 & \text { A/SPACING } \\ \text { ERRER } & 11.143 \\ 1.316\end{array}$
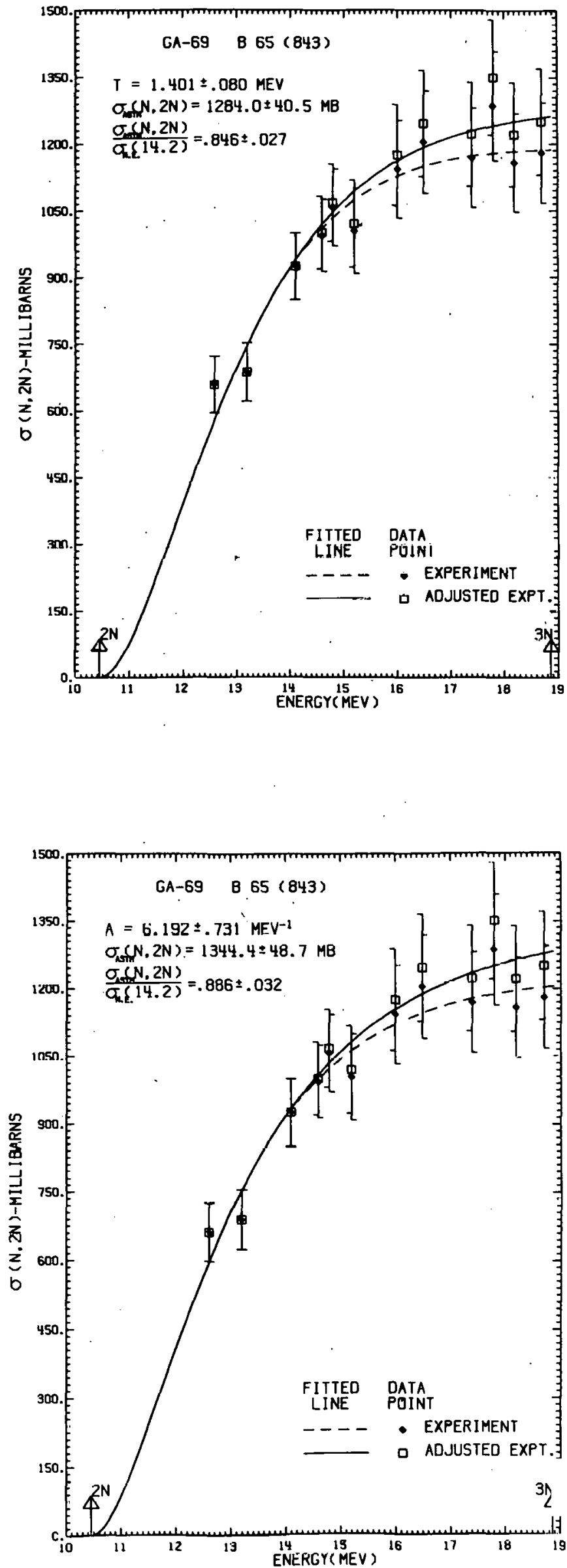


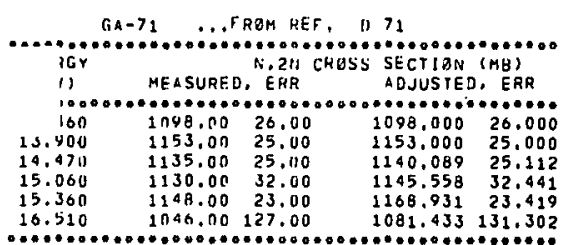

TITTEU PARAMETERS

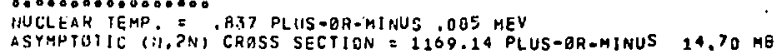

RELATËD GATA

NON-ELASTIC CLOSS SECTIFIN AT 14.2 MEV $=1537.80 \mathrm{MB}$

$(N, 2 N)$ THRESTFI.U $=9.44$ MEV
$(N, 3 N)$ THKESHOLID $=17.20 \mathrm{MEV}$

THIS ISTTRE HAS 40 NEUTRONS, 31 PRBTONS, SHASS: 31

HEUTRGN EXCESS PARAMETEK $=.12676$

RATIR GH ASYPTETIC (N,SN) TU 14.2 MEV NEN-ELASTIC

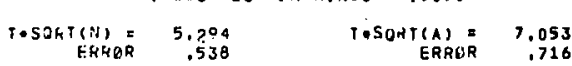

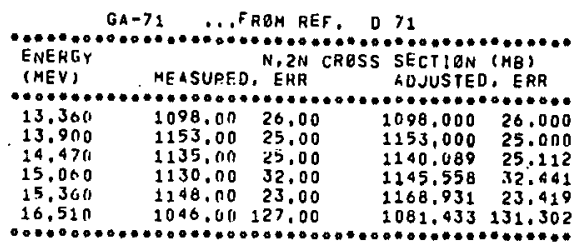

\section{FITTHII PAHAMETERS}

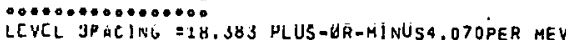

ASYMPTITIC (N,ZN) CKOSS SECTIEH = 1175.19 PLUS-OR-MINUS $16.22 \mathrm{MQ}$

NELATLO DATA

NUN-ELASTIC CROSS SECTION AT 14.2 MEV $=1537,80 \mathrm{MB}$

(N.2H) THFESH:SLI) 9 9.44 HEV

(iN.3N) TMRESHOLD $=17,20$ MEV

THIS ISUTIPE HAS 40 NEUTRONS, 31 PRDTGHS, (MASS $=.71$ )

HEUTAIN EXCESS PARAMETER $=.12676$ RATIS OF ASYMPTUTIC (NI,2N) TH 24.2 MEV NON-ELASTIC
.764? PLUS-GR-MINUS , O11B

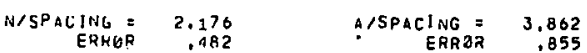
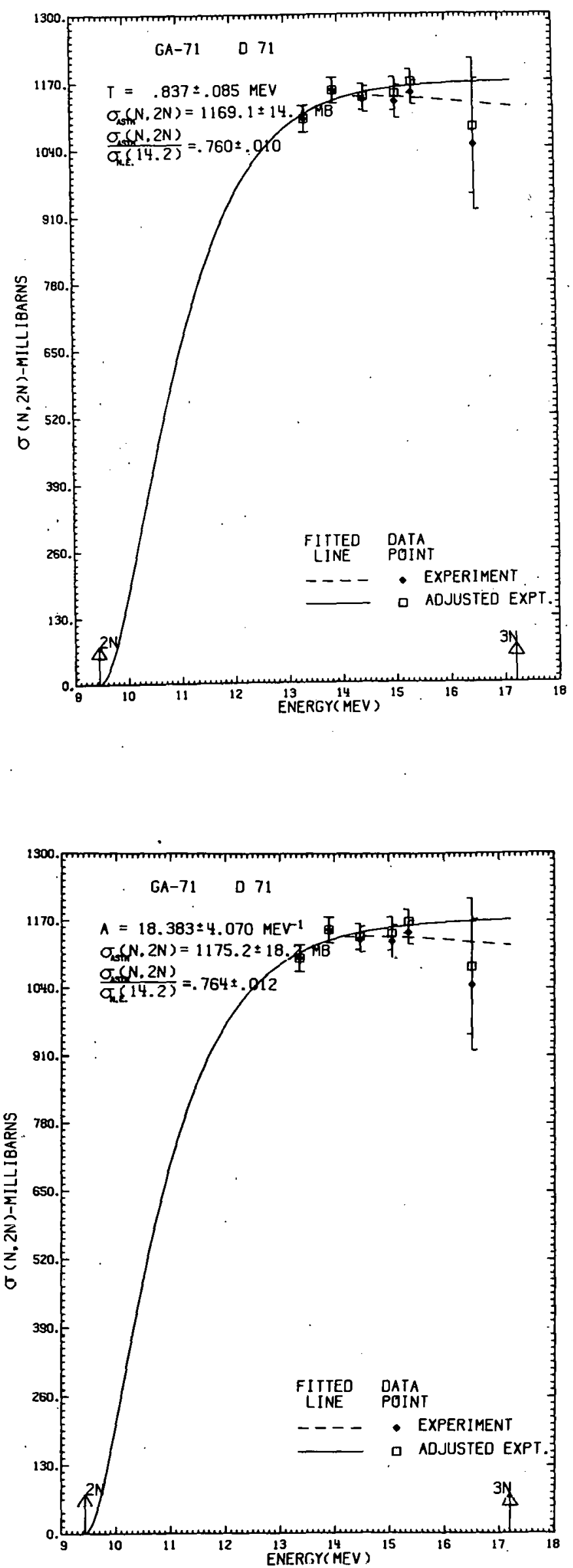


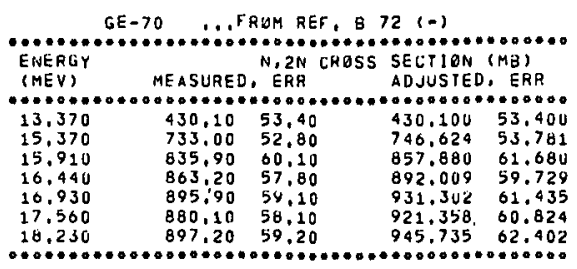

\section{FIITED PARAMETERS}

NUCLEAR TEHP. $=1.161$ PLUS-GH-MINUS .071 MEV

ASYMPTOTIC $(\dot{N}, 2 N)$ CROSS SECTION $=965,41$ PLUS-OR-MINUS $23.04 \mathrm{HB}$

RELATED DATA

NUN-ELASTIC CRRSS SECTION AT $14.2 \mathrm{MEV}=1527.99 \mathrm{MB}$

ND, LN THHESHULD $=11.70$ MEV

$(N, 2 N)$ THHESHULD $=11.70 \mathrm{MEV}$
$(N, 3 N)$ THKESHOLD $=20.10 \mathrm{MEV}$

THIS ISOTOPE HAS 38 NEUTHUNS, 32 PRDTVNS, (NASS = 70)

NEUTRUN EXCESS PARAMETER $=.00571$

RATID OF ASYMPTUTIC (N,2N) TU 14,2 MEV NBN-ELASTIC

.6318 PLUS-2R-MINUS ,
.

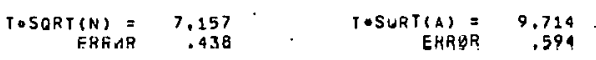

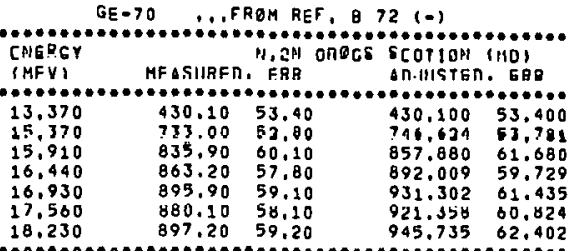

\section{FITTED PARAMETERS}

LEVE SPACING 20.695 PLUS-OR-MINUS1.131PER MEV

ASYMPTOTIC (N,2N) CROSS SECTION $=1000.61$ PLUS-OR-MINUS $26.62 \mathrm{MB}$

HELATED DATA

NON-ELASTIC CRASS SECTIOAN AT 14,? MFV * 1527,99 MB

$(N, 2 N)$ THRESHOLU $=11,10$ MEV

(N,3N) THRESHPLD $=20,10 \mathrm{MEV}$

THIS ISOTOPE HAS 38 NEUTRONS, 32 PRQTONS, (MASS $=70$ )

NEUTRON EXCESS PARAMETER $=.08571$

RATIO DF ASYMPTOTIC (N,2N) TO 14.2 MEV NON-ELASTIC

.6549 PLUS-BR-MINUS .0174

$\begin{array}{rrr}\text { N/SPACING }= & 3.920 \quad \\ \text { ERRER } & .457\end{array} \quad \begin{array}{r}\text { A/SPACING }= \\ \text { ERROR }\end{array}$
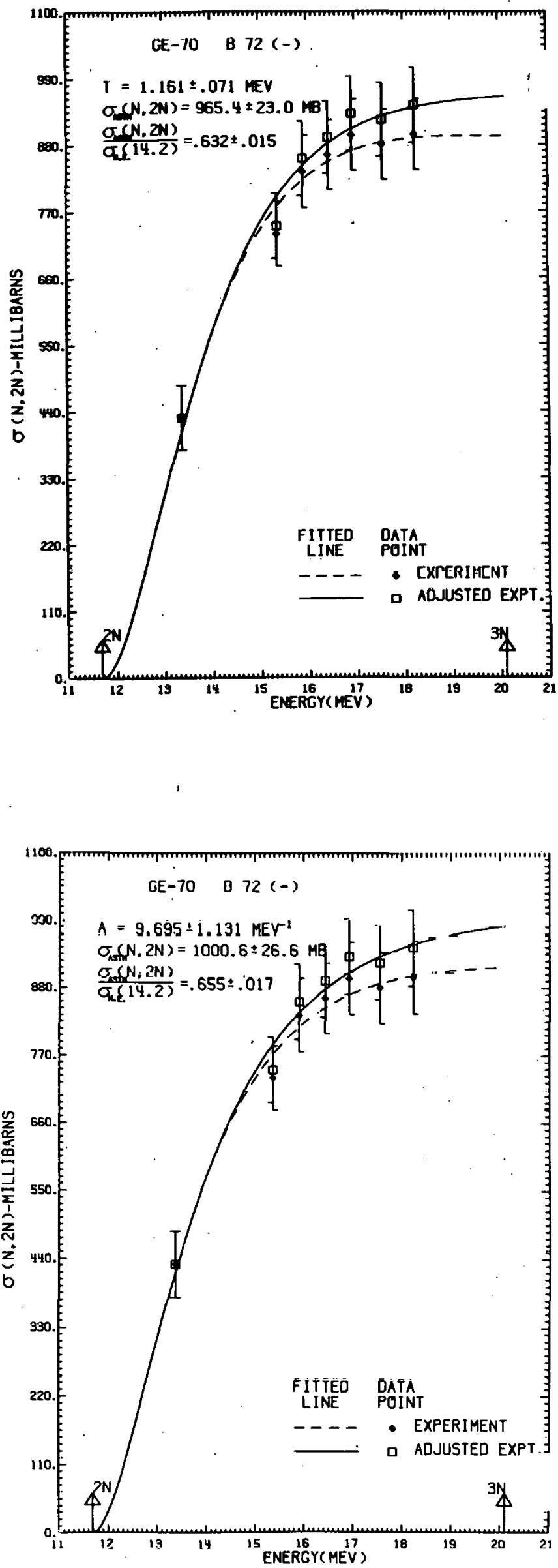


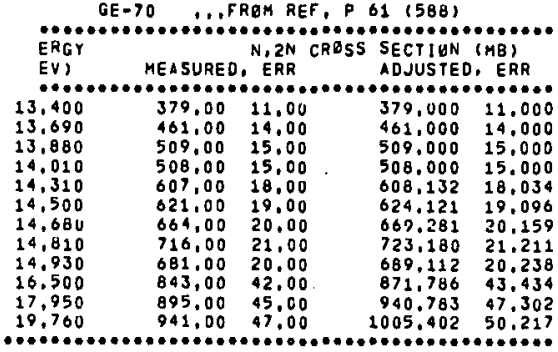

TITTED PAFAMETERS

NUCLEAR TEMP, = 1.292 PLUS•OR-HINUS, $038 \mathrm{MEV}$

ASYMPTOTIC (N, 2N) CROSS SECTION

RELATED DATA

NBN-ELASTIC CROSS SECTION AT 14,2 MEV = $1527,99 \mathrm{MB}$

NBN-ELASTIC CROSS SECTION AT 14,
(N,2N) THRESHELD $=11.70$ MEV
(N,3N) THRESHOLD $=20,10$ MEV

THIS ISOTOPE haS 38 NEUTRONS, 32 PRETONS, (MASS:70)

NEUTRON EXCESS PARAMETER $=.08572$

RATIO OF ASYMPTOTIC (N, $2 N$ ) TE 14,2 MEV NON-ELASTIC

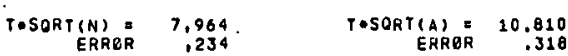

GE-70 ․FRBH REF, $P$ O1 1580

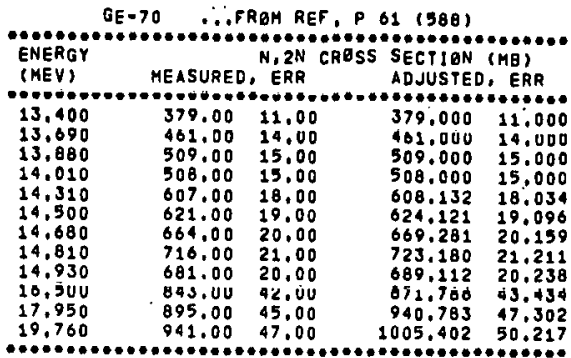

\section{FITTED PARAMETERS}

LEVEL SPACING : 9.499 PLUS-OR-MINUS ; 493 PER MEV

ASYMPTOTIC (N,2N) CROSS SECTION . 1055,25 PLUS QQR.HINUS 33, 2 MB

RELATED DATA

NON-ELASTIC CRESS SECTIÓN AT 14,2 MEV = 1527,99 KO

(N,ZN) THKESSHELO : 11,70 MEV

(N,ZN) THKËSHELIS: $11,70 \mathrm{MEV}$
$(N, 3 N)$ THKESHOLD: $20,10 \mathrm{MEV}$

IHIS ISETUPE haS 38 NEUTRONS, 32 PRETONS, (MASS 90 )

NEUTRON EXCESS PARAMETER \& .08571

RATIO OF ASYMPTOTIC (N, 2N) TO 14,2 MEV NEN-ELASTIC .0906 PLUS-OR-MINUS: .0216

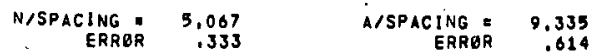
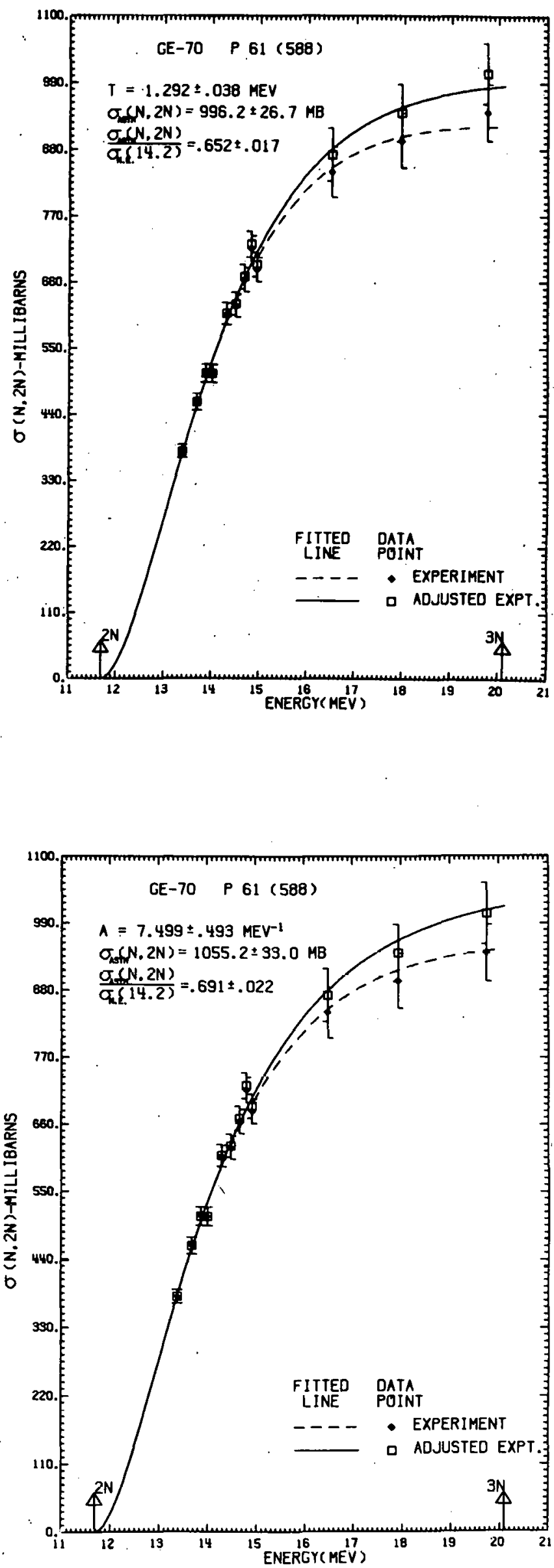


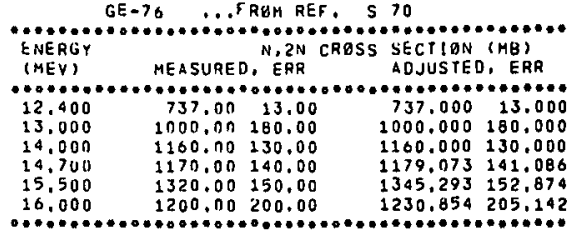

FITTED PARAMETERS

NUCLEAR TEMP, 1.735 PLUS-OR-MINUS, 102 MEV

ASYMPTOTIC $(\because, 2 N)$ CRDSS SECTION $=1521.50$ PLUS-ER-AINUS 93.38 MB

\section{RELATED DATA}

NON-ELASTIC CRASS SECTIBN AT $14.2 \mathrm{MEV}=1585.73 \mathrm{MB}$

$(N, 2 N)$ THKESHELD $=9.57$ ME

(N,SN) THRESHQLO $=16.14 \mathrm{MEV}$

THIS ISGTMPE HAS 44 NEUTRONS, 32 PHOTONS, (MASS $=76$ )

NEUTRUN EXCESS PARAMETER = .15789

RATIG OF ASYMPIOTIC (N.2N) TE 14.2 MEV NGN-ELASIIC

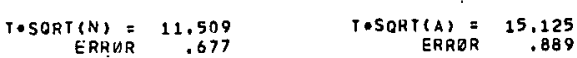

FitTé parameters

LEVEL SPACING 3, 297 PLUS-gR-MINUS, $509 P E R$ MEV

ASYMPIOIIC, (N, 2N) CROSS SECTIUH $=1722,35$ PLUS-QR-MINUS $250.00 \mathrm{MB}$

RELATED DATA

NGN-ELASTIC CRESS SECTION AT 14.2 MEV $=1585.73 \mathrm{HE}$

HBN-ELASTIC CROSS SECTION AT
(N, 2N) THRESHALD $=9,57$ MEV
(N,3N) THRESHALD $=16,14$ MEV

THIS ISUTUPE HAS 44 NEUTRENS, 32 PROTONS, (MASS: 76)

NEUTRON EXCESS PARAMETER = .15789

RATIO JF ASYMPTOTIC (N.2N) TO 14.2 MEV NEN-ELASTIC 1.0862 PLUS- $8 R-M I N U S$ .0946

$\begin{array}{rrr}\text { N/SPACING } & 13.345 \\ \text { ERRER } & 2.050\end{array} \quad$ A/SPACING $=23.051$
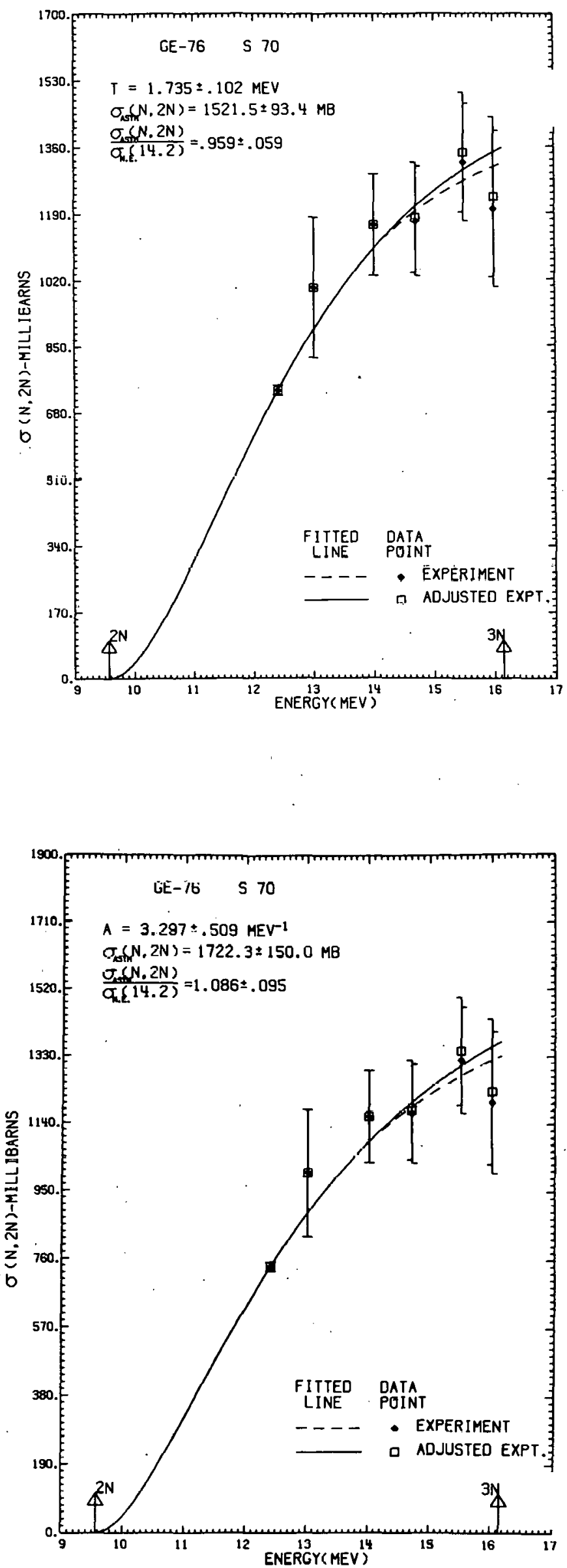
GE-76 AFREM REF, 67 (1871)

ENERGY
IMEV) MEASURED, ERR CROSS SECTIION IMB)

FITTED PARAMETERS

NUCLEAR TEMP, 2,441 PLUS-GR-MINUS .518 MEV

ASYMPTOTIC (N.2N) CROSS SECTION = 2061.09 PLUS-OR-MINUS $419.48 \mathrm{MB}$

RELATED UATA

NOM-ELASTIC ChESS SECTION AT 14,2 HEV $=1585.73 \mathrm{MB}$

$(N, 2 N)$ THKESHALD $=9,57$ MEV

THIS ISOTOPE HAS 94 NEUTRONS, 32 PROTONS, (MASS' $=761$

NEUTRMN EXCESS PARAMETER = .15789

RATIO OF ASYMPTETIC (N, 2N) TU 14.2 MEV NON-ELASTIC

$$
1.2990 \text { PLUS-OR-MINUS }, 2645
$$

T.SORTIN) $=16.192 \quad$ TOSGRTIA) $=21.280$
3.436

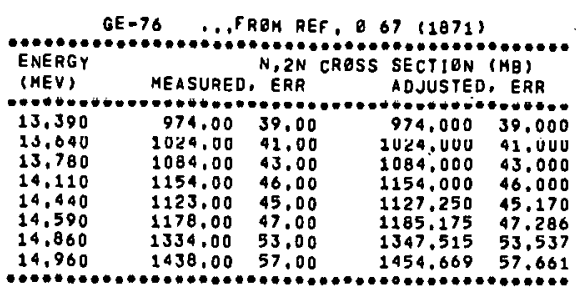

FITTED PARAMETERS

LEVEL SPACING $=1,450$ PLUS-OR-MINUS, B27PER MEV

ASYMPTOTIC (N, $2 N$, CROSS SECTION 2603.73 PLUS-BR-MINUS $864 ; 19$ MB

RELATED DATA

NAN-EI ASTIE CRESS SECTION AT 14.2 MEV $=1585.73 \mathrm{MB}$

(N,2N) THRESHQLD: 9.57 MEV

(N,3N) THRESHQLD: $16.14 \mathrm{MEV}$

THIS ISOTEPE HAS 44 NEUTRONS, 32 PROTONS, (MASS = 76 )

NEUTRON EXCESS PARAMETER $=.15789$

RATIO OF ASYMPTETIC (N,2N) TO 14.2 MEV NON-ELASTIC 1.6790 PLUS-GR-MINUS .5450

N/SPACING $=30.158 \quad$ A/SPACING $=52.090$
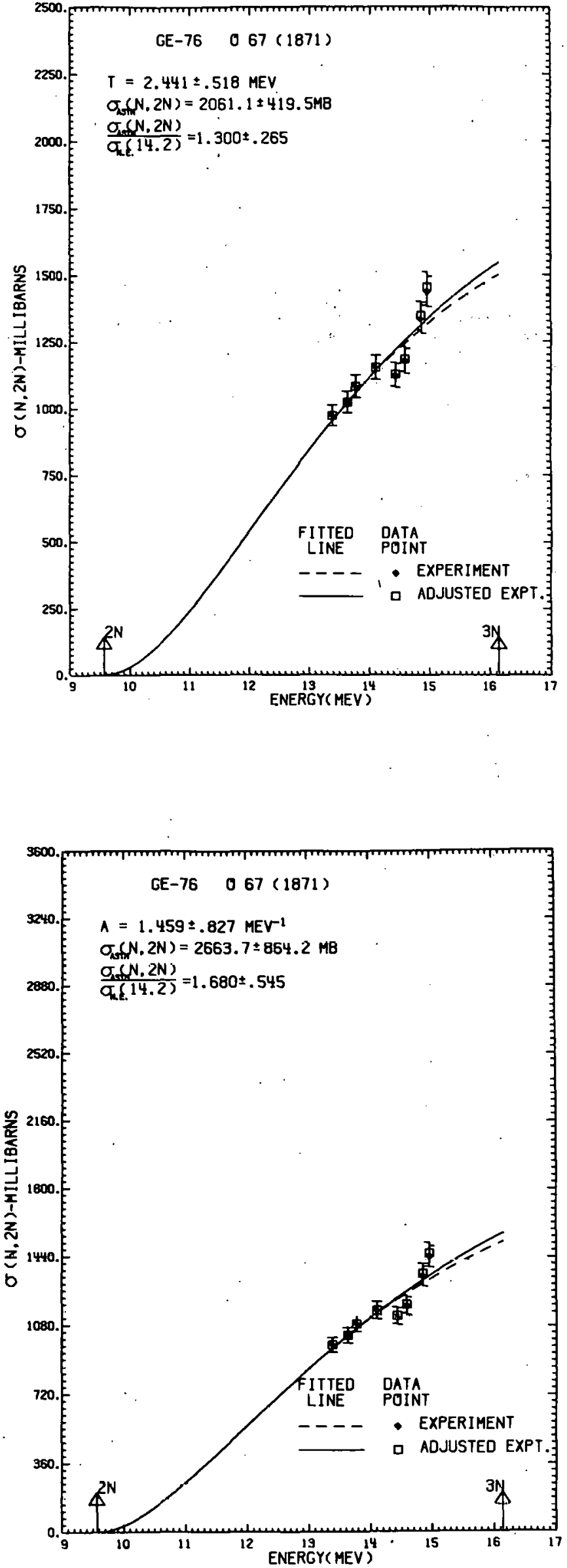


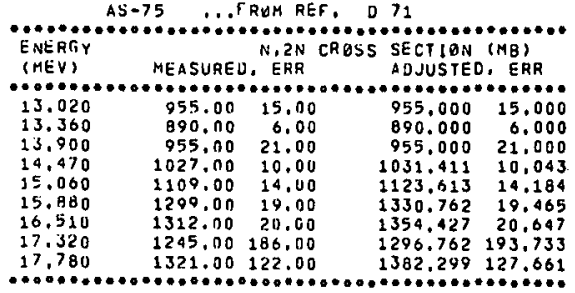

FITTED PARAMETERS

NUCLEAR TEMP, = 1.269 PLUS-UR-MINUS 138 MEY

ASYMPTOTIC (M, 2N) CHOSS SECTION $=1316,63$ PLUS-DR-MINUS $89.43 \mathrm{MB}$

RELATF.D DATA

NQH-ELASTIC CQÜSS SECTION AT 14.2 MEV $=1576,28 \mathrm{MB}$

(N.2N) THRESHELD $=10.30 \mathrm{MEV}$

(N.3N) THKKESH

THIS ISPTOPE HAS 42 NEUTRUMS, 33 PRETONS, (MASS $=75$ )

INEUUTRON EXCESS PARAMETER $=.12000$

RATID OF ASYMPTOTIC $(N, 2 N)$ TO 14.2 MEV NON-ELASTIC
. 4353 PLUS-UR-HINUS .0567

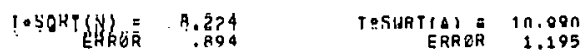
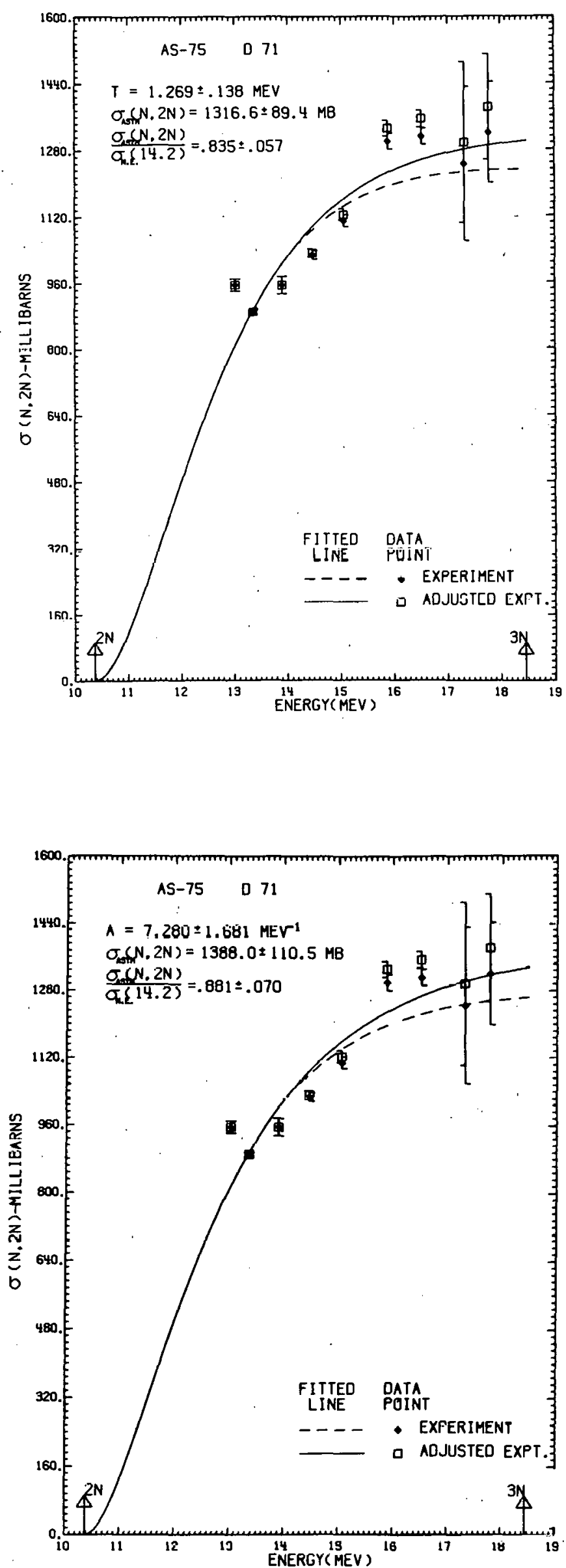

FITTED PARAMETERS

ASYMPTETIC (N, 2N) CROSS SECTION $=1387,97$ PLUS-ER-MINUS 110,53 MB
RELATED DATA

NON-ELASTIC CRESS SECTION AT $14.2 \mathrm{MEV}=1576.28 \mathrm{MB}$

$(N, 2 N)$ THRESHRLD $=10,38 \mathrm{MEV}$

$(N, 3 N)$ THRESHQLD $=18,46 \mathrm{MEV}$

THIS ISOTOPE HAS 42 NEUTRONS, 33 PRETONS; (MASS a 75)

NEUTRON EXCESS PARAMETER = .12000

RATIO OF ASYMPTOTIC (N,2N) TO 14.2 MEV NON-ELASTIC

$\begin{array}{rrrr}\text { N/SPACING } & 5.709 & \\ \text { ERRBR } & 1.332 & \text { A/SPACING } & 10.302 \\ \text { ERROR } & 2.379\end{array}$

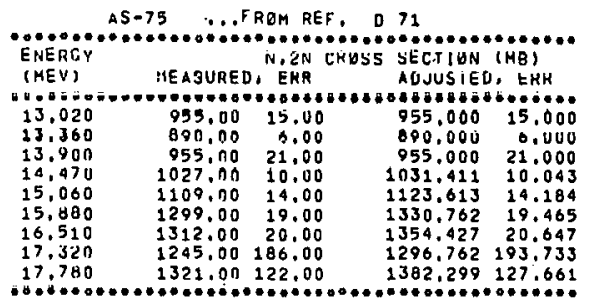




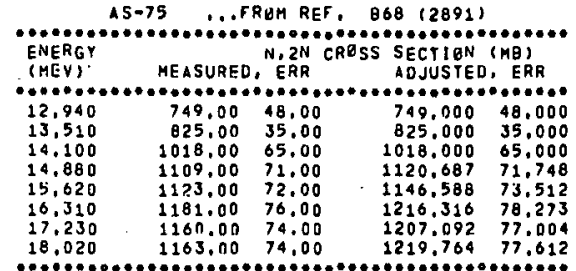

FITTED MARAMETERS

NUCLEAH TEMP. $=1.396$ PLUS-GR̈-MINUS, 003 MÉV

ASYHPTUTIC (N, $2 N$ ) CRBSS SECTION 1273.40 PLUS-OR-MINUS $34,71 \mathrm{MB}$

FELATED DATA

NON-ELASIIC CRBSS SECTIHN AT 14,2 MEV $=1576,28$ MB

$(N, 2 N)$ THAESHQLD $=10,3$ B MEV
$(N, 3 N)$ THRESHPLD $=18,46$ MEV

THIS ISUTOPE HAS 42 NEUTRONS, 33 PROTONS, (MASS = 75 )

NEUTRAM EXEESS PARAMETER $=.12000$

RATIO UF ASYMPTATIC (N,2N) IO 14,2 MEV NON-ELASTIC

$\begin{array}{rrr}\text { TOSORT(N) }= & 8.723 & \text { TOSORT(A) }= \\ \text { ERRER } & .408 & 11.657 \\ \text { ERRQR } & .546\end{array}$

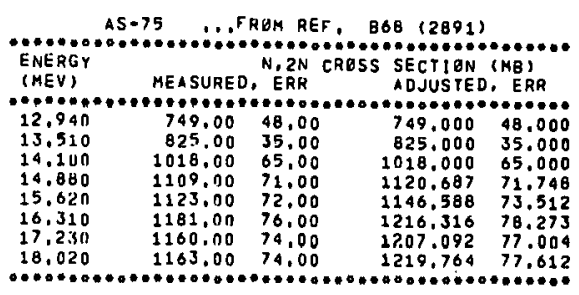

FITTED PARAMETERS

LEVEL SPACING

ASYMPTOTIC (N,2N) CROSS SECTIUN 21326.57 PLUS-OR-MINUS $47,01 . \mathrm{HB}$

\section{RELATED DATA}

NON-ELASTIC CRESS SECTIEN AT 14,2 MEV $=1576.28 \mathrm{HB}$

(N, $2 N$ ) THRESHULD $=10,38 \mathrm{MEV}$

THIS ISGTBPE HAS 42 NEUTRONS, 33 PROTANS, (MASS. 75)

NEUTRON EXCESS PARAMETER = .12000

RATIO OF ASYMPTETIC (N.2N) TO 14.2 MEV NON-ELASTIC .8416 PLUS-AR-MINUS .0296

N/SPACING $=6.232 \quad$ A/SPACING 11.129
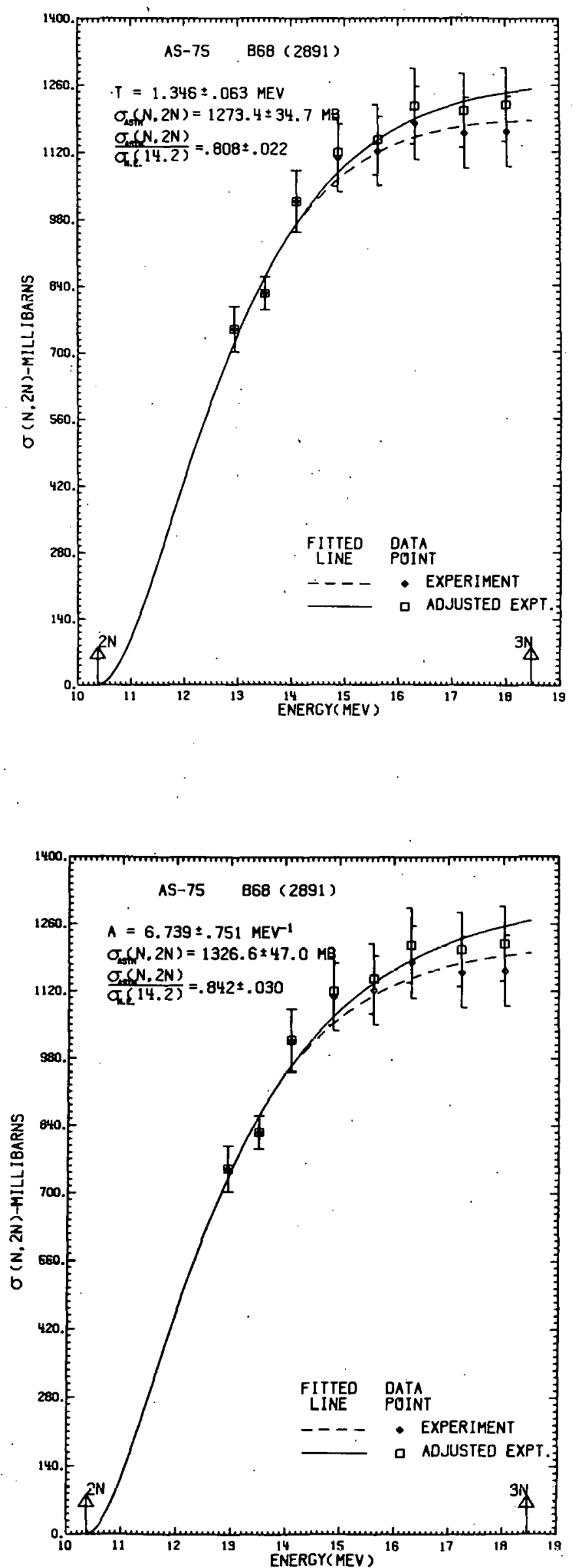
AS 75 . . FREA REF, P OL (588)

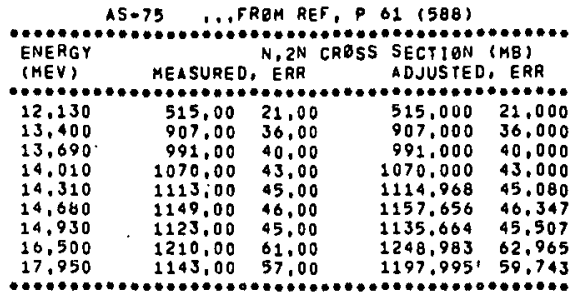

FitTEO PARAMETERS

NUCLEAR TEMP, 1.248 PLUS-OR-MINUS 052 MEV

ASYMPTETIC $(N, 2 N)$ CROSS SECTION $=1310,14$ PLUS-OR-MINUS 35,07 HB

\section{RELATED DATA}

NON-ELASTIC CRESS SECTIGN AT 14,2 MEV $=1576.28 \mathrm{MB}$

$(N, 2 N)$ THEESHOLD $=10.38 \mathrm{MEV}$

THIS ISOTEPE HAS 42 NEUTRONS; 33 PRUTONS, (MASS * 75)

NEUTHON EXCESS PARAMETER $=.12000$

RATIO OF ASYMPTOTIC (N,2N) TO 14.2 MEV NON-ELASTIC .8312 PLUS-GR-MINUS .0222

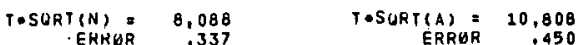

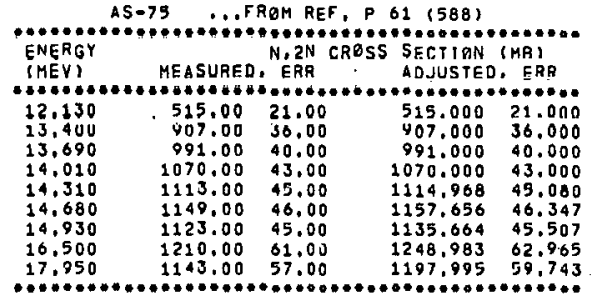

FITIED PARAMETERS

LEVEL SPACING: 7,379 PLUS-OR-MINUS, BA9PER MEV

LEY

MELATED DATA

NON-ELASTIC CRESS SECTION AT $14.2 \mathrm{MEV}=1576.28 \mathrm{MB}$

(N.2N). THRESHOLD $=10,38$ MEV

THIS ISBTOPE HAS 42 NEUTRONS, 33 PROTONS, (MASS = 75 )

NEUTRON EXCESS PARAMETER $=.12000$

AATIO OF ASYMPTOTIC (N,2N) TO 14.2 MEV NON-ELASTIC

$$
\begin{aligned}
& .8759 \text { PLUS-QR-MINUS }, 0374 \\
& .070 T \text { T }
\end{aligned}
$$

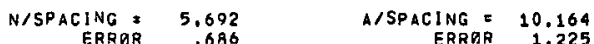
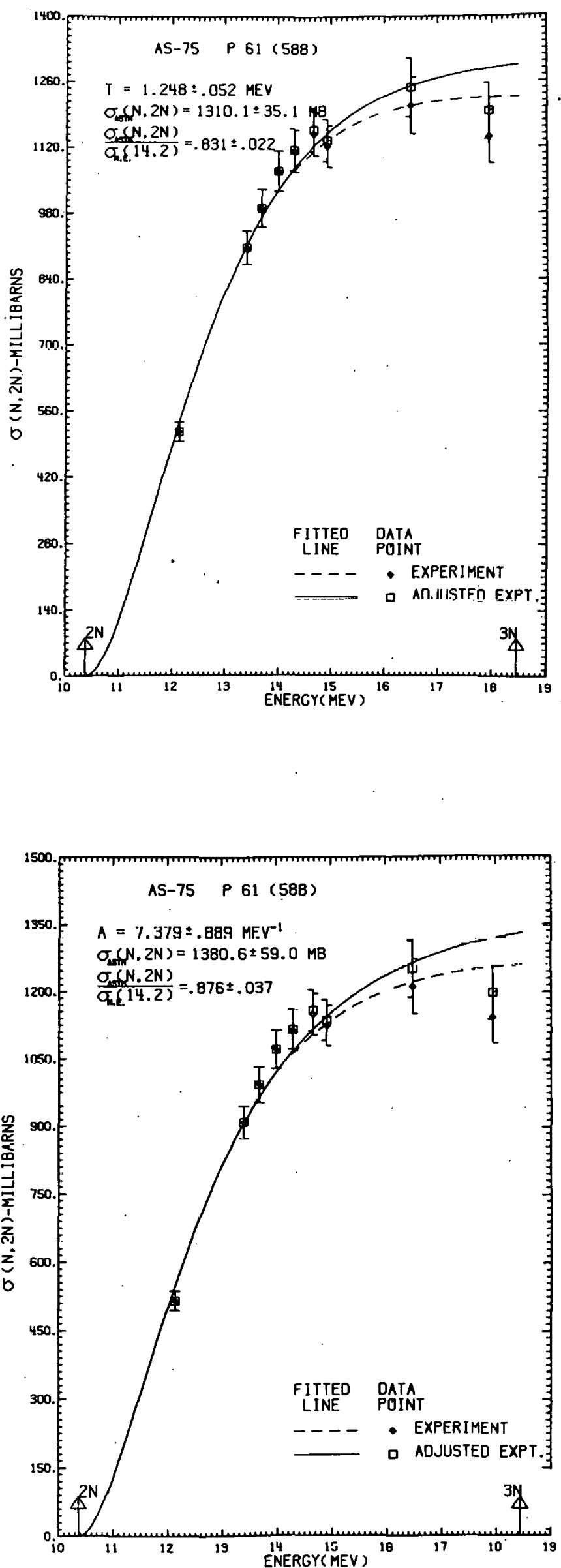


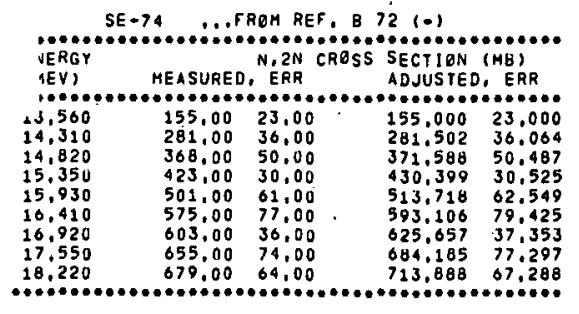

FITIED PARAMETERS

NUCLEAR TEMP. E 1 ,741 PLUS-gR-MINUS, 049 MEV

ASYMPTETIC (N, 2N) CRUSS SECTION $=830,97$ PLUS-DR-MINUS $20,34 \mathrm{MB}$

\section{RELATEO DATA}

NON-ELASTIIC CRESS SECTIBN AT 14,2 MEV $=1566.77 \mathrm{MB}$

(N.2N) THRESHQLD: 12.23 MEV

IHIS ISOTOPE HAS 40 NEUTRONS, 34 PHOTONS, (MASS $=74$ )

NEUTHUN EXCESS PARAMETER $=.08100$

RATID OF ASYMPTETIC (N,2N) TO 14.2 MEV NUN-ELASTIC

$$
\begin{aligned}
& \text { YMPTETIC (N,2N) TQ } 14.2 \text { MEV NUN-ELASTIC } \\
& .5304 \text { PLUS-ER-HINUS } .0130
\end{aligned}
$$

T.SORT(N) = $11.011 \quad T$ TORT (A) $=14.977$

SE-74 $\quad \therefore$ FROM REF, B 72 (-)

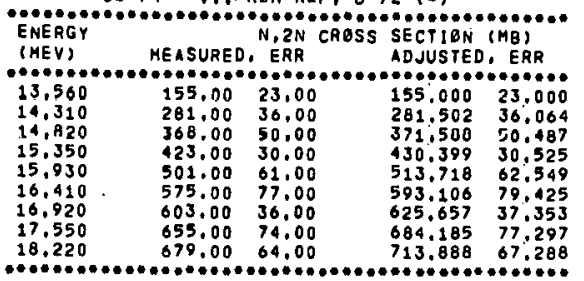

FITTED PARAMETERS

LEVEL SPACING 3,928 PLUS-OR-MINUS 213PER MEV

ASYMPTOTIC (N,2N) CROSS SECTIUN $=942.95$ PLUS-DR-MINUS $25.08 \mathrm{MB}$

\section{RELATED DATA}

NON-ELASTIC CRESS SECTION AT $14.2 \mathrm{KEV}=1566.77 \mathrm{ME}$

(N, 2N) THKESHELLO $12.23 \mathrm{MEV}$
(N,3N) THRESHELD $=21,00 \mathrm{MEV}$

THIS ISOTUPE HAS 40 NEUTRONS, 34 PRETONS, (MASS 74 )

NEUTREN EXCESS PARAMETER $=.08108$

RATIO OF ASYMPTETIC (N,2N) TO 14,2 MEV NON-ELASTIC .0018 PLISS-AR $=$ MINUS 14,2 MEV
.0160

$\begin{array}{rr}\text { N/SPACING } & 10.183 \\ \text { ERRGR } & .552 \quad \text { A/SPACING }=18.839 \\ \text { GRRQR } & 1.029\end{array}$
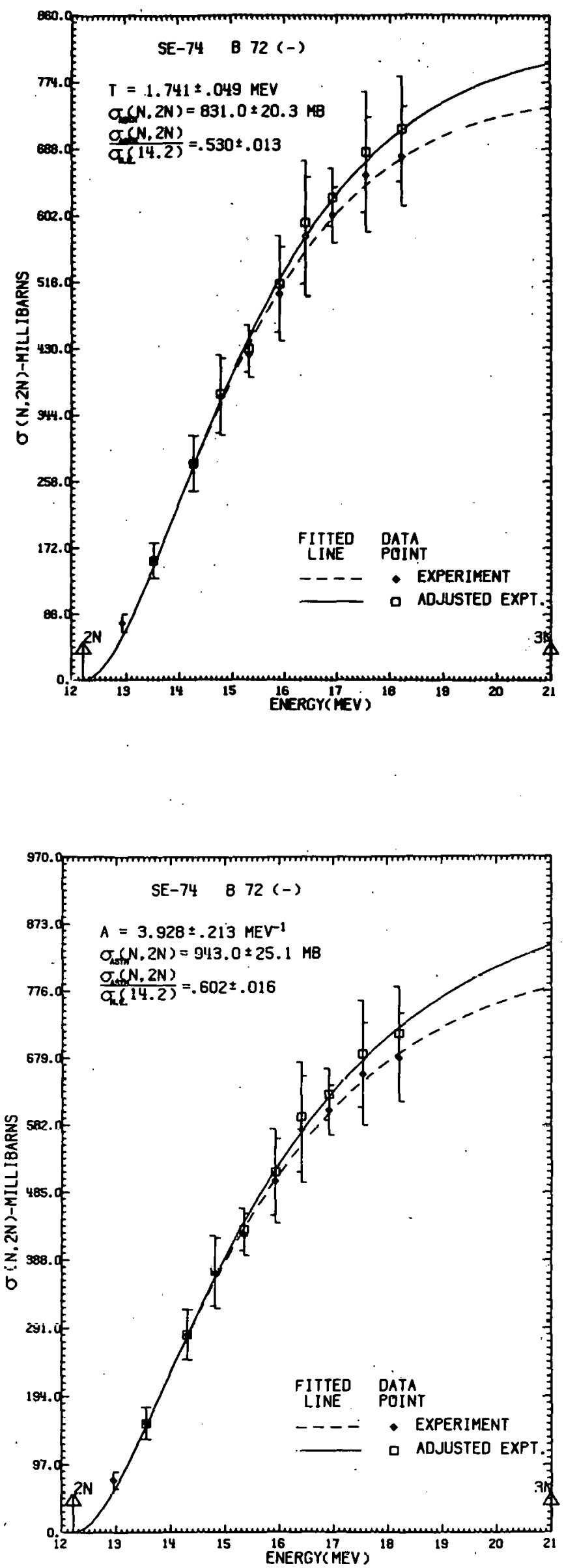


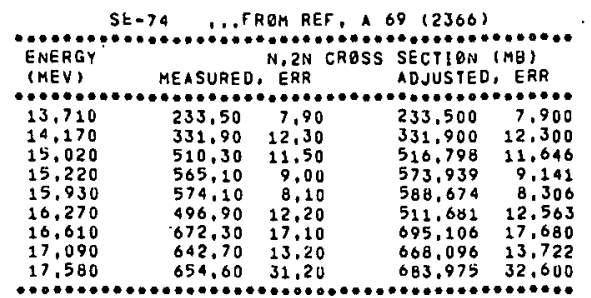

FITTED PARAMETERS

NUCLEAR IEMP. : 1.185 PLUS-OR-MINUS .153 ME

ASYMPTBTIC (N.2N) CROSS SECTIUN $=722.47$ PLUS-OR-MINUS 60.21 ME

RELATED DATA

NON-ELASTIC CRQSS SECTIBN AT 14.2 MEV = $1560.77 \mathrm{MB}$

$(N, 2 N)$ THRESHELD $=12,23$ MEV

THIS ISOTJPE HAS 40 NEUTRONS,. 34 PROTENS, (MASS $=74$ )

NEUTRQN EXCESS PARAMETER $=.00108$

RATIU OF ASYMPTOIIC (N, 2N) IO 14,2 MEV NGN-ELASTIC .4611 PLUS-BR-MINUS .0384

T.SOKT(N) $=7.495 \quad$ TOSQRTIA) $=10.194$
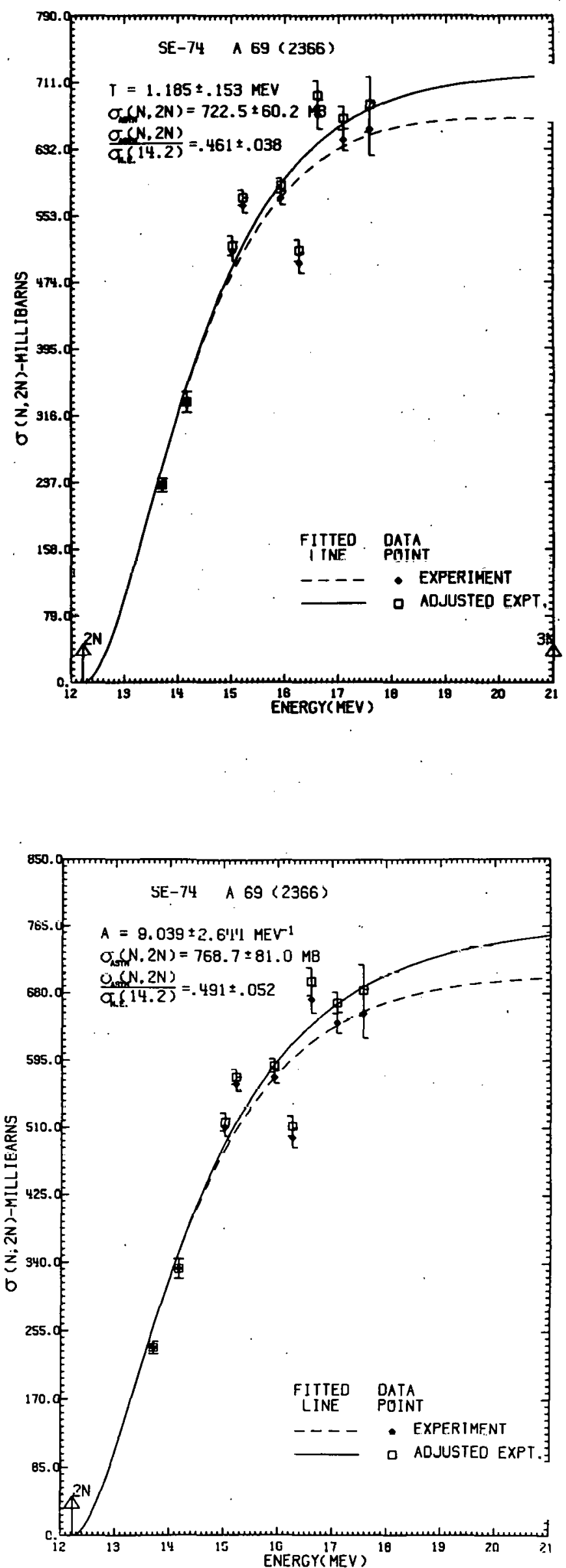

RELATED DATA

NON-ELASTIC CRASS SECTION AT 14.2 MEV $=1560.77 \mathrm{MO}$

$(N, 2 N)$ THRESHQLD $=12,23 \mathrm{MEV}$
$(N, 3 N)$ THRESHZLD $=21,00 \mathrm{MEV}$

THIS ISOTUPE HAS 40 NEUTRONS, 34 PROTONS, (MASS a 74 )

NEUTRON EXCESS PARAMETER $=.0810 \mathrm{~A}$

RATIO OF ASYMPTETIC (N,2N) TO 14.2 MEV NGNAELASTIC

$$
14906 \text { PLUS-OROMINUS } .0517
$$

N/SPACING: 4,425

$$
\begin{array}{rr}
\text { A/SPACING }= & 8.187 \\
\text { ERRER } & 2.395
\end{array}
$$




\begin{tabular}{|c|c|c|c|c|}
\hline $\begin{array}{l}\text { :RGY } \\
\text { (v) } \\
\text { (v) }\end{array}$ & MEASURED & N, 2N C & $\begin{array}{l}\text { CROSS SECTION } \\
\text { ADJUSIE }\end{array}$ & $\begin{array}{l}(M B) \\
D, E R R\end{array}$ \\
\hline $\begin{array}{l}14,100 \\
14,900 \\
16,300 \\
17,200 \\
18,000 \\
19,800\end{array}$ & $\begin{array}{l}300,00 \\
472.00 \\
540.00 \\
608.00 \\
639.00 \\
662.00\end{array}$ & $\begin{array}{l}22,00 \\
47,00 \\
45,00 \\
50,00 \\
53,00 \\
55,00\end{array}$ & $\begin{array}{l}300.000 \\
477.170 \\
556.266 \\
632.774 \\
670.443 \\
704.154\end{array}$ & $\begin{array}{l}22.000 \\
47.515 \\
46.356 \\
52.037 \\
55.008 \\
58.502\end{array}$ \\
\hline
\end{tabular}

FITIED PARAMETERS

NUCLEAR TEMP. : 1.277 PLUS-gR-MINUS, 002 MEV

ASYMPTETIC (N, 2N) CRBSS SECTIGN

RELATEO DATA

NON-ELASTIC CRBSS SECTION AT 14,2 HEV $=1500.77 \mathrm{MB}$

(N, 2N) THRESHELD $=12.23$ MEV

THIS ISOTUPE haS 40 NEUTRONS, 34 PRUTENS, (MASS = 74)

NEUTREN EXCESS PARAMETER $=.08108$

RATIO, OF ASYMPTETIC (N,2N) IS 14,2 MEV NON-ELASTIC .4514 PLUS-DR-MINUS .0146

TESORT(N): $8.076 \quad$ TESQRT(A) $=10.985$
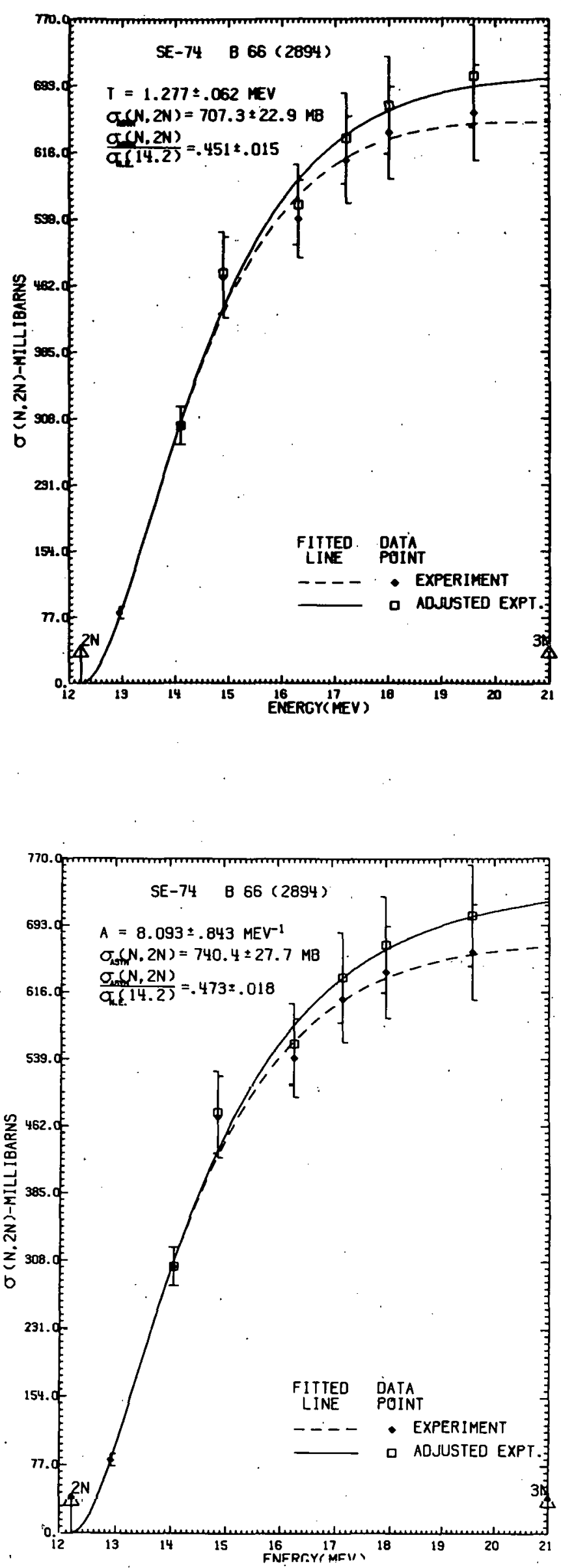

RELATED DATA

NON-ELASTIC CROSS SECTION AT 14.2 MEV $=1566.77 \mathrm{HB}$ (N,2N) THRESHULD $=12,23 \mathrm{HEV}$
$(\mathrm{N}, 3 N)$ THRESHGLD $=21,00 \mathrm{HEV}$

THIS ISETBPE HAS 40 NEUTRONS, 34 PROTONS, (MASS $: 74$ )

NEUTRON EXCESS PARAMETER $=.08108$

RATIS OF ASYMPTETIC (N.ZN) TO 14.2 MEV NON-ELASIIC .4726 PLUS-QR-MINUS . O177

N/SPACING $=4.943$ A/SPACING $=9.144$

us $27.72 \mathrm{MB}$ 


\begin{tabular}{|c|c|c|c|c|}
\hline $\begin{array}{l}\text { ENERGY } \\
\text { (MEV) }\end{array}$ & ME A SURE & $\begin{array}{r}N, 2 N \\
0, \quad E R R\end{array}$ & $\begin{array}{l}\text { SS SECTION } \\
\text { ADJUSTED }\end{array}$ & $\begin{array}{l}\text { (MO) } \\
0, \text { ERR }\end{array}$ \\
\hline $\begin{array}{l}13,160 \\
13,460 \\
13,710 \\
13,980 \\
14,240 \\
14,510 \\
14,100 \\
15,530 \\
16,250\end{array}$ & $\begin{array}{l}791.00 \\
837.00 \\
870.00 \\
912.00 \\
969.00 \\
997.00 \\
968,00 \\
993.00 \\
921.00\end{array}$ & $\begin{array}{r}85.00 \\
89.00 \\
93.00 \\
98.00 \\
104.00 \\
107.00 \\
103.00 \\
106.00 \\
98,00\end{array}$ & $\begin{array}{r}791.000 \\
837.000 \\
870.000 \\
912.000 \\
909.800 \\
1001.701 \\
976.111 \\
1011.800 \\
946.608\end{array}$ & $\begin{array}{r}85.000 \\
89.000 \\
93.000 \\
98.000 \\
104.004 \\
107.505 \\
103.803 \\
108.007 \\
100,731\end{array}$ \\
\hline
\end{tabular}

\section{BTIED PARAMETEFS}

NUCLEAK IEAP. 804 PLUS-DF-NINUS .05A MEV

ASYMPTOTIC (A. $2 N$ ) CRESS SECTION " 1 UiZ,53 PLUS-BR-MIMUS 23.00 MB

RELATEO UATA

NON-ËASTIIC CROSS SECTION AT 14.2 MEV - 1013.65 MB

(N,2N) THRESHOLD: 10.63 MEV
(N,3N) THHESHRLD: 19.22 MEV

THIS ISUTUPE HAS 44 NeUTRONS, 35 PROTGNS. (MASS 70 )

NEUTAON EXCESS PARAHETER . .11302

KATIO OF ASYMPTOTIC IN, 2N) TO 14,2 MEV NON-ELASPIC

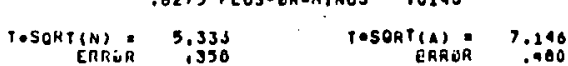

FITIEO PAHAMCTERS

LEVEL SHACIYT, $=19.404$ PLUS-OR-MINUS3.021PER MEV

ASYMPTOTIC (N,2N) CKUSS SECTION = 1024.20 PLUS-DR-MINUS 28.09 ME

RELATEU LATA

HPN-ELASTIC CRMSS SECTIUN AT 14.2 HEV $=2613.65 \mathrm{MB}$

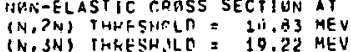

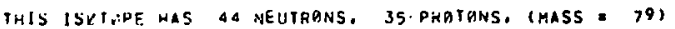

MEUTRAN F.XCESS PARAFETER $=.11392$

RATIS EF ASYMPYRTIC (NE,ZN) TU 14.2 MEV NON-ELASTIC

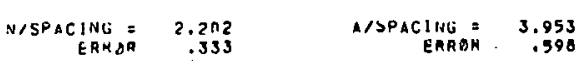
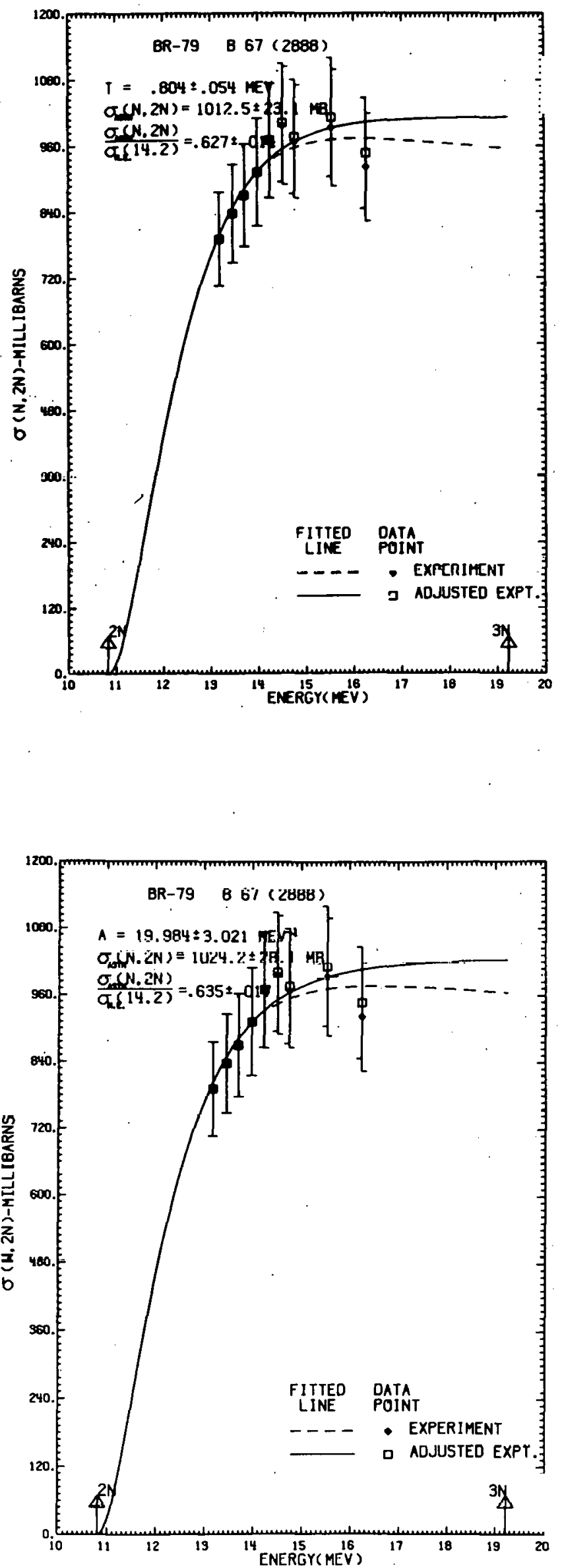


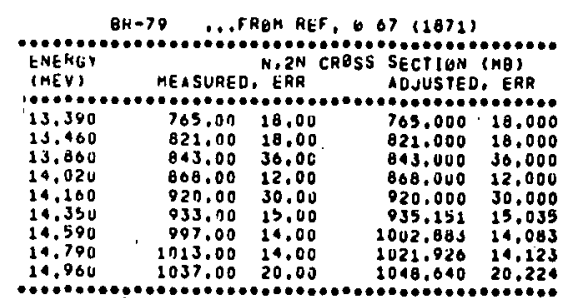

\section{FITTED PARAMETERS}

NUCLEAR TEMP. 1.105 PLUS-OH-MINUS , VET MEV

ASYRPTOTIC (N, $2 N$ ) CRUSS SECTION = 12 U2,64 PLUS-OR-MINUS 52,96 MA

RELATED IATA

NON-ELASTIC CRRSS SECTIUN AT 14,2 MEV $=1013,05$ MO

(N,2N) THRESHELD: 10.03 MEV

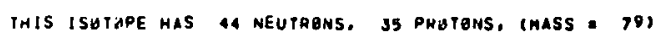

NeUTHUN EXCESS PARAMETER : .11JQ2

RATIV BF ASYMPTOTIC (N,2A) TU 24.2 MEV NON-ELASTIC

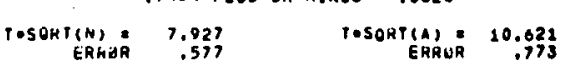

DITTEN PAhRYETERS

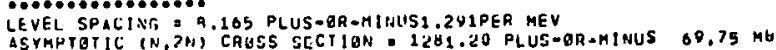

RELATED JATA

OO..........

HUN-ELASTIC CPQSS SECTIO.1 AT

(N,3N) THRESHMLD: 19.22 MEV

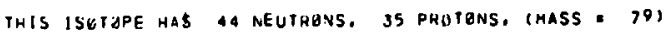

NEUTKUN EXCESS DADAMETER = .11392

Ratla of astrmptatic (n,2Ri) IU 14.2 MEV NaN-ELASTIC

7940 PLUS-DR-MINLLS ,0432

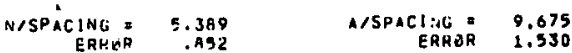
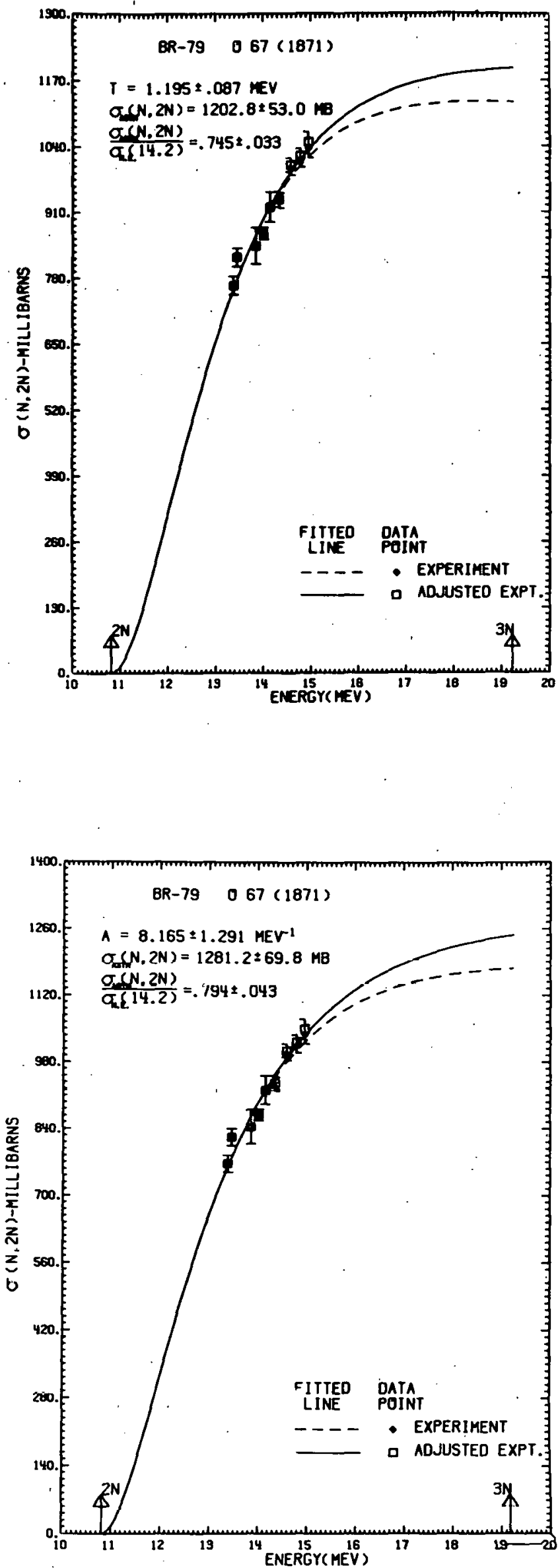


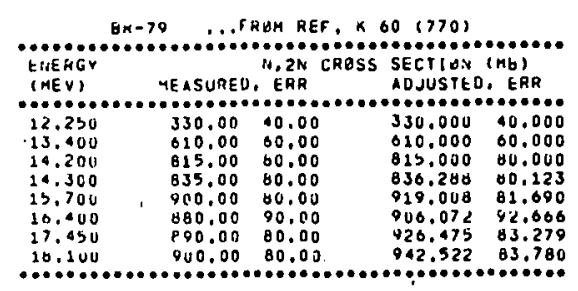

DITLJ PATAMFTEAS

OU.

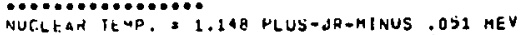

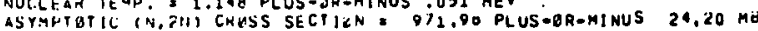

PELATED UATA

NUT.-ELASIIC CRESS SECTIGS AI 14.2 MEV $=1013.65 \mathrm{MB}$

(1..2N) THAESHITLN 10.03 MEV

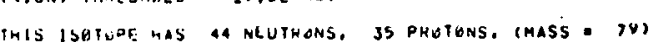

DEUIKGN EXCESS PAPAMETER : .11392

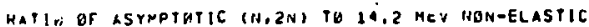

.0023 PLUS-OR-HI.NUS .01>0

TOSUKT(N) $=7.615$
GHOQE

$\begin{array}{lll}\ldots & \\ \ldots & \end{array}$

PITTÉn PAKAMETERS

LEVEL SPACIMG O. 172 PLUS-GR-MINUS1,072PER MEV

ASYMPTOTIC (N.2N) CRGSS SECTIPN $=1006.19$ PLUS-OR-MINUS $35.60 \mathrm{MB}$

RELATEU !IA TA

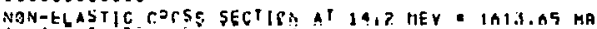

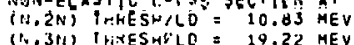

THIS ISOTLPE MAS 44 REUTHONS, 35 PRATENS, (MASS T9)

NEUTKGN FXCESS PARAMETEH $=.11392$

RATIO GF ASYMPTETIC (N,2H) TE 24,2 MEV HON-ELASTIC

.0235 PLUS-UR-MINUS .0221

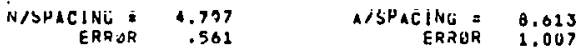
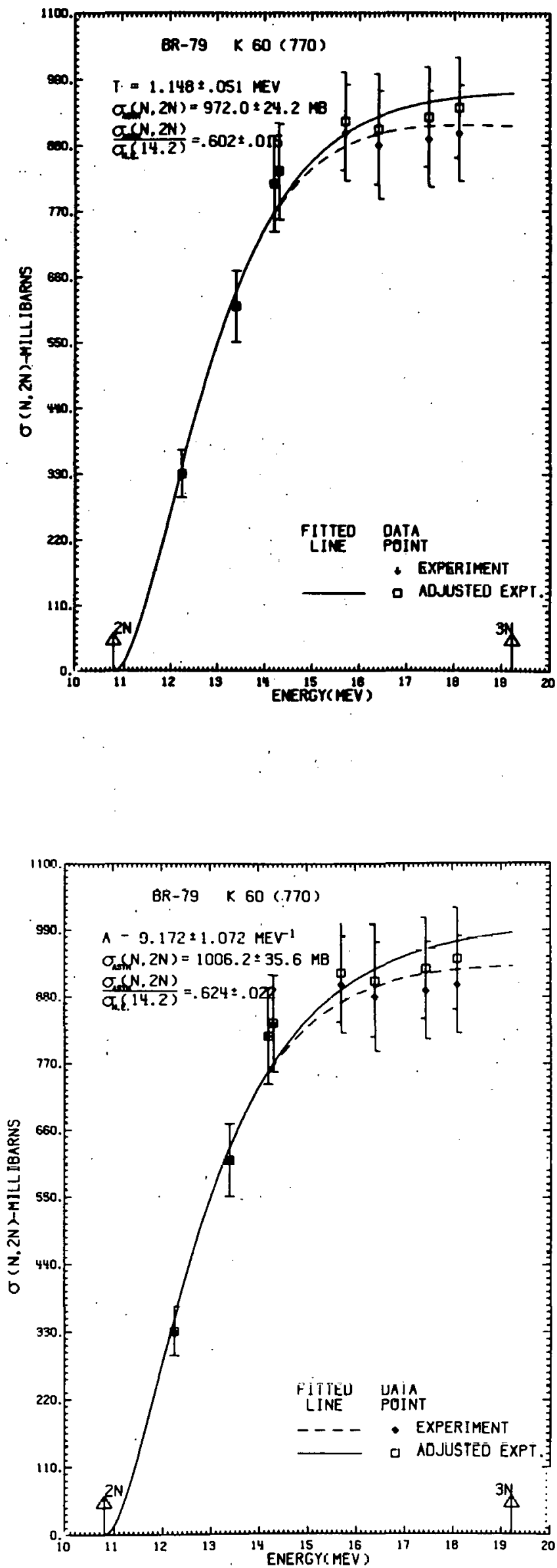


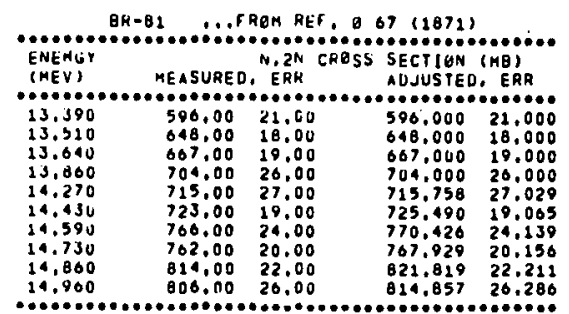

FITTEU PAFAMETERS

Nuclear iemp. 1.360 plls-ur-minus 102 meY

ASYMPTUTIL (N. 2NI CROSS SECTION = 943.41 PLUS-8R-MINUS 43.00 MO

RELATED UATA

NHAN-ELASIIC CROSS SECTION AT 14.2 MEV 1031.05 MB

(N.2N) THMESHOLD $=10.24$ ME

$(N, J N)$ !MKESMOLD $18.21 \mathrm{NE}$

IHIS ISOTCPE HAS 46 NEUTRONS. 35 PROTONS, (MASS - O1)

HEUTRON EXEESS PARAHETEA. .13580

RATIO OF ASYRPTETIC (N,2N) TE 14.2 MEV NON-ELASTIC

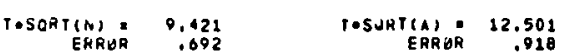

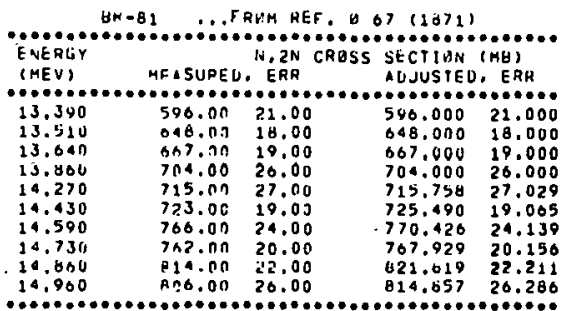

CITTEU PAHANTTCQS

LeVEi spo

ASYMPTETIC (1.,2N) CP.ESS SECTIJN $=1018.22$ PLUS-OR-MINUS O1.50 Md

RELATED UATA

NZN-ELASTIC EAPSS SECTIJN AT 14.2 MEV $=1631,95 \mathrm{MB}$

(V.2N) IMAESHALO $=10.29$ HEV

(1, 3ti) THKESHLLL $=18.27$ MEV

THIS ISOTGDE HAS 46 NEUTRUNS, JS PAOTONS, (MASS a 011

NEUTMGN EXCESS PARAMETER $=.13580$

HATIO UF ASYMPTHTIC IN. ZN) TU 14.2 MEV NON-ELASTIC .6530 PLUS-OR-hINUS .0377

N/SPACING
ERHNR
1.304 $\quad$ A/SPACING $=\begin{array}{r}13.901 \\ \text { ERRAR }\end{array}$
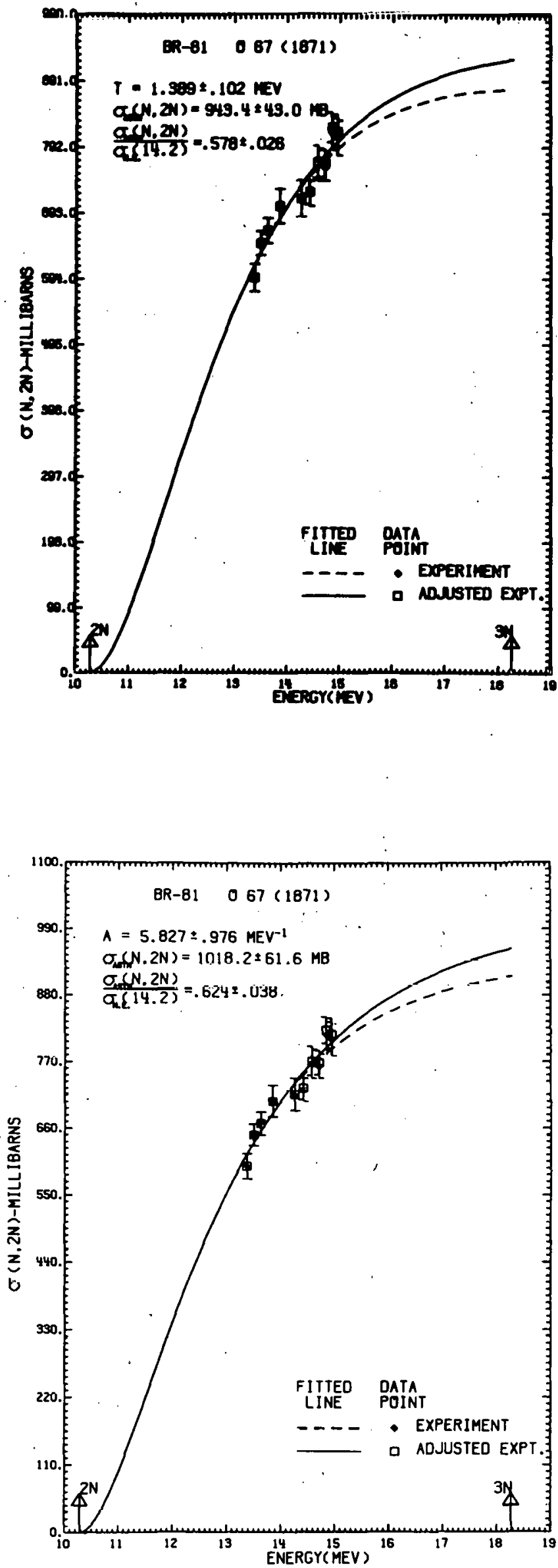


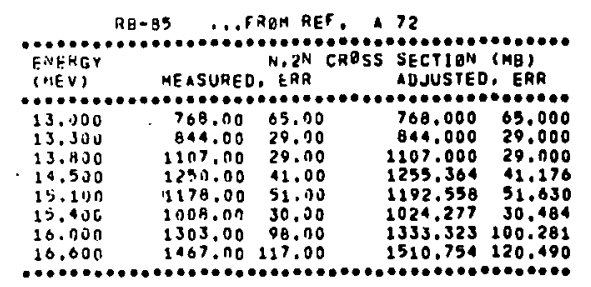

TITTEU PAHAMETERS

VUCLEA teYP.

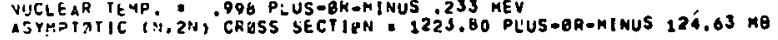

RELATHJ LATA

:ien-ELdSTIE CrESS SECTIZN AT 14.2 MEV = 1667.83 NB

(ii. 2i) InAF SHCL? $=10.61$ MEV

(H.SW) TMASH?LD: 19.3Y MEV

THIS ISUTEPE HAS AS NEUTHEIUS, J7 PAOTBNS, (MASS - 85)

NEIITAHA FXEESS PARAHEIEG * .12941

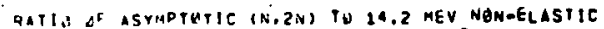

INUS .074 ?

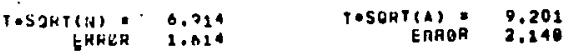

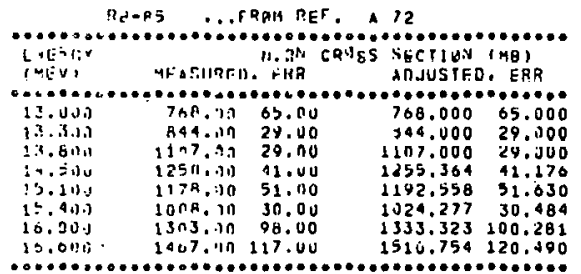

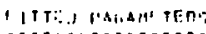

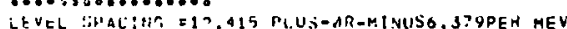

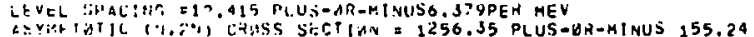

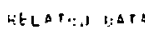

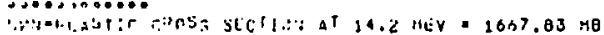

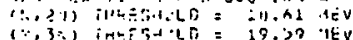

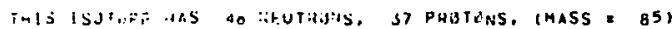

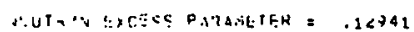

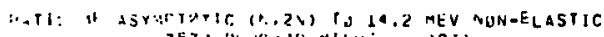

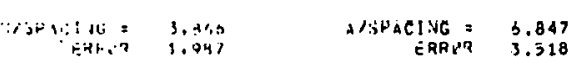
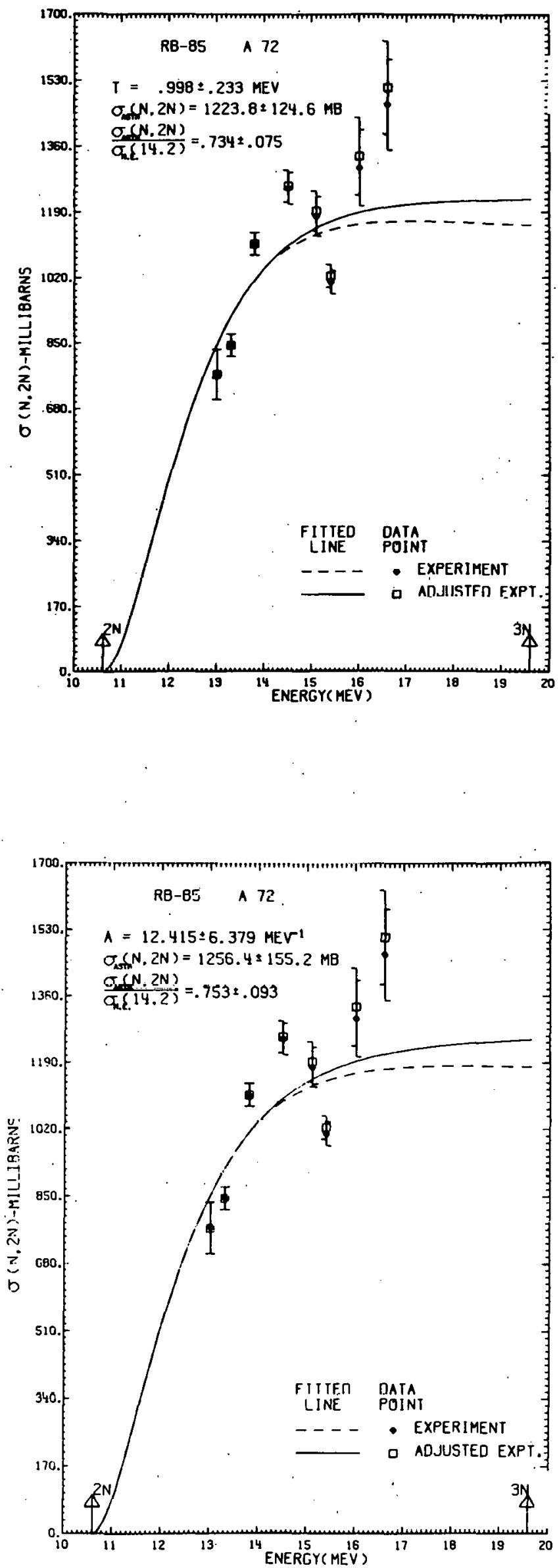
RE-a) . . FRUH REF, o 72 (-)

a

(MEV) MEASURED, ERR CAR SDJUSTED. ERA

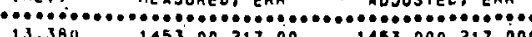

$13.380 \quad 1453.00217 .00 \quad 1453.000217 .000$

$\begin{array}{lll}14.560 & 1832.00276 .00 & 1841.204 \\ 15.620 & 1998.00720 .00 & 2034.822733 .260\end{array}$

$17,120 \quad 1731,00301,00 \quad 1790,340311,320$

FITIED PAHAMETERS

MUCLEAR TEMP. 1.102 PLUS - HR-AINUS 210 MEY

ASTMPTQTIC IN.ZN) CHOSS SECTION * 1915.40 PLUS-ER-MINUS 148.31 Mb

mELATEO VATA

NON-ELASTIC CRESS SECTION AT 14,2 AEV - 1885.43 MO

(N.2N) THHESHOLD: 10.03 MEV

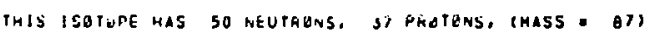

DEUTREA EXCFSS PARAMETER = .19843

HATIA OF ASYMPIOTIC $(N, 2 N)$ IU 29,2 MEV NEN-ELASTIC 1.1365 PLUS - GR $*$ MINUS .0000

$\begin{array}{rrrr}\text { TOSORT(N): } & 8.217 & \text { TOSORT(A)E } & 10.838 \\ \text { ERHEA } & 1.540 & \end{array}$

FITIEU PARAMETERS

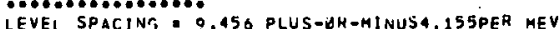

LEVEL SPACINC, O.456 PLUS-DH-MINUS4,155PER MEV

RELATED DATA.

NON-ELASTIC CPASS SECTIEN AT 14,2 KEV = $1685.43 \mathrm{MB}$

NANEELASTIC CPASS SECTIEN AT

(N,2N) TMEESHOLD: 10,03 MEV
(N, SN) THRESHALD 18,78 MEV

THIS ISUTAPE MAS SO NEUTHOVS, 37 PRETONS, (MASS - 97 )

DEUTRON EXCESS PARAMETER = .14943

FATIO OF ASYMPTBTIC (N,2N) TO 14.2 MEV NONEELASTIC 1.1572 PLUS=DR-MINUS .1120

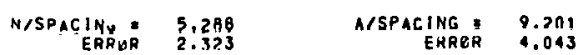
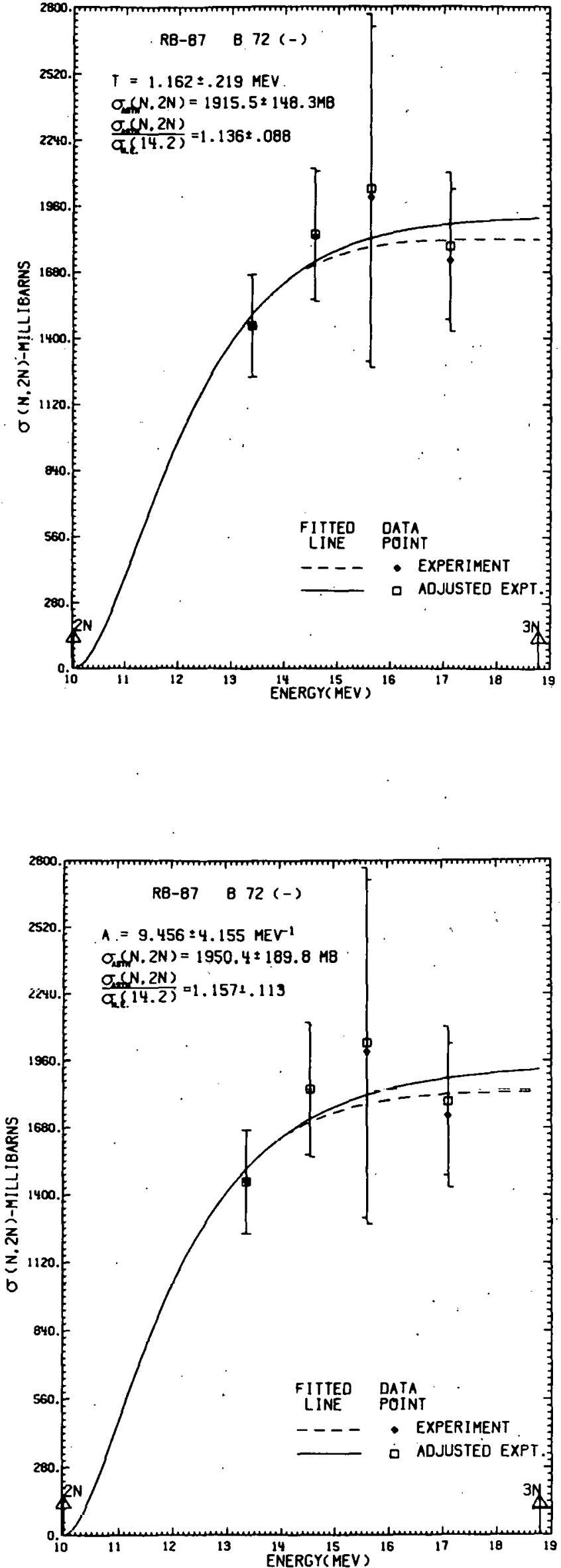


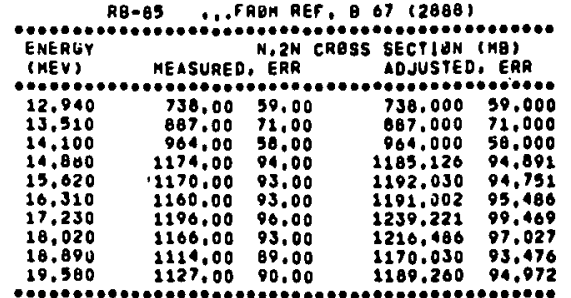

FITTEU PARAMETERS

NUCLEAR TEMP 1.142 PLUS-ZR-MINUS 040 MEV

ASTHPTOTIC (N.ZN) CRUSS SECTION - $22 j_{0}^{0.20}$ PLUS-OA-MINUS 23,52 MO

RELATED DATA

NUN-ELASIIC CRESS SECTION AT 14.2 MEV 1667.03 MB (N,2N) THRESMQLD: 10.61 MEV

IHIS ISOTOPE HAS 40 MEUTRONS, 3̦ PRGTONS, (MASS - OS)

NEUTREN EXCESS PARAMETER - .12042

RATIB OF ASYMPTOTIC (N,2N) TO 14,2 MEV NON-ELASTIC .7376 PLUS-ER-MINUS .0141

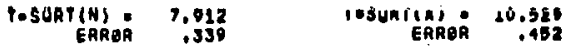

RE-BS
ENERG
(HEV)

FITTHU PAHAMETERS

ienenenenenenen

LEVEL SPACING 9.697 PLUS-OR-MINUS1,029PER MEV
ASYAPTETIC (N, 2N) CRHSS SECTION 1252.28 PLUS-OR-MINUS 30.55 MB

RELATEO DATA

NON-ELASTIC CRASS SECTION AT 14.2 KEV $=1067.83$ MB

(N,2N) TMRESYALD: 10.01 MEV

THIS ISETUFE HAS 48 NEUTRONS. 37 PROTUNS, (MASS 85 )

NEUTMON EXCESS PARAMETER - .12941

RATIB OF ASYMPTOTIC (N,2N) IO 14,2 MEY NGN-ELASTIC .7508 PLUS-OR-MINUS .0163

N/SPACING: 4.850.'. A/SPACING $=8.588$
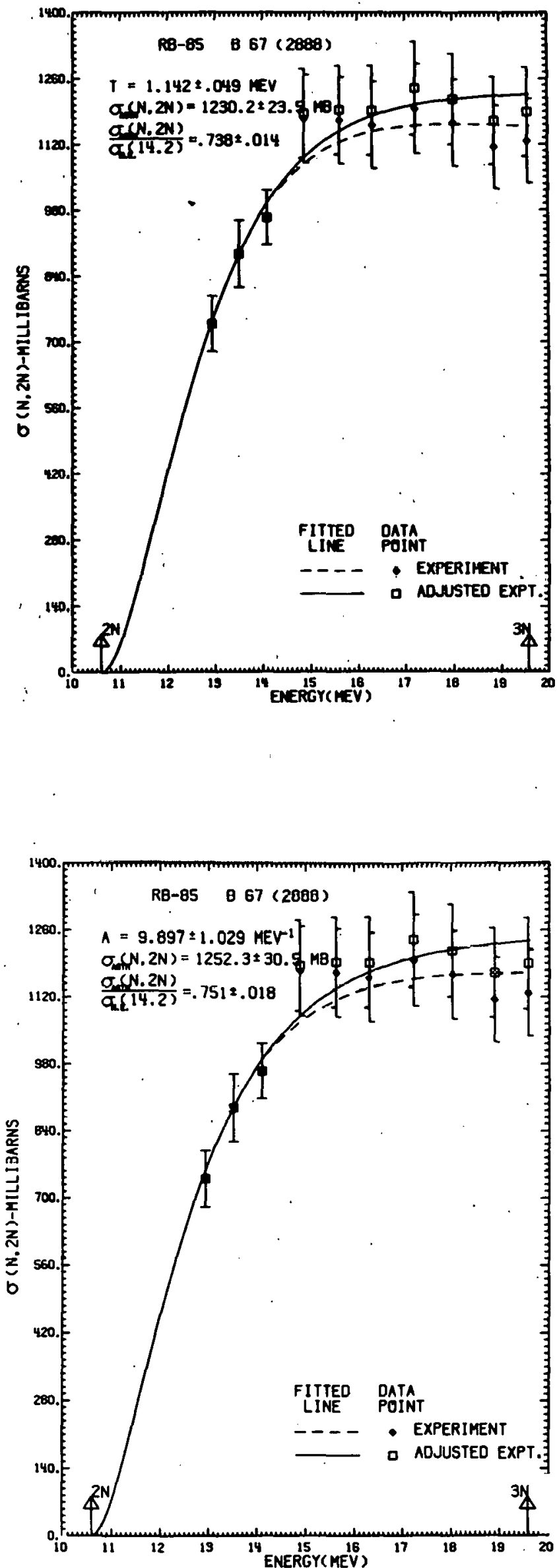


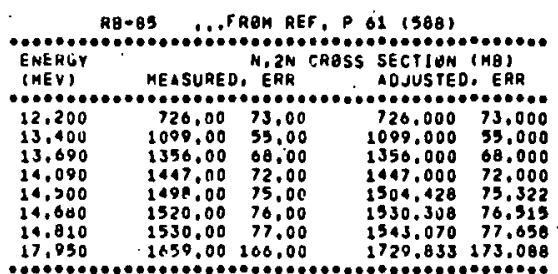

FITTED PAFAMETERS

NUCLEAR TEMP 1.532 DLUS-GA-HINUS 132 MEV

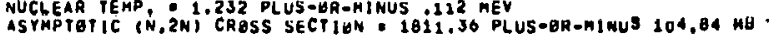

RELATED DATA

NQT-ELASTIC CRESS SECTIEN AT 14.2 MEV $=2667.83$ MQ (N,2N) TMRESHOLD: $10.61 \mathrm{MEV}$

THIS ISOTOPE has 40 meutrons, Ji protons, (MASS. OS)

NEUTRUA EXCESS PARAMETER - .12941

RATIO BF ASYMPTETIC (N, ZN) TO 14,2 MEV NON-ELASTIC 1,0861 PLUS-BR-MINUS , 0029

TESORT(N)E
ERRER
.736

\section{TITTED PaRameters}

LEVEL SPACING T,703 PLUS-EH-hINUS1.545PER MEV

LEVEL SPACING '7, 703 PLUS-EH-HINUS1.545PER MEV

RELATEO LATA

NON-ELASIIC CFOSS SECTIUN AT 14.2 MEV $=1667.03$ MB

$(N, 2 N)$ THRESHELD $=10.61$ MEV

(N.3N) THRESHALU : 19.59 MEV

THIS ISETaPE haS 48 NEUTRONS, 37 PROTUNS, (MASS : B5)

NEUTROON EXCEES PARAMETER * .12041

RATIg of ASYMPIOTIC (N.2N) TO 14.2 MEV NON-ELASTIC 1.1490 PLUS-OR-M!NUS .0017

$\begin{array}{rlr}\text { N/SPACING } & 6.231 \\ \text { ERKOR } & 1.250\end{array}$
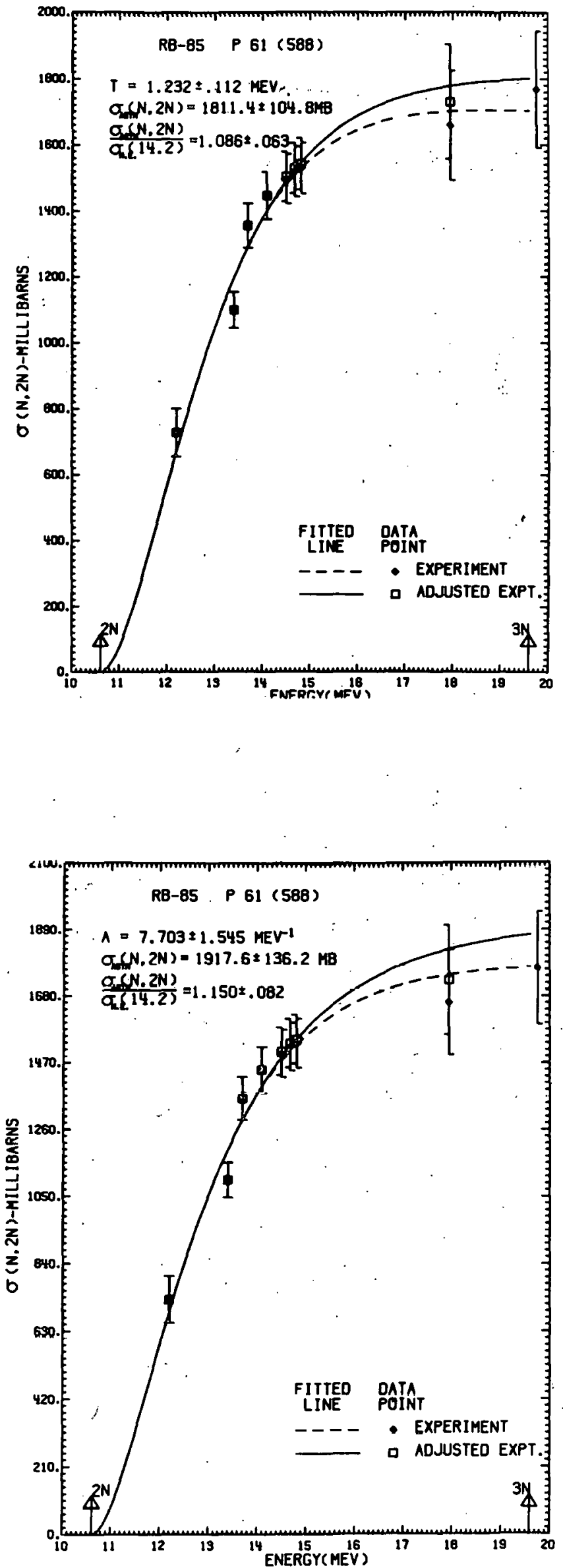


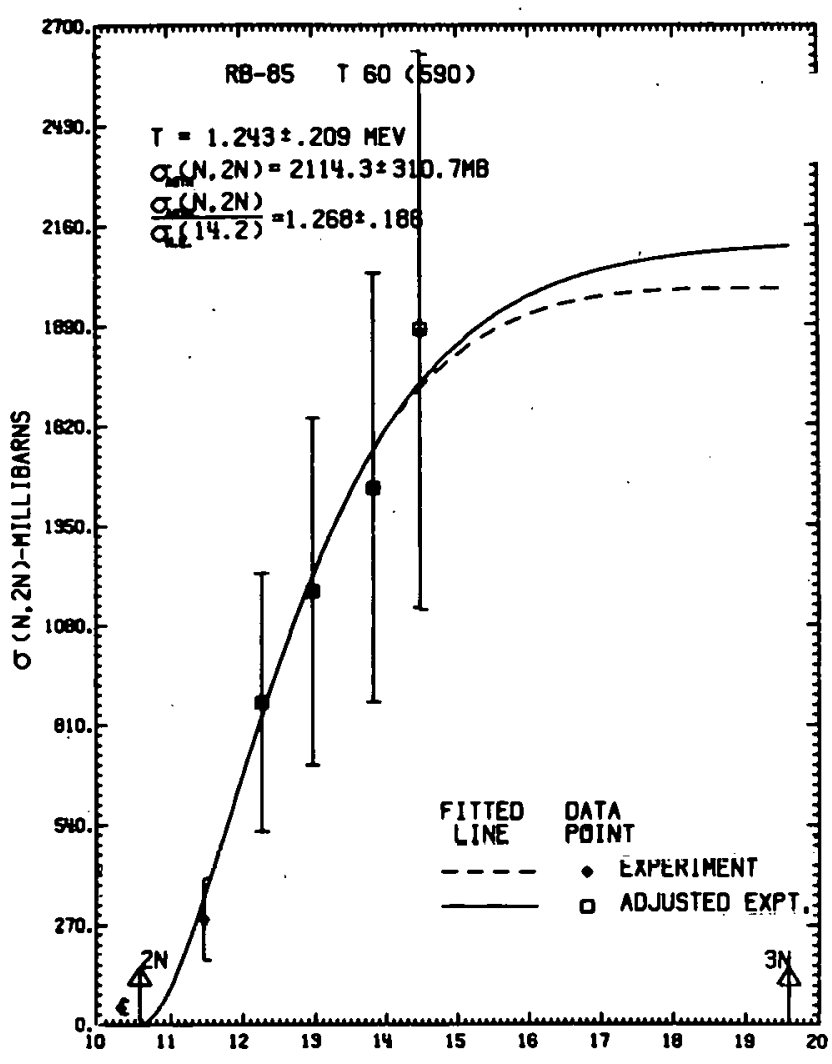

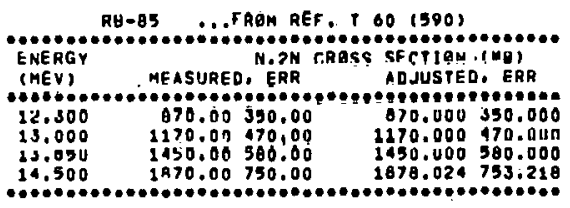

FITTEO PARAHETERS

LEVËL SPACING : O.014 PLUS-OR-MIMUS2 $473 P E R$ MEV

ASYAPTOTIC (N,2N) CRESS SECTION 2336.10 PLUS-OR-MINUS 107,71 MB

\section{RELATED DATA}

NON-ELASTIC CROSS SECTIUN AT 14.2 MEV • 1667.03 NO (N,2N) THWESHQLD: 10,61 NEV

IHIS ISOTRPE haS 48 nEUTRENS, 37 PROTAHS, IMASS - ASI

NEUTHON EXCESS PARAMETER : .12941

RATIE OF ASYMPYRTIC (N.2N) TO 14,2 MEV NBN-ELASTIC
1.4007 PLUS-GR-MINUS ,2445

N/SPACING: 7.044 AISPACING $=412.474$
ERKER 2.547
RELATED GATA

C CROSS SECTION AT 14,2 MEV : 1667.63 MB

IUEUTKUN EXCESS PARAMETER : .12941

PAIIA BF ASYMPTOTIC (N,2N) TO 14.2 MEV NON-ELASTIC 1.2677 PLUS-DH-NINUS .1063

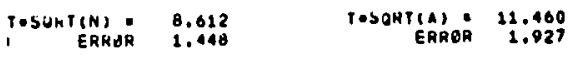

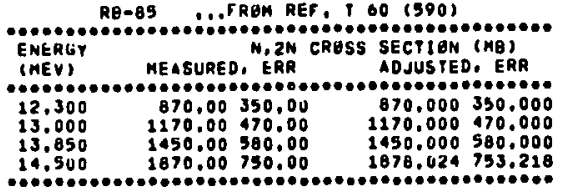

PAHAYETERS

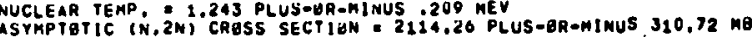

(N.3N) THRESHALD $19,30 \mathrm{MEV}$ 


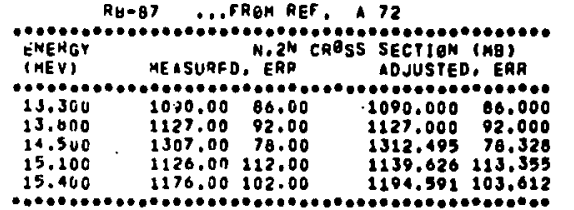

FITTFU PAKAMETERS

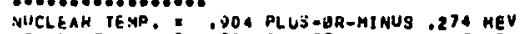

ASYMPTETIC $(Y, 2 N)^{\circ}$ CROSS SECTION $120_{1}$.31 PLUS-gR-NINUS OS.11 $M$

RELATED UATA

NUN-ELASTIC CRASS SECTIBN AT 14.2 MEY = 1085.43 MB

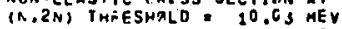

10.70 MEY

THIS ISOTUPE HAS 50 NEUTRONS. S7 PROTENS, (MASS = 87 )

BEUTKUN EXCESS PARAHETER. .14043

HATIE OF ASYMPTPTIC (N.2H) TE 14.2 MEV NON-ELASTIC

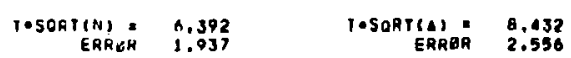

FITIEO PAKAMETERS

LEVEL SPACING E

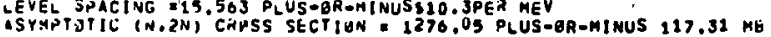

RELATEJ UATA

NUN-ELASTIC CUNSS SECTION AT 14.2 MEV = $1609.43 \mathrm{MB}$

(N.2N) THAESHOLD: $10 ., 35$ HEV

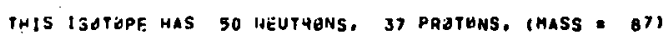

NEUTHJN EXCESS PARAHETEN. .14943

RATIJ GF ASYMPTHTIC (N,2TH) TO 14.2 MEV MEN-ELASTIC .7571 PLUS-AR-MINUS .0690

N/SHACING $=3.213 \quad 4 / S P A C I N G=\$ .590$
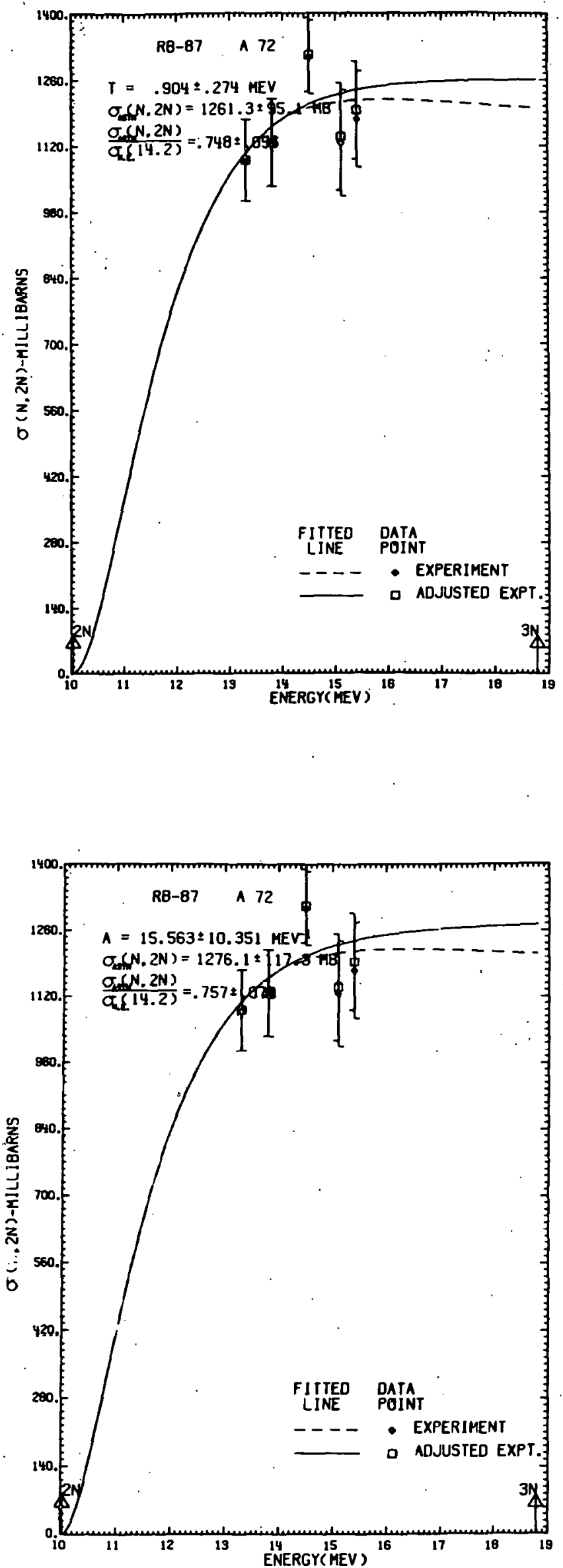


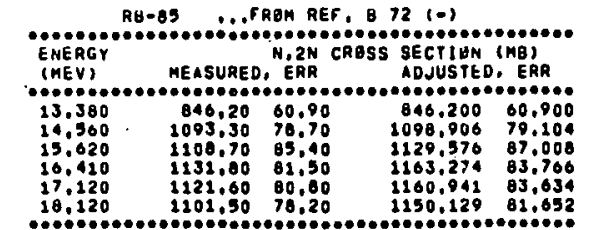

FITTEU PARAMETERS

MUCLEAR TEMP. 11.070 PLUS-OR-MINUS .057 MEV
ASYMPTOTIC (N. $2 N$ ) CHESS SECTIUN 2186.80 PLUS-OR-MINUS 21.04 MB

RELATED UATA

NUN-ELASTIC CROSS SECTION AT 14,2 MEV = 1067.03 MO NUN-ELASTIC CRESS SECTION TM

(N.2N) THRESHOLD: 10.61 MEV

THIS ISOTUPE hAS 4 MEUTRONS, 37 PHOTONS, (MASS - 85 )

NEUTRUN EXCESS PARANETER - .12041 RATIO OF ASYMPTETIC (N,2N) PO 24,2 MEV NONEELASTIC
,7116 PLUS-OR-NINUS .0131

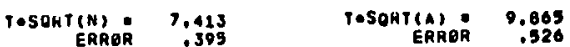
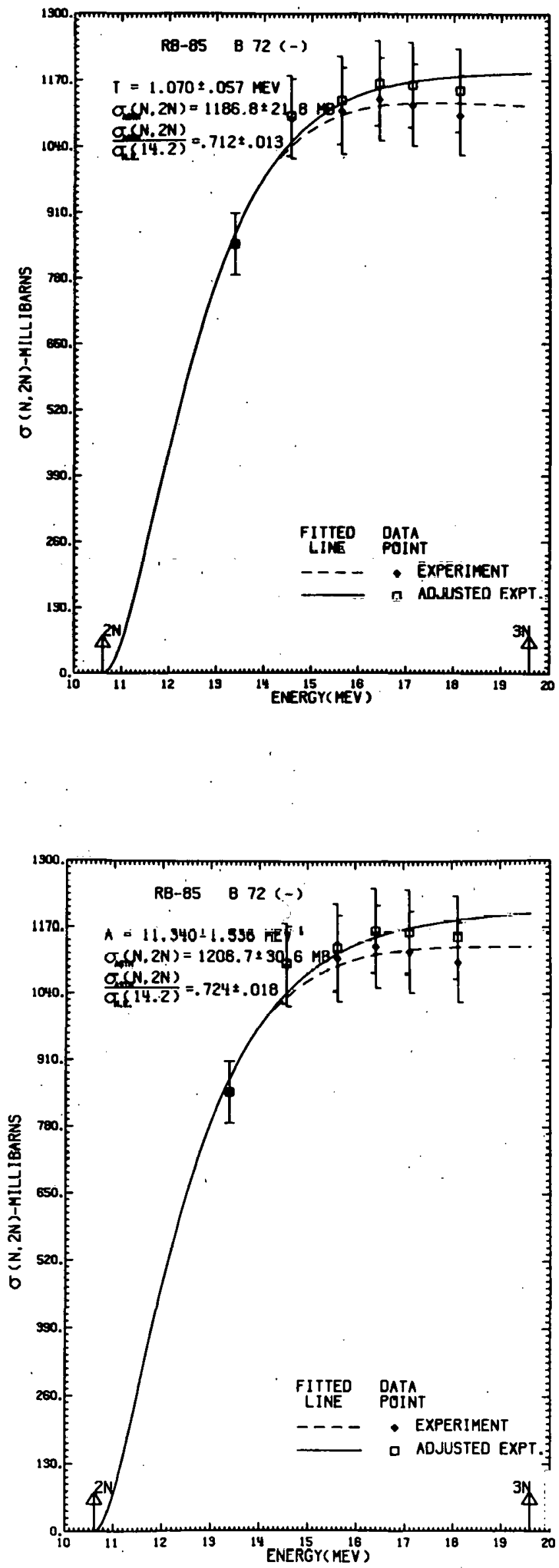

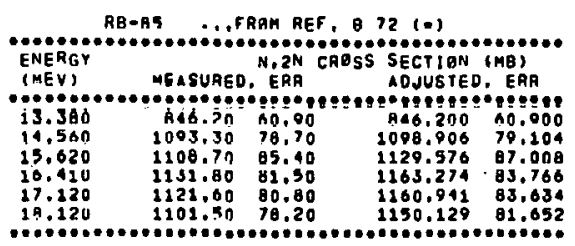

FIITED PARAMETERS

LEVEL SPACING O11.340 PLUS-gR-NINUS1.536PER MEV ASYMPTOTIC (N,2N) CRESS SECTION = 1206.70 PLUS-OR-NINOS 30.5) NB

RELATED DATA

NON-ELASTIC CRESS SECTION AT 14.2 MEV - 1667.83 MB (N.2N) THRESHQL D $: 10.62 \mathrm{MEV}$

THIS ISETOPE haS 4 BEUTRENS, 37 PRETUNS, (MASS : 05

NEUTRON EXCESS PARAMETER - .12941

RATIO OF ASYMPTOTIC (N,2N) TB 14,2 MEV NON-ELASTIC
.7235 PLUS-ER-MINUS

$\begin{array}{rrr}\text { N/SPACING } & 4.233 \\ \text { ERHOR } & .573 & \text { A/SPACING }\end{array}$ 


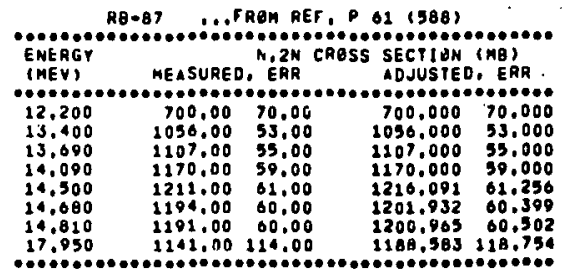

\section{miteu parameters}

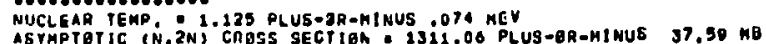

\section{AELATED DATA}

NGN-ELASTIC CRESS SECTION AT 14,2 KEV - 1085,43 NB (N.2N) THAESHELD: 10.03 MEV

TMIS ISOTOPE HAS SO NEUTRUNS, 37 PRUTGNS, (MASS - B7)

NeUthon EXCESS PaRAMETER - .24943

RATIS OF ASYMPTOTIC (N,2N) TO D4.2 MEY NON-ELASTIC

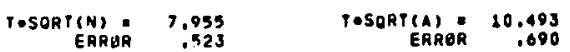

\section{FIITED PARAHF TERS}

LEVFL SHACING

ASYMPIOTIC (N, $2 N$ ) CRESS SECYION * 1355.66 PLUS-ER-AINUS 50,18 MB

RELATED DATA

HGN-ELASTIC CRESS SECTIÓN AT 19.2 MEV - 1645.4S MB

(N.2N) TMKESHALO 20.03 MEV

IN.ZN) THKESHALO: 10.03 MEV

THIS ISBTHPE HAS SO NEUTRONS, J7 PROTGMS, (MASS : 87)

NEUTREN EXEESS PARAMETER • .14943

RATIO OF ASYMPTETTC (N.2N) TO 14.2 MEV NON-ELASTIC

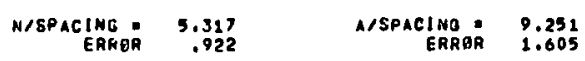
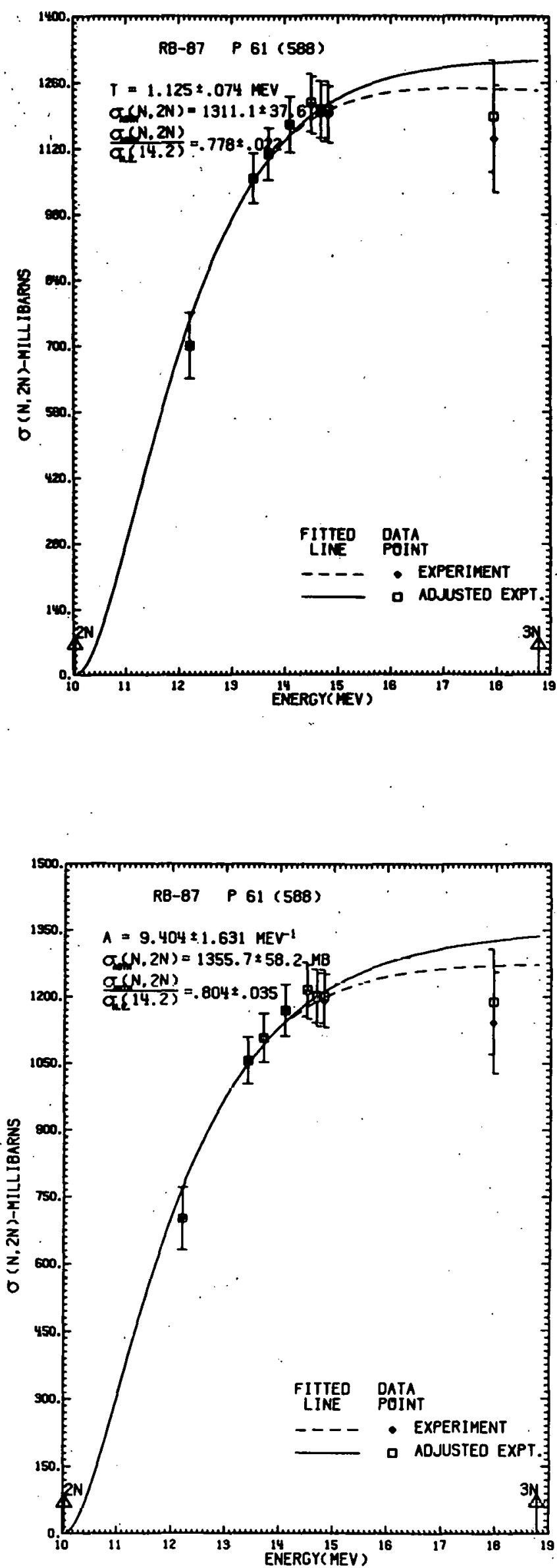


RUEBT
ENEKGY
IHEV

VITIEU PAGAMETERS

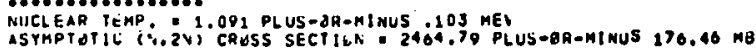

nELATEO JATA

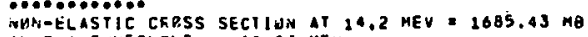

(N,2.N) THHESHPLD: 10,0S MEV

(N.JiN) THRESHALL: 10.78 MEV

THIS ISETAPE HAS SO NEUTHONS, 37 PKOTONS. (MASS : 37 ,

MEUTHAN EXCESS PARAMETEF, .1494J

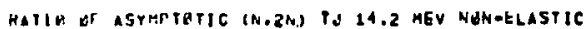

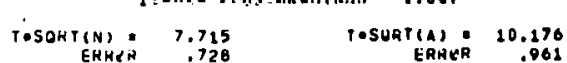

FITTED PARAMETERS

LEVEL SPACING 8,715 PLUG - OR-MIMUST, SPGPER MEY

ASYMPTBTIC (N,2N) CAQSS SECTION 2647.12 PLUS-OR-MIMUS $202.10 \mathrm{M \theta}$

RELATED UATA

MEN-ELASTIC CRESS SECTION AT 24.2 HEV * 1685.43 HB

(N,2N) THRESHALD $=10.03 \mathrm{MEY}$

THIS ISOTOPE MAS 50 MEUTRONS, 37 PRETEMS, (MASS - OTI

meutron excess paraneter - .14043

RATIO OF ASYMPTPTIC (N,2N) TE 24.2 MEV NEN-ELASTIC
1.5706 PLUS-OR-MINUS 1200

M/SPACING 5.737 A/SPACINO. 9.983
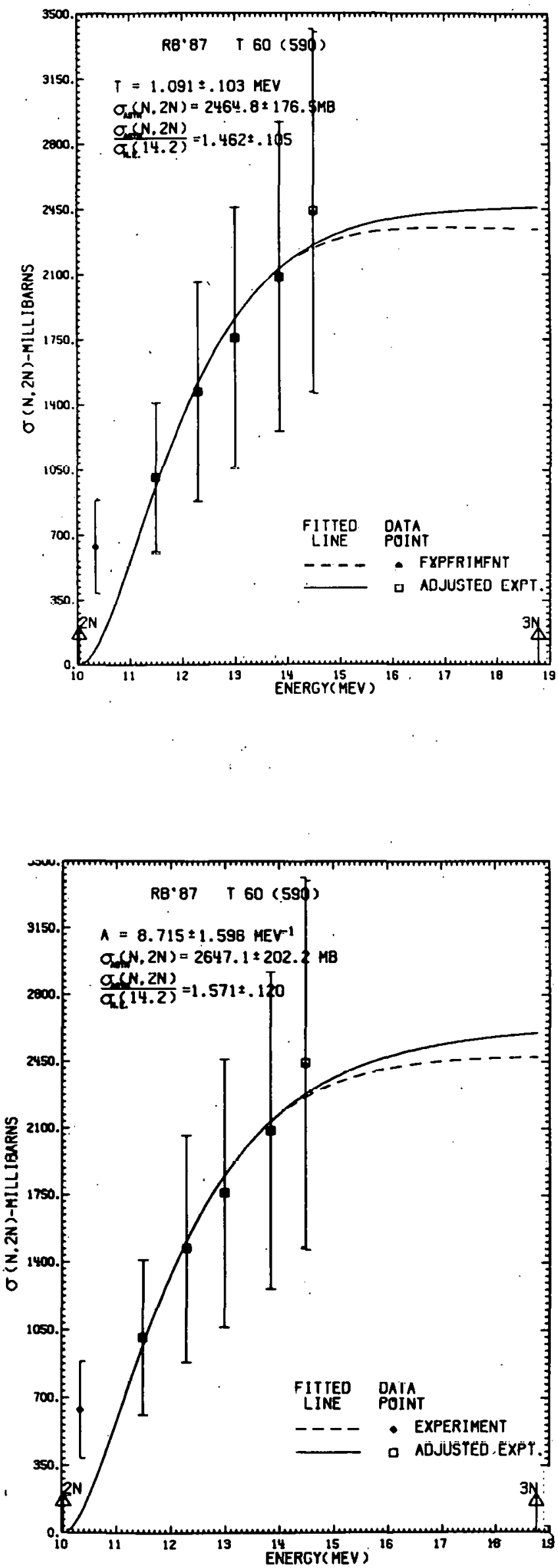


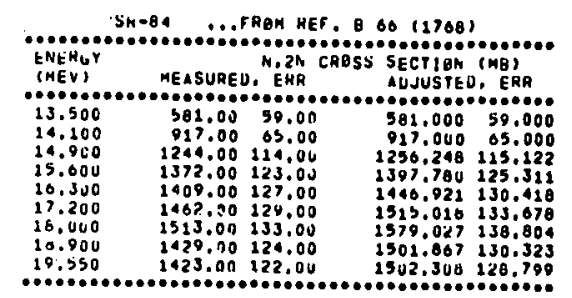

FitThD paikameters

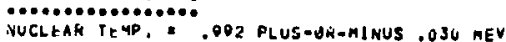

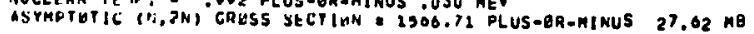

HELATED UATA

NPN-ELASIIC CRESS SECTIEN AT 14.2 MEV = 1658.94 MO

(N,2N) THAESHPLD: 12,10 MEV

TMIS ISATUPE HAS 40 itEUTRUNS, 3d PKOTUNS, (MASS : 84)

NEUTRUN EXCESS PARAMETER - .09524

HATID OF ASYMPTETIC (N,2H) TO 14,2 MEV NUM-ELASTIT.

$$
\text { . VA44 PLUS-QR-MINUS } 14,2 \text { MEV NUM-ELASTI }
$$

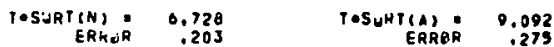

FITTED PARAMETERS

LEVEL SPACING 113.601 PLUS - BR-HINUSI, 104PER MEV

ASYMPTOTIC (N, ZN) CRESS SECTION 1599,16 PLUS-ER OMIMUS $39,57 \mathrm{MB}$

\section{RELATEO DATA}

NON-ELASTIC CRESS SECTION AT 14.2 MEV • $1638.94 \mathrm{MB}$

(N,2N) TWRESHRLD: 12,16 MEV
(N,3N) THRESHELD: 20,90 HEY

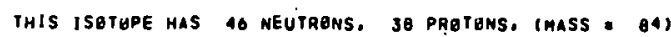

NEUTRGN EXCESS PARAMETER : .09524

RATIO OF ASYMPTOTIC (N,2N) TO 14,2 MEY NON-ELASTIC'

$$
\begin{aligned}
& .9640 \text { PLUS } 9 \text {-OR-MINUS } 14,2 \text { MEV NONOELASTIC } \\
& .0230
\end{aligned}
$$$$
\text { N/SPACING: 3.307 A/SPACING: } 0.149
$$
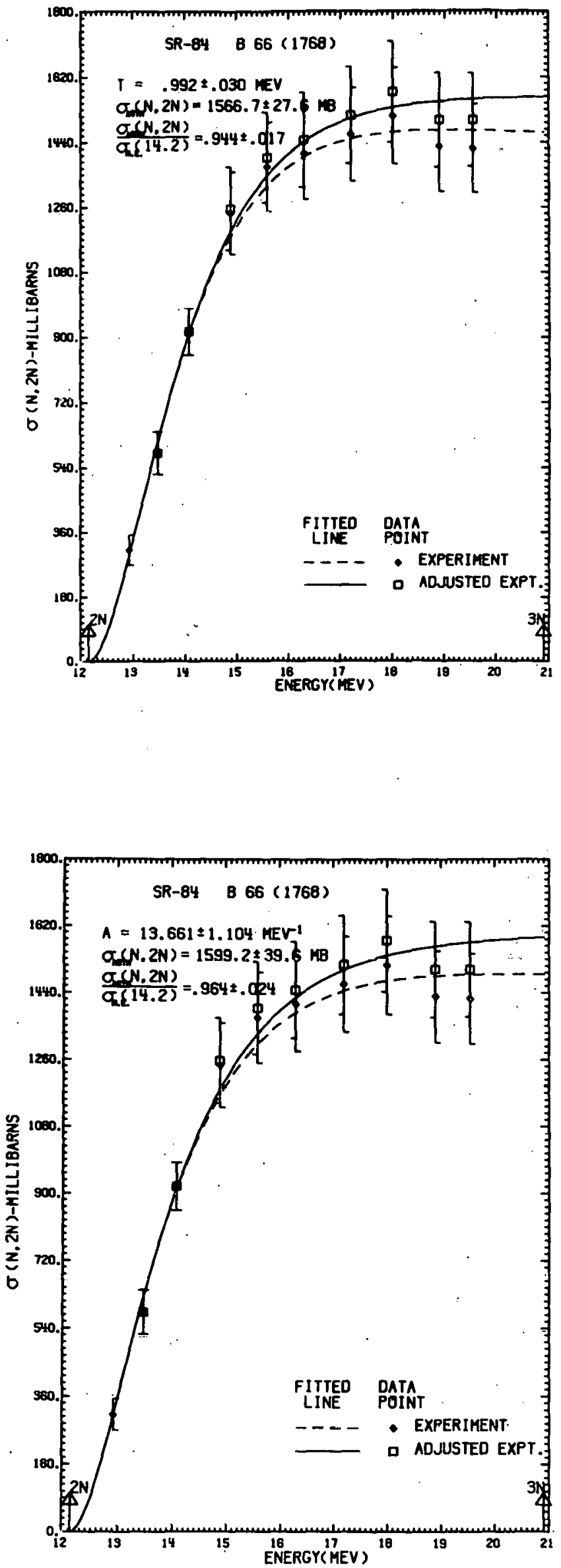


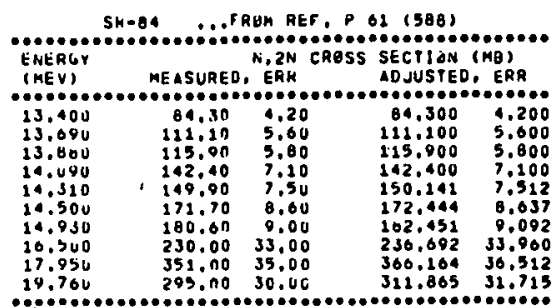

FITTE PAHAME TEPS

iUCLEAR ItMP. 1.232 PLUS-AHEPINUS 096 MEV

AUCLEAL TEMP.

RELATEU WATA

NGN-ELASIIC CRESS SECTIUN AT 14.2 MEV = 1638.04 MB

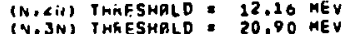

THIS ISUTUPE MAS 40 NEUTKENS, SO PRUTENS, (MAȘS = O4)

NEUTRaN EXCESS PaRAMETEK = .09524'

TATIO UE ASYKPTUTIC (II, 2N) TO 19.2 MEY NÖN-ELASTIC .1805 PLUS-UR-MINUS .0134

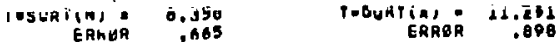

FITTED PARAMETERS

LEVE SPACIMG

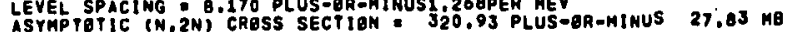

RELATEO DATA

MQN-ELASTIC CRESS SECTION AT 14.2 MEV - 1698.94 NO

NQN,2N) THRESHELD $=12,16$ MEV

(N, SN) THRESHOLD : 20.00 MEV

THIS ISOTUPE MAS 46 NEUTRQNS, 38 PROTENS, (MASS - 44

NEUTREN EXCESS PARAHETER - .09524

RATIO OF ASYMPTETIC (N.2N) TO 14.2 MEV NON-ELASTIC

N/SPACING 5.630 A/SPACING 10.282
ERRER
$.670 \quad 1,506$
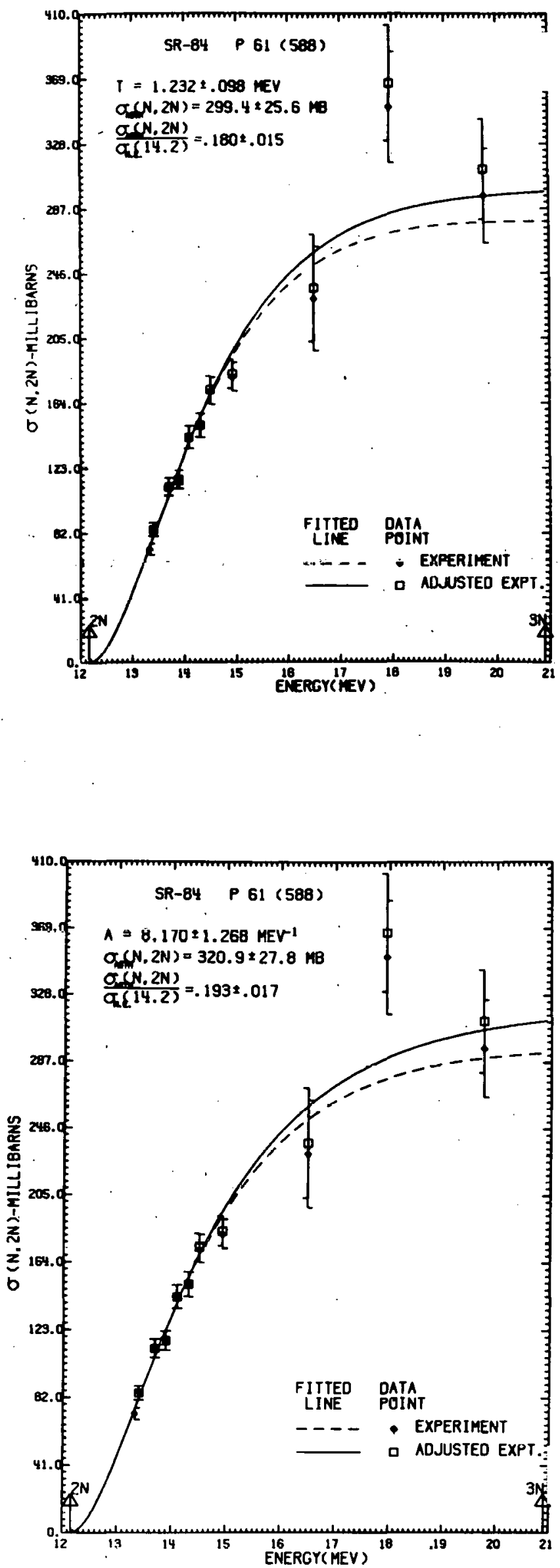


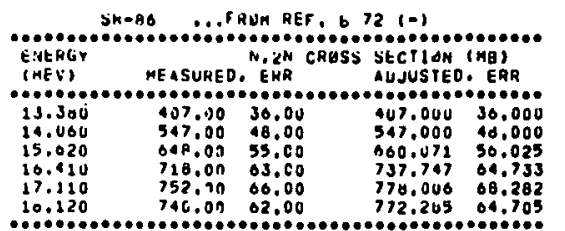

TIITEN PARAMFTERS

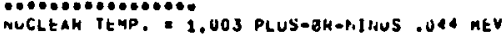

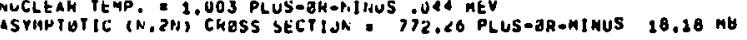

HELATED UATA

MQN-ELASTIC CF.dSS SECTIAH AT 14.Z MEV = $1676.05 \mathrm{ME}$

(N.2N) PHHFSHALD: 11.02 MEV

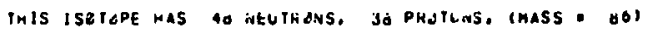

Neution excess parameter : .11020

GATIS UF ASYMPTATIC (N.2N) TO. 24.2 MEV HEN-ELASTIC

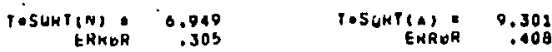

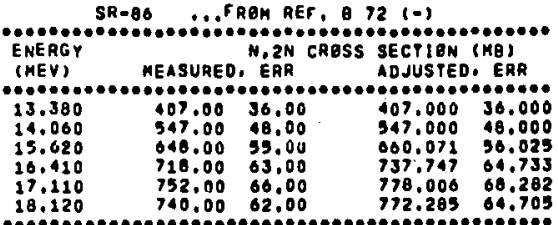

\section{FitTGD Pafanctgfis}

LEVEL SPACING 12.810 PLUS-GR-MINUS1, OT2PER MEV

ASYMPTETIC (N, $2 N$ ) CRESS SECTION POZ.04 PLUS-BR-MINUS 10.71 HO

RELATEO DATA

NON-ELASTIC CROSS SECTION AT 14.2 NEV * 1676.65 NB

(N.2N) THRESHQLO: 11.62 MEV

THIS ISOTOPE MAS 98 MEUTRONS, 38 PRETONS, (MASS - 061

NEUTREN EXCESS PARAMETER. . 11620

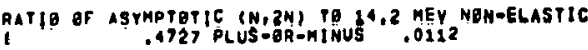

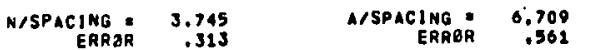
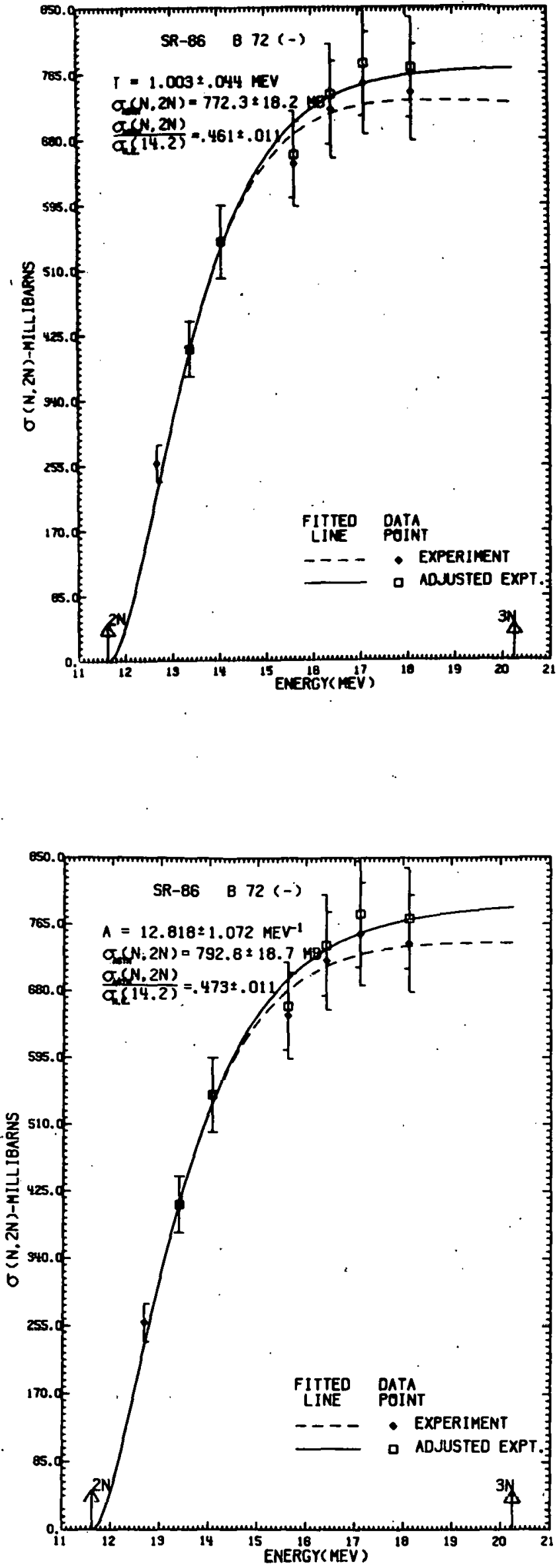


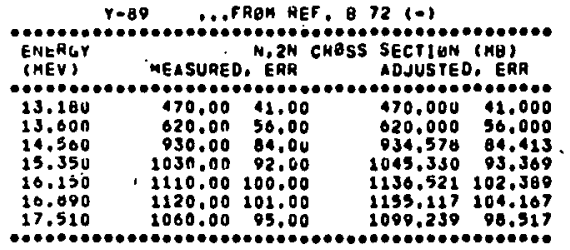

FITTED PAHAMETERS

MUCLEAK TËMP. - I.157 PLUS-OB-HIAUS 052 MEV

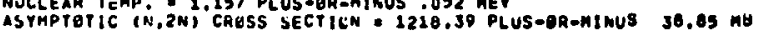

RELATED UATA

NUN-ELASTIC CRASS SECT1ON AT 14.2 MEV - 1702.02 MB

(N.2N) THKESHaLO $=21.00$ MEV

(N.SN) TMRESHBLO: 21,00 MEV

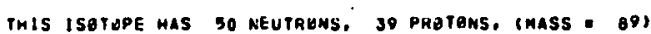

neUtKan EXCESS PaRAKETER : .12300

RATIU EF ASYMPTETIC (N,2N) IS 14.2 NEV NOHELLASTIC .7255 PLUS $* 68-M I N U S$. .0226

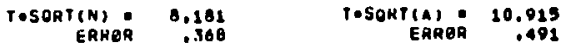

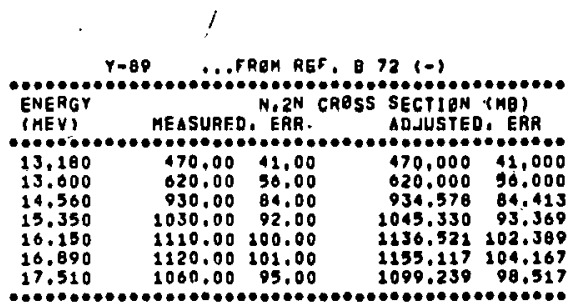

TITTED PAOMHETSOL

HEVE SPACING

ASYMPTOTIC (N, ZN) CROSS SECTION = 1275.93 PLUS-OR-MINUS 36,94 MO

RELATED DATA

MQM-ELASTIC CROSS SECTION AT 14.2 MEV - 1702.02 MB

(N,2N) THRESHALO T 11.60 MEV

(N,2N) THRESHQLD: $11.60 \mathrm{MEV}$

THIS ISOTUPE HAS 50 NEUTRENS, 39 PROTONS, IMASS BO

NEUTRON EXCESS PARAMETER: .12360

RATIO OR ASYMPTETIC (N,2N) TO 14.2 NEV NON-ELASTIC .7493 PLUS=DR-NINUS .0334

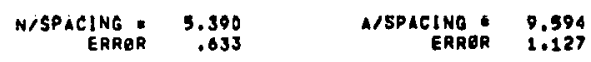
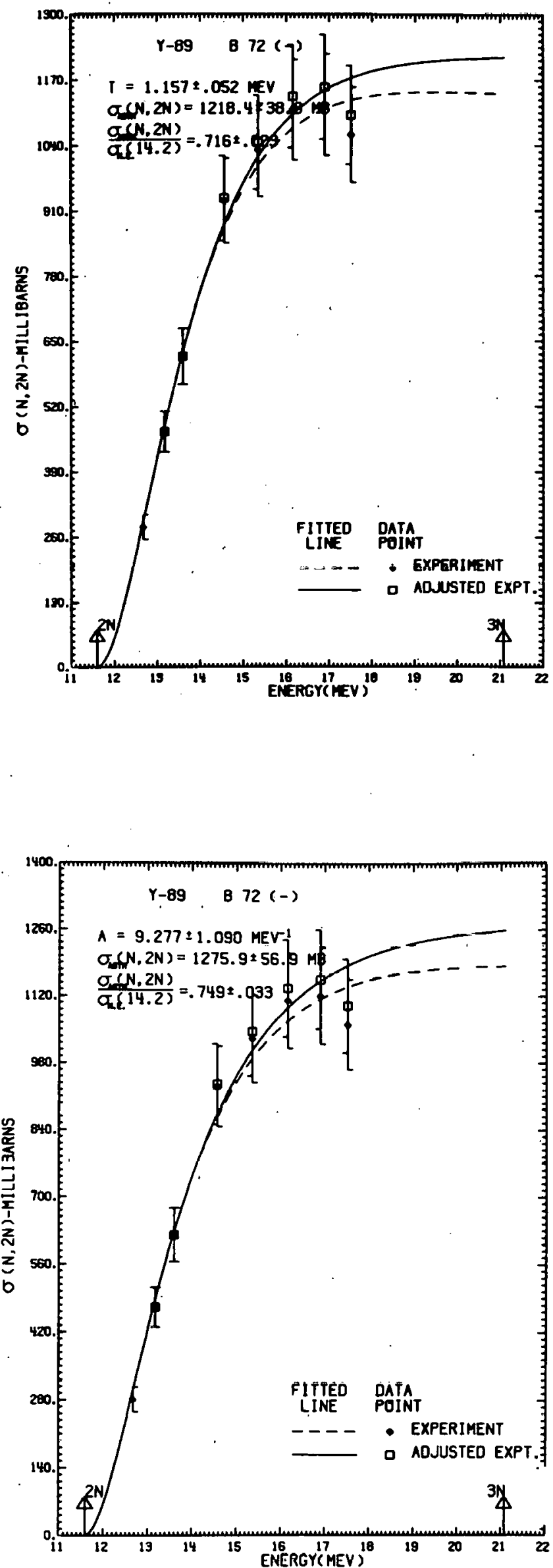


\begin{tabular}{|c|c|c|c|c|}
\hline $\begin{array}{l}\text { ENERGY } \\
\text { (MEV) }\end{array}$ & & D. $\begin{array}{l}N \text {, N } \\
\text { D. }\end{array}$ & $\begin{array}{l}\text { SECTIUN } \\
\text { AOJUSTED }\end{array}$ & $\begin{array}{l}\text { (ME) } \\
\text {, ERA }\end{array}$ \\
\hline $\begin{array}{l}13.290 \\
13.870 \\
15.290 \\
15.790 \\
10.020 \\
10.740 \\
17.500\end{array}$ & $\begin{array}{r}621.90 \\
811.00 \\
1040.00 \\
947.00 \\
954.30 \\
997.411 \\
1128.00\end{array}$ & $\begin{array}{r}7.100 \\
13,100 \\
190.00 \\
46.00 \\
40.90 \\
35.10 \\
72.00\end{array}$ & $\begin{array}{r}621.000 \\
611.000 \\
1054.482 \\
965.072 \\
976.368 \\
1027.228 \\
1170.442\end{array}$ & $\begin{array}{r}7.100 \\
43,100 \\
292.646 \\
46.877 \\
41.847 \\
36.150 \\
74.700\end{array}$ \\
\hline
\end{tabular}

\section{TITTEL PARAMETERS}

DUche.

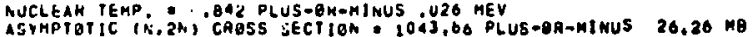

RELATED UATA

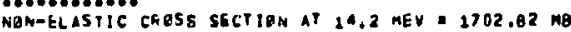

NOM-ELASTIC CAESS STCTTON AT gOA

(N,2N) THRESHOLD: $11,00 \mathrm{MEV}$

THIS ISUTAPE MAS SO NEUTRONS, 30 PRETONS. (MASS - 60 )

NEUTRUN EXCESS PARAMETEH : .12300

RATLO OF ASYMPTOTIC (N,ZW) TO 24.2 MEV NOM-ELASTIC .6130 PLUS-QR-MINUS .0254

$\begin{array}{rr}\text { TOSOHTIN) } & 5.954 \\ \text { ERRDA } & .184\end{array}$

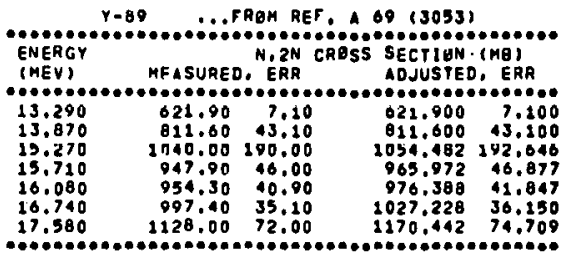

FITTED PARAMETERS

LEVEL SPACING

ASYMPTGIIC (N,ZN) CRESS SECTION 1003.35 PLUS GR-MINUS $26,00 \mathrm{MB}$

\section{RELATED UATA}

NUN-ELASTIC CFOSS SECTION AT 14.2 MEY $=1702, B 2$ MA

(N.ZN) THKESHOLU. 11,60 HEV

IN, BN TRRESHALD: 21.00 MEV

THIS ISOTEPE HAS SO NEUTRENS, 39 PRGTONS, (MASS : 891

NEUTRON EXCESS PARAMETER = .12300

RATIE OF ASYMPTETIC (N.2N) TO 14.2 MEV NON-ELASTIC .6245 PLUS-ER-HINUS .0164

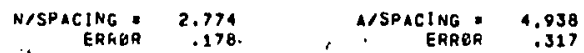

14

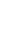

. ș
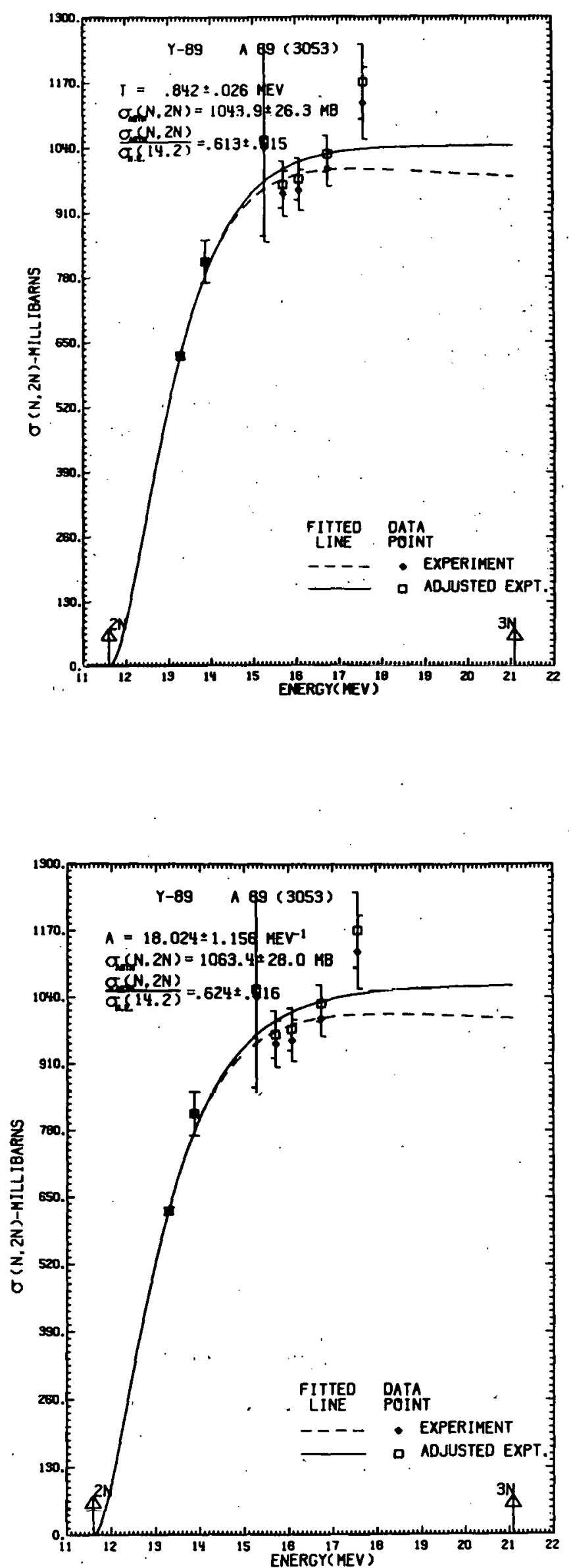


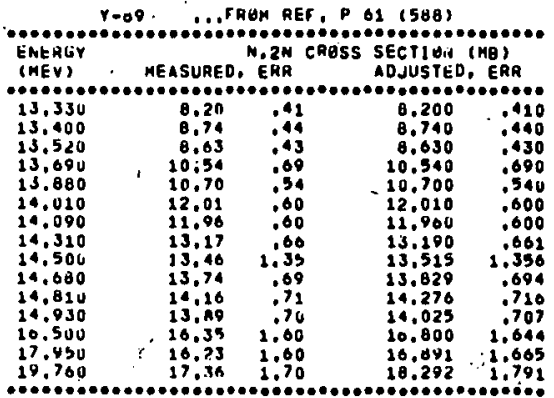

FItTEU Pan AHETERs

RUCLEAH TEMP, I.120 PLUS-GR-MINUS, OA1 HEV

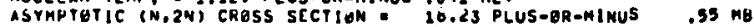

RELATED DATA

NUN-ELASTIC CKESS SECIIUN AT 19.2 REV = 1702.02 MO

(N.2N) THRESHaLD $=11.00 \mathrm{MEV}$

(N,3N) TMKESHMLD. 21.08 MEY

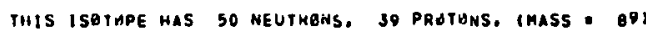

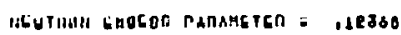

MATIO GF ASYMPTGTIC (N,2.N) TU 14.2 MEV NON-ELASTIC .0107 PLUE-3H=MJHUE .0003

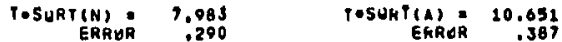

FitTED parameters

LEVEL SPACING 9.790 PLUS-BR-MINUS .828PER MEV

ASYMPTOTIC (N,2N) CRESS SECTION. I9.12 PLUS-ER-MINUS ;2 Ma

RELATED DATA

NON-ELASTIC CROSS SECTION AT 14.2 MEV - 1702.02 MB (N.2N) THRESHOLO: 11.60 MEV

THIS ISOTOPE hAS SO NEUTRENS, 39 PROTONS, (MASS - O9)

NEUTRON EXCESS PARAMETER - .12360

RATIO OF ASYMPTETIC (N,2N) TO 24.2 MEV NOMEELASTIC
OO12. PLUS-GR-MINUS

$\begin{array}{rr}\text { N/SPACING E } & 5.107 \\ \text { EARQR } & .432\end{array}$
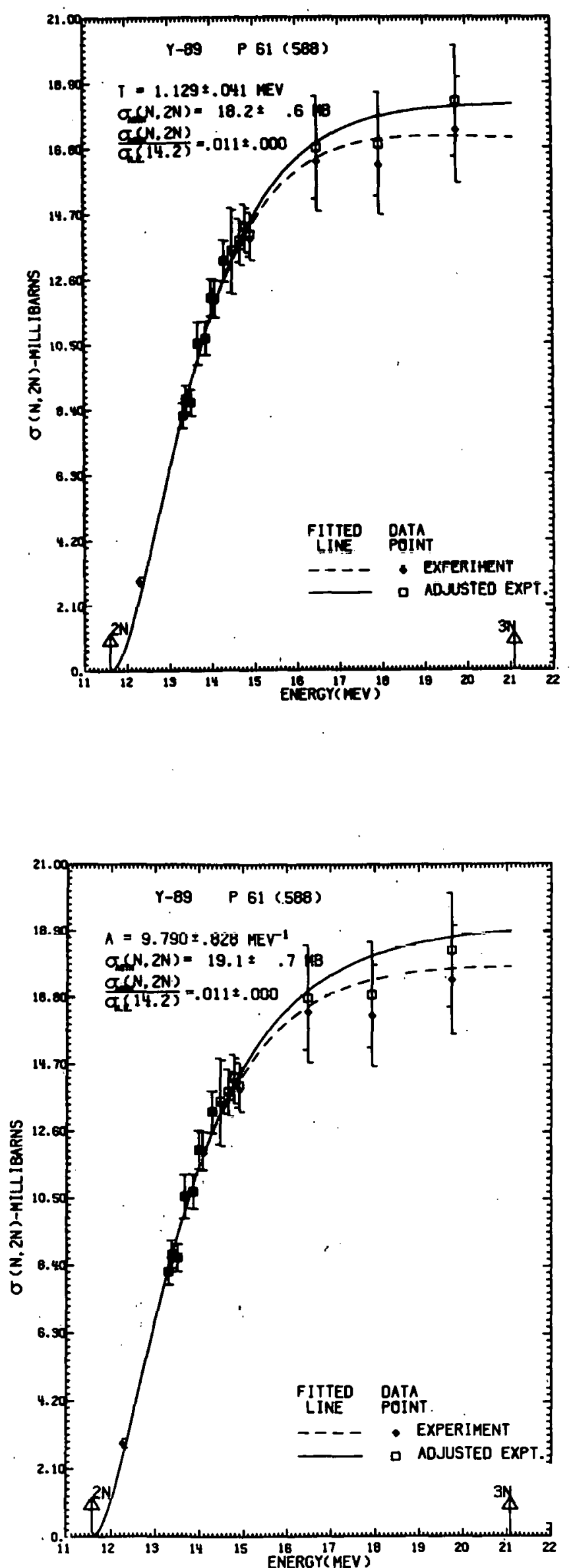


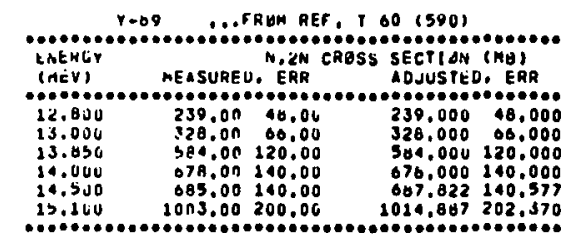

MITEU PAMAME TERS

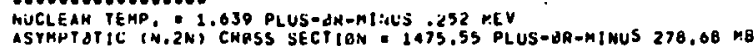

FELATE D DATA

NRN-ELASTIC CROSS SECTIRN AT 14.2 MLN $=1702.82$ M8

(N.2N) TMHESHALD: 11.00 NEN

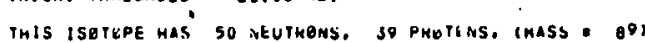

MEUTHUN EXCESS PARAMETER * .12300.

FATIO OF ASYMPTHTIC $(K, 2 N)$ TE 14.2 MEY NEN-ELASTIC .8605 PLUS*6R-Ali,US 1057

TOSGKT(N) 11.389

TOSORT(A) 15,462

Ti i Tey pinhne itehs

LEVEL SPACING : 3.674 PLUS-OR-MINUS1.35OPER MEV

ASTHPTOTIC (N, 2N) CROSS SECTION 1815,74 PLUS-OR-MINUS 444,32 KB

RELATED DATA

MON-ELASTIC CROSS SECTION AT 14.2 MEV = 3702,02 MB

(N.2N) THRESHELD: 11.60 MEV
(N.3N) THRESHELD: 21.08 MEV

THIS ISOTOPE MAS 30 NEUTRENS. 30 PROTONS, (MASS - BVI

NEUTREN EXCESS PARANETER • .22360

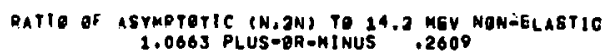

NISPACING $=\begin{array}{r}13.009 \\ 5.001\end{array}$ A/SPACINGER $24.224:$
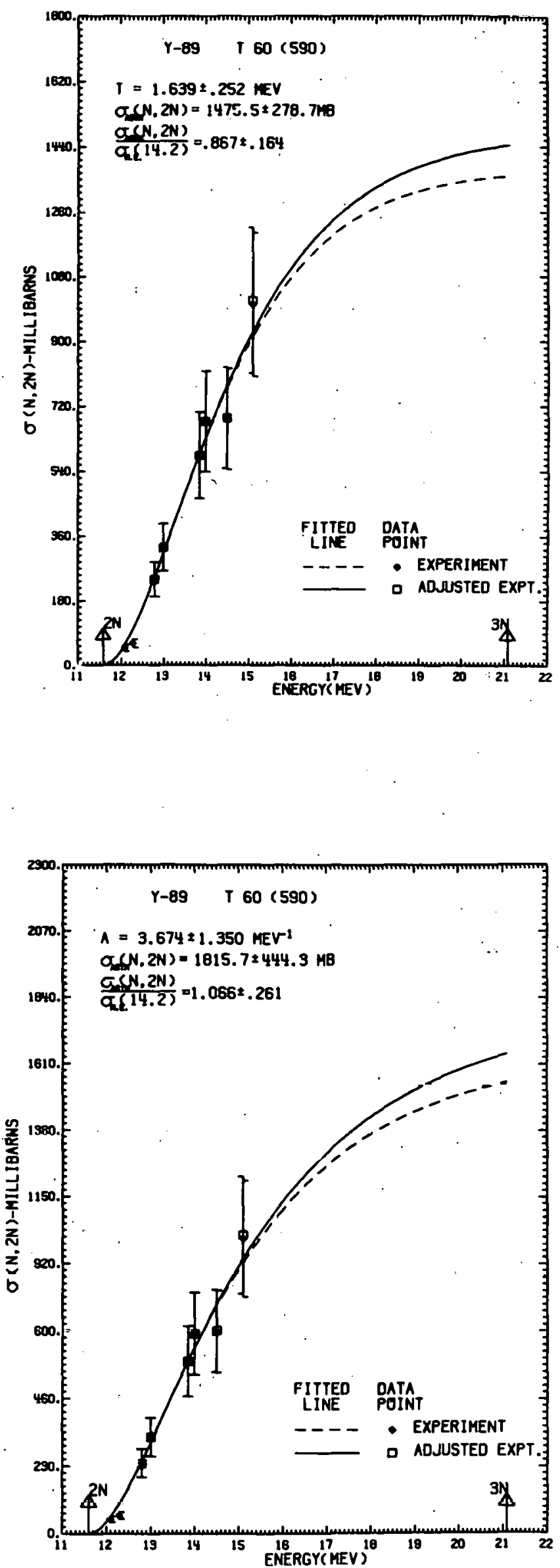


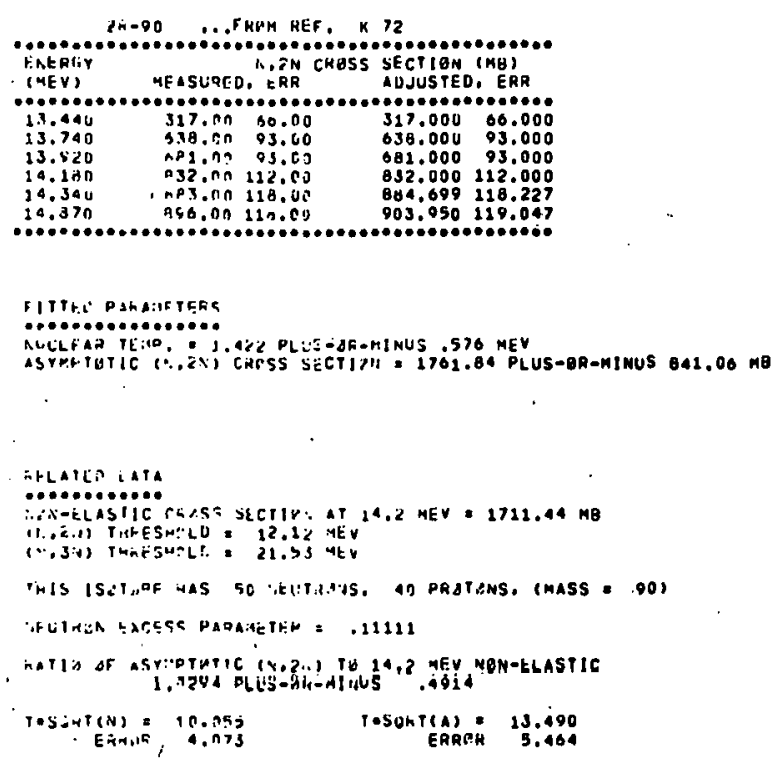

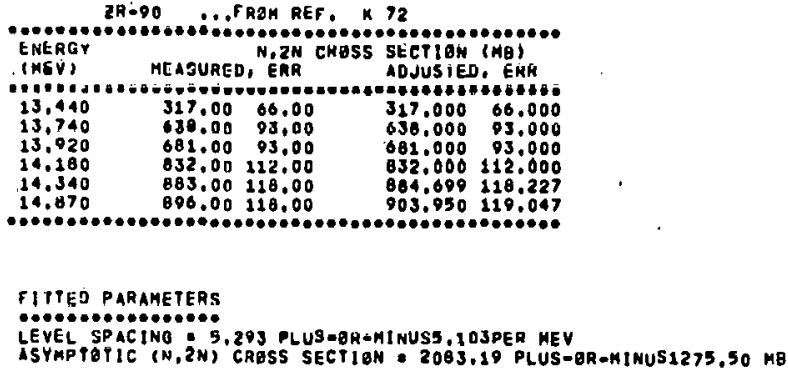

ReLated Data

onta

NON-ELASIIC CRaSS SECTIEN AT 14.2 MEV : 1711, 44 ME

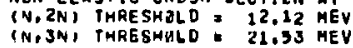

TNIS ISOTJPE has SU NEUTRENS, 40 PRotens, (MASS - 901

neutray excess parameter : .11111

RATIA oF ASYMPTOTIC (N,2N) IO 14,2 MEV NON-ELASTIC

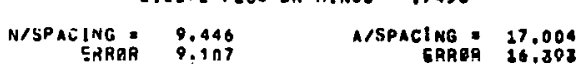
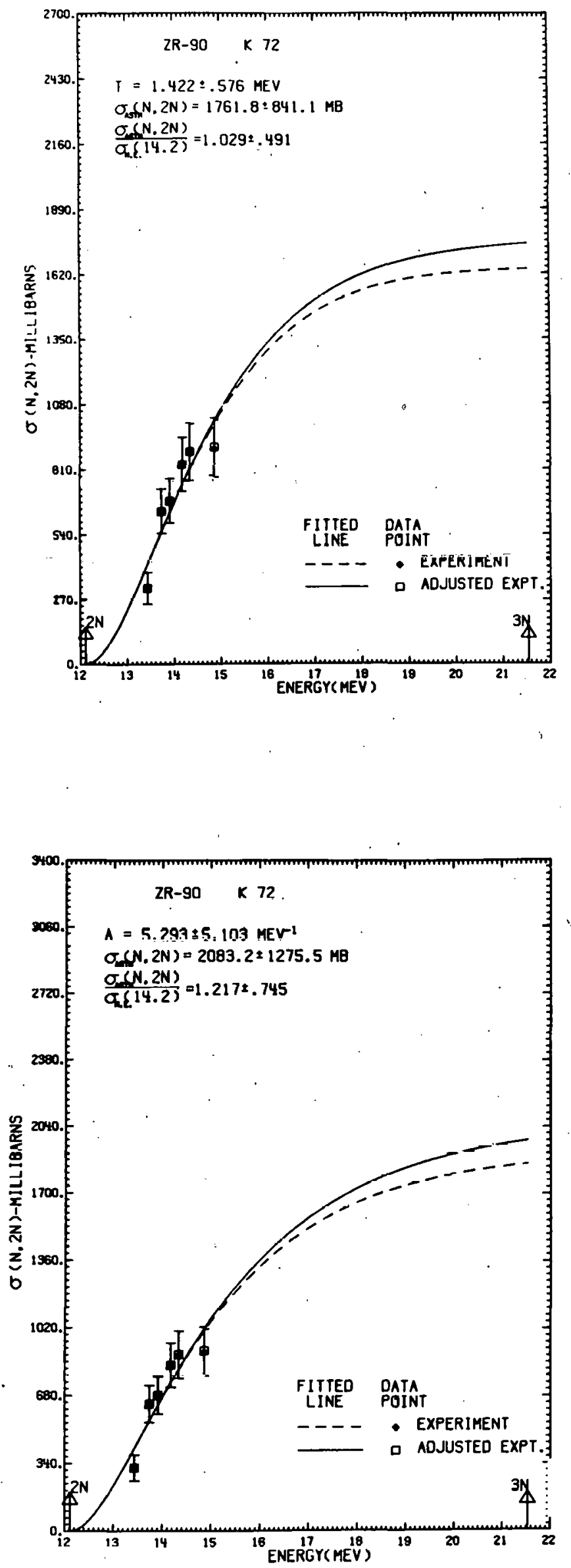


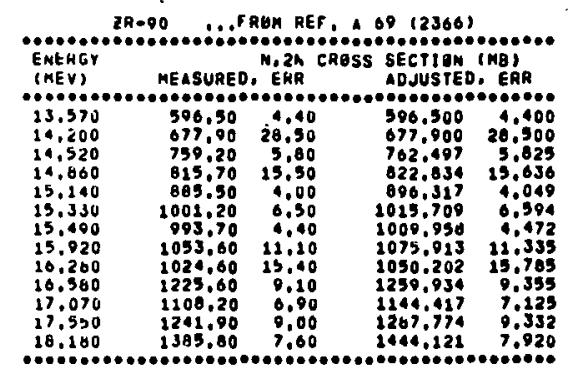

FITTEU PARAMETERS

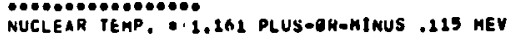

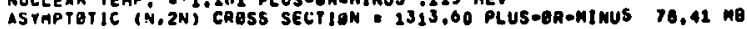

RELATED DATA

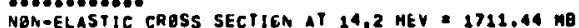

(N.2N) THRESHELD E 12,12 MEV
(N,JN) THKESHOLD 23,33 MEV

THIS ISOTOPE HAS SO NEUTROMS. 40 PRGTONS, (MASS - DO)

MEUTHON EXCESS PARAMETER - .11111

RATIB OF ASYHPTPTIC (N,2N) TO 14,2 MEV NOM-ELASTIC

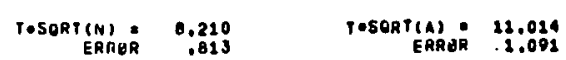

FITTED PARAMETERS

LEVEL SPACING : Q.014 PLUS-ER-MINUS1, 932PER MEV

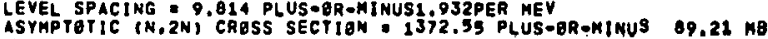

AELATED DATA

NON-ELASTIC CAOSS SECTION AT 14.2 MEV - 1711.44 MB

(N,2N) THRESHELP: 12.12 MEV

THIS ISOTOPE hAS 50 NEUTRONS, 40 PROTONS, (MASS: 90 )

MEUTRON EXCESS PARAMETER - .11111

RATIB OF ASYMPTOTIC (N,2N) TO 14,2 MEV NONOELASTIC .8020 PLUSARATINUS .0921

NPSPACING $=\begin{array}{r}5.095 \\ \text { ERRER } \\ 1.003\end{array}$
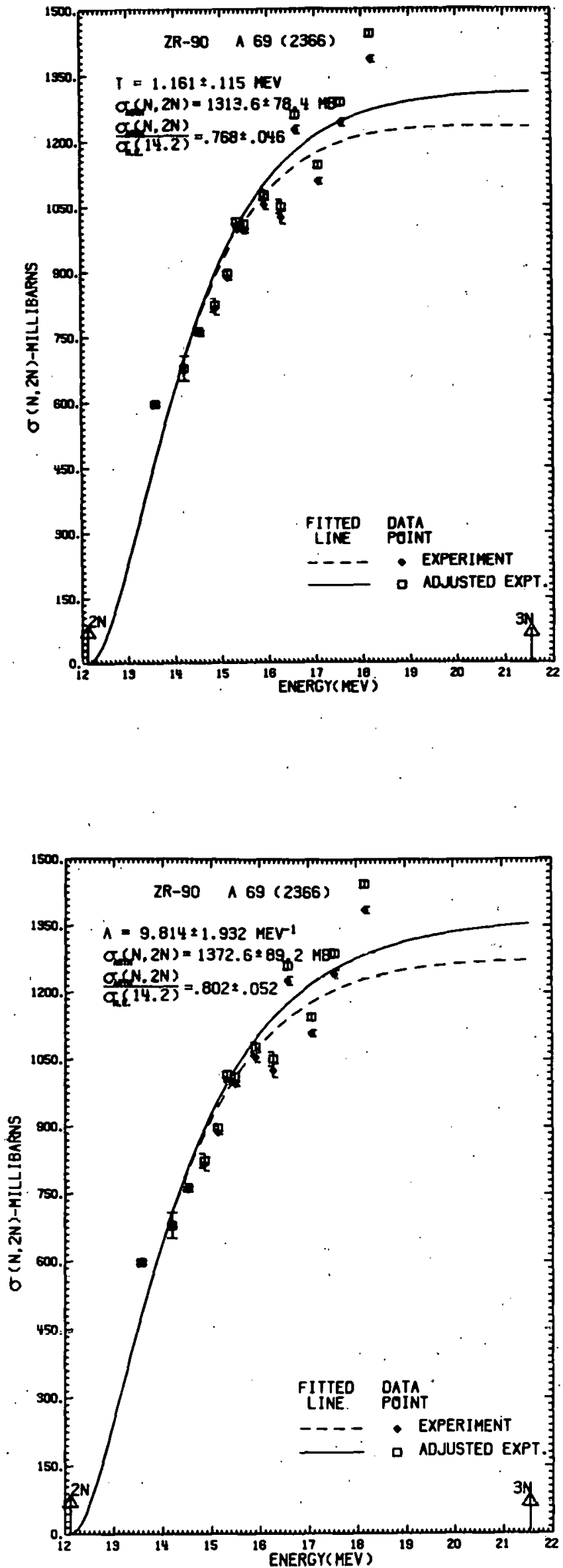


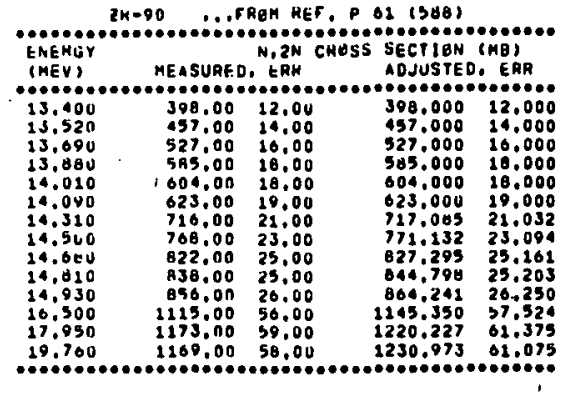

DITTEU PAKAKETERS

NucLEah TEMP. 1.101 PLUS-AK-MIMUS . U20 MEV

ASYMPTETIC (N, 2N) CAESS SECTION * 1210,36 PLUS-OR-MINUS 27,51 HG

hELATED VATA

MeN-ELASTIC CRGSS SECTION AT 14.2 MEV - 1711.44 MB

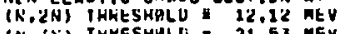

(H,SN) THKESHELL $=22.53$ MEV

THIS ISRTEPE has SO NEUTRONS. 40 PRUTONS, (MASS $=90$ )

HEUTKGN EXCESS PARAMETEH - .13112

RATIS OF ASYMPTATIC (N.2N) TU T4.2 MEV NON-ELASTIC

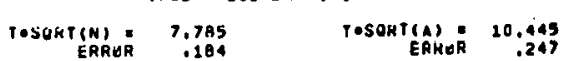

GitTed parameters

LEVEI SPACING

ASYMPTOTIC (N, 2N) CRESS SECTION = 1281.40 PLUS-GR-HINUS 27,25 KB

\section{RELATED DATA}

NOM-ELASTIC CROSS SECTION AT 14.2 MEV = 1711.44 MB

(N,2N) THRESHOLO: 12,12 MEV
(N,3N) THRESHELD : $21,53 \mathrm{MEV}$

THIS ISOTBPE HAS SO NEUTRENS, 40 PROTONS, IMAG6 - 203

neUtARE EXCESS PARAMETER - .11111

RATIE OF ASYMPTETIC (N,2N) TO 14,2 MEY NOH-ELASTIC

,7467 PLUS-BR-HINUS .0350 .

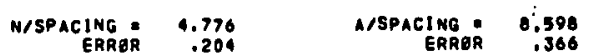
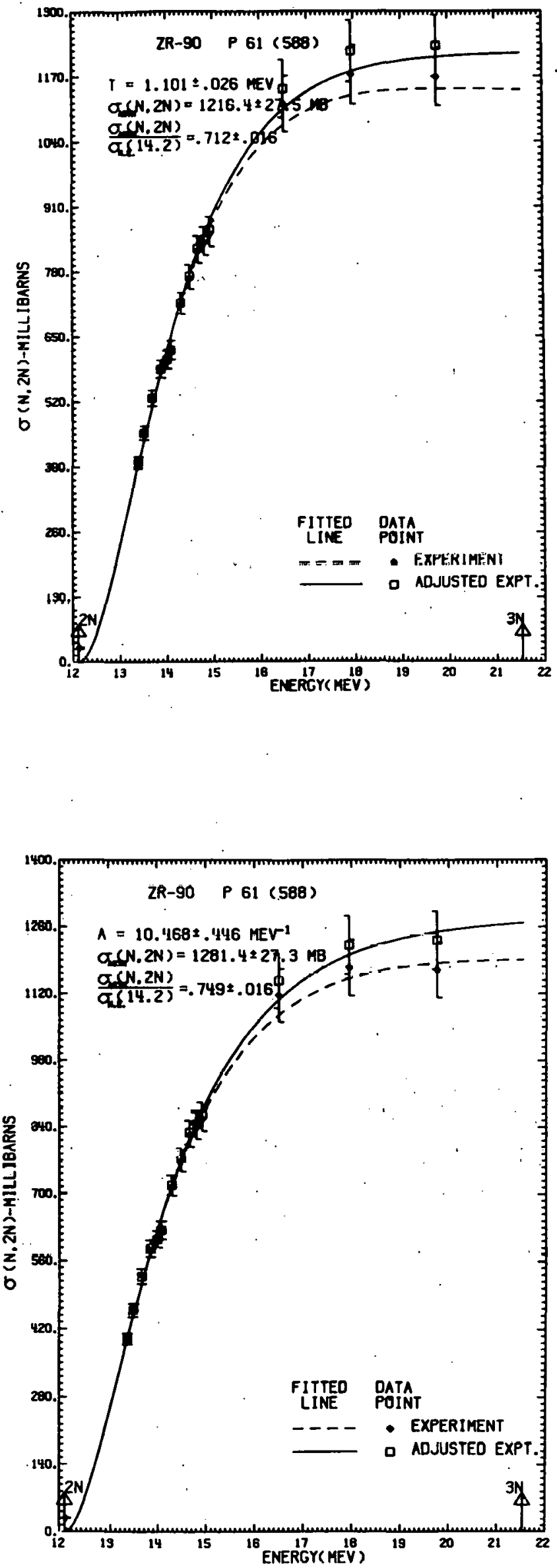


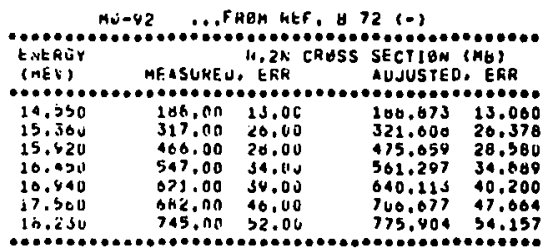

DITLE PAHAMETERS

NuClEAh TERP. 2.406 PLUS-dh-MINUS .203 MEV

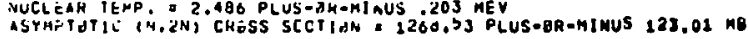

\section{RiLATEU BATA}

WUN-ELLSTIC CARSS SUCTIEN AI $14.2 \mathrm{HSV}$ - $1728.93 \mathrm{mb}$ (N.ZN) THLESHELD: 12,83 MEV

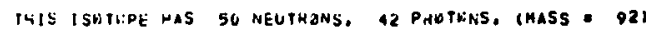

neutain eacess paraheten = .08640

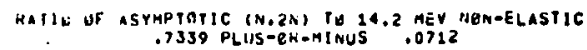

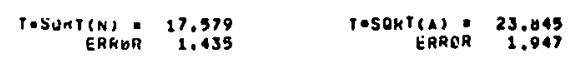

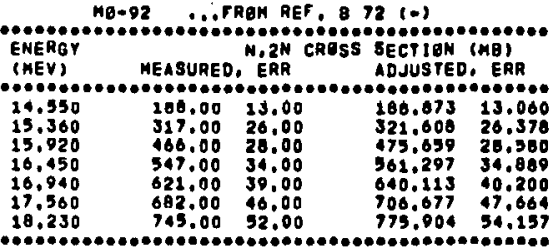

\section{FitTED papame ters}

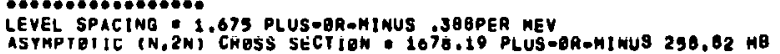

\section{RELATED UATA}

NOA-ELASTIC CRESS SECTION AT 14,2 MEV - 1728.53 MB (N,2N) THRESHGLD: 12.83 MEV
(N, SN) THRESHQLD : 23.02 MEV

this isetape has 50 neutrens. 42 pretans, (mass - 92)

NEUTRQN EXCESS PARAMETER : .00090

RATIU OF ASTMPPOTIC (N,2N) TO 14.2 MEV NON-ELASTIC

$$
\begin{aligned}
& .9109 \text { PLUS-ER-MINUS ,1497 } \\
& 29.851 \quad \text { A/SPACING } \\
& 0.94 .925
\end{aligned}
$$

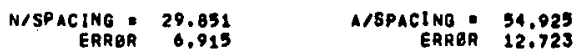
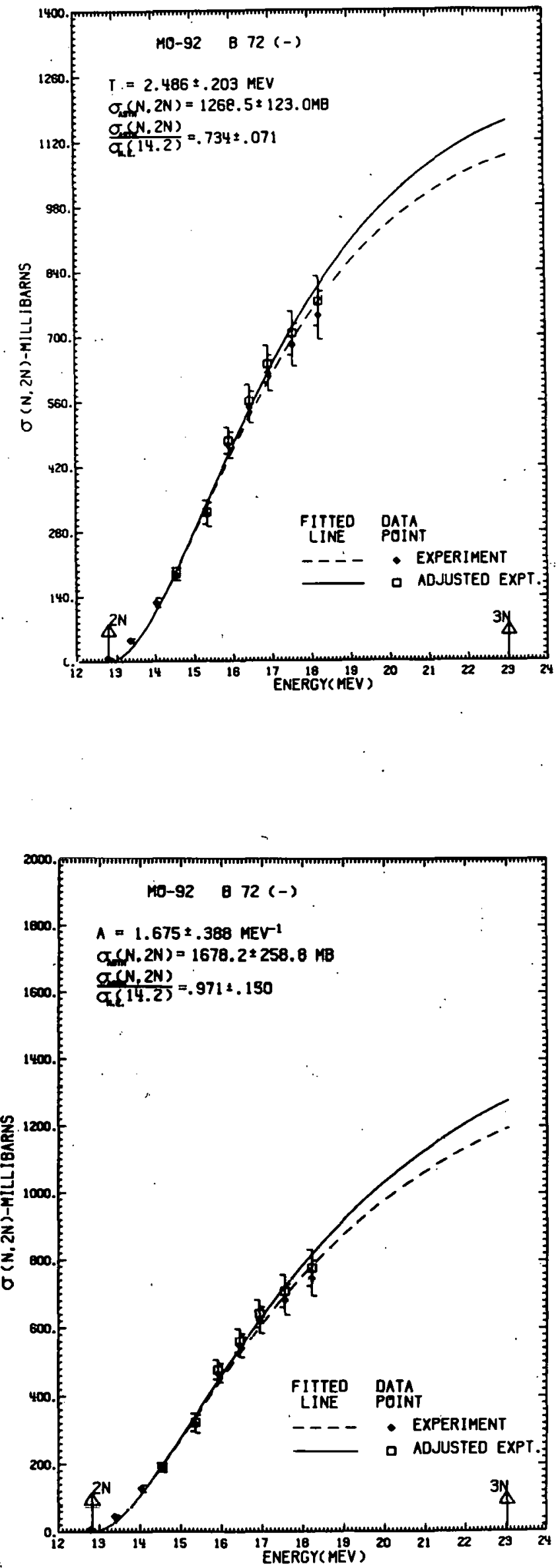


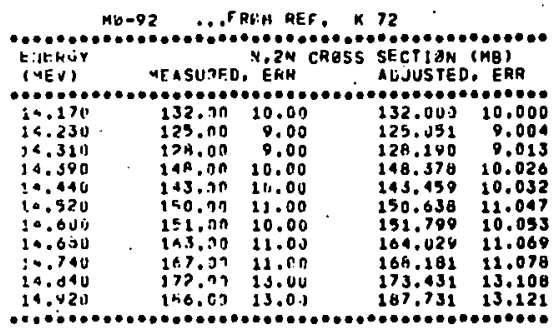

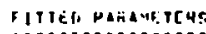

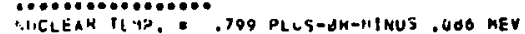

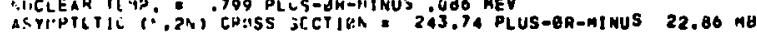

HéLATHL LATA

Iit.-ELASTIC CFASS SECTIUL AT 14.2 MEV $=2726.33 \mathrm{MB}$

(A.2.V) PHFESHYLD: 12.83 MEV

TAIS ISATHDE HAS SO MEUTGONS. 22 PROTONS, IMASS - 921

DEUTAMA EXEESS PARAHEIER = .08606

HATIO OS ASMPTATIC (N.2N) TO 14.2 MEV NON-ELASTIC .1410 PLUS-ER-NINIUS .0132

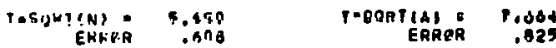

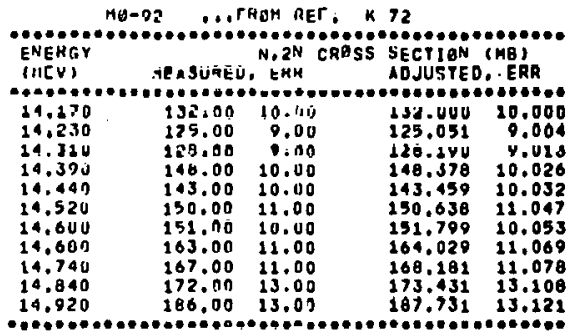

FITTEU PAHAMETERS

CEVE

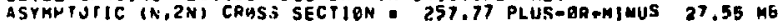

HELATED DATA

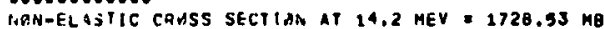

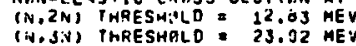

IIIS ISBTUPE HAS 50 NEJTRONS. 12 PAOTONS, IMASS - 92I

NEUTHON EXCESS PARANETER = .08696

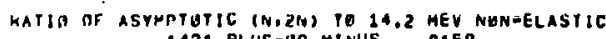
.1401 PLUS HRT $\rightarrow$ MINUS .0150

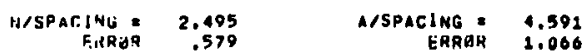
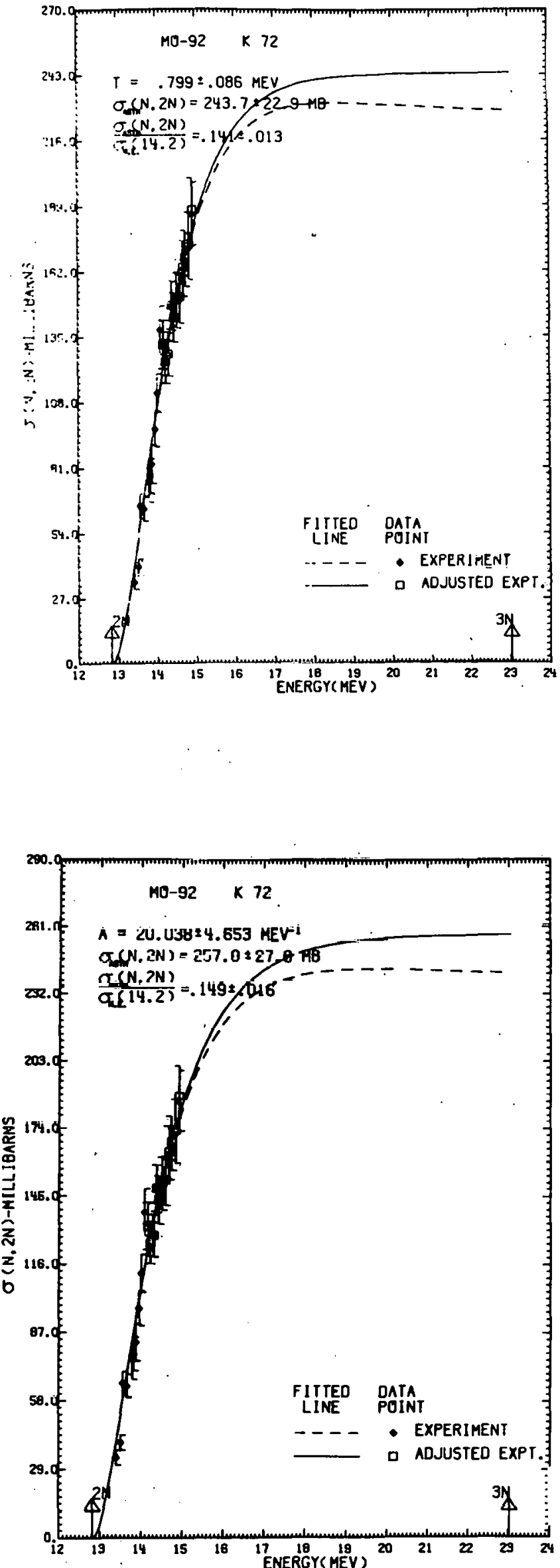


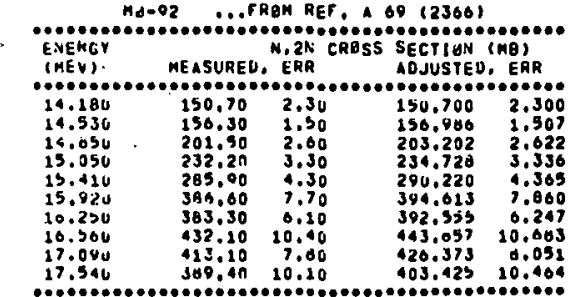

\section{TITED PARAME TEHS}

WUCLEAK ItMP. 1.000 FLUS-8H-MIAUS 2000 MEY

ASYAPTOTIC (N.2N) CHESS SECTIOA j80.94 PLUS-BA-NIMUS 05.72 MB

KELATEJ UATA

NEN-ELASTIC CRPSS SECTIORE AT 24.2 HEV = $1726.53 \mathrm{Mg}$

(N, 2N) THLESHAL. S 12, , AS MEV

TMIS ISOTLPE haS 50 NeUtKuns, 42 PROTUNS, (MASS - 92 )

MEJTHON ERCESS PaRAMETER $=.00090$

MATIE OF ASYMPTHTIC (N,2N) IE 14,2 NEV NOMOELASTIC .3396 PLUS-8K-MIAUS .0440

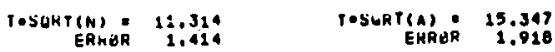

FITTED PARAMETERS

LEVEL SPACING

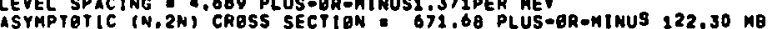

\section{AELATEO DATA}

NQN-ELASTIC CABSS SECTION AT 14,2 MEV 21728,53 hB (N.2N) THAESHGLD: 12,83 ME

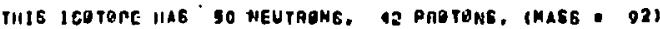

NEUTHON EXCESS PARAMETER - .00600

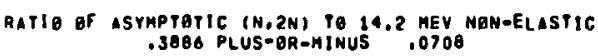

N/SPACING
ERROR
10.663
3.118
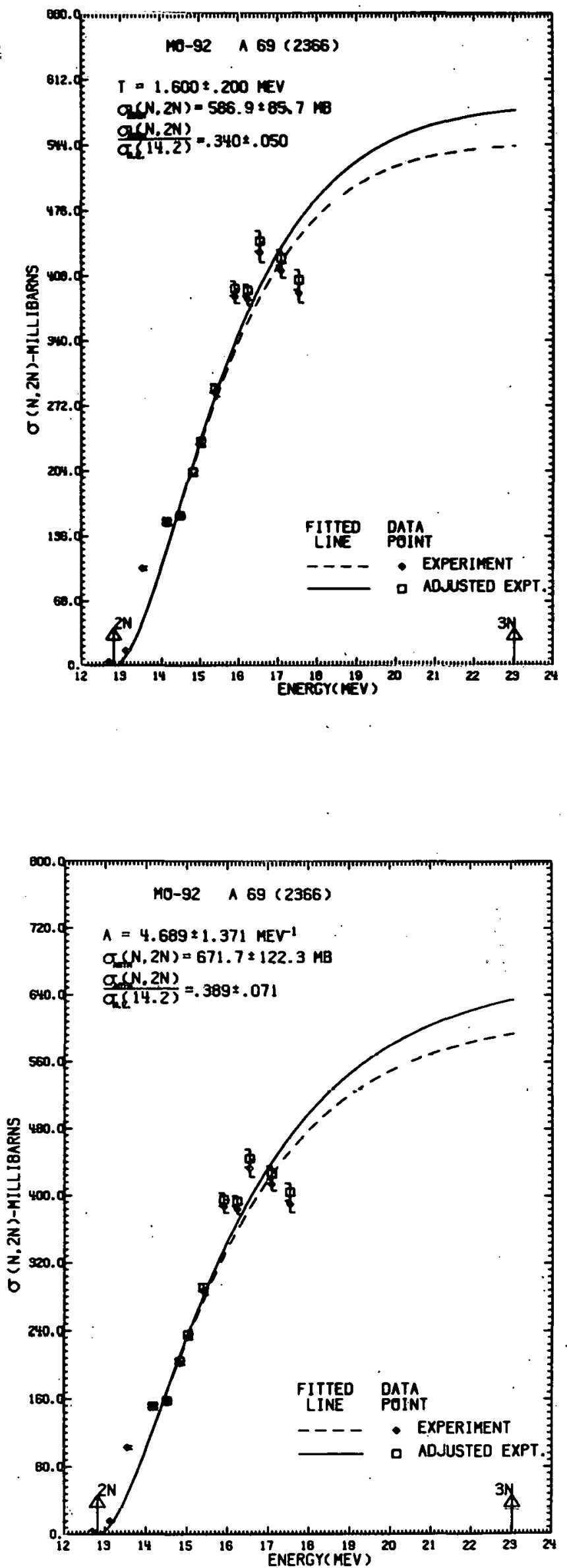


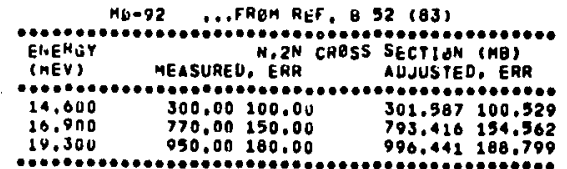

\section{Fitieu pahameters}

NUCLEAK TEHP. = 1.734 PLUS-OKH-MINUS .10S MEV

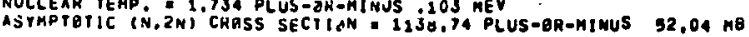

RELATE UATA

NGWVELASTIC CRESS SECTION AT 14.2 MEV = $1728.53 \mathrm{mo}$ $(N, 2 N)$ THLESHRLP : 12,83 MEV
(N.3N) PHTESHALD : 23.02 MEV

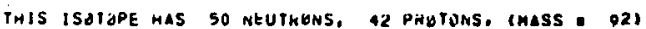

loEUTHE. EXCESS PaRAMETER . 08696 KATIIS OF ASYMPTETIC (N.2N) IO 14.2 MEY NON-ELASTIC
.6588 PLUS-GR-MINUS .0JOL

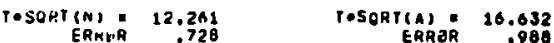

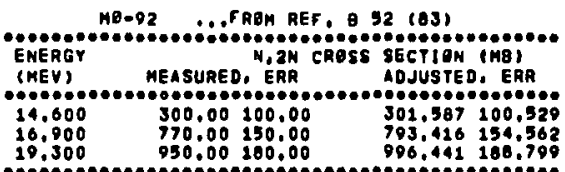

FITTED PARAMETERS

LEVEL SPACING - 4.294 PLUE-OR-MINUS . BBQPEA MEV

ASYMPTETIC (N. 2N) CAESS SECTIGN = 1237,15 PLUS-OA-MINUS 112, 77 MO

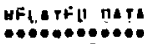

NON-ELASTIC CROSS SECTION AT 14,2 MEV 1726.53 MB

(N,2N) THRESHGLD: 12.83 MEV

THIS ISOTOPE HAS 50 NEUTRONS, 12 PROTONS, (MASS: 92 )

NEUTRON EXCESS PARAHETER = .08690

RATIO OF ASYMPTETIC (N,2N) TO 24.2 MEV NON-ELASTIC , 7273 PLUS-OR-NINUS , 065

N/SPACING 21.644 A/SPACING 21.425
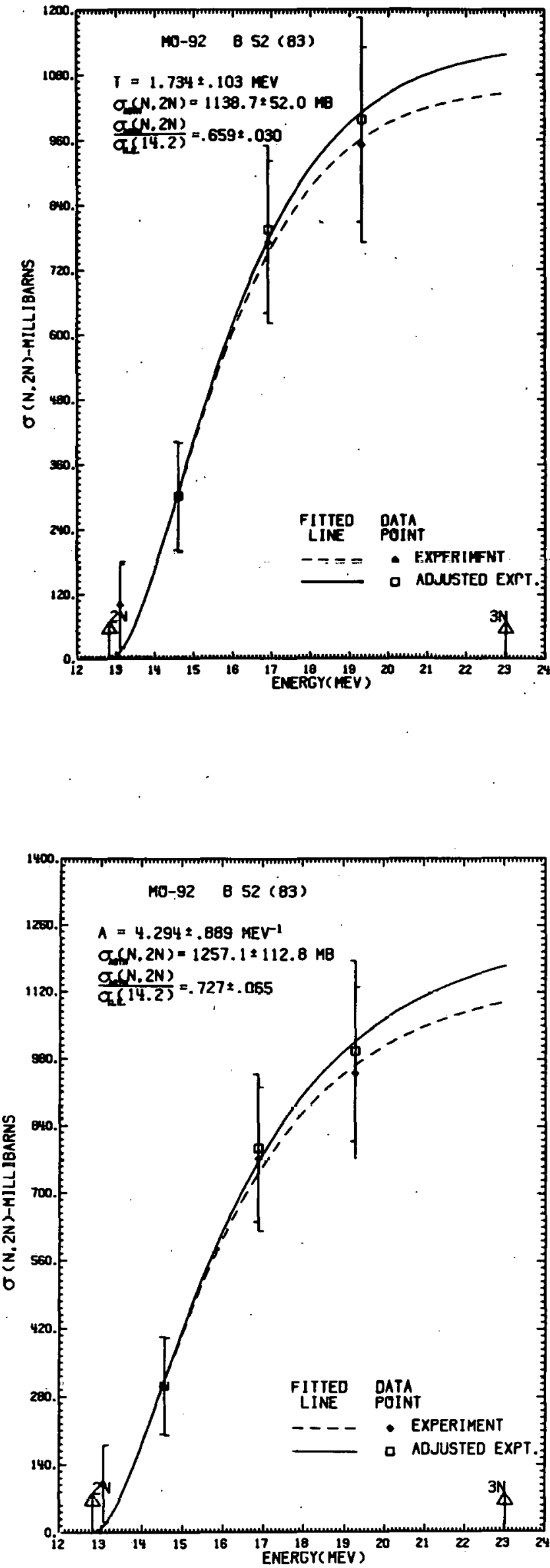


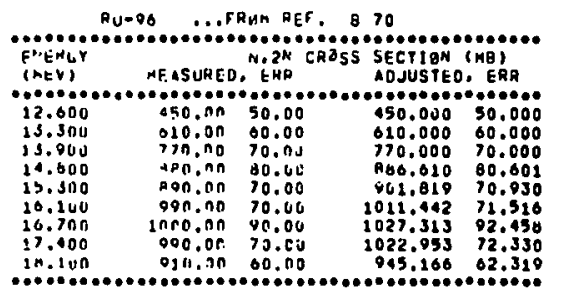

FITTED PAHAMETERS

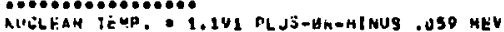

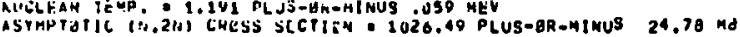

\section{I:ELATEU DATA}

NEN-ELASIIC CaOSS SECTIGN AT 14.2 MEV 1702.10 No

(N.LN) THKESHVLU 10.01 MEV

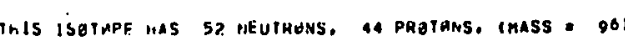

NEUTHAN EXCESS PARAYETEH . .0O33J

HATIO AF ASYMPIETIC ( $W$,ZN) TE 14.2 MEV NUN-ELASTIC S625 PLUS-JR-ALWUS .0141

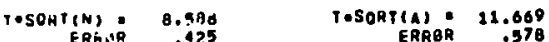

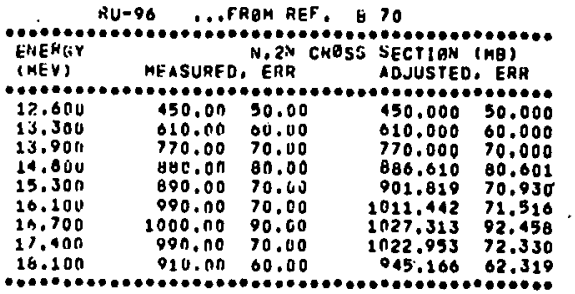

FITTEC. PAPAHETERS

LEVEL JPALING: 0.745 PLUS-OK-HINUST, 002PER MEY

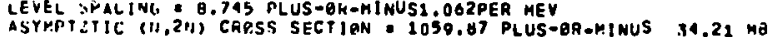

RELATED UATA

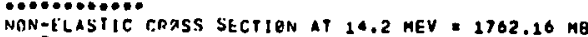

(a.SN) THAESHCLD.

(M.2N) THKESHCLD: 10.01 MEV

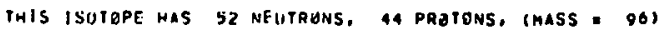

MÇUTKHA EXCESS PARÁMFTFE, .0B333

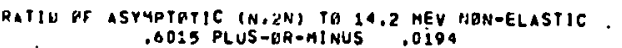

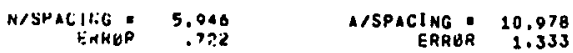
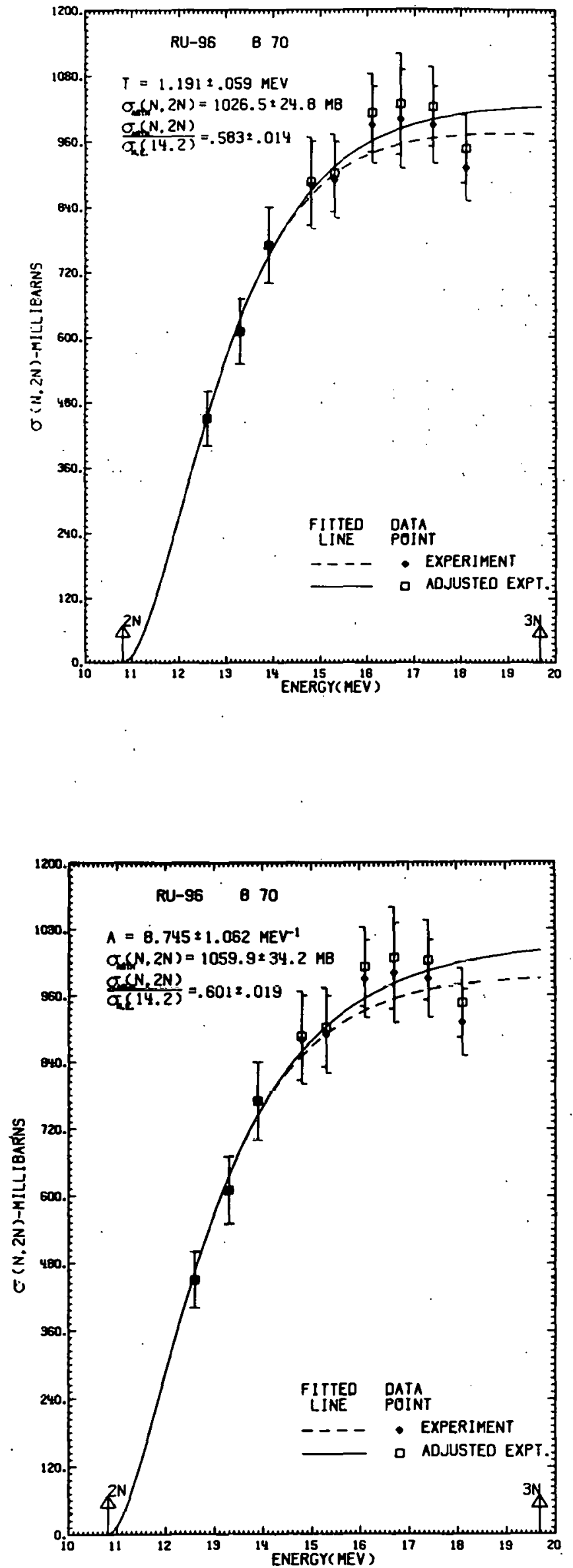


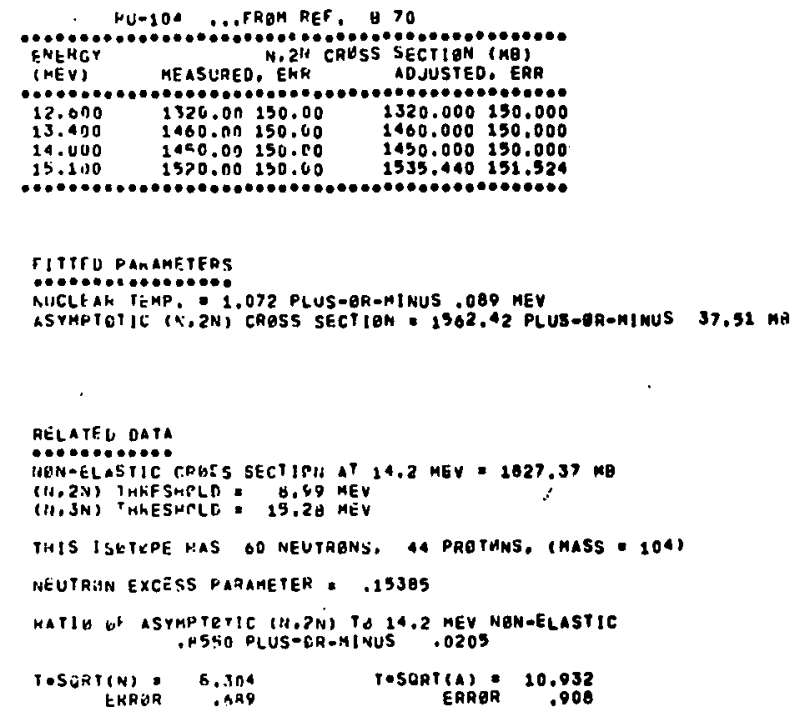

FITTED PARANETERS

LEVEL SPACING O1U.144 PLUS•GR-MINUS1.867PER MEV

ASYMPTATIC (N.2N) CRESS SECTIBN $1594,7_{0}$ PLUS-UR-MINUS $16.98 \mathrm{ME}$

HELATYT J DATA

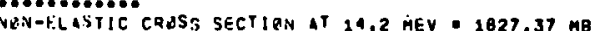

(N,2N) IHRESHPLO $=6.34$ MEV

THIS 1SKTOPE HAS OU NEUTRENS, A4 PRETONS, (MASS - 104 )

NELTKON EACESS PARAFETEM = .15385

RATIS OF ASYAPTOTIC (N,2N) TO 14.2 MEY NON-ELASTIC

$$
. A 727 \text { PLUS:BR=MINUS } .0268
$$

N/SPACING: 5.315 ANSPACIMG 10.252

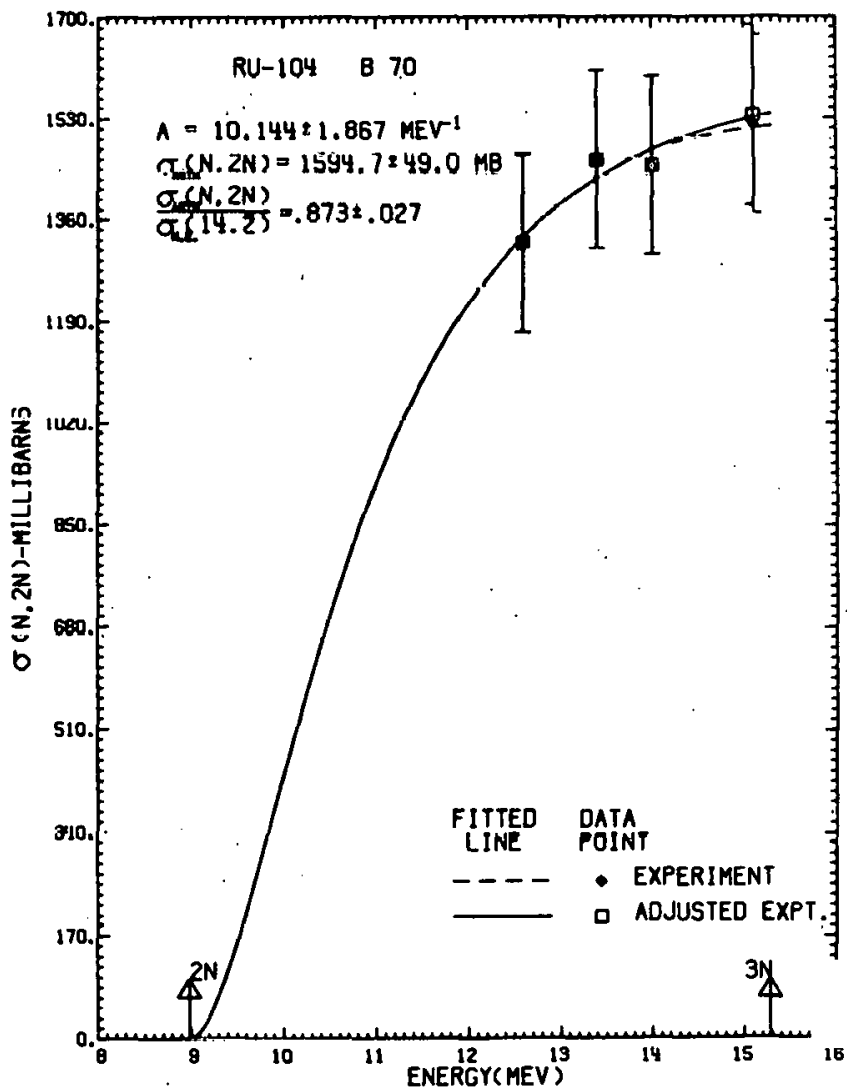




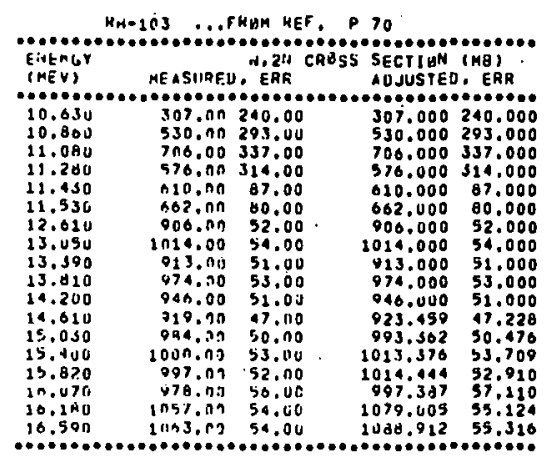

Fitiev paAamf tFes

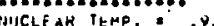

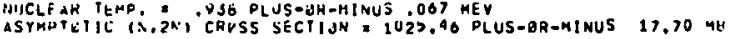

HELATED TATA

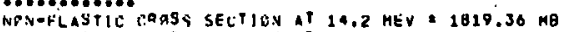

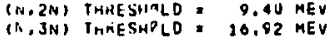

IHIS ISOTCPE MAS 56 MEUTRQNS, 45 PROTINS, (HASS 103 )

hiEUTHUK EXCESS PAQAMETER = .12021

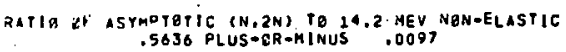

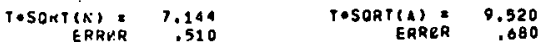

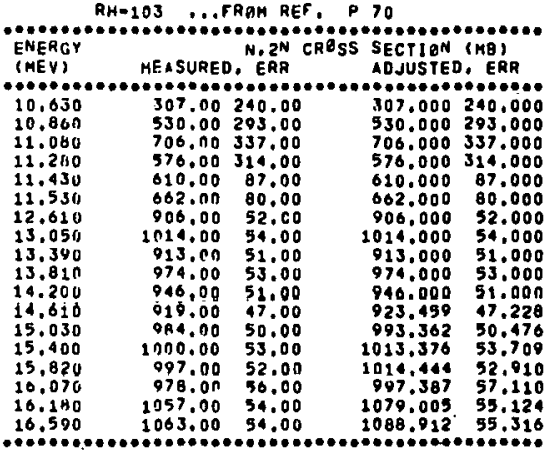

FITTEU PARAMETERS

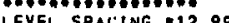

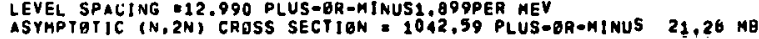

RELATEO DATA

NON-ELASTIC" CRBSS SECTION AT 14.2 MEV = 1810.36 MB.

(N.2N) THRE SHALE: 9.40 MEV

THIS ISUTOPE HAS 5O NEUTRENS. 45 PRATONS, (MASS - 103)

NEUTHEN EXCESS PARAMETER = .12621

RATIY OF ASYMPTOPIC (N,2N) TO 14.2 MEV NON-ELASTIC .5731 PLUS-BR=MINUS .0117

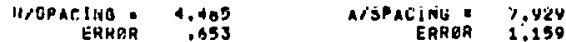
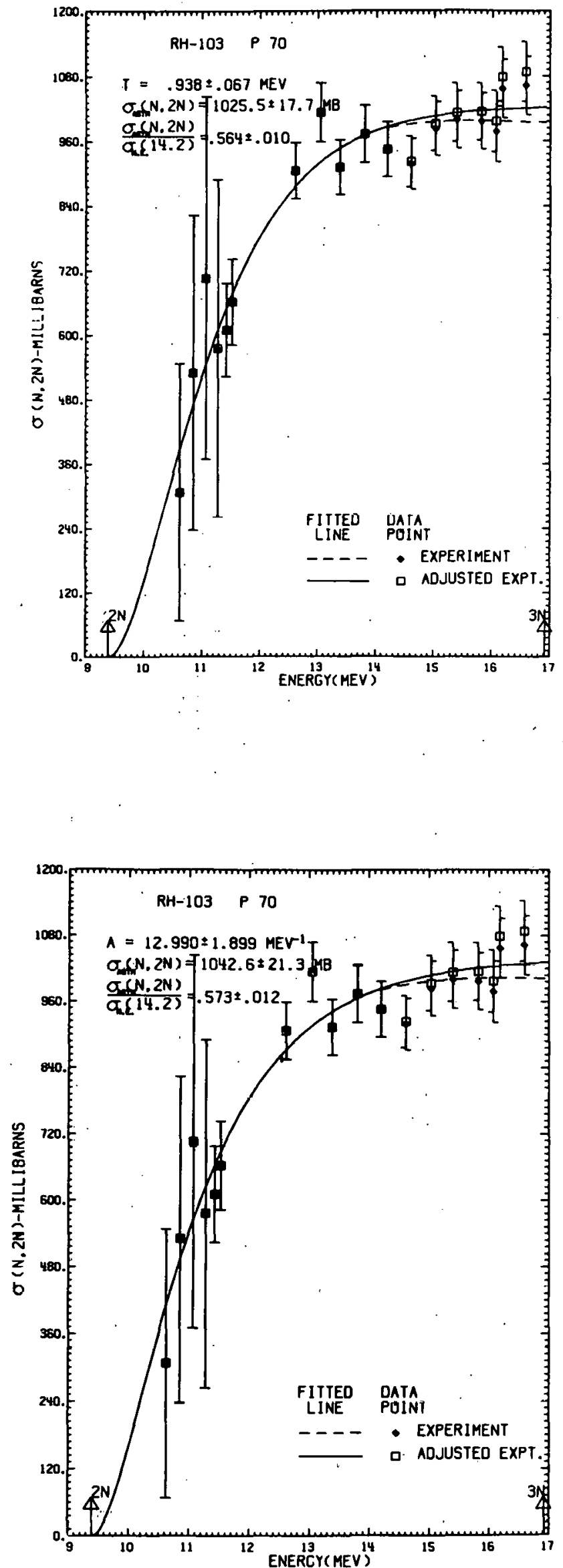


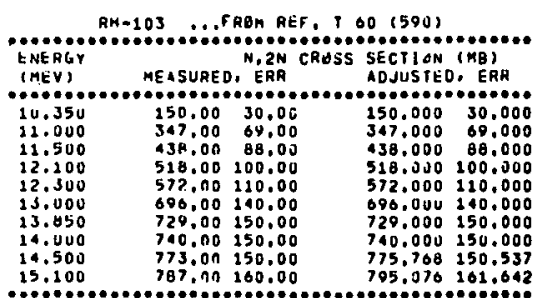

\section{FITTED PAHAMETERS}

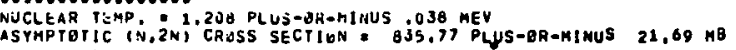

RELATED DATA

MEN-ELABSTIC CROSS SECTIOAN AT 14.2 MEV $=1819.36$ MB

(N,ZN) TARESHRLD: 9,40 MEV

(N,2N) TAARESHRLD: 9,40 MEV

IMIS ISUTUPE haS 58 NEUTRUNS, 95 PRUTUNS, (MASS - 103)

NEUTRUN EXCESS PARAMETER = .12621

HATIO OF ASYMPTUTIC (N.2N) TO 14.2 NEY NON-ELASTIC .4594 PLUS-OR-MINUS .0119

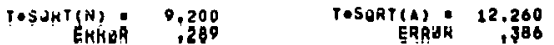

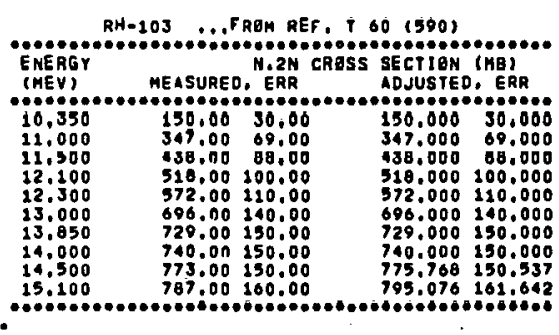

FIITED PARAMETERS

IEVEL SPACING

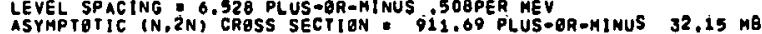

RELATED DATA

NON-ELASTIC CRESS SECTION AT 14.2 MEV = 1010.36 ME

(N,2N) THRESHTLO : 9,40 MEV

(N. JN) THRESHELD $16: 92$ MEV

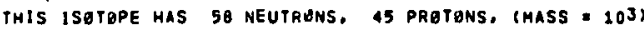

NEUTROA EXCESS PARAMETER - .12021

RATIO OF ASYMPTOTIC (N.2N) TO 14.2 MEY NON-ELASTIC .5011 PLUS-BR-MINUS .0177

N/SPACING $6.885 \quad$ A/SPACING $=13.778$
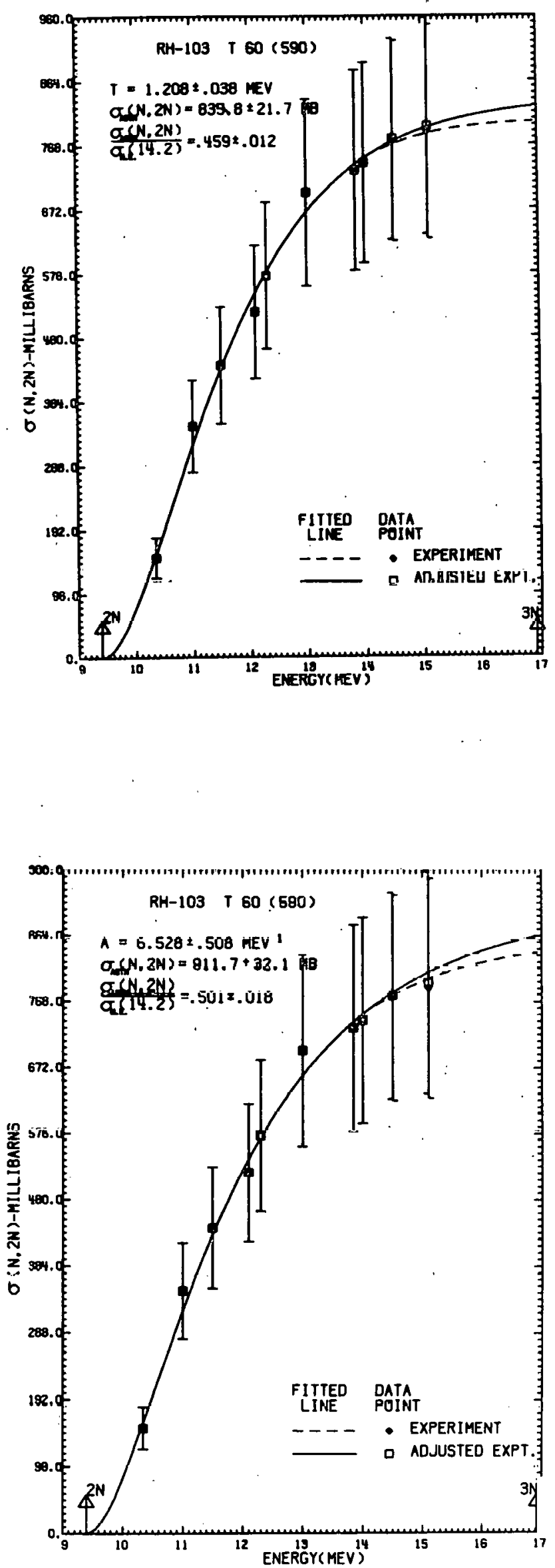


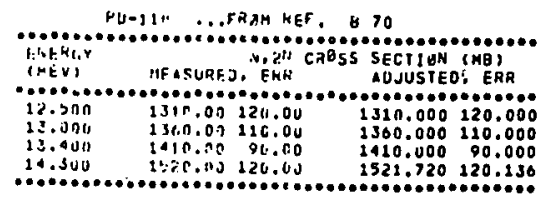

bitron miniameteks

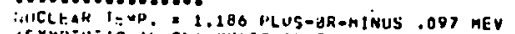

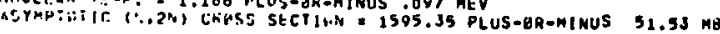

WELATED ULPA

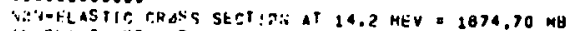

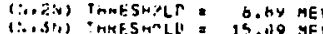

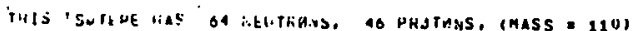

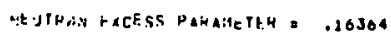

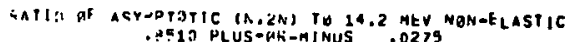

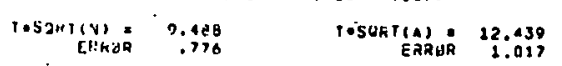

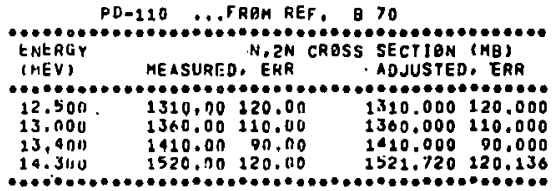

FITILD PARAMETEPS

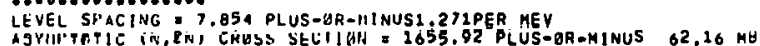

RELTED DRTA

NON-ELASIIC CROSS SECTIHN AT 14.2 MEV $=1874.70 \mathrm{MB}$

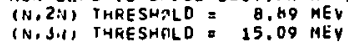

THIS ISMTUPE HAS OA NEUTRONS. 46 PRATENS. (MASS - 120)

M.UTHIIT EXCESS PARAMETER = .16 .364 PATIB AT ASYMPTETIC (N.2N) TO $24 . Z$ MEV NON-ELASTIC
.PBS3 PLUS-GR-MINUS .0332

$\begin{array}{ll}\text { HSPACIRG } & =0.149 \\ \text { EKHUK } & 1.319\end{array}$

1/SPACINGE 14.0NG
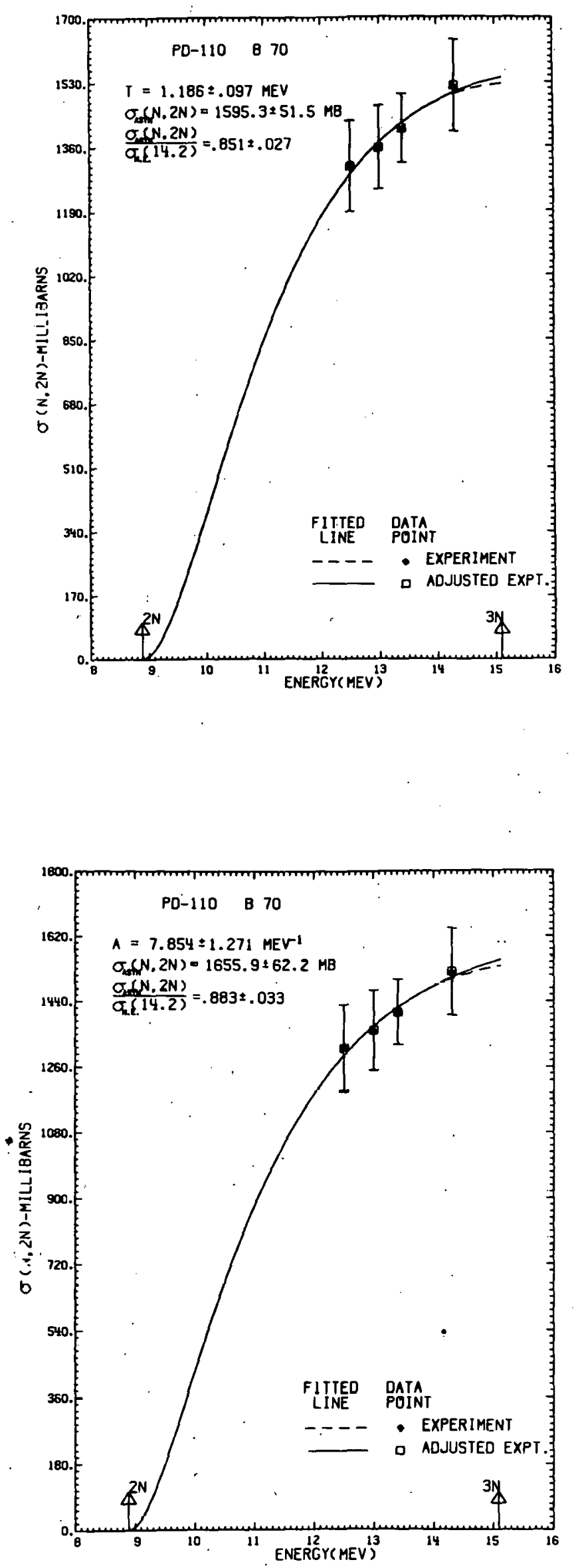


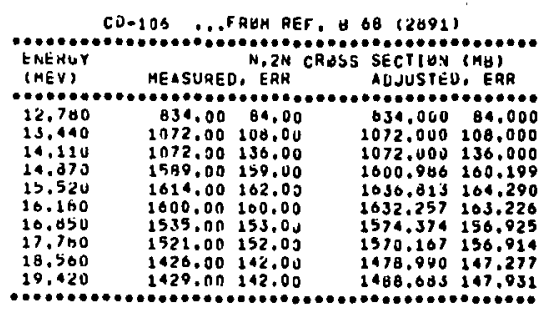

FITTEL PANAMETERS

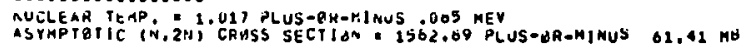

HELATED LATA

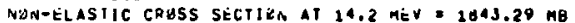

(N,2N) TANESHaLO: 11.02 MEV

IHIS ISOIJPE HAS SO NEUTHENS. AO PHATONS. (MASS = 100)

nEUThai EXEESS PAMAMETCR - .09434

WATIO OF ASYMPTOTIC (N.2V) IU 14.2 MEV NON-ELASTIC
.9587 PLUS-OK-HINUS

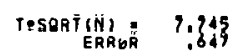

BOSURT(A) 20.412

FITTED PARAMETERS

LEVEL SPACING 12, 464 PLUS-OR-HINUS2, 261 PER MEV

LEVEL SPACTNG 112,464 PLUS-GR-MINUS2,201PER MEV
ASYHPTOTIC (N,2N) CRESS SECTION = 1007.19 PLUS-GR-NINUS 70.90 NO

MEL PTEO NATA

NON-ELASTIC CRESS SECTION AT 14.2 MEV = $1843.29 \mathrm{MB}$

(N,2N) THRESHQLD: 11.02 MEV
(N,3N) THRESHOLD : 19,60 MEV

THIS ISOTOPE HAS SB NEUTRONS, 48 PROTONS, (HASS = 206 )

MEUTRON CXCESS PARAHETER - .09434

RATIO OF ASYMPTATIC (N, ZN) TE 14,2 MEV NON-ELASTIC .0710 PLUS* UH-MINUS , OJGS

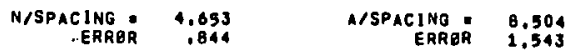




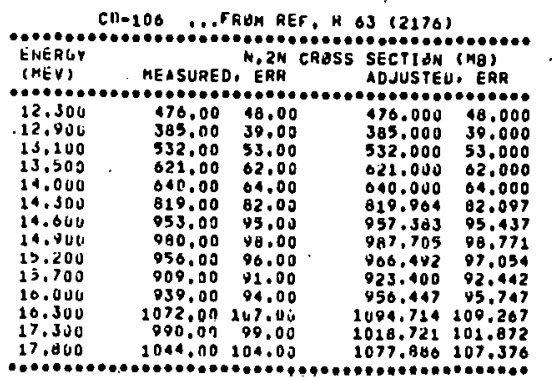

Fitteu pahameters

SUCLEAR TEMP. 1.280 PLUS-GH-NINUS IA9 MEV

ASTMPTQTIC (N.2N) CRDSS SECTIUN 1101.52 PLUS-OR-NINUS $92.99 \mathrm{KH}$

RELATED VATA

NBN-ELASTIC CRBSS SECT1ON AT 14.2 MEV $=1843.29 \mathrm{MB}$

(N, 2N) TMRESHOLD: 11.02 MEV
$(N, 3 N)$ THKESHALD 19,60 MEV

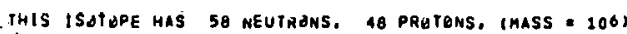

NEUTHEN EXCESS PARAHETER : .00434

RATIS EF ASYMPTETIC (N,2N) TH 14,2 MEY NEN-ELASTIC

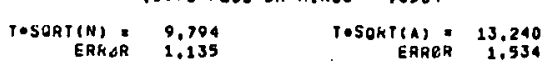

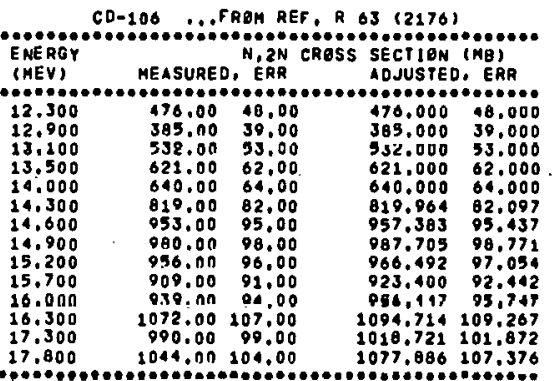

FITTED PARAMETERS

LEVEL SPACING ; 206 PLUS-OR-MINUS1. O1BPER MEV

LEVEL SPACING =7.206 PLLUS-OR-AINUS1.016PER MEV

RELATED DATA

NON-ELASTIC CROSS SECTION AT 14.2 MEV $2843.29 \mathrm{MB}$

(N,ZN) THEESHOLD : 11,02 HEV

THIS ISOTOPE HAS 58 NEUTRONS. 48 PROTONS, (HASS - 206)

NEUTREN EXCESS PARAMETER = .09434 HATIG OF ASYHPTETIC (N.2N) TE 14.2 MEY NON-ELASTIC
.6320 PLUS-OQ-HINUS

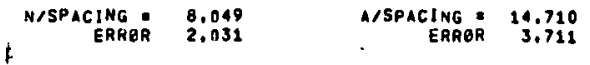
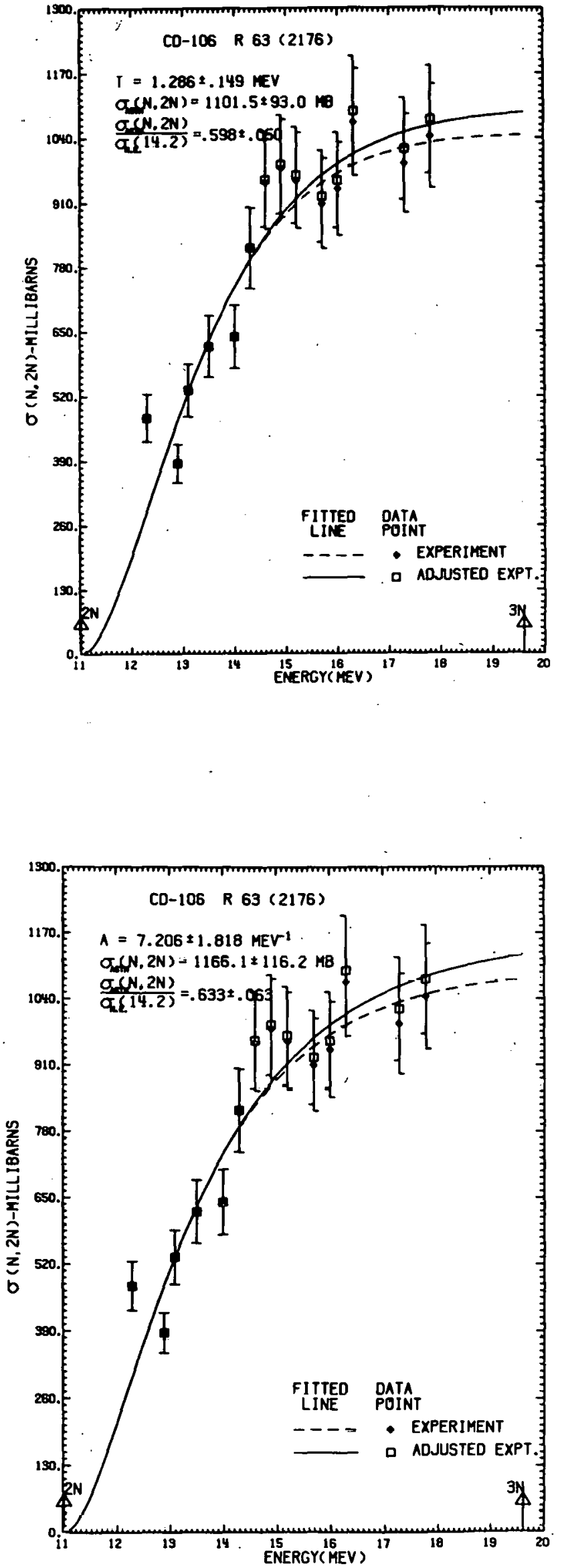


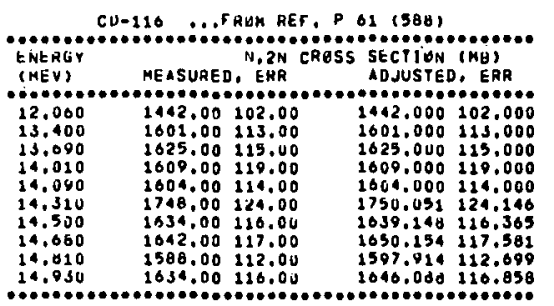

5itTEU pamaMETERS

MUCLEAR TEKP, .933 PLUS-OH-MIMUS 070 MEY

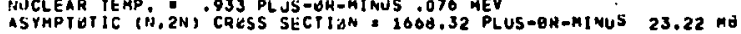

RELATEU UATA

NAN-ELASTIC CAOSS SECIIQN AT 14.2 MEV $=1920.03 \mathrm{MO}$

(N),2N) TMHESHELD: 2.77 MEV

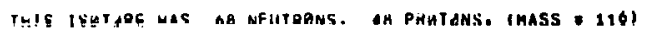

NEUTKOAN EXCESS PARAMETEQ : .17241 HATIA OF ASYMPTETIC (N,2N) TU 14.2 MEV NUN-ELASTIC
.86B5 PLUS-GR-MINUS ,0121

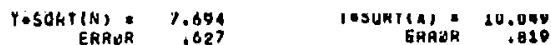

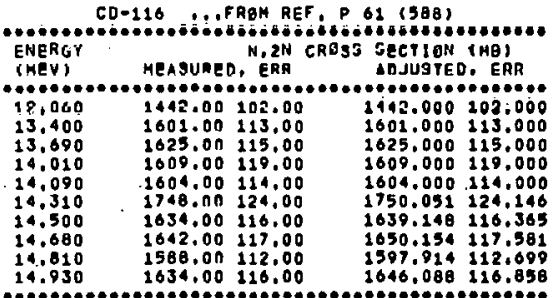

FITTED PARAHETERS

LEVEL SPACING 13,224 PLUS $-0 R-M I N U S 2,363 P E R$ MEV

LEVEL SPACING 13,224 PLUS-OR-MINUS2,362PER MEV
ASYMPTETIC $(N, 2 N)$ CROSS SECTION 1689,34 PLUS-OR-MINUS $30.68 \mathrm{MB}$

RELATED DATA

NEN-ELASTIC CRESS SECTION AT 14.2 MEV $=2920.03$ MB

(N.2N) THRESHELD: 8.77 MEV
(N.3N) THRESHALD: 14.97 MEV

THIS ISOTOPE haS 6 B NEUTRENS, 48 PRETUNS, (MASS : 116)

NEUTREN EXCESS PARAHETER - .17241

RATIO OF ASYMPTOTIC (N.2N) TO \$4,2 MEV NENAELASTIC

$\begin{array}{rrrr}\text { N/SPACING } & 5.142 & \text { A/SPACING } & 8.772 \\ \text { ERRGR } & .918 & 1.567\end{array}$
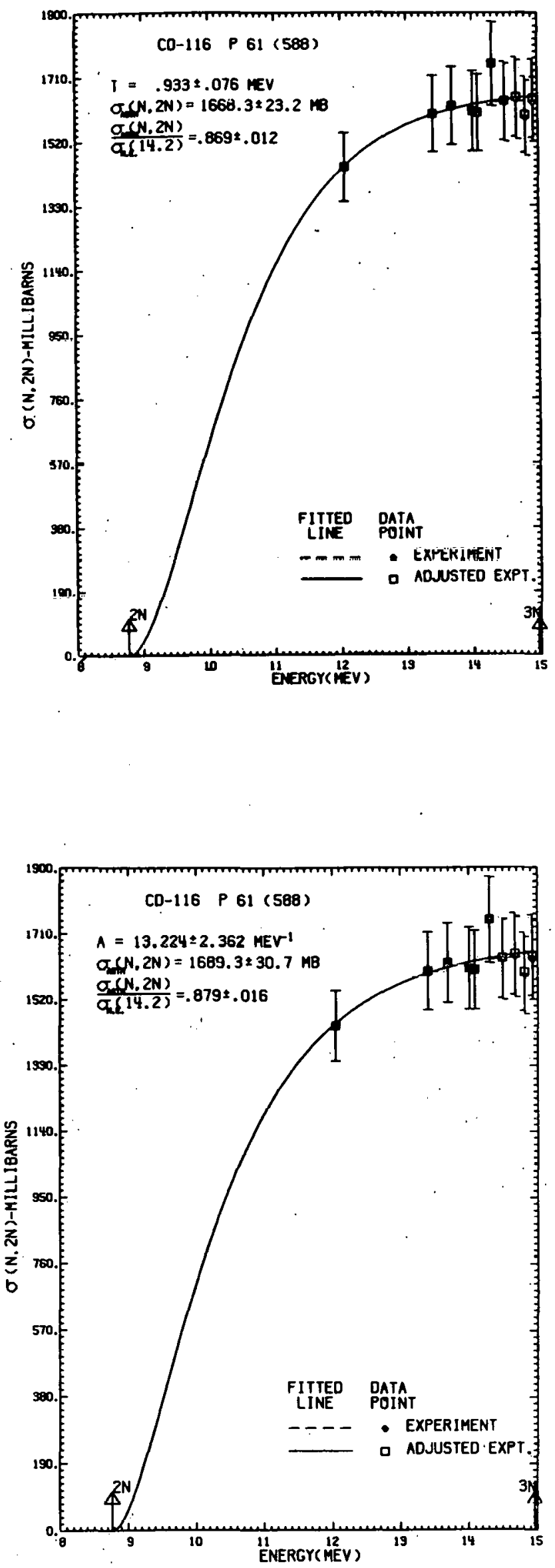


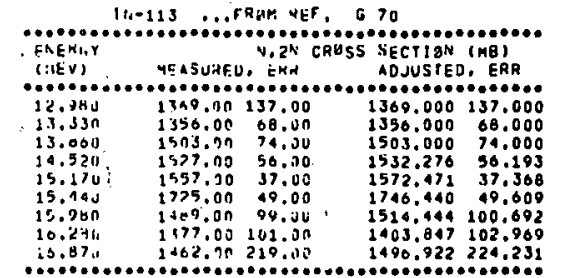

Hitrol maitamiters

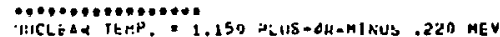

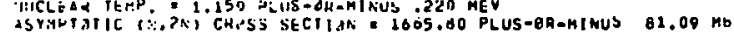

BELATLD IIRTA

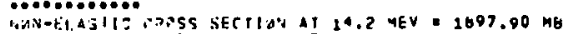

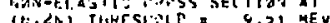

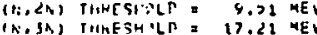

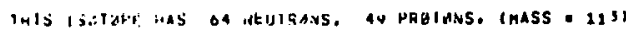

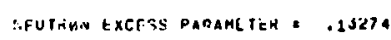

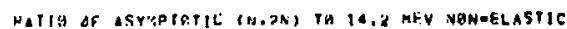
, $\rightarrow 17$ PLUS-HA-M1KUS . . V42?

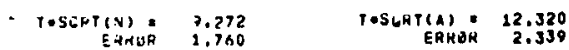

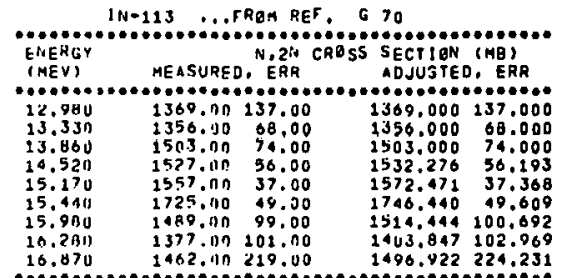

TITTE PAPAMETERs

LEVËL STACING Q. 3 S PLUS-gR-MINUS3.93OPER MEV

ASYMPTITIC (N, ZH) CROSS SECTIGH = 1700.85 PLUS-OR-AINUS 110.37 HB

PELATR.D UATA

OAOA.COB.

NÜU-LLASTIC RQAMS SËCTIMN AT

(1,3H) THKESHALD = 17.21 MEV

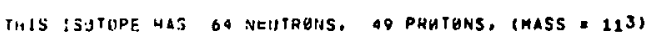

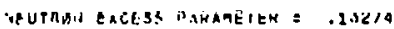

RATIN OF ASYAFTETIC (N.ZN) TU 14.2 MEV NBN-ELASTIC

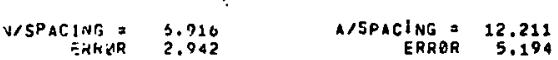
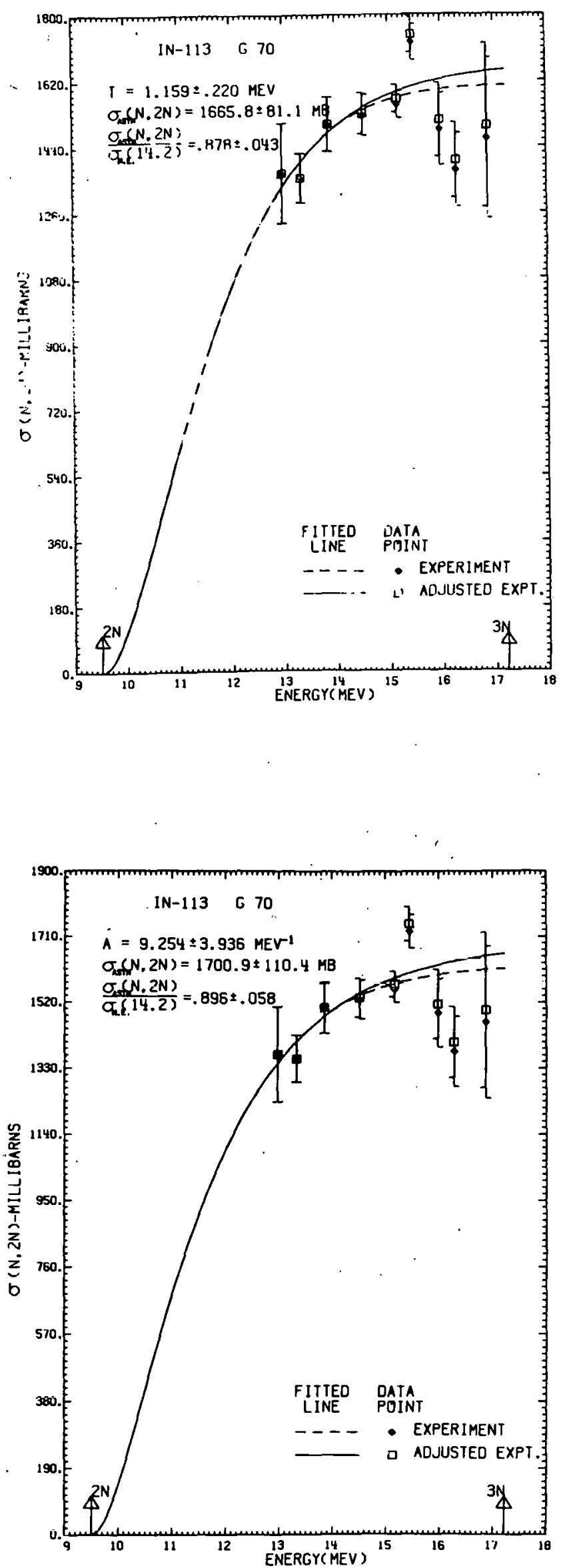
ii-115 W. FRUM RET, G 70

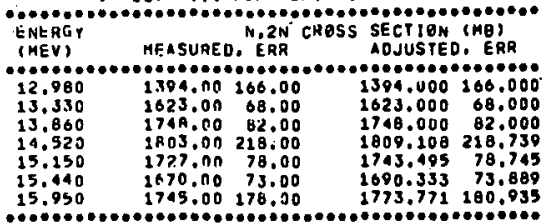

FITTED PARAMETEKS

VUELEAR TERP, 1.021 PLUS-gh-MINUS 161 MEY

ASYMPTaPIC (N.2N) CHESS SECTIUN 1767.09 PLUS-OR-HINUS 30.22 MG

NELATEOO DATA

NGN-ELASTIC CRPSS SECTIUN AT 14.2 MEV $=1913.22 \mathrm{MB}$ (N,2N) THAFSHMLD: 9.11 MEV

THIS ISDTUPE HAS DG NTUTRUNS, 99 PROTONS, (MASS - 115)

NEUTHOA EXCESS PARAMETER = .14783

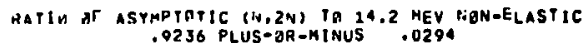

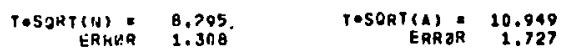

IN-115 W.FRQM HEF, G 70

ENEHGY
EHEVI

FITTED PAHAMETERS

LEVEL SPACING 112,047 PLUS-OR-11INUS4, 27 JPER MEV

ASYAPTATIC (N,2Ni CRIS'SECTIEIA = 1785.17 PLUS-ER-MINÚS 71.96 ME

HELATFII OATA

HEN-EL.ASTIC COESS SECTIJN AT $14.2 \mathrm{NEV}=1913.22 \mathrm{MB}$

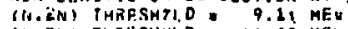

(N.SN) THFESHINLD: 16.48 MEV

THIS ISIJTIPE HAS 60 NEUTRONS. 49 PROTONS. (MASS : 115)

NEUTHUN EXCESS PAPAMETER = .14783

RATIO GS ASYYPTETIC (N.2N) TO ZH.2 MEV NON-ELASTIC

N/SPACING $\quad 5.478$

\begin{tabular}{c} 
A/SPACING \\
ERROA \\
\hline .3466
\end{tabular}
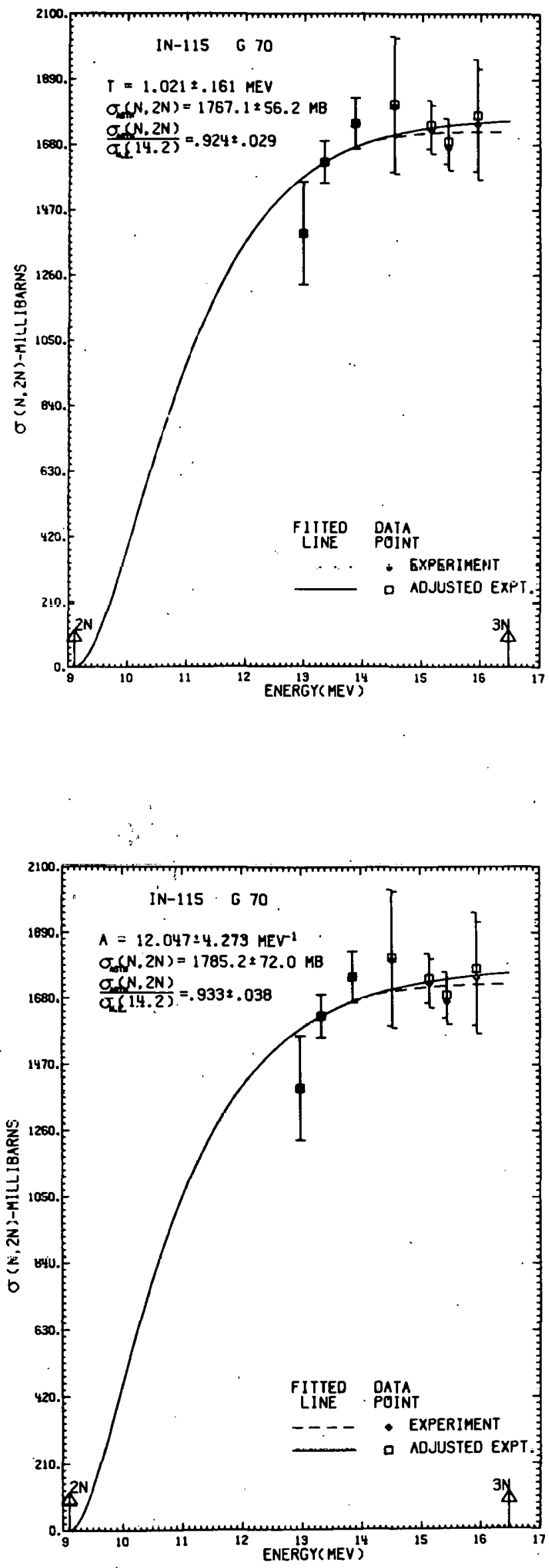


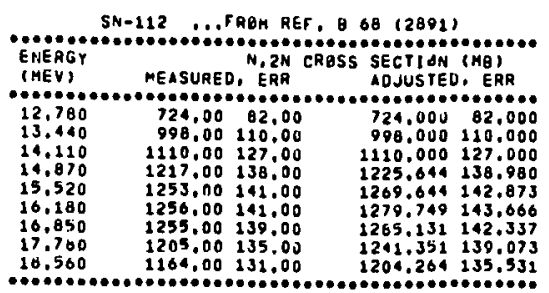

FITTED PARAMETERS

NUCLEA TEKP. . 045 PLUS-ah-HINUS .043 HEV

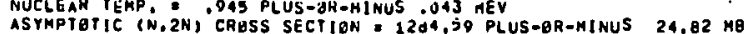

RELATED DATA

NGN-ELASTIC CRESS SECTIEN AT 14.2 MEV = 1890.20 MB

(N.2N) THEESHOLD. 20,90 MEV

(N.2N) THRESHOLD: $20,90 \mathrm{MEV}$
(N.JN). THKESHQLD $19,30 \mathrm{HEV}$

THIS ISOTUPE. HAS 02 NEUTRUNS, SO PRÓTENS, (MASS : 112)

NEUTROA EXCESS PARAMETER = .10714 RATHO OF ASYMPTETIC (N, 2N) TO 24.2 MEV NEN-ELASTIC
.6796 PLUS-BR=MINUS , OIJ1

TOSORTIN)
ERFUR
7.441
.339

SN-112 .. FROM REF, 860 (2801)

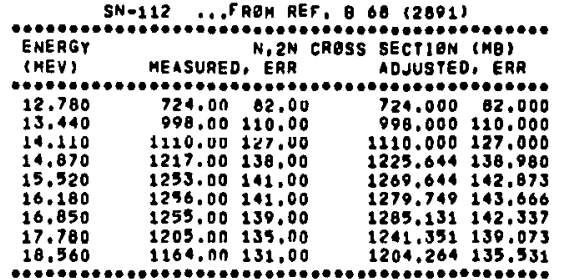

FITTED PARAMETERS

LEVE SPACING

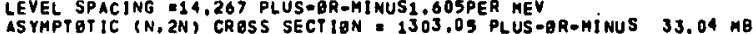

AELATED DATA

NBN-ELASTIC CRESS SECTION AT 14.2 MEV = $1890.20 \mathrm{MB}$

(N,2N) THRESHGLD: 1 M, PO MFV

THIS ISOTOPE HAS O2 NEUTRONS, SO PROTUNS, (MASS 112)

NEUTROH CXEESS PARANETER - .10714

RATIO EF ASYMPTOTIC (N,2N) TO 14,2 MEV NEN-ELASTIC

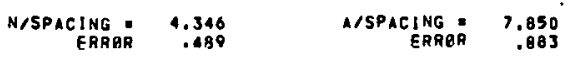
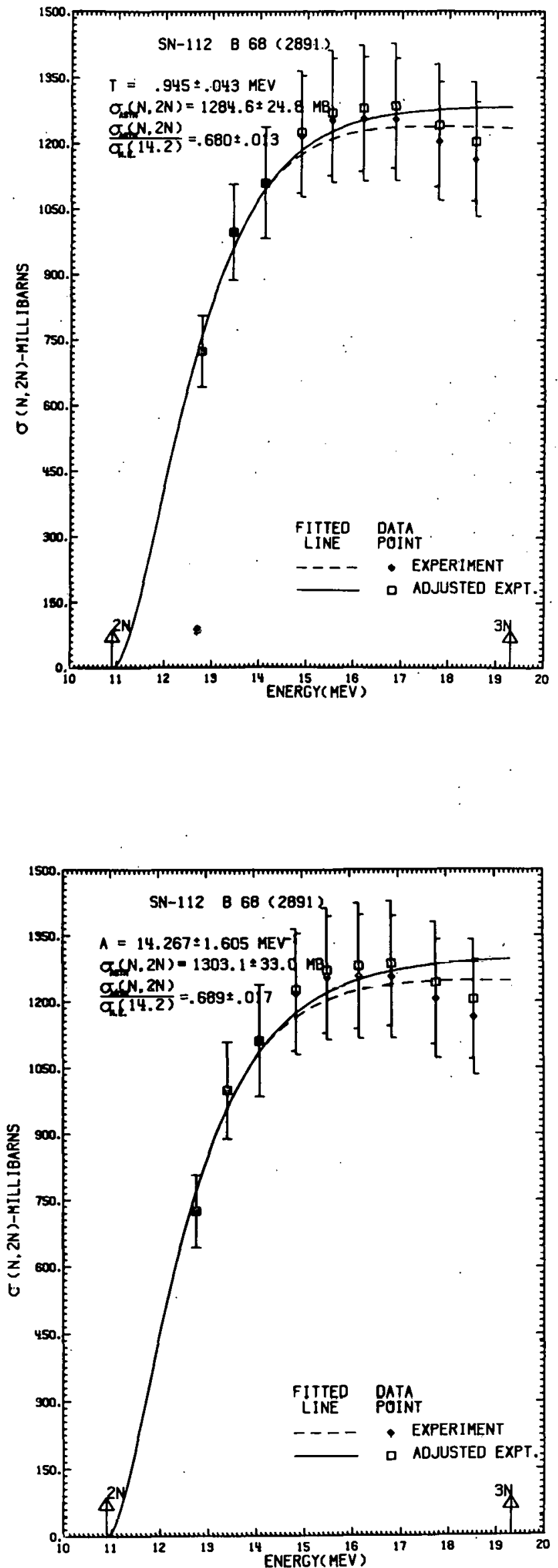


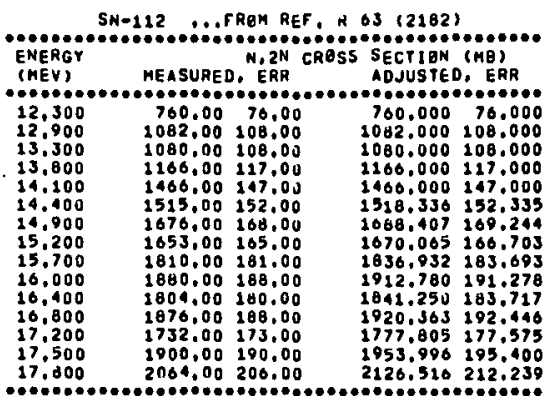

FITTED PARAMETERS

NUCLEAR TEMP. 1.172 PLUS-OR-MINUS . U75 MEV

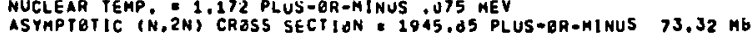

RELATEO VATA

NQN-ELASTIC CROSS SECIION AT 14.2 MEV $=1890.20 \mathrm{MB}$

(N,2N) THAESHQLD $=10,90$ MEV

THIS ISBTUPE has 62 NEUTRONS, SO PRQTANS. (MASS : 112)

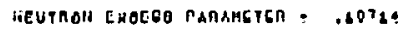

RATIV of ASYMPTETIC (N,2N) TU 14.2 MEY NON-ELASTIC

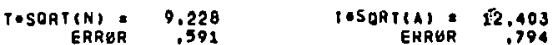

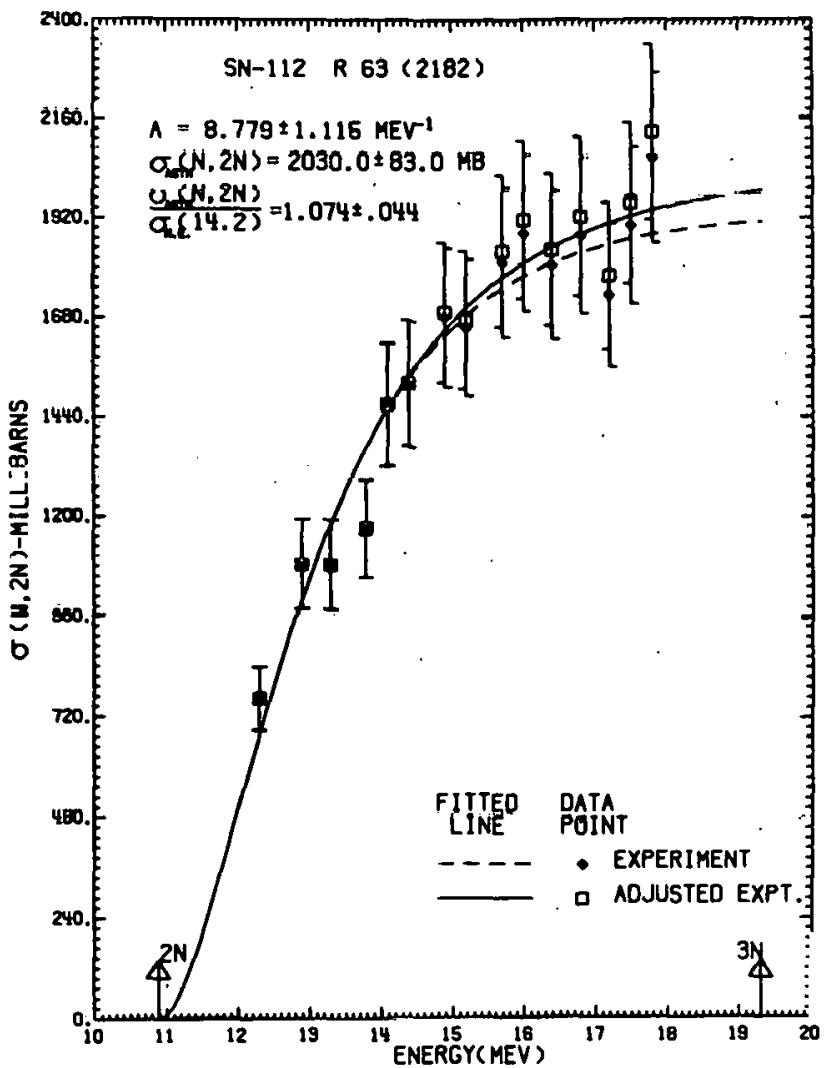

RELATED DATA

NON-ELASTIC CROSS SECTION AT 24.2 MEV $=1890,20$ MO

(N, 2N) THRESHQLD $=10,90$ MEV

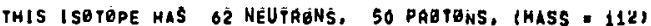

NEUTRON EXCESS PARAMETER - .10714

RATID OF ASYMPYQTIC (N, 2N) TO 14,2 MEV NON-ELASTIC

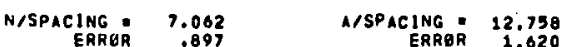

$83.00 \mathrm{MB}$ 
SH-112 ... TREM REF, P 01 (388)

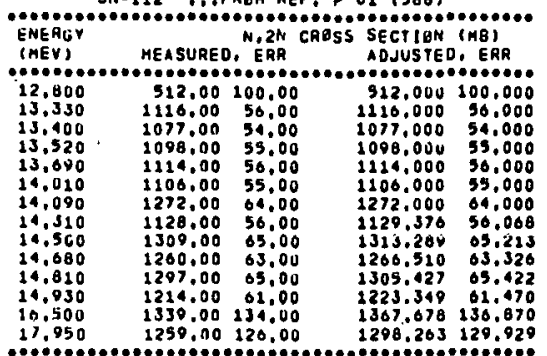

FITTEU PARAMETERS

NUCLEAR TEMP 900 PLUS-RR-MINUS 111 MEV

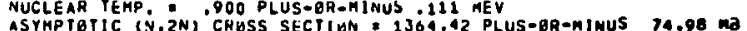

RELAPED DATA

NGN-ELASTIC CROSS SECTION AT 14,2 HEV $=1890.20$ MO

(N,2N) THAESHQLD $=10,90 \mathrm{ME}$

IHIS ISETUPE haS 62 NeUtauns, 30 PHOTUNS. (MASS - 12ZI

neutron EXCESS Parameteh = .10114

RATIO OF ASYMPTBTIC (N,2N) TO 14,2 HEV NGN-ELASTIC .7218 PLUS-GR-MINUS , OSY7

TOSURTSNSE 7.087 TESORT(A) 0.529

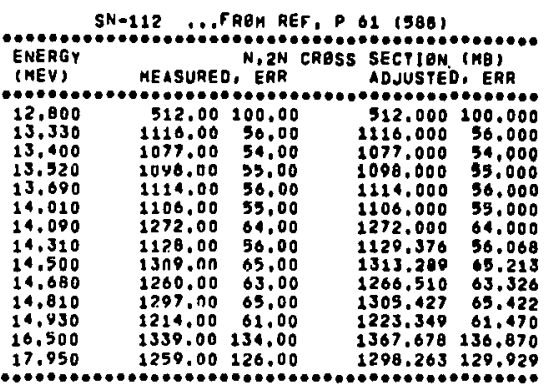

FITTED PARAMETERS

LEVEL SPACING i15.480 PLUS-GR-MINUS4, 110 OPER MEV

ASYMPIOTIC (N, ZN) CROSS SECTION = 1306,35 PLUS-9R-MINUS $90.26 \mathrm{MB}$

RELATED DATA

NON-ELASTIC CRESS SECTION AT 14.2 MEV $=1890.20 \mathrm{MB}$

(N, 2N) THRESHOLO $10,00 \mathrm{MEV}$

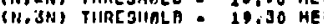

THIS ISOTOPE HAS 62 NEUTRONS. SO PAOTENS, (MASS : 112)

NEUTRGN EXCESS PARAMETER ".10714

RATIO OF ASYMPTETIC (N,2N) TE 14,2 MEV NON-ELASTIC .7367 PLUS-BR-HINUS .0478

N/SPACING $\quad 1.005$ A/SPACING 7,235
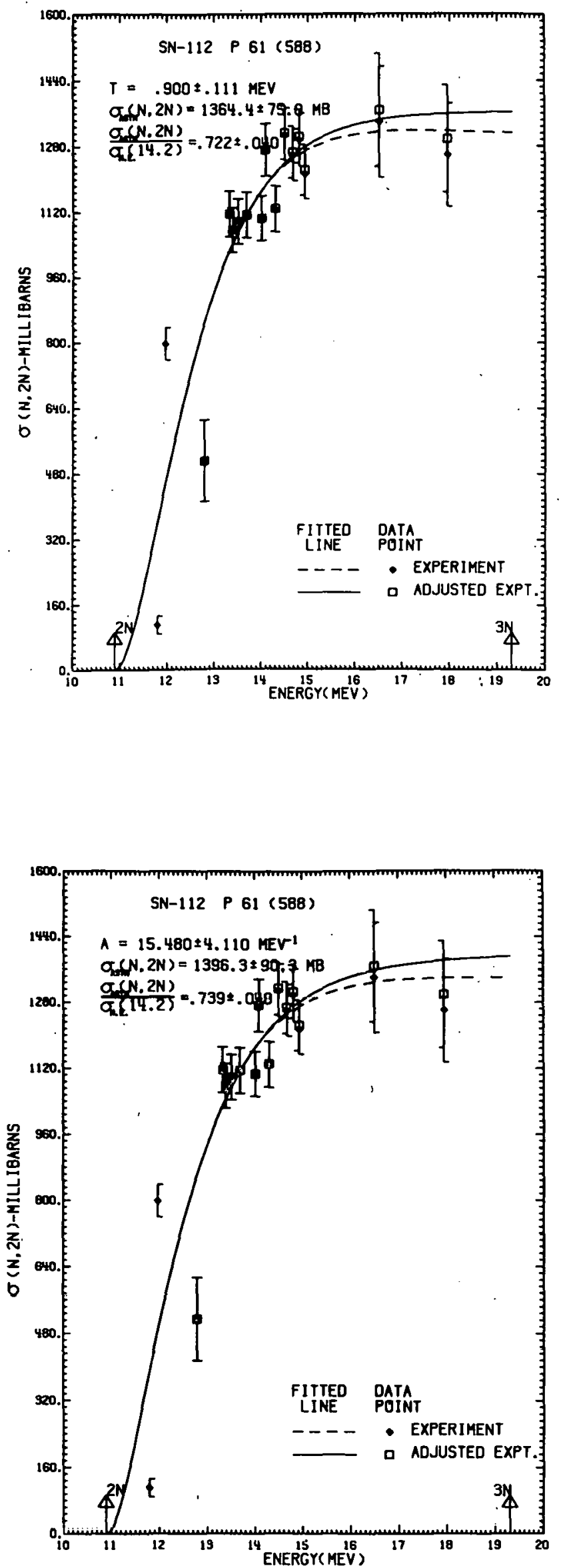


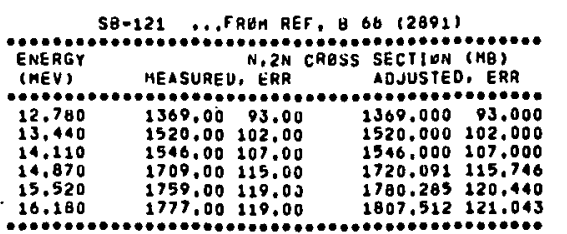

FITIEU PAHAHETERS

NUCLEAR TEMP. 1. JSA PLUS-QR-NINUS .070 MEV

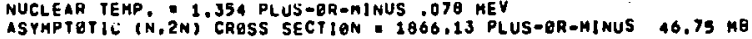

RELATEU CATA

NGN-ELASTIC CROSS SECTIBN AT 14,2 MEV = 1950.45 MO (N,2N) THKESHALO: 9,32 MEV

THIS ISGTgPe haS 70 meUtauns, 51 PAgTENS, (MASS 121 )

NEUTRON EXCESS PARAMETER * .15702

RATIU of ASYMPTOTIC $(N, 2 N)$ ID 24,2 MEY MEN-ELASIIC

TOSORT(N): 11.326 TESUKT(A) 14.894

\section{Fitted parameters}

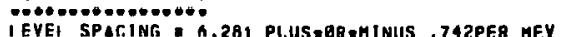

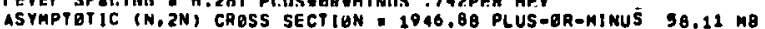

RELATED DATA

NON-ELASTIC CAOSS SECTION AT 14.2 MEV $=1958.45$ MB

(N, ZN) THRESHALD: 9,32 MEV

THIS ISOTOPE HAS 70 NEUTRONS, 51 PRETONS, (MASS = 121)

NEUTROA EXCESS PARAMETER : .15702

RATIO OF ASYHPTETIC (N.2N) TO 14.2 MEV NON-ELASTIC .0941 PLUS-OR-MINUS .0207

N/SPACING
ERROA 11.145 A/SPACING
ERROR
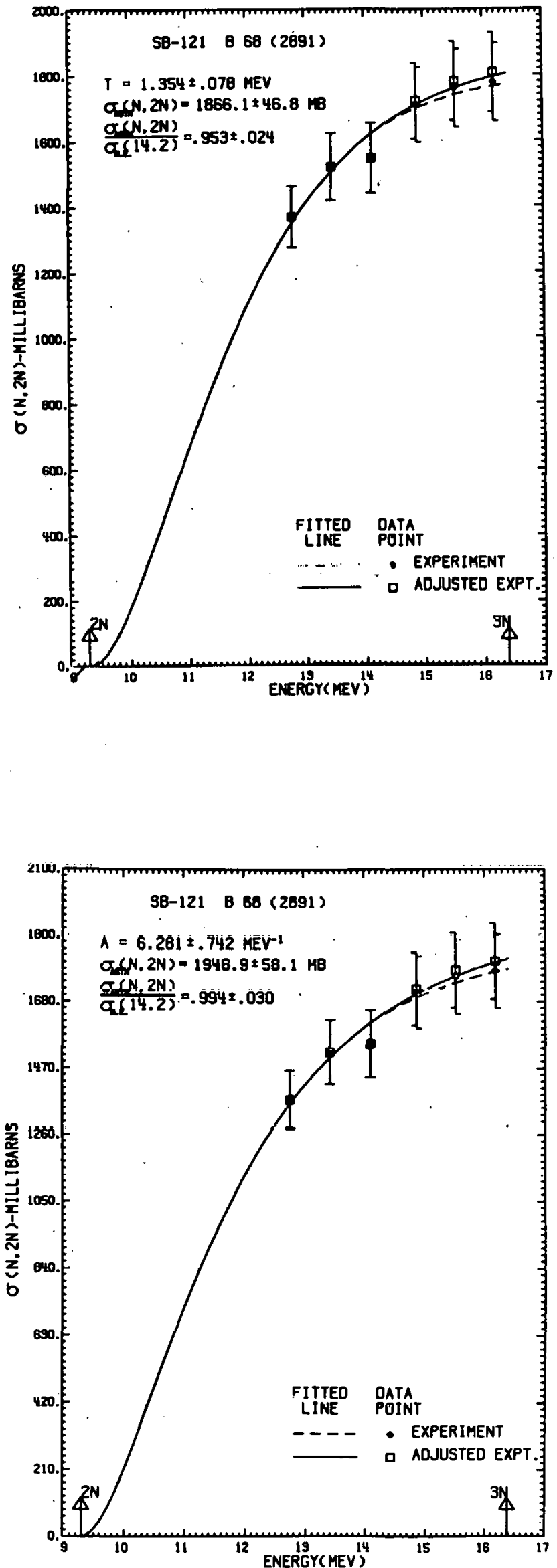


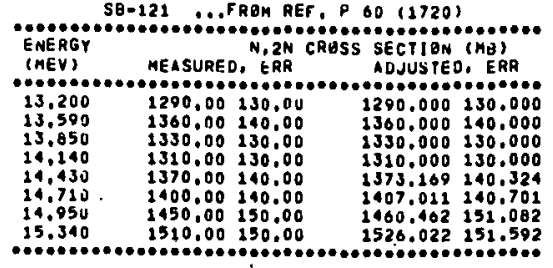

FITTED PARAMETERS

NUCLEAR TEMP

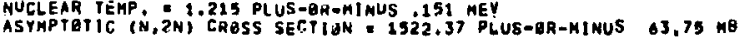

\section{RELATEU DATA}

NON-ELASTIC CPQSS SECTIION AT 14,2 MEV $: 1950,45$ MB

(N,2N) THKESHQLD: 9.32 MEV

THIS ISOTAPE haS 70 mEUTRONS, S1 PRJTUNS. (MASS - 121)

NEUTRON EXCESS PAGAHETER - .13702

RATIO OF ASYMPYOTIC (N,2N) TU 14.2 MEV MUN-ELASTIC , 7773 PLUS-DR-HINUS 0.0326

TESERT(N)= $\begin{array}{r}10.165 \text { TESORT(A) } \\ 1.263\end{array}$

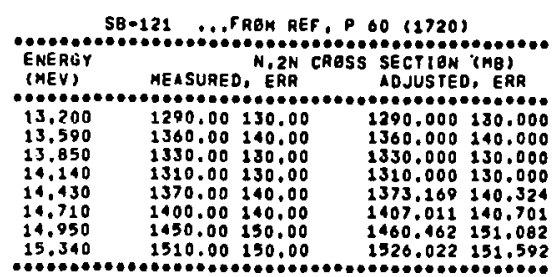

FitTED parameteas

LEVEL SPACING = 7.958 PLUS-GR-MINUSZ,129PER MEY

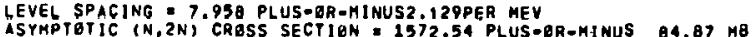

RELATFD DATA

NaN-EL ASTIC CRASS SECTION AT 14.2 MEV = 1050.45 MO

IN,

(N,2N) THRESHPLD $: 9.32$ MEV
(N,3N) TMRESHOLD $: 16,38 \mathrm{MEV}$

thIS ISgTUPE haS 70 nEUTRONS, S1 PROTENS, (MASS - 121)

NEUTRON EXCESS PARAMETER = .15702

RATIO OF ASYHPTETIC (N,2N) TE 14.2 MEV NON-ELASTIC .8030 PLUS-BR-HINUS .0433

N/SPACING $8.796 \quad$ A/SPACING 15.205
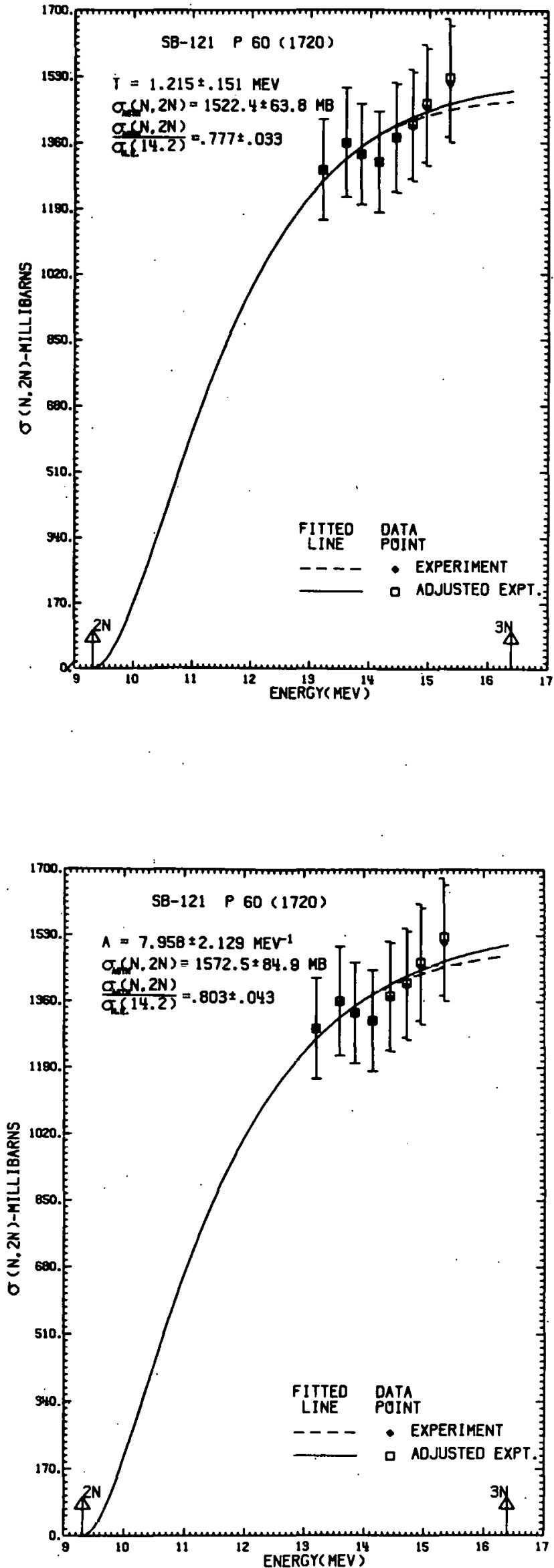
SH-123 .. FRUH KEF, $\triangle 80(2691)$

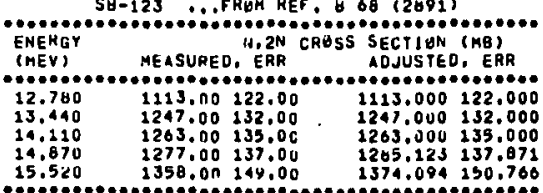

PITTEU PARAMETEHS

NUCLEAR TEMP

NUCLEAR TEMP, DE $1.22 U$ PLUS-DK-MINUS 103 MEV

RELATED DATA

NEN-ELASTIC CRESS SECTIUN AT 14.2 MEV = $1973.31 \mathrm{MB}$

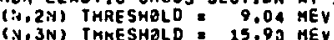

THIS ISOIGPE haS 12 AEUTAONS, SI PRUTANS, (MASS $=123$ )

NEUTMUN EXCESS PARAMETER : $: 17073$

RATIO UF ASYMPTETIC (N, 2N) TE 14.2 MEV NOH-ELASTIC .7030 PLUS-UR=MINUS .0200

TESURTIN): 10.352 TOSOKT(A) 13.530

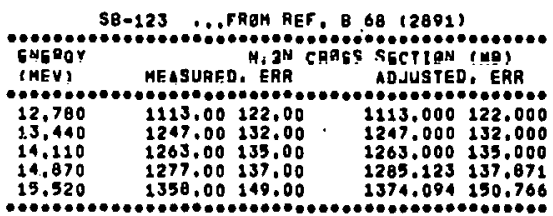

FitTEd PaRAMETERS

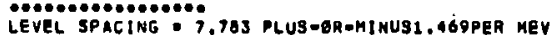

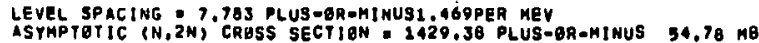

RELATED LATA

NGN-ELASTIC CROSS SECTIBN AT 14.2 MEV 1973.31 MB

(N,2N) THRESHOLD: $9.04 \mathrm{MEV}$
(N,JN) THRESHELD $=15.90 \mathrm{MEV}$

THIS ISETEPE haS 72 NEUTRENS, 51 PROTONS, inass = 123

NEUTRON EXCESS PaRAMETER : .17073

RATIO OF ASYMPTEYIC (N,2N) TO 14,2 MEV NON-ELASTIC , 7244 PLUS-ER-NINUS .0278

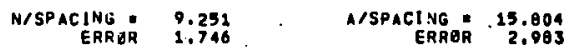
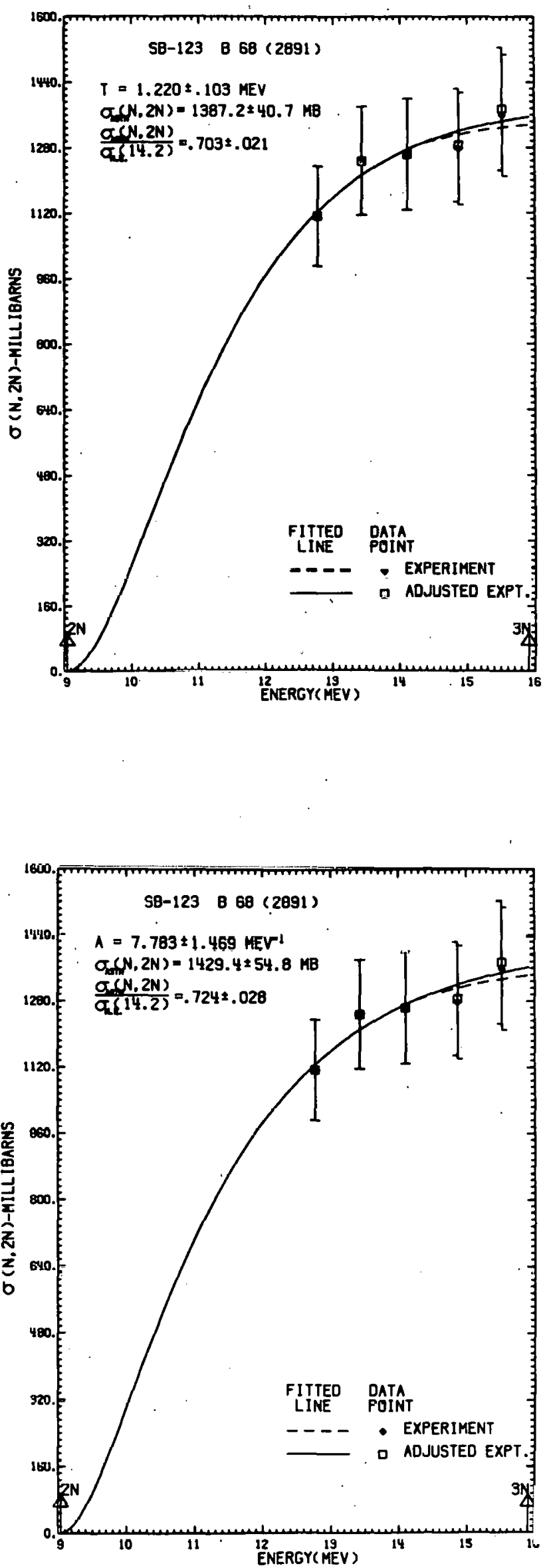


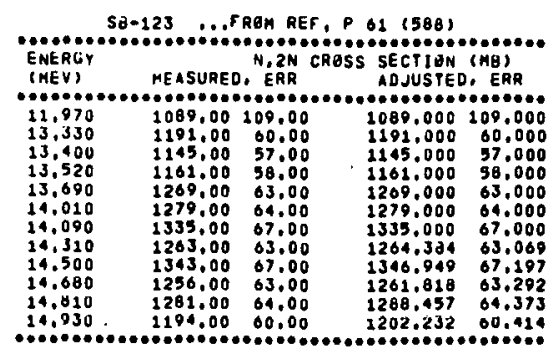

fitteu parameters

NUCLEAR TEMP. 1.025 PLUS-GR-ALNUS 161 MEY

ASYMPTOTIC (N, 2N) CROSS SECTIGN 1307,07 PLUS-OR-MINUS 44,50 MO

Relateo oATA

NBN-ELASTIC CRESS SECTIEN AT 14,2 MEV = 1913,31 HE

(N,2N) THRESHELD: 9,04 MEV

THIS ISOTOPE HAS 72 NEUTRONS, 51 PRUTONS, (MASS 123 )

NEUTREN EXCESS PARAMETER = .17073 RAIIO OF ASYMPTETIC (N,2N) TA 14,2 MEV NEN-ELASTIC
.S624 PLUS-UR-MINUS .0226

TESQRTIN): 8.697 TESORT(A) 11.360

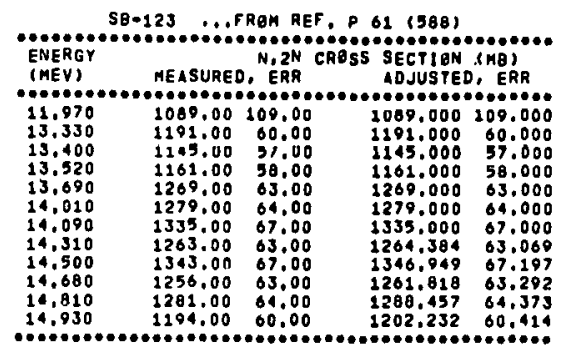

\section{FITTED PARAMETERS}

LEVEL SPACING

ASYAPTOTIC (N, 2N) CRESS SECTION : 1331.61 PLUS-QR-MINUS $59.66 \mathrm{HB}$

RELATED DATA

NON-ELASTIC CRESS SECTION AT 14.2 MEV =.1973.31 MB

(N,2N) THRESHQLD: 9.04 MEV

THIS ISOTOPE hAS 72 NEUTRUNS, 31 PRBTENS, (MASS 123)

NEUTRON EXEESS PARAMETER - .17073

RATIO OF ASYHPTOTIC (N, 2N) TO 14,2 MEV NON-ELASTIC

$$
.0748 \text { PLUS-BR-MINUS } .0302
$$

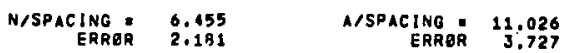

4
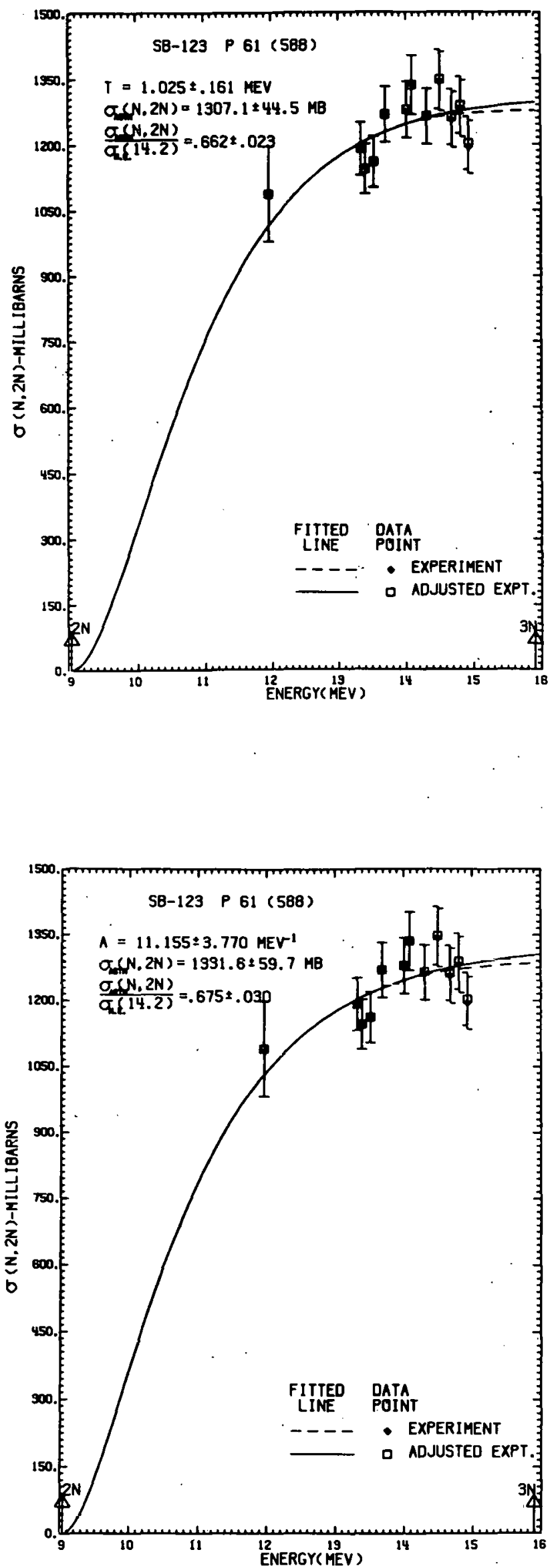


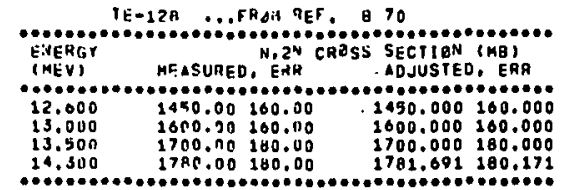

EITTED PAKAHETENS

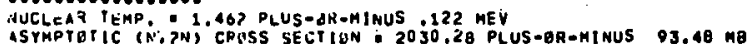

RELATEL UATA

MON-ELASTIC CR?SS SECTJON AT 14.2 MEV = 2010.00 NO

iv.2WI TRRESHEL: $=8.04$ MEV

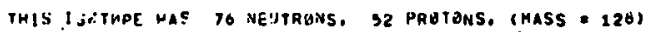

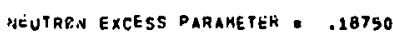

FATIA HO ASYMPTPTIC (N.2N) TO 14.2 MEV HON-ELASTIC

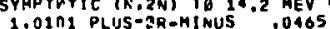

TESUKT(N): 12.745 EIIRER TOSORT(A)E 16.541
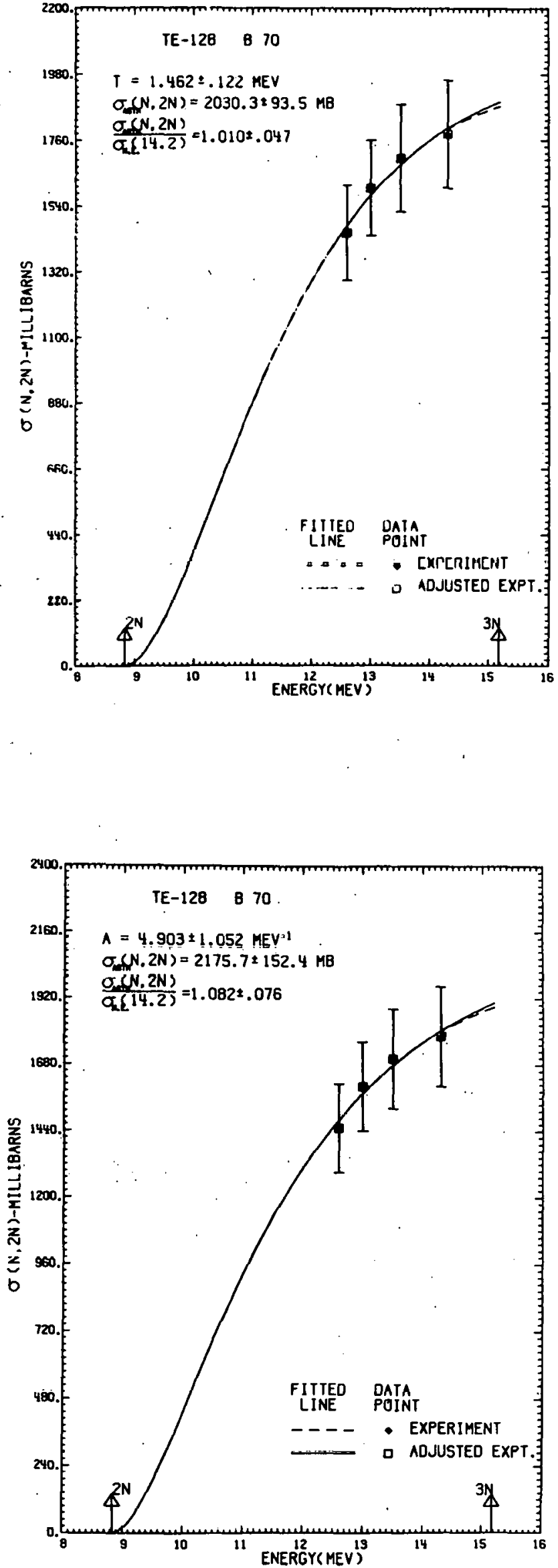

FItTED PafamF TERS

LEVEL SPACING U, OUS PLUS-GR-HIRUST,052PEA MEV

ASYHATDIC (N.2N) CRESS SECTIOH = 2175.72 PLUS-6R-MINUS 152.41 MB

RELLATLD JATA

NON-ELASTIC CQBSS SECTION AT 14.2 MÉ $=2020.00$ MB (N.2W) THRFSHIIL $=6.84 \mathrm{MEV}$
(N.3N) THEESHPLI $=13.18 \mathrm{MEV}$

PHIS ISOTOPE HAS 26 NEUTRONG, JQ RRUTONS, (HAES - 120 )

NEUTHGS EXCESS PARAHETER = .18750

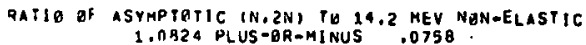

15.501
3.3720 A/SPACING 20.106 


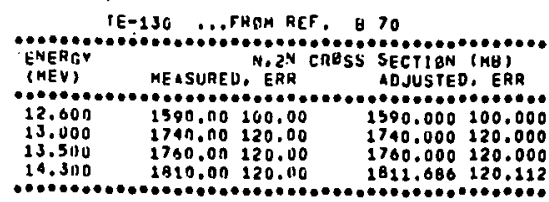

FITTEU PARAMFTERS

KUCLEAR IEMP. 1.271 PLUS̈-gR-AINUS 150 MEV

ASYMPTUTIC (H. 2N) CRUSS SECTIUN - 1030.80 PLUS-QR-MSMUS

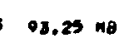

RELATES UATA

NON-ELASTIC CROSS SECTION AI 14.2 MEV = 2024.51 MB

$(N, 2 N)$. PHKESH,

THIS I GUTEPE HAS TO NEUTHEVS. 52 PROTONS. IMASS = 130 S

NEUTKan EXCESS PaRAMETER $=.20000$

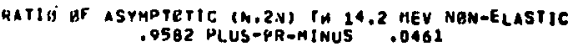

TESORT(N) $\begin{array}{r}11.225 \\ \text { CRHER } \\ 1.404\end{array}$

THSOHT(A): 14,492

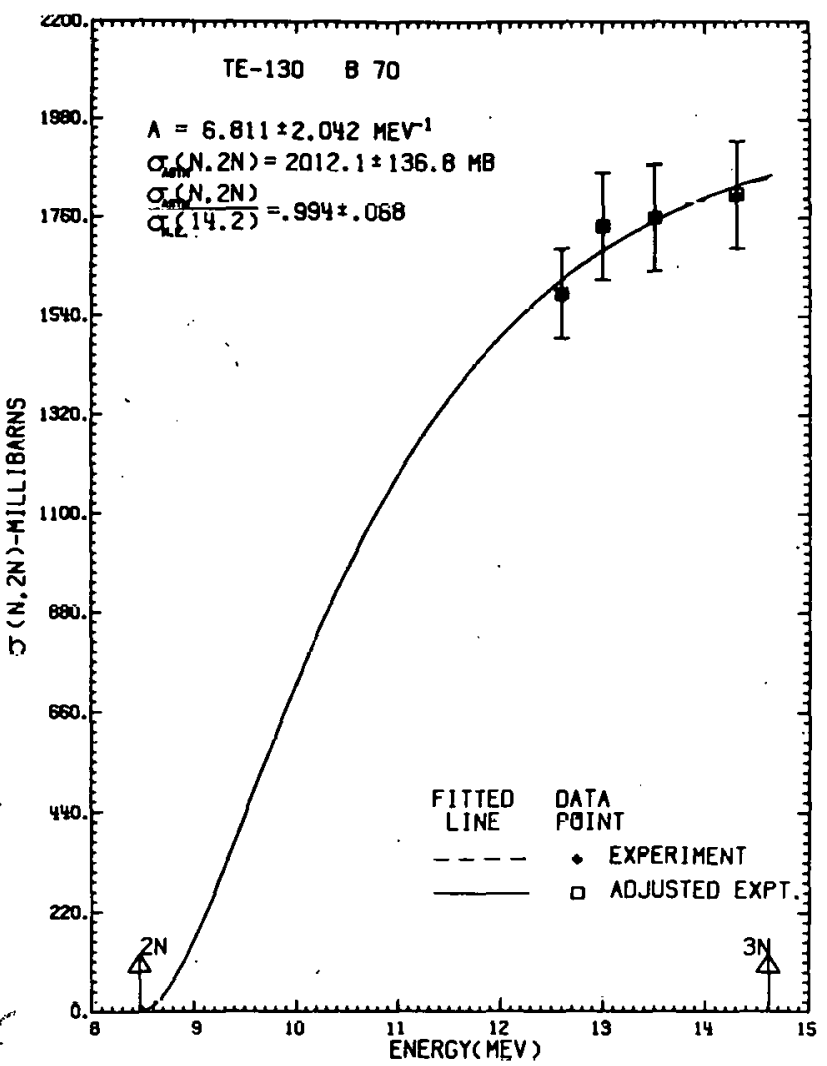

$(N)=2012.1 \pm 136.8 \mathrm{MB}$ $\sigma(N, 2 N)$

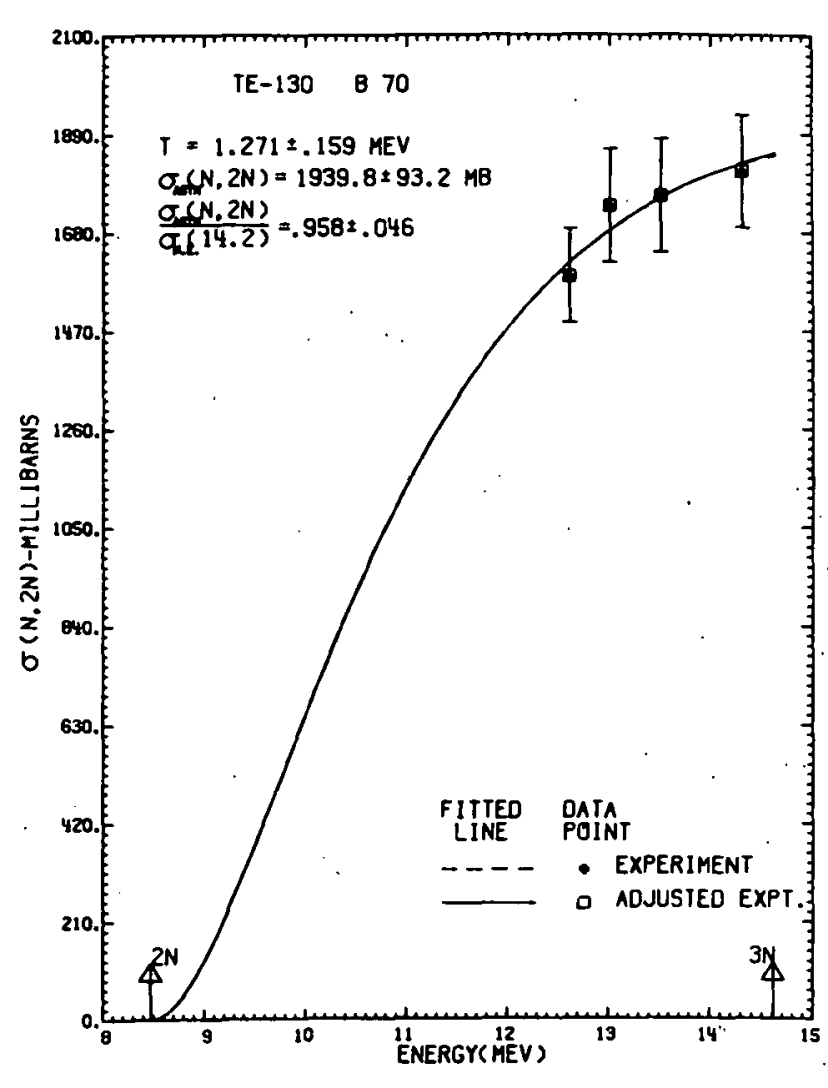

\section{RELATED DATA}

HIHN-ELASTIC CPASS SECTIAN AT 14.2 MEV $2024.51 \mathrm{MB}$

(N. Zi1) THKESHGLD : B.4B MEV

IHIS ISOTEPE HAS 70 NEUTRONS, 52 PRETUNS, (MASS 130 )

NEUTKLIN EXCESS PARAMETEK = .201100 .0930 PLUS-DR-MINUS .0670

N/SPACING $=11.452$ AISPACING ERRE 19.997
RATIS JE ASVITPTETIC (H, ZN) TU 14.2 MEV NEN-ELASIIC

1590.000100 .000 $17 \times 0.000120 .000$ 1611.686120 .112

FITTLU PAKAMETEHS

LEVEL SPACIHG $=$ G.O11 PLUS-OR-MINUS2.042PER MEV

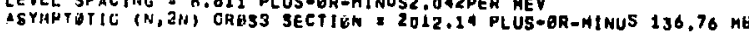




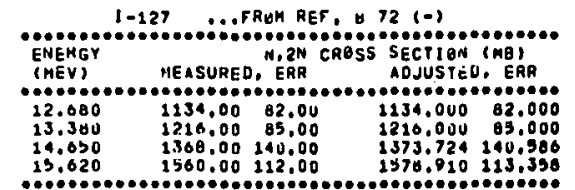

\section{FITIÉ PARAMETERS}

NUCLEAH TEMP I S30 PLUS-gh-HINUS 107 MEV

NUCLEAH TEMP

RELATEO WATA

NPX-ELASTIC CRESS SECTIOA AT 14,2 MEV 2002,72 MB

(N,2N) I HKESHALD: Q,22 MEV

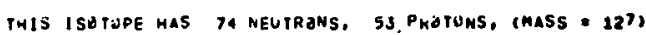

REUTRGN EXCESS PARAMETER - .10535

RATIS AF ASYMPTOTIC (N,2N) TO 14.2 MEV NON-ELASTIC .8286 PLUS-8R-MINUS .0602

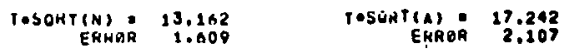

\section{FitTEO Parameters}

LEVEL SPACING 4.638 PLUS-BR-MINUS1, 200 OPER KEV

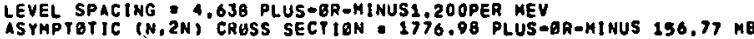

RELATED DATA

MON-ELASTIC CRESS SECTION AT 14.2 MEV * 2002.72 MB

(N,2N) THAESHELD: 9,21 MEV

THIS ISBTUPE haS 74 NEUTRENS, 53 PRETONS, (MASS 127 )

NEUTHON EXCESS PARAMETER : .16535

FATIO OF ASYMPTOTIC (N.2N) PB 14.2 MEV NEN-ELASTIC $.8 B 73$ PLUS-BR-MINUS .07B3

N/SPACING $=$
ERKGR
4.955
4.128 $\quad$ A/SPACING $=27.382$
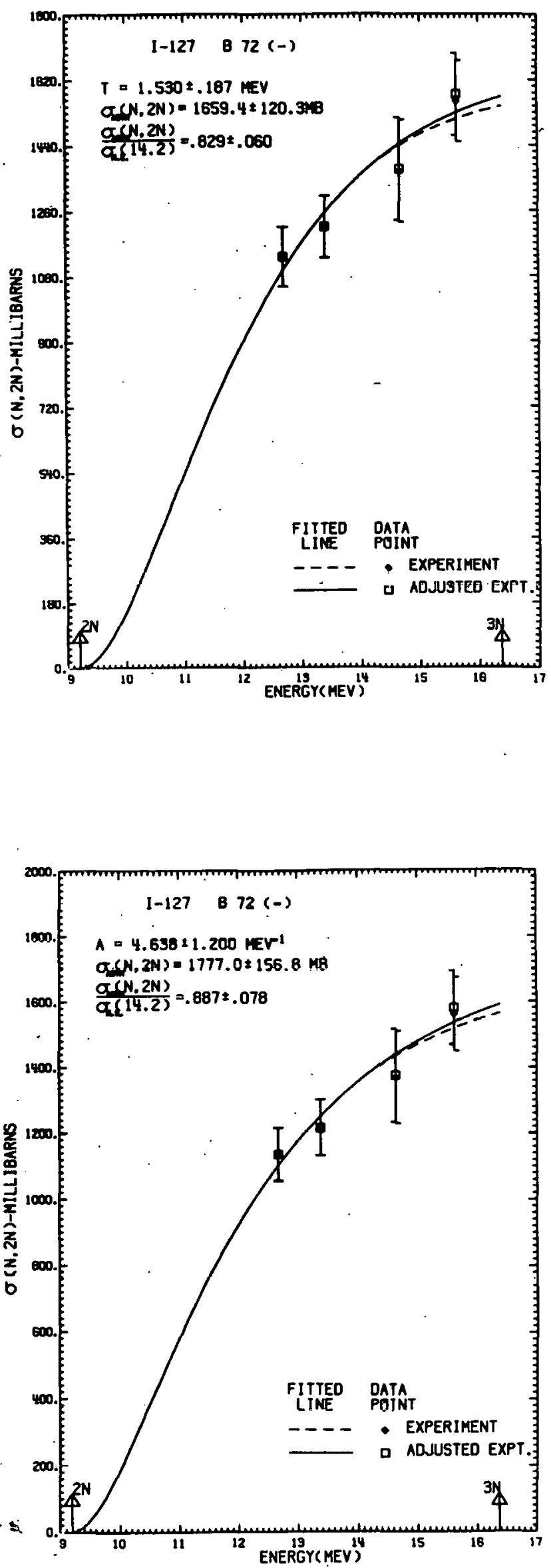


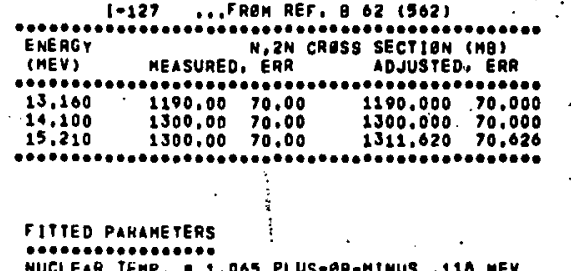

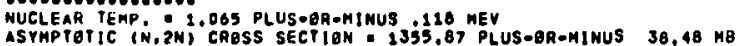

RELATED DATA

MON-ELASTIC CRESS SECTION AT 14.2 MEV $=.2002 .72$ MB

(N, 2N) THRE SHALD. Q,21 MEV

(N, 2N) THRES THQLD: 9,21 MEV

THIS ISQTUPE haS 74 MEUTRENS, 53 PRQTONS, (MASS = 127 )

NEUTREN EXCESS PARATETER $=.16535$

RATIO OF ASYMPTETIC (N,2N) TO 14.2 MEV NON-ELASTIC 6770 PLUS-ER-HINUS .0292

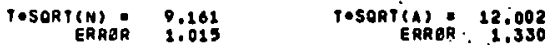

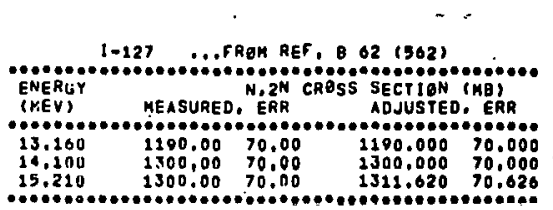

FITTED PARAMETERS

LEVEL SPACING IN, 736 PLUS-OR-NINUSR, OB7PER HEV

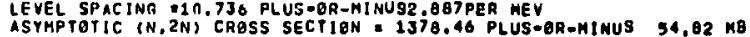

RELATED DATA

NGN-FLASTIC CROSS SECTIEN AT 14.2 HEV - 2002,12 MO

NGNAFLASTIC CROSS SECTIUN AT

(N,2N) THRESHQLD: $9,21 \mathrm{MEV}$
(N,3N) THRESHPLD
(16,37 MEV

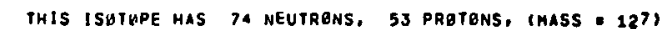

NEUTRON EXCESS PARAMETER = .20535

RATIG OF ASYMPTCTIC (N, 2N) IO 24.2 MEV NÖN-ELASTIC

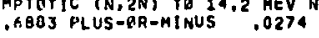

N/SPACIHG 6.893 A/SPACING 12,020
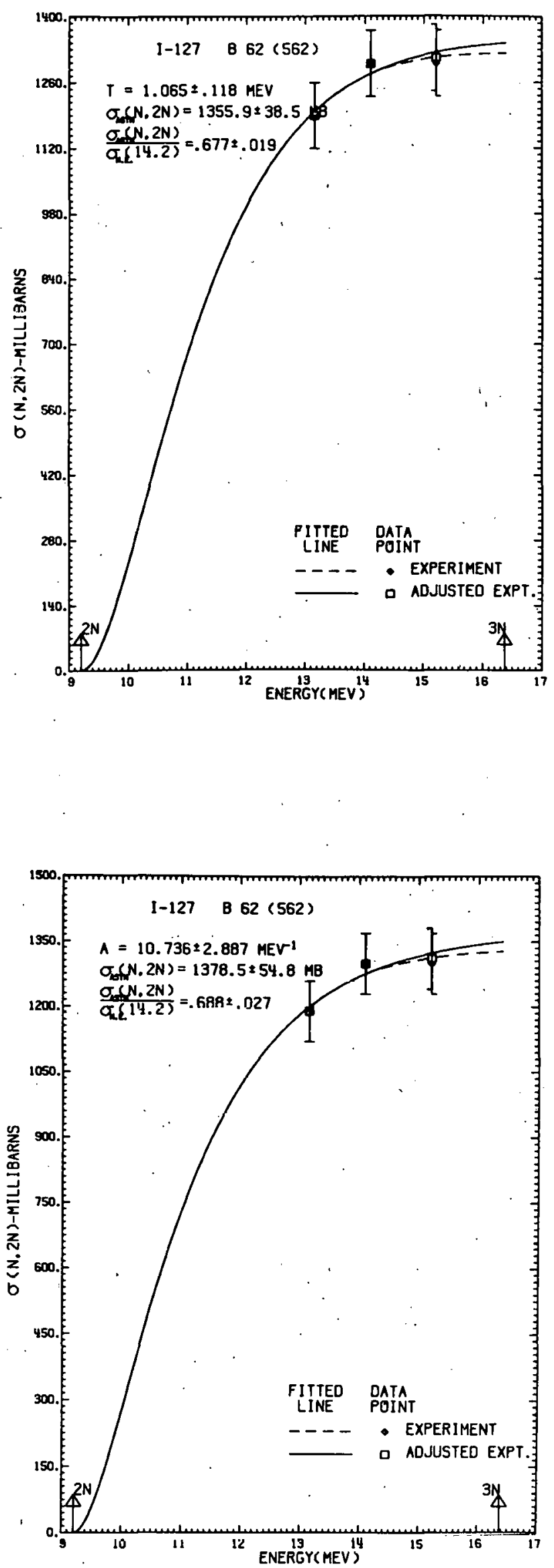


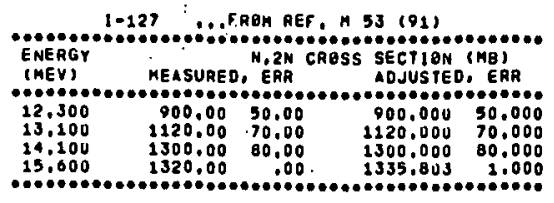

FITTEL PARAMETERS

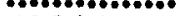

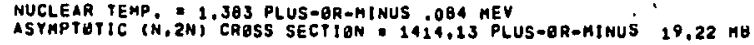

RELATEO DATA

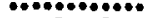

NUNAELASTIC CRESS SECTION AT 14,2 MEV = 2002.72 ME

(N,2N) INHESHELD: 9.21 MEV

THIS ISETKPE MAS 14 MEUTRONS, 53 PROTGNS, (MASS - 127 )

NEUTRGN EXCESS PARANETER : $\$ 10535$

RATID OF ASYMPTETIC (N,2N) TH 14.2 MEV NON-ELASTIC

TOSORTSNS: 11.697 TOSORT(A) 15.586
$.723 \quad .947$

\section{FITED PARAMETERS}

LEVEL SPACING S.811 PLUS-9R-MINUS O37PER MEV

ASYMPTETIC (N, 2N) CROSS SECTION 1402,01 . PLUS-OR-HINUS $40.92 \mathrm{MB}$

KELAIEU UATA

CRESS SECTION AT 14.2 MEV = 2002:72 MB

(N,2N) THRESHQLD: 9.21 MEV
(N,JN) TMRESHRLD 16.37 MEV

TMIS ISOTOPE HAS T4 NEUTRONS, 53 PRETONS, (HASS - 127)

NEUTRON EXCESS PARAMETER * .10335

RATIO OF ASYMPTOTIC (N,2N) TB 14.2 MEV NON-ELASTIC. .7405 PLUS-GR-MINUS .0204

$\begin{array}{rr}\text { N/SPACING } & 12,734 \\ \text { ERRER } & 2.053\end{array}$
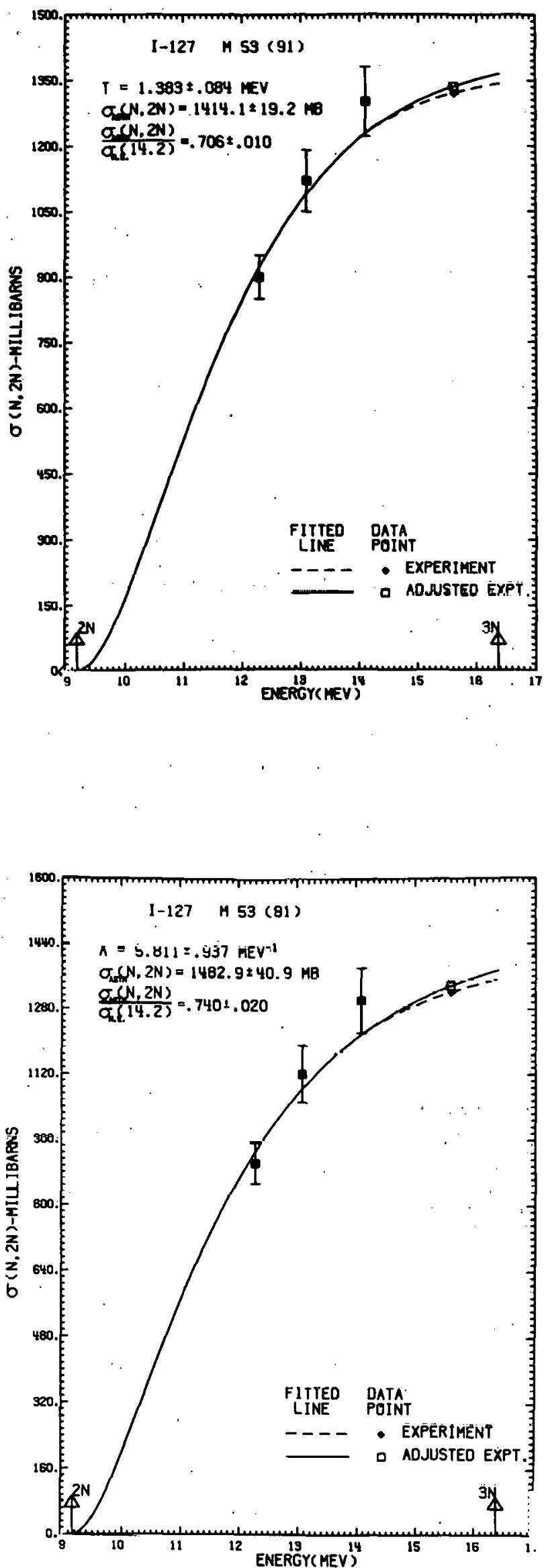


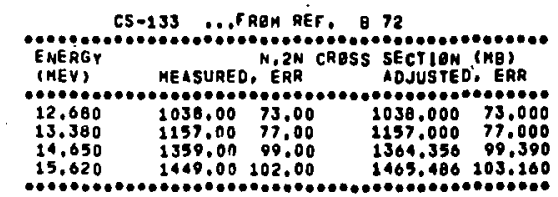

MTTEOO PARAMETEPS

NUCLEAR TEHP. 1.607 PLUS-OR-MINUS .065 MEV

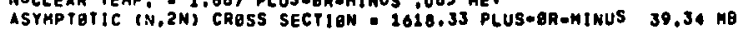

\section{RELATEO DATA}

NON-ELASTIC CRESS SECTIEN AT 14.2 MEV * 2046.10 MB

(N,2N) THRESHPLD: 9.05 MEV

this ISOTGPe has 9 a neutrons, 55 protens, (mass - 133)

NEUTREN EACESS PARAMETER : .17293

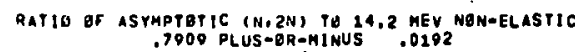

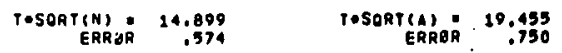

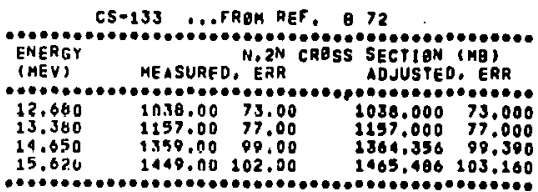

FitTEU parameters

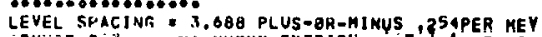

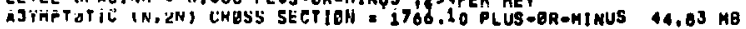

RELATEU DATA

HON-ELSSTIC CRESS SECTIZN AT 14.2 MEV $=2046.10 \mathrm{MB}$

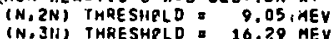

THIS ISETEPE has 78 NEUTRUNS, 55 PRQTONS. (MASS: 133)

NEUTRAM EXCESS PAPAMETER : .17203

RATIE OF ASYMPTOIIC (N.2N) TE 14.2 MEV NON-ELASTIC

N/SPACING $=21.150$
GIROR
1.497
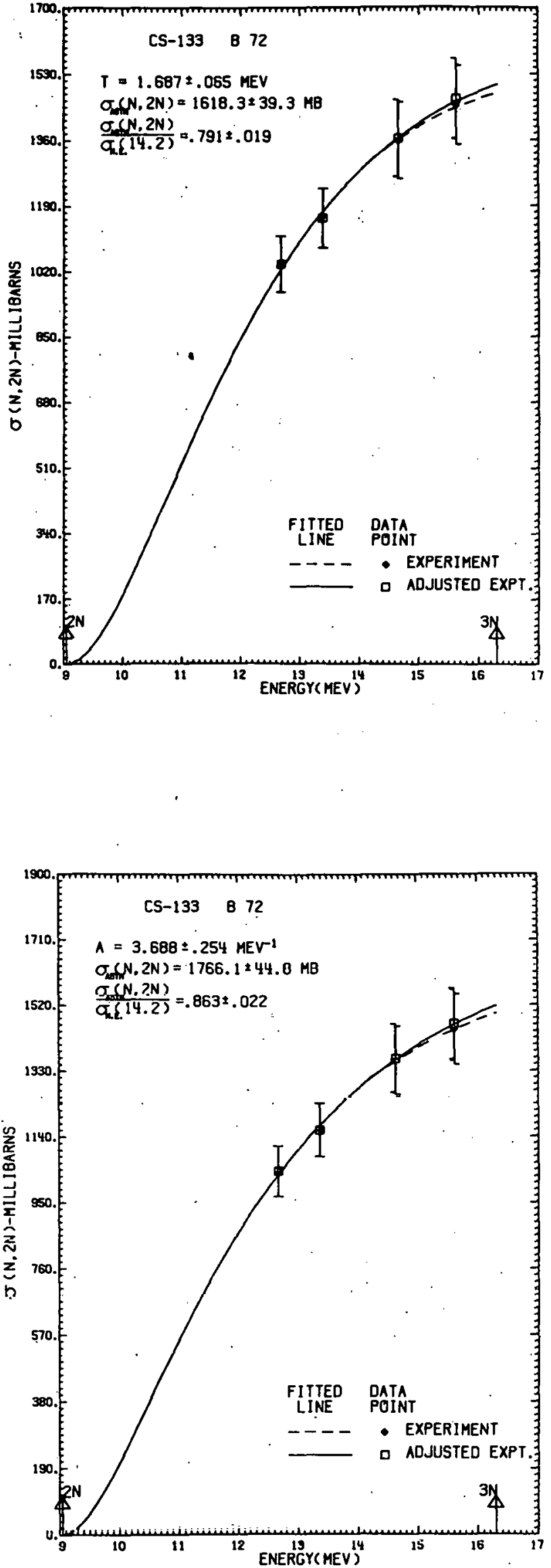


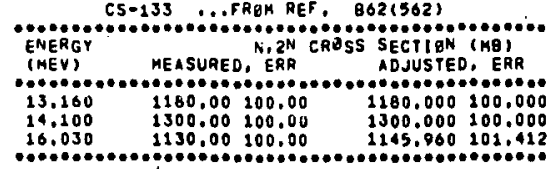

FITTED PARAMETERS

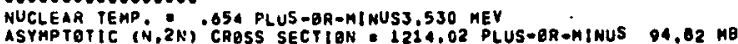

AELATED DATA

NON-ELASTIC CRESS SECTION AT 14.2 MEV = 2046.10 MO

(N,2N) TMRESHALD: 9.05 MEY

(N,3N) THAESHaLD: 16.29 MEV

THIS ISETEPE HAS 70 NEUTRONS, 55 PRETONS, (MASS $=133$ )

NEUTRGN EXCESS PARAHETER - .17293

RAIHO OF ASYMPTATIC (N,2N) TO 14.2 MEV NEN-ELASTIC .3933 PLUS-GR=MINUS .0403

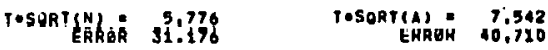

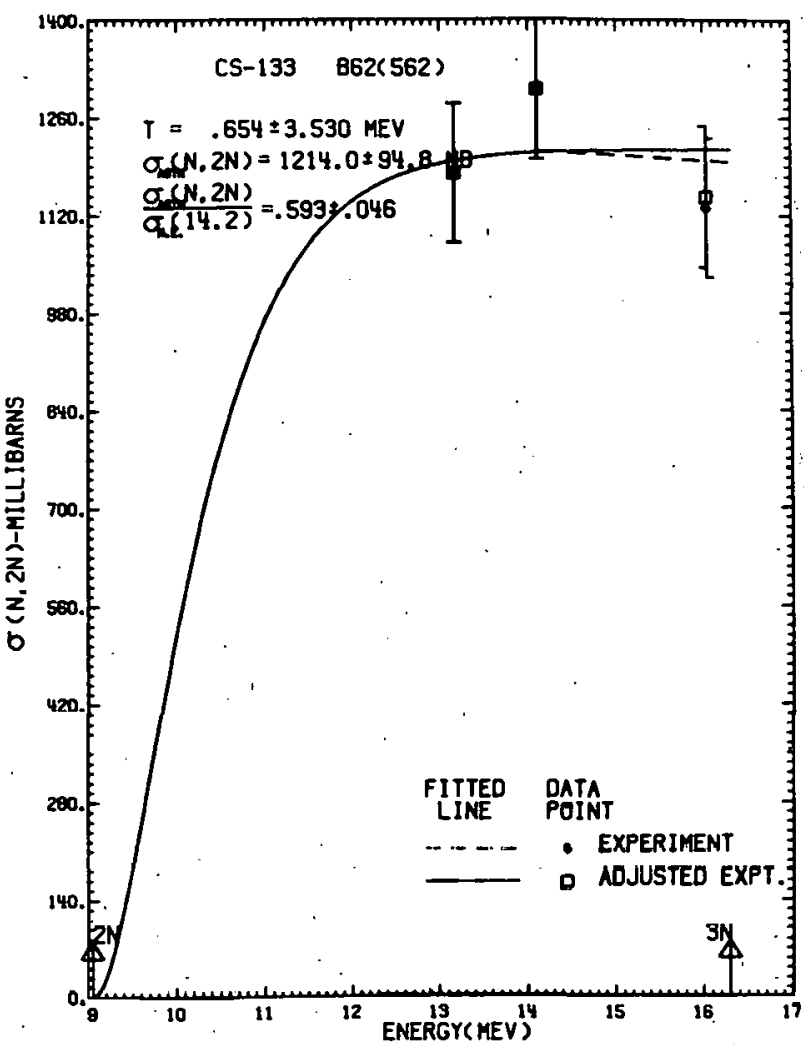

CS-133 ...FREM REF, O62(562)

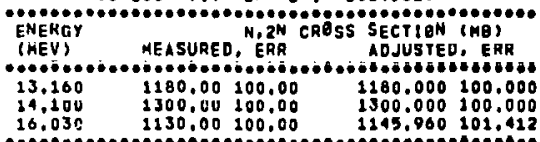

PITTEU PARAMETERS

OE.

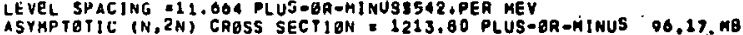

HELATEL UATA

HON-ELASTIC CAPSS SECTIRN AT 14.2 MEV = 2040,10 MB

(N,2ii) TMRESHALD $=9.05$ HEV

(N,JN) THAESHULD = 16,29 HEV

THIS ISOTGPE maS 78 NEUTRONS, 55 PROTONS. (MASS 133 )

NEUTHOA EXCESS PADARETEK : .17293

RATIN OF ASYMPTOTIC (N.2N) TH 14.2 MEV NON-ELASTIC 593 ? PLUS-UR-AINUS .0470

H/SPACING 6.687

A/SPACING 11.403

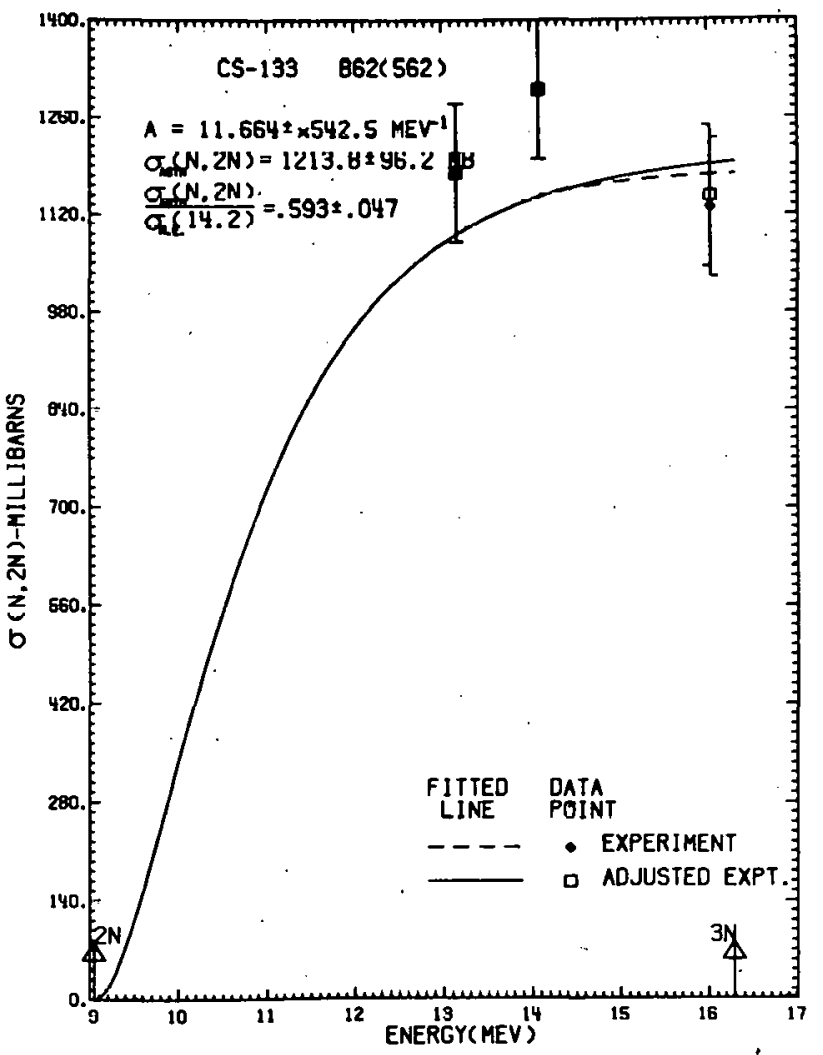


CE-140 …rREH REF, O6812801)

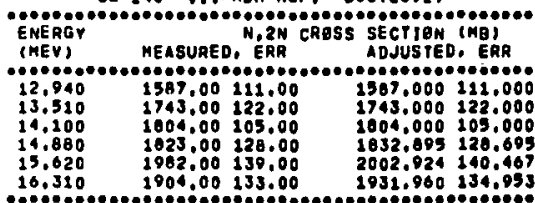

FitTED PARAMETERS

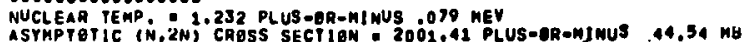

RELATED DATA

NON-ELASTIC CAESS SECTIEN AT 14.2 NEV - 2095,72 MB

(N,2N) THRESHOLD: 9,27 MEY

THIS ISOTOPF hAS 82 NEUTAONS, 58 PRETONS, (MABS -140 )

NEUTRGN EXCESS PARAMETER . .17143

RATIO OF ASYMPTOTIC (N.2N) TO 14.2 MEY NONOELABIIC .0530 PLUS-ER-MINUS .0213

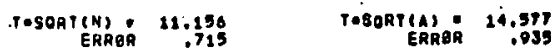
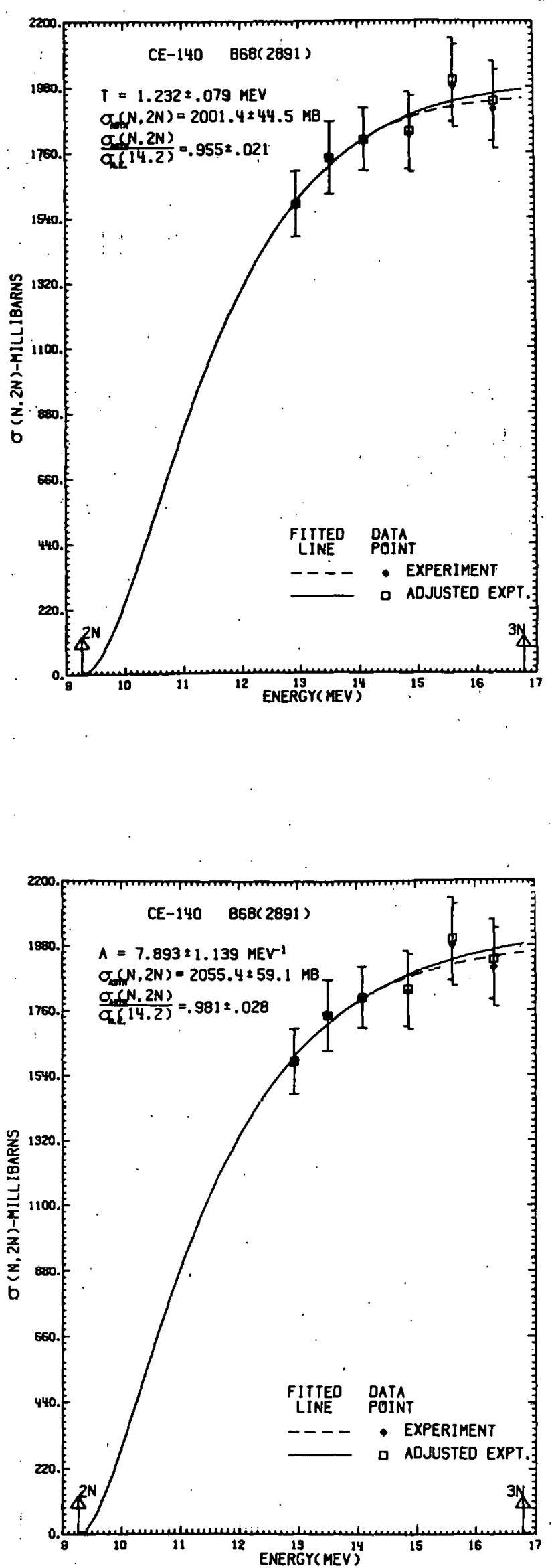

TItThu PaRameters

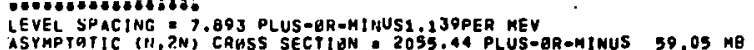

RELATED UATA

HEN-ELASTIC CRESS SECTIJN AT 14.2 MEV = 2095.72 MO

(W.2A) IHRESHELD: $9.27 \mathrm{ME}$

THIS ISETUPE IIAS 82 NEUTKanS, SB PRETONS, (MASS 1401

NeUthen EXEess PaAametën - .17243

RATIA GO ASYMPTATIC (N,2N) TO 14,2 MEY NON-ELASTIC .0808 PLUS-ER-MINUS .0282.

N/SPACING $=10.389$ A/SPACING 17.737 


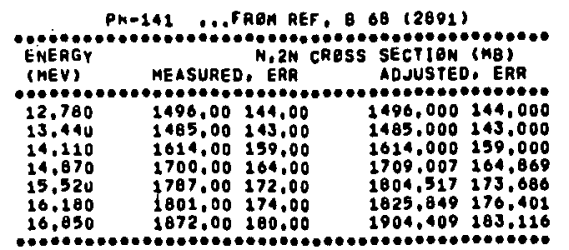

\section{FITTED PARAMETERS}

MUCLEAR TEMP. 1. 228 PLUS-BR-MINUS 100 MEV

MUCLEAR TEMP, 1.228 PLUS-BR-NINUS 1006 MEV $\because$.

\section{RELATED DATA}

NEN-ELASTIC CROSS SECTION AT 14.2 MEV = 2102.73 MO (N,2N) THRESHELD: 9,46 MEV

THIS 1 SOTUPE haS 82 NEUTHENS, 59 PRETENS, (MASS - 141 ) NEUTRON EXCESS PARAMETER . . .16312

MATIO OF ASYMPTOTIC (N,2N) TO 14,2 MEV NON-ELASTIC

IISORT(H): 11.120 TESURT(A) $14.582^{\circ}$

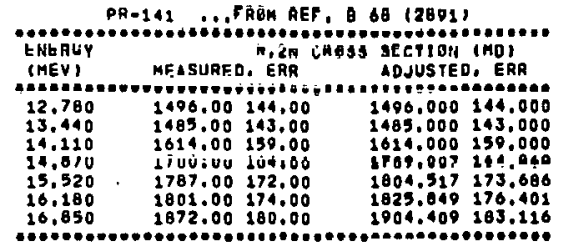

FITTED PARAMETERS
IEVE SPACING T.

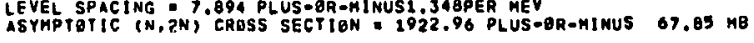

RELATED DATA

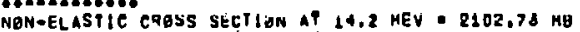

ND, 2N) TMRESHELD : 9,40 MEV

thIS ISBTape has az NeUtrons, 59 Padtuns, (MASS - 141)

NEUTAON EXCESS PARAMETER : . .16312

RATIO OF ASYMPTOTIC (N,2N) IO 24,2 MEV NON-ELASTIC

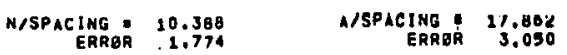
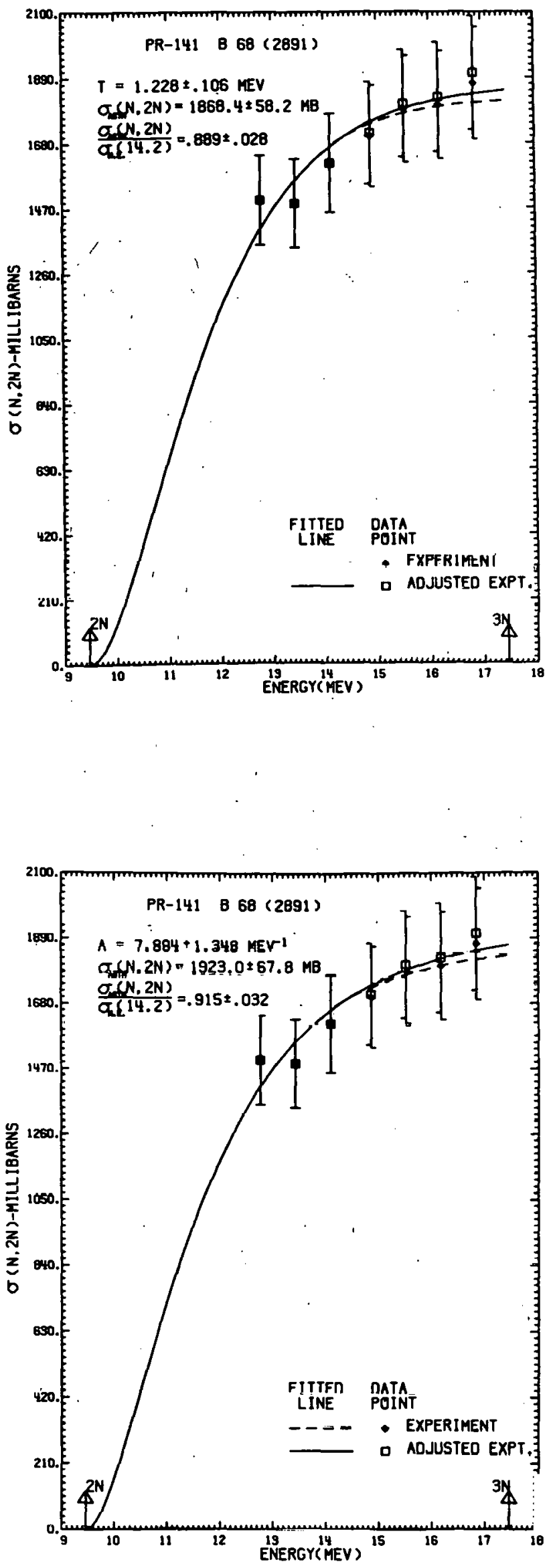


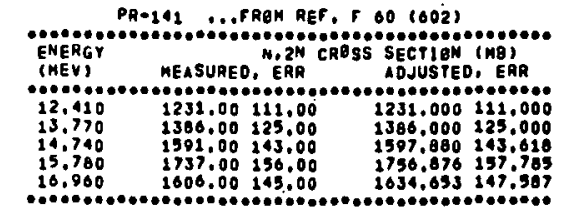

FITTEC PARAMETERS

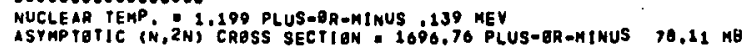

\section{RELATED DATA}

NON-FLASTIC CRQSS SECTION AT 14,2 MEV - 2102,73 NO

(N.2Ni) THRESHALO : Q.46 MEV

THIS ISOTEPE HAS B2 NEUTRONS. 59 PAOTENS. (MASS - 141)

NEUTRGN EXCESS PARAMETER - .16312

RATIO OF ASYMPTOTIC (N,2N) TO 14,2 MEV NON-ELASTIC $.8000^{\circ}$ PLUS-GR-FINUS ,0371

$\begin{array}{rr}\text { TOSORT (N) } & 10.037 \\ \text { ERRBR } & 1.250\end{array}$

FITTED PARAMETERS

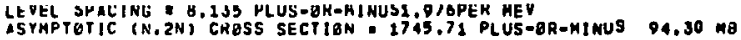

RELAIED DATA

NON-ELASTIC CPOSS SECTION AT T4.2 nEV = $2102.73 \mathrm{MB}$

(N.2N) THRESHPLD : 9.46 MEV

IHIS ISUTUPE HAS B2 NEUTRONS. 30 PROTONS, (MASS - 141)

REUTHGN EXCESS PARANETER = .16312

RATIO OF ASYMPTAIIC (N,2N) TO 24.2 MEY MEN-ELASTIC
.8302 PLUS-BR-MINUS .0448

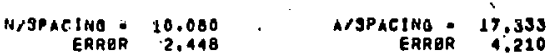
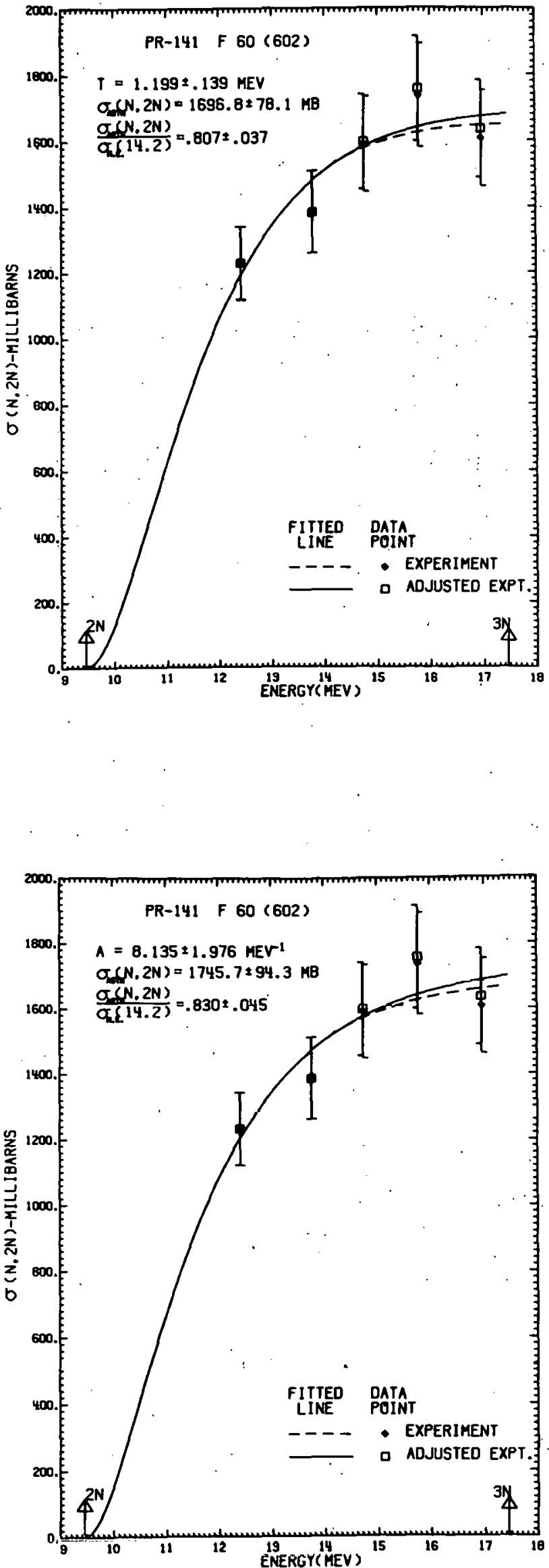


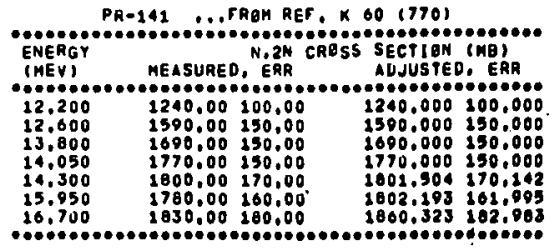

FITIED PARAKETERS

nuclear

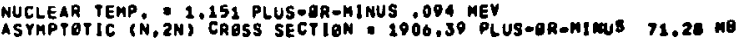

RELATED DATA

NON-ELASTIC CRESS SECTION AT 14,2 MEV - 2102.73 Ma (N,2N) THRESHELD = 9,46 MEV

THIS ISETGPE haS 62 NEUTRENS. 59 PROTONS, (MASS - 2411

MEUTRUN EXCESS PARAMETER - .20312

RATIO OF ASYMPTOTIC (N,2N) IO 14,2 MEY NON-ELASTIC

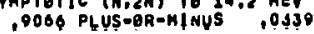

TESORT (N) 10.423 TESOAT(A) 13.609

PR-141 D. FRQM REF, $K$ (T) $(770)$

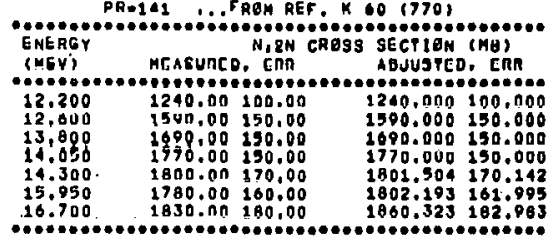

FitTEO PARAMETERS

LEVEL SPACING 8.703 PLUS-gA-MINUS1.68JPER MEV

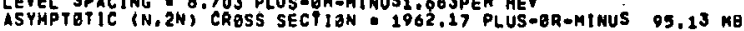

RELATED DATA

NON-ELASTIC CROSS SECTION AT 14,2 MEV - 2102,73 ME (N,2N) THRESHQLO: 9.46 MEV
(N,3N) THRESHELO : 17,45 MEV

this isötape has 82 neUtrons, 59 protons, (MASS - 141)

NEUTRBN EXCESS PARAMETER - .16312

RATIO OF ASYMPTOTIC (N,2N) TO 14,2 MEY NON-ELASTIC .9332 PLUS-OR-MINUS ,0452

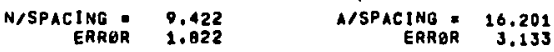
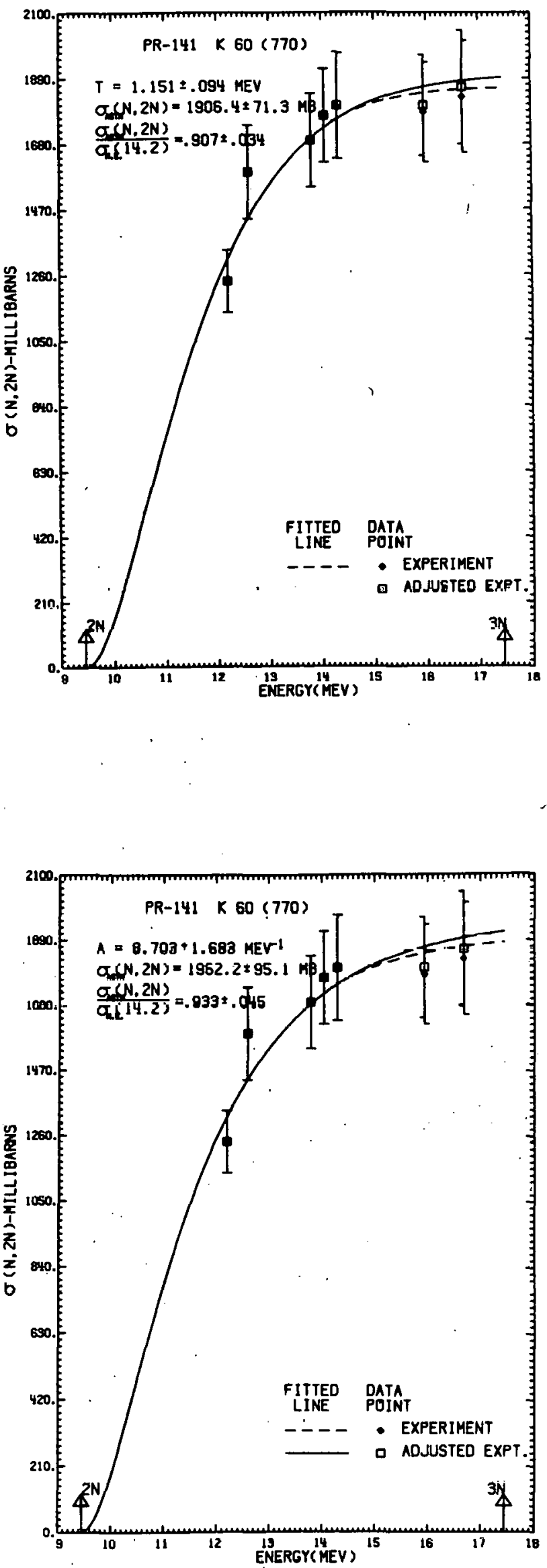


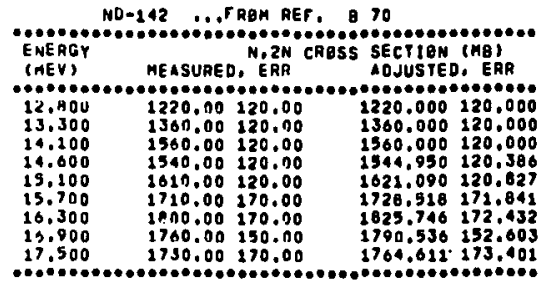

\section{TITTEO PARAMETERS}

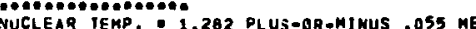

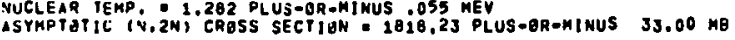

AELATEJ UATA

NEN-ELASTIC CRASS SECTION AT 14.2 MEV I 2100.72 MO

(N,2N) THRESHRLD: 9, AQ MEV

THIS ISPTUPE HAS B2. NEUTRENS, 60 PROTENS, (MASS - 142)

NEUTRan EXCESS PaRAMETER , .15493

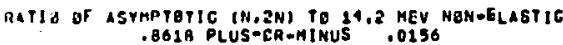

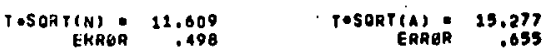

ND-142 ‥FRAM REF, 870

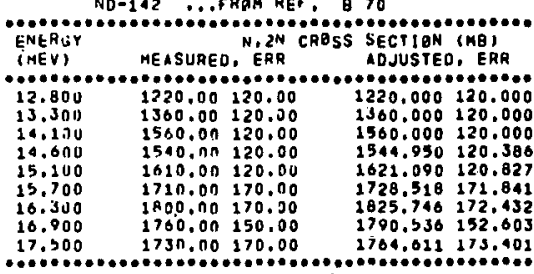

TitTED PARAMETEQS

OE...............?

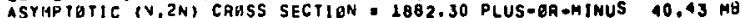

RELATHO DATA

WUN-TLASTIC CAASS SECTION AI $14.2 \mathrm{MEV}=2109.72 \mathrm{MB}$ (N, 2hi) THRESHRLD: 9.88 MEV

THIS ISOTUPE HAS 62 NEUTRENS, 60 PRDTENS, (MASS = 142)

NEUTREN EXCESS PARAMETER . .15493

RATII) OF ASYMPTOTIC (N.2N) TO 14.2 MEY NON-ELASTIC

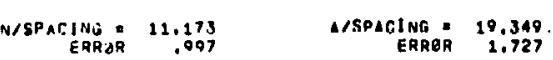
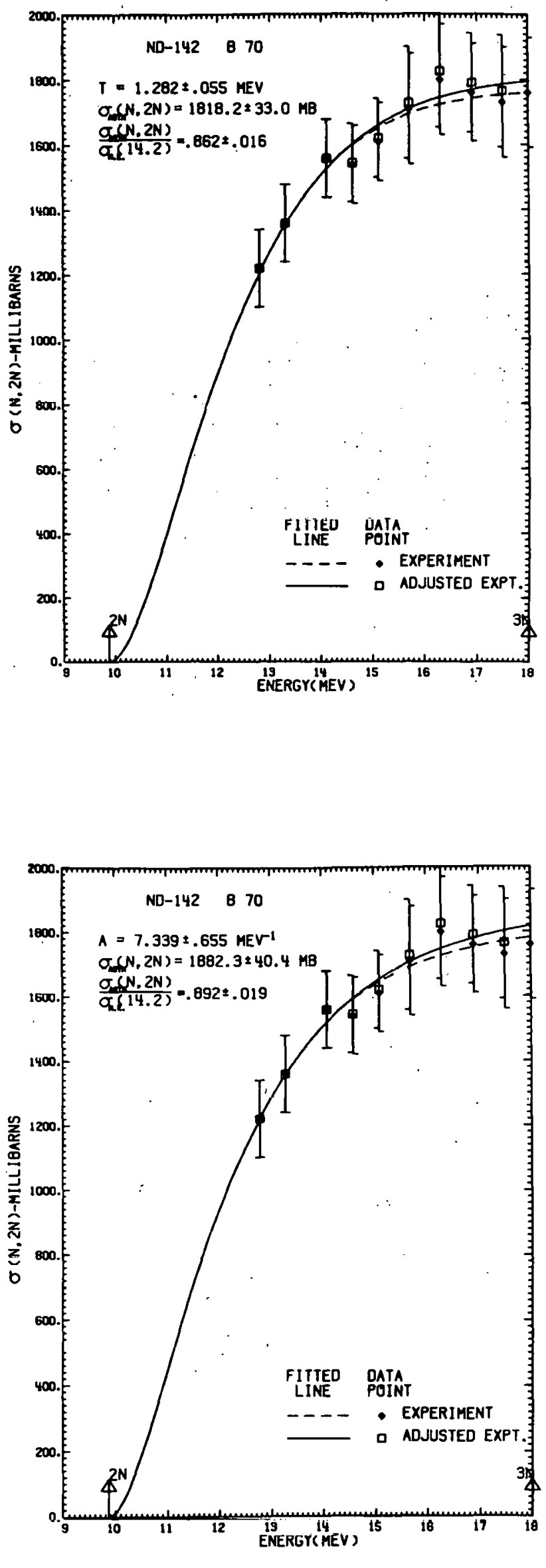


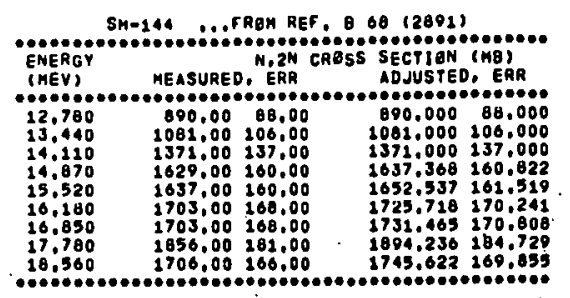

fitTEd PARAMETERS

NUCLEAR TEMP, 1.370 PLUS-gr-nINUS .061 MEV

ASYHPTETIC $(\dot{N}, 2 N)$ CRESS SECTIEN 1870.00 PLUS-QR-MINUS 40.07 MO

\section{AELATED DATA}

NBN-ELASTIC CRESS SECTION AT 14,2 MEV - 2123.64 MB

(N,2N) THKESHELD: 10.62 MEV

THIS ISATEPE HAS 82 MEUTRONS, 62 PRQTUNS, (MASS - 244

NEUTRON EXCESS PARAMETEA - .13849

PATL OF ASYHPTBTIC (N,2N) YQ \$4.2 MEV NON-ELASTIC

TOSORT(N)= 22.406 GAROA TOSURT(A). 16,740

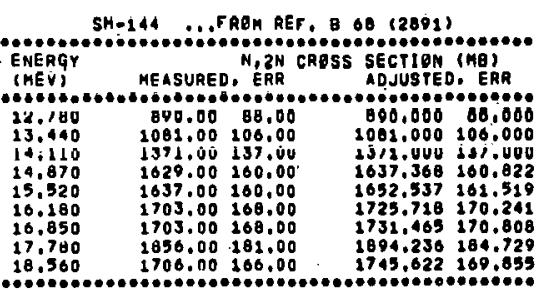

TitTCD taIMa,IETERT

LEVEL SPACING O.462 PLUS-OR-MIMUS .700PER MEV

ASYMPTOTIC (N, 2N) CROSS SECTION 1960.30 PLUS-OR-HINUS $60^{\circ} .61$ NO

RELATED DATA

NON-ELASTIC CROSS SECTION AT 14:\% MEV : 2123.64 MR

(N.2H) THAESHPLD: 10.62 MEV

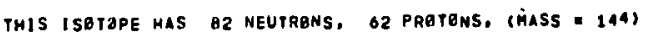

NEUTRON EXCESS PARAMETER : .13809

RATIG OF ASYMPTOTIC (N.2N) TO 14,2 MEV NGN-ELASTIC

.0259 PLUS-OR.HINUS .0328

N/SPACINGE $\begin{array}{r}12.690 \\ 1.386\end{array} \quad$ ASPACINGE 22.284
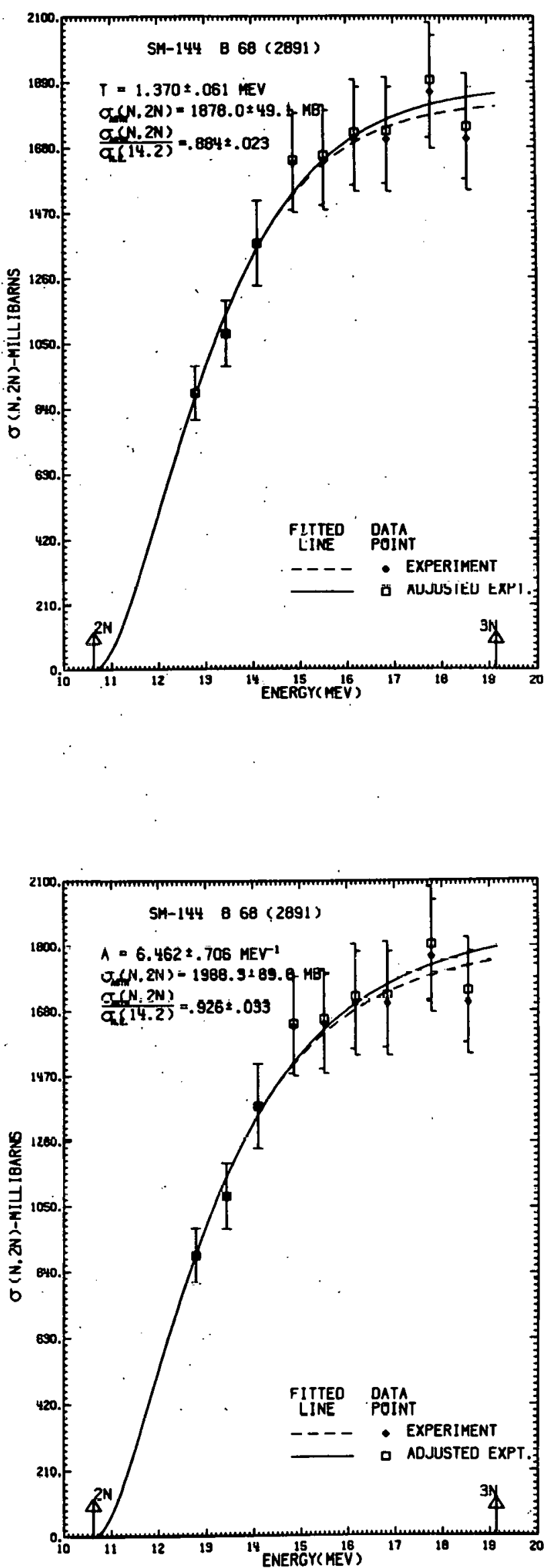


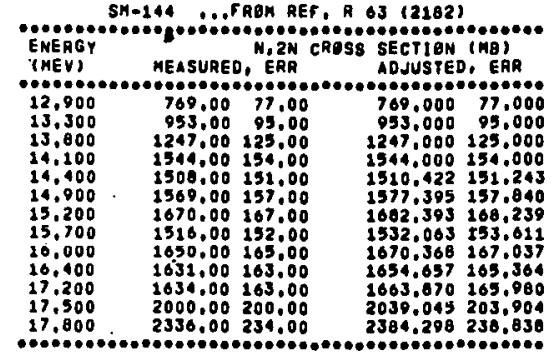

\section{ftTTEO paraheteas}

NUCLEAR TEMP

ASYMPTOTIC IN,2N) CROSS SECTIEN - 2093,13 PLUS-OR-MINUS 153.55 HB

RELATED DATA

MOM-ELASTIC CRESS SECTIOM AT 14,2 MEY = 2123,64 MB

(N,2N) THRESHRLD: 10,02 MEV

THIS ISOTUPE haS Q2 NEUTREMS, GD PROTOMS, (MASS - 144)

NEUTRON EXCESS PARAMETER : .13880 .RATIO GF ASYMPTETIC IN, 2N) TE 24,2 MEY NON-ELASTIC
.98SG PLUS-BR-MINUS .0723

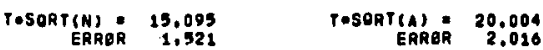

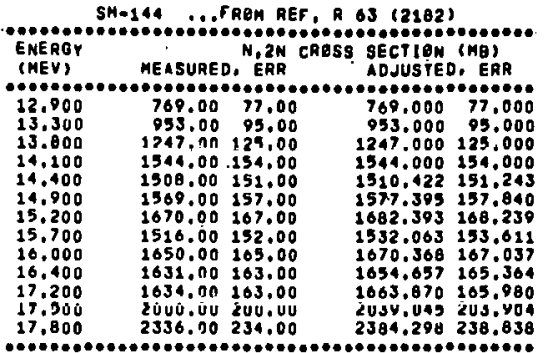

FItTED PARAMETERS

LEVEL SPACING 4.042 PLUS-GR-MINUS .964PER MEV

ASYHPTOTIC (N,2N) CRESS SECTIOH 2305.03 PLUS-QR-MINUS 220,14 MB

\section{RELATED DATA}

NON-ELASTIC CROSS SECTION AT 14.2 MEV $=2123.64 \mathrm{MB}$

(N.2N) THRESHBLD: 10.62 MEY

(N,JN) THKESHPLD: 19.13 MEV

THIS ISOTGPE HAS BZ NEUTRONS. OZ PROTONS, (MASS - 144)

NEUTREN EXCESS PARAMETER * .13089

RATIO of ASYMPTOTIC (N.2N) TO 14.2 MEV NON-ELASTIC 1.0857 PLUS+ER-MINUS , 1074

$\begin{array}{rrr}\text { N/SPACING } & 20.287 \\ \text { ERRER } & 4.838\end{array} \quad$ A/SPACINOE 35.626
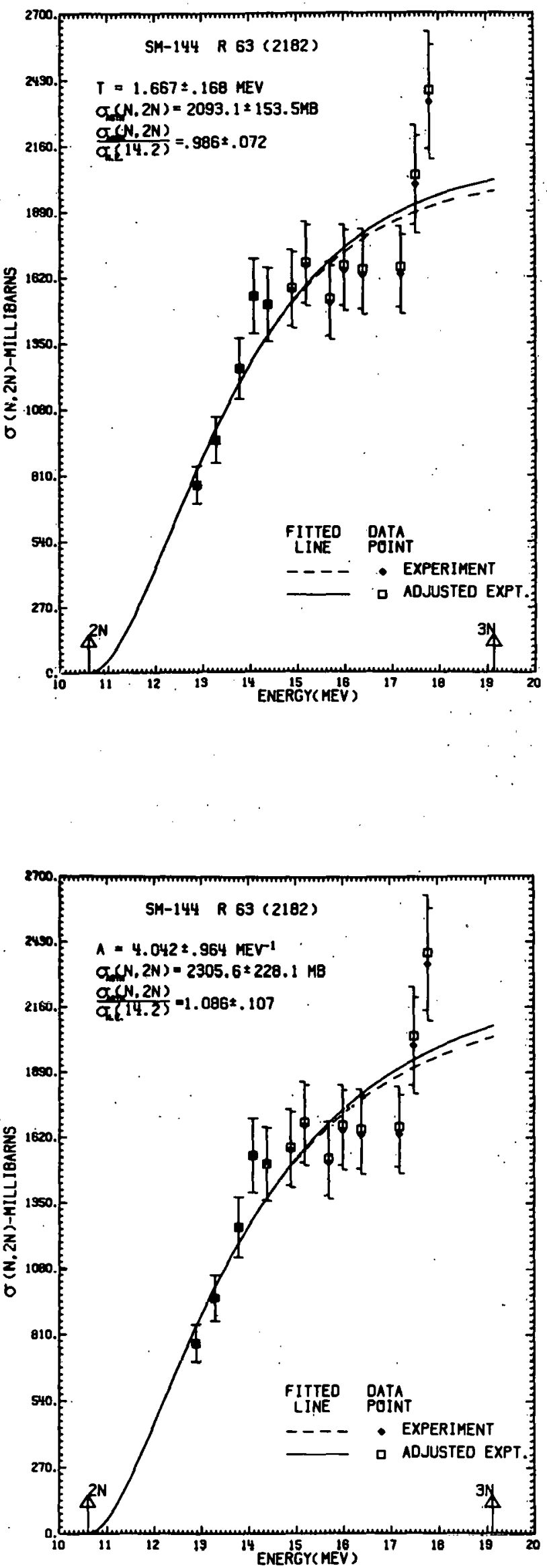


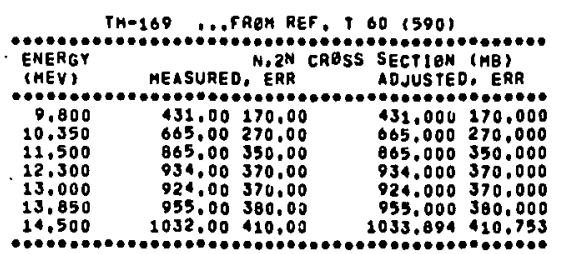

\section{FITTED PAKAMETERS}

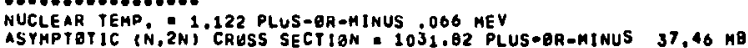

\section{RELATED UATA}

NON-ELASTIC CRBSS SECTION AT 14,2 MEV -2292.22 MB

(N,ZN) THKESHBLD: B,11 MEV
(N,3N) THRESHOLD : 24,96 MEV

THIS ISBTUPE HAS 100 NEUTRENS, 69 PRGTONS, IMASS - 169 )

MEUTREN EXCESS PARAMETER = .18343

RATIB UF ASYMPTETIC (N.2N) TU 14,2 MEY NON-ELASTIC 4501 PLUS-DH-MINUS .0103

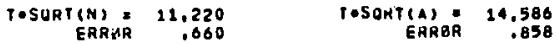

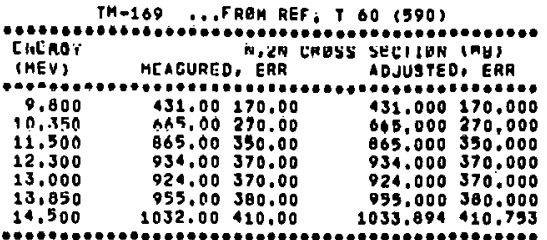

PITTE PARAMETRAS

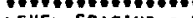

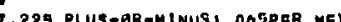

ASYMPTOTIC (N, ZNI C2S PLUS -OR-MINUS1,005PEA MEV

RELATED DAT

NON-ELASTIC CAPSS SECTIEN AT 14.2 MEV $=2292.22 \mathrm{MB}$

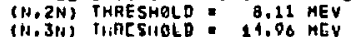

THIS ISOTUPE haS 100 NEUTRONS, 69 PRBTKNS, IMASS .1691

NEUTRON EXCESS PARAMETER = .18343

RATIO OF ASYMPTOTIC (N,2N) TO 14,2 MEV NON-ELASTIC .4751 PLUS-DR-MINUS .0240

N/SPACING 13.841 A/SPACING 23.391
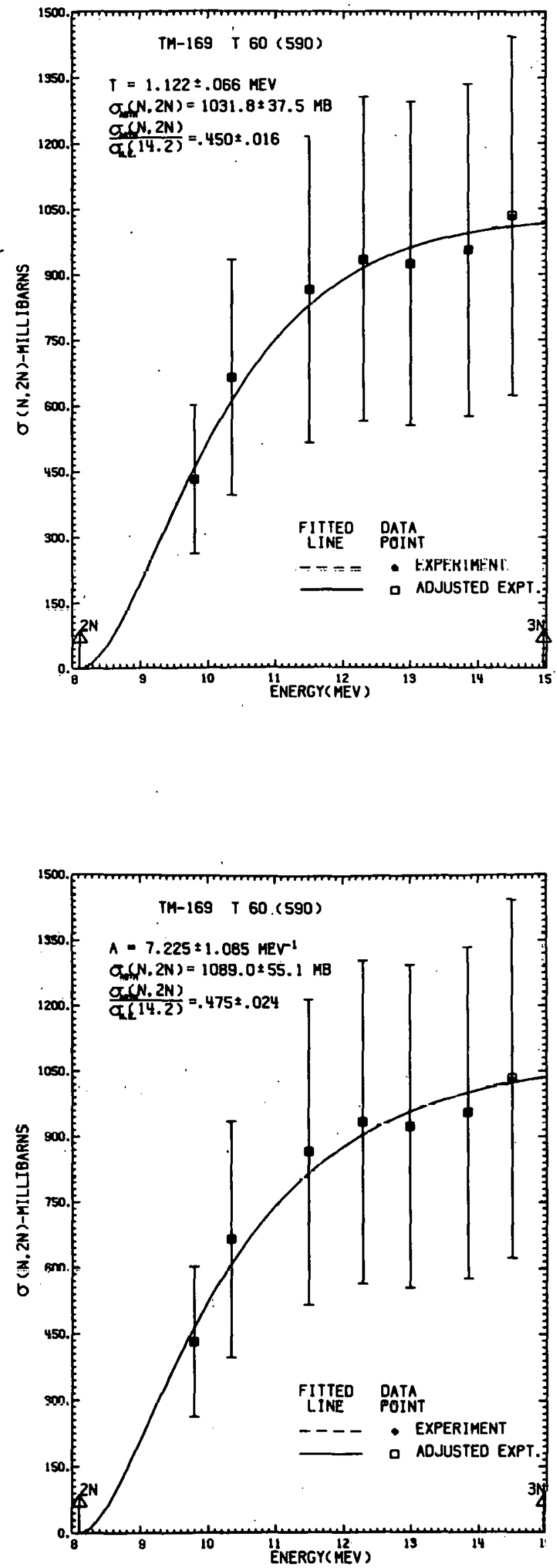


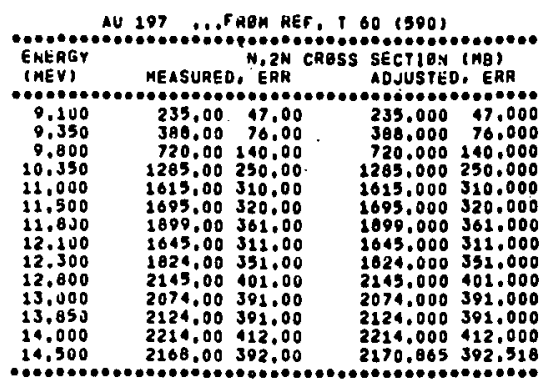

FITIED Parameters

NUCLEAR TEMP. 1.787 PLUS-Gh-hINUS 140 meV

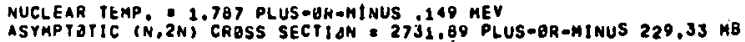

RELATED UATA

NON-ELASTIC CRESS SECTION AT 14.2 MEV' 2472.01 MB $(N, 2 N)$ THKESHOLD: 9,12 MEV
$(N, 3 N)$ THKESHELD : 14.82 MEV

TMIS ISOIGPE HAS 118 NEUTRBNS, 70 PRATUNS, (MASS 197

NEUTAON EXCESS PARAMETER - .19797

RATIO OF ASYMPTOTIC (N,2N) TO 14,2 MEV NUN-ELASTIC

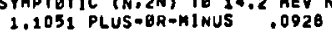

TESORT(N)= 19.412 TESORT(A) 23,082

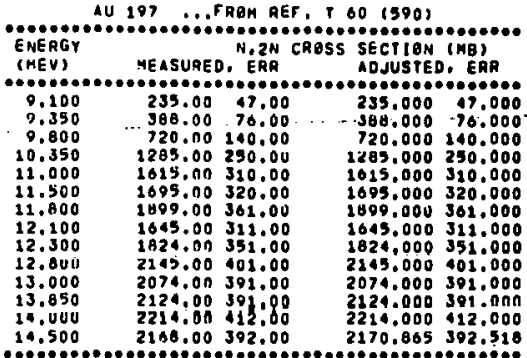

TITTEO PARAMETERS

LEVEL SPACING O. 219 PLUS-GK-MINUS 524 PEA HEV

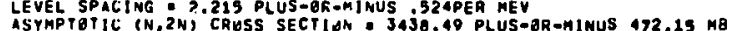

RELATED DATA

NAN-ELASTIC CRASS SECTIEN AT 14.2 MEV $=2472.01$ MB (N,2N) THAESHALD: 8,12 MEV

THIS ISOTUPE haS 110 NEUTRONS, TO PROTUNS, (maSS $=107$ )

NEUTREN EXCESS PARAMEIER = .19707 RATIO OF ASYHPTOTIC IN.2N) IO 14.2 MEV NON-ELASTIC

N/SPACING
ERHER
12.673
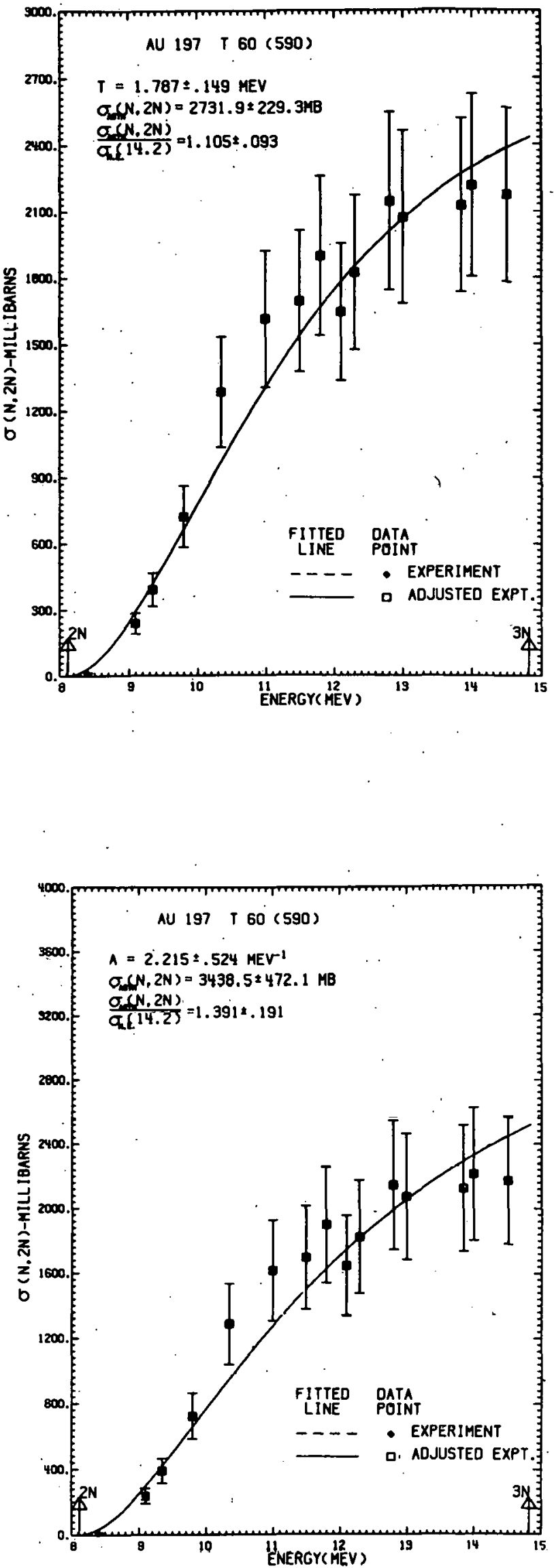


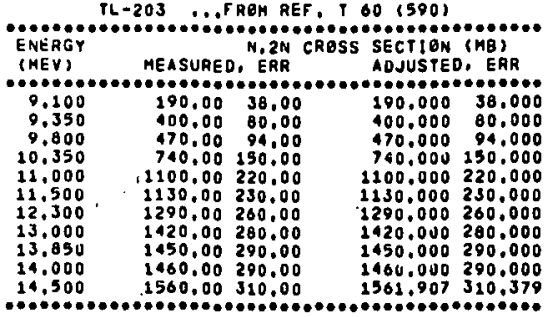

FITTED PARAMETERS

NUCLEAR TEMP, 2.283 PLUS-OB-MINUS 270 MEY

ASYMPTOTIC (N, $2 N$ ) CRESS SECTION = 2079,07 PLUS-gR-MINUS 279.25 KB

RELATED LATA

NON-ELASTIC CROSS SECTION AT 14.2 MEV $=2900.65$ ME

(N,2N) THRESHQLD 7.76 MEV

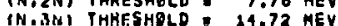

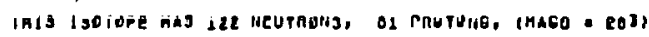

NeUtran EXCESS Parametea : .20197

RATIO OF ASYMPTOTIC (N,2N) TO 14,2 MEV NOH-ELASTIC

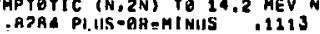

$\begin{array}{rrr}\text { TOSORT(M): } & 25.217 \\ 2.982 & \text { TESURT(A) } & 32.528 \\ \text { ERRER } & \end{array}$

MITTEO PAhAHE TERS

LEVEL SPACING I. LOS PLUS-UF-MINUS 4210 EK MEV

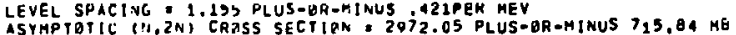

Lisatín Rista

NQN-ELASTIC CRESS SECTION AT 14.2 MEV $=2509.05 \mathrm{MB}$ (N, 2N) THAESH:LD : 7.76 MEV

IHIS ISOTJPE HAS 122 HEUTRONS. BI PROTONS, (MASS = 203)

MEUTHUM EXCESS PARAHETER *.20197

FATIU OF ASYMPTHTIC (A,2N) TO 19.2 MEY NON-ELASTIC

W/SPACING $=\begin{array}{r}105.628 \\ 30.502\end{array}$

AISPACING = 175.758
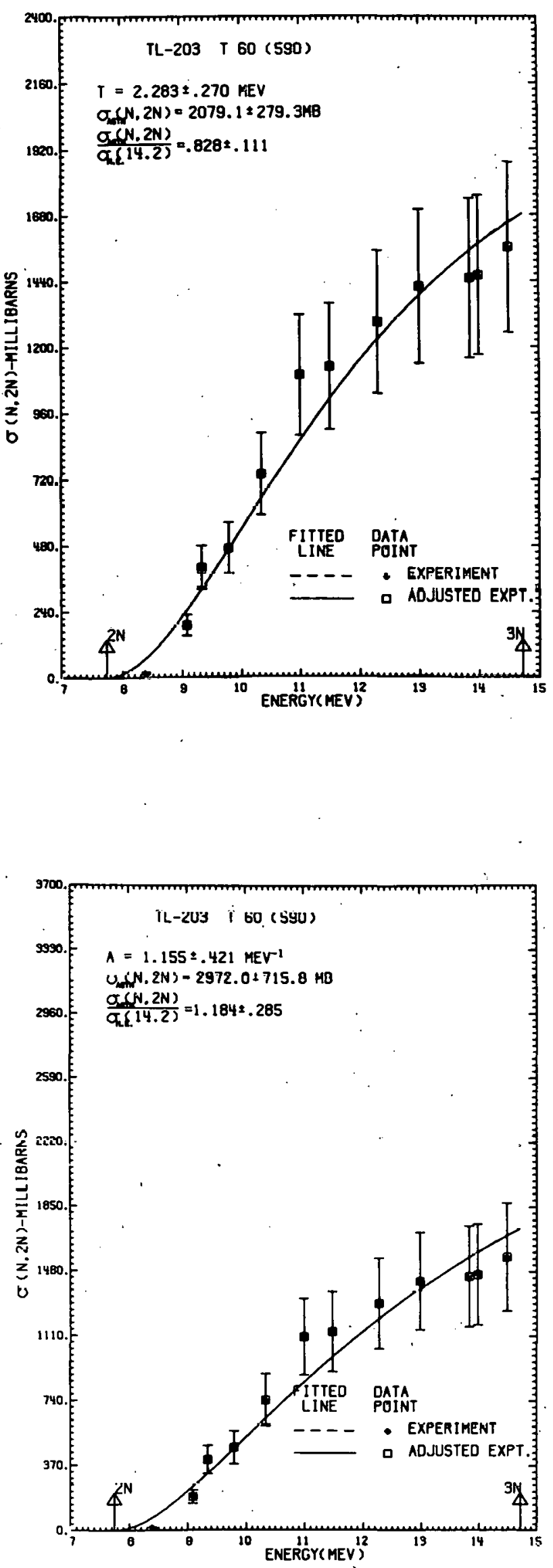


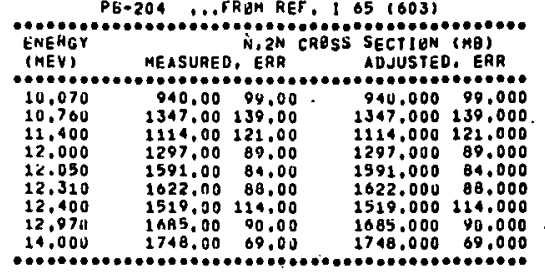

fitted paraheters

NUCLEAH TEMP, 1. U27 PLUSAOR-MIMUS .156 NEV

A5YMPTUTIC (N,2N) CROSS SECTIEN O 1735.90 PLUS-BR-MINUS 100,56 MB

RELATED UATA

NGN-ELASTHC CROSS SECTIUN AT 14,2 KEV 2515.90 ME (N.2N) THKESHELD: 8,44 MEY
(N,3N) THKESHBLD: 15,20 MEV

THIS ISOTZPE haS 122 meUtrons, H2 Pagíns, (MASS - 204)

NEUTKIN EXCESS PARAMETER . .1960

RATID OF ASYMPTETIC (N.2N) TO 14.2 MEY NON-ELASTIC
.0979 PLUS-ER-MINUS 0432

TESURTIN) 11.344 TESURT(A)E 14.606
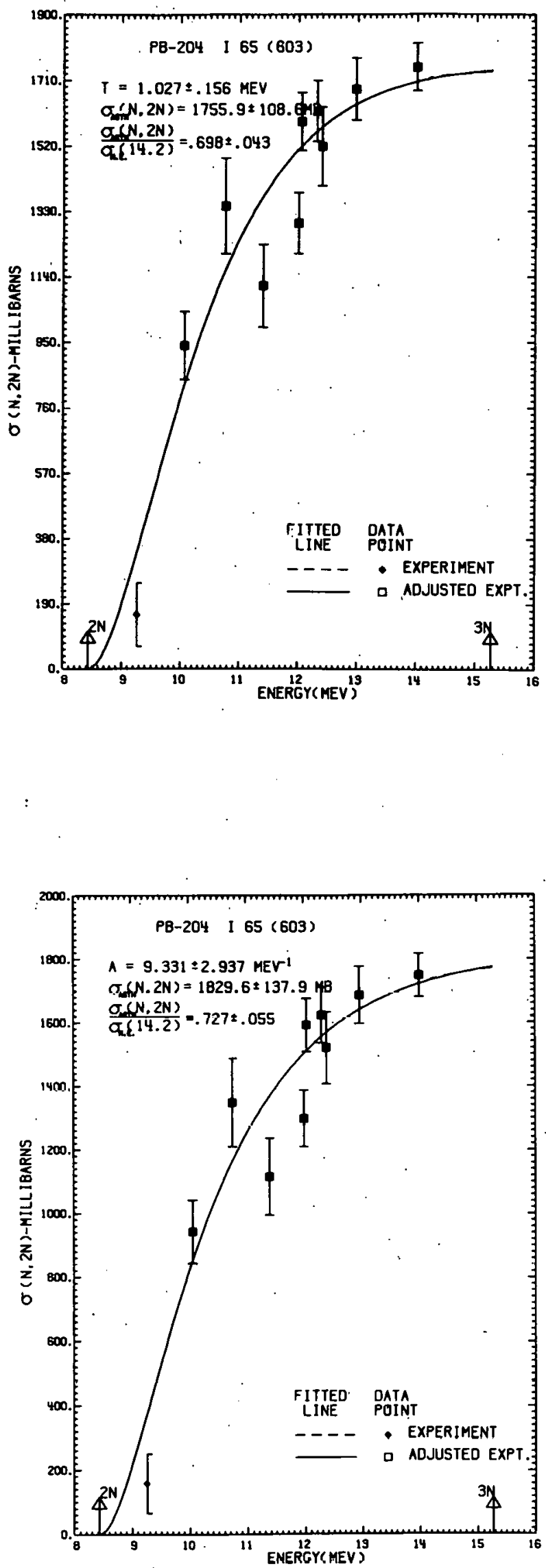

PELATED IIATA

NON-ELASTIC COQSS SECTIEN AT 14.2 MEV = $2519.90 \mathrm{MB}$ (N.2N) THKESHGLD: B,A4 MEV
(N.SN) THRESHTLD: 15.20 HEV

THIS ISOTGPE HAS 122 NEUTRUNS, B2 PHETUNS, (MASS - 204 )

NeUthan EXCESS PARAKETER: .19608

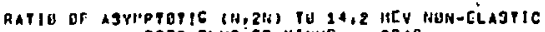

.7272 PLUS $-6 R=M I$ NUS .0548

N/SPACING 13.075 ERAXR 4.115 A/SPACINGE 21.803 


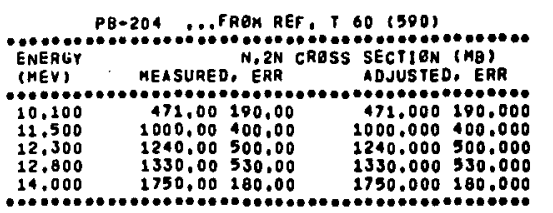

FITTED PAMAKETERS

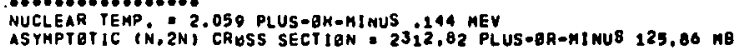

RELATEO DATA

MON-ELASTIC CRESS SECTION AT 14.2 MEV $=2915.90$ MB (N, 2N) TMFESHBLD: 8.44 MEV
(N,SN) THKESHALD : 25,26 MEV

THIS ISGTOPE haS 122 NEUTHENS, 82 PRUTBNS, (MASS : 2041

NEUTRON EXEESS PARAHETER * .19008

RATIU OF ASTMPIOTIC (N,2N) TI 14:2 MEV NAN-ELASTIC
,9193 PLUS-OR-MINUS .OSOO

TESORT(N): 22.742 ERRER T.501 TESORT(A) 29.400

\section{FITIED PARAMETERS}

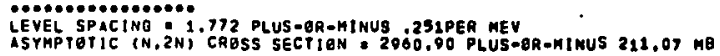

RELATED DATA

NON-ELASTIC CRASS SECTIEN AT 14.2 MEV • $2313.90 \mathrm{MQ}$

$(N, 2 N)$ PHRESHELD: 0.414 MEV
$(N, 3 N)$ THRESHOLD : 15.20 MEV

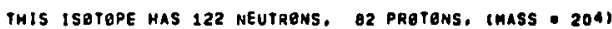

NEUTREA EXCESS PAMAMETER : .19600

RATIO UF ASYMPTOTIC (N,2N) TO 14,2 MEV NON-ELASTIC

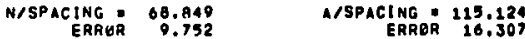
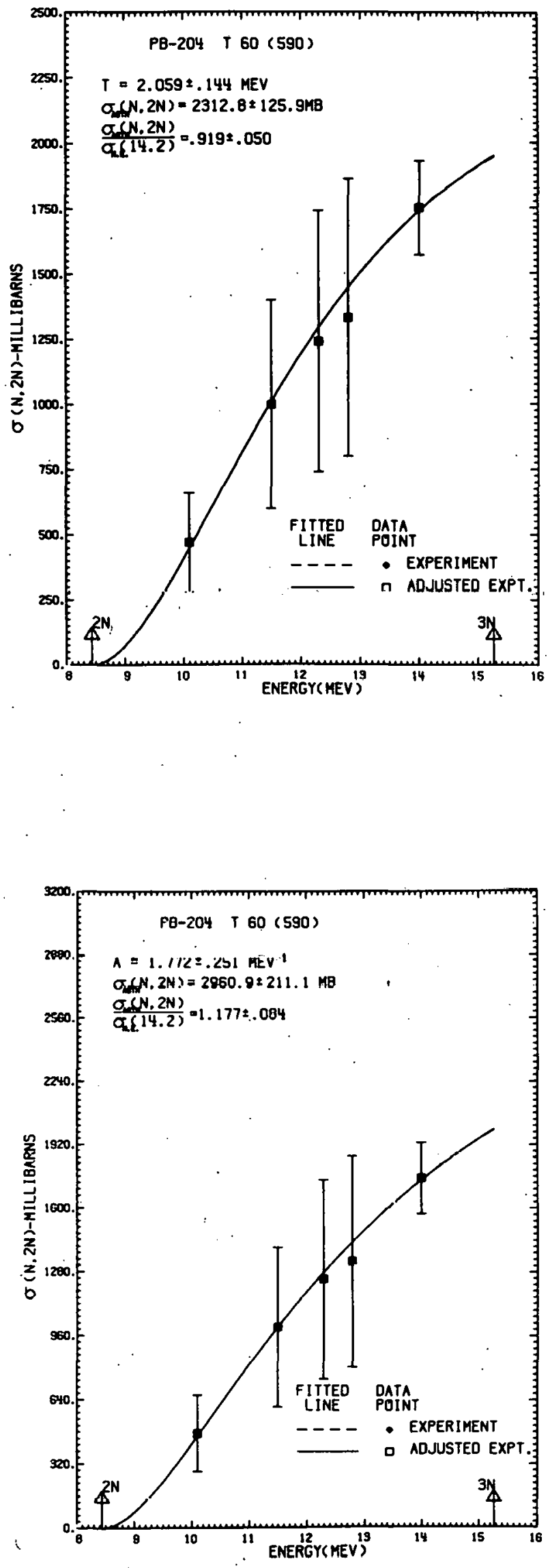


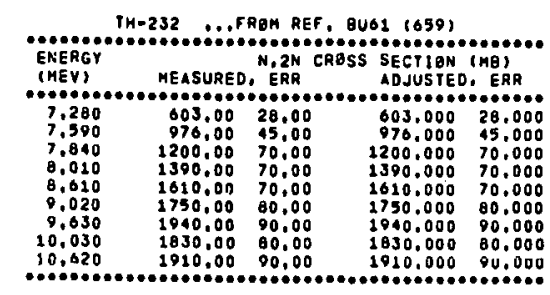

fitted parameters

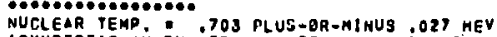

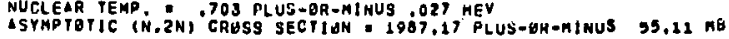

\section{RELATED UATA}

NBN-ELASTIC CRBSS SECTION AT 14,2 MEV : 2608.42 MB (N, 2N) TMRESHBLD: 0.40 MEV
(N,JN) THAESHELD: 11.01 MEV

THIS ISBTBPE HAS 142 NEUTAONS, 9O PRUTONS, (MASS - 252) NEUTRUN EXCESS PARANETER * .22414

RATIO OF ASYMPTOTIC (N,ZN) TO 14.2 MEV NON-ELASTIC 73P? PLUS-QRA A INUS .0205

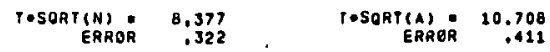

FITTED PARAHETERS

LEVE SPACING 14 , 05, PLUS-GR-MINUS

LEVEL SPACING 119.051 PLUS-6R-MINUS1, 110 PER MEV

RELATEO DATA

NON-ELASTIC CAOSS SECTION AT 14.2 MEV - 2600.41 MB

(N,2N) TMAESHALD: 6.16 MEV

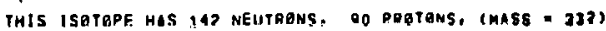

NeUtran EXCESS PaRaReTER : .22414

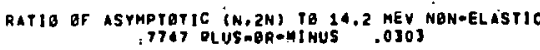

N/SPACINGE $\begin{aligned} & 20.106 \\ & 1.014\end{aligned}$
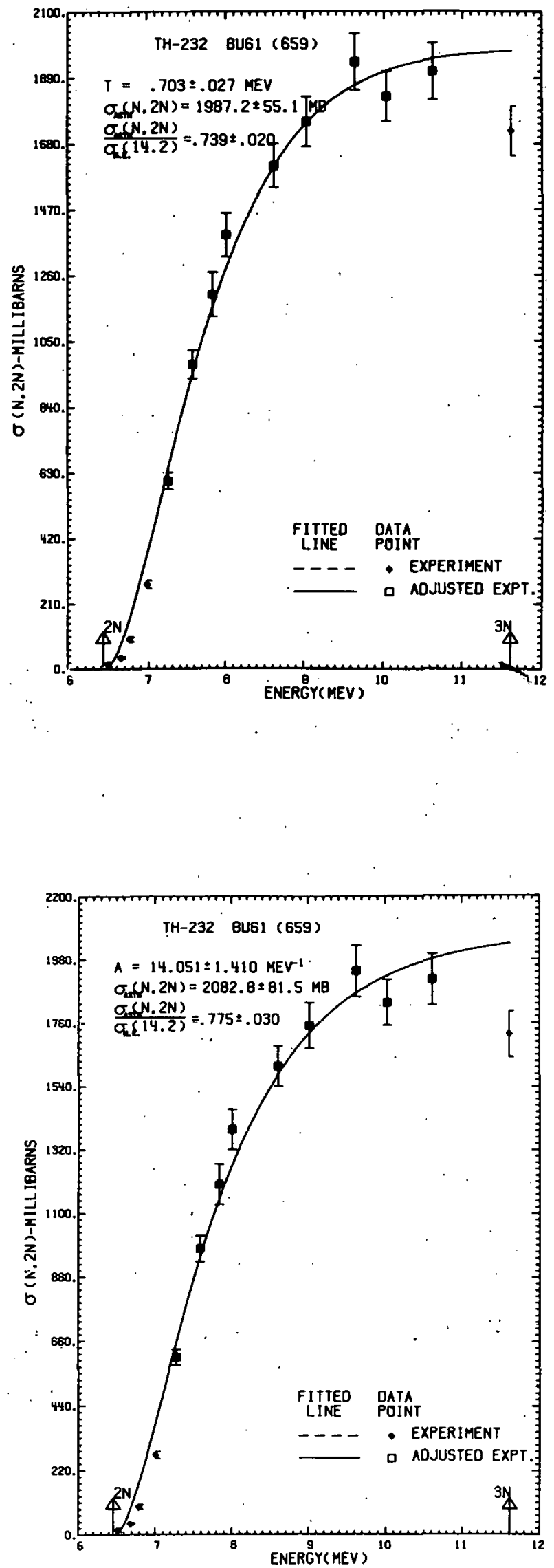


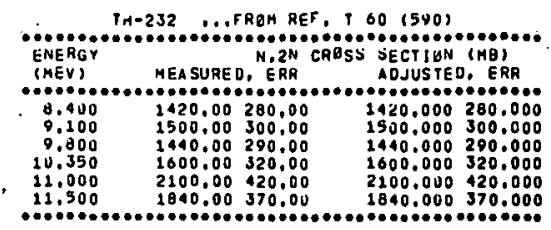

FitTED PAHAMETERS

n...............

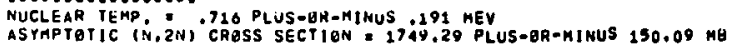

RELATED DATA

NBN-ELASTIC CHOSS SECTIUH AT 14,2 MEV = $2088.42 \mathrm{MB}$

$(N, 2 N)$ THAESHALD $=0.40 \mathrm{MEV}$
$(\mathrm{N}, 3 \mathrm{~B})$ THKESHELU $=11.61 \mathrm{MEV}$

IHIS ISUTUPE HAS 142 NEUTRENS, 9O PRUTUNS, (MASS = 232)

NEUTKON EXCESS PARAMETEK = .22414

RATIO OF ASYHPTETIC (N.2N) TE 14,2 MEV NON-ELASTIC .6507 PLUS- $\square$-HINUS

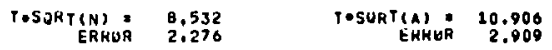

TH-232 $\therefore$, RAQH REF, T $60(590)$

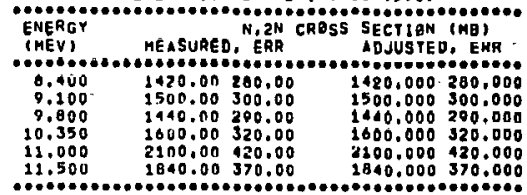

\section{GITTED PAHAHETERS}

LEVEL SPACING 125,048 PLUS-CR-MINUSB, 1 J3PER MEV

ASYMPTOTIC $(N, 2 N)$ CRPSS SECTION 1706.50 PLUS-ER-NINUS 100.49 ME

RELATED DATA

NON-ELASIIC CROSS SECTION AT 14.2 MEV - 2008.41 ME

(N.2N) THRESHPLD O.46 HEV

THIS ISOTEPE has 142 NEUTRENS, 90 PRDTONS, (MASS 232)

NEUTRON EXCESS PARAMETER = .22414

RATIO OF ASYMPIETIC (N,2N) 19 14,2 MEV NON-ELASTIC

N/SPACINGE 8.436 ARPBR $5.100 \quad$ A/SPACIMGER 15.417
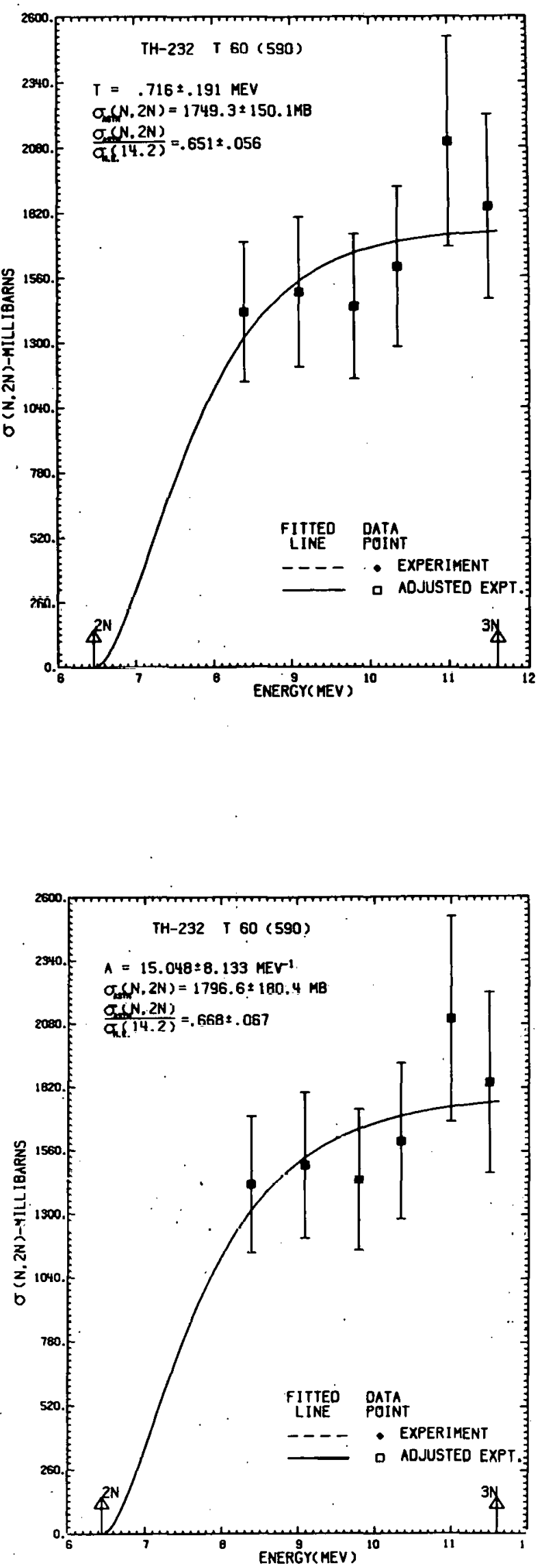


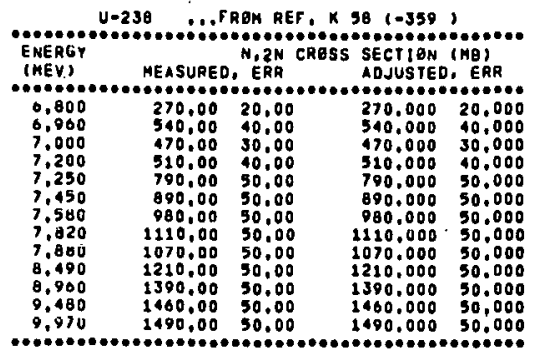

FITIED PARAMETERS

NUCLEAR TEAP, 738 PLUS-OR-MINUS, 045 MEV

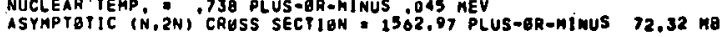

\section{RELATEO DATA}

NUN-ELASTIC CABSS SECTION AT 14,2 MEV $2724.80 \mathrm{~KB}$ (N,2N) THAESHOLO: 0.17 MEV

ThIS ISUTOPE has 146 neutrans, 22 PaUtons, (hass = 230 )

NEUTRON EXCESS PARAMETER - .22609

RATIO OF ASYMPTOTIC (N.2N) TO 14.2 MEV NOH-ELASTIC

5736 PLUS-6R-HIMUS .0265

TESORT(N): 8.917 ERRGR TESORT(A) $\quad .544$ ERRER 11.385

Fitied parameters

iE................

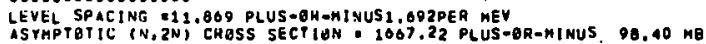

RELATED DATA

HEN-ELASTIC CARSS SECTION AT 14.2 MEV $=2724,09$ MO

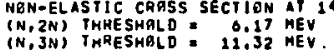

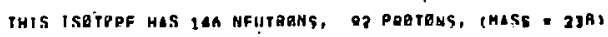

NEUTREN EXCESS PARAMETER * .22689

RATIO OF ASYMPTETIC (N.2N) IO 14.2 MEV NON-ELASTIC .6119 PLUS-ER-HINUS .0J81

N/SPACING E
ERAGR
2.301
1.754
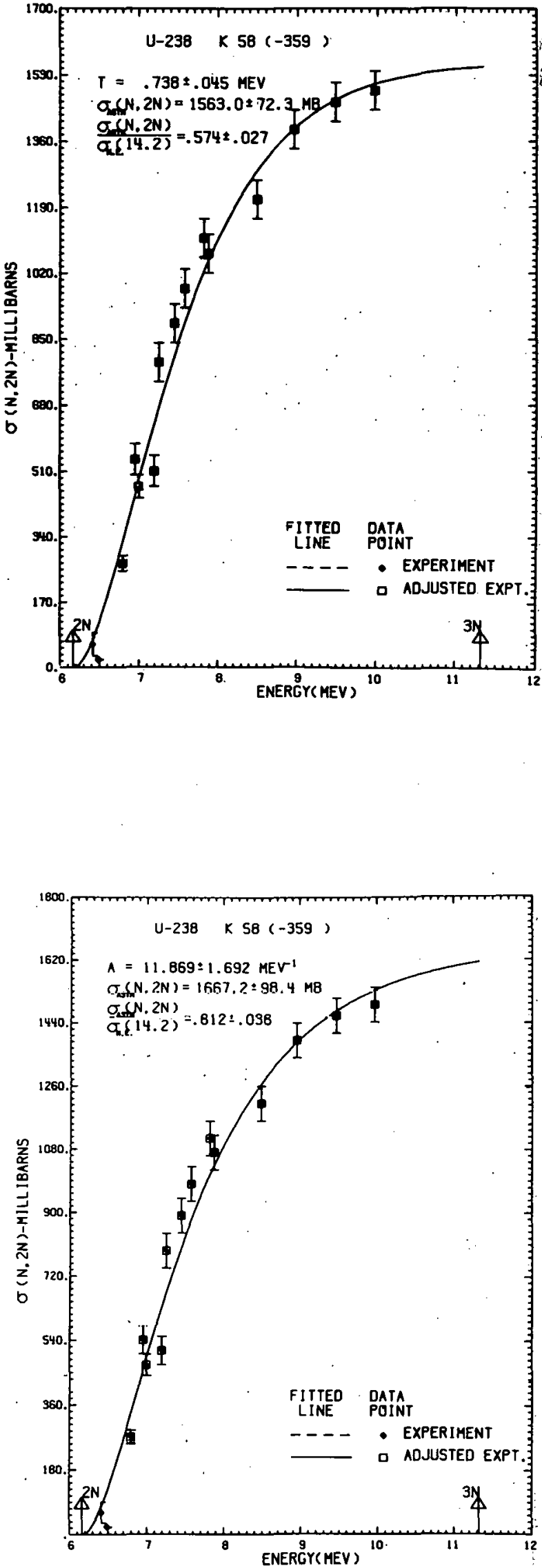


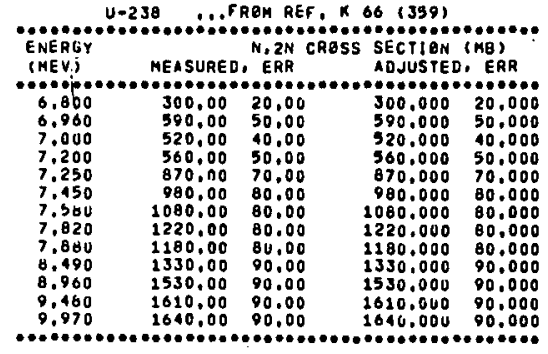

FITTED PARAMETERS

NUCLEAR TEMP. 770 PLUS-OR-MINUS . USL MEV

ASYMPTBTIL IN, 2N) CRESS SECTIUN - 2730,50 PLUS-3R-MINUS 107.34 MO

RELATED LATA

NEN-ELASTIC CRASS SECTIOA AT 14,2 MEV $=2724,89$ nQ (N.ZN) THKESHELD : 0.17 MEY

ThIS ISUTUPE haS 146 NEUTKENS, 92 PHUTUNS., (HASS : 238 )

NEUTREN EXCESS PARAMETER * .22069

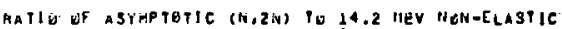

- .8954 Pluseoneminuś busg.

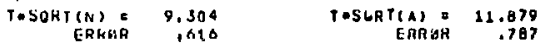

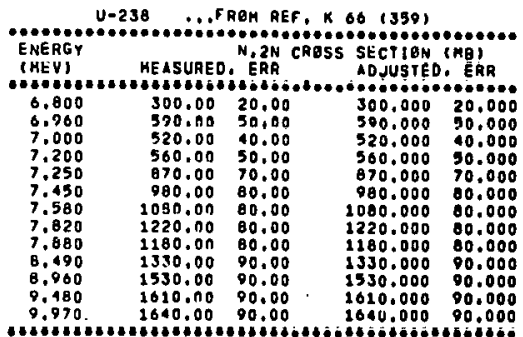

Ditin patamitas

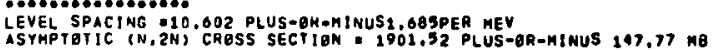

RELATED DATA

MEN-ELASTIC CRASS SECIION AT 14.2 MEV = 2724.09 MB

(N, 2N) THRESHALD : 6,17 MEV

THIS ISUIAPE has 140 NeUtrons, 92 PRETENS, (MASS $=238$ )

NEUTHON EXCESS PARAMETER * .22689

RATIO OF ASYMPTRTIC (N, ZN) IP 24.2 MGV NON-ELASTIC

N/SPACING E 13.772 ERRUR 2.189 A/SPACIMG 22.449
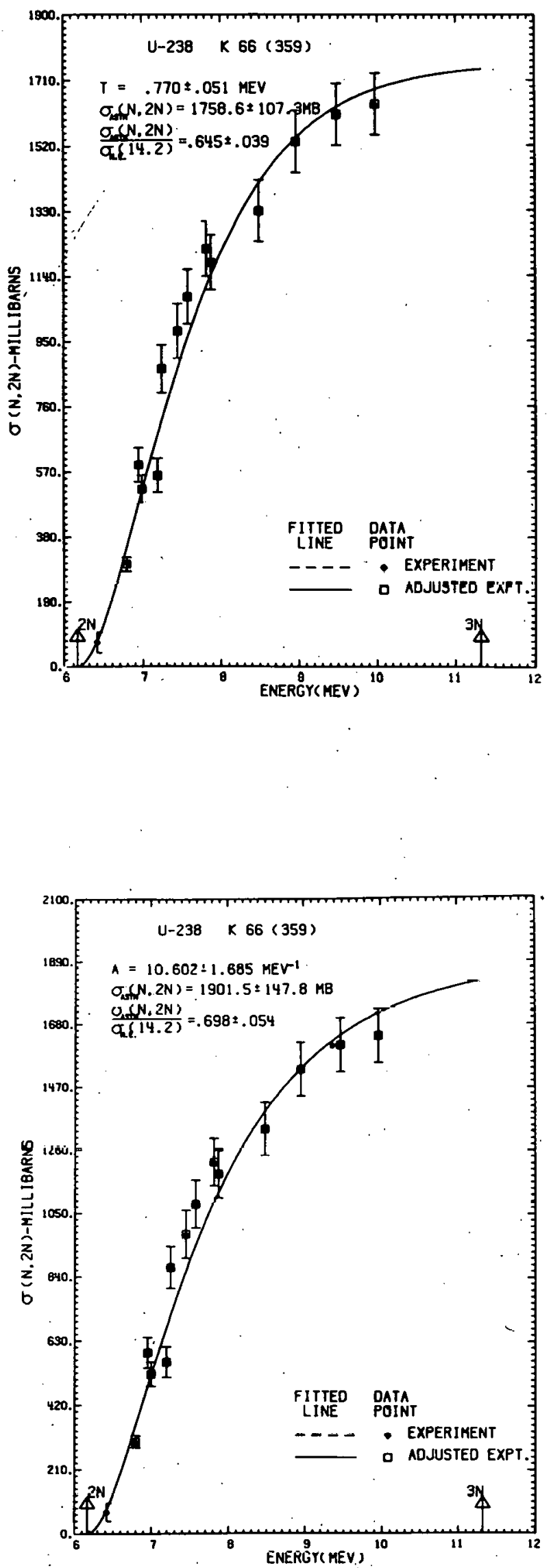


\section{REFERENCES}

1. D. W. Barr, C. I. Browne, and J. S. Gilmore, Phys. Rev. 123, 859 (1961).

2. R. J. Prestwood and B. P. Bayhurst, Phys. Rev. 121, 1438 (1961).

3. J. D. Knight, R. K. Smith, and B. Warren, Phys. Rev. 112, 259 (1958).

4. N. N. Flerov and V. M. Talyzin, J. Nucl. Energy 4, 529 (1957).

5. S. Pearlstein, Nuc1. Sc1. Eng. 23, 238 (1965).

6. S. Pearlstein, J. Nuc1. Energy 27, 81 (1973).

7. Internationa1 Atomic Energy Agency, CINDA 73, Vols. I and II and Supplement, Vienna (1973).

8. S. T. Perkins and R. J. Howerton, UCRL-50400, Vol. 10 (June 1971).

9. R. H. Moore and R. K. Zeigler, LA-2367 (Oct 1959).

10. D. S. Mather, P. F. Bampton, R. E. Coles, G. James, and P. J. Nind, Meaeurement of $(n, 2 n)$ Cross Sections for Incident Energies Between 6 and $14 \mathrm{MeV}$, AWRE-0 72/72, EANDC (UK), 142-AC (Nov 1972). 